Alessandro José Castroviejo Ribeiro

\title{
Edifícios Modernos e o Centro Histórico de São Paulo: dificuldades de textura e forma
}

Tese apresentada à Faculdade de Arquitetura da Universidade de São Paulo para obtenção do título de Doutor em Arquitetura e Urbanismo

Área de concentração: História e Fundamentos da Arquitetura e do Urbanismo

Orientador: Prof. Dr. Luiz Américo de Souza Munari 
À

Eliane 


\section{Agradecimentos}

Ao Mestre Luiz Munari pelo costume da arte, por ensinar-me a uma maneira de olhar - o mundo das ideias e o mundo das coisas. .

Ao Marcos José Carrilho por tudo no decorrer deste trabalho.

Ao Paulo Del Negro amigo que me mostrou um caminho.

À Monica Junqueira de Camargo e José Geraldo Simões Junior pelas contribuições na qualificação.

À Eneida pelo compartilhamento na jornada.

À Alberto Xavier e José Paulo De Bem pelas confirmações.

Ao Tiago Azzi Collet e Silva, Mariza Passos e Cristina Koppany pela ajuda na reta final.

À Mara Silva e Marina Amado pela ajuda nos levantamentos.

Ao Mário Figueroa pelos desenhos

À Tatiane Schilaro Santa Rosa da associação Viva o Centro pelos inúmeros contatos agendados.

À Beatriz Ayroza Galvão da Superintendência Regional do IPHAN pela consulta aos arquivos do Instituto.

Aos zeladores e síndicos dos condomínios visitados em particular o Sr. Oswaldo Ferreirinha do Conde de Prates.

Às bibliotecárias da FAU-USP e da FAU-Mackenzie.

À Rosana Soares boa ouvinte.

E especialmente agradeço a minha família pelo apoio e preocupação. 


\section{Resumo}

O objeto de estudo são os edifícios modernos localizados no Centro Histórico de São Paulo. O objetivo foi compreender a relação entre esses edifícios modernos e a cidade tradicional.

Estrutura-se, aqui, a hipótese de que o edifício moderno construído no Centro Histórico de São Paulo trás consigo as ideias da arquitetura da cidade moderna e quando essas foram postas diante de uma formação ao caráter da cidade tradicional, deparou-se com ambiguidades e contradições, de origem: das concepções de cidade ao manuseio de uma linguagem. Admite-se que esses edifícios carregam em suas formas e expressões os princípios modernos manifestados nas cartas, nos projetos de cidade ideais. Admite-se, portanto, que esse edifício moderno está diretamente vinculado a uma ideia de cidade: embora nela tenha sobressaído como um objeto autônomo.

Nesses termos admite-se que o moderno já nasce como forma difícil, adaptada e pragmática: nasce no jogo da lei e dos interesses, nasce tópico. Se por um lado o ideário e a linguagem contaminam-se e afastam-se das idealidades, por outro lado, é rica em lidar com as circunstâncias topológicas, tipológicas e formais encontradas na morfologia da cidade tradicional.

\section{Abstract}

The object of study are the modern buildings located in the Historical Center of São Paulo. The objective was to understand the relationship between these modern buildings and the traditional city.

It is structured here the hypothesis that the modern building built in the Historical Center of São Paulo brings with it the ideas of the architecture of the modern city and when they were put before a character formation of the traditional city, it faced ambiguities and contradictions of origin: from the city conceptions to the handling of a language. It is admitted that these buildings carry in their shape and expression the modern principals expressed in the letters, on designs of ideal cities. It is admitted, therefore, that this modern building is directly linked to an idea of city: although it has excelled as an autonomous object.

On these terms it is admitted that the modern is already born as a difficult shape, adapted and pragmatic: it is born in the game of the law and interests, it is born topic. If in one hand the city ideals and the language are contaminated and moved away from the idealities, on the other hand it is rich in dealing with the topological, typological and formal circumstances found on the morphology of the traditional city. 


\section{Sumário}

1. Introdução 011

2. Entre dois modelos de cidade 019

3. Nova York/São Paulo: aproximação necessária 051

4. São Paulo/Nova York: dos traçados aos edifícios 069

5. Objeto-tipo: moderno e brasileiro 091

$\begin{array}{ll}\text { 6. Ossatura independente } & 117\end{array}$

7. Primeiros encontros no Centro Histórico de São Paulo 137

$\begin{array}{ll}\text { Esther e Arthur Nogueira: usina paulistana } & 137\end{array}$

Thomaz Edison: composição exemplar 144

$\begin{array}{ll}\text { Banco Paulista do Comércio: tipicidade suficiente } & 149\end{array}$

Uma quadra em formação e três edifícios de Oswaldo Bratke 153

8. Oscar Niemeyer situações abrangentes 187

Edifício e Galeria Califórnia: um encaixe entre ruas $\quad 187$

Triângulo: a extrusão de uma quadra colonial 191

Eiffel: adaptação a partir do arranha-céu cartesiano 192

COPAN: a expressão do objeto 196

Montreal: uma esquina encurvada 200

Seguradoras: o lote de meio de quadra 202

9. Rumo aos anos 60

CBI-Esplanada: preso a um apêndice $\quad 235$

Conde de Prates: o palacete e a torre 241

Itália: um ponto focal 245

Conjunto Metropolitano: racionalidade e matéria 249

10. Discussão final 281

11. Bibliografia 290

12. Índice e fonte das llustrações 300 


\section{Introdução}

A origem e motivação deste trabalho acham-se em quatro aproximações que vieram posteriormente a estruturar a tese exposta a seguir.

A primeira remonta a um estudo para o Docomomo São Paulo onde foram tratados três edifícios de Oswaldo Bratke no Centro Novo de São Paulo; uma esquina. Nesse estudo ${ }^{1}$ abordou-se a linguagem moderna e a relação entre o edifício e a cidade, ou seja, especulouse a relação entre as normativas urbanas e o edifício moderno: a leitura e sobreposição das diversas cartografias da cidade foram relevantes na construção de uma maneira de ver e controlar o objeto: um item da metodologia.

A segunda tem origem numa ideia persistente e difusa guardada na memória. As relações entre os edifícios modernos e o Centro Histórico de São Paulo apresentavam-se como formas difíceis. Os sinais indicavam os desarranjos compositivos e as formas esconsas dos lotes. Pura intuição. Depois, com algum esforço de memória veio-me a origem dessa imagem conceitual: o livro de Rodrigo Naves " $A$ forma difícil", que havia lido anos atrás.

Naves fez nesse livro uma interpretação da arte brasileira, defendendo que essa se movimenta das dificuldades de forma à forma difícil. Ao analisar obras de Tarsila do Amaral, Anita Malfatti, Volpi, Guignard, Milton Dacosta, Mira Schendel, Helio Oiticica, Ligia Clark e Amílcar de Castro e outros, vai construindo argumentos de uma arte brasileira que incorpora mudanças modernas com renitente timidez formal. Segundo Naves, a produção moderna internacional caracterizou-se por uma aparência forte, devido a uma significativa redução da natureza representativa de seus elementos; linha, cor, superfície adquiriram um novo estatuto, na medida em que não apenas evocavam seres e coisas ausentes como também se mostravam com uma intensidade até então desconhecida (1996, p. 12).

Essa dificuldade de forma de fato perpassa boa parte da melhor arte brasileira. A relutância em estruturar fortemente os trabalhos, e com isso, entregá-los a uma convivência mais positiva e conflituada com o mundo, leva-os a um movimento íntimo e retraído, distante do caráter prospectivo de parcela considerável da arte moderna. [...] A feição um tanto primitiva dos trabalhos de Guignard e Volpi - vistos mais detidamente nos ensaios que seguem - tem uma significação profunda. A recusa à violenta sociedade do trabalho marcaos do princípio ao fim. Essas obras tímidas supõem um modo suave de moldar as coisas, e estão mais para um artesanato amoroso ou para um extrativismo rústico do que para a

\footnotetext{
${ }^{1}$ Estudo produzido com Paulo Del Negro.
} 
conformação taxativa da indústria" (1996, p. 21). Contudo, algumas poéticas praticam um fazer por meio do qual se sobressai uma forma difícil e não mais aquela relutância formal: Iberê Camargo, com a materialidade da pintura e o lado opaco da vida; Mira Schendel, "com seu traço que se move custosamente, sempre acossado por uma descontinuidade iminente, pronta a interromper a inteireza do gesto" (1996, p. 33); Amilcar de Castro, nos enfrentamentos da matéria e forma, "[...] dessa resistência do ferro ao rigor formal surgem estruturas poderosas, mas que retiram sua força de uma indefinição radical, e não de uma conformação violenta da matéria" (1996, p. 34).

Essas referências de Naves aclararam um problema e contribuíram para a formulação das hipóteses.

Tanto nas artes plásticas, quanto na arquitetura brasileira as questões entre a produção internacional e nacional sugerem distanciamentos no rigor dos conceitos ou aceite dos pressupostos. A arquitetura, guardando as enormes diferenças no modo de produzir, enfrentou problemas semelhantes aos ocorridos nas demais artes. Quando a arquitetura moderna é construída no Centro Histórico de São Paulo, a matéria [o aço] a ser trabalhada ou enfrentada é a cidade tradicional e a força de sua constituição. $O$ encontro ocorre, mas não sem as dificuldades de forma. Nesses casos as formas difíceis são produtos do encontro entre os ideais modernos, plantados pelas vanguardas racionalistas dos anos de 1920 e a cidade tradicional constituída pelos imperativos da geografia e da história.

A terceira conectou essa forma difícil às dificuldades de textura entre a arquitetura da cidade moderna e a arquitetura da cidade tradicional. O aporte teórico surge por Colin Rowe e Fred Koetter, que estruturam os elementos da crise entre a cidade moderna e a tradicional. A imagem que se fixa é a das relações entre figura e fundo, entre o construído e o vazio; uma leitura gestaltiana por excelência.

A quarta é a vivência e o envolvimento nas pesquisas em torno do Centro Histórico de São Paulo, coordenadas por Marcos Carrilho, que promoveu uma reaproximação sistemática com essa parte da cidade. Conviver em meio aos objetos de pesquisa foi um privilégio e uma oportunidade única.

Dadas essas circunstâncias foi possível estruturar as hipóteses da pesquisa e levá-la adiante, realimentado o quadro teórico de referências, conhecendo melhor os edifícios modernos construídos no Centro Histórico de São Paulo: que corresponde à área compreendida no interior do anel central previsto no Plano Prestes Maia. 


\section{Dificuldades de textura e forma: hipóteses}

O objeto de estudo são os edifícios modernos localizados no Centro Histórico de São Paulo (CHSP). Há um entendimento que delimita o centro histórico como contido pelo primeiro perímetro de irradiação do Plano de Avenidas de Prestes Maia, admite-se um longo processo sedimentado. O perímetro é composto pela Av. São Luís, Av. Ipiranga, Rua Senador Queiróz, Parque Dom Pedro II, Tabatinguera, Praça João Mendes, Viaduto Dona Paulina, Rua Maria Paula e fechando no Viaduto 9 de Julho. Para efeito desse estudo as escolhas dos edifícios limitaram-se às duas colinas que contêm o Centro Velho (triângulo histórico) e o Centro Novo.

O objetivo foi entender a relação entre esses edifícios modernos e a cidade tradicional.

A atual estrutura urbana do Centro Histórico de São Paulo apresenta uma configuração cujos principais delineamentos guardam relações com os processos de ocupação que remontam às origens da formação da antiga vila colonial.

Mas, além disso, documenta as transformações sucessivas por que passou a cidade, notadamente aquelas que testemunham sua transição de vila colonial a cidade cosmopolita na virada do século XIX para o século XX. Inicialmente, a transposição do Vale do Anhangabaú permitiu a ampliação da malha urbana dando início à formação do bairro de Santa Ifigênia, em seguida os Campos Elíseos e outros que viriam a configurar a assim chamada "Cidade Nova". Na primeira metade do século XX, a área central foi objeto de uma sucessão de projetos de "melhoramentos" e reformas urbanas que buscaram atender a vertiginosa transformação pela qual a cidade passou no período. Das diretrizes pioneiramente formuladas por Silva Telles até a reurbanização do vale do Anhangabaú, muitas mudanças ocorreram. Da mesma forma, de Silva Freire a Prestes Maia, embora os sucessivos planos urbanísticos tenham trazido grandes contribuições para a modernização da nascente metrópole, a maioria deles não se implantou integralmente, sofrendo adaptações e acomodando-se às contingências políticas e administrativas.

A partir dos anos de 1920 tem inicio uma intensa ocupação; logo substituída, nos anos 30 por edifícios de altura máxima de seis pavimentos, tendência à verticalização que seria potencializada a partir de 1940. Nesse território uma estrutura viária e fundiária que remonta às origens coloniais foi alargada e ampliada rapidamente. Um tecido foi constituído ao longo do tempo, nos moldes de uma cidade tradicional; guardando ainda as marcas da geografia e da história. Nesse mesmo período, sistemas construtivos e estilos são substituídos; e não raro passam a conviver juntos. 
Em paralelo desenvolveu-se a partir das vanguardas dos anos 20 o movimento moderno: com seu ideário, preceitos e proposições. Seus desdobramentos podem ser observados no Centro Histórico de São Paulo. Mas ali, aquilo que se pode chamar de estilo moderno (estrito senso) no Brasil, conviveu em seu nascimento com outros estilos que se não são modernos na linguagem, o eram nas técnicas construtivas, no manuseio programático e na busca da economia de meios. No decorrer das décadas seguintes uma predominância em favor da arquitetura moderna e depois de seus desdobramentos expressados no denominado "estilo internacional" veio a se concretizar. No Brasil e em São Paulo teve forte influência, embora não única, os preceitos contidos no ideário do movimento moderno, em particular na arquitetura derivada das vanguardas arquitetônicas dos anos de 1920, conforme definição abrangente de Giulio Carlo Argan em "A Arte Moderna". Particularmente ao racionalismo formal representado na figura de Le Corbusier.

Entretanto, esse moderno que se edificou no Centro Histórico de São Paulo nasceu com dificuldades de textura e forma, pois a matéria a ser defrontada era a cidade tradicional: cuja estrutura foi tecida num tempo longo. Para arquitetura moderna as préexistências urbanas foram decisivas em sua conformação. Os traços e os preceitos da arquitetura moderna lá estão, mas modificados, contaminados.

Estrutura-se, aqui, a hipótese de que o edifício moderno construído no Centro Histórico de São Paulo, trás consigo as ideias da arquitetura da cidade moderna e quando essas foram postas diante de uma formação ao caráter da cidade tradicional, deparou-se com ambiguidades e contradições, de origem: das concepções de cidade ao manuseio de uma linguagem. Admite-se que esses edifícios carregam em suas formas e expressões os princípios modernos plantados [sintetizados] por Le Corbusier e manifestados indiretamente na Carta de Atenas e nos projetos de cidade ideais ou não ${ }^{2}$. Admite-se, portanto, que esse edifício moderno está diretamente vinculado a uma ideia de cidade: embora nela tenha sobressaído como um objeto autônomo.

Nesses termos admite-se que o moderno já nasce como forma difícil, adaptada e pragmática: nasce no jogo da lei e dos interesses, nasce tópico. Se por um lado o ideário e a linguagem contaminam-se e afastam-se das idealidades, por outro lado, é rica em lidar com as circunstâncias topológicas, tipológicas e formais encontradas na morfologia da cidade tradicional.

A partir dessas hipóteses foram pensadas quatro escalas de descrições tipos que alimentaram os aportes teóricos em torno do moderno e que permeiam os diversos

\footnotetext{
${ }^{2}$ Pondera-se que as tendências modernas não são vozes em uníssono, entretanto, os princípios gerais do funcionalismo como exposto por Argan em Arte Moderna possuem universalidade suficiente para contê-los. Ver capítulo 6.
} 
capítulos. No plano da cidade, a Carta de Atenas e as cidades idealizadas de Le Corbusier. No plano das grandes obras, o Ministério da Educação, como objeto-tipo brasileiro. No plano do edifício ou de sua lógica interna, a ossatura independente. O quarto plano, seria os edifícios modernos propriamente ditos, que tipificam situações urbanas no Centro Histórico de São Paulo. O tipo é aqui entendido como estrutura portadora de qualidades e características capazes de delimitar parâmetros de análises, permitindo no cotejamento de obras e situações uma melhor descrição dos objetos estudados.

No segundo capítulo, Entre dois modelos de cidade, discute-se a da cidade tradicional e a da cidade moderna. Em outros termos, discuti-se o encontro entre a idealidade moderna e a matéria resistente representada pela cidade tradicional constituída no decorrer de um longo processo de formação. Inicialmente, abarcam-se definições e características da cidade tradicional e da cidade moderna. Da cidade tradicional recorre-se às descrições já aceitas nos manuais de morfologia urbana. Da cidade moderna recorre-se a um tipo ideal de cidade que pode ser reconhecido nas prescrições, cartas e manifestações do movimento moderno principalmente nos primeiros CIAMs; particularmente, na Carta de Atenas e nas cidades idealizadas por Le Corbusier. A intenção é identificar os elementos centrais que distinguem uma cidade da outra, admitindo-se que o tipo ideal de cidade fornece elementos claros precisos para o cotejamento pretendido.

As análises prosseguem por meio dos problemas levantados por Giulio Carlo Argan em torno da relação conflituosa entre cidade e cidade real, por extensão da cidade moderna e os centros históricos.

Colin Rowe e Fred Koetter teorizam a cidade da arquitetura moderna contraposta à cidade histórica: o tema central é a denominada crise do objeto - ou a dificuldade do edifício moderno em configurar o espaço público, em favor de um continuum espacial que privilegia o edifício solto no espaço. Por fim, aproxima-se da arquitetura construída no Centro Histórico de São Paulo na intenção de confrontar os aportes teóricos recortados diante da singularidade de sua ocupação: isto é, ir das universalidades ao caso em particular, por meio de um reconhecimento abrangente.

Nos capítulos 3 e 4, estabelece-se uma relação entre São Paulo e Nova York. O procedimento mais uma vez é o da aproximação e afastamento, para melhor entender a formação de São Paulo. A verticalização (multiplicação do solo), a legislação e o dinamismo aproximam essas metrópoles. O assoalho topográfico e a constituição do tecido urbano as afastam. Do traçado aos edifícios é possível identificar os desvios. Nesse sentido, não é possível ver edifícios modernos no Centro de São Paulo sem seus vínculos com 
Manhattanização generalizante, nem sem uma visão dos planos modernizadores para a cidade.

No capítulo 5 o assunto é o Objeto-tipo, moderno e brasileiro. A porta de entrada é o Ministério da Educação (MESP): que sintetiza em sua forma e linguagem relações urbanas modelares entre a arquitetura moderna e a cidade tradicional. Intervenção decisiva para a arquitetura brasileira. No entendimento do Ministério percorrem-se as intervenções de Le Corbusier, no Centrosoyus, em Moscou, e a Citè du Refuge, em Paris. Duas intervenções do mestre em contextos pré-existentes, que colocam o conflito entre os dois modelos de cidade numa perspectiva mais ampla, confirmando a conjunção entre os edifícios e as ideias de cidade que a ele subjazem. Assim, muitas das relações identificadas no MESP foram retomadas na descrição e interpretação dos casos.

Em a Ossatura Independente, no capítulo 6, enfrenta-se inicialmente a questão de quão moderno se trata esse estudo. Embora nos capítulos anteriores a descrição deixa poucas dúvidas, um olhar próximo fixa no âmbito da linguagem essa questão. A compreensão da ossatura independente, como exposta por Lucio Costa, não só esclarece um ponto central da doutrina como o relaciona aos demais elementos formais da linguagem. Como aponta para as particularidades que melhor diferenciam os edifícios modernos dos outros no Centro Histórico de São Paulo; uma tarefa de certa complexidade. Pois, sob muitos aspectos boa parte dos edifícios construídos na colina histórica (o triângulo) e o Centro Novo e no primeiro anel do Plano de Avenidas, são modernos: ou, parte constituinte do fenômeno da modernização refletida numa verticalização acelerada. A Modernidade como um fenômeno amplo envolve um conjunto de manifestações estilísticas. Também, para os propósitos deste trabalho, não interessa a generalidade do fenômeno, embora se reconheça as interpenetrações de significados e tecnologias. Em resumo, admite-se a ossatura independente como elemento central de uma linguagem que se inicia no esquema Dom-ino - na seriação da habitação.

Nos capítulos 7, 8 e 9, são tratados os edifícios propriamente ditos e suas relações com a cidade. A escolha procurou identificar situações e linguagens típicas. Caso a caso foram retomados, na medida da pertinência, os aspectos teóricos desenvolvidos nos capítulos anteriores. Para melhor controle dessas descrições e interpretações, estabeleceuse um roteiro que contempla:

- a formação e descrição dos arruamentos e lote;

- a descrição da volumetria, por meio da legislação, pela composição, pelos acertos;

- a relação dos edifícios no plano do chão; 
- O pavimento-tipo e as definições de estrutura e dos elementos de arquitetura: aberturas, brises, fachada e planta livre; a disposição dos núcleos (rígido) de circulação vertical (elevadores, escadas, sanitários);

- a relação entre o edifício e a situação urbana;

- interpretação entre a relação da arquitetura da moderna e a cidade tradicional.

Assim, no capítulo 7, são discutidos Os primeiros encontros modernos no Centro Histórico de São Paulo. De imediato faz-se o cotejamento diante do objeto-tipo brasileiro. Em São Paulo esses encontros já começam numa outra relação, distante da intervenção oficial do estado. A arquitetura já enfrenta suas dificuldades e mostra também seu domínio sobre as resistências.

No capitulo 8 analisa-se as obras de Oscar Niemeyer: Obras que cobrem um amplo espectro de situações, uma tipologia quase completa, pois no centro, pondera-se, não há estrito senso dois terrenos iguais. Obras que mais se aproximam da influência de Le Corbusier; e por outro, distantes da origem.

No capítulo 9, Rumo aos ano 60, a abordagem procura contemplar outras situações urbanas e variações nas relações entre a arquitetura moderna e a cidade. Há, pelas escolhas, uma predominância de torres relacionadas a seus embasamentos. Uma tendência indicava que o edifício se "desprenderia" parcialmente do lote e das amarras da ruacorredor. Naquele momento, percebe-se que outras formas do edifício moderno se relacionar com a cidade; já fruto de décadas de experiências modernas internacionais. 


\section{Entre dois modelos de Cidade}

A cidade ideal existe sempre dentro ou debaixo da cidade real. Diferente dessa, como difere o mundo do pensamento do mundo dos feitos. ${ }^{3}$

A questão não é se a cidade tradicional, em termos absolutos, seja boa ou má, relevante ou irrelevante, em sintonia ou não com o Zeitgeist. Tampouco se trata dos óbvios defeitos da arquitetura moderna (...). O que se tem são dois modelos de cidade. ${ }^{4}$

Dois modelos de cidade demarcam as argumentações em torno da tese que aqui se constrói: a da cidade tradicional e a da cidade moderna. Em outros termos, discuti-se o encontro entre a idealidade moderna e a matéria resistente representada pela cidade tradicional constituída no decorrer de um longo processo de formação.

Inicialmente, abarcam-se definições e características da cidade tradicional e da cidade moderna. Da cidade tradicional recorre-se às descrições já aceitas nos manuais de morfologia urbana. Da cidade moderna recorre-se a um tipo ideal de cidade que pode ser reconhecido nas prescrições, cartas e manifestações do movimento moderno principalmente nos primeiros CIAMs; particularmente, na Carta de Atenas e nas cidades idealizadas por Le Corbusier. A intenção é identificar os elementos centrais que distinguem uma cidade da outra.

Os cotejamentos prosseguem pelos problemas levantados por Giulio Carlo Argan em torno da relação conflituosa entre cidade e cidade real, por extensão da cidade moderna e os centros históricos.

Colin Rowe e Fred Koetter teorizam a cidade da arquitetura moderna contraposta à cidade histórica: o tema central é a denominada crise do objeto - ou a dificuldade do edifício moderno em configurar o espaço público, em favor de um continuum espacial que privilegia o edifício solto no espaço.

Por fim, aproxima-se da arquitetura construída no Centro Histórico de São Paulo na intenção de confrontar os aportes teóricos recortados diante da singularidade de sua ocupação: isto é, ir das universalidades ao caso em particular.

\footnotetext{
${ }^{3}$ Argan: $1984 a$, p. 73 , trad. nossa.

${ }^{4}$ Rowe; Koetter, 1998, p. 68, trad. nossa.
} 


\section{Um tipo ideal para a cidade moderna}

Definições clássicas da morfologia urbana identificam como elementos constituintes de uma cidade tradicional:

- o solo;

- os edifícios (o elemento mínimo);

- o lote (a parcela fundiária);

- o quarteirão, a fachada (o plano marginal);

- o logradouro (espaço privado do lote sem construção);

- o traçado/a rua, a praça, o monumento, árvore e a vegetação;

- o mobiliário urbano (Lamas, 2007, p. 79-110).

Esses elementos segundo Lamas serão utilizados no desenho das cidades [ou de suas partes] - sobretudo a partir do renascimento até ao período moderno. Assim, sistemas de relações entre esses elementos morfológicos de diversas formas promoveram variações decorrentes de intenções espaciais, estéticas, de estilo e gosto, de condicionantes préexistentes, topográficas ou territoriais. Nessa descrição o traçado ou a rua; o quarteirão subdividido em lotes; edifícios e logradouros; a praça e seus recintos; os prédios com suas fachadas; os edifícios singulares; [...] não só constituíram essas cidades, mas se revelariam igualmente importantes para a compreensão da urbanística moderna e contemporânea (2007, p. 227).

Nas ideias e desenho das cidades modernas esses elementos - um a um - seriam sistematicamente questionados, desmontados ou revistos. As razões encontram-se num amplo espectro de situações e complexidades, mas a industrialização e questões dela decorrentes como o inchaço populacional e a insalubridade das cidades insuflam uma mentalidade de época. Sob essas condições, o sistema viário (e devidas hierarquias), a divisão fundiária e a relação do edifício com a rua e lote foram radicalmente interpretados, independentemente das diversas variações em torno do moderno ${ }^{5}$.

\footnotetext{
${ }^{5}$ Lamas descreve a morfologia da cidade moderna introduzindo a seguinte observação: "A revolução industrial havia já introduzido as primeiras grandes modificações estruturais nas cidades. O período moderno irá produzir uma ruptura radical na estrutura, na forma, na organização distributiva e nos conteúdos e propósitos da urbanística e da cidade[...] A formulação da 'cidade moderna', como todas as transformações históricas importantes, processou-se em moldes difíceis de sintetizar, compreendendo um grande número de experiências e formulações teóricas que não seguiram um processo linear nem tiveram num único lugar, tempo ou ambiente cultural" (2007, p. 297).
} 
$\mathrm{Na}$ mais discutida manifestação dos CIAMs - a Carta de Atenas $^{6}$ - as argumentações, descrições e elementos da cidade moderna são reiteradamente apresentados. Passo a passo são inventariados os elementos da cidade tradicional [em particular de seus centros históricos] que devem ser debelados, quais as razões, formas e estruturas correspondentes aos novos tempos da máquina e do movimento que deveriam então ser levadas ao cabo.

$\mathrm{Na}$ apresentação das generalidades da carta além da atenção às profundas alterações da industrialização - que produz profunda rotura no mundo do artesanato esvaziando o campo e entupindo as cidades - já se esboça uma primeira crítica em torno da rua: os congestionamentos. Outras tantas virão no "Estado atual crítico das cidades": altas densidades de ocupação e degradação no interior do núcleo histórico das cidades [um obstáculo]; insuficiência da superfície habitável, mediocridade das aberturas, ausência de sol; presença de germes mórbidos; ausência de instalações sanitárias; má orientação dos imóveis, construções compridas e privadas de espaço. Assim, foram apresentados pela primeira vez os problemas relativos à densidade, à insalubridade e a insolação: argumentos centrais decorrentes dos graves problemas de saúde pública e principalmente das descobertas na área da infectologia.

Os primeiros argumentos da carta têm nas espacialidades centrais o alvo preciso da crítica da época [moderna]. Embora a referência esteja diretamente vinculada na historicidade europeia, muito dessas "desqualificações" reproduziram-se no Centro Histórico de São Paulo. Algumas como o sentido de profundidade e estreiteza dos lotes marcarão a forma dos edifícios modernos em São Paulo ${ }^{7}$. Outras como as questões de insolação serão determinantes nas definições formais dos edifícios modernos seja nos novos assentamentos (cidades) ou mesmo no CHSP: onde as orientações ótimas serão oportunidades raras dadas aos arquitetos. Sob esse aspecto, sublinham-se as críticas apresentadas pelos modernos quanto às orientações das edificações condicionadas pelo traçado e disposição das ruas e por decorrência da forma dos lotes impostas pelo sistema e circunstâncias da cidade tradicional. A condenação está ancorada nos estudos e esquemas de insolação, nesse caso, tendo em vista as sombras projetadas pelos edifícios nas ruas e pátios internos: projeções que criavam enormes áreas de sombra permanentes; gerando contaminações etc. Reagindo a essas disposições surgiram diversas tipologias modernas, nas quais se

${ }^{6}$ CARTA DE ATENAS. CIAM: Congresso Internacional de Arquitetura Moderna. Novembro de 1933: versão pdf; IPHAN.

${ }^{7} \mathrm{Na}$ carta de Atenas há menção às habitações dos ricos, que ocupam zonas favorecidas, ao abrigo dos ventos hostis, com a vista e espaços grandiosos dando para perspectivas amplas e com insolação abundante. Nesses casos o lote e as edificações nele isoladas (em São Paulo os palacetes) funcionam de certa maneira como exemplos a serem estendidos aos demais: ou incorporado no desenho das novas cidades. 
privilegiavam as orientações que permitiam maiores insolações e pouca projeção de sombra nas construções próximas. Como decorrência criou-se os blocos de edifícios laminares, cujas faces menores (uma empena cega) encontravam-se frequentemente voltadas para a orientação norte: nessas condições, as zonas de sombras projetadas diariamente no sentido dessa face seriam menores. Outras medidas de mesmo caráter, como distanciamento entre edifícios segundo variação de altura, seriam incorporadas ao repertório projetivo moderno (Figura 2.1 e 2.2).

$\mathrm{Na}$ Cidade Contemporânea para três milhões de habitantes, Le Corbusier dispõe parte significativa dos blocos de habitação no sentido norte/sul privilegiando as fachadas leste e oeste, para melhor insolação. Como o arranjo dos blocos tem conformação denteada, alguns blocos tinham suas faces maiores na posição invertida: nesse caso, a sombra projetada não seria um problema devido à altura e boa distância entre edifícios. $\mathrm{Na}$ Cidade Radiosa, esse esquema encontra-se melhor detalhado: ou seja, os edifícios contíguos guardavam afastamentos entre si que variavam de 200 a 100 metros. Em circunstâncias de espelhamento ficavam entre 50 e 30 metros. Nos dois projetos, os blocos dispostos na direção norte/sul, não possuíam apartamentos dúplex encaixados com circulação central: a solução suprimia uma metade, dispondo as circulações horizontais na fachada norte menos iluminada (figuras 2.3 e 2.4 ).

$\mathrm{Na}$ carta as deficiências da cidade histórica continuam sendo apontadas na ausência de parques e áreas verdes, resultando no postulado de que o sol, a vegetação, o espaço são as três matérias-primas do urbanismo. No mesmo sentido arrolam-se os argumentos contrários à rua-corredor: "as construções edificadas ao longo das vias e ao redor dos cruzamentos são prejudiciais à habitação [...]; "o alinhamento tradicional das habitações à beira das ruas só garante insolação a uma parcela mínima de moradias"; "os alinhamentos das habitações ao longo das vias de comunicação deve ser proibido"; "as construções elevadas erguidas a grande distância uma das outras devem liberar o solo para amplas superfícies verdes".

Os raciocínios tinham com epicentro a questão habitacional, embora pudessem ser estendidos também a outras tipologias como edifícios de negócios. Nas justificativas em favor de uma melhor iluminação ficam claras as críticas (recusas) aos blocos construídos, à rua e aos pátios internos. O argumento inicial condena a implantação dos blocos das edificações nos alinhamento das ruas: condição primeira, que determinava circunstâncias desiguais quanto à iluminação para as unidades de moradia.

\footnotetext{
${ }^{8}$ A rua-corredor é um termo usualmente empregado por Le Corbusier, como pilotis etc. A carta possui um texto mais formal, contudo, marcada pela dominante personalidade de Corbusier.
} 
"O alinhamento tradicional dos imóveis ao longo das ruas acarreta uma disposição obrigatória do volume construído. Ao serem cortadas, ruas paralelas ou oblíquas desenham superfícies quadradas ou retangulares, trapezoidais, ou triangulares, de capacidades diversas que, uma vez edificadas, constituem os blocos. A necessidade de iluminar o centro desses blocos engendra pátios internos de dimensões variadas. As regulamentações edilícias deixam, infelizmente, àqueles que buscam o lucro, a liberdade de restringir esses pátios às dimensões verdadeiramente escandalosas. Chega-se então a esse triste resultado: uma fachada, em quatro, seja ela voltada para a rua ou para o pátio, está orientada para o norte e não conhece o sol, enquanto as outras três, em consequência da estreiteza das ruas, dos pátios e da sombra projetada disso resultante, são também parcialmente privadas de sol [...] (Carta de Atenas, IPHAN, p. 9).

Como se verá adiante esta descrição de uma cidade tradicional nos termos da Carta de Atenas poderia ser usada - praticamente em sua totalidade para se ver o Centro Histórico de São Paulo. Em "Urbanismo" (2000) Le Corbusier é mais enfático na condenação da rua-corredor e do prédio construído sob medida: dois elementos característicos e constituintes da morfologia do Centro paulistano. Assim, expõe Le Corbusier:

Sucintamente: para que o canteiro de obras se industrialize, é necessário passar da construção anacrônica de um imóvel isolado, "sob medida", com todos os seus casos particulares, para a construção de ruas inteiras, de bairros inteiros. Trata-se então de estudar bem a célula, ou seja, o alojamento do homem, de fixar-Ihe o módulo, e de passar para a execução em séries uniformes. O quadriculado monótono e tranquilo assim formado de inumeráveis células se estenderá em grandes movimentos de arquitetura, movimentos diferentes da indigente rua em corredor: o urbanismo abandonará a "rua-corredor" atual pelo traçado de loteamentos novos, criará, numa escala muito mais vasta, a sinfonia arquitetural que se trata de realizar $(2000$, p. 68$)$.

Se o diagnóstico dos problemas gerados pela industrialização [era da máquina] sobre a trama da cidade tradicional avança em item após item, em determinado ponto tocam duas questões relevantes: a dissolução da rua, pela sua especialização funcional excessiva e o fim da divisão fundiária baseada no lote individual. Nos termos da carta os alinhamentos das habitações ao longo das vias de comunicação deveriam ser proibidos, as construções deveriam ser elevadas (devido aos modernos recursos técnicos [concreto armado em particular], afastadas uma das outras, liberando o solo para amplas superfícies verdes. Nessa condição a construção da cidade não poderia ser abandonada, sem programa, à iniciativa privada (Carta, IPHAN, p. 12-14). Sobre esse continuum espacial, encontrar-se-iam os volumes edificados amalgamados às superfícies verdes que os cercam (figura 2.5). 
Sobre os escritórios, ou centro de negócios "tudo aconselha ao agrupamento, melhores condições de funcionamento: circulação desembaraçada, comunicação fáceis com o exterior, iluminação, silêncio, boa qualidade do ar, instalações de aquecimento e de refrigeração. [...] O centro de negócios encontra-se na confluência das vias de circulação que servem ao mesmo tempo os setores de habitação, os setores de indústria e de artesanato, as administrações públicas, alguns hotéis e diversas estações (ferroviária, rodoviária, marítima, aérea) (IPHAN, p. 21)". Ou seja, o centro de negócios deveria se encontrar na confluência das vias de circulação que servem ao mesmo tempo diversos setores ${ }^{9}$.

O patrimônio histórico também é tratado na Carta. Não se nega os valores arquitetônicos do passado: os edifícios isolados ou conjuntos urbanos de verdadeiros valores arquitetônicos deveriam ser salvaguardados. No entanto, é expressa em afirmar que em nenhum momento o culto ao pitoresco e da história deve ter primazia sobre a salubridade da moradia: nesse sentido, edifícios e conjuntos deveriam se demolidos para permitir as reformas urbanas indispensáveis.

No âmbito de suas proposições gerais a Carta de Atenas [e sua versão formal a Cidade Contemporânea] é uma precisa descrição em negativo da estrutura urbana encontrada no CHSP: ou quase sua antítese. O corolário dos elementos contrapostos abarca amplo espectro, mesmo ponderando outros aspectos de fundo da modernização como a presença do elevador, do redesenho de sistema viário (plano de Avenidas) e uma legislação também decorrente das preocupações higienistas. Por outro lado, há certa similaridade nos conteúdos funcionais: o Centro Histórico, também uma centralidade, verticalizou-se intensamente abrigando atividades de negócios e comércio como relatado na Carta. Como a carta e a Cidade Contemporânea foram em certa medida decorrentes das análises empreendidas sobre tecidos urbanos pré-existentes ${ }^{10}$, elas incorporam ou fundem diversos traçados antigos como bem descritos no item "Circulação, observações" (IPHAN, p. 21). O relato identifica e associa redes de circulações às ramificações desenvolvidas a partir das principais vias de comunicação já na antiguidade. Posteriormente, menciona a regularidade dos traçados nos acampamentos romanos, o fato das cidades nascerem dos

9 Segundo Curtis, essa descrição espelha o traçado (mandala) proposto na Cidade Contemporânea. Le Corbusier os modificaria na Ville Radieuse: onde a centralidade ocupada pelos edifícios altos de negócio é substituída por uma concepção linear, desenho já influenciado pela sua visita à America do Sul. Nesse rearranjo, além da linearidade dos assentamentos observa-se forte analogia com corpo humano: nessa nova situação os edifícios de negócios são a cabeça de uma cidade de caráter tecnocrática; cuja distinção de classes não foi reconhecida no domínio da propriedade (Curtis, 2006, p. 118-121).

${ }^{10}$ No CIAM de Atenas foram apresentados estudos de 33 cidades. Apenas Los Angeles e Baltimore estavam em território americano. 
cruzamentos dessas vias de comunicação e finalmente articulando-os (ou fazendo-os convergir) num único ponto: ou seja, como proposto no sistema viário da Cidade Contemporânea (figura 2.6).

\section{O edifício na cidade moderna: vontade de ser}

Se a Carta de Atenas pode ser entendida como um tipo ideal moderno de cidade, para 1933, na versão europeia não pode evidentemente ser estendida indiscriminadamente. Lamas faz uma panorâmica leitura que circunda a gênese da cidade moderna: o primeiro, situado entre as duas primeiras guerras e o segundo abarcando o fim da Segunda Grande Guerra; quando a demanda decorrente das reconstruções das cidades [entende-se europeias] e das necessidades habitacionais (da industrialização de demais fenômenos sociais) torna-se de grande monta, quando serão necessários novos bairros e cidades. A primeira fase coincide com o período "heroico" das formulações teóricas. Fase em que os arquitetos fariam oposição à urbanística formal e na organização da estrutura e morfologia da cidade, propondo em suas experiências a "destruição" do quarteirão, da rua, e até da praça. Em seu lugar se propõem as tipologias da torre, da banda (da fita) e do bloco e alta prioridade aos sistemas de circulação (viário). No centro gerador dessa cidade a questão habitacional; as habitações. Nos termos de Ernst May - por um processo somatório e linear: várias camas formam uma célula de vivenda, várias células uma unidade tipológica, o edifício, vários edifícios um bairro e vários bairros conformam uma cidade; uma construção demasiadamente reduzida (e linear) da cidade moderna, porém precisa - vai-se da célula à cidade.

Lamas sublinha ainda alguns tópicos que caracterizam a cidade moderna; como a ruptura com a história, o papel dos novos materiais e tecnologias, o alojamento, o funcionalismo e o zoneamento. Mas, outros três têm relevância e devem ser vistos com mais atenção no desenvolvimento do capítulo:

- o primeiro trata da questão fundiária;

- o segundo do fascínio pelos edifícios isolados;

- o terceiro a reação à rua-corredor.

A rua como espaço das trocas - sempre muito movimentada - é elemento central na estruturação urbana tradicional. Por isso mesmo, foi comum às manifestações modernas, o combate à rua-corredor que estrangulava a circulação, sobretudo, dos automóveis; para Le Corbusier foi bandeira levantada em diversos textos e ocasiões. 
A questão fundiária é pedra fundamental na cidade tradicional e na cidade moderna; pelo menos, nas condições propositivas. Na cidade tradicional, o desenho urbano assimila o parcelamento e a divisão cadastral, separando o solo privado do solo público. A urbanística moderna está associada, de acordo com Lamas, a operações em que o Estado ou a municipalidade detém a totalidade do solo e urbanizam sem uma redivisão fundiária as unidades habitacionais - em condições especiais, sob os pilotis - onde o solo é também "público". Assim, a questão fundiária assume um papel relevante nos embates ideológicos e políticos enfrentados pelas vanguardas modernas. Nessas condições, o edifício "moderno" (constituído a partir de uma célula primordial, ideal e operativamente lógica) evolui com consistência na idealidade moderna. Entretanto, a cidade tradicional the impõe restrições categóricas: o lote é privado.

Portanto, o edifício moderno nasce ideologicamente liberto do lote, "fascinado por si mesmo", mas, constrito nas contradições entre a realidade (interesses) e a idealidade (o sonho delirante).

O fascínio pelo edifício isolado, segundo Lamas, percorre longa trajetória na história da arquitetura; Zevi, Giedion, Benevolo etc. As análises e interpretações a partir do exemplares fundadores como a Unité d'Habitation, Pavilhão de Barcelona, Seagram e outros demonstram a prioridade de leitura (Lamas, p. 297-310). Mais recentemente a tônica parece não ser outra.

Também na dimensão das idealidades, Solà-Morales recoloca a questão posta por Alberti de que a cidade não era senão uma casa grande e uma casa não era outra coisa senão uma pequena cidade. Segundo Solà-Morales, os arquitetos modernos têm tentado mil vezes fazer as cidades à imagem e semelhança de seus edifícios, ao mesmo tempo que se sentiam satisfeitos quando ao projetar seus edifícios o faziam dirigidos pela lógica da construção da cidade. A confusão da cultura moderna, tão fragmentada e especializada, é de que cada um dos paradigmas tende a fazer-se autônomo e absoluto. Dessa forma, há para a economia uma cidade como mercado; para a semiótica uma cidade como sistema de informação; para a política uma cidade, civitas, em que se canalizam os valores coletivos e há também uma cidade como arquitetura. Solà-Morales afirma então que a história da arquitetura urbana dos últimos cinquenta anos é também a história desse desejo de fazer a cidade desde a arquitetura (em Territórios, Fazer a cidade, Fazer a arquitetura (1945-1993, p. 35). 


\section{Cidade ideal e cidade real}

Giulio Carlo Argan (1984a) inicia seu texto Cidade ideal e cidade real citando Lewis Munford: "A cidade favorece a arte, é arte ela mesma"; ou seja, ela não é apenas um lugar que abriga as obras de arte, mas é ela mesma uma obra de arte. Mais à frente tratando das mudanças históricas da cidade tradicional para a moderna dirá que na transformação de um sistema geral de produção para outro, aquilo que era um produto artístico é hoje um produto industrial. Esse conceito segundo Argan foi delineado a partir do momento que ficou superada a estética idealista, considerando-se que a obra de arte não é fruto apenas da personalidade do artista, singular e bem individualizada, mas também de uma soma de componentes, não necessariamente depositados numa pessoa ou época. A concepção de arte como expressão da personalidade teve início nas concepções de arte do Renascimento: período onde se formularam como hipóteses a possibilidade da existência de uma cidade ideal concebida como uma obra de arte única, de um único artista. "Porém, a cidade ideal existe sempre dentro ou debaixo da cidade real, diferente desta como difere o mundo do pensamento do mundo dos feitos" (Argan: 1984a, p. 73, trad. nossa).

A ideia de cidade ideal está profundamente enraizada em todos os períodos históricos, é inerente à sacralidade anexa à instituição e se vê confirmada pela contraposição recorrente entre cidade metafísica ou celeste e cidade terrena ou humana. Argan ainda dirá que mesmo que algumas cidades ideais tenham sido realizadas, a cidade ideal não é mais do que um ponto de referência com o qual se medem os problemas da cidade real: que se pode conceber como uma obra de arte que no curso de sua existência há sofrido modificações, alterações, agregações, diminuições, deformações e até verdadeiras crises destrutivas. A cidade real reflete a dificuldade de fazer arte nas circunstâncias de resistência do mundo em que se faz. Nesse sentido, a cidade ideal, mais do que um modelo é um módulo do qual sempre se pode encontrar múltiplos ou submúltiplos que mudam sua medida, mas não sua substância. Em geral, o desenho da cidade ideal implica a ideia de que na cidade se realiza um valor de qualidade que se mantém praticamente imutável com as mudanças de quantidade: considerando-se que qualidade e quantidade são entidades proporcionais e comensuráveis.

$\mathrm{Na}$ construção desses raciocínios Argan problematiza a relação entre cidades históricas e cidades modernas:

É justamente isso, segundo acredito, o que explica a não continuidade de desenvolvimento entre as cidades históricas e as cidades modernas, entre cidades préindustriais e cidades industriais ou pós-industriais. É essa ruptura da continuidade ou impossibilidade de desenvolvimento que dá lugar à artificiosa concentração da historicidade intrínseca da cidade no centro antigo, dando-se por admitido que esse é por definição 
histórico, assim como o centro moderno - já o sublinhou Maltese - em sua realidade e atualidade seria por definição não histórico ou diretamente anti-histórico (1984a, p. 74, tradução nossa).

Sob essa teorização Argan problematiza a relação entre a arquitetura moderna e a realidade da cidade europeia, em particular de seus centros históricos. Em São Paulo e no seu Centro Histórico essa condição não pode ser discutida nos mesmos termos de Argan porque aqui a arquitetura moderna encontra-se imbricada ao Centro Histórico: a ele confere características e dele incorpora formas e traços de sua formação. Mais do que isso, podese até dizer que arquitetura moderna no CHSP é ela mesma um dos fatos históricos a ser [re]visto: pois hoje ela é parte relevante de sua constituição.

\section{A crise do objeto?}

Colin Rowe e Fred Koetter em "Ciudad Collage" (1998) formulam uma teoria crítica sobre a cidade. Utilizando-se dos mapas de figura e fundo (cheios e vazios) confrontam por essas categorias a cidade tradicional e a cidade moderna. Os edifícios modernos e a cidade moderna, nos termos dos autores, promoveram aquilo que chamaram de "A crise do objeto". Ou seja, na cidade tradicional os elementos primários como lote, quadra, rua, praça, e os edifícios construídos, formam um tecido no decorrer de um longo período. De tal maneira que aquilo que se identifica ou se nomeia como figura é o espaço público; conformado pelo conjunto dos edifícios que os delimitam e lhe dão forma. Ao contrário, na cidade moderna (sobretudo a idealizada), o tecido tradicional é substituído por grandes sistemas de circulação e novas divisões fundiárias: assim, os edifícios se apresentam soltos no espaço. A figura então passa a ser o edifício, e por decorrência, tem-se a dissolução (dispersão) e descaracterização daquilo que se denomina como espaço público. Por meio, sobretudo, de um novo ideário funcionalista e de legislações próprias procura-se fazer uma cidade onde os edifícios progressivamente isolaram-se no lote ou nas novas formas de ocupação que foram desenhadas. Nesse sentido, uma linguagem arquitetônica nova encontra os meios para se expressar plenamente por um objeto solto no espaço; dissociado das amarras do lote. A crise do objeto seria, então, a incapacidade do edifício moderno de sugerir ou conformar o espaço público nos termos e relações anteriormente edificados (figuras 2.7, 2.8 e 2.9).

Elementos e conceitos embutidos no ideário da cidade moderna sinalizaram algumas mitologias de origem que de alguma maneira promoveram uma progressiva ideia da arquitetura como um objeto, como uma peça isolada da trama urbana. A cidade moderna, nos termos da "Ville Radieuse", teria como uma de suas mitologias a visão do homem puro; o homem com uma tábula rasa. Abrigar o nobre selvagem, esboçando uma 
volta à natureza, seria um dos pressupostos da nova arquitetura. Outras ideias (e práticas) higienistas reforçariam essa disposição. Munford (apud Rowe; Koetter, 1998, p. 55) sublinha essas condições e enfatiza na moderna planificação funcional o abandono de concepções arquitetônicas mais tradicionais que enfatizavam apenas o plano ou as fachadas: arquiteturas coladas umas às outras, sem recuos laterais. A moderna arquitetura, pelo contrário, abole a distinção entre frente e parte posterior, criando estruturas que são harmoniosas em cada direção: em suma, liberta o edifício do contato insalubre típico das cidades tradicionais.

Progressivamente altera-se a maneira de projetar o edifício e a cidade, sobretudo, pelas novas demandas habitacionais. Rumo aos anos 30, a desintegração da rua e de todo o espaço público parece inevitável. Seriam duas as razões principais: a nova e racionalizada forma de se projetar as habitações e as novas necessidades ditadas pelos veículos. A nova maneira de se projetar enfatizava um processo gerador das habitações dentro para fora ou seja, a partir das necessidades lógicas da unidade residencial (Rowe; Koetter, 1998, p. 58). Um raciocínio de causa e efeito, decorrente de demandas programáticas racionais.

As novas demandas programáticas e técnicas abriram caminho para outras racionalizações como diagramas de iluminação e ventilação, de maneira a se abandonar qualquer justificativa futura em termos da história e de princípios de alguma forma vinculados à cidade tradicional. Esse processo em favor do objeto isolado não evoluiu sem contradições. Se o objeto e todas as suas faces são axiomas defendidos para uma "nova arquitetura", os grandes blocos de habitação contínuos e isolados devem ser escondidos atrás de abundante vegetação como nas visões de Le Corbusier. "De fato, na arquitetura moderna, o orgulho posto nos objetos e o desejo de dissimular esse orgulho, que se revela em todas as partes, é algo tão extraordinário que se faz ocioso qualquer comentário" (Rowe; Koetter, 1998, p. 58).

A ambiguidade entre a afirmação do objeto e sua desintegração, ou o desiderato teórico segundo o qual o edifício racional deve ser um objeto, encontra-se subordinado a uma hierarquia invertida: que em última instância valoriza mais tempo e espaço do que a matéria. A óbvia sensação de que o espaço, em certo modo, é mais sublime do que a matéria - inevitavelmente grosseira - valoriza o continuum espacial que pode facilitar as demandas de liberdade, natureza e espírito; ou uma quase volta ao mundo natural. E, segundo os autores, a noção de espaço é menos importante do que o tempo; na medida em que a insistência no espaço fechado pode inibir o desenvolvimento do futuro e advento natural da "sociedade universal" (Rowe; Koetter, 1998, p. 60). 
Ao confrontar, por mapas de figura e fundo, a cidade moderna e a tradicional, Rowe e Koetter procuraram expor as dificuldades de textura ${ }^{11}$ da cidade moderna: que vão além das simples relações entre o sólido e o vazio. Pelo contrário, apontam para uma nova dimensão do que é privado, do que é público. Na cidade tradicional, a massa das edificações promove de certa maneira a estabilidade pública, ao fazer figurar o vazio, dando-Ihe forma: nesse caso, tem-se a estabilidade pública por um lado e por outro a imprevisibilidade privada; contida nos seus limites. A cidade moderna ao figurar o objeto que se expressa a partir de relações internas sinceras, programáticas ou técnicas conferindo-Ihe um status universal, promove a demolição da vida pública e do decoro, reduzindo o domínio público, o mundo tradicional do civismo visível a um resto amorfo (Rowe; Koetter, 1998, p. 64).

Por outro lado, pode-se argumentar a favor dos lógicos e defensáveis pressupostos da arquitetura moderna: luz, ar, higiene, aparência exterior, perspectiva, lazer, movimento e abertura. "A questão não é se a cidade tradicional, em termos absolutos, seja boa ou má, relevante ou irrelevante, em sintonia ou não com o Zeitgeist. Tampouco se trata dos óbvios defeitos da arquitetura moderna (...). O que se tem são dois modelos de cidade" (Rowe; Koetter, 1998, p. 68).

Tal crise do objeto estendeu-se como prática e mentalidade, contribuindo para uma crise geral da cidade da arquitetura moderna ${ }^{12}$. Em ensaio intitulado " $A$ terceira era da cidade" (1997), Christian de Portazamparc reflete acerca dessas duas ideias de cidade e da crise em questão: sua intenção foi propor uma alternativa conciliadora. Na aproximação do problema retoma as questões higienistas que sabidamente têm enorme importância nas formulações da cidade moderna e dos seus edifícios; entraram no centro dos debates com intensidade a partir dos meados do século XIX. Muitos argumentos nessa linha justificaram intervenções urbanas, a implantação dos edifícios e seus desenhos: nesse sentido, foram constituintes de um processo de ação e ideologia que viriam a substituir, ainda que com algumas exceções, o tecido da cidade tradicional em favor de uma concepção mais

${ }^{11}$ A textura aqui é entendida nos termos amplos contidos abaixo segundo dicionário Houaiss. Mas também no sentido da conformação de espaços dispostos nos termos da cidade tradicional conforme as entende Rowe e Koetter. Textura segundo definição do dicionário Houaiss: ato ou efeito de tecer 1 tecido, trama 2 união íntima das partes de um corpo; contextura 3 ligação ou arranjo das partes de uma obra [...] ETIM lat. textúra, ae 'ação de tecer, tecido, encadeamento, ligação', do v.lat. texère 'tecer'; na acp. geol já se documenta nos sXVII-XVIII, embora seu uso entre geólogos só se tenha generalizado na $2^{\mathrm{a}}$ met. sXIX; a acp. paleog gráf por infl. do al. Textur; ver text; a datação é para a acp. 'tecido'

${ }^{12}$ Segundo Rowe e Koetter, "a cidade da arquitetura moderna (que pode ser também chamada de Cidade Moderna) contudo não foi construída. Apesar de toda a boa vontade e as boas intenções de seus protagonistas, ficou contida ora como projeto ora como um aborto, e não parece que exista nenhuma razão convincente para se supor que esse estado de coisas irão se modificar" (1998, p. 9, trad. nossa). 
estandardizada universal e abstrata. Para ele "a cidade da $1^{\underline{a}}$ Era é contida, compacta, fechada como concentração defensiva, uma proteção contra a imensidão, contra o informe, 0 desconhecido. A cidade da $2^{\text {a }}$ Era desenvolve o movimento de conquista territorial e "arrazoamento" do planeta, que é o grande destino do ocidente. A lógica é de libertar-se do lugar, das amarras da matéria e, dentro em pouco, do corpo físico" (1997, p. 39).

Nesse sentido Portzamparc propõe a ideia e o desenho da quadra aberta: sua convicção é recuperar a rua como elemento chave para se propor uma reaproximação com o elo perdido; "A quadra definiu a repartição do cheio e do vazio, a relação entre o edifício e

a cidade. É preciso redefinir relações. E é essa indagação que me conduziu ao esquema de quadra aberta, a qual sintetiza, em uma única forma, essa dupla herança da $1^{\underline{a}}$ e $2^{\underline{a}}$ eras (da cidade). A quadra aberta permite reinventar a rua: legível e ao mesmo tempo realçada por aberturas visuais e pela luz do sol. Os objetos continuam sempre autônomos, mas ligados entre eles por regras que impõem vazios e alinhamentos parciais. Formas individuais e formas coletivas coexistem. Uma arquitetura moderna, isto é, uma arquitetura relativamente livre de convenção, de volumetria, de modenatura, pode desabrochar sem ser contida por um exercício de fachada imposto entre duas paredes contíguas." Seus argumentos são a favor do edifício isolado, como condição fundamental para a expressão da arquitetura moderna: [...] "Mas temos realmente necessidade de edificações sempre diferentes? Sem dúvida não. E, no entanto, elas aí estão. Edificações objetos, diferentes, separados. Elas são a cultura arquitetônica de hoje. Retornar à parede-meia das edificações antigas - nos bairros novos - significa impedir a arquitetura moderna de existir" (1997, p. 46-47).

As diversas reflexões teóricas apresentadas discutem as contraditórias relações entre a cidade da arquitetura moderna e as cidades tradicionais. Em que medida essas visões e interpretações podem ser rebatidas para o entendimento da arquitetura moderna contida no Centro Histórico de São Paulo? Que elementos dessa arquitetura moderna são ou não reveladores de uma relação plena de ambiguidades no CHSP? Que aspectos fazem da arquitetura moderna no CHSP um caso singular e distinto das proposições mais generalizantes em torno do movimento? Indagações, espera-se, sejam respondidas no desenrolar desta tese.

\section{A arquitetura moderna no tecido da cidade tradicional: São Paulo}

Os aportes teóricos e documentos abordados neste capítulo relacionam uma série de conceitos e referências importantes para a compreensão da arquitetura moderna no Centro Histórico de São Paulo. Admite-se que as ideias - ou mentalidades modernas informaram e alimentaram a produção dos edifícios modernos no CHSP. A hipótese é de 
que os edifícios modernos, como descritos até aqui, estão intimamente vinculados ao ideário da arquitetura moderna; mais do que isso, da cidade da arquitetura moderna.

Admite-se que esses edifícios, mesmo distantes das idealidades e cartas, carregam em suas expressões os princípios modernos principalmente aqueles plantados [sintetizados] por Le Corbusier (melhor analisados nos capítulos seguintes) e manifestados indiretamente na Carta de Atenas ${ }^{13}$, diretamente no Urbanismo e nos projetos da Cidade Contemporânea e Radiosa ${ }^{14}$. Essa noção descarta maniqueísmos fáceis: a aparente sincronização entre a lógica da técnica (estrutura independente), passando pela célula de habitação até um todo acabado, não ocorreu sem ajustes. O todo articulado na forma de uma cidade ideal é o amálgama que dissolve um processo dinâmico de acertos e aplicações. Ainda assim, acredita-se que os edifícios modernos mesmo fora dessas situações ideais manifestam as lógicas modernas: das orientações, dos edifícios em lâmina (com empenas cegas), da estrutura independente, dos pilotis, das fachadas envidraçadas e livres, das técnicas industriais.

Se a cidade da arquitetura moderna pouco se realizou, seus arranjos fragmentados, conjuntos habitacionais ou edifícios isolados proliferaram mundo afora, reproduzindo muitos de seus princípios com satisfatória integridade de princípios e formas. Entretanto, as ideias e formas modernas não foram e não puderam ser transportadas literalmente para as condições do Centro Histórico de São Paulo, pois ali encontraram uma matéria difícil de ser trabalhada: ou seja, a cidade de formação predominante tradicional e pragmática; permeada por significativos interesses econômicos particulares - mesmo tendo em conta as inúmeras intervenções modernizadoras que lhe abriram avenidas e alargaram ruas.

O cotejamento entre as universalidades (ideais) modernas e sua prática, num território do Centro de São Paulo, permite identificar singularidades e valores próprios dessa arquitetura moderna na cidade tradicional. Ou aquilo que de certa maneira foi esboçado como programa das vanguardas artísticas e foi depois assimilado de diversas formas, em diversas partes do mundo.

Os confrontos propostos por Rowe e Koetter em Saint-Dié e Parma, Uffizi e Unidade de Habitação de Marselhe, Plano Voisin e Paris, são contundentes e esclarecedores ${ }^{15}$. No

${ }^{13}$ A Carta de Atenas (1933) foi demasiadamente marcada pela personalidade de Le Corbusier: ela ditou e informou os rumos da cidade e da arquitetura moderna até os percalços do VIII CIAM e perde força definitivamente com o aparecimento do Team X. No Brasil pairou como um paradigma postado na retaguarda até os anos 60.

${ }^{14}$ As influências de Le Corbusier são bem maiores do que essas fundadoras referências dos anos 20 e 30 . No decorrer do trabalho outras serão mencionadas, conforme a situação apresentada.

${ }^{15}$ Os autores não deixam de apontar casos como o projeto para a Chancelaria Real em Estocolmo, de Gunnar Asplund, 1922, que apresenta uma solução híbrida que reconcilia a cidade moderna com a tradicional. 
Brasil, a capital federal - Brasília - é nos limites de seu plano piloto exemplar. Porém, no Centro Histórico de São Paulo ${ }^{16}$ não é possível uma distinção tão clara. Pelo contrário, ali a arquitetura moderna já nasce marcada pela geografia, pelo tecido antigo, pela legislação e pela lógica da verticalização. Ali o cotejamento entre os dois modelos de cidade - a tradicional e a moderna - expõe contradições, ambiguidades e assimilações; aparentemente prenunciadores de algo inconcluso ou inconciliável.

Mas, se no plano das ideias (e das cartas) o encontro era indesejável e improvável, no plano da existência e da materialidade foi muitas vezes possível, como se verá à frente. Nesse sentido, as dificuldades de textura do edifício moderno a que se referem Rowe/Koetter não se reproduzem por inteiro no Centro de São Paulo: pelo contrário, em diversas situações seus edifícios modernos encontram-se desempenhando o papel de fachada pública ("parede interna" do espaço público). Ou seja, pelas características de seu tecido - traçados (vias) e ocupações - o Centro "impõe" aos edifícios nele edificados a contingência da contiguidade e continuidade das massas construídas. Assim, os edifícios estão mais sujeitos às "contaminações" das edificações vizinhas e dificilmente expressamse como objetos soltos no espaço.

Numa primeira visualização do mapa de figura e fundo do Centro Histórico de São Paulo (sobre base Gegran - Viva O Centro) é difícil perceber uma trama moderna: embora ela exista, sobretudo, no traçado de algumas das avenidas São João, Ipiranga, São Luís, Consolação, Rangel Pestana e na urbanização do Anhangabaú. São marcas modernas, mas não necessariamente modernistas. O primeiro anel do Plano de Avenidas e as radiais nele propostas são elementos demarcadores evidentes, ainda que essas circulações conformem grandes espaços, elas ainda encontram-se circundadas por formações densas de edifícios que ocupam quase que integralmente os lotes e suas testadas. Sob esse olhar, a configuração que se apresenta é a da formação de quadras a partir do traçado de ruas; que posteriormente foram subdivididas em lotes, à maneira de uma formação tradicional.

Num segundo momento é possível distinguir quais são os edifícios e espaços públicos que desempenham o papel de figuras nos termos colocados por Rowe/Koetter. De imediato percebem-se os espaços das praças e largos, depois dos edifícios geralmente públicos anexos a esses lugares e finalmente as próprias ruas fechando a descrição de uma cidade tradicional. Assim, pode-se identificar na colina histórica o Pátio do Colégio, as

${ }^{16}$ Considera-se o Centro Histórico de São Paulo como composto pelo Centro Velho (triângulo histórico) e o Centro Novo, delimitado pelo primeiro perímetro de irradiação do Plano de Avenidas de Prestes Maia: basicamente, Av. São Luís, Av. Ipiranga, Rua Senador Queiróz, Parque Dom Pedro II, Tabatinguera, Praça João Mendes, Viaduto Dona Paulina, Rua Maria Paula e fechando no Viaduto 9 de Julho. Para efeito desse estudo limitou-se o Centro às duas colinas que contêm o Centro Velho e Novo. 
praças da Sé, Patriarca, os largo de São Bento, São Francisco. No Centro Novo, o Largo do Paissandu, as praças da República, Dom José Gaspar e Ramos de Azevedo. Continuando vê-se ainda algumas formas (edifícios) isolados e contíguos aos logradouros públicos; ainda prédios institucionais: a Igreja de Anchieta , a Catedral da Sé, a Igreja do Paissandu, a Escola Caetano de Campos, a biblioteca Mário de Andrade, o teatro Municipal (figuras 2.10, 2.11 e 2.12 ).

Se o recorte ou atenção se prende às duas formações mais centrais a Colina Histórica e o Centro Novo, intermediados pelo vale do Anhangabaú, o que se vê são os rastros das antigas formações: quadras irregulares subdivididas por lotes profundos decorrentes das constituições coloniais nas quais havia forte hierarquia entre ruas, determinado frontalidades e fundos nem sempre edificados (figura 2.12).

Mesmo nas primeiras ocupações a geografia e a lógica de crescimento orgânico já impunham suas condições. De Bem, em São Paulo, cidade, memória e projeto (2006), faz uma interpretação das transformações do Centro Histórico a partir do relevo geográfico, das continuidades e descontinuidades, o núcleo urbano e a rede fluvial. Colina, Várzea do Carmo, Rio Tamanduateí: toponímias de origem. A geografia prefigura a história; Euclides da Cunha (apud De Bem, 2006, p. 11). De partida os vestígios de um tecido que será em ritmos distintos construído por sucessivas cumulações: caminhos, fluxos, parcelamentos. $O$ padrão das linhas convergentes afunilando para as entradas é determinante na constituição desses antigos tecidos (2006, p. 15). Geografia e arquitetura são tecidas juntas definindo objetividades e destinos. "A arquitetura define o espaço dessa estrutura, calhas de ruas e largos, balizando posições com as edificações religiosas, constituindo um todo coerente entre topografia, percursos e edificações" (Mantziaras apud De Bem, 2006, p-17) (figura 2.14).

Na carta da capital de São Paulo de $1842^{17}$, De Bem descreve estas tessituras na colina histórica: "No limite leste da colina, na hipotenusa do triângulo, voltada para a extensa várzea do Rio Tamanduateí, o talvegue estratégico da encosta onde se implantava o Convento dos Jesuítas causava uma descontinuidade na linha dessa borda contornada pela sequência ortogonal das ruas niveladas. [...] A urbanização do triângulo na altura paralela à encosta do Anhangabaú define-se com o rigor da linha reta, barroca, da Rua São Bento, balizada nos seus extremos pelos dois largos de igrejas e seus conventos e secundada, já na beira para o vale, pela Rua São José (Líbero Badaró). O confronto entre hipotenusa e altura, resultante da organização das quadras ortogonais a essas duas linhas, se equaciona com um ziguezague de ruas conformando quadras triangulares, que se endireitam face ao

\footnotetext{
${ }^{17}$ Carta da Capital de São Paulo, 1842, executada por José Jacques da Costa Ourique.
} 
rigor da linha reta da Rua São Bento, com uma sequência de pequenas inflexões em encontros a $90^{\circ}$, que tem culminância na ordenação do eixo da Rua Direita". Esse encontro com as duas ruas "direitas" e uma ordenação a partir de um dos vértices do ziguezague encontra uma ligação possível na encosta do Anhangabaú, no eixo da Rua de São João: ambos constituindo um extravasar do tecido urbano da colina do Centro Velho rumo à Cidade Nova (De Bem, 2006, p. 16,17, 18 e 19).

Segundo De Bem, é possível ver no mapa Sara Brasil que o Centro Histórico fundiuse pelo vale do Anhangabaú em perfeita cerzidura com o Centro Novo, alternado com as duas travessias mais antigas dois viadutos; Santa Efigênia e do Chá (figura 2.15). Novos edifícios e intervenções continuaram a induzir e a atrair prolongamentos. "Na sequência da construção do Centro da cidade, cada nova peça parece se assentar na interpretação dos fatos urbanos pré-existentes e, nesse sentido, considera-se que o espaço do Centro da cidade evolui suas formas no Plano de Avenidas" (De Bem, 2006, p. 43).

Simões Jr. em Anhangabaú - história e urbanismo (2004) - também percorre a ocupação e a estruturação viária da cidade já a partir das primeiras trilhas indígenas (caminho Peabiru), dos espaços religiosos, do Rio Tamanduateí, dos caminhos dos tropeiros (ao longo dos séculos XVIII e XIX) e da entrada da ferrovia (Café). As transformações nos processos produtivos vão sucessivamente conferindo diretrizes e estruturas nas áreas centrais. "A inauguração do Parque do Anhangabaú, em 1917, transformaria o local no ponto mais importante da área central, invertendo uma situação observada até pouco tempo antes, quando a vertente oeste da colina era considerada os "fundos" da cidade" (2004, p. 18).

A inversão da polaridade e a nova centralidade consolidariam a expansão do Centro antigo rumo ao Centro Novo, unindo as duas colinas, que foram tempos depois amarradas na ordem contida no Plano de Avenidas. Uma lógica de caráter orgânico, com ajustes ali e acolá, com partes soltas [inacabadas] e outras contidas, circunscrita a fragmentos formais estáveis.

Quando da implantação da estação da Luz, o trinômio café, ferrovia e imigração fazse sentir impondo novos parâmetros para a urbanização central. Nesse momento, o crescimento da cidade é intenso: a população paulistana de 31 mil habitantes em 1872 atingiria em 1886 a marca de 47.696 pessoas. Em 1890, chegaria a 64.934 e dez anos depois a 239.934 habitantes. Como decorrência houve uma expansão da cidade e um intenso processo de parcelamento de terras. Assim, nas décadas de 1880 e 1890, diversas chácaras foram loteadas como a Chácara do Chá (Centro Novo), Chácara do Campo 
Redondo (bairro dos Campos Elíseos e parte da Santa Efigênia) (Simões Jr., 2004, p. 3940).

A partir do código de Posturas de São Paulo de 1875 é possível observar uma série de medidas por parte do estado para disciplinar as construções, definindo novo padrão urbanístico, que somadas a outras medidas sanitárias ${ }^{18}$ indicavam movimentos rumo à modernização e à urbanidade. No código de Posturas havia normas definindo: alinhamentos; padronização de fachadas; dimensão de aberturas, portas e janelas, largura para ruas e travessas (mínimo de 13,20 m). Duas observações chamam atenção: as ruas deveriam manter as larguras definidas, salvo quando por algum obstáculo invencível não for possível dar-Ihes essa largura; e as praças e largos deveriam ser quadrados, tanto quanto o terreno permitir. Segundo Simões, o estabelecimento de largura associada aos contornos regulares das praças, mais disposições complementares que definiam que as ruas deveriam ter largura de pelo menos $16 \mathrm{~m}$ (e não poderiam ser tortas), caracterizavam a intenção de se constituir um padrão retilíneo traduzido numa malha viária xadrez (Simões Jr., 2004, p. 60$62)$.

Observando-se a Planta da Cidade de São Paulo (1881 - figura 2.13) ${ }^{19}$ é possível identificar esses traçados mais retilíneos, com alguns percalços, nas imediações da Santa Efigênia e já projetados no sentido dos Campos Elíseos. No Centro Novo, a regularidade quase não existe. Nela ficam evidentes as marcas das antigas ligações e caminhos: a inclinação da Av. São João, o alinhamento da Rua Formosa com o ribeirão do Anhangabaú, a sinuosidade entre a Ladeira da Memória e a Sete de Abril rumo ao Largo dos Curros, encerrando o polígono as ruas Ipiranga e São Luís (ainda desocupada).

Nessa planta cadastral, dois padrões ficam claros: a intensa ocupação do Triângulo Histórico e a rarefeita ocupação do Centro Novo. Na Colina Histórica a irregularidade e a profundidade dos lotes são ainda maiores. No Centro Novo, delimitado pelo Anhangabaú, São João, Ipiranga e São Luís pelo parcelamento em parte decorrente das grandes chácaras (Barão de Itapetininga) há uma regularidade maior. Mas, nada que se compare a um traçado regulador extenso como nos termos da Cidade Radiosa ou da quadrícula de Nova York (a ser visto nos capítulos seguintes).

No Triângulo, a irregularidade está presente nos arruamentos e quadras e por consequência nos lotes e edificações. Vê-se uma intensa ocupação do lote - que não será

\footnotetext{
${ }^{18}$ Do código sanitário (Decreto-Estadual nํㅜ 233, de 2-3-1894).

${ }^{19}$ Planta da Cidade de São Paulo, levantada pela companhia Cantareira de Esgotos - Henry B. Joynler [M.I.C.E.] - engenheiro chefe.
} 
abandonada nas ocupações futuras - nem mesmo na verticalização iniciada já nos anos de 1920 e intensificada nas décadas seguintes - à plena força modernizadora.

Se a análise se volta para as cartas de Sara-Brasil e Gegran é possível observar que as ocupações continuam a manter a constante dos alinhamentos das edificações à rua e a ausência dos recuos laterais entre as edificações. Aliás, padrão que continuará definindo ocupações, a despeito, das modificações na legislação, da verticalização e modernizações.

Portanto, no Centro Novo a tendência foi a intensa ocupação do lote, mesmo em áreas como a Av. São Luís : pouco ocupada pelos palacetes - no início dos anos 30, como se vê no mapa Sara-Brasil (figura 2.15).

Se o foco é ajustado para alguns trechos, pode-se identificar uma ou outra arquitetura moderna desgarrando-se da trama urbana e conformando-se como uma figura: agora não mais ligada às instituições - mas ao mundo privado das habitações e edifícios de negócios. Os edifícios Copan, Itália, Eifell e Triângulo são figuras destacáveis, mais por suas volumetrias do que projeções. Outros também o serão, no entanto, sob uma observação mais aguda: caso a caso, lote a lote (figura 2.16).

\section{Um todo [des]contínuo}

Numa análise puramente gráfica não há dúvidas de que nosso Centro Histórico tem características de uma cidade tradicional com altas taxas de ocupação por edificações construídas nos limites e alinhamentos do lotes. Os grandes vazios caracterizam inicialmente os vales, campos e praças. Outros indicam abertura de grandes avenidas marcas da modernização que contudo não apaga a formação histórica.

Cidade e ambientes urbanos podem ser percebidos [apreendidos] como uma massa quase única de edifícios à semelhança de "uma cidade de pedras e monumento" ${ }^{20}$, como Aldo Rossi viu e comparou Nova York a Veneza, ou pelo seu averso: como uma massa que se dissolve em sua própria homogeneidade, como a vê Angelo Bucci ${ }^{21}$. Na visão de Rossi é

${ }^{20}$ Como Aldo Rossi viu Nova York: "Não creio que exista cidade que pode confirmar melhor as teses contidas na "A arquitetura da Cidade" do que Nova York; uma cidade de pedra e monumentos, como nunca eu pensei existir, e a partir de seu conhecimento compreendi até que ponto o projeto para $\mathrm{O}$ Chicago Tribune, de Adolf Loos, é uma interpretação da América e, não como afirmaram, um divertimento vienense. Pelo contrário, constitui a síntese das transformações perturbadoras, que em todos os campos, provocaram na América a quantidade e a aplicação descontextualizada do estilo. E a cidade-monumento está rodeada por um imenso território de campos. Somente em tais cenários adquirem valor as grandes arquiteturas e as obras primas. Do mesmo modo que é secundário, em Veneza, saber se uma obra é de Palladio ou de Longhena: pois se trata, antes de tudo, de pedras de Veneza (Rossi, 1981, p. 92).

21 "É por isso que o edifício a ser abordado aqui deve ser visto na sua substância, naquilo que ele compartilha com todos e que o faz, nesse aspecto, o ordinário" (BUCCl, Angelo, 2005, p. 33). 
nesse cenário apreendido como um todo que adquirem valor as grandes arquiteturas e as obras primas. Na de Bucci, a "individualidade" do edifício dissolve-se na massa do ambiente urbano; nesse sentido, as qualidades esculturais perderam importância para as qualidades espaciais e o edifício adquire substância pela sua condição ordinária.

Se o olhar se volta especificamente para o Centro de São Paulo não se vê propriamente Nova York ${ }^{22}$ muito menos Veneza. A primeira impressão é de uma enorme massa verticalizada, de alturas distintas, contudo de caráter uniforme aparentemente indissociável (figuras 2.17 e 2.18). Ao percorrê-las essas unidades se desfazem em partes ou fragmentos: ruas de volumetria uniformes emparedadas por altos edifícios (Boa Vista, Marconi, São Luís, Ipiranga) espaços de praças dispersas (Sé) ou densas (Praça Antonio Prado). Essa massa pode também ser rejuntada pelas permeabilidades territoriais se vivenciadas pelas ruas e galerias comerciais e assim fundir-se novamente. Da mesma forma que muito de seus edifícios podem ser recortados desse conjunto e serem vistos como figuras (individualidades) quase autônomas em relação ao lote (Edifício Itália, CBI, Conde de Prates e Copan) ou fundidos incondicionalmente ao lote (Edifício Jaçatuba, Thomas Edison, Banco Paulista). Porém, é preciso atentar para as espacialidades e gabaritos que nos legam uma configuração mais uniforme; assim como, para a mais descontínua, rua a rua (figura 2.19 a 2.22$)$.

Se descontinuidades e massas uniformes são impressões ou apreensões possíveis de serem interpretadas no Centro de São Paulo, outras relações vão apontar definições mais enfáticas. A rua e o lote - como elementos formais da estrutura urbana - são decisivos na definição formal dos edifícios sejam modernos ou não. A legislação baseada nos escalonamentos sucessivos para garantir boas condições de iluminação e ventilação é decorrente da largura da rua, que em última estância definirá a altura final das edificações. Outros itens, como normativas para poços internos e recuos laterais, estarão sempre presentes; no entanto, a predominância sempre estará na rua. Nesse sentido, tendo-se em mente que o assunto que aqui se discute é a relação dos edifícios modernos e o Centro Histórico; a "rua-corredor" é o termo central que contradiz os pressupostos manifestados nas cartas ideais. Assim, como o lote, nega de antemão, uma alternativa na divisão fundiária; trazendo para a dimensão urbana os pilotis enquanto elemento de arquitetura que permite o continuum espacial pelo rés do chão. Embora seu uso formal ocorra, em muitos edifícios modernos, o uso público sobre suas projeções decorre de fatores comerciais fora do alcance dos discursos idealizados.

${ }^{22}$ Evidentemente Nova York e São Paulo são distintas: entretanto, há entre elas semelhanças como a verticalização que serão cotejadas nos capítulos seguintes. 
Seja qual for a relação entre os edifícios modernos e o Centro Histórico de São Paulo, a rua é o elemento determinante em sua configuração final. Por isso, ao se caminhar pelo centro o que se vê, com frequência, é a contínua sucessão de fachadas, modernas ou não, conformado [delimitando] o espaço público da rua. Fachadas bem tratadas e normatizadas. Por outro lado, esses mesmos edifícios quando observados pelas suas fachadas posteriores (ou pelo interior das quadras) não possuem o mesmo tratamento nem mesmo igual importância hierárquica: o que se vê são empenas e faces inexpressivas das massas construídas; raramente tratadas ao caráter dado às fachadas principais (figura 2.21)

Contudo é atendo-se a esses aspectos dominantes que se percebe o jogo e a dificuldade de forma do edifício moderno no Centro Histórico de São Paulo. De maneira ambígua, em diversos casos, esses mesmos edifícios modernos encontraram os termos de suas melhores expressões quando imbuídos de seus propósitos de manifestarem-se como um objeto solto no espaço, nos casos em questão, por meio do tratamento de suas diversas faces. Desse ponto de vista, ser um objeto expressivo no espaço, liberto das amarras do lote, pode ser ter sido uma qualidade admirável. Porém, nem sempre essa expressão resultou numa textura rica entre programa, formas e o lote. Em algumas circunstâncias o que se vê ainda são formas e implantações retiradas das idealidades modernas como os edifícios Copan e Eifell que funcionam como figuras destoadas ou despregadas da lógica à sua volta: estabelecendo apenas no rés do chão as relações com a cidade tradicional; por meio das típicas galerias comerciais.

Evidentemente, nem todas as proposições contidas nas cartas modernas podem ser consideradas numa análise dos edifícios modernos no centro. Como um recorte ideal ela é precisa em fornecer saliências; contrapontos. Assim, fica facilitada a análise. Como se verá à frente, aquelas formas de edifícios soltos no espaço - apoiados sobre pilotis, definidos por lâminas compostas por fachadas cegas laterais e outras intensamente iluminadas conforme caminhamento do sol - defrontaram-se com circunstâncias adversas CHSP: repetição, industrialização (geral de componentes) e tipo ideal, serão substituídos por singularidade, artesania (concreto) e composição lote a lote.

Os edifícios modernos no Centro de São Paulo parecem superar, na maioria dos casos, as dificuldades de textura, mas continuam a se deparar com as dificuldades de forma, pois se encontram submetidos aos imperativos da cidade tradicional, aos interesses da verticalização. Nesse sentido mais abrangente não é possível afirmar categoricamente uma crise do objeto, nos termos colocados por Rowe e Koetter no CHSP. Pelo contrário, o edifício moderno continua a funcionar na maioria das situações mais como fundo do que figura; embora tenha dificuldades com as amarras do lote. Nesse sentido, a rua e os demais 
espaços públicos abertos e os internos pelas galerias comerciais continuam ainda a figurar como nas cidades tradicionais. 

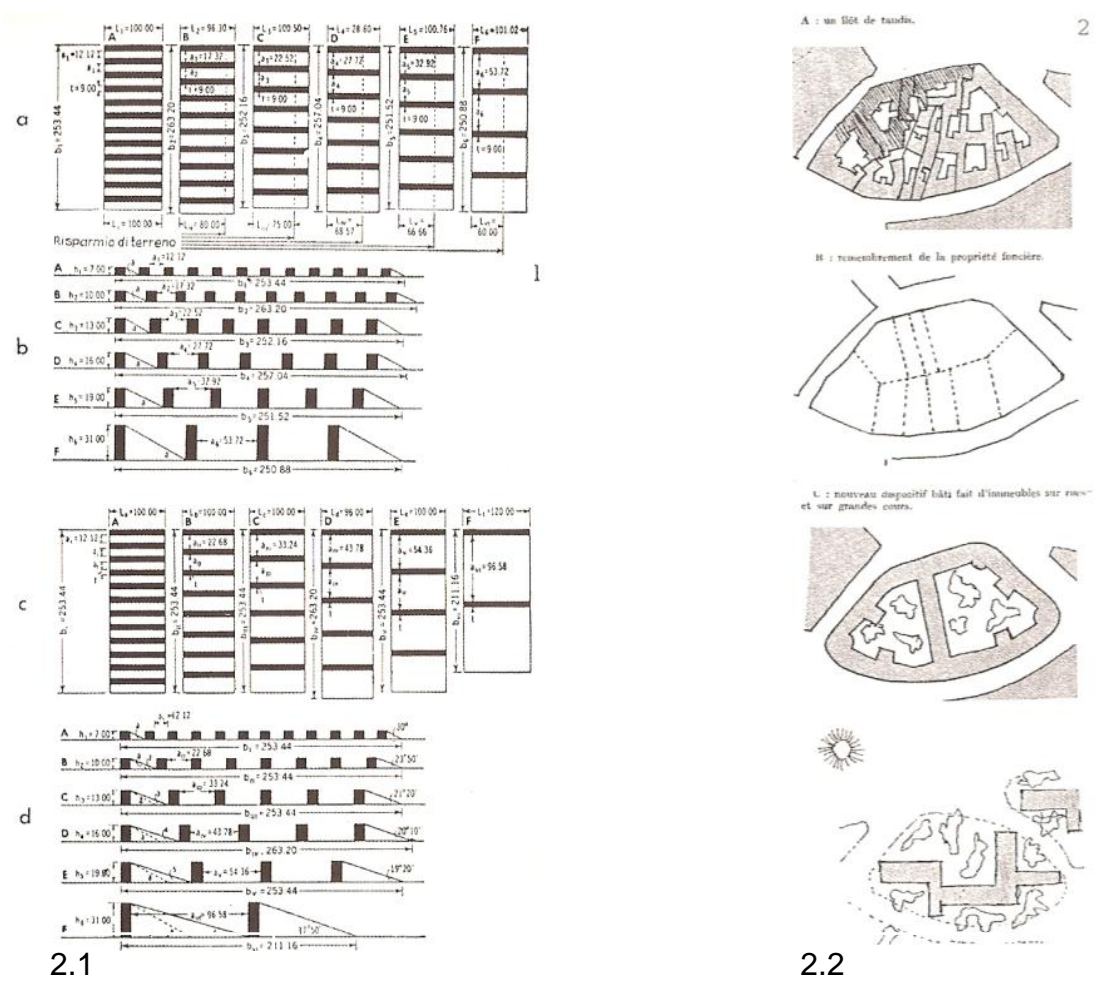

2.1: Walter Gropius: Diagrama ilustrativo para casas unifamiliares, edifícios médios ou blocos altos, apresentado nos CIAM de 1930. Desenvolvimento de um terreno retangular com filas paralelas de diferentes alturas, relacionando superfície, insolação, distância ao bloco vizinho e a libertação de solo. 2.2: Le Corbusier; desenhos ilustrando o caminho percorrido pelo urbanismo e as formas da cidade.

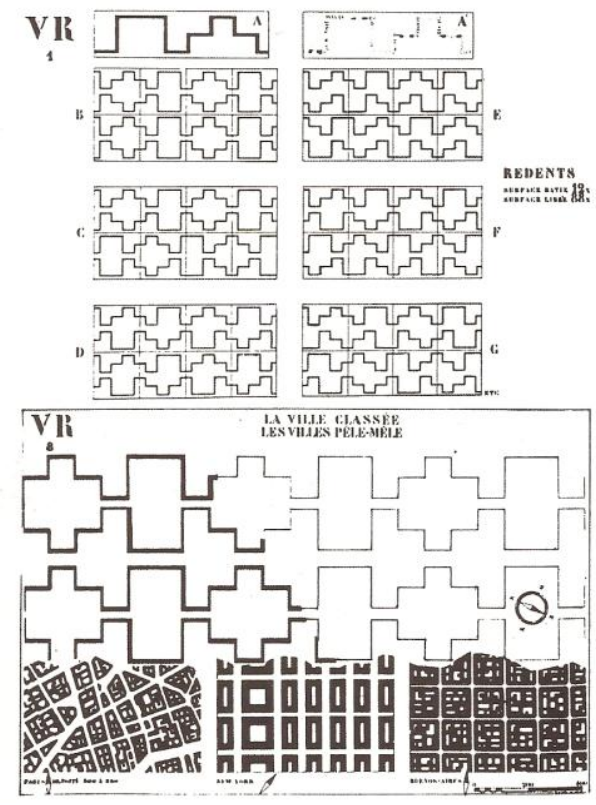

2.3

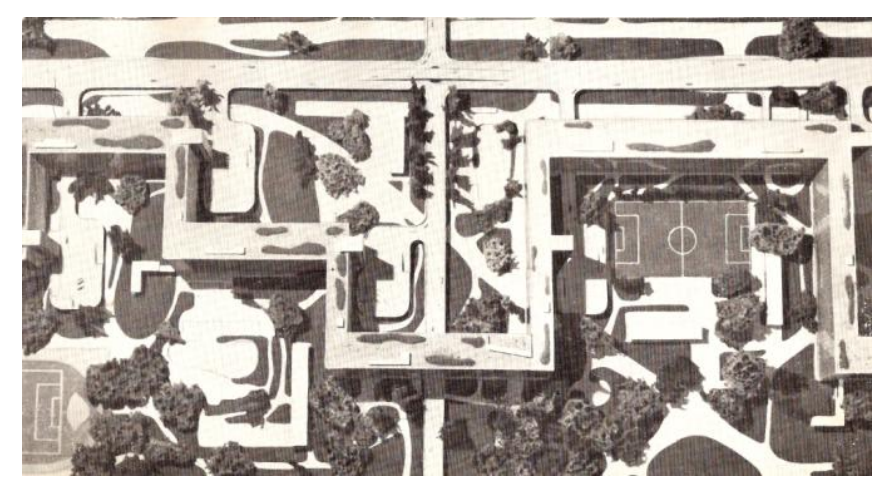

2.4

2.3: Dois painéis apresentados no Congresso CIAM, 1930; Le Corbusier. A Cidade Radiosa e a formação denteada (redents), confrontada com os tecidos de Paris, Nova York e Buenos Aires.

2.4: fragmento de um trecho residencial tipo Cidade Radiosa, 1935. 


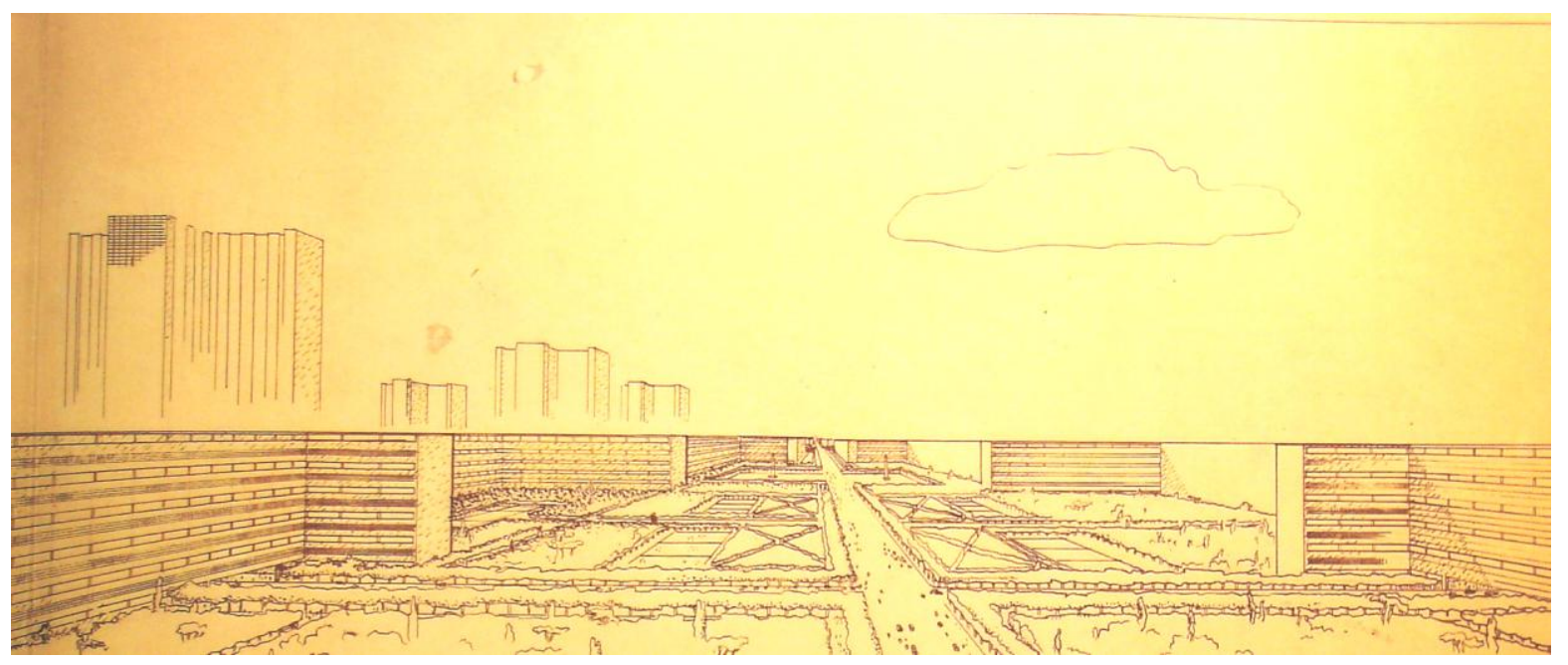

2.5: Cidade Contemporânea, 1922, perspectiva e ilustração do centro de negócios.

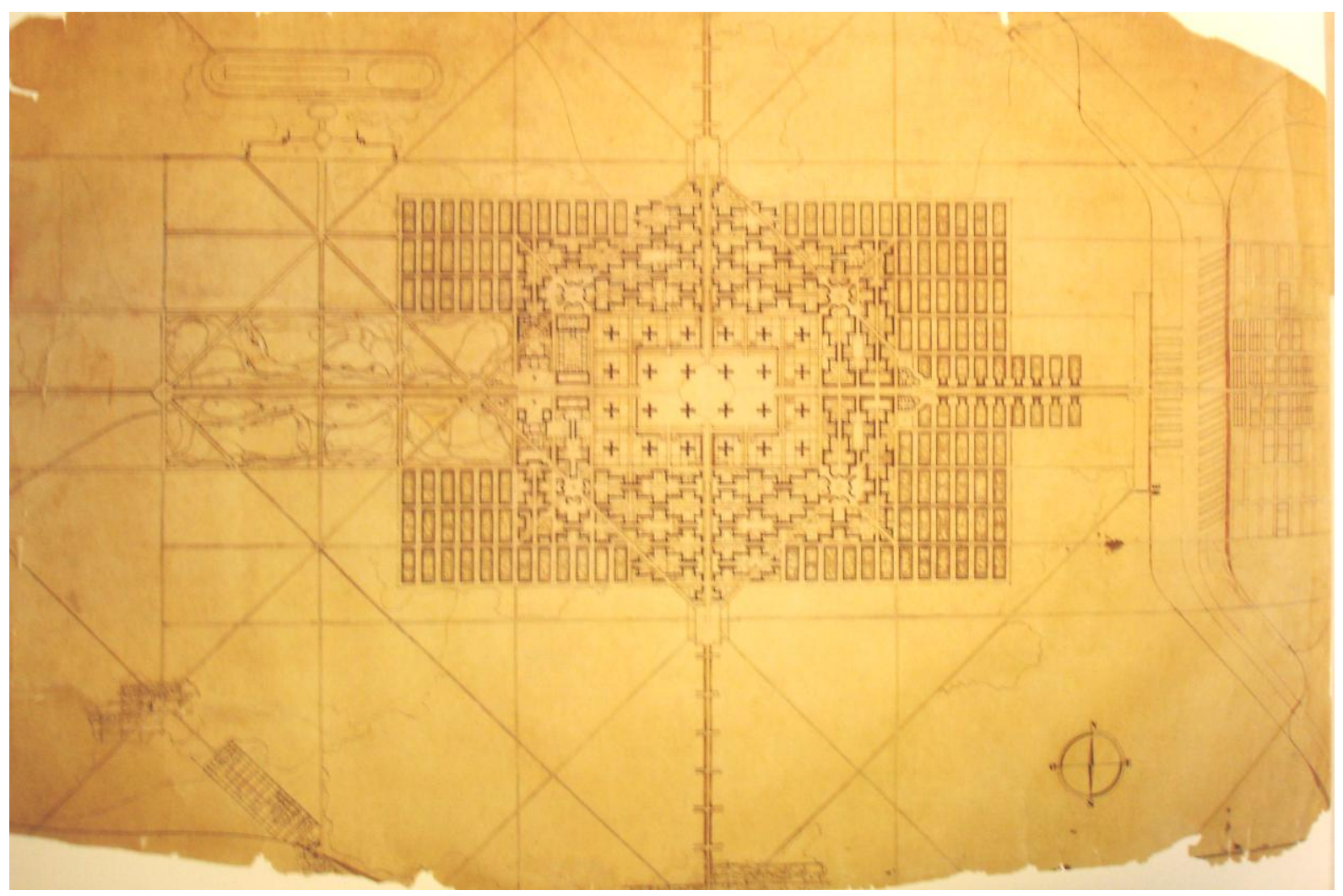

2.6: Plano da Cidade Contemporânea para três milhões de pessoas. 

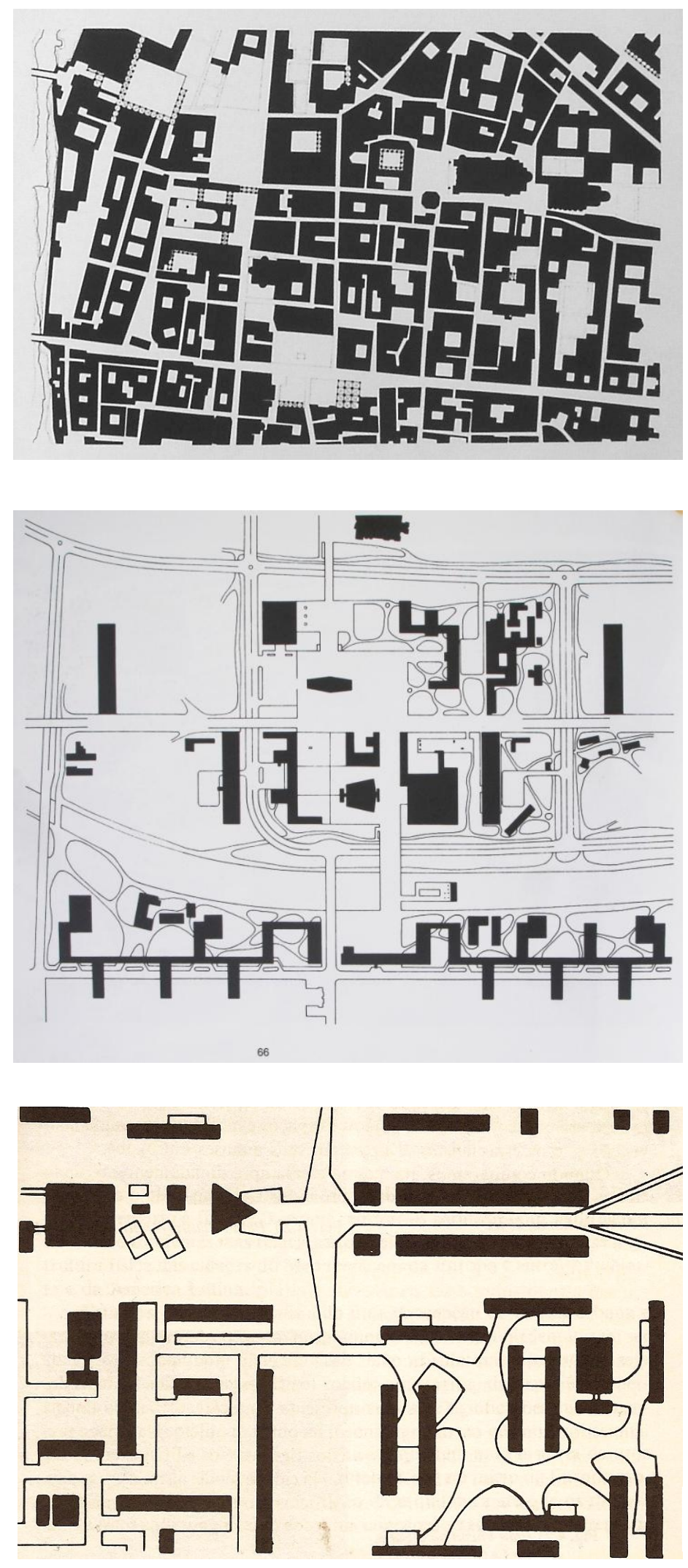

2.7, 2.8 e 2.9: Planos de massas de figura e Parma e Brasília, respectivamente. 


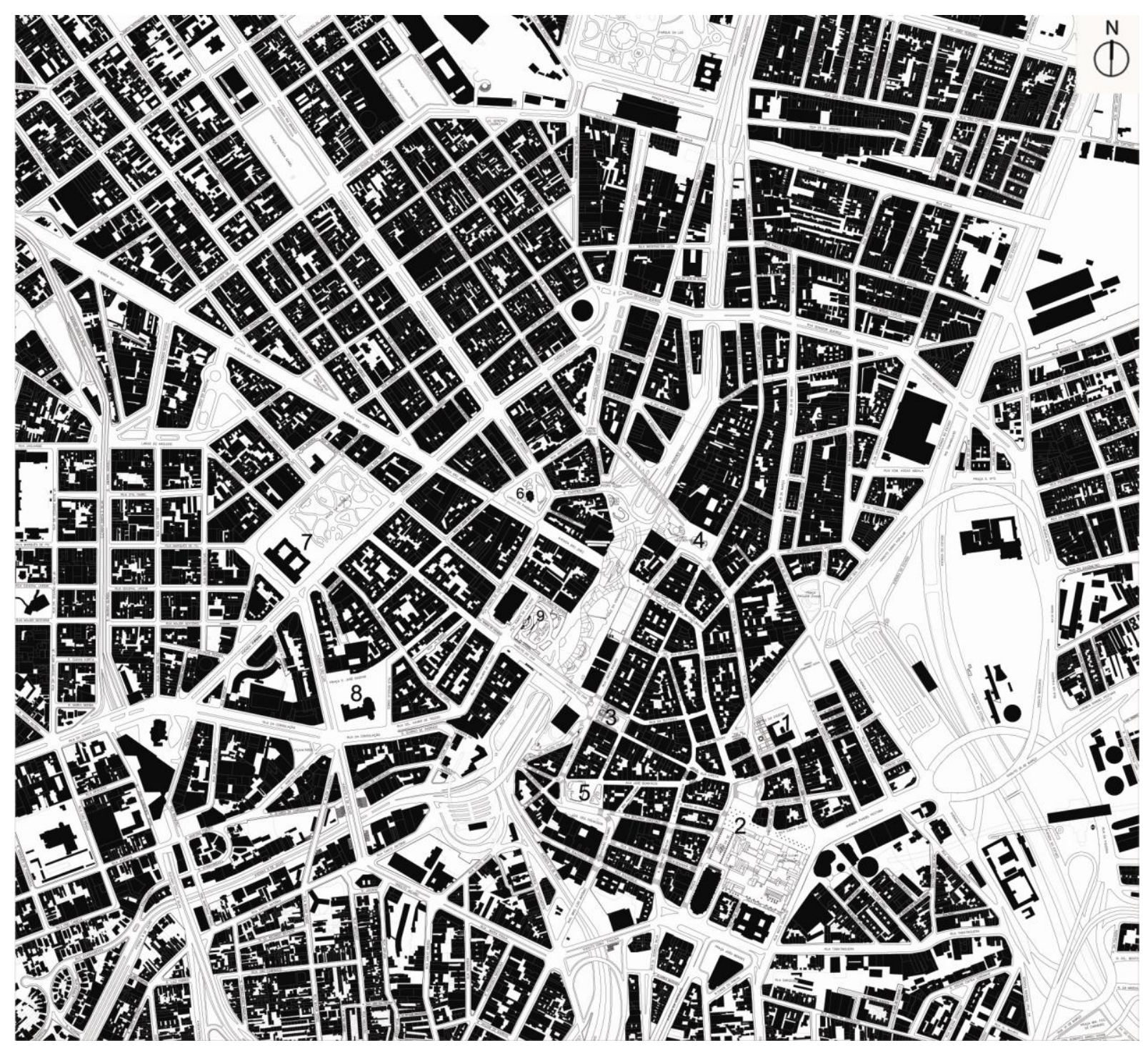

2.10: Centro Histórico de São Paulo - Mapa Figura e Fundo 1) Pátio do Colégio,

2) Praça da Sé, 3) Praça do Patriarca, 4) Largo de São Bento, 5) Largo de São

Francisco, 6) Largo do Paissandu, 7) Praça da República, 8) Praça Dom José de

Gaspar, 9) Praça Ramos de Azevedo, 


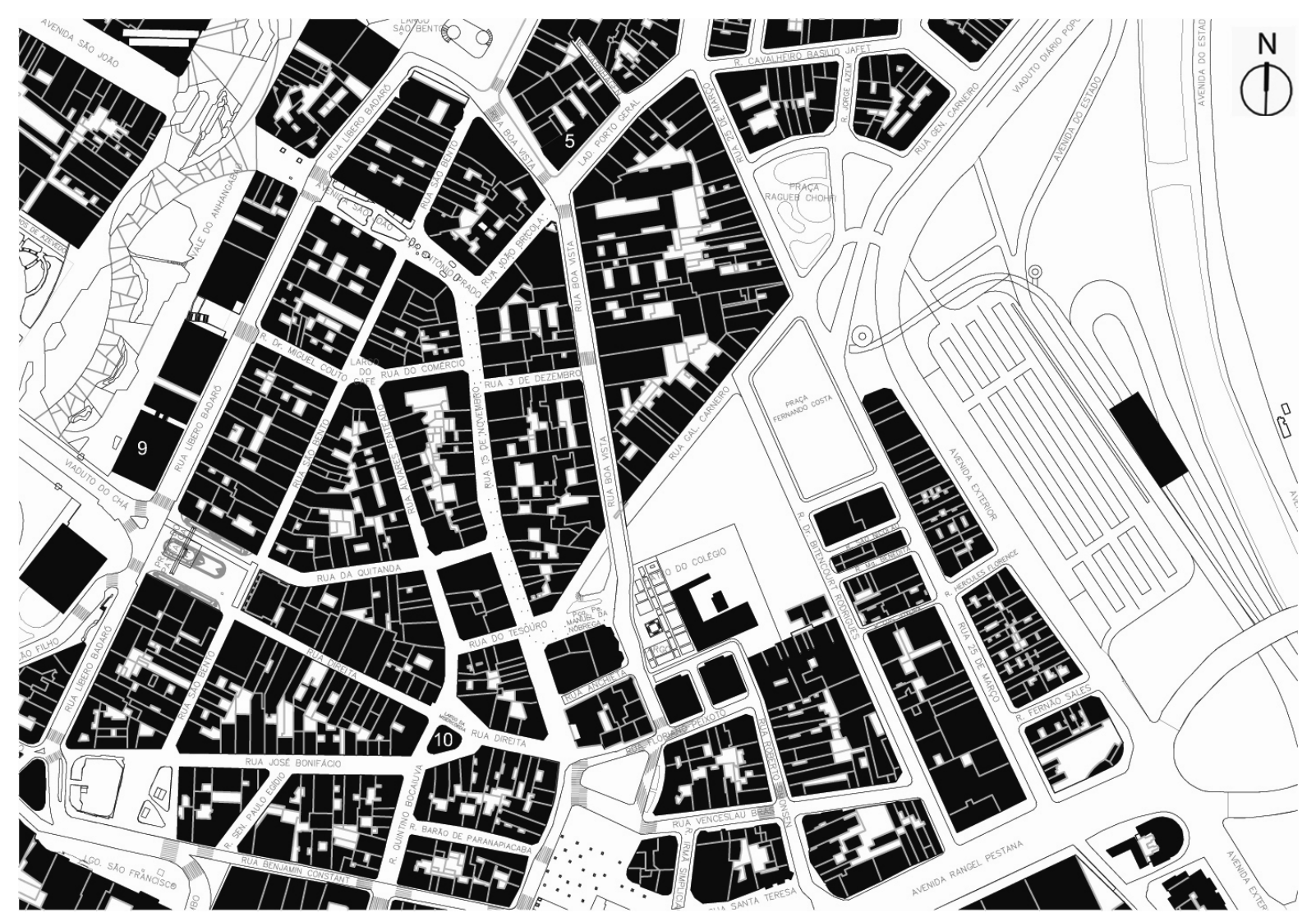

2.11: Recorte pelo Centro Velho- Mapa Figura e Fundo - Colina Histórica; Edifícios Modernos Estudados: 5) Banco Paulista do Comércio; 9) Conde de Prates, 10) Triângulo . 


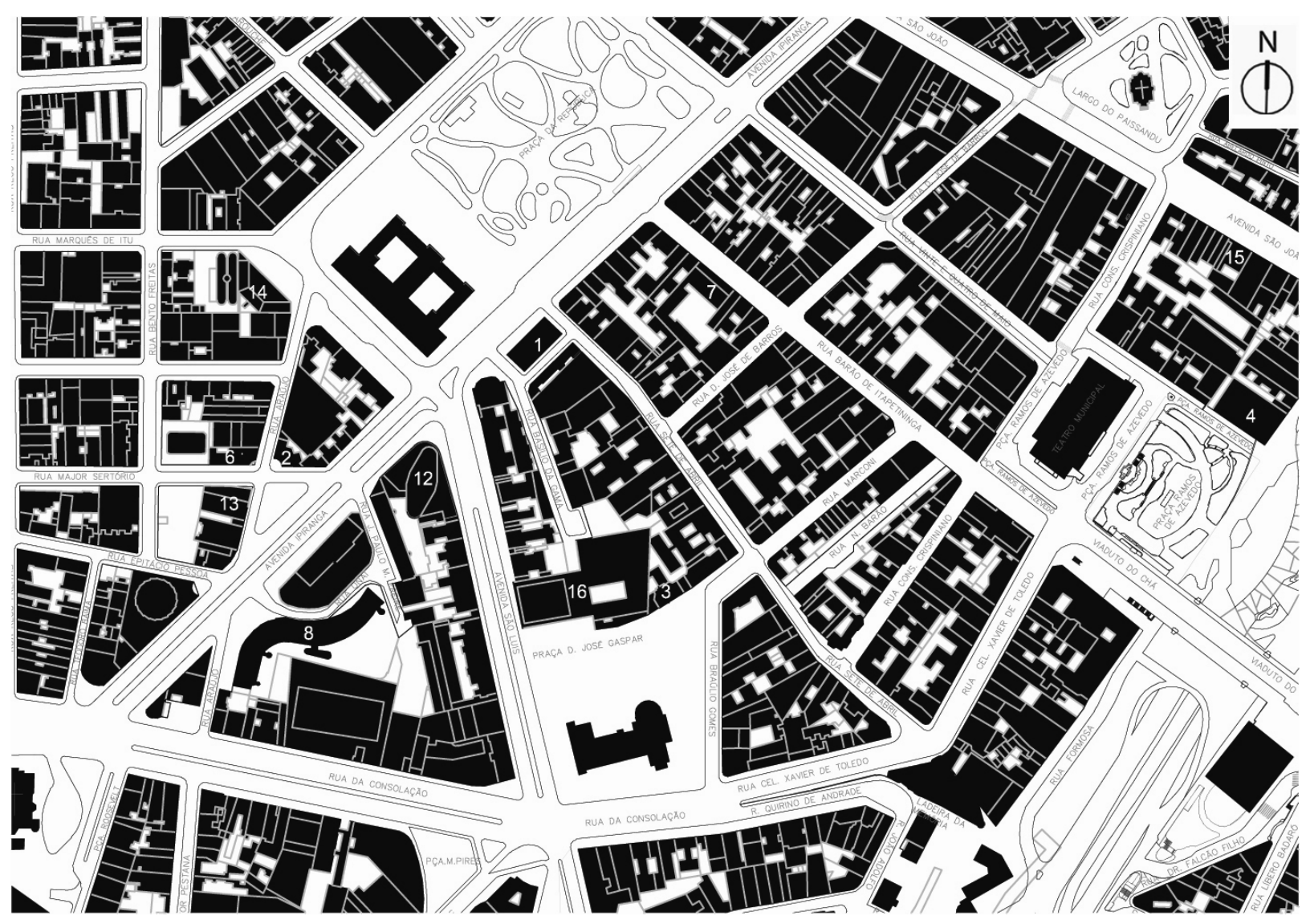

2.12: Recorte pelo Centro Novo - Mapa Figura e Fundo, Edifícios Modernos Estudados: 1) Esther e Arthur Nogueira, 2) Jaçatuba, 3) Thomaz Edison, 4) CBI-Esplanada, 6) ABC, 7) Edifício e Galeria Califórnia, 8) COPAN, 12) Itália, 14) Eiffel, 15) Seguradoras e 16) Conjunto Metropolitano 


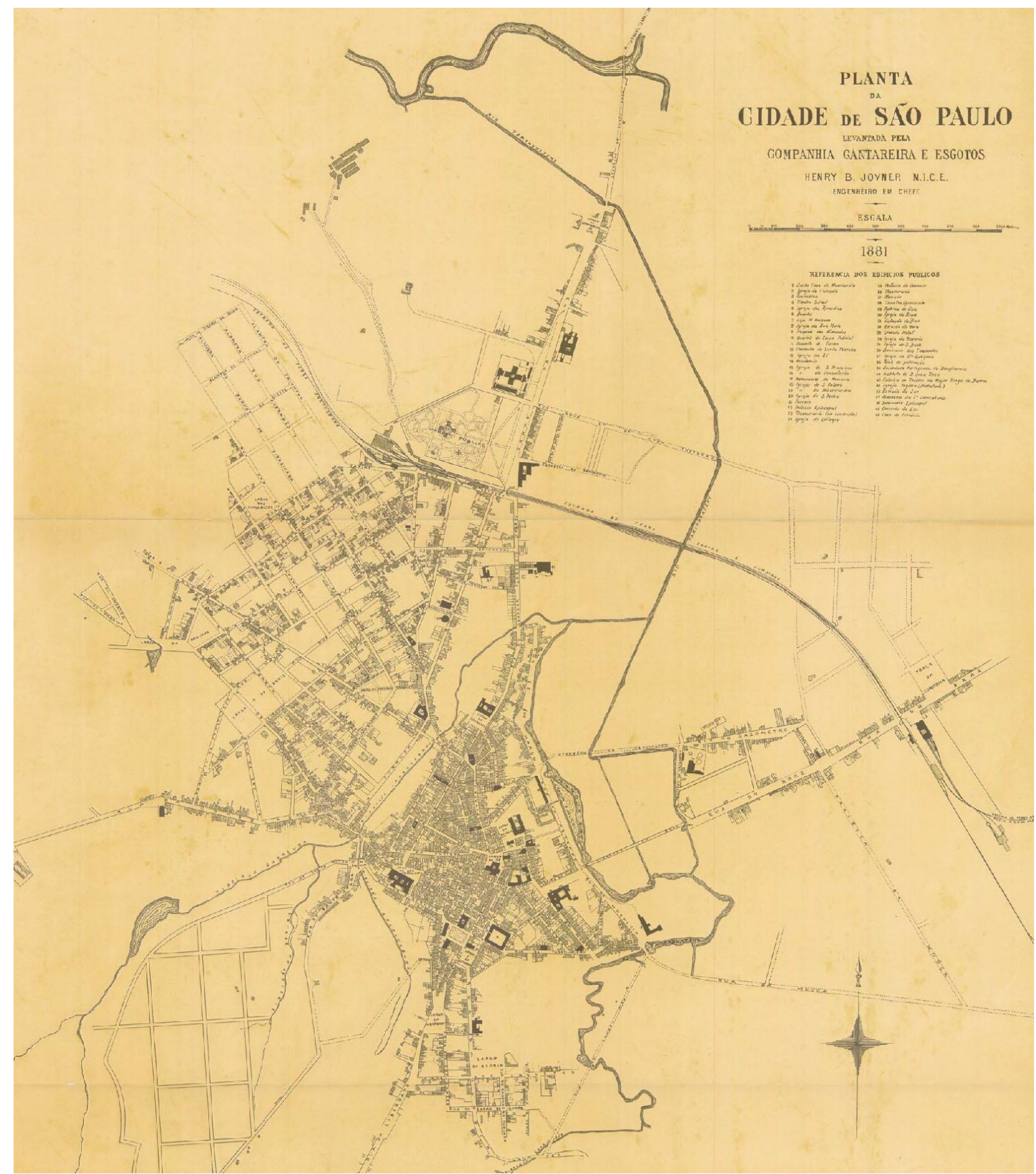

2.13: Planta da cidade de São Paulo - Companhia de Cantareira e Esgotos - Henry B. Joyner M. I. C. E. (engenheiro em chefe) - 1881. 


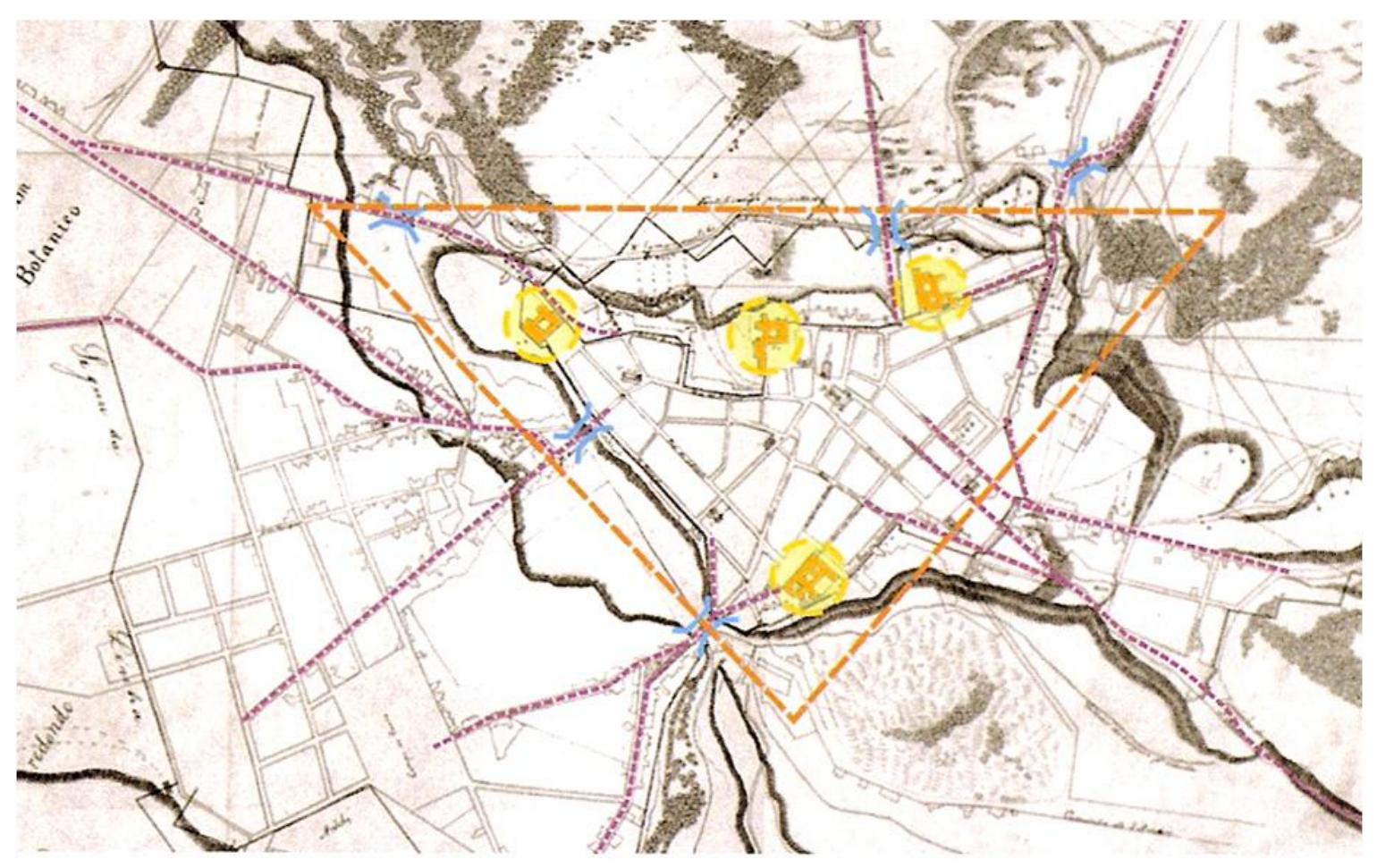

2.14. Na colina histórica estão demarcados os edifícios aglutinadores dos traçados das ruas e as Interligações entre os dois centros pela São João e Ladeira da Memória.

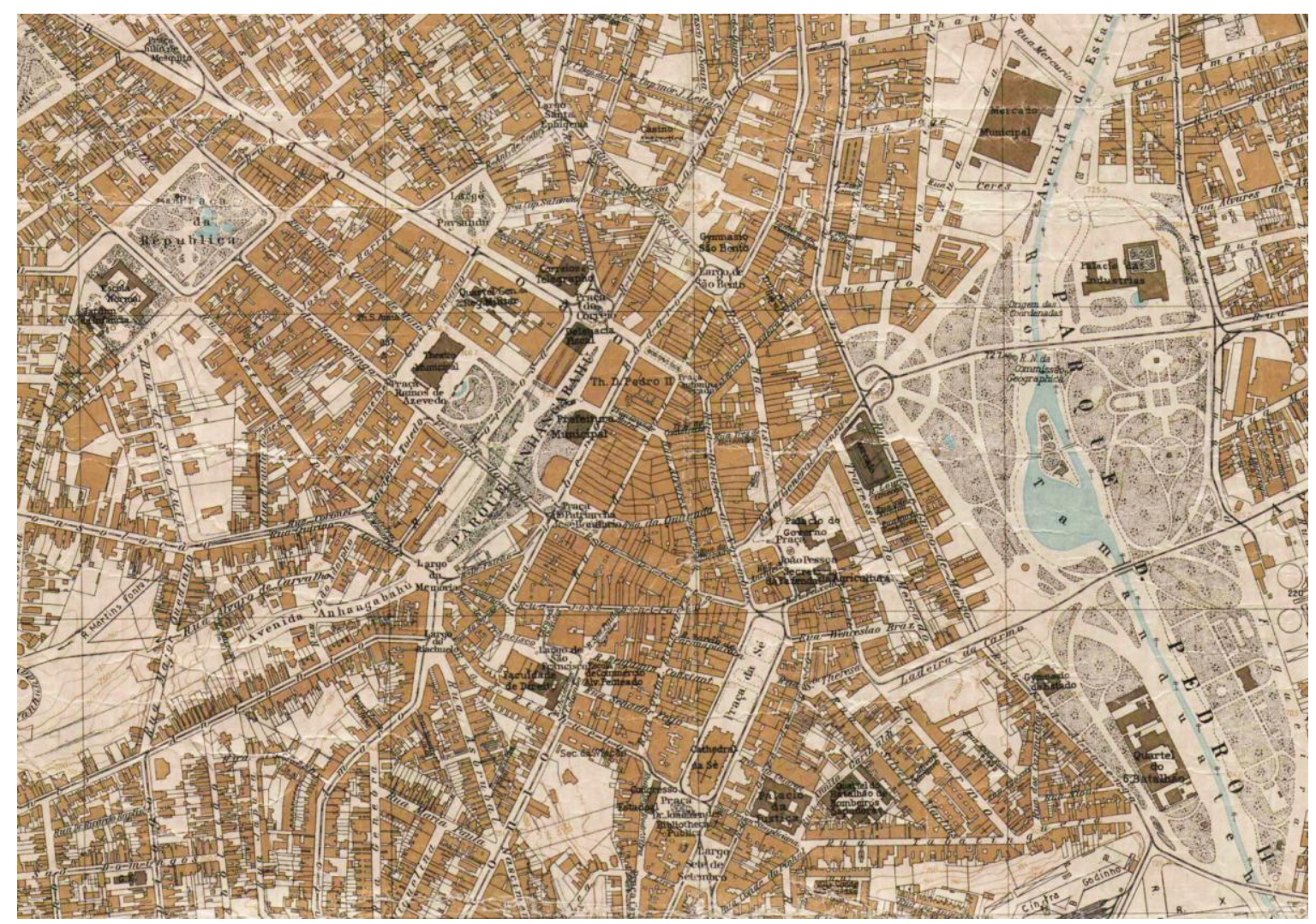

2.15: Mapa Sara-Brasil- 1930 - Recorte pelo Centro Velho, Vale do Anhangabaú e Centro Novo em perfeita cerzidura. 


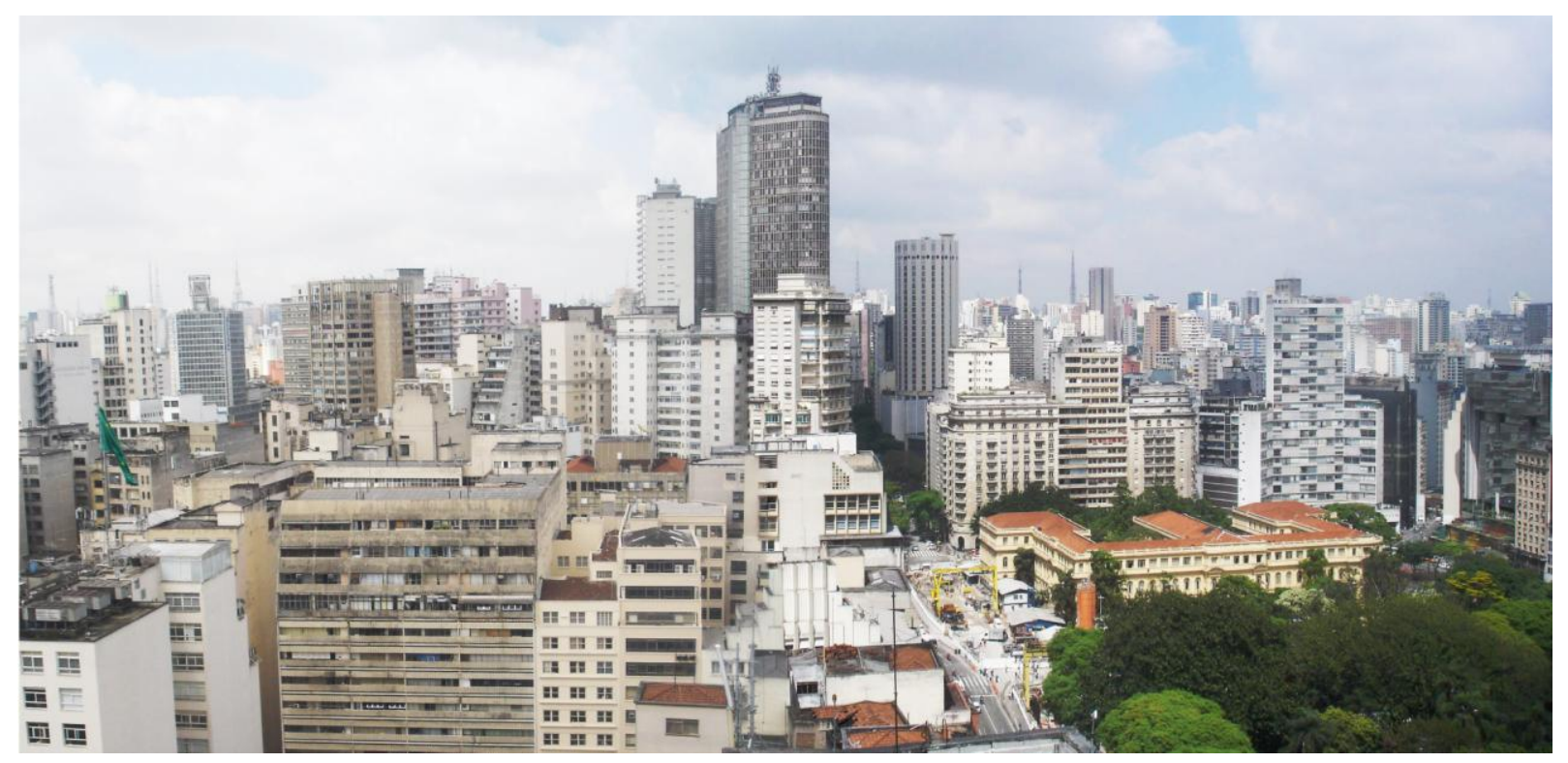

2.16: Em destaque edifícios Itália, COPAN e Eiffel, vista pelo Edifício Excelsior, 2009

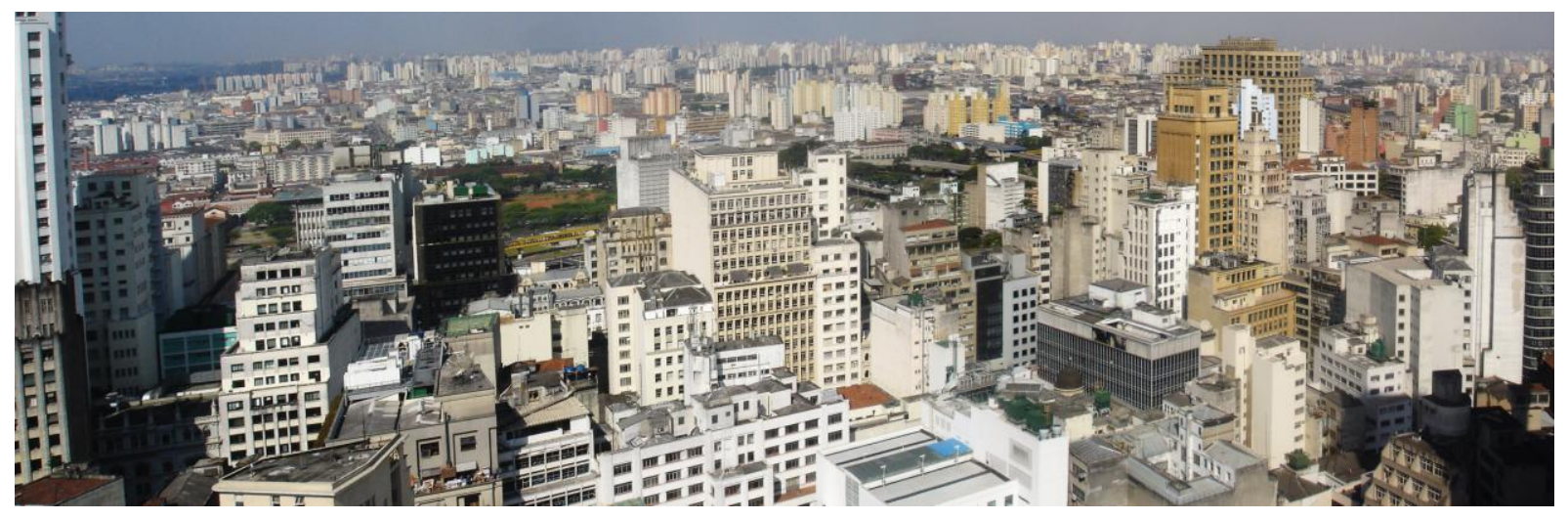

2.17: Vista a partir do Conde de Prates, parte do Triângulo Histórico, 2009

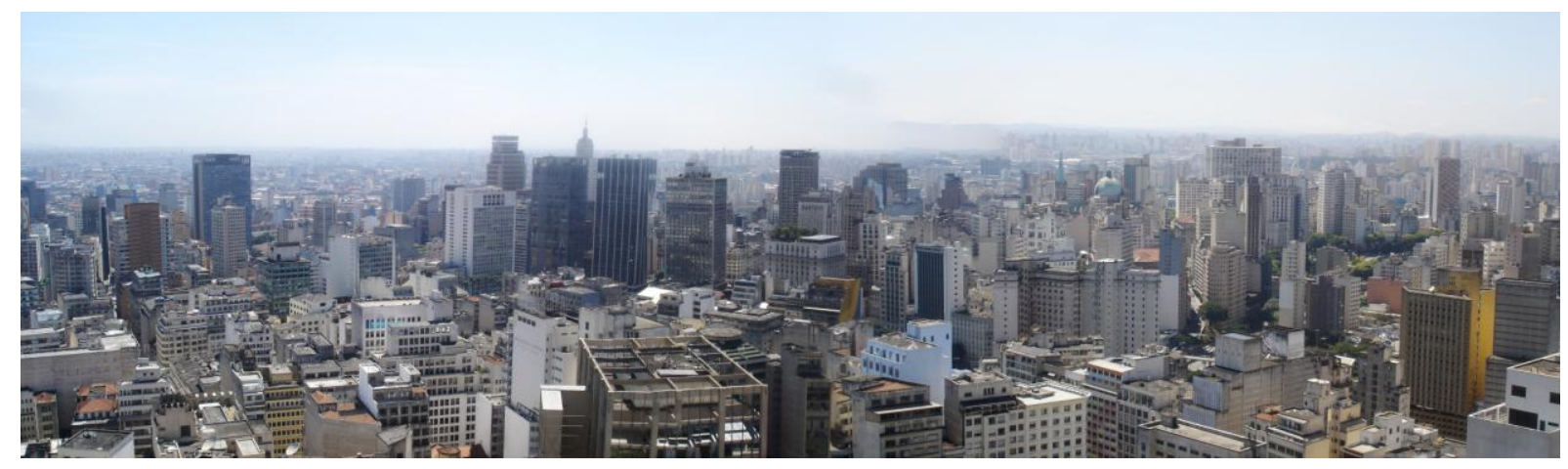

2.18: Vista pelo COPAN, 2008 

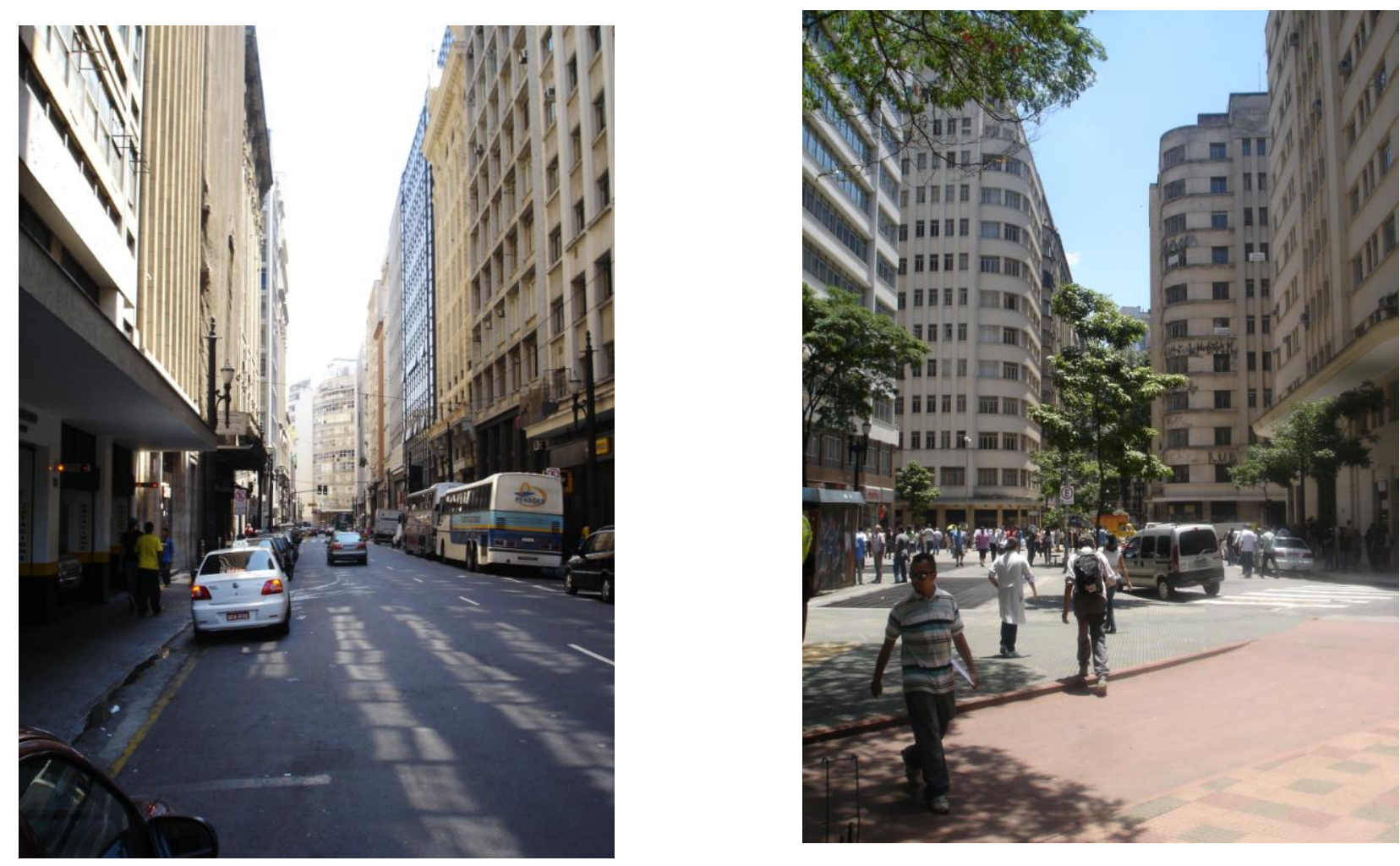

2.19 e 2.20: Rua Bráulio Gomes e Marconi, 2008
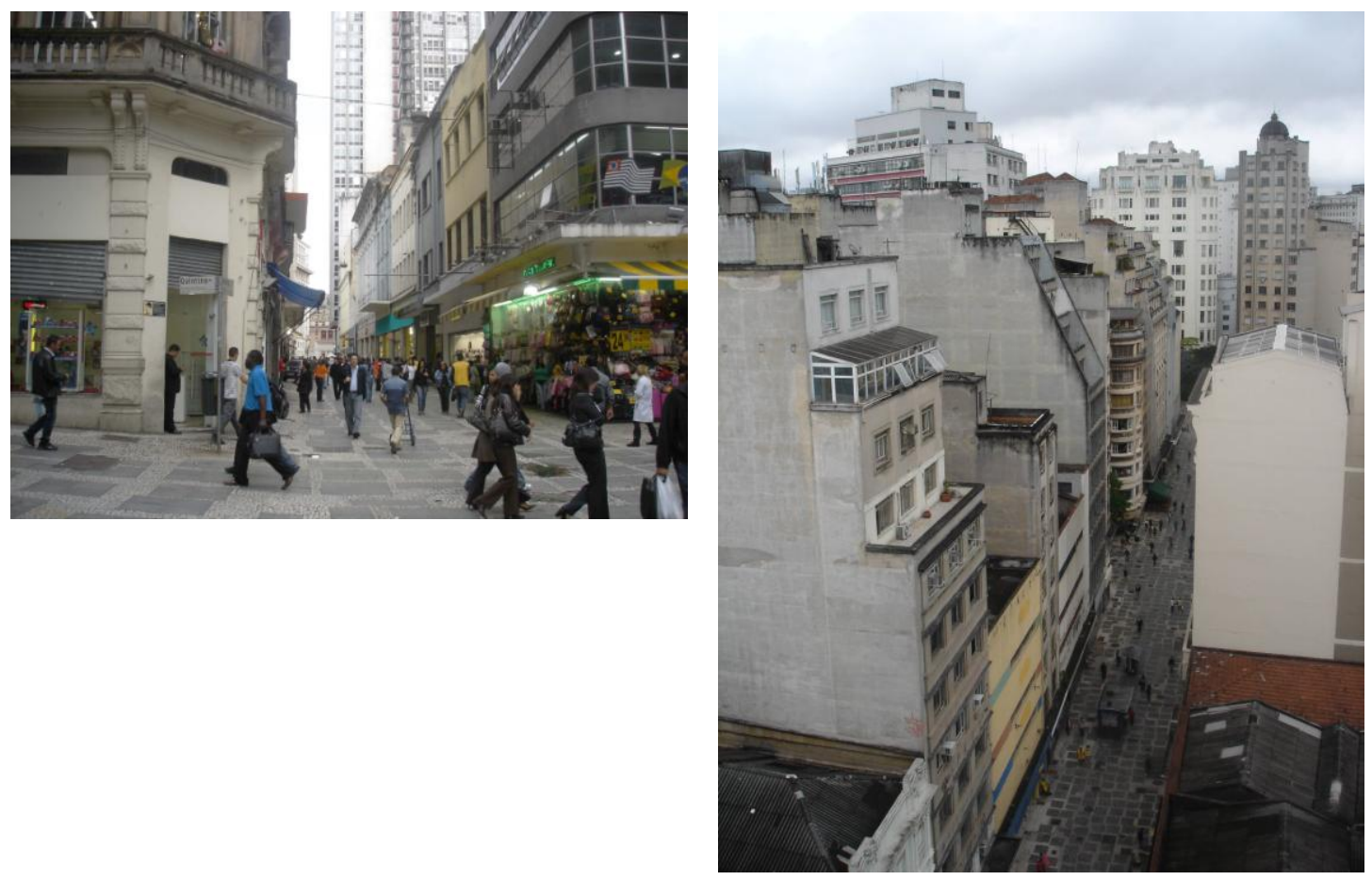

2.21 e 2.22: Vista da José Bonifácio,

a partir do Edifício Triângulo, 2009 


\title{
3. Nova York/São Paulo: aproximação necessária
}

\begin{abstract}
"Nas cidades do Novo Mundo, seja Nova York, Chicago ou São Paulo, que muitas vezes Ihe foi comparada, o que me impressiona não é a falta de vestígios: essa ausência é um elemento de seu significado [...] Para as cidades europeias, a passagem dos séculos constitui uma promoção; para as americanas, a dos anos é uma decadência. Pois não são apenas construídas recentemente; são construídas para se renovarem com a mesma rapidez com que foram erguidas, quer dizer, mal. [...] E, contudo, São Paulo nunca me pareceu feia: era uma cidade selvagem, como o são todas as cidades americanas [..]. Quanto a São Paulo, era, na época, indômita."
\end{abstract}

Claude Lévi-Strauss (1996, p. 91-93)

"Fundamental factors of function and economics make tall buildings everywhere take similar forms, yet skyscrapers in New York and Chicago developed very differently in the first half of this century. Some have explained these variations as expressions of different design personalities or philosophies - the Chicago and New York "schools". This study argues that the variations can best be understood as products of standard real estate formulas that were modified by local conditions such as the city's historic grid, municipal regulations and zoning. Distinct vernaculars of capitalism evolved in each city from this combination of economics logic and the particulars of place."

Carol Willis (1995, p. 19)

\section{Manhattanismo}

No ano de 1916 foram aprovados em Nova York leis de zoneamento e o código de construção $^{23}$, que disciplinavam as construções dos edifícios, sobretudo os verticais e os arranha-céus. Naquele momento foram introduzidos na legislação os conhecidos "setback": um esquema que regrava a altura dos edifícios por meio de escalonamentos sucessivos, em razão da largura das avenidas e ruas.

Essa fórmula permitia o controle de diversos parâmetros: gabarito nos alinhamentos da rua, coeficiente de aproveitamento do lote por zona e índices recomendados de iluminação e ventilação dos espaços. Nessa época, Nova York revelava-se como a nova capital financeira, administrativa e cultural do mundo (Rykwert, 2004, p. 265) e o termo manhattanismo e a manhattanização é cunhado para expressar o processo de tornar as cidades mais ou menos parecidas com Manhattan: termo que hoje pode ser admitido, em

${ }^{23}$ New York City Zoning (NYCZO), primeira legislação de zoneamento que formulou o denominado "zoning envelope", que resultou no conhecido setback ou escalonamento. 
parte, para também descrever o processo de verticalização que ocorreu em São Paulo, principalmente a partir dos anos 30, quando é consolidado o "Código Arthur Saboya".

Em 1820, Nova York possuía aproximadamente 119 mil habitantes; um século depois teria 5,6 milhões de habitantes - a pressão imobiliária empurrava a cidade para 0 alto. No decorrer do século XX esse crescimento ainda seria enorme; em 2004, atingiria aproximadamente 8 milhões de habitantes. No hemisfério sul, São Paulo passaria por um crescimento até mais vertiginoso no decorrer do século passado: sairia de 580 mil habitantes em 1920 para cerca de 11 milhões em 2008: em 1950, em pleno desenvolvimento São Paulo chegaria a 2.227.517 habitantes, representando crescimento da ordem de $68 \%$, taxas acima de Nova York e Chicago ${ }^{24}$. Se as diferenças entre as duas metrópoles quanto à formação, aos planos urbanísticos, à pujança e importância para o mundo são evidentes, em outros aspectos há muitos pontos de contato. O ambiente no qual se debate as diversas ideias de cidade, sobretudo, a cidade moderna, são em certa medida equivalentes: nossos planejadores, diretores de obras e prefeitos do início do século (e meados) estão tão envolvidos e cientes das questões técnicas, políticas e conceituais quanto seus pares em Nova York e na Europa (figuras 3.1 e 3.2).

Não há dúvidas de que a verticalização vai se tornar um fenômeno central nas duas cidades, como, também, não há dúvidas de que em ambas as cidades a verticalização significou e talvez ainda signifique mais do que a evidente reprodução e multiplicação dos lucros pela multiplicação ou "extrusão" do lote; como quer e aponta Rem Koolhaas em Nova York Delirante (2008). O capitalismo guardando as diferenças de identidade, convicção e formação em ambas as cidades (países) deixa os rastros de sua lógica. Mas, essa lógica não explica, por si só, os desejos e fantasias contidos e expressos na cidade e nos edifícios; ou estes não se reduzem somente a ela.

Muitos outros aspectos da cultura, dos estilos, das ideias, das práticas construtivas, da geografia e das legislações deixarão suas marcas, ainda que contidas nos irracionalismos e pragmatismos; como enfatiza Koolhaas ou como expõe Carol Willis de maneira mais direta em Form Follows Finance (1995). Willis demonstra em seu estudo sobre os arranha-céus de Chicago e Nova York a correlação direta entre as formas dos edifícios, os interesses econômicos, a legislação e as fórmulas pragmáticas que geraram a estandardização dos espaços de escritórios. Em São Paulo, outros fatores como a técnica do concreto armado e uma industrialização mais incipiente serão também determinantes; diferentemente dos EUA onde a indústria do aço forneceu aos arquitetos e engenheiros um arsenal de opções em estruturas metálicas, a partir do segundo quartel do século XIX, que anos 50, p. 72.

${ }^{24}$ Anos 50, segundo Regina Maria Prosperi Meyer, em Metrópole e Urbanismo: São Paulo 
foram amplamente incorporados e utilizados na construção dos arranha-céus, desde seus primórdios.

A partir de 1934, com a consolidação do código de obras "Arthur Saboya", a cidade de São Paulo incorpora em sua legislação, normas edilícias mais ao caráter daquelas propostas para Nova York: a verticalização, o escalonamento e os altos coeficientes de construção, de certa maneira, representam mais abertamente a passagem do ciclo exportador do café para o ciclo industrial; manifestando-se com mais intensidade o frenesi da cidade industrial. Entretanto, o percurso das ideias aos planos urbanos para a cidade moderna não se fez sem embates importantes: Haussmann, Camillo Site, Hénard e Le Corbusier alimentaram e frequentaram com suas ideias o imaginário dos urbanistas brasileiros, deixando, por meio de seus planos, desenhos e obstinadas convicções marcas indeléveis sobre a cidade. Discute-se a cidade orgânica, a cidade jardim, a cidade racionalista. Porém, a cidade que se faz é a pragmática, conciliadora e híbrida; na medida em que nela se mesclam idealidades de origens divergentes e interesses conflitantes.

Ao longo desse percurso, aspectos das idealidades modernas vão se estendendo sobre as cidades, de forma que os edifícios paulatinamente deixam de desenhar ou conformar o espaço público - uma cidade onde os edifícios serão, sobretudo, objetos isolados no lote. Esse processo de influência hegemônica do alto modernismo também marcará a arquitetura americana (Willis, 1995, p. 8). Nesse sentido, há uma capitulação ao rolo compressor moderno, melhor expressado no "estilo Internacional". Em algum momento, aquelas torres "delirantes" e de estilos modernos diversos transformaram-se em volumes prismáticos e envidraçados. Chicago, Nova York, São Paulo; lá como aqui, a legislação correu atrás do moderno e consolidou o edifício isolado no lote, assemelhado e almejado nos termos das idealizações plantadas e cultivadas (com ardor) pelo racionalismo moderno. A cidade da congestão (como quer e "inventa" Koolhaas) e a cidade histórica resistiram (e ainda resistem) em alguns territórios e fragmentos espaciais: como nos centros históricos.

Rever Nova York por meio das lentes contemporâneas de Koolhaas, Willis e Rykwert e de seus protagonistas arquitetos - Raymond Hood, Hugh Ferris e Ely J. Kahn - é fascinante porque se pode estabelecer um contraponto isolando algumas questões que, embora distintas, ocorreram também em São Paulo; em particular em seu Centro Histórico densamente verticalizado e congestionado: mais modesto, porém, tão efervescente quanto a capital mundial. Este capítulo identifica e explora aspectos que estruturam Nova York e que também estão presentes na cidade de São Paulo. A intenção é estabelecer um contraponto que esclareça a similitudes e diferenças entres as duas cidades. No capítulo seguinte, esses elementos serão retomados a partir das ideias e planos para São Paulo. 


\section{Forma e finanças}

A Historiografia dos arranha-céus comumente os divide em três fases: a primeira compreendendo o último quartel do século XIX até 1929; a segunda, entre a depressão e a II Guerra Mundial; a terceira, a partir dos anos 50 - quando ocorreu a hegemonia do "International Style". Willis propõe uma divisão semelhante, entretanto, salienta a enorme riqueza no período do entre Guerras, muitas vezes ignorada, nos quais foram desenvolvidos novos materiais, tecnologias de engenharias para a construção. Assim, ela afirma que, até os anos 40 - ou o período "Vernacular do Capitalismo" - as formas desses edifícios estavam necessariamente relacionadas ao ambiente: luz e o sítio foram elementos-chave para o período. Se o elevador é o fato tecnológico mais importante que impulsiona e permite a construção de edifícios altos, a invenção da luz fluorescente e do ar-condicionado também foram igualmente relevantes nas conformações dos edifícios: até 1940, os interiores dos edifícios dependiam principalmente da luz e ventilação natural, portanto, intimamente ligados/vinculados às divisas do lote; o escalonamento sucessivo é a fórmula que responde a essas necessidades, mas o foram também os recursos obtidos por meio de pátios internos, poços e reentrâncias. As novas invenções técnicas caminharam para o advento do "International Style", na medida em que são acrescidas novas artificialidades (conforto) e que são evocados outros elementos estéticos como aço, vidro, volumes espaciais ("soltos no espaço") e a expressão estrutural. Porém, essa denominação não se refere exclusivamente aos aspectos estilísticos: mas também ao relacionamento entre o edifício com seu sítio (lugar) e contexto. Para Willis, então, o estilo internacional refere-se tanto às inovações tecnológicas, quanto às mudanças na ideologia arquitetônica manifestadas nos edifícios altos, então independentes ao sítio e intercambiáveis de uma cidade a outra (Willis, 1995, p. 8-9).

O estudo dos arranha-céus e dos edifícios verticalizados de Willis abarca as cidades de Chicago e Nova York, duas origens para o mesmo fenômeno arquitetônico e urbano, porém, com distinções significativas entre ambos: em Chicago havia uma legislação reguladora enquanto em Nova York predominava o laissez-faire ${ }^{25}$.

${ }^{25}$ Por volta de 1893, a câmara municipal de Chicago limitava os edifícios em 39,62 m (130 pés) ou o equivalente a dez ou onze andares, nas três seguintes elevou a altura máxima para $79 \mathrm{~m}$ (260 pés), mesmo assim essas restrições desencorajavam o desenvolvimento. Em Nova York, após 1889, quando as estruturas (ossaturas) metálicas foram permitidas pelo código de obras (normatizadas), não havia restrições quanto à altura dos edifícios; elas viriam mais tarde, em 1916, para controlar e permitir a insolação suficiente e necessária para todos os prédios. 
Nessas primeiras décadas de proliferação dos edifícios altos em Nova York e Chicago ocorreram tipificações singulares: em Nova York os arranha-céus eram altos e esbeltos e os pavimentos organizavam-se em torno de um núcleo central de circulação vertical e serviços. Segundo Willis a torre foi uma maneira mais proveitosa de construir numa cidade onde os lotes eram geralmente pequenos e a altura não era regulamentada. Ao contrário, em Chicago as alturas dos edifícios eram restritas e os lotes eram geralmente grandes: dessa condição derivou-se uma tipologia de edifícios caracterizados por uma caixa retangular, perfurada ou recortada, nos fundos ou no centro por pátios para iluminação. Nos anos 20, ocorreram duas modificações na legislação das duas cidades: em Nova York foram introduzidos os "setbacks" (ou escalonamentos sucessivos), que frequentemente eram finalizados com uma fina torre central ${ }^{26}$ (figuras 3.3 e 3.4).

Além desses, Willis demonstra que o dimensionamento dos postos de trabalho (salas) nos escritórios, nos primórdios de sua formulação, determinou a modulação estrutural e espacial dos edifícios (1995, p. 24-33). Ou seja, o edifício nasce tanto de dentro para fora, quanto de fora para dentro (setback). A questão chave encontrava-se nas necessidades de iluminação e ventilação natural para os compartimentos de trabalho, uma vez que a iluminação artificial geral proporcionada pelas lâmpadas incandescentes que eram insuficientes, exigindo imensa quantidade lâmpadas que aqueciam demasiadamente os ambientes; por isso, utilizavam-se luminárias sobre as mesas de trabalho para amenizar o aquecimento geral dos compartimentos. Nestas condições, ter ambientes muito distantes das aberturas implicava num aumento de custos e deficiência da iluminação: estudos demonstravam que quanto mais profundos os escritórios mais baratos os aluguéis. No decorrer destas décadas, passa-se progressivamente das primeiras experimentações à formatação de um sistema estandardizado para os edifícios de escritório que conciliava mobiliários, profundidades dos espaços, modulação espacial e estrutural, cuidado com bom desenho das fachadas; considerado como fator de vendas agregador de valores e principalmente rentabilidade econômica para os empreendedores (figura 3.5).

Até 1916, Nova York não possuía uma legislação que controlasse a rigor a construção dos edifícios. Prevalecia uma forte ideologia do modelo laissez-faire, representada nos arranha-céus que expressavam também a enorme vitalidade comercial e crescimento da cidade; naqueles anos, concentrada na baixa Manhattan, próximo à área portuária. Sob estas condições o preço da terra subiu vertiginosamente. Entretanto, a cidade

${ }^{26}$ Em Chicago, o zoneamento permitiu o aumento das torres, mas limitou-as em seus volumes. A partir dessas regulamentações, evoluíram-se dois tipos: um composto por uma base grande encimada por uma torre pequena; outro, composto por uma base integrada/conjugada com a torre (Willis, 1995, p. 23). 
não impôs restrições quanto á altura dos edifícios nem quanto à taxa de ocupação ${ }^{27}$. Segundo, Willis: "Em teoria, os proprietários de terra e imóveis poderiam construir a partir dos alinhamentos do lote até as alturas do céu ou até aonde seus desejos ou dinheiro os permitisse" (1995, p. 34).

Ainda segundo Willis, três fatores combinados contribuíram para a caracterização dos primeiros arranha-céus de Nova York: uma grande demanda por espaços comerciais; a falta de regulamentação da altura dos edifícios e os mapeamentos históricos de Manhattan. Mapeamentos que se iniciam nos primeiros padrões de ruas e quadras coloniais, que são depois complementados pelas esconsas [para os padrões de Manhattan] grades em seu entorno mais próximo e finalmente concluído pela uniformizadora grade das quadrículas implantadas por toda a ilha, a partir de 1811 pela comissão de planejamento. (Willis, 1995, p. 35).

$\mathrm{Na}$ baixa Manhattan os lotes desde sua origem colonial eram relativamente pequenos e estreitos, sobretudo, pela necessidade da multiplicação das fachadas principais (figura 3.6). Mesmo após o plano de 1811, as quadras padronizadas ainda eram subdividas em lotes modestos. As quadras mediam no sentido norte-sul, 200 pés $(60,96 \mathrm{~m})$, no sentido leste-oeste, 600 ou 800 pés (182,8 m e 243, $84 \mathrm{~m}$ respectivamente). Estas quadras eram subdividas em lotes com frente de 25 pés $(7,62 \mathrm{~m})$ e fundos de 100 pés (30,48 m); medidas adequadas para casa e lojas. O esquema completava-se com as padronizadas as avenidas (medindo 100 pés) e ruas (medindo 50 pés). Havia exceções quanto à dimensão dos lotes, entretanto, a regra era de lotes pequenos e custo alto de remembramentos: estes fatos conformaram uma lógica econômica de alta rentabilidade que impulsionou a proliferação das torres altas, coladas a edifícios mais baixos, que configuraram o cenário da Manhattan na ultima década do século XIX. À época, a tipologia predominante era dos espaços para salas comerciais em torno de um core central. Nos primeiros anos do século XX, os edifícios tornaram-se mais altos e rentáveis: algumas razões encontram-se no aumento de remembramentos de pequenos lotes, na melhoria dos elevadores e sistemas mecânicos e na maior eficiência das armações estruturais de aço. Outro fator de relevância achava-se na competição entre corporações, mas adverte Willis, que a busca pela luz natural tem tanta relevância quanto aos interesses pautados na publicidade competitiva entre as torres (1995, p. 41-43).

A primeira lei de zoneamento de Nova York surge em 1916. Com ela mudam-se também as regras para o desenho dos arranha-céus. No zoneamento foram distinguidas três zonas principais; comercial, residencial e irrestrita. Quanto aos edifícios, a lei regulava

${ }^{27} \mathrm{O}$ código que regulamentava o esqueleto estrutural em aço foi aprovado em 1889. As restrições quanto à altura dos edifícios, mesmo depois desta data eram ausentes em Nova York. 
suas alturas através da fórmula denominada de "zoning envelope": criada para garantir luz e ventilação para os canyons em formação em Manhattan. A regra adotada foi a dos recuos sucessivos e escalonados (segundo uma razão) ou "setbacks": um ângulo fixado a partir do meio da rua ou avenida prolongava-se pelo terreno definindo uma linha (ou hipotenusa) para além da qual não se podia construir. A lei permitia, ainda, construir uma torre de altura ilimitada sobre um quarto do lote ${ }^{28}$. Embora a altura fosse ilimitada em um quarto do lote, nos demais três quartos, havia um modelo que controlava a volumetria regulando a altura máxima das edificações. Essa modelagem da legislação eternizou-se nos desenhos expressionistas Hugh Ferriss; que demonstravam o processo de interpretação e aplicação da lei. O zoneamento de 1916 definia ainda cinco fórmulas ou razões para os diferentes distritos ou zonas (1995, p. 67-79). A lei e suas demonstrações explicitadas, somadas aos interesses dos proprietários deram as condições e as regras que definiriam o skyline de Nova York e influenciariam diversas outras cidades; inclusive São Paulo.

\section{A retícula e a congestão da cidade moderna}

Se Carol Willis uma leitura de Nova York sem canduras, Rem Koolhaas em "Nova York Delirante" (2008), exacerbará seu fascínio, sua vitalidade e suas condições de concentração e da diversidade; entendo-as como "cultura da congestão". Em outros termos, ele nos faz ver a irracionalidade ou a suprarracionalidade na construção do Manhattanismo ou as lógicas de construção da cidade e da multiplicação vertiginosa do solo; por meio dos arranha-céus. Embora Koolhaas faça uma crítica irônica e descarada das intenções e procedimentos do capitalismo americano, deixa-se levar pela fascinação e delírio dos inventores americanos, que na interpretação de Adrián Gorelik ${ }^{29}$; ergueram uma fantasia delirante de edifícios saturados de prazeres - por sobreposição e mixagem de múltiplos usos: hotéis, moradias, escritórios academias de ginástica; "cidades dentro de outra cidade". A retomada dos edifícios altos e arranha-céus por parte de Willis caminhou numa direção menos apaixonada, entretanto, mais minuciosa na descrição e nas lógicas internas, inovações e interesses que impulsionaram e desenharam esses edifícios; uma tese na dimensão conveniente de afastamento. Koolhaas, a exemplo de Aldo Rossi e Robert

${ }^{28}$ Em São Paulo, na consolidação do código "Arthur Saboya" de 1934, foi adotado escalonamento semelhante, porém com desenho e limitações distintas; sobretudo, quanto ao teto máximo das edificações.

29 Gorelik, Adrián. "Arquitetura e capitalismo: os usos de Nova York"; apresentação da edição Brasileira de Nova York Delirante, p. 6. 
Venturi - ao estudar a cidade, a teorizá-las ${ }^{30}$, a despeito das enormes contribuições e rigor, está prioritariamente construindo os argumentos de sua própria poética.

$\mathrm{Na}$ apresentação de Nova York Delirante, Gorelik sintetiza algumas questões centrais elaboradas por Koolhaas acerca de Nova York, que são fundamentais para a reflexão que aqui se pretende sobre os edifícios modernos no Centro Histórico de São Paulo: inevitavelmente, edifícios altos, em alguns casos arranha-céus ${ }^{31}$. Uma primeira questão surge em torno do papel e dos sentidos dos traçados em quadrículas, como ocorrido em Manhattan em 1811, pelo plano dos Comissionados. Naquele momento, "quando a ilha encontrava-se praticamente vazia, foi traçada uma retícula homogeneizante de quadras retangulares: "o paraíso da especulação, e Koolhaas, engenhoso, joga com o duplo sentido conceitual desse termo, já que a malha regular implica, sobretudo, 'um programa intelectual' que reivindica a 'superioridade da construção mental sobre a realidade"'. No entender de Gorelik, "Koolhaas celebra a retícula não como forma urbana, mas como malha flexível que permite o máximo de controle para o máximo de descontrole: "ela impõe uma disciplina bidimensional muito restritiva (a quadra isolada como máxima unidade de intervenção), mas que obriga a uma anarquia completa na terceira dimensão, já que cada quadra tem necessidade de sobressair para triunfar dentro da competição selvagem, e o incremento do valor do solo tem como único teto o céu". ${ }^{32}$

Nos termos de Koolhaas a quadrícula anuncia ao mesmo tempo a subjugação da natureza ${ }^{33}$ e os artífices da cidade tradicional. "A retícula é uma especulação conceitual [...] e apesar da aparente neutralidade, ela implica um programa intelectual para a ilha: com sua indiferença à topografia, ao que existe, ela afirma a superioridade da construção mental sobre a realidade [...] todas as quadras são iguais; sua equivalência invalida de uma só vez todos os sistemas de articulação e diferenciação que orientam o desenho das cidades tradicionais" (Koolhaas, 2008, p. 37).

A formação dessa quadrícula estimula interpretações e reflexões: Rykwert descreve, assim, o processo de formação da quadrícula de Manhattan:

"À medida que a população de Manhattan crescia já em fins do século XVIII, surgiram debates sobre a necessidade de algum tipo de projeto geral para a ilha. As parcelas da

${ }^{30}$ Em Nova York delirante, Koolhaas recorre ao Método crítico Paranoico proposto Salvador Dalí. A paranoia é entendida ali como um delírio de interpretação. 2008, p. 269.

${ }^{31}$ Koolhaas entende os arranha-céus como edifícios muitos altos com enorme diversidade de usos. Em São Paulo, embora havendo sobreposições de uso, principalmente comércio nos pavimentos térreos, prevaleceu, no Centro Histórico, o uso predominante de escritórios. Segundo Willis, em Nova York ocorreu ocupação ou especialização semelhante. A modulação espacial a partir dos mobiliários e conjuntos para escritórios demonstra em seu estudo a predominância do uso.

${ }^{32}$ Ibid. p. 8.

${ }^{33}$ Para Koolhaas, o Central Park é uma preservação taxidérmica da natureza, op. cit., p. 39. 
cidade que haviam sido dispostas de forma ordenada eram episódicas, como quando, por volta de 1790 , os descendentes de Peter Stuyvesant lotearam a sua enorme propriedade segundo uma trama ortogonal no sentido norte-sul. Após uma série de projetos extravagantes e abortados, as autoridades da cidade entraram em ação: foi empossada uma Comissão de Ruas, para a qual um jovem avaliador, John Randel Jr., mapeou com doze avenidas (com 30 metros de largura) e 155 ruas (com 15 metros de largura), do qual foi feita, imediatamente, uma gravura. Esse plano estabelecia uma trama uniforme - independente das irregularidades do sítio e dos direitos dos proprietários de terras - para todo o norte da Houston Street (figuras 3.7, 3.8 e 3.9 ).

São notáveis as observações de Rykwert quanto à trama que "desconhece" e se sobrepõe ao sítio e às propriedades (ainda que houvesse alguns interesses a serem acomodados). Ainda que o sítio de Manhattan apresentasse uma série de acidentes e ainda que contivesse uma "formação rochosa pitoresca e variada", não se tratava de um relevo de colinas tão acidentado como o de São Paulo. Essas condições de origem serão, também, percebidas por Koolhaas que prossegue em seus elogios à retícula. Para ele a disciplina bidimensional da retícula cria uma liberdade jamais sonhada para a anarquia tridimensional: assim, os construtores de Manhattan estavam obrigados a desenvolver "um novo sistema de valores formais, a inventar estratégias para diferenciar uma quadra da outra (2004, p. 266 $67)$.

Inventar estratégias e se apropriar das invenções tecnológicas são dados constituintes de um por fazer - no caso os edifícios altos - que dependem das máquinas, principalmente, da máquina de Otis: leitmotiv do futuro desenvolvimento da ilha e de todas as ilhas. Porém, nos termos de Koolhaas (2008, p. 106) o elevador gerará a primeira estética baseada na ausência de articulação pela repetição de andares empilhados ao redor de um poço. Um procedimento operativo quase autômato, apenas decorrente da lógica especulativa e tecnológica, sem esquecer os delírios e os prazeres contidos (ou escondidos) nos pisos sobrepostos dos arranha-céus.

Dadas as condições da ilha e a necessidade de erguer novos espaços para escritórios, Manhattan não teve escolhas a não ser "a extrusão da própria retícula rumo ao alto"(Koolhaas, 2008, p. 111). O tema da extrusão é posto por Koolhaas e outros como uma das características mais relevantes dos arranha-céus de Nova York. Inicialmente ele está associado aos primeiros edifícios altos que antecedem a lei de 1916 em Nova York: os edifícios erguiam-se acima de 39 pavimentos e tinham taxa de ocupação praticamente correspondente às dimensões do $\operatorname{lote}^{34}$, dado que não existiam restrições quanto à altura ou

\footnotetext{
${ }^{34} \mathrm{O}$ edifício Equitable multiplica o lote em 39 vezes.
} 
aos recuos dos edifícios. Mesmo depois da lei de 1916, esses edifícios permaneciam na visão de Koolhaas extrudados a partir da forma original do lote.

Mas quando o edifício ocupa quase uma quadra inteira, quando seu conteúdo programático torna-se mais e mais diversificado, principalmente a partir de seus térreos, essa quadra original pode se converter num enclave fechado: que adquire sentido e consistência na multiplicação da torre - que paga [literalmente] pelas metáforas no térreo (Koolhaas, 2008, p. 123).

A verticalização excessiva dos edifícios, muitos deles criando sombras sobre seus vizinhos mais baixos, desvalorizando-os, contribuiu para a regulamentação da lei de 1916: zoneamento e o código de construção. O diagrama técnico esquematizado no escalonamento tinha a intenção de propiciar luz e ar adequados para os edifícios conforme a largura de avenidas e ruas. A nova lei foi um invólucro imaginário que definiu as alturas máximas permitidas para a construção, mas foi, sobretudo, segundo Koolhaas, um projeto de design (2008, p. 136).

Nesse sentido, são emblemáticos os desenhos de Hugh Ferriss, que além de demonstrar passo a passo as aplicações das regras contidas na lei sob determinadas condições de lote e quadra, impregnou o imaginário dos arquitetos e empreendedores: formatando, assim, a expressiva arquitetura dos arranha-céus de Nova York, independente dos arquitetos que a tenham feito. Se a expressão da lei cabe a Ferriss, a interpretação e edificação cabem a arquitetos como Raymond Hood, Harvey Wiley Corbett e Ely Kahn: que põem de pé grandes edifícios, por meio do envolvimento direto com os empreendedores, da agudez e do trabalho de equipes multidisciplinares, num fazer frenético permeado por enorme pragmatismo (figuras 3.10 e 3.11 ).

Para Koolhaas o Empire State Building é a última manifestação do manhattanismo como puro processo irrefletido, o clímax da Manhattan subconsciente. Mais à frente explica: enquanto a vanguarda europeia faz experiência com a escrita automática, o Empire State é uma forma de arquitetura automática, uma rendição sensorial de seus construtores coletivos - do contador ao encanador e ao processo de construção. Como tipo arquitetônico o edifício é uma pirâmide formada por um espaço (núcleo) no centro que contém circulação vertical, banheiros, poços e corredores; cercado por outra pirâmide de espaços arrendáveis. Como produto de um processo o Empire State não pode ter conteúdo, pois o edifício sendo uma repetição de pisos - é mero invólucro (2008, p. 164-5).

Se Empire State foi a Manhattan subconsciente, o novo edifício do Waldorf-Astoria foi a Manhattan consciente, e ambos foram, segundo Koolhaas, a síntese das fases do urbanismo de Manhattan, mostrando todas as estratégias, teoremas, paradigmas e 
ambições que sustentaram o progresso inexorável do manhattanismo. No caso do WaldorfAstoria - que ocupa uma quadra inteira - ficam transparentes toda a rede de complexidades projetuais e sobreposições programáticas de um edifício épico: um hotel para hóspedes temporários, um bloco de apartamentos, um grande salão de bailes, áreas de lazer, uma garagem para vagões particulares (vindo dos trilhos da Central de Nova York) e vários salões de exposição; ou seja, o arranha-céu como unidade residencial da megavila, a representar nos anos de 1930, o que de mais teatral e refinado poderia ser edificado (3.12).

Em Manhattan constrói-se o megacomplexo Rockefeller Center; uma "arquitetura de comitê", sob coordenação de Raymond Hood e participação de muitos outros arquitetos. Ocupando três quadras, o Rockefeller Center conformou uma colossal montanha esculpida pelo invólucro do zoneamento: depois transformado em um colossal complexo arquitetônico, pelas operações de especificação, de forma, materiais, funcionamentos, estrutura, decoração, simbolismo e finança. Uma "obra-prima sem gênio" sob o caráter "inviolável da retícula".

Se os edifícios contêm em si diversos programas, muitos deles ambientados interiormente por fantasias, decorações e cenografias disparatadas, há, segundo Koolhaas (2008, p. 126) uma dissociação entre interior e exterior dos edifícios; em seus termos, uma lobotomia. Ou seja, a correspondência moral, entre continente e conteúdo, encontra-se rompida. Essa teorização, muito a caráter da arquitetura de Manhattan, estabelece contrapontos importantes para se aprofundar algumas questões em torno da arquitetura moderna; cujas correspondências entre causa e efeito, entre funcionalidades, entre exterior e interior desencadearam (e desencadeiam) diversos processos, linguagens e manifestações de arquiteturas. A incerteza torna-se mais interessante pelo fato de que muitas dessas arquiteturas de Manhattan (com suas tecnologias de ponta e ideologias pragmáticas) e aquelas denominadas de Modernas ocorrem muitas vezes no mesmo espaço e tempo. Nesse ambiente, a questão de que modernos se trata todas essas manifestações incorpora sempre novos significados.

Nesse sentido, as leituras críticas de Koolhaas, sobre as ideias de Le Corbusier acerca de Nova York e seus arranha-céus, são relevantes para se ampliar e confrontar as diversas ideias de moderno que se materializam ao mesmo tempo em Nova York, Paris ou São Paulo. Primeiramente, Koolhaas $(2008,281)$ vai dizer que a ambição de Le Corbusier ${ }^{35}$ é inventar e construir a Cidade Nova compatível com as demandas e glórias potenciais da civilização da máquina. Porém, ao visitar Manhattan percebe que essa cidade já existe: então, de alguma forma, precisa destruir sua credibilidade, ora dizendo que os edifícios são

\footnotetext{
${ }^{35}$ Le Corbusier esteve em Nova York pela primeira vez em 1935.
} 
muito baixos, ora dizendo que são decorrentes da romântica Lei de Zoneamento de 1916 construções ainda imaturas, ainda não modernas. Le Corbusier permanecerá envolvido e alimentado pela concretude de Nova York por quinze anos, segundo Koolhaas, quando finalmente apresenta seu antiarranha-céu:

"[...] ele faz o arranha-céu americano desaparecer no bolso de veludo negro de seu universo especulativo, acrescenta a mata (a natureza em sua forma mais pura possível), então sacode os elementos incompatíveis dentro de sua cartola crítico-paranoica e surpresa! - pula fora o "arranha-céu horizontal", o coelho cartesiano de Le Corbusier".

Ao propor seu arranha-céu diluído na vegetação da Cidade Radiosa, Le Corbusier amputou do modelo de Manhattan o topo e a base; a parte intermediária é então desnudada de seu revestimento de pedra e recoberta de vidro e estendida a 220 metros. "É exatamente o arranha-céu racional que os pensadores de Manhattan sempre fingiram que queriam realizar, enquanto na prática se desviariam dele o máximo possível. O faz de conta dos arquitetos de Manhattan - o pragmatismo, a eficiência, a racionalidade - colonizou a mente de um europeu (2008, p. 284-5)." Ao envidraçar o edifício, ao propor a transparência literal entre interior e exterior, Le Corbusier desfaz a lobotomia tão defendida por Koolhaas que atribui a seu arranha-céu horizontal um absoluto vazio cultural. Se os edifícios da Vila Radiosa são antípodas das infantis e primitivas torres de Manhattan, a Cidade Radiosa é, por outro lado, a anti-Manhattan descongestionada, ligada aos automóveis e pela distância (400 m) entre edifícios, contra o pedestre; mas a favor de uma natureza idealizada, abstrata e redentora (figura 3.13).

Nessa afirmação de uma anti-Manhattan, Le Corbusier manifesta-se contra os arranha-céus de Nova York (pequenos demais), contra sua retícula (perfeita [...] na era dos cavalos) e contra o central parque (grande demais) que deveria ser reduzido e seu verde espalhado por toda a ilha (Koolhaas, 2008, p. 301). Entretanto, segundo Koolhaas, Le Corbusier teve paciência e como acontecem com todos os paranoicos, as coisas seguem como ele quer e, após a Segunda Guerra, com a construção da sede da ONU o manhattanismo engasgou, mas finalmente digeriu Le Corbusier que afinal - não tragou Manhattan (2008, p. 315).

Se Le Corbusier não engoliu Manhattan tampouco engoliu São Paulo. Sua proposta para a cidade é uma crítica ao centro geográfico e de negócios ${ }^{36}$, e ao mesmo tempo uma abstração do assoalho topográfico. Em certa medida, aqueles viadutos cidade são também frutos da racionalidade delirante de Le Corbusier.

\footnotetext{
${ }^{36}$ SANTOS, Cecília Rodrigues do [et al..], 1987, p. 92-92.
} 


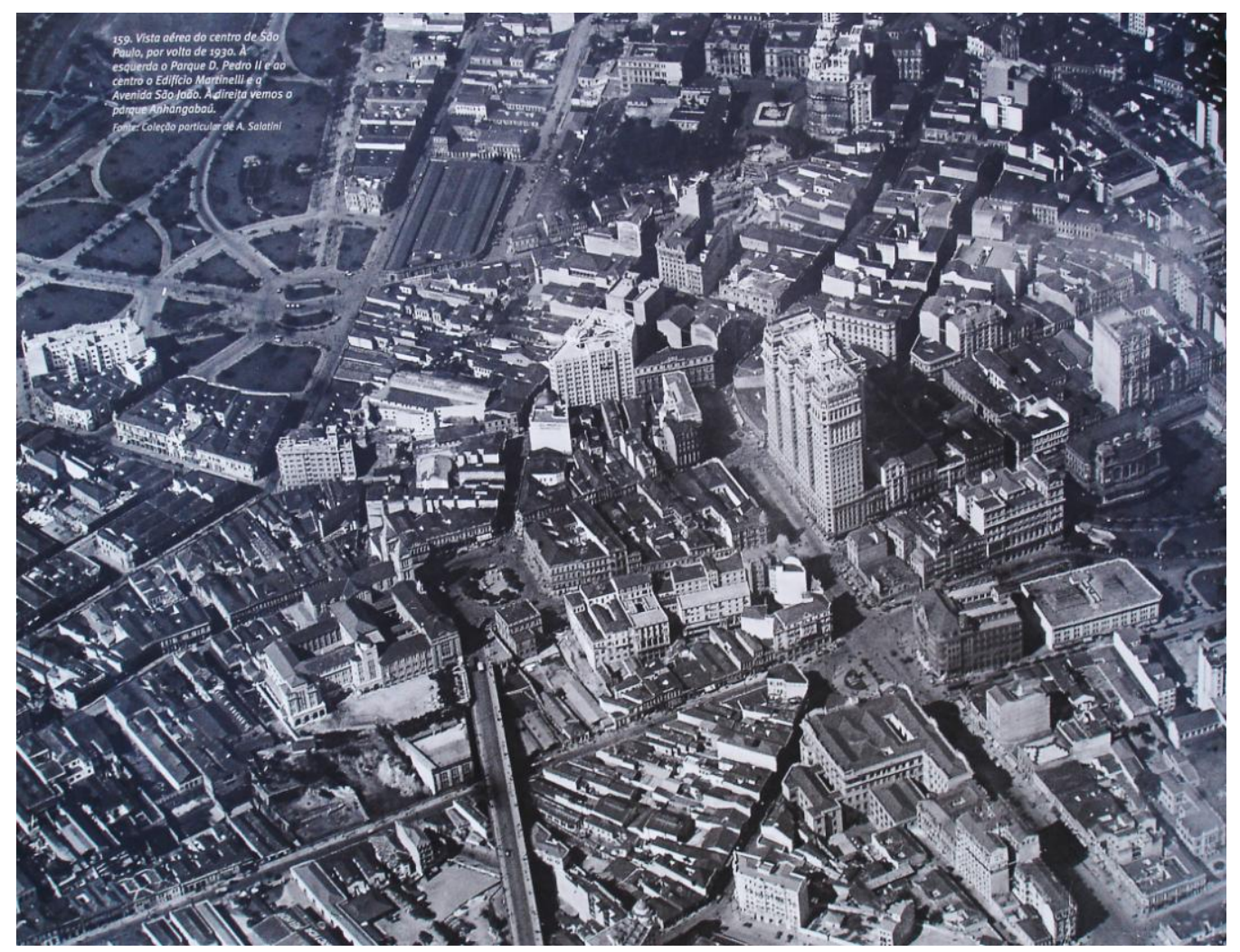

3.1: São Paulo por volta de 1930

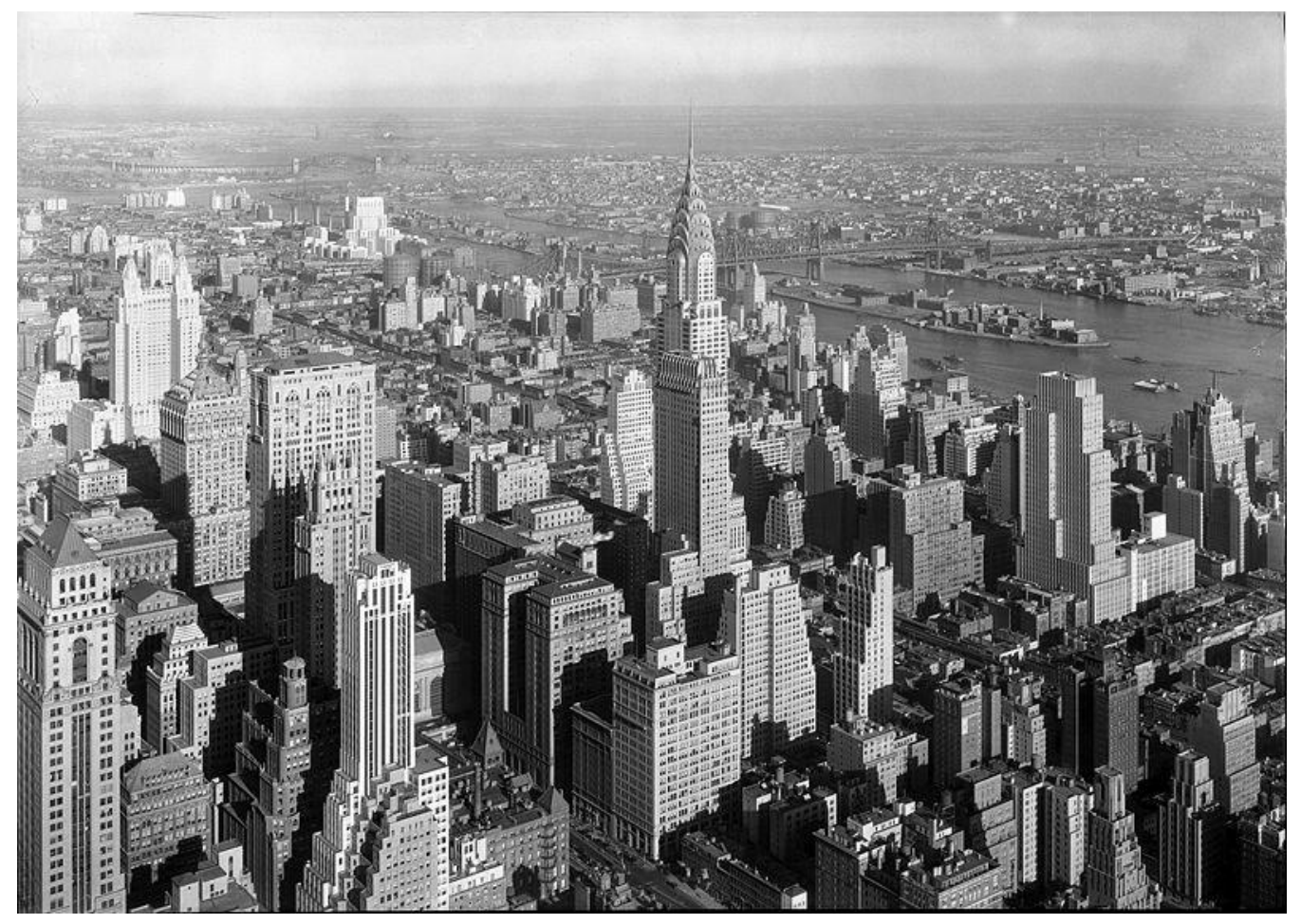

3.2: Nova York 1932 

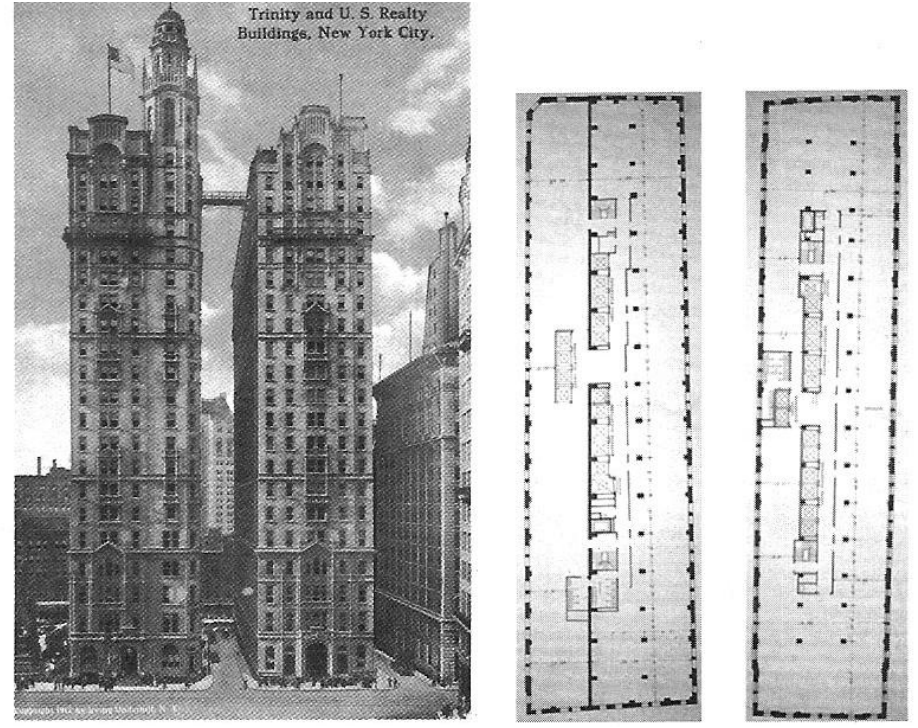

3.3: T e U.S. Realty Building, Nova York, 1905-06
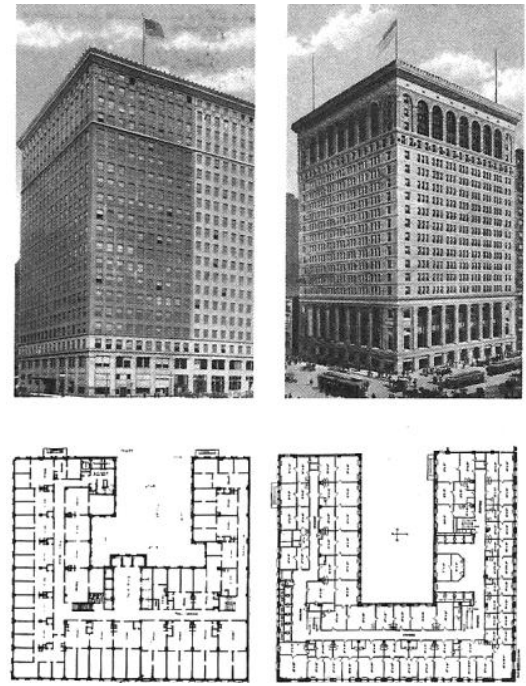

3.4: McCornich Building, 1910-12 e Commercial National Bank, 1895, Chicago
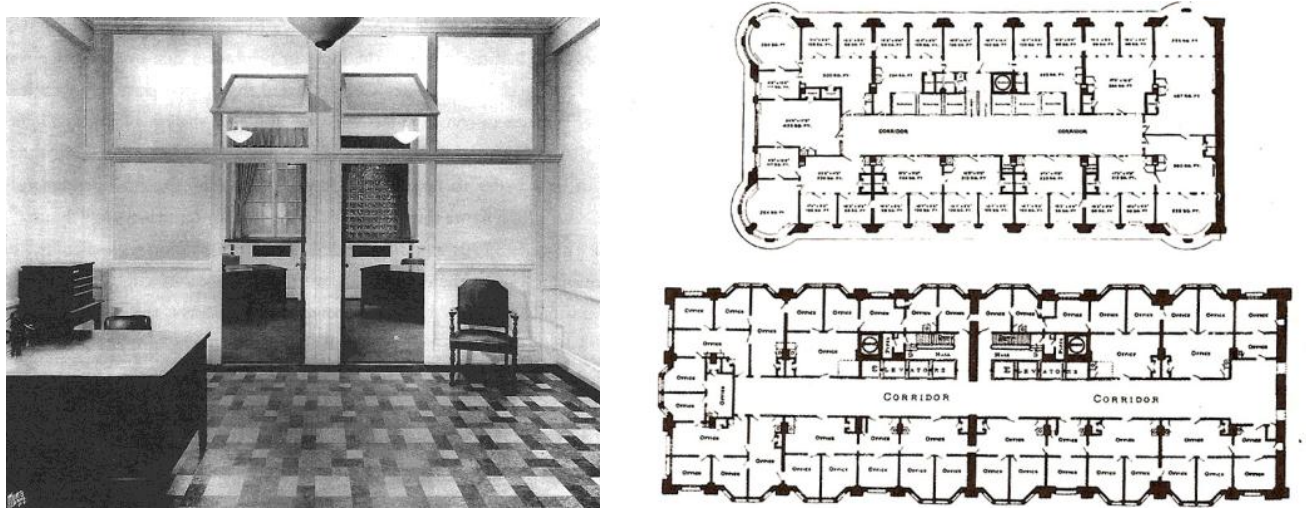

3.5: Interior de um escritório de Nova York, anos 20 e planta de dois edifícios (Old Colony e Monadnock Addition) de Chicago, com suas plantas tipo de pequenos escritórios: notam-se duas janelas, tendo ao fundo outra sala de recepção e secretárias. 

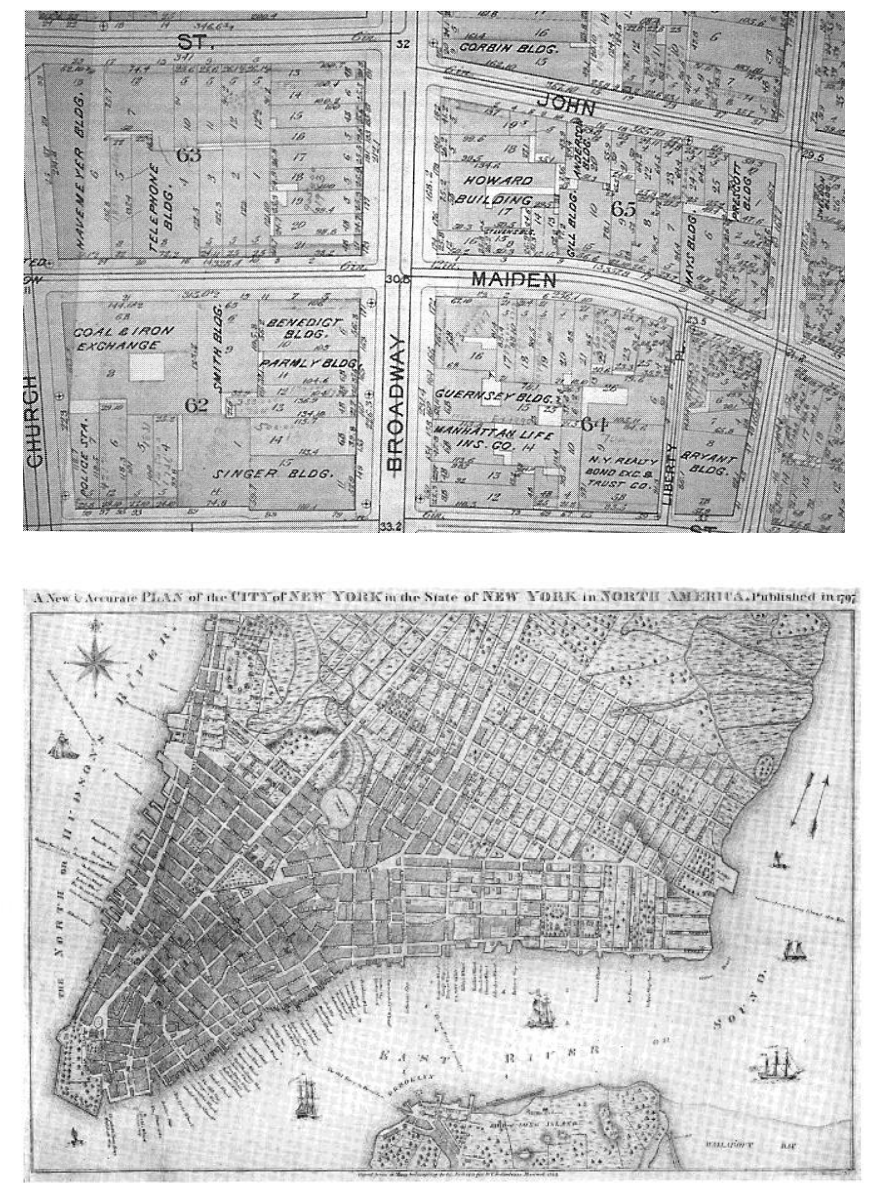

3.7

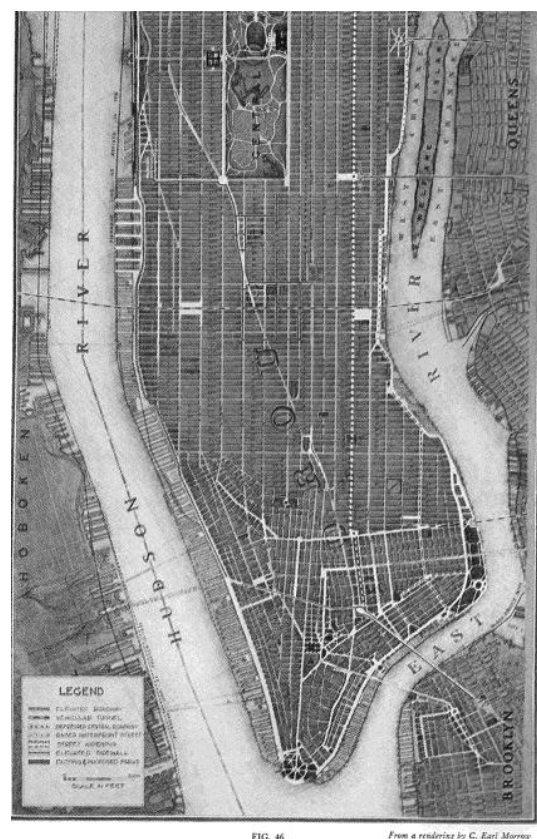

3.9
3.6: Manhattan, 1899: por menor da Broadway e Maiden Lane. A observar o parcelamento de lotes com pequena testada e significativa regularidade. 


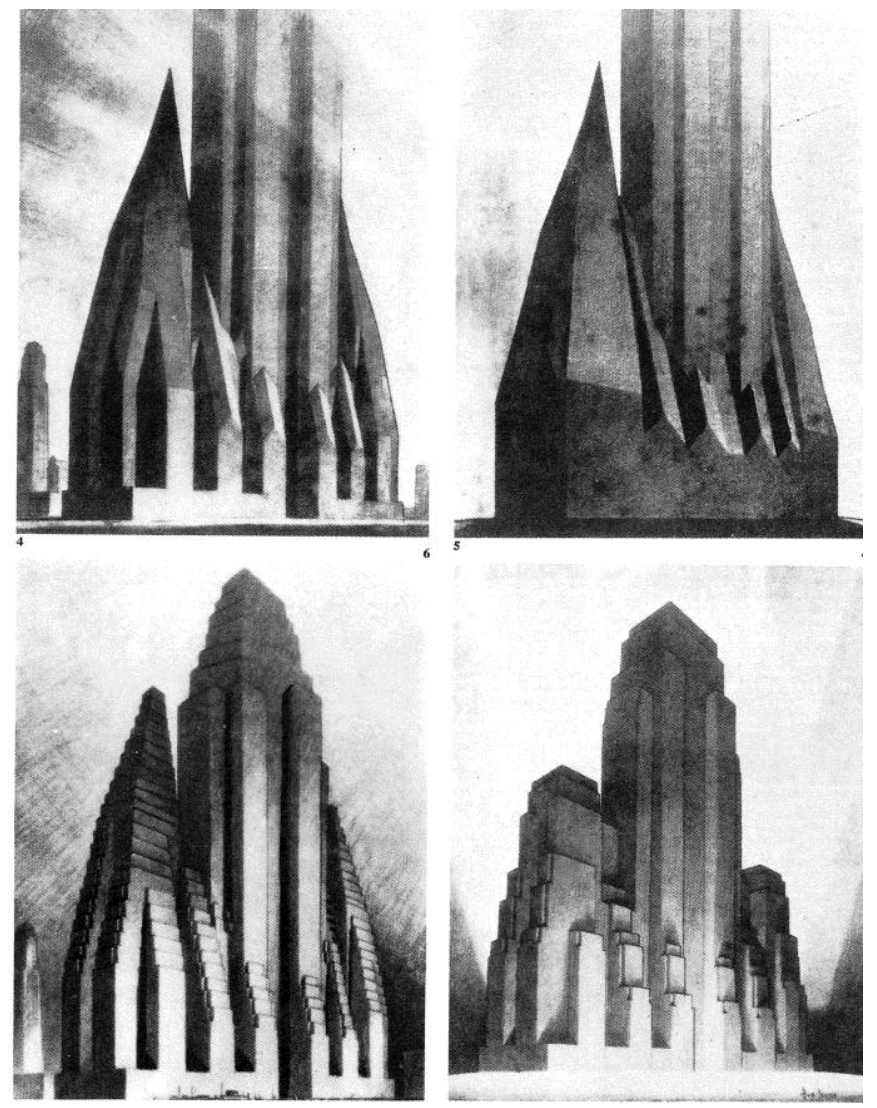

3.10: A lei de 1916 sob os

desenhos de Hugh Ferriss
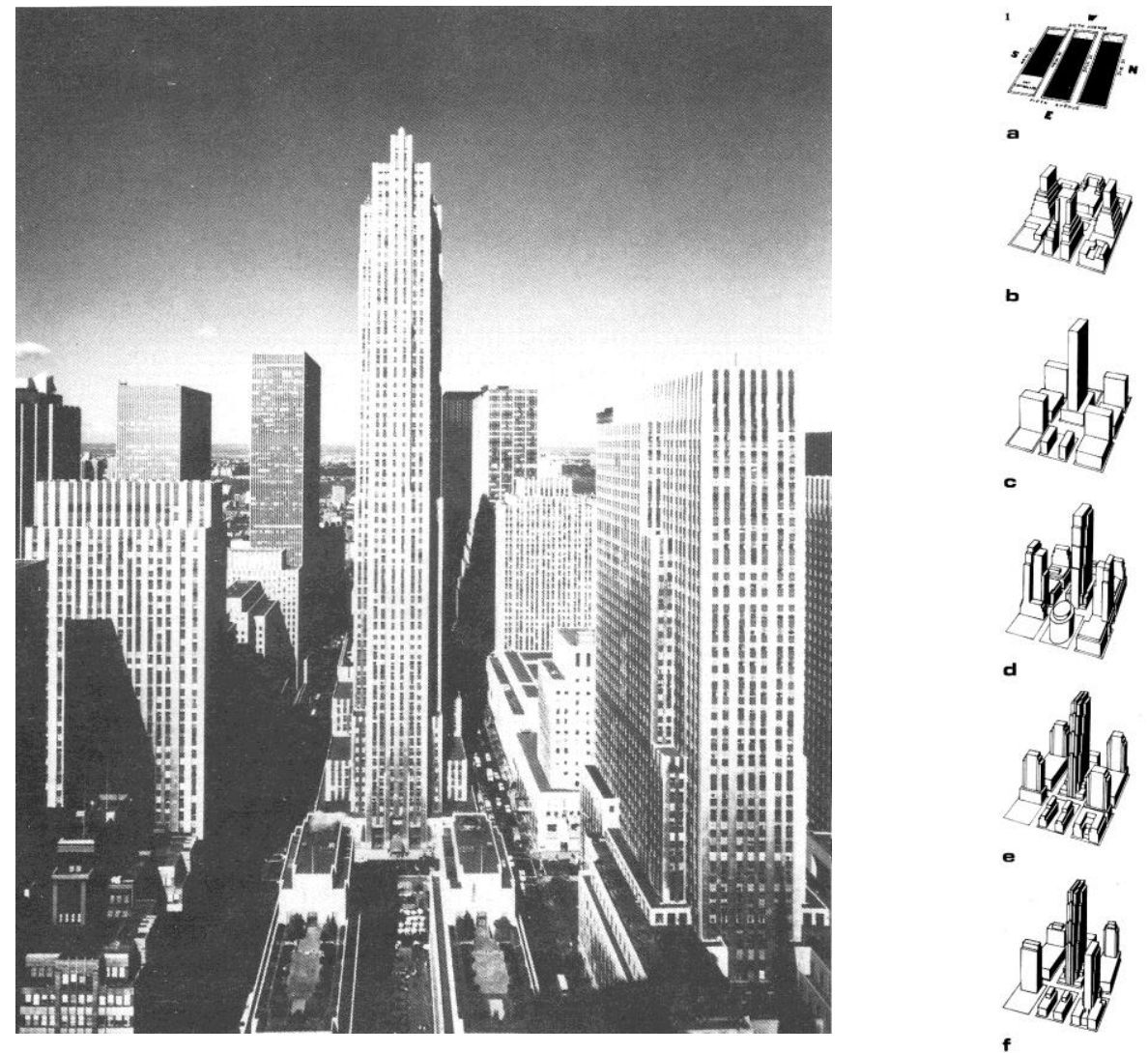

3.11: Rochefeleller Center, 1928-38, Raymond Hood, evolução dos diversos esquemas volumétricos 

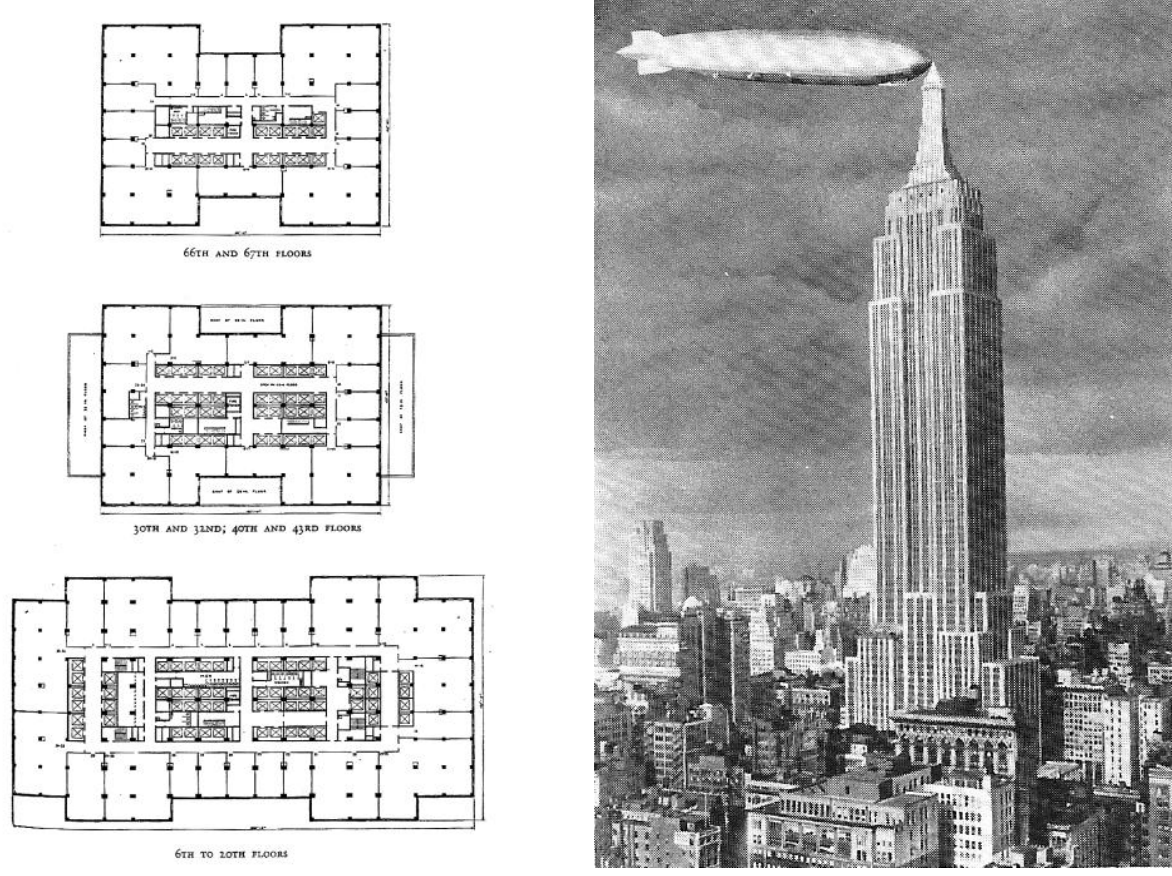

3.12: Empire State Building, 1931 (Shereve, Lamb e Harmon); de baixo para cima; plantas dos pisos, $6^{\circ}$ ao $20^{\circ}, 30^{\circ}$ ao $43^{\circ}, 66$ a0 $67^{\circ}$
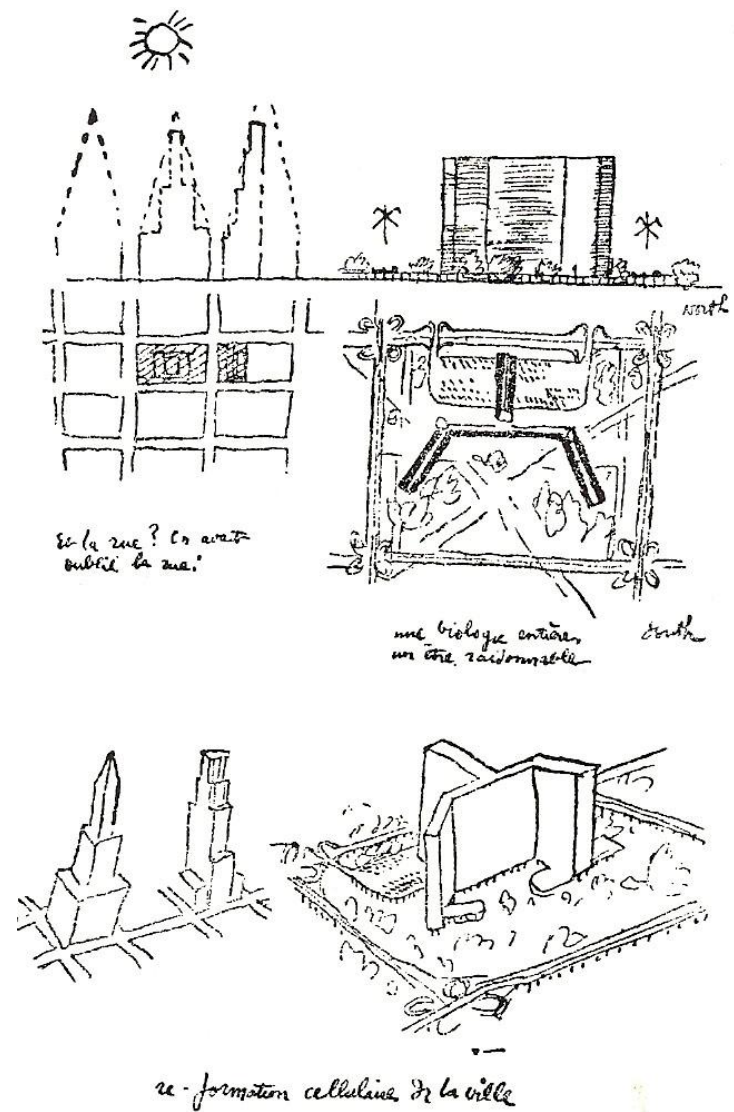

3.13: O arranha-céu cartesiano, 1938, como um contraponto tardio à Nova York. 


\section{São Paulo/Nova York: dos traçados aos edifícios}

Se a forma de muitos edifícios, no Centro Histórico de São Paulo, reporta-se pelo seu escalonamento, estilo e excessivo aproveitamento do lote aos arranha-céus de Nova York, um olhar mais próximo indica diferenças substanciais que têm origem na geografia, no assoalho topográfico, na formação social, econômica e política, na legislação (semelhante, mas com distinções relevantes) e, principalmente, na constituição daqueles elementos primários e formadores do tecido urbano tradicional.

\section{Ideias e planos para São Paulo: organicidade e pragmatismo}

Candido Malta Campos em "Os rumos da Cidade" (2002) faz uma consistente descrição e análise das ideias e dos pensadores da cidade de São Paulo do império até os meados da década de 1940. Nesse relato são apresentados e revelados os planos, as contradições, os contratempos, os principais protagonistas das tramas que tecem essa deslumbrante empreitada que é a construção da cidade; complexidade praticamente insondável. Malta Campos introduz assim a questão: "ao final da primeira década do século XIX a euforia agroexportadora e o boom imobiliário elevaram o patamar dos debates sobre as intervenções urbanísticas em São Paulo". Naquele momento, agentes privados e públicos estudavam propostas para a remodelação da área central: modelos ecléticos e, estéticas urbanas europeias eram contempladas como alternativas para a colina histórica e para o "triângulo", então centro comercial, institucional e simbólico de São Paulo (Malta Campos, 2002, p. 107-8). A multiplicação de intervenções pontuais pareciam ser a tônica das intervenções, pelas demolições de quarteirões e alargamento de ruas para implantação de palácios para a administração da república que se estruturava (figuras 4.1 e 4.2).

Por volta de 1910, nota-se que São Paulo, em plena construção da república, não tem ainda um plano e nem uma ideia de plano que controle o desenvolvimento da cidade. Há os Códigos de Posturas e Leis que tratam das edificações e aspectos pontuais como regulamentação de uso de toldos, assentamento de postes, usos especiais no Centro Velho, melhoramentos de ruas etc. ${ }^{37}$ Porém, a tônica predominante era a das intervenções pontuais. Esse cenário viria a modificar-se, segundo José Geraldo Simões Júnior (2004, p. 96 e 97) com o trabalho "Melhoramentos de São Paulo" de Vítor Freire, no seu entender o primeiro plano urbanístico de São Paulo.

${ }^{37}$ Simões Júnior (2004, p. 187 e 188) lista a legislação de São Paulo de 1873 a 1934 e a do Estado de São Paulo de 1894 a 1911. 
Em Nova York também não se tem um plano global ou código de obras estabelecido até 1916: o traçado de 1811 que desenha uma quadrícula para a cidade (Ilha) estabeleceu ou ditou um destino para a cidade; uma pré-forma que se antecede e se impõe aos planos e leis que o sucederam. De qualquer modo, até a legislação aprovada em 1916, a construção dos edifícios em Nova York não possuía restrições acerca de suas alturas.

Tendo Vítor Freire como figura central na condição de Diretor de Obras da cidade ${ }^{38}$, São Paulo produziu seus primeiros planos até a consolidação do código de obras Arthur Saboya: que reflete os longos anos de preparação e estudos, inclusive o Plano de Avenidas de 1930, elaborado por Prestes Maia, a partir de ideia inicial de Ulhôa Cintra. Nessa época, foram muitas as ideias e planos de melhoramentos para São Paulo: o projeto Silva Teles para o Anhangabaú e para a Rua Líbero Badaró, Alexandre de Albuquerque e as "Grandes Avenidas", o projeto Freire-Guilhem, as Conferências de Vítor Freire e outros.

Esta profícua produção acerca da cidade e de seus destinos está permeada pela cultura bem informada de nossos urbanistas de então: frequentadores e participantes de muitos congressos internacionais nos Estados Unidos e na Europa. Vitor Freire e Alexandre Albuquerque, por exemplo, participavam de congressos e viagens culturais à Europa: nesses contatos não só promoviam "uma cidade importada" pelos estilos dos edifícios; mas traziam para nosso território o debate de ideias e planos para os melhoramentos das cidades; que poderiam ser dispostos sob duas vertentes ou duas polaridades importantes vinculadas a uma "haussmannização" da cidade que privilegiava grandes avenidas (Albuquerque) e, outra, por Vítor Freire que se afinava mais às ideias e propostas de Camilo Sitte e da Urbanística Alemã. Simões Jr. (2004, p. 96 a 128) ao analisar as propostas e referências contidas nos "Melhoramentos de São Paulo" de Vítor Freire, expõe os traços dessas influências, advindas inclusive de sua formação europeia. De início, Freire expõe sua resistência ao plano proposto por Samuel das Neves, marcante pela relevância dada ao sistema viário, pelo seu caráter haussmaniano e excessiva contemplação dos interesses do conde de Prates. Em seguida, são demonstradas algumas referências teóricas e práticas com origem na urbanística de Camillo Sitte $^{39}$ que vão das soluções e desenhos para o encontro de várias ruas, passando pelos argumentos que sustentavam o respeito aos "traçados históricos" existentes nas áreas centrais das cidades e às limitações impostas pela topografia. Em outros termos, uma estética do pinturesco, da paisagem, na qual são valorizadas as curvaturas, as ligeiras mudanças de direção, a diversidade no alinhamento das construções em relação às ruas etc. (Simões Jr., 2004, p. 116). Alguns outros

\footnotetext{
${ }^{38}$ Vítor Freire exerceu a função de diretor da Diretoria de Obras Municipais de São Paulo por 26 anos.

39 "A construção das Cidades segundo seus princípios artísticos", Camillo Sitte, 1889.
} 
exemplos foram retirados da urbanística alemã, propriamente dita, como os desenhos do plano para um subúrbio na cidade de Darmstadt: neste as ruas são desalinhadas, evitando encontros e cruzamentos diretos; as edificações teriam baixa ocupação com os recuos em várias direções e significativas áreas verdes. Num outro desenho, que mostra um fragmento da cidade de Nuremberg ${ }^{40}$, enfatizava-se a riqueza dos alinhamentos encurvados e desalinhados (não perpendiculares) ao eixo das ruas.

Embora as ideias de Freire não se resumissem a essas duas correntes, pode-se dizer que elas predominavam como fundo dos debates que se prolongariam nos anos seguintes. Vítor Freire em suas conferências criticava além dos projetos de Samuel das Neves alguns outros aspectos propostos por Alexandre de Albuquerque (Malta Campos, 2002, p. 128) que tinham origem ainda nos planos de Haussmann para Paris: em sua visão as propostas de alinhamentos em linha reta eram descontextualizadas, ultrapassadas e antiestéticas. Discordando dessa estética, Freire defendia que os traçados fossem tratados por uma irregularidade cuidadosamente controlada, que tivessem variedade volumétrica espacial, que recusassem a monotonia ortogonal. Convicto do pitoresco e dos princípios do urbanismo científico de Sitte, Freire propunha para o centro esses procedimentos e operações: fazendo ver as características do terreno acidentado, a situação do centro sobre uma colina a cavaleiro de dois vales e as linhas de penetração para os bairros. Ao seu olhar, tudo levava à adoção dos traçados não ortogonais e sugeria o pitoresco como recurso de valorização paisagística. É marcante essa postura de Freire, principalmente pela sensibilidade e atenção às condições do sítio. A cidade de São Paulo, como descreve Ab'Sáber (2007, p. 13-5) tem sua originalidade geográfica caracterizada "por um mosaico de colinas, terraços fluviais e planícies de inundações". O Centro da cidade, Triângulo e Praça da República, é discriminado como colinas tabulares de nível intermediário com plataformas de grande importância como elementos do sítio urbano, dispostos de 15 a 25 metros acima do nível dos baixos terraços fluviais e planícies de inundação do Tietê e Pinheiros (Ab'Sáber, 2007, p. 107). Essa condição do sítio de São Paulo deixa suas marcas desde o início dos primeiros traçados coloniais que ligavam os primeiros monumentos (conventos e mosteiros) da cidade, adaptando-os a essas condições geográficas. Por outro lado, a ilha de Manhattan não era destituída de obstáculos ou acidentes geográficos; entretanto, sua topografia em comparação a São Paulo era bem mais plana; o que provavelmente favoreceu, além das escolhas de cultura, a doção de uma retícula para toda a ilha - que corrigiu e fez a transição entre os primeiros traçados de origem holandesa e a configuração predominante de Manhattan.

\footnotetext{
${ }^{40}$ Desenho extraído da obra do engenheiro belga Arthur Virendeel intitulada Traçado de
} ruas e praças públicas, de 1905: Simões Jr., 2004, p. 113. 
Vítor Freire, além de compartilhar as ideias de Camilo Sitte, também teve contatos com os engenheiros municipais nova-iorquinos Nelson Lewis e Frank Backus Williams, que buscavam na Europa subsídios para o zoneamento de Nova York que seria aprovado em 1916 (Malta Campos, 2002, p. 131) ${ }^{41}$.

Em 1914, quando volta da viagem à Europa, Freire faz conferência, no Grêmio Politécnico, onde trata de questões relevantes para a cidade como: a insalubridade das casas individuais construídas em lotes estreitos; a inadequação do padrão de ruas de 16 metros (adotado pelo código de 1886), compatível com a ocupação residencial centroeuropeia, com seus quarteirões compactos, lotes quadrados e blocos de apartamentos com grandes pátios internos (Malta Campos: idem). Ao seu entender, a ocupação de São Paulo se aproximava do existente na Holanda e Inglaterra: com ranques de habitações individuais em lotes compridos, edificações transversais ao terreno e quintais ao fundo: em outros termos; ruas locais estreitas, parcelamento por lotes familiares e ocupação com maior proporção de terreno livre ${ }^{42}$.

Ainda segundo Malta Campos, Freire combatia as normas de inspiração francesa mais especificamente expressa nos padrões geométricos, nas perspectivas de grandes avenidas, bulevares, traçados em xadrez com ou sem diagonais (como em Belo Horizonte) e blocos homogêneos de edificações. Como Sitte, Freire era contra a ideia da solução racional e abstrata da linha reta, particularmente no caso paulistano (2002; p. 133). Nesse sentido, tanto Vítor Freire como Saturnino de Brito defendiam soluções adequadas às situações locais, às particularidades do sítio urbano e a recusa de modelos urbanos arbitrários; ou seja, os acidentes (do relevo e da geografia) deveriam ser "aproveitados para sobre eles se bordarem belezas de realce sugestivo" (Malta Campo apud Saturnino de Brito; 2002; p. 141).

Em torno dessas questões, já se estabelecia um contraponto entre as ideias organicistas de Freire (e outros) e o modelo racionalista, ambos importados ou sintonizados com as discussões de seu tempo. Uma solução híbrida e uma acomodação desenhavam-se à frente, pelo Plano de Avenidas engendrado inicialmente por Ulhôa Cintra e ampliado e concretizado por Francisco Prestes Maia. No entremeio soluções intermediárias procuraram

${ }^{41}$ Vitor Freire participou na Europa do Congresso Internacional e Exposição comparada de Cidades e do Congresso de Saneamento e Salubridade de Berlim e de Estradas em Londres. Freire chegou a trazer para São Paulo relatório elaborado por Lewis e Williams (Malta Campos: 2002; p. 131).

${ }^{42}$ No Brasil essa tradição de origem no urbanismo medieval-renascentista de Portugal (Reis Filho:1973: p. 32) correspondeu a um tipo de lote padronizado e este a um tipo de arquitetura bastante padronizado nas plantas e técnicas construtivas. 
conciliações, como as propostas de Joseph-Antonie Bouvard, então no papel de consultor urbanístico em São Paulo a convite de Freire. Suas propostas e intervenções, para os parques no vale do Anhangabaú e várzea do Carmo, resolveriam ao mesmo tempo problemas paisagísticos, arquitetônicos e econômicos. De alguma forma, seus desenhos para os parques teceram continuidades a partir da colina histórica rumo ao Centro novo e zona leste - e assim, parcialmente desafogaram o congestionado no triângulo e criaram áreas verdes então escassas. Enquanto Freire e Bouvard sonhavam com uma harmonização entre topografia, arquitetura e paisagismo, formando um conjunto de rara integridade e qualidade, intervenções fragmentadas foram incorporadas por aberturas de ruas e melhoramentos; nem sempre articulados numa visão mais ampla (Malta Campos, 2002 p. 181-2).

Segundo Benedito Lima de Toledo (1996), o "Plano de Avenidas", 1930, foi o primeiro "plano de atuação de caráter global" para a cidade de São Paulo, antevendo a questão industrial. Nele encontrava-se o pensamento urbanístico de Francisco Prestes Maia. Toledo (idem) relata as diversas intervenções urbanas do final do século XIX até 1930; manifestações e ideias que abrangem a fase em que se deu a formação do pensamento de Prestes Maia. No próprio estudo para o plano, Prestes Maia menciona diversos autores, urbanistas, planos de cidades diversas dos Estados Unidos e Europa, deixando à mostra o universo pelo qual transitava Donat-Alfred Agache, Georges Haussmann, Nelson Lewis, Frank Backus Williams, Eugene Hénard, Le Corbusier e muitos outros.

Toledo entende a visão urbanística de Prestes Maia como uma defesa das grandes aglomerações urbanas e o urbanismo como uma forma de torná-las mais racionais e eficientes. O sistema viário era base dessa estruturação, sob o qual as demais questões urbanas se articulariam. Esse sistema de avenidas teve origem nos modelos radiaisperimetrais de Stübben e o perímetro de irradiação proposto por Ulhôa Cintra derivado dos estudos de Hénard. Esses elementos, somados à análise de várias experiências urbanísticas internacionais estruturam sua concepção de cidade de caráter pragmático, porém, como pondera Toledo; "sua linha de intervenção, contudo, assemelhava-se mais ao urbanismo praticado nos Estados Unidos nas duas primeiras décadas desse século do que às formulações posteriores, que atingiriam maior maturidade em finais da década de 20 " (1996, p. 267-68). Segundo Samuel Kruchin, o Plano de Avenidas por seu princípio radialperimetral, abria caminho à modernização capitalista e industrial e a sucessão de anéis em torno do centro parece sintetizar no âmbito formal a condição de uma expansão permanente 
(Kruchin apud Malta Campos, 2002, p. 397) ${ }^{43}$. O "esquema teórico para São Paulo", proposto por Prestes Maia, constitui-se tanto numa idealidade, já expressa na perfeição das cidades circulares, que apreende e articula na abstração geométrica todas as singularidades topológicas do sítio, todos os fluxos e futuros, como uma lógica de produção do espaço. $O$ Plano de Avenidas pelas diversas influências que o conformaram teve um caráter híbrido que intencionava a conciliação de teorias diversas: em alguns aspectos serão evidentes as contradições ou ambiguidades: sobretudo na relação entre edifícios altos (espelhados nos arranha-céus de Nova York) e o traçado viário, que pelo seu esquema teórico encontrava-se mais próximo das fontes europeias.

\section{A legislação: a rua e os recuos sucessivos}

"Em 1916 a Diretoria de Obras e a Câmara Municipal haviam organizado a coletânea de obras acumuladas desde o Código de posturas de 1886: exigências para aprovação de plantas (procedimento exigido desde 1893); padrões "haussmannianos" estabelecidos para ruas nobres do centro em 1912; divisão do município em quatro zonas (central, urbana, suburbana e rural), criadas em 1914, recuos especiais nas avenidas mais valorizadas e prescrições para casas operárias" (Malta Campos:2002, p. 217).

Segundo Malta Campos, as concepções higienistas vigentes desde o começo do século XIX tinham para questões de salubridade uma medida baseada na cubagem mínima de ar (30 ou $40 \mathrm{~m}^{3}$ para cada ocupante de um aposento); o que levava à adoção de pésdireitos mínimos entre 4 e 5 metros. Vítor Freire e Alexandre Albuquerque defendiam critérios baseados na insolação e ventilação; "para isso, era imperativo estabelecer recuos e alturas máximas para as edificações, proporcionais à largura das vias e regulamentar as dimensões de pátios e outras áreas livres internas do lote em função da orientação solar e da altura do prédio". Esses critérios surgem das conclusões tiradas do III Congresso de Saneamento e Salubridade da Habitação, em Dresden. Essas novas posturas teriam desdobramentos diretamente ligados ao urbanismo; ou aos seus traçados viários. Em 1917, após congresso Médico de 1916, o novo Código Sanitário do Estado de São Paulo reduziria o pé-direito mínimo para 3 metros. Em 1918 essas mudanças seriam também incorporadas ao código municipal.

${ }^{43}$ Malta Campos faz referências também à obra "The Planning of the Modern City" (1916), de Nelson Lewis, da qual Prestes Maia se aproximaria pelos aspectos de priorizar e regulamentar os edifícios altos e por priorizar os aspectos viários e de transportes, ancorando-se nos aportes ou ponto de vista da engenharia municipal. 
As transformações da legislação da cidade de São Paulo acompanharam, como natural, as mudanças e os embates no plano das ideias urbanísticas: resistia-se aos volumes compactos construídos no alinhamento, típicos da cidade "haussmanniana" (segundo alguns), preferindo-se prédios mais recortados e recuados. Em São Paulo, como em Nova York, procurava-se estabelecer critérios de salubridade e zoneamento, entretanto em São Paulo eram adotados maiores controles nas taxas máximas de ocupação dos lotes e altura das edificações. O projeto elaborado em 1918 no Instituto de Engenharia, por Vítor Freire, Alexandre Albuquerque, Ricardo Severo e outros, estabelecia teto máximo de 30 metros para as edificações. Além de estipular altura máxima conforme a largura das ruas e número máximo de pavimentos, as volumetrias teriam um caráter mais homogêneo, variando de 3 a 9 pisos no triângulo comercial. Segundo Malta Campos, o projeto trazia um dispositivo original semelhante ao escalonamento adotado no zoning de Nova York, porém invertido: o escalonamento ocorreria no sentido dos fundos do lote, garantindo ventilação e insolação dos miolos de quadra.

Em 1920/21 é aprovado o Padrão Municipal para município de São Paulo, com significativas modificações na proposta elaborada no Instituto de Engenharia. Além das definições dos usos (industrial, comercial e residencial) modificavam-se as alturas máximas permitidas: que não seriam mais determinadas por número máximo de pavimentos conforme largura da rua, mas apenas pela largura da rua. Na zona central, que incluiria o triângulo comercial, os índices variavam de 2 vezes a largura da rua (para ruas menores que 9 metros), 2,5 vezes a largura da rua (para ruas entre 9 e 12 metros) e de 3 vezes a largura da rua (para ruas maiores que 12 metros), com teto máximo sem restrições. Restrições de altura eram estipuladas apenas paras as zonas urbanas e suburbanas. Essas modificações romperiam a compactação e homogeneidade "desenhada" nas propostas de Vítor Freire e do Instituto de Engenharia: que para a zona central teriam uma variação média entre 5 e 9 pavimentos. Na Rua São Bento, um exemplo no padrão inferior, com 8 metros de largura ${ }^{44}$, os edifícios passariam de 3 pavimentos para 6 pavimentos (máximo); e em ruas mais largas como a Rua Boa Vista, os edifícios saltariam de 9 pavimentos para 16 pavimentos.

Para Malta Campos, a preconização de coeficientes matemáticos (e "geométricos") abstratos de insolação e ventilação, aplicável a qualquer volumetria, "abriria caminho para o deslocamento entre volume edificado e traçado viário, quebrando os volumes compactos do urbanismo 'europeu' e possibilitando prédios altos".

${ }^{44}$ O Código Athur Saboya, p. 43, II Altura dos edifícios: $\S^{10}-$ para os efeitos deste artigo fica admitida a largura de 9 metros para a Rua São Bento. 
Estava em curso um processo de verticalização, pela construção dos edifícios altos e dos arranha-céus: "Foi também marcante na produção do espaço urbano em São Paulo a inovação do arranha-céu, que surge nos Estados Unidos, e a reação urbanística a ele consubstanciada no zoneamento de Nova York. O Building Code e o zoning de Nova York têm influência direta no nosso Código de Obras Arthur Saboya (1929-1934), que assume as características dos zoneamentos da época, principalmente em relação à definição de alturas" (Somekh, 1997, p. 16). Mais adiante, Somekh acrescentaria que "embora o primeiro período de construção verticalizada tivesse sido denominada 'verticalização europeia', constata-se, entretanto, que a influência predominante na época era americana" (idem, p. 17)(figuras $4.3,4.4$ e 4.5$)$.

No Código Arthur Saboya, aprovado em 1929, novas modificações na altura máxima das edificações e teto máximo confirmam a progressiva liberação das restrições construtivas na zona central. As alturas máximas continuavam a ser determinadas em função da largura da rua, segundo os mesmos índices estabelecidos pelo Padrão Municipal de 1921, porém sem restrições de teto máximo ou limitações de número de pavimentos. A consolidação do código em 1934 introduzia a modificação mais ao caráter de Manhattan: o escalonamento resultado dos recuos sucessivos que permitiam elevação e construção suplementar. Para a zona central, centro tradicional e triângulo, a altura máxima correspondia ao aprovado em 1929, com a introdução do teto máximo, de 80 metros, que poderia ser atingido mediante escalonamento. No Centro Novo, o teto máximo, mediante escalonamento, poderia chegar a 50 metros ou 10 pavimentos. O Código de Obras Arthur Saboya sofreria uma série de alterações e adendos, pelas Leis, Decretos-Lei e Decretos: em casos especiais, como para Avenida Ipiranga ${ }^{45}$, entre outras disposições, determinava-se para os edifícios altura mínima de 39 metros e altura máxima de 115 metros. Nas esquinas dos logradouros com largura mínima de 30 metros esta altura poderia chegar a 135 metros. Outros artigos determinavam recuos laterais a partir de determinada altura e impunham como no art. 5, § 1.que: "Caso dentro de 10 anos, a contar da data da aprovação do projeto, não tendo a edificação alcançado a altura de fixada no art. 3, serão cobrados emolumentos acrescidos, correspondentes a tantas vezes os emolumentos simples da construção total, já pagos, quantos forem os pavimentos ainda não concluídos (Ayres Neto, 1962, p. 318-19)". Esses dispositivos (coercitivos) forçavam uma verticalização forçada em alguns trechos do centro; bem diferente dos problemas enfrentados em Nova York; cuja disposição era construir quase sempre no limite possível da lei. Entretanto há exceções: o Decreto-Lei no 92, de 02 de Maio de 1941, revê no Art. 2, a altura máxima das edificações: "nos pontos focais ou de

${ }^{45}$ Decreto-Lei no 41, de 03 de Agôsto de 1940 - regulamenta as construções na Avenida Ipiranga e dá outras providências. Ayres Neto, 1962, p. 318. 
grande interesse arquitetônico, a juízo da prefeitura, poderão ser admitidas alturas além dos limites deste artigo, desde que os corpos elevados acima de 80 metros não ocupem mais de $25 \%$ da área do lote, se este for interno, 30\% se for de esquina e $35 \%$ se for isolado de todos os lados da rua". Este adendo à lei ratifica dispositivo semelhante contido na legislação de Nova York: que não especificava particularidades de interesse ou não (figuras 4.6, 4.7 e 4.8).

Um novo código seria aprovado pela Lei no 4.615, de 13 de janeiro de 1955, quando foram introduzidas novas leis e normas que mudariam (ou consolidariam) a relação entre o edifício e a rua, na medida em que introduzia coeficientes de aproveitamento do lote, vinculado à sua área: de seis vezes para edifícios comerciais e de quatro vezes para edifícios de habitação ${ }^{46}$. Esses coeficientes procuravam limitar a verticalização e o adensamento: no centro, até então, os coeficientes de aproveitamento chegavam, conforme o caso, acima de 20 vezes a área do lote. Para o centro ainda valia para edifícios no alinhamento, conforme o caso, as normas baseadas na largura da rua e escalonamento; entretanto, como a lei mais restritiva prevalece sobre as demais, a tendência foi a diminuição de investimento no centro: umas das razões de sua decadência, ou obsolescência. Nota-se, que em Chicago e Nova York, ocorre o fenômeno semelhante: "o cálculo da razão entre andar e área, conhecido pela sigla FAR - ou seja, "floor-to-area ratio" -, teve que ser repensado quando Chicago aboliu suas limitações de altura em 1955 e as leis de zoneamento de Nova York de 1916 foram totalmente revistas em 1961" (Rykwert, 2004, p. 307).

\section{Dos traçados aos edifícios}

Como já apontado no capítulo anterior, as diferenças entre Nova York e São Paulo são significativas, senão imensas. Entretanto, alguns rumos ou tendências são compatíveis e a distância (das ideias e do fazer) entre a capital e a "periferia" são mais curtas do que apresentado em alguns discursos. Há, sim, inovações tecnológicas que tem origem nos Estados Unidos como o elevador e o emprego em larga escala das estrutura em aço (industrialização de perfis, montagens, etc.), que foram ( e estão) sendo adotadas em escala no Brasil somente nos últimas décadas ${ }^{47}$. Mas, há também as consideráveis

${ }^{46}$ Lei no 5261, de 4 de Julho de1957 - Estabelece coeficiente de aproveitamento de lotes, densidade demográfica, área mínima de lote por habitação e área mínima de espaços livres, e dá outras providências.

${ }^{47} \mathrm{O}$ edifício Palácio do Comércio de Lucjan Korngold pode ser considerado, segundo Falbel, o primeiro edifício em estrutura metálica construído pela FEM - Fábrica de Estruturas Metálicas- subsidiária da CSN (2003, p. 276). Localizado em frente ao Teatro Municipal ainda hoje é um raro exemplar de estrutura metálica no Centro. 
simultaneidades e semelhanças nos pensamentos urbanísticos, sobretudo, as visões higienistas e seus inúmeros desdobramentos. Há outras como a imensa verticalização ocorrida a partir dos centros históricos, a regulamentação das construções e até o desfecho dominante do "estilo internacional": aqui entremeado pela forte expressão do racionalismo formal e outras variações do estilo moderno vinculado às fontes européias: seja pela proximidade de formação (Le Corbusier), seja pela própria origem européia de muitos dos principais protagonistas.

Como exposto até aqui, nossos principais urbanistas, do início do século passado, conviveram e compartilharam ideias com seus pares nos Estados Unidos e na Europa. As marcas destas trocas encontram-se na cidade; algumas como o Parque do Anhangabaú de Bouvard estão quase apagadas (Bouvard), outras como o Plano de Avenidas, ainda se completam. No período que aqui se estuda, ou seja, as décadas de 30, 40 e 50, a importância quantos aos planos repousa sobre a consolidação do Código Arthur Saboya: que continha os instrumentos da verticalização à maneira de Manhattan. O "Plano de Avenidas" em construção consolidava uma das vertentes surgida nas primeiras décadas do século passado. Como enfatizado por Malta Campos e Simões, a figura de Vítor Freire foi fundamental neste processo: resistiu enquanto pode (e podia) à liberação da verticalização. Freire não se contrapunha apenas à verticalização; muitas de suas convicções, próximas ao ideário de Camillo Sitte, tinham um sentido de pertinência notável quanto ao sítio da cidade de São Paulo, principalmente, tendo em vista a transição dos traçados da colina histórica para as áreas limítrofes como Centro Novo, Várzea do Carmo, Luz e outros (figura 4.9).

No âmbito destes aportes são relevantes as concepções organicistas e compositivas de Sitte, para quem "[...] a construção urbana não deveria ser apenas uma questão técnica, mas também artística; em seu sentido mais próprio e elevado." (Sitte, 1992, p. 15). Princípios artísticos que deveriam estar presentes na configuração das ruas, praças, construções e monumentos; captando através da sensibilidade e olhar treinado as singularidades do lugar e das construções urbanas; que se tornariam "pura obra de arte ao longo dos séculos". Neste sentido, estes fundamentos operativos eram pertinentes para enfrentar uma topografia irregular e acidentada como a de São Paulo, como formar repertórios arquitetônicos para uma cidade ainda por se fazer. Cidade cujos primeiros caminhos e traçados, ao conectar os primeiros monumentos, tinham que se adaptar às dificuldades das encostas e talvegues.

Esta percepção e sensibilidade de Freire quanto ao sítio de São Paulo, seria posta em prática em muitas de suas atitudes. A contratação de Bouvard para consultorias e projeto do parque do Anhangabaú é fruto desta ótica: o projeto do vale teceu as duas 
colinas tabulares Triângulo e Centro Novo (Praça da República), proporcionando ao antigo vale do Chá um novo papel no centro da cidade.

No Plano de Avenidas há de fato um número considerável de influências (citações) informações e reflexões: não há dúvidas que se trata de um plano de características híbridas e de cunho pragmático que confere ordem e significado a um processo de formação fragmentado em andamento até então. Nesta perspectiva é o esquema teórico radialperimetral que amarra e confere sentido à trama urbana. Mas este esquema tem suas dissonâncias internas: seus traçados - as grandes avenidas e as volumetrias das quadras são composições e ordenamento de inspiração européia; Haussmann e Hérnard foram referências diretas. Porém, a referência americana, mais particularmente de Nova York, foi marcante na arquitetura dos edifícios monumentais e simbólicos - como o novo Paço Municipal - e no privilégio dado ao automóvel. No plano estes elementos ajustam-se sob a lógica e os argumentos da idealidade teórica, comprovada nos desenhos harmonizados; não há contradições evidenciadas no patamar das ideias. No entanto, a verticalização intensa, figurada nos edifícios altos ( e arranha-céus) já se esboçava nas silhuetas de fundo dos edifícios secundários representados nas perspectivas dos edifícios institucionais no vale do Anhangabaú. Em novembro de 1929 já era aprovado o Código Arthur Saboya que incorporava o escalonamento (setback) em função da largura da rua.

A desmontagem da harmonia das quadras e suas volumetrias, contidas no plano, prossegue (a verticalização em 1930 já era um fato) na consolidação do Código Arthur Saboya de 1934: no qual se encontra definida a liberação de teto máximo mediante escalonamento até 80 metros: ruas como a Boa Vista com 16 metros de largura, cuja altura máxima no alinhamento poderia atingir 48 metros, poderia acrescentar mais 32 metros, dependendo da profundidade do lote e da área útil dos pavimentos mais recuados.

Em São Paulo, segundo Toledo, o primeiro plano de caráter mais global pensado para cidade industrial é concebido por Prestes Maia ${ }^{48}$, tendo como base um sistema viário, que entre, muitas outras coisas, estabelecia uma articulação ampla entre partes da cidade: que já possuíam um tecido (ruas, quadras e lotes) que se estruturaram gradualmente desde o período colonial, sobretudo, com incrementos mais significativos a partir do final do século XIX. Quando o crescimento acelera-se com a cafeicultura e a industrialização, estes tecidos construídos num tempo razoavelmente longo de maturação da cidade, já se encontram suficientemente estruturados para deixar suas marcas sobre a cidade em expansão. $O$ esquema radial-perimetral adotado por Prestes Maia, procurava ordenar e disciplinar em sua abstração conceitual, aquilo que havia se desenvolvido se formado através de um jogo

\footnotetext{
${ }^{48}$ Simões defende que "melhoramentos de São Paulo", 1911, de Vítor da Silva Freire, seja
} considerado o primeiro plano urbanístico de São Paulo. Op.cit, p. 97. 
complexo de interesses (patrimoniais, econômicos, etc.) e uma geografia (relevo, topografia) que sempre impôs condições difíceis de passagens entre colinas e ocupação das encostas. A implantação do plano mostrou ser possível nos limites dos planejamentos urbanísticos diante de uma metrópole rumo a um crescimento vertiginoso.

\section{Quadrícula x sistema radial-perimetral}

Neste cotejamento entre Nova York e São Paulo uma questão merece ser contemplada, ou seja, a relação entre as quadrículas propostas para Nova York e a formação das quadras em São Paulo decorrentes dos sucessivos planos para a cidade. Num mapa de 1797, na parte baixa de Manhattan vê-se uma primeira trama ortogonal, que seria depois estendida em 1811 até o Rio Harlem. Esta disposição inicial tinha lá suas exceções ao incorporar a antiga trilha indígena, então, denominada Broadway. Mas, como enfatiza Koolhaas a quadrícula impõe um programa intelectual para a ilha, e sua disciplina bidimensional libera a anarquia tridimensional, assim, os construtores estavam obrigados a desenvolver novas estratégias para diferenciar uma quadra da outra: através dos edifícios em lotes ou ocupando quadras inteiras. A quadrícula tem, portanto, um duplo significado; uniformiza (ou iguala) e libera, mostrando-se flexível. Embora, a quadrícula por si só não seja uma condição que define a priori uma isotropia, ela com certeza submete planos e edifícios, que de alguma forma, ajustam-se há a ela ${ }^{49}$. Se em Nova York tem-se esta condição de partida, quando a cidade ainda tinha cerca de 120 mil habitantes, em São Paulo, como visto esta configuração toma forma conceitual mais consistente no Plano de Avenidas. Mas neste momento, São Paulo tem cerca de 900 mil habitantes e uma série de arruamentos e parcelamentos que já eram realidade e frutos, como no Centro Histórico, das trilhas, caminhos, parcelamento de sítios e chácaras e planos de melhoramentos. Neste sentido, aqui se fez uma cidade (enquanto, contida num certo controle) de caráter mais orgânico, adaptativo e pragmático. Se a malha regular implica um programa intelectual sobre a realidade, em São Paulo o esquema radial-perimetral procurou ordenar uma série de fragmentos ou partes dispersas da cidade. Ou melhor, continuou a tecer (religar) partes desta realidade com traçados já pré-estabelecidos na colina histórica, no centro novo, nos

${ }^{49}$ Rykwert (2006, p. 91-3) adverte, discorrendo sobre os traçados ortogonais e suas origens, que a cidade hipodâmica, embora, ortogonal era subdivida em zonas conforme as distintas classes de seus habitantes e segundo a forma da posse da terra: guerreiros, agricultores e artesãos; sagrada, pública ou privada. Nesta complexidade das origens, Rykwert alerta que Hipódamo foi urbanista, teórico da política e estudioso dos fenômenos celestes. Este fato confere à trama ortogonal outro significado, além do aspecto geométrico. Em outras passagens, dirá que os traçados ortogonais antecedem as realizações gregas e estão vinculados a ritos muito antigos e que para entendê-los seria necessário retomar os ritos em seu sentido de ação e repetição. 
parques do Anhangabaú e do Carmo, nos vales, nas avenidas e nos anéis perimetrais (figuras 4.10 e 4.11 ).

O esquema teórico proposto por Prestes Maia para São Paulo não deixa de estabelecer uma ordem e um sentido para as diferentes partes então conectadas. Longe ele está da ideia da quadrícula, pois ele mais costura do que define uma lógica formal de ocupação, sobretudo, tendo em vista o centro histórico de São Paulo. Em Manhattan as tramas são ortogonais, com algumas modulações distintas de quadras; mas, mesmo no sul da ilha, local das primeiras ocupações, esta formação ocorre com algumas poucas transições esconsas. Sob este aspecto, podem-se entender as generalizações de Koolhaas a respeito dos edifícios em Manhattan; delírios, verticalização (reprodução do lote) e a formas dos edifícios como extrusões decorrentes do zoneamento e do código de edificação de $1916^{50}$. Os desenhos expressivos de Ferriss a partir dos estudos de Raymond Hood, Willey Corbett e outros, pela sua força e demonstração da lei dos setbacks constroem em parte esta leitura de Koolhaas; impregnada ainda pelo resultado tanto qualitativo como quantitativo da enorme massa construída, verticalizada, recortada e expressiva: imagens e fatos de um manhattanismo; que de muitas maneiras deitou seu "estilo" mundo afora (figuras 4.12 e 4.13 ).

\section{Extrusão x Composição}

Koolhaas defende em uma Nova York Delirante a ideia de que a forma dos edifícios (arranha-céus) é decorrente, entre outros fatores, de uma extrusão (saída forçada; expulsão) da lei e da lógica da reprodução do lote - seu discurso "paranóico delirante" identifica uma lógica verossímil, mas sua eloqüência parece reduzir estas formas apenas ao papel inegável da legislação.

Carol Willis comunga em parte as mesmas ideias: porém, a um "envelopamento" ou extrusão imperativa, ela acrescenta tanto condicionantes construtivas como de ordem interna ao layout dos escritórios. O sistema em aço da estrutura, "steel-cage" (gaiola de aço ou grelha de aço), exigia um intervalo regular para as massas a serem construídas a partir da legislação: o recuo determinado pela legislação deveria compatibilizar-se com a modulação estrutural (Willis, 1995, p. 72-3), dentro de parâmetros aceitáveis; além de incorporar medidas padronizadas para os compartimentos de trabalho. Se para Nova York esta afirmação precisa ser vista com restrições, para o Centro Histórico de São Paulo, esta condição não pode ser admitida sem reservas (figuras 4.14, e 4.15).

\footnotetext{
${ }^{50}$ As leis de zoneamento de Nova York de 1916 foram revistas depois da liberação das alturas dos edifícios em Chicago em 1955. Rykwert, 2004, p. 307.
} 
Pelo contrário, em São Paulo, enquanto ainda vigorava o escalonamento, o que ocorreu foi mais uma composição difícil, do que uma extrusão resultante da direta aplicação da lei sobre as potencialidades construtivas do lote. Não se nega a força da lei , entretanto, tem tanto peso quanto a formação orgânica do tecido urbano: através dos traçados dos caminhos e arruamentos pouco regulares; que resultariam em quadras com formatos irregulares; que parceladas conformariam lotes também irregulares; muitas vezes esconsos e frutos de diversos parcelamentos e remembramentos complexos.

Admitindo-se que as quadras no perfeito esquadro (quadradas ou retangulares) eram (e são) raras no Centro Histórico de São Paulo, suas subdivisões em lotes regulares também o eram: mesmo que as testadas dos lotes tivessem uma medida padrão, como atestam alguns autores. Desta forma, numa quadra irregular ou não, alinhava-se a testada do lote ortogonalmente ao alinhamento da rua; por sua vez, o lote oposto também era alinhado ortogonalmente à respectiva rua, gerando assim, no encontro dos lotes desalinhamentos e conformações poligonais das mais diferentes configurações. Quando as linhas demarcadoras dos lotes iam de uma rua à outra, ficava mais caracterizada a forma irregular que viria mais à frente impor acertos e operações de projeto que as dominassem em favor de uma conduta estética harmonizada; que corrigisse as formas dos compartimentos, sobretudo, junto às dividas do terreno, pois não havia recuos laterais obrigatórios.

Em Nova York, a força imperativa da quadrícula propiciou uma subdivisão de quadras e lotes mais regulares e ortogonais às ruas e avenidas (há como sempre exceções): a abstração quase isotrópica da quadrícula manifesta-se também na divisão dos lotes e vincula-se mais profundamente aos valores de igualdade, impessoalidade, marcantes da cultura americana: sob este aspecto, a nomeação codificada das ruas (como em Brasília) paira acima de toponímias e singularidades ${ }^{51}$.

Embora, em Nova York muitos remembramentos tenham gerado terrenos irregulares, estes foram constituídos por agrupamentos mais retangulares. Esta disposição contribuiu para a maior uniformidade e caracterização das massas (volumetrias) dos edifícios; ainda que na singularidade de cada um seja possível ver variações nos acertos dos escalonamentos e alturas; nem sempre se levantavam os edifícios até aonde a lei permitia.

De qualquer maneira, em São Paulo, além destes fatores relevantes da formação, podem-se acrescentar outros que indicam um afastamento das referências e cultura de Nova York; neste sentido, dois tópicos relativos à legislação são oportunos para

${ }^{51}$ Nas origens o lugar parece sempre se reportar às toponímias e Nova York não é diferente:. segundo Rykwert, Manna-hata ;"talvez significando ilha-montanha", 2004, p. 264. 
demonstração: na legislação paulistana havia um artigo que permitia que edifícios de esquina tivessem um rebatimento (20 metros) em sua volumetria, adotando-se as restrições relativas à rua de maior largura; outro artigo privilegiava os lotes situados nas esquinas das grandes avenidas (pontos focais relevantes), permitindo-Ihes maiores índices construtivos e alturas $^{52}$ : para estes casos, foi adotado em 1941, artigo semelhante à legislação de Nova York de 1916, que já liberava as torres, até o limite da técnica e das viabilidades econômicas, desde que contidas numa ocupação de $25 \%$ da área do lote.

Em Nova York o escalonamento era pautado pela largura da rua simplesmente, não casos aparentes fora do zoneamento: por isso os edifícios mais altos encontram-se geralmente implantados nas grandes avenidas, ou nas esquinas dessas. Estas particularidades locais não só revelam os acomodamentos legislativos aos interesses de diversas ordens e às circunstâncias físicas, mas os sentidos de nossa cultura híbrida; já exposta na sucessão de ideias para a cidade e seus edifícios.

Estes fatores de formação promoveram uma configuração bem distinta entre as duas cidades. Em Nova York os edifícios são mais altos e "homogêneos" e parecem saídos de uma mesma fôrma [com reservas], não há tantas empenas cegas entre os arranha-céus. Em São Paulo, os edifícios são mais baixos - com exceção dos poucos arranha-céus - e heterogêneos. Num certo sentido, cada edifício é grosso modo um caso singular: ou seja, uma composição difícil. Portanto, residem nesta característica as virtudes e peculiaridades desta arquitetura edificada no Centro de São Paulo: independente das questões estilísticas ou de que moderno se trata.

Para esta tese em construção, que trabalha a partir de um recorte da arquitetura e da cidade moderna, a questão compositiva assume relevância ainda maior, pois os princípios de uma arquitetura sistêmica e racionalizada como manifestadas nas doutrinas modernas não se ajusta a um contexto tão adverso: mas é desta relação ambígua que faz a arquitetura moderna no Centro Histórico de São Paulo.

52 Decreto-Lei no 92, de 02 de maio de 1941. Neste decreto, no art.2, inciso III, § único , introduz condição para corpos elevados acima de 80 metros, segundo uma porcentagem da área do lote; disposição semelhante à legislação de 1916 em Nova York. Ayres Neto (1962, p. 326). 


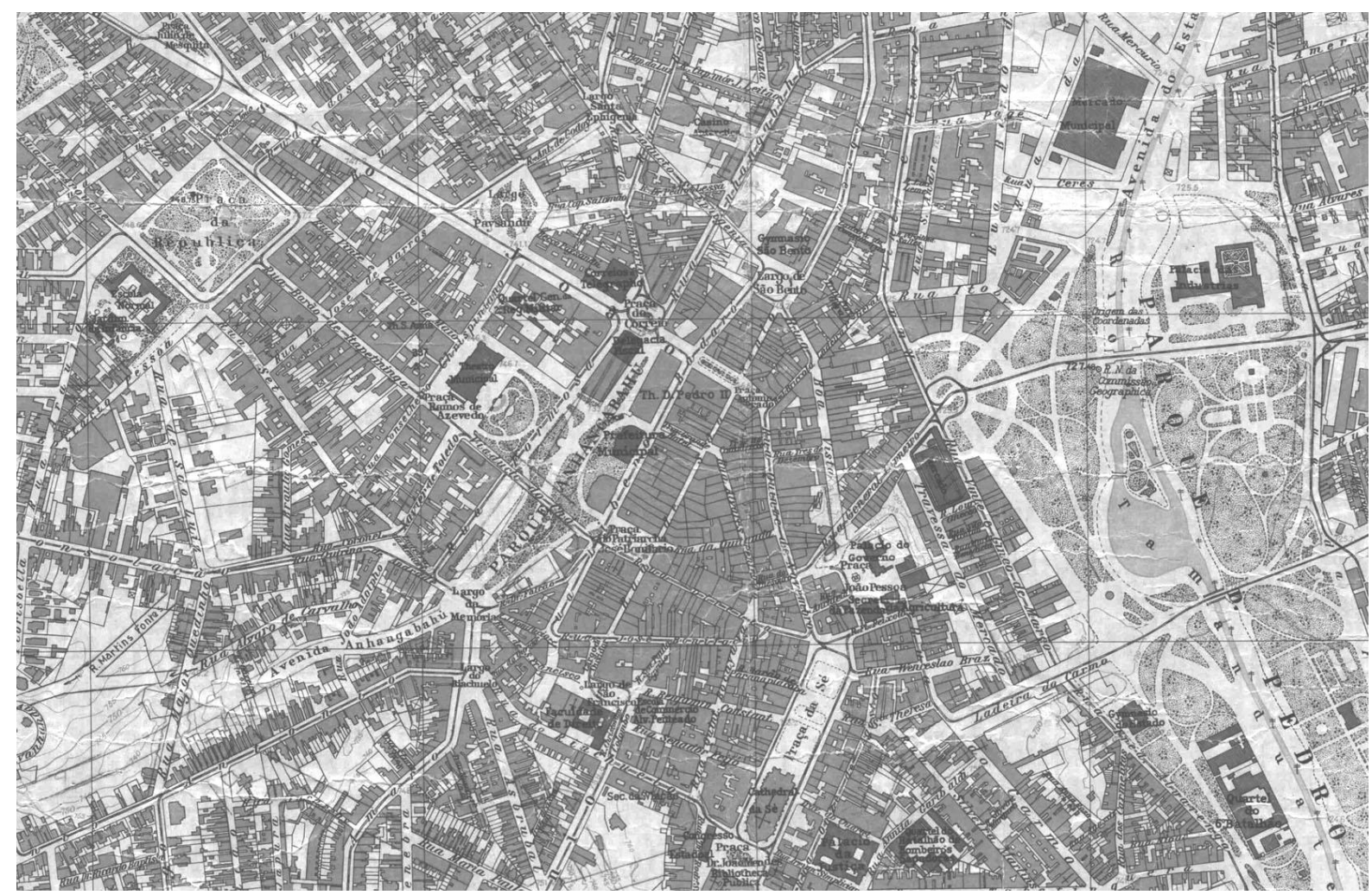

4.1: Sara Brasil, 1930. Colina Histórica e Centro Novo.

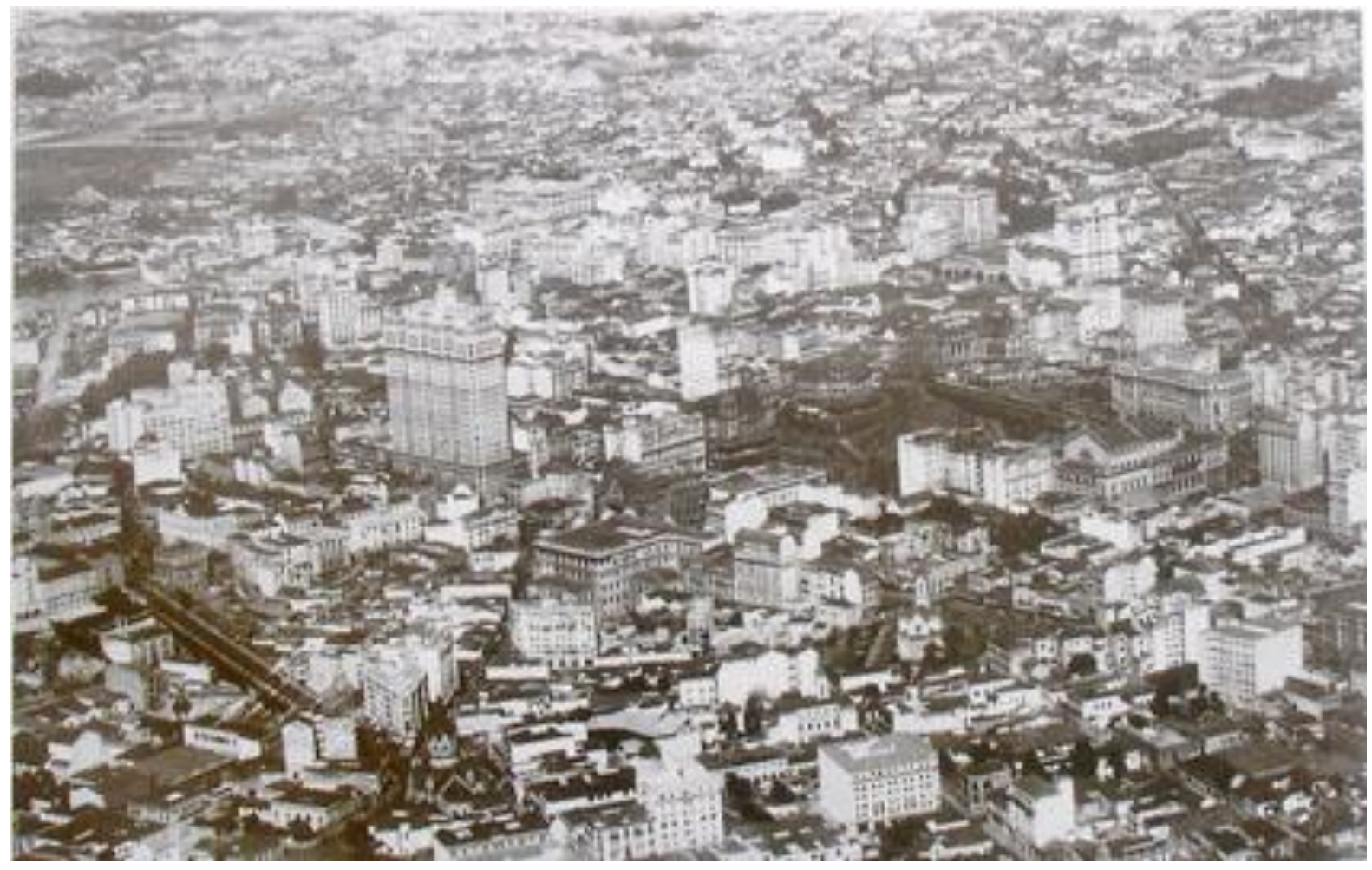

4.2: São Paulo, 1930. Colina Histórica e Centro Novo. 

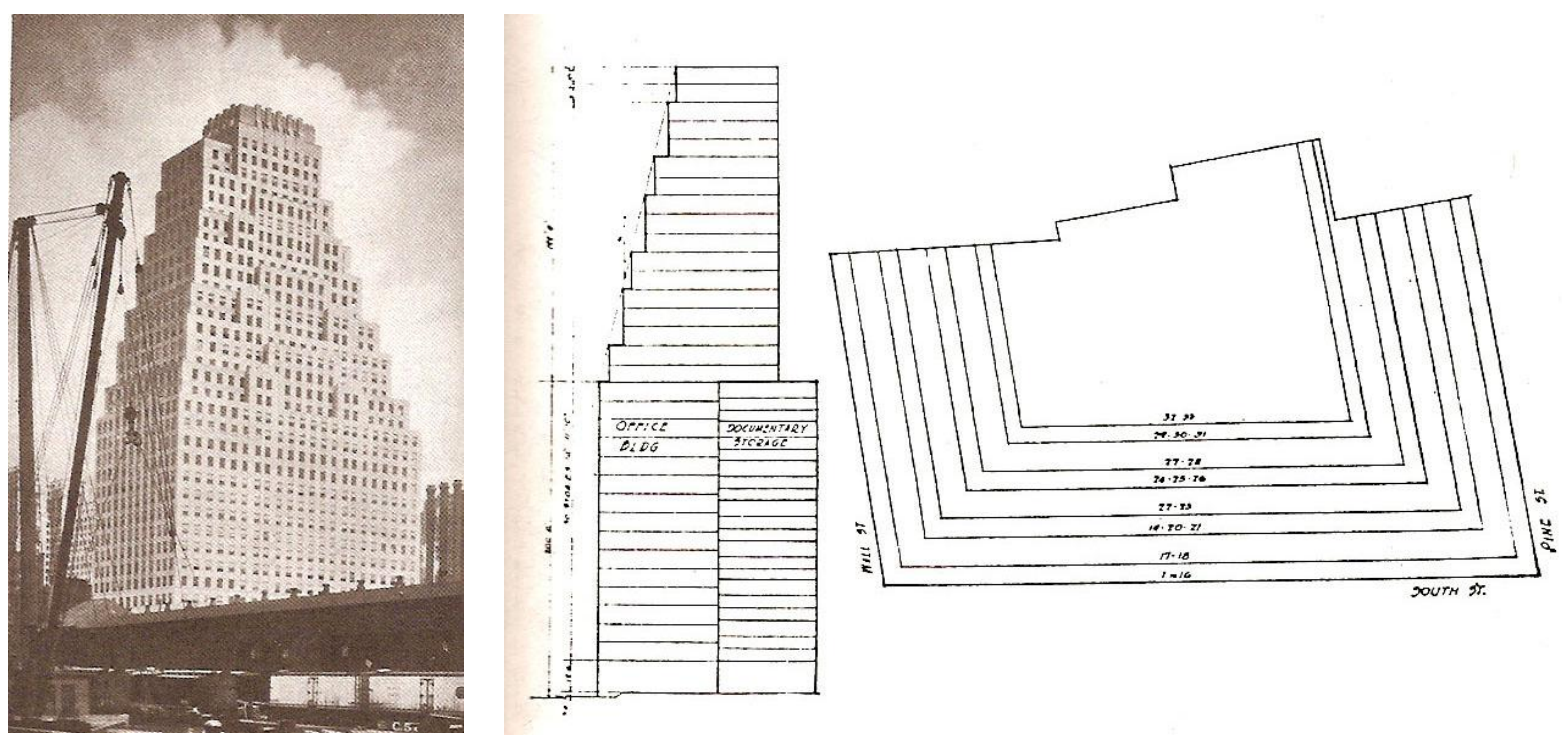

4.3: Edifício 120 Wall Street, 1930; Ely Kahan - estudos de aproveitamento do lote e estrutura segundo legislação, visando o acerto das concordâncias pelas diagonais das arestas..

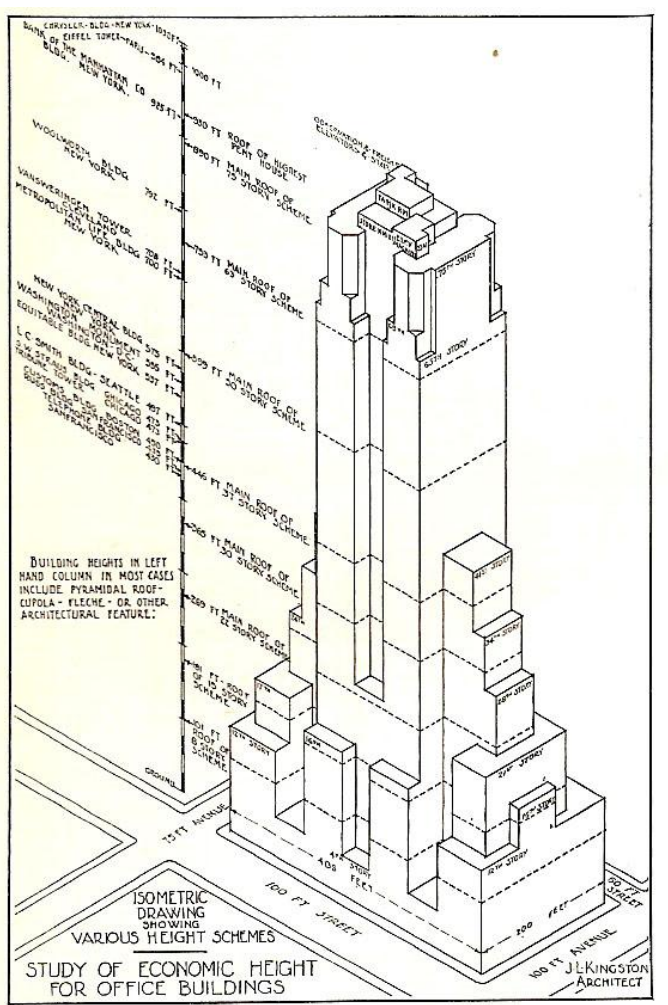

4.4: Diagrama demonstrativo da altura econômica mais viável.

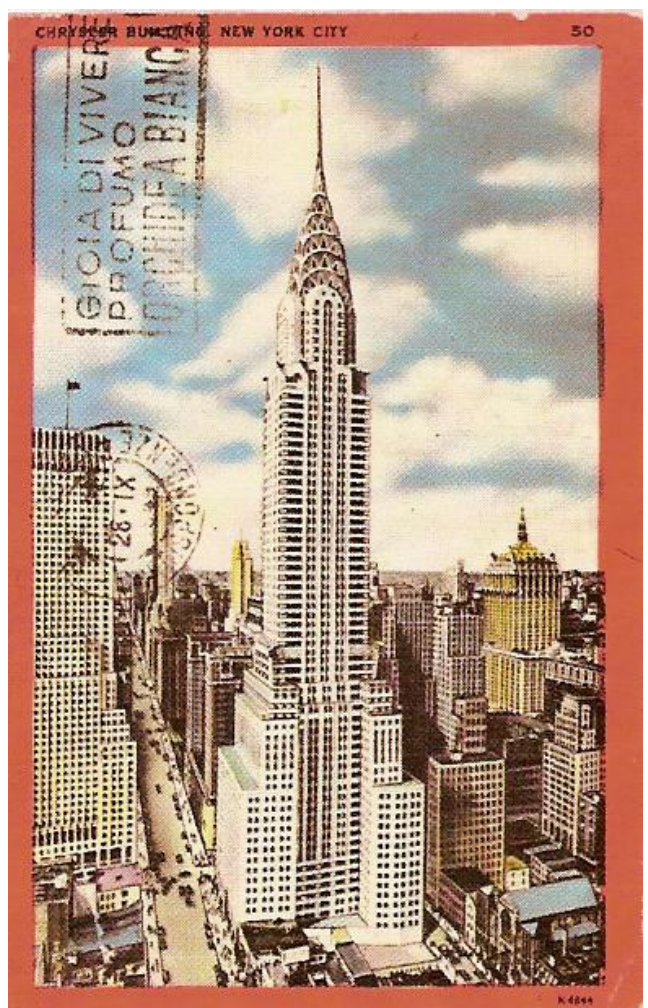

4.5: Chrysler Building, 1930, NY, William van.Alen. 


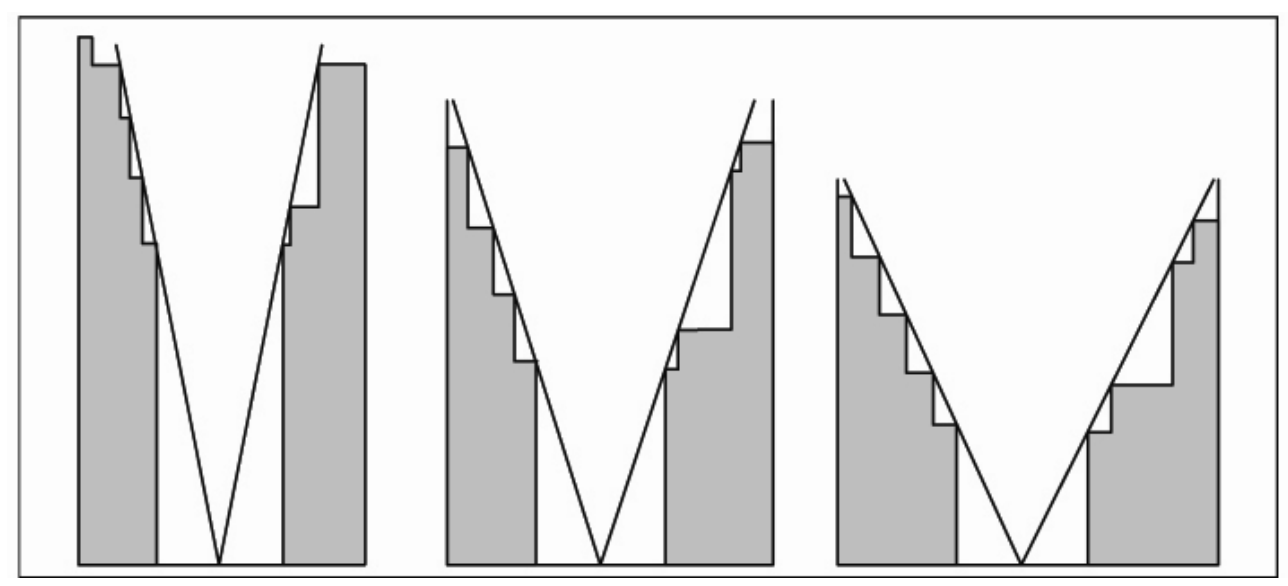

4.6: diagrama do zoneamento em Nova York em função da largura da rua. A hipotenusa que determina o setback tem origem no meio da via.

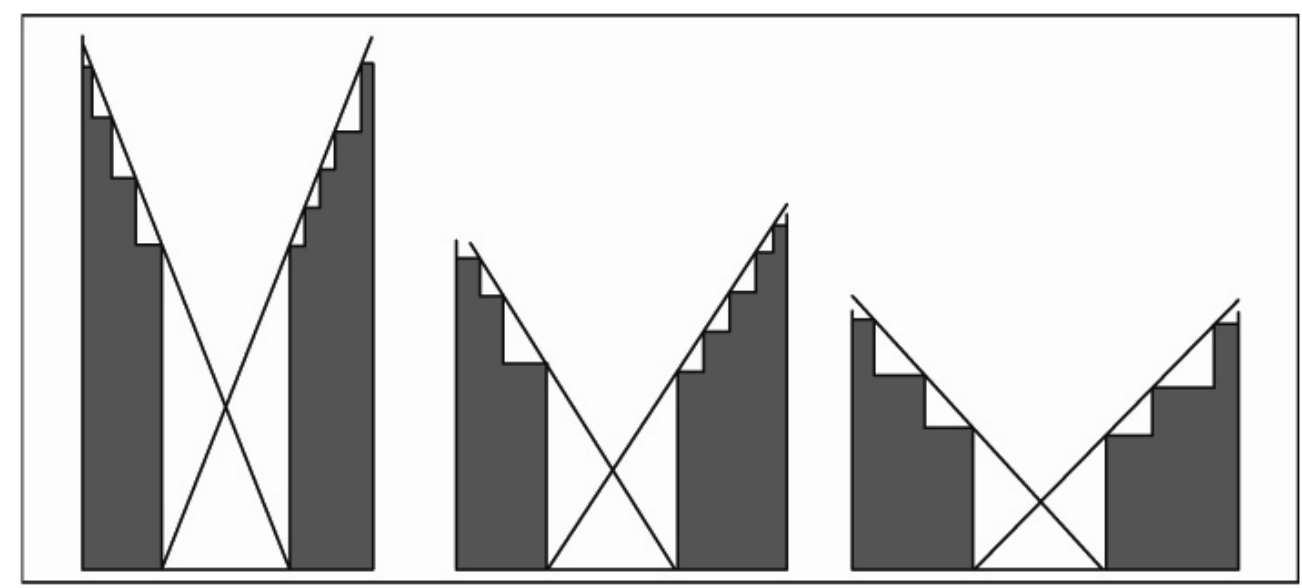

4.7: ensaio sobre diagrama de Nova York sob legislação de São Paulo, cuja hipotenusa é posta no alinhamento oposto. Nota-se menor altura.
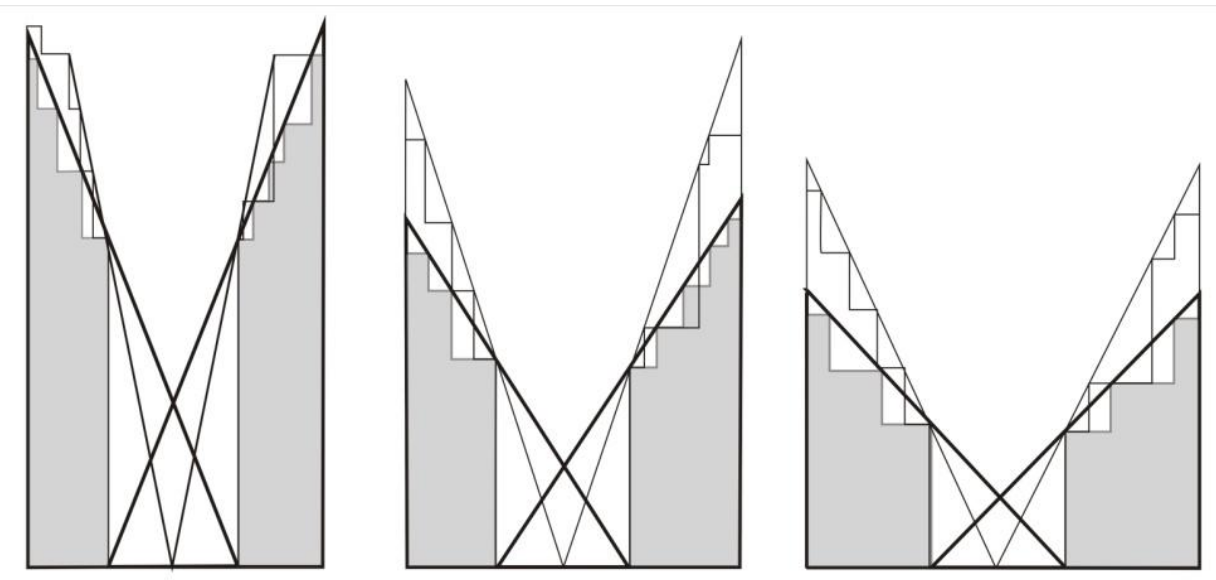

4.8: Sobreposição dos diagramas das duas legislações. 


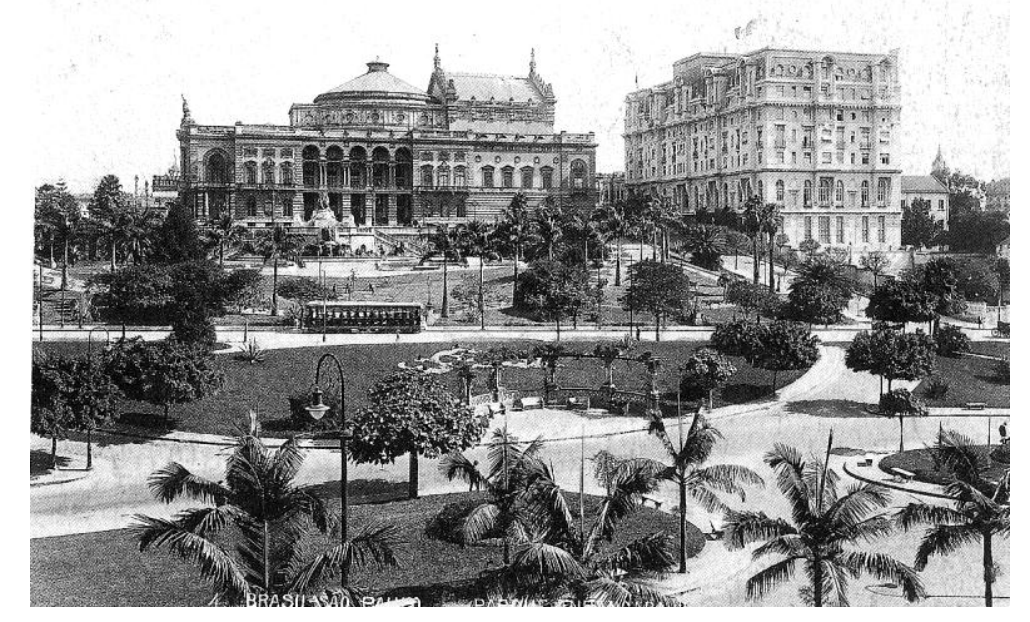

4.9: Parque do Anhangabaú: Bouvard.

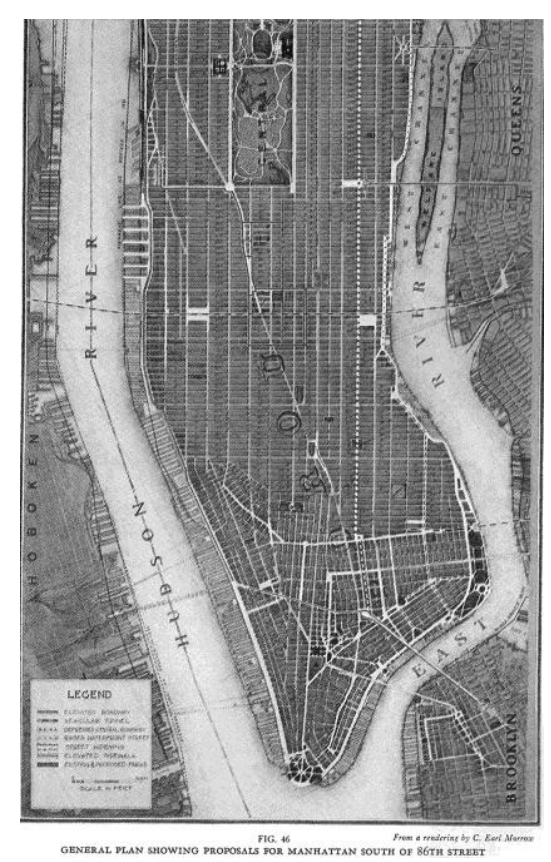

4.10: Manhattan - quadrícula

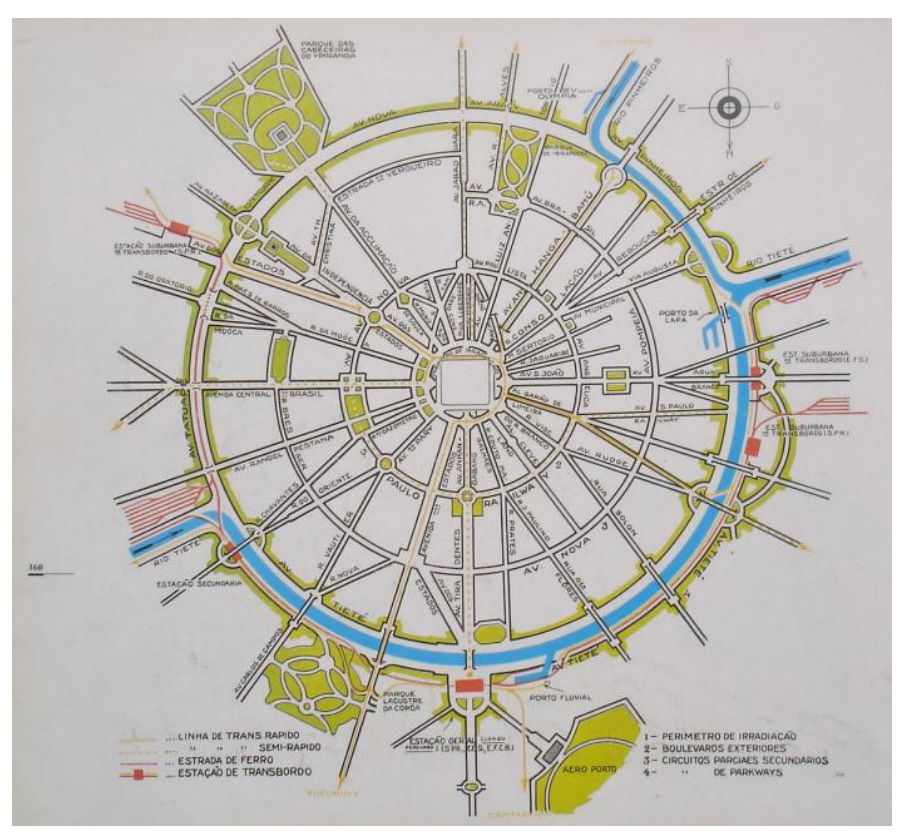

4.11:Esquema conceitual Plano de Avenidas.

A quadrícula deita de antemão uma ordem sobre o território: uma bastração que acomoda um por vir. O esquema de Prestes Maia retoma o sistema radial-perimetral, procura ordenar um território admitindo suas singularidades. 


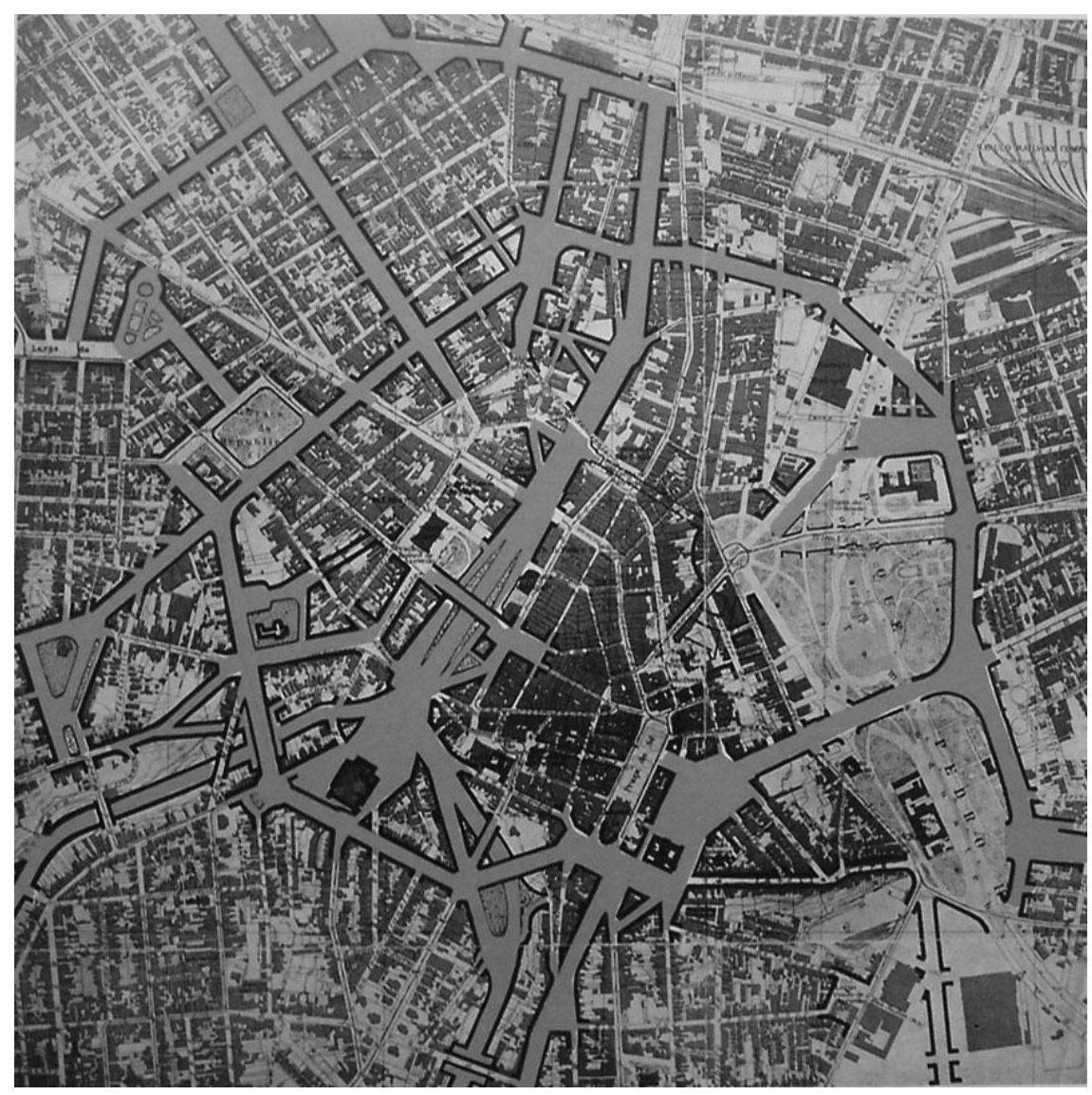

4.12: Traçado do perímetro de irradiação - Plano de Avenidas, sobre base Sara Brasil

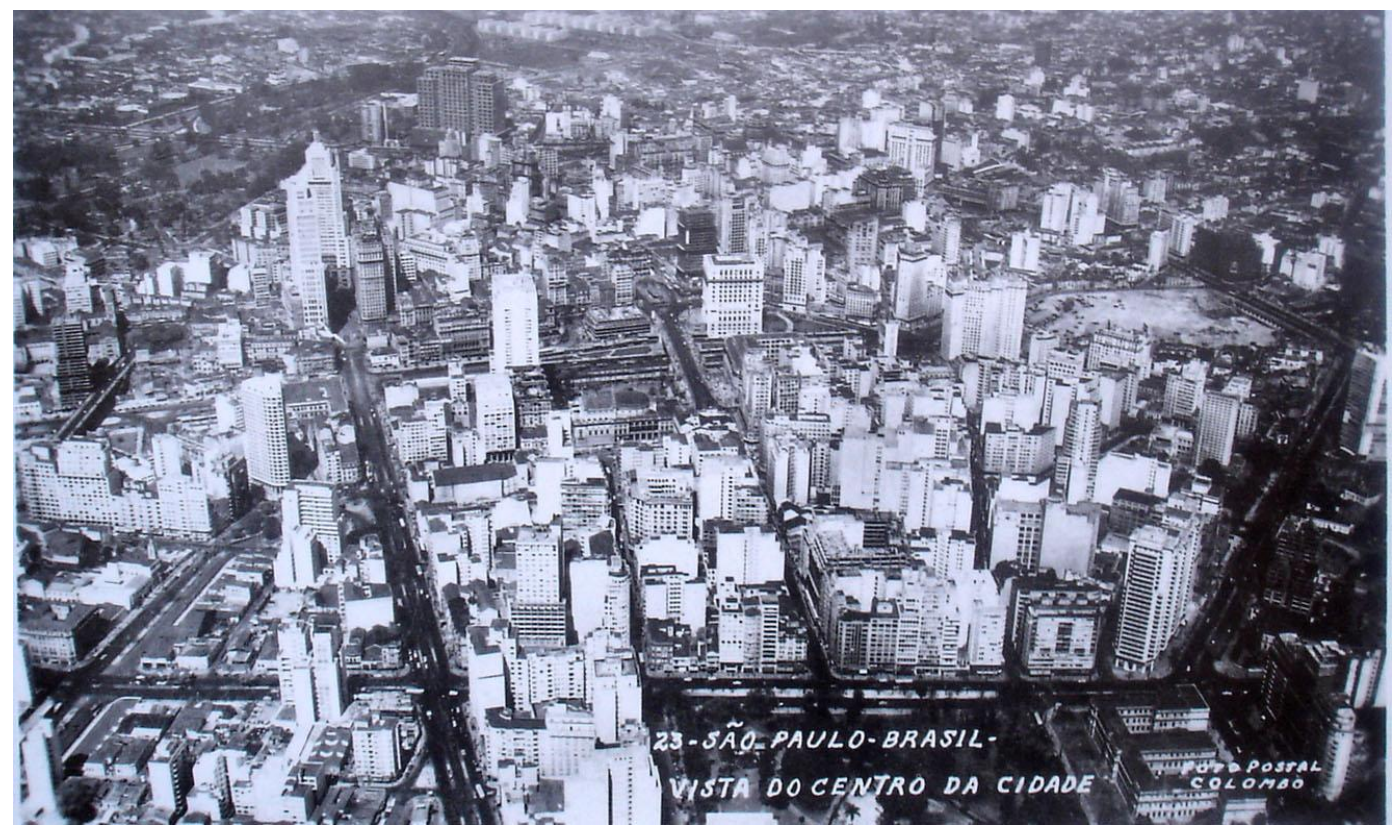

4.13: São Paulo década de 50 com as avenidas implantadas. 

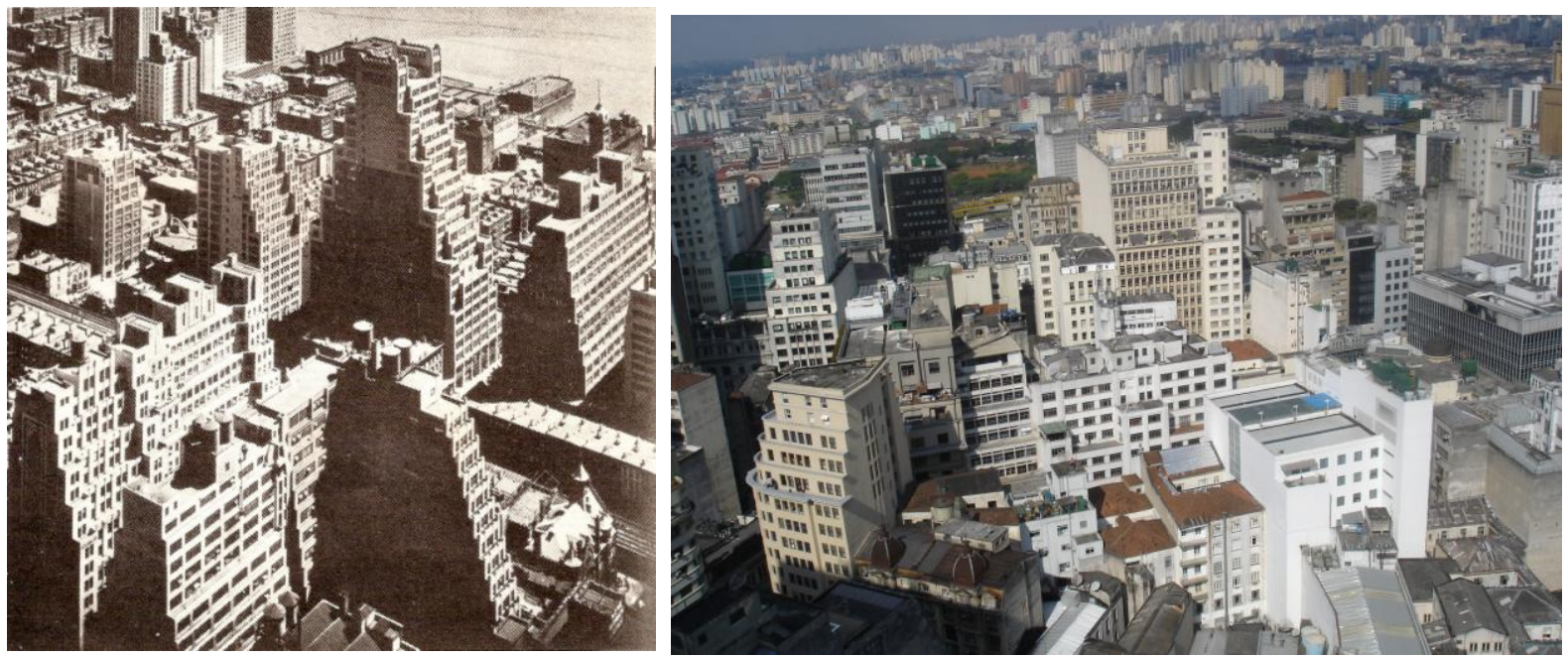

4.14: Pormenores de Nova York ( Mid-Town, Manhattan)e São Paulo (triângulo): extrusão $\mathrm{x}$ composição

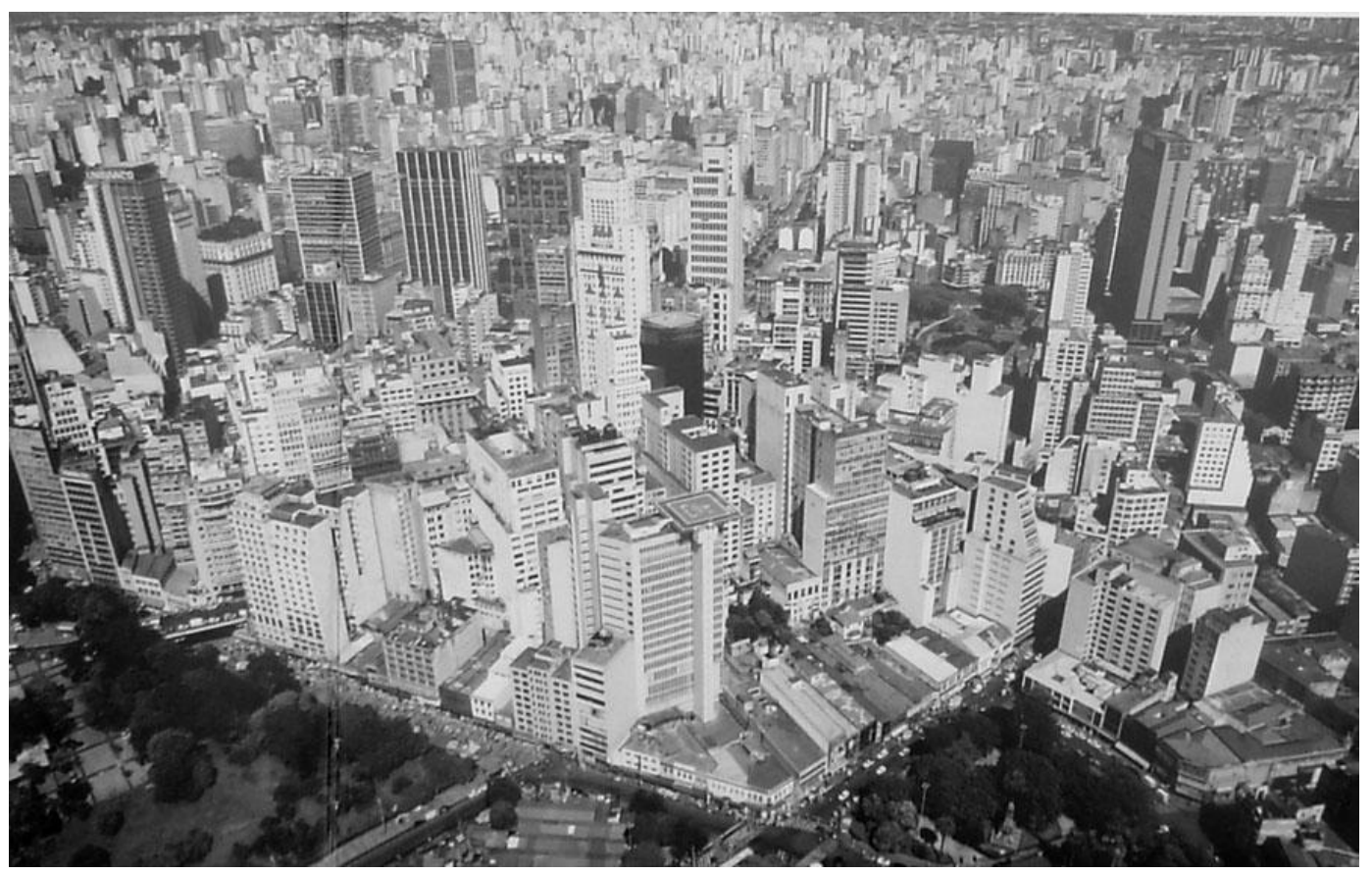

4.15: Vista aérea: Colina Histórica 


\section{Objeto-tipo: moderno e brasileiro}

"O Ministério da Educação, por sua pureza formal e pela ideia que dá do domínio da razão sobre a inércia da matéria, contrasta fortemente com a maior parte dos edifícios circunvizinhos que foram construídos na mesma época, com os mesmos materiais e para o mesmo fim utilitário. Além de belo, o edifício tem valor simbólico, porquanto representa a vitória das novas tendências sobre o conformismo e o dogmatismo predominante." (Lucio Costa apud Argan, Xavier, 2003, p.173.)

"Ainda que aderente, no que diz respeito à tipologia formal, aos modos da arquitetura europeia, a arquitetura brasileira desenvolveu-se em sentido paralelo porém contrário: começou por colocar-se o problema dos grandes centros administrativos e só posteriormente "desceu" às questões da habitação, da edificação popular , do urbanismo." (Argan, Xavier, 2003, p.172.)

O MESP - Ministério da Educação e Saúde Pública, 1936 - é tido como marco fundamental da arquitetura moderna brasileira. Algumas obras modernas o antecederam no Rio de Janeiro e em São Paulo. O Edifício-Sede do IPASE (1933) e o Edifício Esther (1935) são exemplos citados pela historiografia. As construções desses prédios demarcaram os primeiros encontros entre a arquitetura moderna e a cidade tradicional nas duas cidades. Entre uma idealidade (ou programa) em formação e as cidades em processos de modernização guardando ainda as características de um tecido urbano à maneira da cidade tradicional.

$\mathrm{Na}$ região central da cidade do Rio de Janeiro o plano Agache prescrevia uma tipologia composta por blocos de edifícios na periferia da quadra, deixando pátios em seu interior. Uma tipologia na qual a quadra e o sistema viário assumem papel relevante na configuração da cidade. Nesse urbanismo o controle das alturas das edificações, a partir de um gabarito uniformizador, propõe uma estética de caráter europeia. Nestes termos, a quadra foi pensada como uma unidade formal.

Em São Paulo, principalmente a partir do código Arthur Saboya, ocorreu algo bem diferente: uma estetização europeia com controles de gabaritos para os edifícios tratando a quadra como unidade formal foi abandonada: a rua (e sua largura) fora o elemento que definiu alturas e formas dos edifícios e por decorrência conformou a volumetria das quadras $^{53}$.

Essas duas condições demarcam inícios bem diferentes entre as arquiteturas modernas nas duas cidades. Mas além desse fato o MESP encarna a ideia da arquitetura

\footnotetext{
${ }^{53}$ Ver capítulo 7: Primeiros Encontros
} 
moderna brasileira patrocinada pelo Estado. Em São Paulo, pelo contrário, em seu Centro Histórico a arquitetura moderna nasce em meio aos processos de modernização e particularmente vinculados aos interesses privados.

O MESP não inaugura esses encontros entre a arquitetura moderna e os tecidos tradicionais - mas pelo seu caráter excepcional - político-cultural - encabeça a frente de batalha entre essas concepções muitas vezes conflitantes. O prédio do Ministério é fundamental - não só por ser uma das primeiras realizações em grande escala e a nível internacional, das ideias de Le Corbusier (Xavier, 1991, p.37) - mas também por expor o confronto e as ambiguidades entre o edifício moderno e a cidade de caráter tradicional que privilegia a rua-corredor como espaço público primordial: especialmente porque o edifício moderno (ou os diversos edifícios na versão corbusieriana) nasce vinculado a uma ideia de cidade racionalizada. Lato senso, o edifício é uma célula ampliada que conformará setores de uma cidade, que entre muitas negações ou reações, procurará desmanchar o lote e a quadra tradicional e a rua-corredor. Esses edifícios quando exercitados fora do contexto dos projetos urbanos funcionaram como objetos-tipo; que realimentaram as próprias ideias de cidade de alguma forma neles contido. Num certo sentido, a cidade estava contida numa célula e num edifício.

Sob esse aspecto o MESP é também o momento em que Le Corbusier enfrenta naqueles dias com mais liberdade o edifício de grande porte tratando-o como um fragmento retirado de uma de suas cidades ideais. Outros edifícios de Le Corbusier desempenharam papel semelhante: Centrosoyus,1928-36, em Moscou; Cité du Refuge,1929-33, em Paris, Pavilhão Suíço, 1930-31, em Paris. Todos são anteriores ao Ministério da Educação. O Centrosoyus, por exemplo, foi referência direta para as equipes brasileiras de caráter moderno que participaram do concurso do MESP. Pelo seu porte e disposição ele já se colocava como um grande complexo construído à parte da trama urbana. Mas foi no projeto do Cité du Refuge que Le Corbusier enfrentou todas as dificuldades em lidar com um lote tradicional e com as novas tecnologias; na escala de um grande edifício.

Este capítulo prossegue discutindo inicialmente Le Corbusier e seus objetos-tipo. Em seguida, aborda-se sua primeira experiência concreta no Brasil pelo projeto do MESP. A intenção é reencontrar o fio dessas experiências e fazer a transposição para São Paulo: especificamente para o Centro Histórico de São Paulo: cuja formação e legislação já delineavam outros caminhos. O MESP contém os elementos arquitetônicos e urbanos formadores de uma obra paradigmática - um objeto-tipo a ser confrontado nos capítulos seguintes. 


\section{Le Corbusier das unidades de habitação à cidade}

Conforme salienta Argan o edifício moderno nasce interligado às questões de habitação e por extensão aos problemas da cidade, na dimensão do urbanismo. Para a arquitetura moderna brasileira estritamente vinculada à Le Corbusier esse aspecto é relevante, pois parte considerável dessa produção ocorreu em condições adversas: os primeiros edifícios modernos no Rio de Janeiro e São Paulo são inicialmente destinados às torres de serviços. Há exceções; o Edifício Esther, por exemplo, foi concebido como de uso misto; porém a predominância no CHSP tendeu para os de serviço e comércio ${ }^{54}$.

A gênese e as transformações das obras de Le Corbusier demonstram um percurso no qual os edifícios mesmo quando projetados isoladamente ou em contextos pré-existentes estavam vinculados às suas ideias de cidade.

Os projetos e esquemas como Dom-ino, Citrohan e o pavilhão do Espírito Novo são os embriões dos Edifícios-Villas e dos loteamentos à redent presentes na Cidade Contemporânea, Plano Voisin (figura 5.1) e Cidade Radiosa ${ }^{55}$. Autores como Alan Colquhoun, Stanislaus von Moos e William Curtis descrevem esse processo: as casas La Roche, Stein, Baizeau e Savoye conformaram uma síntese compositiva, nas quais os cinco pontos são esquematizados, como elementos a serem experimentados na prática urbana. Embora novos esquemas, protótipos e elementos de arquitetura surgissem no decorrer do trabalho de Le Corbusier, muitas vezes isoladamente, eles foram sempre incorporados no arranjo de uma nova ideia para a cidade da era da máquina - racionalizada e hierarquizada - ou testados em um de seus objetos-tipo.

Portanto, os edifícios isolados projetados e construídos por Le Corbusier não podem, somente, ser entendidos separadamente de suas concepções de cidade. Pelo contrário, nelas os edifícios para habitação ou para os negócios (arranha-céus) estão articulados em um sistema viário e estrutura fundiária que confronta a formação e divisão tradicional. Nas cidades idealizadas a forma dos edifícios, sejam as lâminas à redent ou os arranha-céus cruciformes (depois cartesiano), é decorrente, primordialmente, das condições ótimas de ventilação, iluminação e insolação, de maneira a propiciar insolação diária a três fachadas: sul, leste e oeste (figura à redent/com norte).

Além desses aspectos lembremos a condenação peremptória da rua-corredor como raiz das mazelas da insalubridade e da circulação: elemento da tradição que deve ser combatido e eliminado. Por decorrência, são condenadas as construções situadas sobre os

\footnotetext{
${ }^{54} \mathrm{Na}$ Avenida São Luís também houve um grande número de edifícios destinados à habitação.

${ }^{55}$ Os primeiros arranjos propostos a partir do esquema Dom-ino, 1914, já esboçavam arranjos (composições) à redents: que seriam renovadas para os planos subsequentes.
} 
alinhamentos da rua ou sobre as divisas do lote: em outros termos, propõem-se uma nova divisão fundiária e um traçado regulador que dê conta das novas questões de circulação surgidas com advento da industrialização.

$\mathrm{Na}$ "Cidade Contemporânea para três milhões de pessoas" o centro da cidade é o cruzamento de um complexo sistema de circulação, envolto por arranha-céus de negócios de 60 pavimentos (aproximadamente 200 metros) de altura. Coincidentemente, os arranhacéus e edifícios altos de negócios são a tipologia predominante no Centro de São Paulo. Todavia, esses edifícios não foram edificados isoladamente um dos outros e envoltos por enorme área verde. Ao contrário, eles ergueram-se lado a lado, colados e determinados pelas contingências da divisão fundiária, da legislação e, principalmente, da rua: pois a partir dela são determinadas alturas, ocupações e densidades - nos mesmos moldes da verticalização e dos arranha-céus de Nova York ${ }^{56}$, como já exposto nos capítulos 3 e 4.

\section{Os objetos-tipo e os contextos pré-existentes}

Le Corbusier foi uma personalidade complexa e multifacetada, assim como sua arquitetura e proposições. Ele caminhou pela utopia com plena consciência de sua empreitada e de suas limitações, manifestadas, muitas vezes, em suas obras em contextos urbanos pré-existentes. Alan Colquhoun analisa algumas delas em "As estratégias dos grands-travaux", em especial o Centrosoyus, em Moscou, e a Citè de Refuge ${ }^{57}$, em Paris. Esses edifícios formaram, do seu ponto de vista, "complexos que supõem a escala e a textura de fragmentos urbanos". Na sequência do texto anota a tendência de Le Corbusier para "tratar cada um dos projetos não somente como solução para determinado conjunto de problemas, mas também como um elemento protótipo em uma nova totalidade urbana" (2004, p. 125-6).

Segundo Colquhoun, esses edifícios tornaram-se híbridos, pois hesitaram entre o status de objetos-tipo ou órgãos dentro de nova cidade e as dificuldades de textura na zona urbana, onde esses objetos poderiam se destacar como figuras. Nessas circunstâncias, esses edifícios deveriam se adaptar a um contexto urbano específico, expressar um caráter simbólico e ser representante de um tipo, funcionando como condensadores sociais.

Nesses termos, esses grandes projetos e obras apresentavam princípios compositivos distinto dos esquemas tradicionais com pátios internos e fechados onde os

${ }^{56}$ Em São Paulo foi adotada, a partir dos anos 30, uma legislação semelhante ao codebuilding de 1916, em Nova York.

${ }^{57}$ Colquhoun, ao analisar a Cité de Refuge, considera seu complexo ampliado por uma Cité d' Hospitalisation que não chegou a ser construída. 
volumes pragmáticos não se distinguiam dos demais. No Centrosoyus e Cité de Refuge cada elemento do programa possui forma própria e é claramente distinta da de seu vizinho. Desses princípios decorrem as lâminas ou blocos lineares (contendo acomodações celulares) e as massas centróides (locais de assembleia). Outras volumetrias de caráter escultural contendo elementos como banheiros, closets e escadas seriam incorporadas ao sistema compositivo que admitia uma dialética entre exterior e interior, entre a pura geometria e a forma livre. Nas palavras de Le Corbusier: "no exterior afirma-se uma vontade arquitetônica, no interior, são atendidas todas as necessidades funcionais" (Le Corbusier apud Colquhoun, 2004, p. 129).

As cidades ideais de Le Corbusier supõem terrenos ideais e, ao defendê-los ele tinha o cuidado de indicar seu caráter esquemático intencional, ao contrário das encomendas públicas da década de 20 , onde a adequação às condições locais, às irregularidades do terreno e legislações eram fatos concretos a serem enfrentados. Na introdução de Uma cidade contemporânea de três milhões de habitantes Le Corbusier observa: "Procedendo à maneira do prático em seu laboratório, fugi dos casos específicos: afastei todos os acidentes; concedi-me um terreno ideal" (Urbanismo: 2000; p. 156).

Nesse sentido, Colquhoun adverte que:

Para Le Corbusier, portanto, a adequação ao terreno exigia mais do que simplesmente fazer um edifício se conformar às linhas de limite e a terrenos de forma irregular. Implicava colocar um sistema de formas e massas relacionado a um observador que ocupa posições específicas no espaço; em resumo, era "composição", o que significa - no sentido a ela atribuído por Choisy - a resolução artística de exigências imprevistas, e não a aplicação de regras a priori (2004, p. 131).

Assim, nesses termos, entrava em jogo - e com plena consciência do autor - um sentido compositivo, instrumental capaz de promover e resolver na concretude do particular o objeto esquematizado na dimensão do universal ${ }^{58}$. Também por isso, foi possível a vários autores inventariar e descrever o vocabulário corbusieriano. Stanislaus von Moos em "Le Corbusier: Elements of a Synthesis" assim o fez, como outros autores a partir do final da década de 1960.

Moos teve o mérito de ampliar consideravelmente os cinco pontos iniciais da doutrina: pilotis, terraço jardim, planta livre, janela cortina e fachada livre. Além desses propôs cerca de dez elementos e estratégias operativas: a casa como uma caixa; simetria e equilíbrio precário (diálogo com a herança das Belas-Artes; espaços servidos e servidores, expansão da caixa, o simbolismo da rampa, vidros e metal [neutralizando paredes]; quebra-

\footnotetext{
${ }^{58}$ Esse sentido compositivo estará fortemente presente nas arquiteturas modernas no Centro de São Paulo.
} 
sóis; e outros complementares como coberturas onduladas; tetos como guarda-chuva; pavilhões de exposição; a espiral em forma arredondada. Na ampliação desse repertório formal Moos salienta a relativa independência entre programas funcionais e 0 desenvolvimento das formas na arquitetura de Le Corbusier (Moos:1979, p. 69).

De fato esse repertório de elementos conformou-se, como enfatiza Colquhoun, segundo um sentido artístico sob o imperativo das circunstâncias. Sob essa perspectiva o Centrosoyus e a Cité são exemplares para se aproximar da produção moderna brasileira, em especial da corbusieriana, e por extensão, fazer mais adiante um contraponto, à produção moderna paulistana.

Os objetos-tipo quando testados fora das situações controladas dos projetos ideais, (re)alimentaram tanto outras ideias de cidades quanto muitos outros edifícios construídos isoladamente em contextos pré-existentes. Em certo sentido, esses edifícios, recortados dos esquemas genéricos dos planos urbanísticos, tornaram-se símbolos e referências capitais para a arquitetura moderna, sobretudo a brasileira.

\section{Centrosoyus}

O Centrosoyus (Moscou, 1928) foi referência importante para os projetos de cunho moderno participantes no concurso para o MESP. Nas propostas de Jorge Moreira e Ernani Vasconcelos, Affonso Eduardo Reidy e posteriormente no projeto de Lucio Costa e equipe, são evidentes as transposições de elementos e arranjos compositivos das volumetrias desenhadas para o Centrosoyus e já esboçados no Palácio para Sociedade das Nações em Genebra, 1927.

Embora existissem diferenças entre essas propostas, o tipo em questão é facilmente reconhecido: dois pavilhões paralelos são articulados a um terceiro perpendicular a eles: desse terceiro, sai um quarto volume destinado aos auditórios. Entre pavilhões criam-se generosos espaços entre eles - diluindo qualquer configuração que se assemelhasse a pátios fechados. Na esteira do vocabulário corbusieriano, podem ainda serem identificadas volumetrias próprias nas escadas, rampas, sanitários, auditórios e demais espaços servidores. Dessas propostas para o MESP a de Reidy pela composição mais assimétrica e pelo volume das rampas com uma terminação curva (semicírculo) é a que melhor se aproxima da origem corbusieriana.

Ao analisar o Palácio das Nações, Colquhoun nos chama atenção para o fato de que as soluções à redents (denteadas) - as lâminas - nos planos da Cidade Contemporânea e Plano Voisin atravessam o continuum espacial uniforme e indiferenciado. No Palácio das 
Nações, as circunstâncias concretas de projeto promoveram adaptações no sentido de criar duas regiões ou interioridades: uma pública e outra privada (Colquhoun, 2004, p. 131-34).

No projeto do Centrosoyus, implantado em terreno urbano, as dificuldades foram ainda maiores. O terreno era delimitado por três ruas: duas avenidas no mesmo sentido, mas não paralelas, e uma menor mais curta transversal à avenida principal ( hoje, Myasnitskaya Ulitsa). Uma ligação direta, entre as duas avenidas, foi incorporada ao projeto, constituindo numa segunda entrada lateral. Segundo Colquhoun, Le Corbusier descartou o sistema articulado de lâminas adotado para o Palácio das Nações [e nos mesmos moldes das variações à redents]. Optando por "um simples quarteirão fechado com pátio dividido em quadrantes, com o auditório na intersecção de um sistema cruciforme de circulação e com um quadrante omitido para evitar se estender além do limite do terreno".

Dos croquis iniciais à proposta final ficam expostas as operações compositivas em que uma idealidade plantada nas cidades ou projetos ideais é posta à prova. Colquhoun arrola uma série de croquis nos quais Le Corbusier procura o posicionamento mais adequado para o corpo de auditórios e para os demais pavilhões. A solução final dispõe a curvatura do auditório para a fachada secundária; oposta ao acesso frontal. Os esboços de 1928 deixam claro algumas decisões relevantes: a face menor da lâmina lateral é alinhada num ângulo de $90^{\circ} \mathrm{com}$ a avenida posterior, numa mesma atitude, a "fachada principal" por onde ocorrem os acessos principais, também, foi alinhada à avenida principal. Essas duas operações na busca de ortogonalidades relacionadas às ruas determinam a implantação final, próxima de um trapézio inacabado (figuras 5.2 e 5.3 ).

Um conhecido desenho, publicado nas obras completas de Le Corbusier e Pierre Jeanneret, assinala um intervalo de incertezas. A ortogonalidade abstrata - contida nas plantas das cidades ideais - é materializada em um desenho no qual os pavilhões (ou lâminas) laterais são alinhados ao pavilhão frontal (figura 5.5). A solução final parece indicar um passo atrás: rumo a uma contextualização sugerida (ou imposta) pela trama da préexistência.

A esse respeito Colquhoun pondera: "No Centrosoyus percebe-se a tensão não resolvida, geralmente encontrada no trabalho de Le Corbusier, entre a necessidade de o edifício fazer parte de uma estrutura urbana existente, constituindo-se com fachadas frontalizadas e demarcando as esquinas das ruas, e a necessidade de existir como um objeto autoportante" (Colquhoun, 2004, p. 139).

Essas aproximações em entorno do Centrosoyus e o do Palácio das Nações abrem perspectivas instigantes rumo à arquitetura brasileira e seu mais importante formador. As dificuldades de Le Corbusier ao lidar com contextos pré-existentes foram relevantes: tanto 
realimentaram seus esquemas teóricos como traçaram caminhos para seus discípulos diretos e indiretos: que estenderam essas experiências em contextos muito diferentes; reinterpretando esse fazer moderno repleto de ambiguidades; e por vezes contradições.

\section{Cité du Refuge}

A Cité du Refuge, 1929-33, foi uma obra encomendada pelo Exército da Salvação, em Paris. Nela as imbricações urbanas foram ainda mais limitadoras ou dificultosas para Le Corbusier: embora tenham sido mais compensadoras do ponto de vista moral e programático, como defende William Curtis em "Le Corbusier: ideas and forms" (2006). Pois no seu entender por meio dessa obra foi possível a Le Corbusier praticar seu reformismo sem ser revolucionário, transladando o ethos do cristianismo - claridade e moral - segundo suas próprias ideias reformistas contidas nas primeiras cidades modernas (2006, p. 99).

A materialização desse ethos seria manifestada, sobretudo, na valorização da luz [radiosa] e na clareza da composição: através da grande fachada envidraçada e da disposição do programa sob volumetrias específicas ${ }^{59}$. O terreno destinado à construção da Cité du Refuge foi resultado de um remembramento de dois lotes irregulares, conformando um novo lote com frente para duas ruas: Chevaleret e Cantagruel (na qual se encontram os acessos) (figura 5.6) Na visão de Curtis o lugar do terreno na Rua Cantagruel ofereceu uma oportunidade para Le Corbusier fazer uma demonstração de como cortar fora - numa radical cirurgia - a obstrução de um tecido tradicional, inserindo-lhe um novo mecanismo, para geração de luz, espaço, horta, bem-estar humano e moral elevada (2006, p. 99-102).

Porém, as transformações do projeto dos primeiros esboços até a solução final contradizem de certa forma as pretensões de Le Corbusier, nos termos postos por Curtis. A genealogia da concepção, empreendida por Curtis e Colquhoun, nas análises da Cité, demonstram que esse penoso percurso tomou rumos mais constritos. A cidade ou seu tecido tradicional impôs seus termos, marcando a forma final do edifício (figura 5.7).

No primeiro projeto um volume alinhado à divisa maior do lote é interceptado perpendicularmente por dois outros. Uma série de volumes mais baixos (destinado às atividades mais públicas) encerra a composição. Nessa disposição sobrava pouca superfície para a fachada sul, a mais insolada no hemisfério norte ${ }^{60}$; além de que segundo os autores,

${ }^{59}$ O programa da Cité de Refuge continha: acomodações noturnas para homens e mulheres; creche para crianças de mães casadas, solteiras e trabalhadoras; cantina para os internos ou visitantes casuais; oficinas e ateliês para treinamento.

${ }^{60}$ Há profundas diferenças quanto às orientações e insolações entre os hemisférios sul e norte. Além da inversão no "caminhamento" do sol em relação à terra, deve-se considerar além de 
o edifício teria pouca visibilidade. O que do ponto de vista do edifício moderno desenhava-se como um problema. A solução final contempla então uma única lâmina no sentido do maior cumprimento do terreno, favorecendo ao mesmo tempo uma maior exposição do edifício tanto à luz quanto às visuais; reafirmando seu caráter simbólico. Segundo Colquhoun, dado o deslocamento, ainda foi possível promover programaticamente a promenade como "uma série de atos de iniciação, necessários antes de se entrar no santuário interno do edifício, e esses atos são simbolizados por uma série de elementos arquitetônicos: o pórtico, a rotunda, a passarelle" (2004, p. 144) (figuras 5.8 ).

Le Corbusier ao converter os três blocos em apenas um, atingiu seus propósitos; ao menos parcialmente. Porém, é preciso atentar para o fato de que a primeira solução parte da concepção de dois blocos encontrando um terceiro num ângulo de 90; ainda uma solução com origem nos redents - ou seja, para um continuum espacial pensado para uma cidade com divisões fundiárias distintas do lote, nas quais os edifícios podem receber as devidas insolações e, expressar-se plasticamente como formas livres no espaço. Em uma perspectiva de 1932 é possível visualizar uma proposta de ampliação para o complexo hospitalar da Cité, na qual outros edifícios são incorporados ao programa inicial da Cité de Refuge: a expansão nesse caso ocorre por entre os terrenos vizinhos, estendendo-se e articulando-se nos mesmos padrões propostos para habitação na Cidade Contemporânea ,

Embora na solução final da Citè se tenha encontrado os termos de uma visibilidade, a forma final do conjunto ficou atrelada às conformidades do lote e da legislação: o grande bloco encontra-se encostado quase por inteiro na maior divisa do lote (dois poços de iluminação e ventilação interrompem a continuidade); o bloco mais baixo dos serviços sociais também está encostado a uma divisa de lote; e a fachada voltada para a Rua Chevaleret apresenta um escalonamento assemelhado aos setbacks comuns a São Paulo e Nova York - provavelmente decorrente de uma legislação assemelhada.

Se a forma final do edifício foi marcada pelas contingências do sítio, exigindo perícia dos arquitetos (e certo afastamento das proposições iniciais), outras operações e intenções confirmam aqueles elementos formadores da tipologia e do método de concepção empregados por Le Corbusier em suas diversas obras. Daqueles listados por Moos são relevantes nesse caso: a estrutura independente, as volumetrias "funcionais", a fachada e plantas livres e o uso do vidro e do metal $(5.9,5.10$ e 5.11).

A estrutura chama atenção principalmente pelo fato de que Le Corbusier as constrói soltas; mesmo aquelas postadas contra as divisas do lote, deslocando-as para o interior dos

outras complexidades do clima, os diversos graus relativos às várias latitudes; que alteram profundamente a incidência dos raios solares nos solstícios de verão e de inverno. 
ambientes. Procedimento desnecessário do ponto de vista estritamente pragmático, se se admite que os pilares poderiam estar embutidos na espessura da parede. Entretanto, relevantes se o que se deseja é a coerência ou manifestação de princípios, nos termos de uma expressão ou intenção formal central para a questão moderna: a estrutura independente como será vista no capítulo seguinte.

No caminho dessas mesmas hipóteses vão as decisões em torno da fachada de metal e vidro, e do sistema do ar-condicionado. Esses dois elementos são emblemáticos para se avaliar muitas das atitudes modernas diante das inovações tecnológicas, independente do lugar de onde tenham se concretizado. Ou seja, essas inovações antecipam um por fazer - ou estavam - um passo à frente das possibilidades técnicas enquanto uma prática com resultados testados e confiáveis. O fato foi que tanto a fachada como o sistema de ar-condicionado falharam no primeiro verão parisiense. Num certo sentido, o descompasso entre o desejo e a construção (ou o processo de maturação de determinadas técnicas) foi transportado para a arquitetura brasileira: implicando um longo processo de incorporação e desenvolvimento do brise-soleil: usados muitas vezes de maneira contraditória (fechando em demasia aquilo que se abriu) ou simplesmente não respondendo ao propósito inicial ${ }^{61}$. No Centro Histórico de São Paulo, dadas as condições de lote e insolação, as dificuldades foram inúmeras, pois as orientações, as fachadas, nem sempre estavam voltadas para as melhores condições como desenhadas por Le Corbusier nas cidades ideais ou no Ministério da Educação no Rio de Janeiro.

\section{MESP: objeto-tipo para os trópicos}

Esses problemas e situações defrontadas por Le Corbusier estenderam-se para além da experiência europeia, alcançando realidades como a brasileira: o projeto do Ministério da Educação e Saúde Pública no Rio de Janeiro, 1936-45, em conjunto com arquitetos brasileiros, é sintomático. Mais do que isso, é exemplar porque a partir dele se desenvolveu uma cultura arquitetônica moderna com a imperativa necessidade de adaptá-la aos inconvenientes dos trópicos.

Os assuntos decorrentes do MESP são inúmeros e tiveram amplas consequências e interpretações para a arquitetura moderna brasileira. A obra tornou-se um paradigma para a arquitetura nos trópicos e obteve desdobramentos para além de suas fronteiras. Assim, o

${ }^{61}$ A história do uso do brise na arquitetura brasileira é um capítulo à parte: de sucessos e insucessos. O brise do Edifício Triângulo, por exemplo, foi desativado por excesso de barulho nos dias de chuva. Outros como o Edifício e Galeria Monteiro (Rino Levi) sequer foram construídos. Ao nosso entender, os brises do Edifício Renata Sampaio (Oswaldo Bratke) e Itália (Frans Heep) criam uma excessiva zona de penumbra e por vezes estão posicionados em fachadas pouco ensolaradas. 
MESP é retomado neste texto sob o olhar dos objetos-tipo: nesse sentido, um objeto-tipo de origem corbusieriana e finalização brasileira. O reconhecimento desse fato não implica conter a moderna arquitetura brasileira no âmbito dessa experiência e nem descartar outras manifestações modernas que recortam outros objetos-tipo provenientes da sintaxe corbusieriana ou de origem em outros mestres e referências do movimento moderno. ${ }^{62}$ No lato senso o MESP também deixou suas marcas na arquitetura moderna feita no Centro Histórico de São Paulo. Entretanto sem a dimensão alcançada no Rio de Janeiro: sua condição de monumento e obra pública o fizera único naquele contexto. Em São Paulo seus elementos foram trabalhados de outra forma, muitos dos quais com timidez e restrições significativas.

A intenção de se reler, mais uma vez, o Ministério, justifica-se pela necessidade de eleger princípios e formas importantes para esclarecer as variações da arquitetura moderna edificada no Centro Histórico de São Paulo, admitindo-se de antemão que o edifício tem um caráter paradigmático. Além de seu caráter monumental, discutem-se: os elementos e aspectos de sua inserção na malha urbana e na relação com o lote, a relação dos pilotis; a estrutura independente, as fachadas e suas orientações; os arranjos das massas construídas.

Do concurso anulado à proposta final, nota-se um longo percurso de atritos e interesses em favor da arquitetura moderna. Em "Colunas da Educação", Lissovsky e Sá, relatam e documentam todo o processo que dá início à "institucionalização da arquitetura brasileira" (Lissovsky e Sá, 1996, xvii): nesse particular enfatizam o papel do ministro Gustavo Capanema como um fruidor privilegiado envolvido com laços de amizade com os artistas e arquitetos modernos. A vinda de Corbusier como consultor reforça essa versão já em andamento por proposta elaborada pela equipe brasileira constituída por Lucio Costa, Affonso Eduardo Reidy, Carlos Leão, Ernani Vasconcelos, Jorge Moreira e Oscar Niemeyer. Nesse processo em que se anula um concurso é notável a força do movimento moderno engajado em uma visão modernizadora do Brasil; naquele momento atrelado a uma visão oficial.

Nas polêmicas do concurso, paira sempre uma contraposição entre a trama da cidade tradicional europeia representada pelo plano Agache e as ideias modernas por Le Corbusier. Marcos Carrilho, em "Lucio Costa Patrimônio Histórico e Arquitetura Moderna", reportando-se à questão, sublinha artigo de Carmem Portinho em defesa dos projetos de caráter modernista de Reidy e Jorge Moreira: as dúvidas envolviam as normas do edital "que prescreviam limite orçamentário e subordinação às posturas municipais do plano observação.

${ }^{62}$ Os edifícios Eifel e Itália, tratados mais à frente, reelaborações que se encaixam nesta 
Agache". Ainda segundo Carrilho, "a revista publicou neste mesmo número o projeto vencedor do concurso da Caixa de Aposentadoria de Praga, cuja solução final fora alcançada graças à recusa em atender à determinação da municipalidade, que fixava previamente a forma do edifício constituída de bloco fechado em torno de pátios" (Carrilho, 2002, 177-).

O plano de Alfred Agache, para o centro do Rio de Janeiro, 1927-30, propunha uma tipologia de quadras com blocos construídos na periferia da quadra, voltados para pátios internos. Essa disposição reafirmava a rua-corredor como elemento primordial de circulação, ordenamento das quadras e lotes; e caracterização do espaço urbano. Ou seja, tudo aquilo que Le Corbusier contrapunha em seus planos de cidade: ou melhor, vital nas suas concepções urbanas ancoradas em rígido sistema de circulação e zoneamento, sustentados por um ideal sanitarista excessivo que ao admitir como essencial o continuum espacial em meio a um ambiente natural, negou de certa forma a própria cidade (figuras 5.12 e 5.13).

Não por acaso, Le Corbusier procura outra solução à proposta brasileira em U que estava amarrada às limitações da legislação (gabarito e alinhamentos) contida no plano Agache. A saída de Le Corbusier foi propor um novo edifício à beira-mar: mais isolado das inconvenientes volumetrias previstas no plano Agache, que de imediato não lhe agradou: "Fui visitar o terreno no próprio local. Este, como seus arredores estão livres de qualquer construção - mas a viabilidade já está traçada, os gabaritos já estão determinados pela prefeitura -, pode desde agora nos dar uma ideia do sítio sobre o qual se erguerá o palácio" (Lissosvsky e Sá, 1996, p.109).

No prosseguimento de seus argumentos para um novo projeto para o MESP, Le Corbusier esquiva-se de uma crítica direta ao projeto brasileiro, jogando peso na má localização do terreno ${ }^{63}$. São nessas justificativas e na busca de um novo terreno para MESP que ficam claras as estratégias de Le Corbusier para construção de seu objeto-tipo; montado nos trópicos nos termos de suas cidades ideais.

Justificando que o novo terreno [na orla] não tem comparação possível com o precedente, Le Corbusier arrola uma série de argumentos: "sua perspectiva está assegurada pela presença do aeroporto, uma vasta extensão de água que se estende a esse sítio para interditar qualquer construção"; a possibilidade importante de um estacionamento para automóveis; a execução da obra num prazo menor; custos

${ }^{63}$ Diz Le Corbusier: "Insisto no fato de que não se trata de um novo palácio, mas do mesmo, cujas alas simplesmente se abriram. Em consequência, o novo palácio comporta os mesmos cortes de construção, os mesmos locais e, em princípio, a mesma disposição, em compensação, os serviços de sala de conferências e do saguão puderam ser consideravelmente melhorados" (Lissovsky e Sá: 1996, p. 111-12). 
equivalentes ao do palácio no Castelo; a valorização dos esplendores naturais do Rio de Janeiro. E por fim reitera: "Estou convencido de que o palácio, situado neste local, irá tornar-se alvo de admiração, pois a forma do terreno permite proporcioná-lo de acordo com as mais belas regras da arquitetura" (Lissovsky-Sá; 1996. p. 111-113). Mesmo após o descarte do terreno à beira-mar, Le Corbusier continua a manifestar, em correspondências, seu desagrado com o a decisão tomada em favor do antigo lote ${ }^{64}$.

A resistência ao plano Agache também fora manifestada no memorial da equipe brasileira que explica o partido em U. O croqui da figura 1 anexado ao memorial mostra no plano do chão a projeção de duas galerias, fato que permitia uma permeabilidade até então não contemplada nas massas ilustrativas do plano Agache. Além dessa condição outras são explicitadas pelos autores deixando claro quais eram as estratégias modernas diante das formas ensaiadas para a cidade tradicional:

“ (...) partido que apresenta as seguintes vantagens: primeiro, o recuo do corpo principal torna possível apreender em um mesmo golpe de vista todo o conjunto do edifício, o que - respeitando o alinhamento - se não daria [não ocorreria]; segundo, os corpos laterais, suspensos sobre pilotis, não cortam a perspectiva - a vista prolonga-se desembaraçada através dos mesmos, por toda a quadra de uma a outra rua, conseguindo-se assim agradável sensação de espaço e desafogo; terceiro, as duas grandes galerias cobertas - cuja utilidade em nosso clima torna-se supérfluo acentuar - facilitam a aproximação, em condições favoráveis, por qualquer dos lados da quadra. Tal disposição não foi, no entanto, estabelecida a priori - resultou das imposições de orientação devidamente controladas pelo desejo de obter, como resultado final, um conjunto rigorosamente equilibrado e plasticamente "puro" (Lissovsky e Sá, 1996, p. 62).

Portanto, fica evidente no memorial descritivo da equipe brasileira sua fidelidade às ideias urbanas de Le Corbusier, sublinhando-se: as reações à rua-corredor, à quadra perimetral por um lado; e por outro lado, promovendo-se quase que integralmente os pilotis por meio de duas grandes galerias, parcialmente diluídas por uma generosa vegetação .

As tentativas de mudança do terreno justificam-se tendo em vista os princípios plantados nas cidades idealizadas de Le Corbusier, que em todas as circunstâncias rediscute o papel da rua e da divisão fundiária ${ }^{65}$. Assim, ele viu com clareza que a nova situação era mais adequada aos seus propósitos contidos na Cidade Contemporânea e Radieuse: onde a divisão fundiária se funde à natureza ao continuum natural favorecendo a

${ }^{64}$ Tempos depois, o projeto e o MESP seriam construídos no terreno original. Em carta a Lucio Costa, Le Corbusier comenta: " [...] Fiquei desapontado, com dor no coração, pois já imaginava erguer-se no céu o produto de nossa colaboração, bem como a sinfonia paisagística em meio àquele sítio admirável. É um crime não o ter feito" (Santos et alii, 1987: 177).

${ }^{65}$ Mesmo nos riscos propostos para Rio De Janeiro e São Paulo em 1929. 
"correta" orientação dos edifícios, respondendo às conveniências da salubridade, sem o incômodo das ruas e construções vizinhas; por decorrência obtêm-se um objeto que pode ser contemplado por todos os seus lados, quando a vegetação não o encobre.

O edifício do MESP acabou construído no primeiro terreno e sua forma final prosseguiu no progressivo afastamento das normas edilícias então vigentes. Nesse sentido, lê-se no memorial da equipe brasileira, no item II - Local:

"Trata-se da quadra F, na esplanada do Castelo. No intuito de manter a padronização prevista pelo plano Agache, os edifícios circunzinhos, destinados à renda, obedecem ou deverão obedecer - acham-se apenas em início as construções - a determinação de "gabarito", para que os blocos apresentem, uma vez concluídos, certa harmonia. Dispondo, porém, o edifício em projeto de toda uma quadra, não se deverá razoavelmente confundir por sua própria natureza e finalidades, com os demais e sim destacar-se sem esforço do conjunto uniformizado que o emoldura, tornando-se para tanto aconselhável - dentro dos limites impostos pelas regras de arte e do bom senso - a quadra do modelo pré-estabelecido (5.14) .Assim também o entendeu a Secretaria de Viação e Obras Públicas do Distrito Federal" (Lissovsky e Sá; 1996, p. 61).

Vê-se que a polêmica história do MESP ramificou-se em várias direções: da identificação simbólica de uma modernidade particular ao desenho concreto de uma quadra. O edifício foi construído como uma ruptura a muitos parâmetros e sua configuração final o dissocia do contexto pré-existente assinalando sua condição de objeto isolado: ou melhor, com um fragmento recortado da cidade Contemporânea e Radiosa. Fragmento posteriormente adaptado a um contexto pré-existente e concreto, guardando forte identidade com as referências de origem, principalmente se a atenção estiver voltada para a disposição da forma em "lâmina" dos edifícios e a composição à redent que os articula por meio de ângulos a 90․ Nas maquetes da Cidade Radiosa é possível identificar essas relações, inclusive a penetração de um volume mais baixo sob outro mais elevado. No caso do MESP, a composição final nos deixou um edifício - objeto-tipo - de significativa autonomia formal em relação ao seu entorno imediato.

Num certo sentido, como ressalta Queiroz, os riscos de Le Corbusier funcionaram mais como tipo e modelo do que como solução de projeto: "O edifício construído do MESP é um projeto de autoria exclusiva da equipe de jovens arquitetos. O risco revelador de Niemeyer assimila o risco original de Le Corbusier, não como uma solução de projeto, mas como um esquema formal que, por basear-se em pressupostos estandartizados, se permite adaptar às circunstâncias mais distintas" (2007: p. 71).

Embora na obra do MESP seja inegável a contribuição brasileira é preciso enfatizar que é o mestre quem desmonta a proposta brasileira em $U$, e propõe o edifício lâmina 
perpassado por um corpo na transversal. Por outro lado, Le Corbusier estava ensaiando mais um de seus objetos-tipo, ainda colado às suas ideias de cidade, ao caráter universal da sociedade industrial. Como visto anteriormente, as adaptações dos objetos-tipo de Le Corbusier sempre estiveram condicionadas pelas circunstâncias específicas e assim mesmo não deixaram de estabelecer nexo com a dimensão urbana - tanto a idealizada, quanto a local. O MESP foi o primeiro objeto-tipo moderno em grande escala produzido nos trópicos: com enorme contribuição da equipe de arquitetos brasileiros, mas não exclusiva. Mesmo tendo-se em conta a importante implantação proposta por Niemeyer.

Rodrigo Queiroz, em "Oscar Niemeyer e Le Corbusier: encontros", analisa os problemas decorrentes do retorno do projeto do MESP à antiga quadra F. Na proposta linear de Corbusier a fachada sul encontra-se envidraçada e a norte com aberturas quadradas à semelhança do pavilhão Suíço. Ao transpô-la para o antigo terreno o bloco em fita ficou posicionado numa orientação equivocada - leste-oeste - inviabilizando o envidraçamento dos planos (Queiroz: 2007, p. 55 - 59). Na versão corbusieriana o bloco principal e mais alto (dez pavimentos) encontrava-se alinhado à Av. Graça Aranha: o que ainda estabelecia uma relação entre o edifício e a avenida. Sob esse aspecto, a proposta brasileira ao girar o bloco principal a $90^{\circ}$ e afastá-lo dos limites do lote, foi mais fielmente moderna do que os riscos apressados pelo mestre fraco-suíço ${ }^{66}$.

Nos termos das hipóteses aqui discutidas, o Ministério adquiriu status de um objetotipo corbusieriano (moderno) e brasileiro. Além desses atributos, o MESP desempenhou importante papel como monumento moderno.

Abordando esse tema, Carrilho sublinha um duplo aspecto a ser cumprido pelo Ministério: "a realização de um edifício significativo e a demonstração inequívoca das conquistas do Movimento Moderno" (2002: p. 179). Essa significação passou por um turbulento caminho representado nos diversos projetos: tanto para o terreno da quadra $\mathrm{F}$, quanto à beira-mar. Nesse processo, anota Carrilho, houve além das diversas operações compositivas, um progressivo aumento dos pavimentos do edifício, que contribuíram para a consolidação de seu caráter monumental. Se considerada a primeira proposta do grupo brasileiro, passando pela proposta à beira-mar (Le Corbusier), até a proposta final de 15 pavimentos, foram acrescidos cerca de oito pavimentos a mais no edifício (figuras 5.15 a 5.19).

${ }^{66}$ Capanema em carta de 11/08/1936 solicita a Le Corbusier as mudanças que faria ao projeto brasileiro, uma vez que era incerta a construção do Ministério à beira-mar. Le Corbusier faz os riscos da nova proposta em 13/08/1936 (Lissovsky e Sá; 1996, p. 114). No dia 14 embarca rumo à Europa. 
Esse crescimento denota não só procedimentos em busca de um caráter mais adequado ao ministério, como interpretações da lei sempre sujeita aos casos e acasos. De qualquer maneira, as dificuldades de se adaptar a proposta de Le Corbusier ao antigo terreno foram consideráveis: e chegaram a um bom termo graças à intervenção de Niemeyer; que inverteu a solução dada por Corbusier.

Ainda segundo Carrilho as reduzidas dimensões da área do Castelo dificultavam uma implantação que desse relevo ao bloco administrativo. "Essa solução mantinha o espírito do esquema anterior, com o grande bloco de escritórios administrativos contraposto agora por um único volume que reúne auditório e salão de exposições - todo o conjunto situado na extremidade do quarteirão, de modo a permitir ainda uma grande esplanada livre, para assegurar uma perspectiva adequada do edifício." Porém, essa solução, "embora tenha mantido os aspectos principais da primeira solução, resultou algo 'contrafeita", pois, dadas as dimensões do terreno, o volume principal teve de ser desenvolvido na dimensão maior do terreno, o que obrigou com que as faces principais do edifício ficassem voltadas para a pior orientação (2002: p. 181).

Ainda segundo Carrilho, a solução de Niemeyer "permitia compensar a reduzida dimensão transversal do terreno, recuperando com isso a orientação mais adequada e a preconizada vista para a baía. Nessa alternativa, o bloco principal foi localizado no centro do terreno, sendo retomada a disposição linear do auditório e do salão de exposições, situados agora no limite do alinhamento de modo a gerar duas grandes áreas livres diante do edifício".

De outra maneira, mais particular, complementa: "por meio desses vazios e recuos, a implantação do edifício amplia e acentua a dimensão urbana. Não há hierarquia, não há marcação de um acesso principal, não há sequer um degrau que delimite alguma distinção entre exterior e interior. A esplanada prossegue contínua através do edifício. A dimensão urbana, assim ampliada, se funde com o edifício. arquitetura e urbanismo tornam-se idênticos, não podem ser dissociados" (Carrilho: 2002, p.83).

É justamente nessa dimensão que o MESP reafirma sua condição de objeto-tipo que [re]alimenta as idealidades e exemplifica particularidades. Em outros termos, esse objetotipo, agora de caráter brasileiro/corbusieriano, insere-se num contexto urbano acentuando suas diferenças - e [re]construindo por meio das circunstâncias locais aquilo que foi posto na origem de uma cidade idealizada. O edifício do MESP pode ser um objeto isolado na trama da cidade tradicional (nos termos de Agache); mas, nos moldes do urbanismo moderno poderia ter sido uma unidade, ou melhor, um corte [retrabalhado] no enorme 
continuum dos edifícios modernos dispostos nas cidades ideais de Corbusier: sobretudo, na solução à redent.

Essa visão nem sempre é compartilhada por outros autores. Carlos Eduardo Comas em "Protótipo e Monumento, um ministério, o ministério" (1987), constrói uma variante distinta e não menos importante; pelo contrário, ela é permeada de contatos e afastamentos relevantes, que merecem importantes reflexões. Ele elabora e complementa dois conceitos centrais para os argumentos que aqui se constroem: as ideias do MESP como protótipo e monumento; entrelaçando em parte a discussão até aqui enredada.

Em sua consistente argumentação Comas chama atenção para a disposição final da composição: descrevendo as aproximações ao edifício, as hierarquias quanto aos acessos [ou seja, aqueles que melhor conformam a transparência e permeabilidade do chão] e as linhas de visibilidade do edifício. Nesse controle das aproximações e acessos "se enfatizam a rota preferencial oblíqua e o impacto das visões diagonais de esquina, as únicas em que a composição pode ser percebida quase por completo e em que a interseção dos dois blocos aparece em foco, denunciando a localização correta da entrada principal” (1987: p. 140). Em outra passagem menciona que as aproximações ao Ministério pelos encontros da Av. Graça Aranha com Araújo Porto Alegre, e Graça Aranha com Pedro Lessa, são os pontos de acesso privilegiados que desencorajam "as aproximações frontais a qualquer fachada do edifício" (1987: p. 140).

A disposição dos demais elementos arquitetônicos e programáticos postos no térreo (esplanada, pórtico, vestíbulo, salão de exposição e auditório) reiteram o sentido de diluir a frontalidade do conjunto edificado como as ruas que o delimitam; ou seja, com a "ruacorredor". Ainda que essas frontalidades não pudessem ser descartadas totalmente, foram pelo menos diluídas: as faces cegas da torre de serviços são suficientemente estreitas para não adquirirem papel relevante e a fachada de vidro é "desmaterializada" pela transparência das esquadrias.

Essas estratégias compositivas e percepções visuais corroboram para a construção da ideia do edifício moderno, pensado como um objeto solto no espaço: e nesse caso, enfatizado pelos pilotis - abertos ou não - que resumem categoricamente a relação entre o edifício moderno e a cidade; sob a luz de uma divisão fundiária radical.

No MESP não são poucos os elementos arquitetônicos modernos manifestados. Se ao edifício pode se atribuir um caráter de protótipo é porque nele e dele emanam soluções que deveriam (e foram) replicadas exemplarmente. Phillip Goodwin o via como solução 
padrão de um prédio de escritórios em clima tropical ${ }^{67}$. Nos termos de Comas, como uma solução exemplar, ilustrativa da aplicação de uma metodologia funcionalista de projeto, à maneira do Pavilhão Suíço. Como Goodwin, Moos recortara, tempos depois, os elementos de composição de Corbusier relacionando-os a especificidades programáticas, espaciais e geométricas; auditórios, escadas etc. Embora seja possível estabelecer essas relações entre funcionalidades e formas em Le Corbusier, é prudente não ser peremptório: o arranhacéu cartesiano servia tanto para torres de escritório como para de habitação e o MESP assemelha-se muito a um fragmento das soluções à redent.

Nesse sentido Comas acrescenta: "O ministério daria testemunho irrefutável da autoridade da função enquanto matriz formal. Essa autoridade se exerce, contudo, em correlação com a autoridade da tecnologia característica da modernidade. É a partir da aliança entre função, materiais e procedimentos construtivos que Le Corbusier havia estabelecido os seus cinco pontos de uma arquitetura nova, defendido o pano de vidro e inventado o brise-soleil" (Comas: 1987 p. 141).

Esses elementos de arquitetura e esquemas compositivos corbusierianos foram empregados no MESP e mostraram-se pertinentes em nosso meio ambiente. Mais do que isso foram aplicados, estudados, reinventados largamente na arquitetura moderna brasileira. Contudo, nem sempre com o mesmo sucesso: ora a experimentação formal não era acompanhada pelo devido recurso tecnológico, ora encarecia demais a obra. No Centro Histórico de São Paulo, pelas posições determinantes dos lotes e suas orientações, as condições foram ainda mais dificultosas exigindo dos arquitetos soluções mais híbridas e enorme esforços compositivos.

Além desses aspectos Comas relembra, nos mesmos termos de Argan, que o MESP também foi solução antecipatória do centro de negócios da cidade ideal, como esboçada na Carta de Atenas: "a cidade das torres e barras em pilotis sobre um grande parque (...)" (1987: p. 142).

Ainda na tese de Comas o MESP se tornaria um monumento moderno. A altura final do prédio, sua posição na quadra, a altura dos pilotis (10 metros) e a grande esplanada pronunciaram tal condição. Comas incorporando novos argumentos à sua tese, também, recorrendo às análises teóricas de figura e fundo, de sólido e vazio, engendradas por Rowe em Ciudade Collage (1998: p. 54) e centrais para a tese que aqui se constrói.

Segundo Comas, Lucio Costa deixa claro nas memórias do projeto a intenção compositiva de circundar o edifício por espaços livres, de maneira a diferenciá-lo do contexto à sua volta: subvertendo, assim, as normas da rua-corredor e do quarteirão

${ }^{67}$ Phillip Goodwin apud Comas: 1987; p. 141. 
fechado. Recurso de valorização de figuras sobre um fundo, encontrado e já previsto "por um paradigma da cidade tradicional": no qual edifícios importantes (como em Ouro Preto) são implantados em frente a largo, praça ou lugares privilegiados, "constituindo situações de singularidade relativa dentro de um tecido ordinário de ruas-corredor e quarteirões fechados (...)" (1987: p. 144-45).

No MESP se faz uso de um recurso tradicional para fazer um prédio moderno funcionar como monumento: fato garantido principalmente pela posição do entorno dada pelo tecido tradicional. No caso uma estratégia isolada que marca sim uma intenção monumental, mas que se estendida como uma prática para todos os edifícios reforça a crítica elaborada por Rowe de que essas posições promovem a crise do objeto e por decorrência da cidade moderna e da cidade tradicional. São justamente nessas situações que se estabelecem as contradições (dificuldades de textura e forma) entre os edifícios modernos e os tecidos antigos.

Retomando-se os aportes de Colquhoun, o MESP paradoxalmente contradiz sua afirmação de que esses edifícios modernos, implantados em contextos tradicionais, tornaram-se híbridos hesitando entre o status de objetos-tipo e as dificuldades de textura na zona urbana. Pelo contrário, o MESP ao ser implantado afastado das divisas do lote, mantendo sua integridade "formal" reafirmou sua qualidade de monumento. Assim, o MESP firmou-se como um objeto-tipo; moderno e brasileiro: e se Comas tem razão, numa figura moderna em meio à cidade tradicional.

Contudo, no Centro Histórico de São Paulo, os edifícios modernos tiveram mais dificuldades em manter suas idealidades formais e espaciais, como expostas no MESP: uma implantação norte/sul categórica, a utilização "limpa" do brise-soleil, os pilotis e principalmente sua condição de objeto isolado no lote. Embora conflituosas as relações dos edifícios modernos no CHSP, mostraram-se ricas aos se depararem com os contextos préexistentes, com a legislação e mesmo diante dos interesses comerciais: matérias difíceis para serem trabalhadas, como descritas e interpretadas nos capítulos 7, 8 e 9 . 


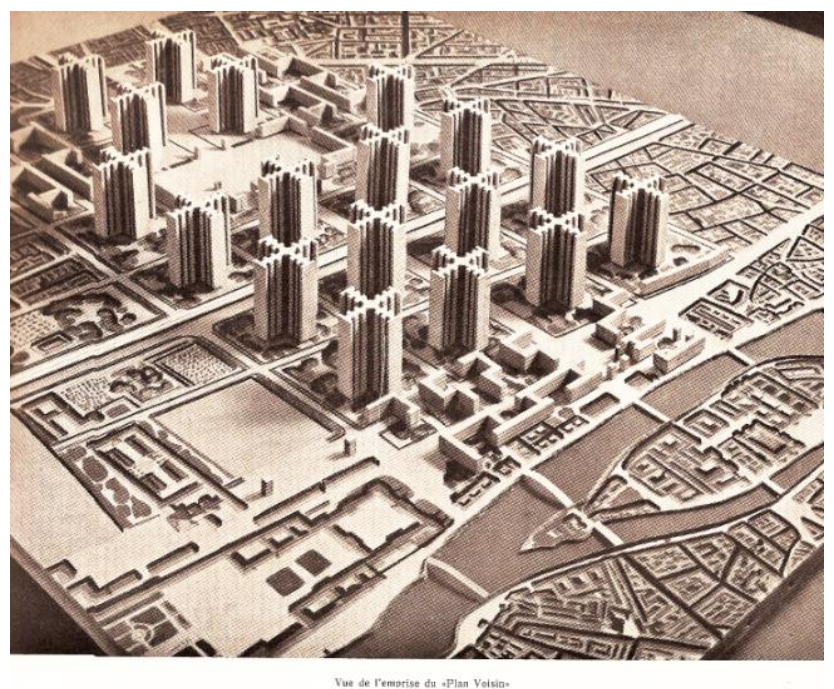

5.1: Plano Voisin, 1930.

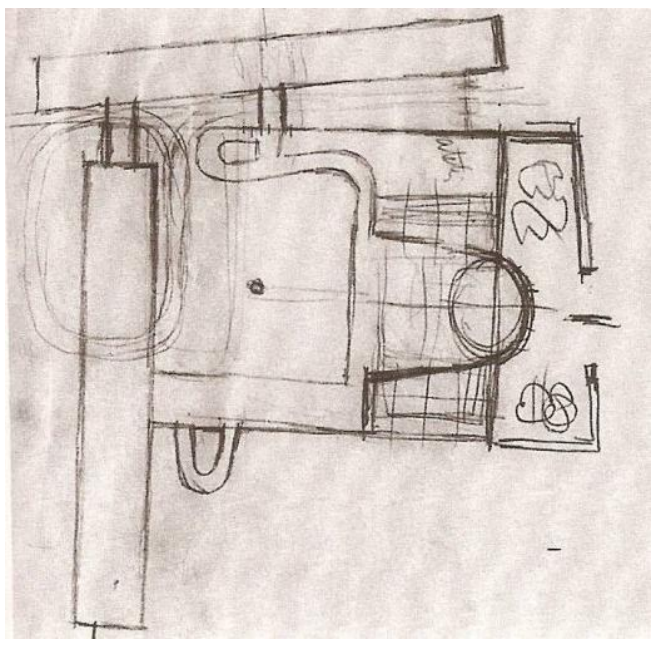

5.2: Centrosouys, 1928

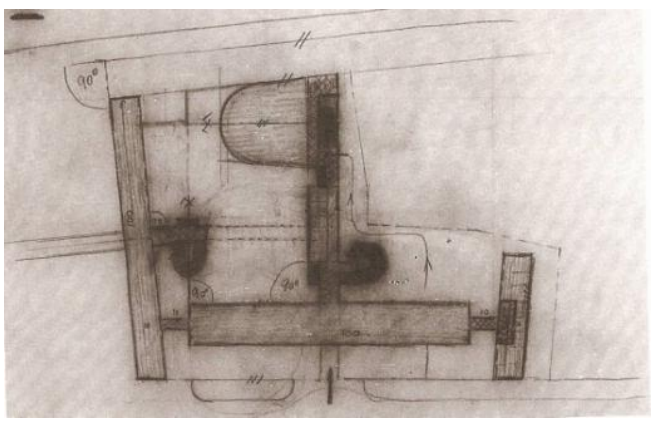

5.2 e 5.3: Centrosoyus, 1928, esboços de permutação.

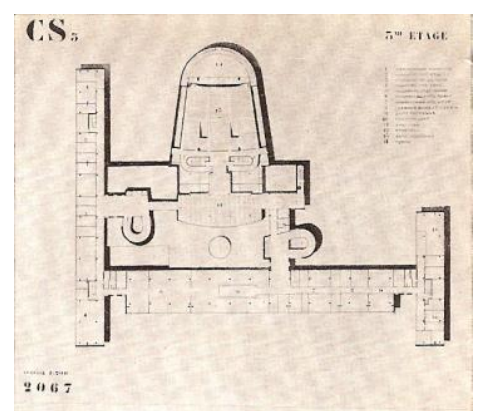

5.4: Centrosoyus, proposta intermeidária

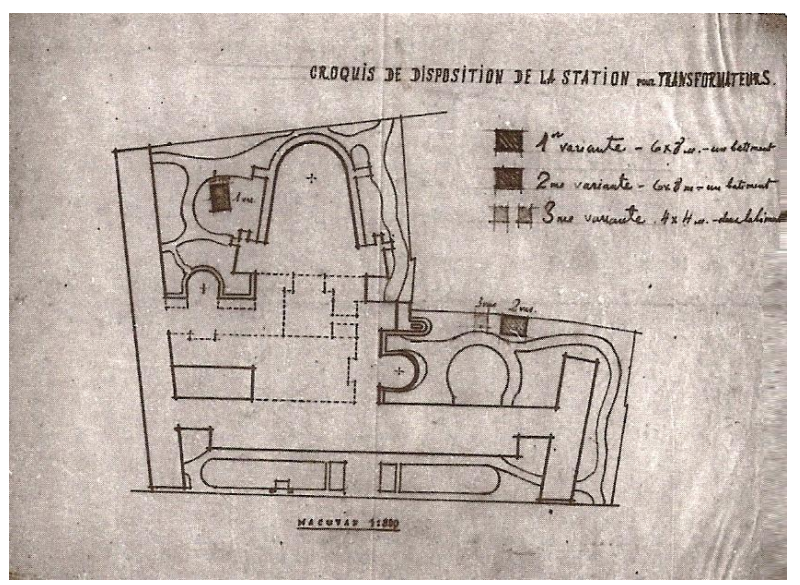

5.5: Centrosoyus, Croquis do projeto construído, 1929 


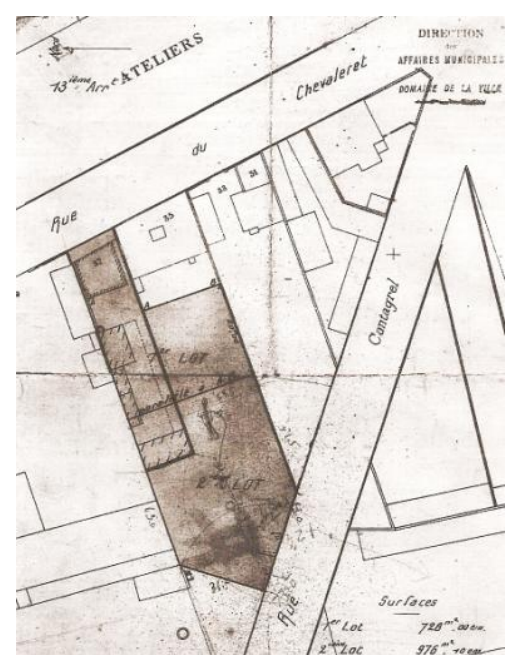

5.6: Cité du Refuge, 1929-33

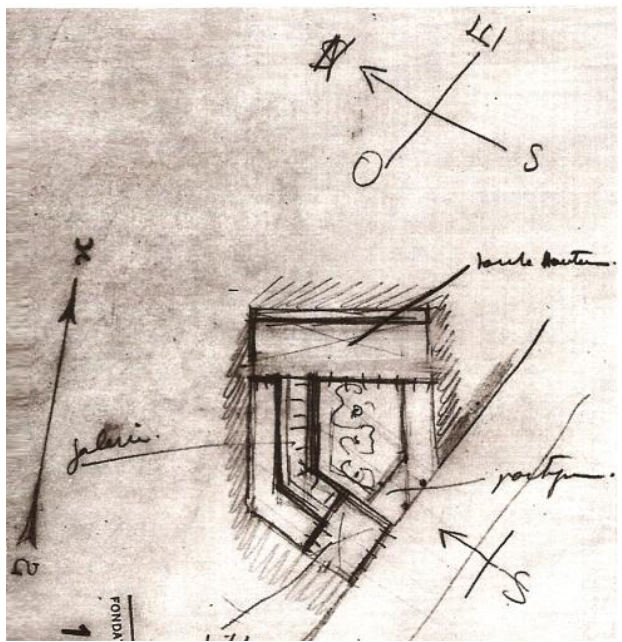

5.7: Cité du Refuge, croqui incial

i.s.

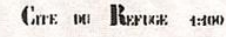
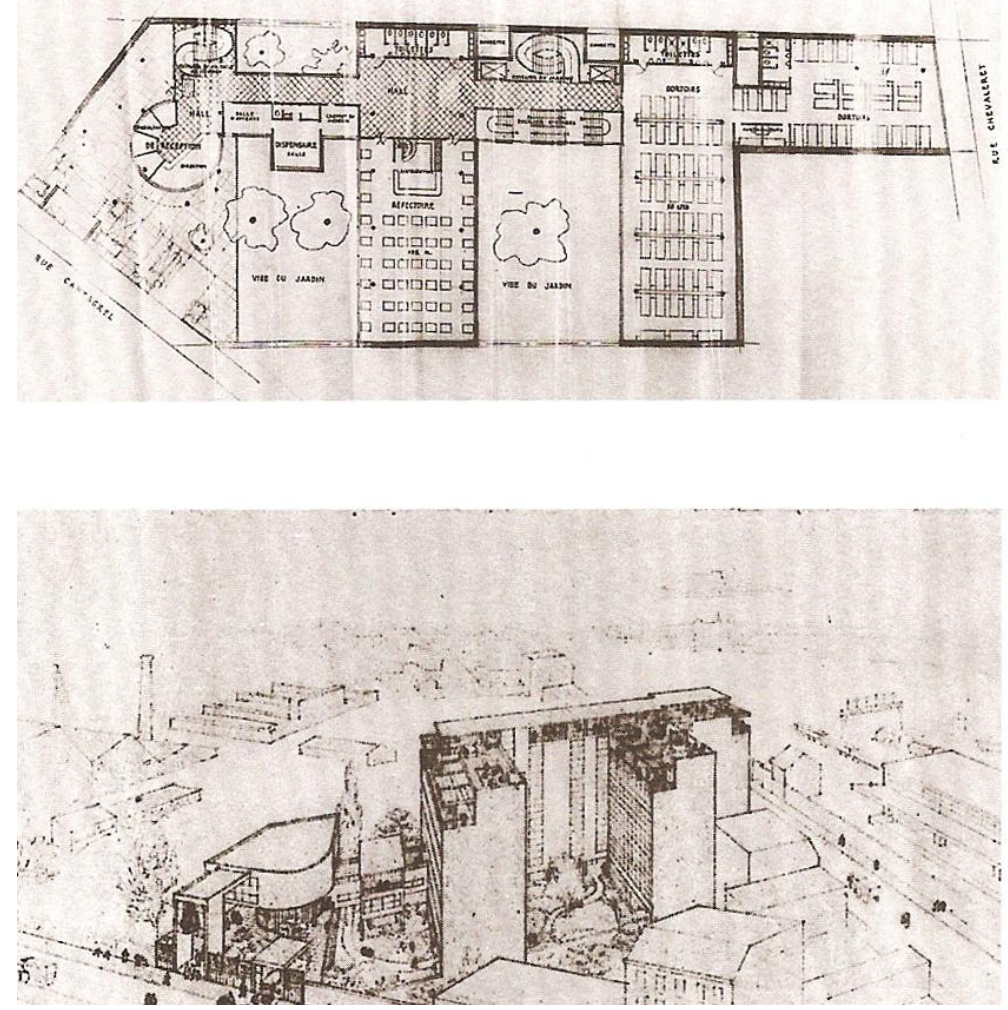

5.8: Cité du Refuge, planta primeiro projeto e perspectiva aéra . 


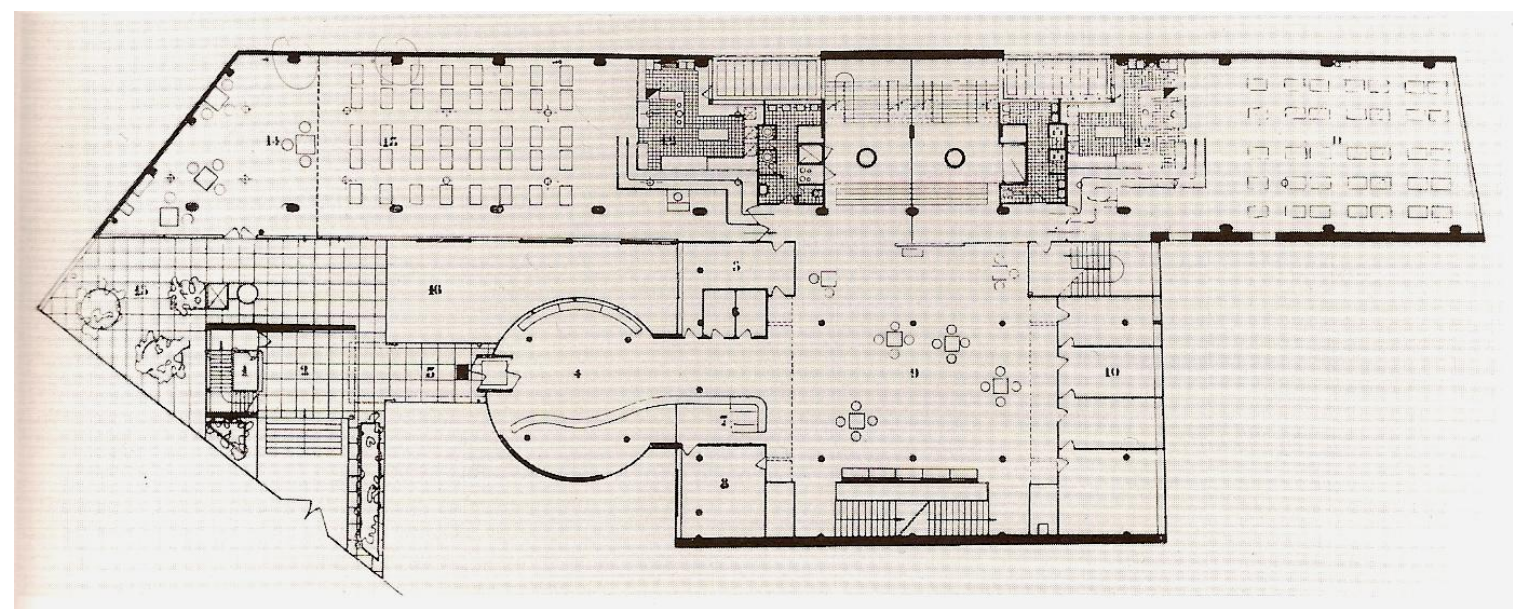

5.9: Cité du Refuge,planta da entrada projeto final 1931

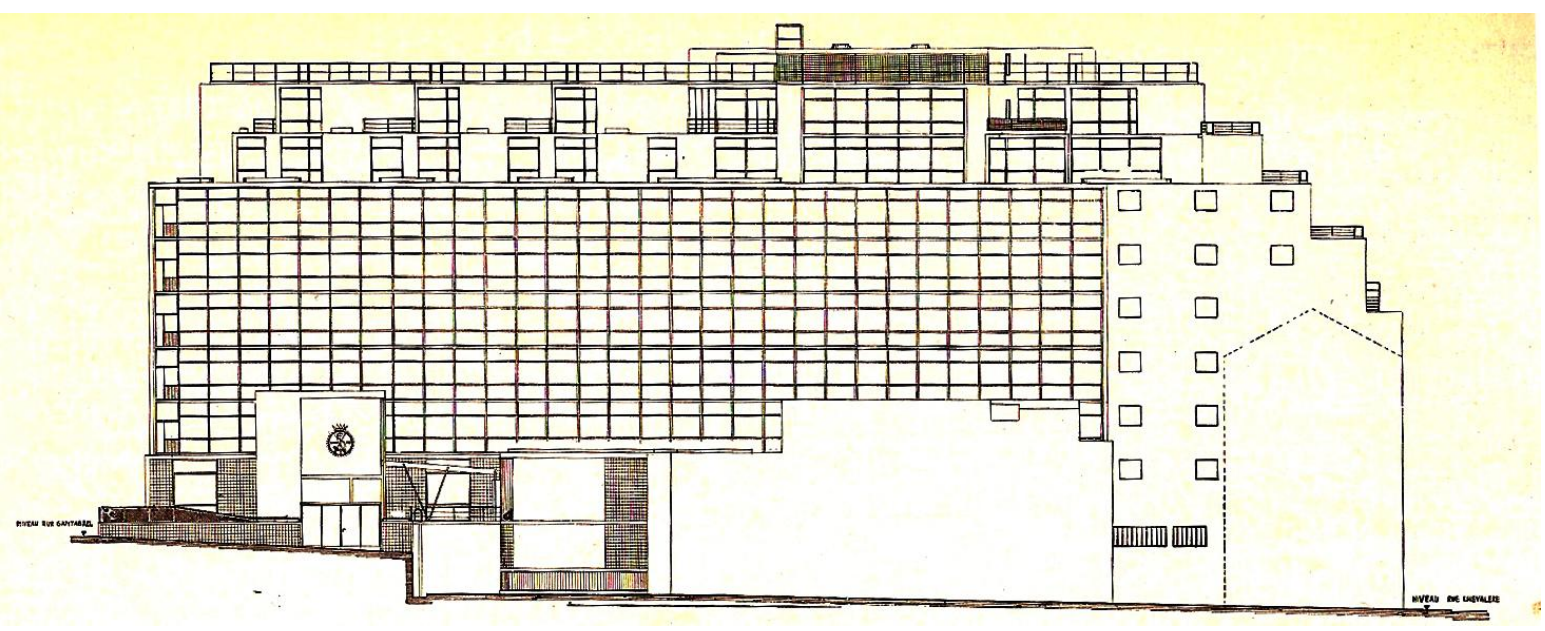

5.10: Cité du Refuge, elevação pela Cantagruel, 1931

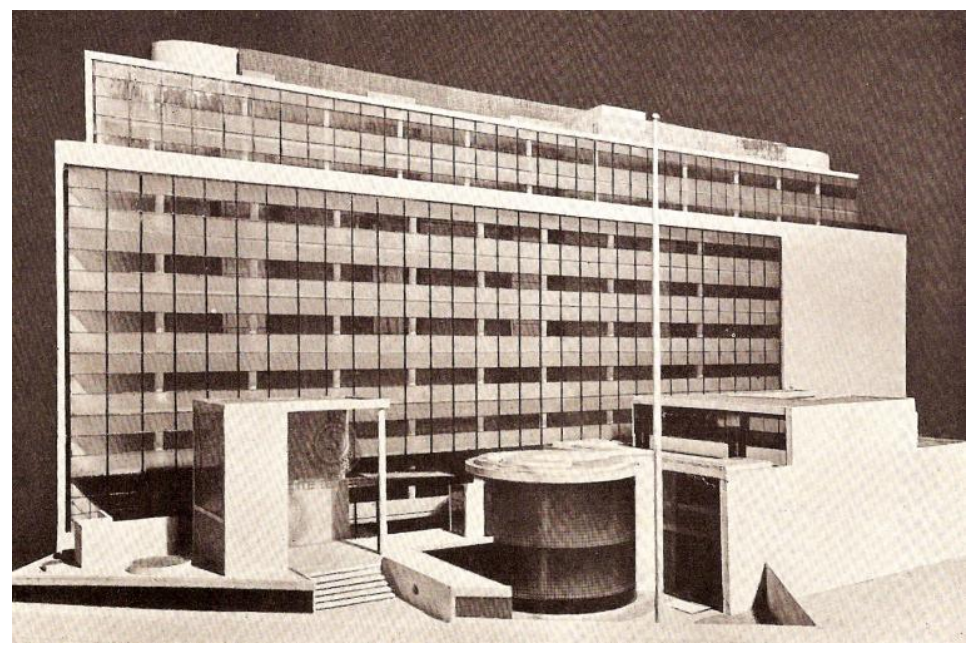

5.11: Cité du Refuge, maquete vista pela Cantagruel, 


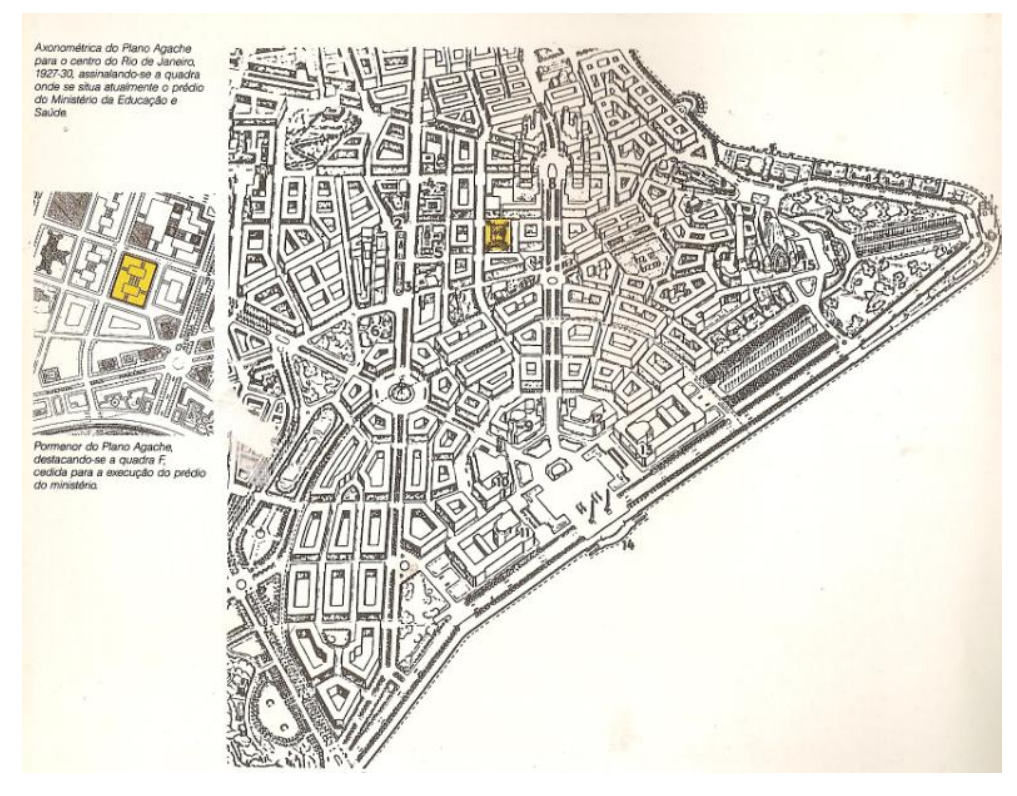

5.12: Plano Agache

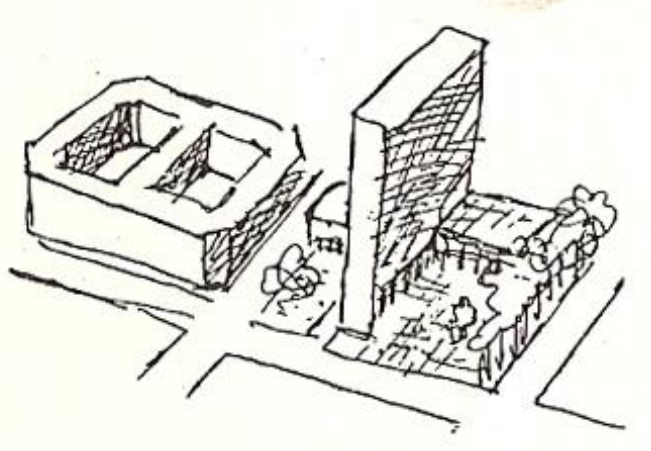

5.13: Desenho de Le Corbusier representando o aproveitamento tradicional do terreno e a solução do Ministério
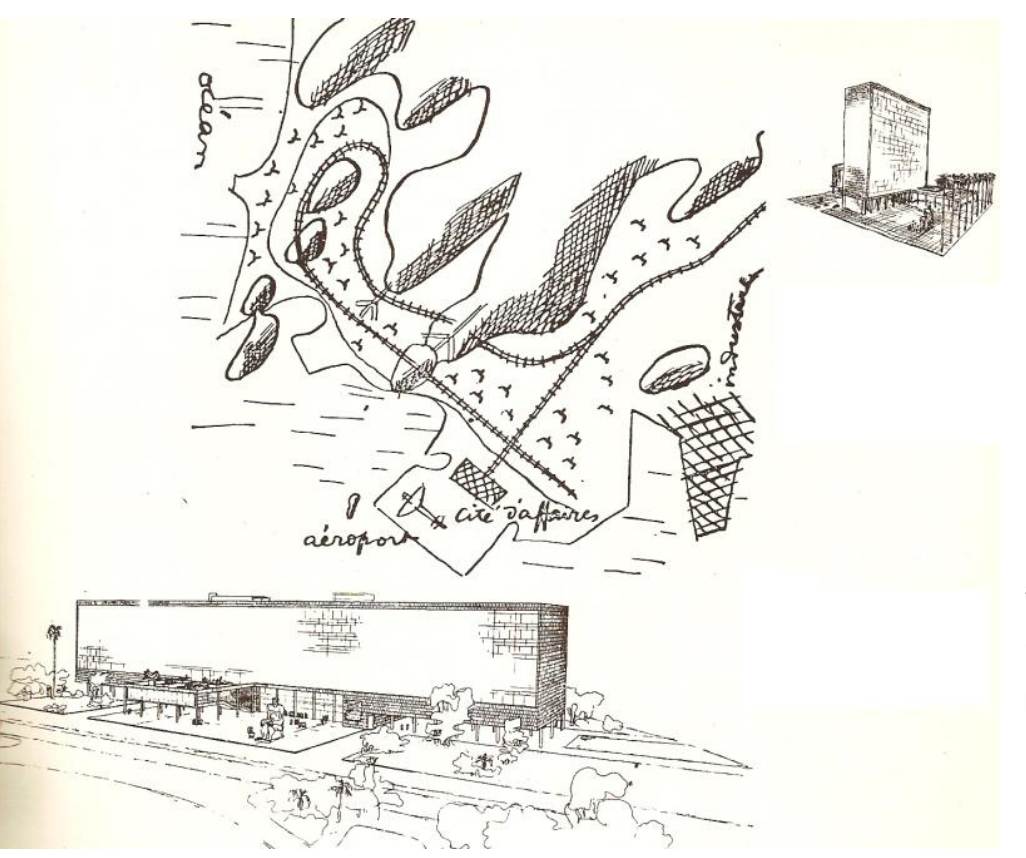

5.14: Ministério da Educação e Saúde , proposta de Le Corbusier para esplanada do Castelo 

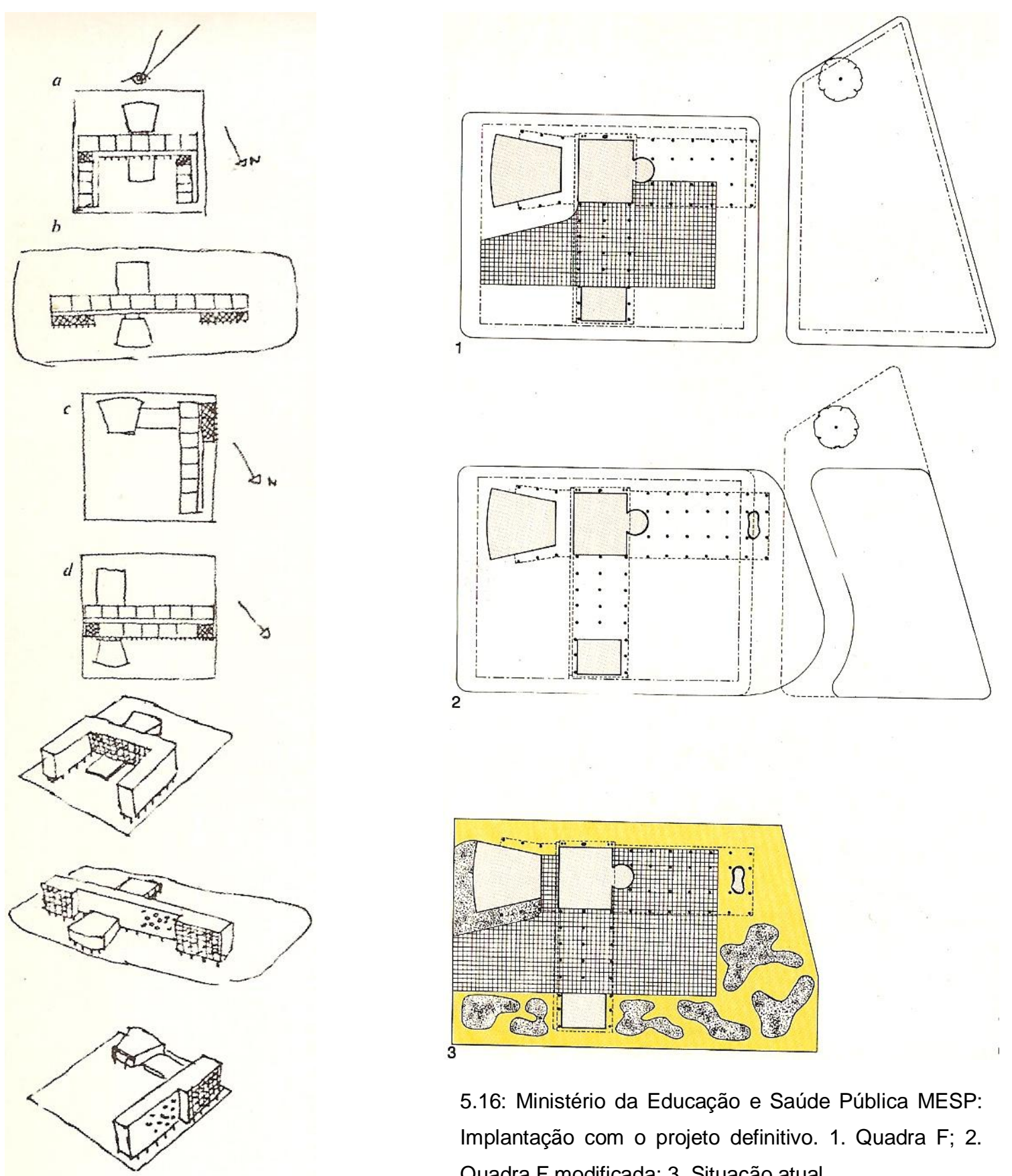

5.16: Ministério da Educação e Saúde Pública MESP: Implantação com o projeto definitivo. 1. Quadra F; 2. Quadra F modificada; 3. Situação atual

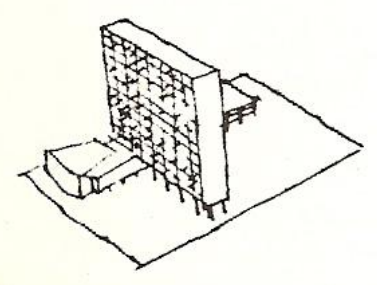

5.15: MESP: Quatro propostas para o projeto:a) primeira ambientação realizada pelo grupo brasileiro b) croqui de Le Corbusier para o terreno da Beira-Mar; c) croquide Le Corbusier para o terreno atual e d) implantação definitiva.. 

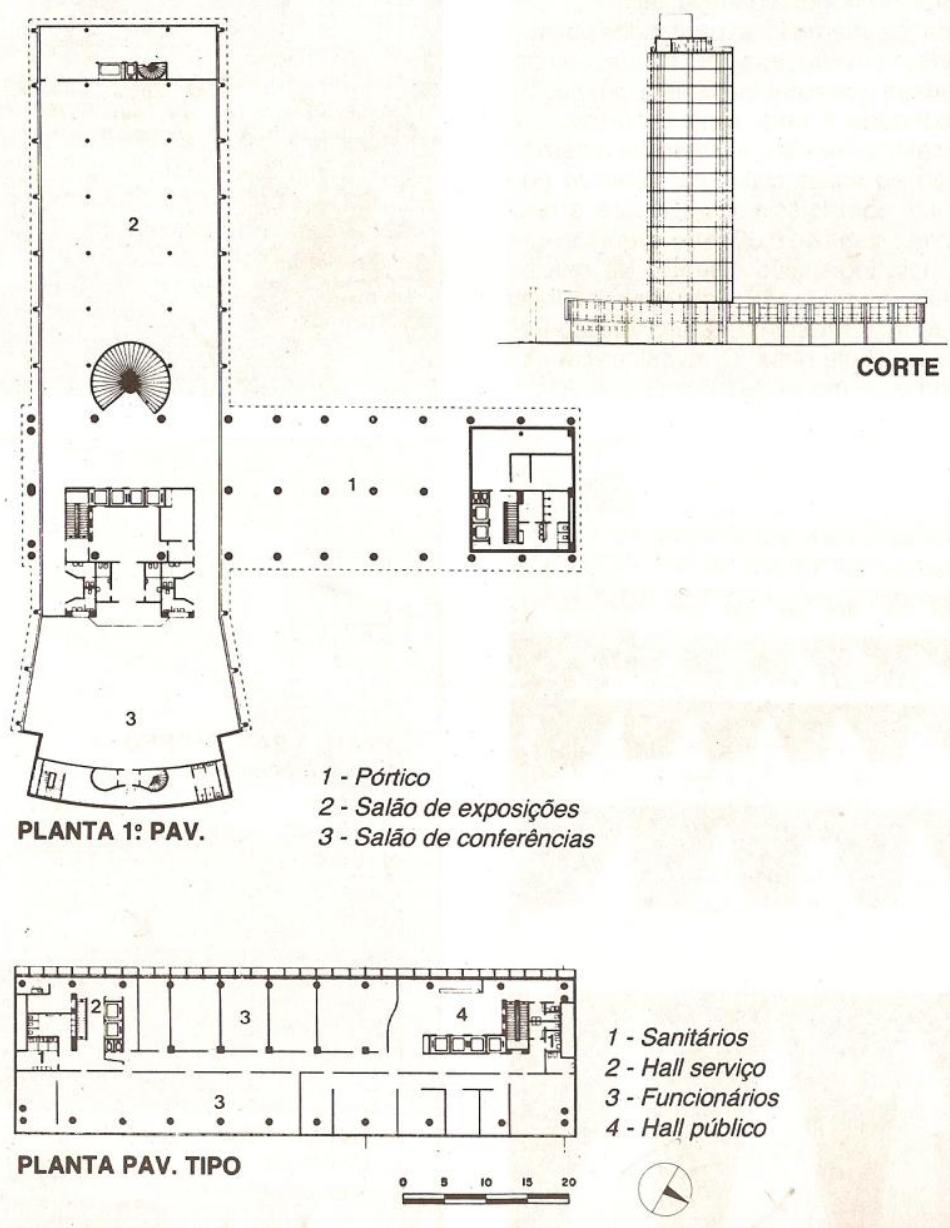

5.17: Térreo, tipo e corte

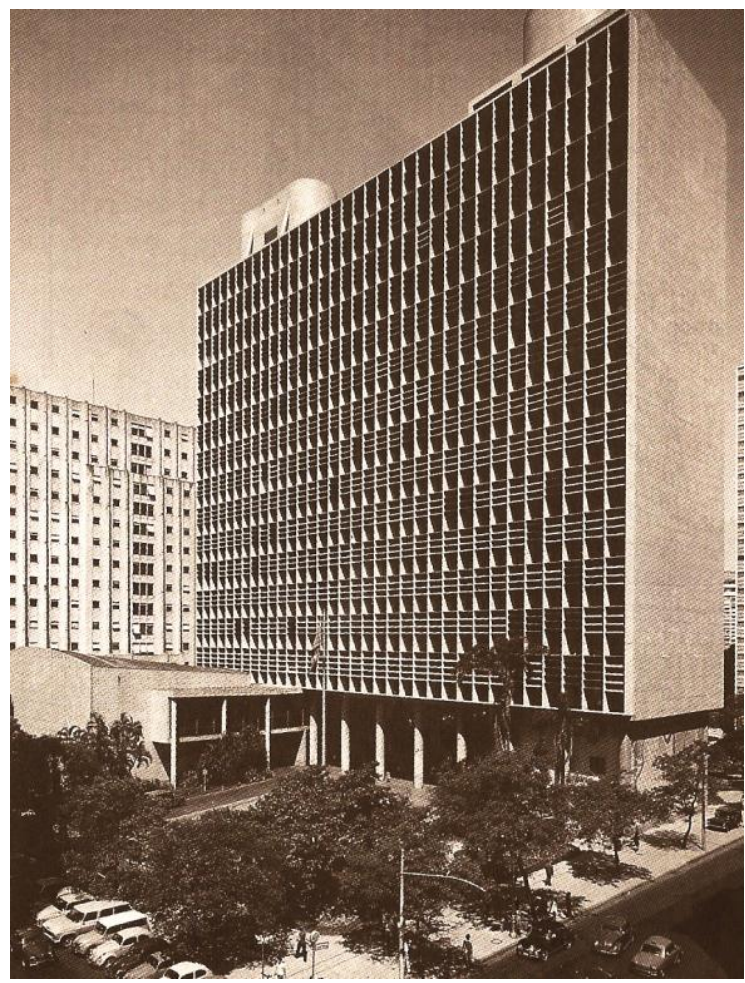

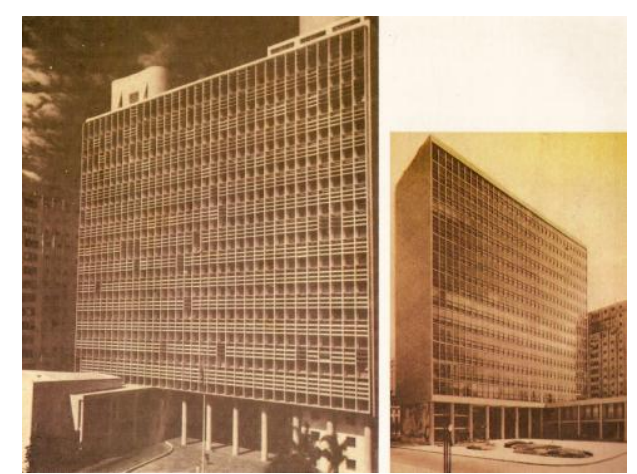

5.19

5.18: Ministério da Educação e Saúde Pública, 1936. 


\section{Ossatura independente}

"A nova técnica reclama a revisão dos valores plásticos tradicionais. O que a caracteriza e, de certo modo, comanda a transformação radical de todos os antigos processos de construção - é a ossatura independente" (Costa, 2007, p. 27).

No capítulo anterior elegeu-se e descreveu-se o objeto-tipo moderno e brasileiro: seus temas serão rediscutidos nos capítulos 7, 8 e 9. Embora se tenha nele levantado uma série de elementos típicos do edifício moderno e de sua relação com a cidade, um tópico em particular merece ser esmiuçado: a ossatura independente, elemento central na definição do edifício moderno. Lucio Costa assim a entendeu.

A descrição da ossatura independente vai de encontro à necessidade de identificar e recortar quais edifícios modernos se estuda no Centro Histórico de São Paulo; uma tarefa de certa complexidade. Pois, sob muitos aspectos boa parte dos edifícios construídos na colina histórica (o triângulo) e o Centro Novo e no primeiro anel do Plano de Avenidas, são modernos: ou, parte constituinte do fenômeno da modernização refletida numa verticalização acelerada.

A Modernidade como um fenômeno amplo envolve um conjunto de manifestações estilísticas. Segundo Marshall Berman, ela seria um turbilhão de quinhentos anos que une a espécie humana: "[...] é uma unidade paradoxal, uma unidade de desunidade: ela nos despeja a todos num turbilhão de permanente desintegração e mudança, de luta e contradição, de ambiguidade e angústia". Desse turbilhão de renovações fragmentárias emergem os significados de modernismo e modernização; "o pensamento atual sobre a modernidade se divide em dois compartimentos distintos, hermeticamente lacrados um em relação ao outro: "modernização" em economia e política, "modernismo" em arte, cultura e sensibilidade" (Berman, 1986, p. 15-87). Sua tentativa seria a de captar e reconstruir a visão da vida moderna como um todo. De fato a modernidade abarca diversos movimentos e essa dicotomia também está presente tanto nas abordagens teóricas sobre a modernização em São Paulo, quanto nos próprios planos modernizadores para cidade ${ }^{68}$. Sob essa divisão também são vistos os edifícios e seus estilos.

Quando se olha de perto os planos para a cidade e os edifícios dúvidas ainda persistem, pois esses dois movimentos encontram-se entrelaçados. A modernidade é um

\footnotetext{
${ }^{68}$ Ver capítulo 5.
} 
fenômeno complexo sujeito a interpretações diversas. Pode-se vê-la sob a ótica das tecnologias, dos estilos dos edifícios e das ideias de cidade e urbanização.

Se há muitos modernismos, há também o edifício moderno que nasce imbricado com as ideias da cidade da arquitetura moderna, nos termos plantados pelas vanguardas modernas. Embora sua concretização tivesse ocorrida - em boa parte dos casos - de maneira fragmentada, seus traços de origem permaneceram como marca indelével. No Centro Histórico de São Paulo existem diversos modernos, principalmente, se o olhar se ater à modernização como um fenômeno universal que os informa, que os enforma. Contudo, abordar todos os edifícios como "modernos" na amplitude das interpretações não se contribui muito para os objetivos desse estudo, que faz um recorte por um tipo particular de edifícios modernos. Na dúvida é indispensável responder de que moderno se trata? Por isso, este capítulo procura precisar esse edifício moderno e ao fazê-lo procura-se identificar os elementos centrais que the conferem caráter e os diferenciam dos demais modernismos. Em sua totalidade, esses edifícios modernos são também construções verticalizadas que em sua lógica interna pressupõe reprodução do solo e piso até os limites da lei e da técnica. Por isso, um elemento como a ossatura independente e suas consequências construtivas e formais são importantes na distinção de uma linguagem.

\section{Art Déco, expressionismos e escola americana dos arranha-céus: transições ou outros modernos?}

São Paulo foi palco de uma progressiva verticalização a partir dos anos 20. Nesse processo ocorreram tanto substituições quanto sobreposições estilísticas: conviveram num mesmo período e numa mesma espacialidade edifícios ecléticos, art décos e modernos. Esses estilos são frutos de uma modernização que de alguma maneira abarca essas variações. Um olhar sobre esses edifícios no Centro Histórico de São Paulo revela de imediato alguns temas que os perpassam igualmente: uma limitada industrialização de componentes, a presença dos elevadores, a estrutura em concreto armado, uma mesma legislação, uma mesma configuração para os lotes, decorrente das formações de um tecido urbano ao caráter da cidade tradicional, além da intensa verticalização.

A historiografia da arquitetura brasileira, em particular de São Paulo, tem tratado dessas manifestações arquitetônicas e seus estilos de maneiras distintas. $O$ arco das abordagens vai das concepções que - mesmo reconhecendo valores nessas manifestações estilísticas - as tratam como uma transição para a genuína arquitetura moderna e aquelas outras que as consideram como uma das formas que o moderno se fez representar. Vitor Campos (2003) defende tese de que o Art Déco jamais se caracterizou como um estilo, 
mas, sim, como uma corrente da arquitetura moderna transformada em fenômeno estético internacional. Embora se façam distinções entre as nuances estilísticas nas décadas de 30 e 40, a tônica é tratá-las como um bloco único e genérico, onde prevalecem alguns traços significativos: o uso do concreto armado, uma simplificação e limpeza das fachadas em ralação ao ecletismo dos anos 20. Assim, o Art Déco' e, outros estilos modernizantes, representavam num contexto de intensa verticalização comercial em São Paulo, estilos de transição que figuraram nessa fase de indecisão da arquitetura brasileira (Branco, 1989).

Nesse mesmo caminho, outras análises e interpretações identificam nas estilizações e geometrizações uma tendência à abstração, derivadas diretamente dos movimentos artísticos de vanguarda; embora, sem a profundidade desses (Pinheiro, 1997). Pinheiro reconhecendo alguns valores e operações compositivas acrescenta uma pertinente observação: "Outro aspecto inovador desenvolvido por alguns arquitetos Art Déco a partir das vanguardas artísticas é que a noção de decoração extrapola as fachadas principais do edifício para estender-se à volumetria em si, isto é, a própria volumetria passa a ser considerada um elemento decorativo, à maneira dos projetos Art Déco de Mallet-Stevens." [...] Porém, é importante salientar que, nesses casos, é sempre patente a intenção decorativa; a volumetria decorre principalmente dessa intenção decorativa [...] e não apenas da correta solução de todos os parâmetros relativos ao projeto, como se propõe a arquitetura moderna" (Pinheiro, p. 128). Otimismos e crenças à parte, sua tese corrobora com uma arquitetura moderna pautada na racionalidade das formas arquitetônicas, no caso a referência é Argan. Em algumas passagens, a autora põe em suspensão - pelas circunstâncias e contradições da produção local - a questão de economia de meios e os recursos sistemáticos a tecnologia industrial - a arquitetura moderna brasileira - em seus primórdios - talvez nunca tenha sido mais econômica do que suas precedentes modernizantes (Pinheiro,1997, p. 232).

$\mathrm{Na}$ década de 30 Mumford discorre sobre princípios da arquitetura moderna ponderando que: "talvez o princípio orientador da arquitetura moderna seja o de economia: economia de material, economia de meios, economia de expressão". Os novos materiais, sobretudo, o aço e o concreto somados aos cálculos mais precisos induziram de certa forma à diminuição de grandes peças sólidas que se incorporavam às grandes massas esculturais. "O próprio interesse pela economia deu uma sanção especial aos materiais mais leves, que são mais fáceis de transportar e, habitualmente, mais fáceis de erigir: a estrutura metálica, a superfície de vidro ou compósita destinada a servir de revestimento para o interior, a divisão flexível, tomaram o lugar das peças mais embaraçosas e estáticas" (1961, p. 430).

Mumford fala de uma arquitetura moderna no geral, mas circundado pelas experiências modernas americanas da década de 20. Em 1928, faz uma avaliação e defesa 
seletiva da arquitetura americana dos anos 20; a arquitetura dos grandes arranha-céus, principalmente de Nova York. Ele clama, então, para uma retomada das origens da arquitetura vertical nos termos praticados em Chicago (Root, Sullivan e Wright), pelos princípios funcionalistas: em outros termos, chama atenção para novo papel conferido à estrutura. A crítica de fundo recai sobre aqueles edifícios de estilos e motivos fantasiosos. Nesse cenário, procura distinguir e defender essa prática americana, sobretudo na arquitetura de Buchman e Ely Kahn, no Parking Avenue Building: carregadas de um décor difícil de ser assimilado pelas vanguardas europeias - Le Corbusier e Gropius; fixados demais na estética [da máquina] mais ideológica do que pragmática. Segundo Mumford, o emprego do aço, concreto, tijolo e terracotas para os edifícios altos ou não estavam resolvidos, principalmente, quanto à necessária proteção e revestimento das peças metálicas contra possíveis incêndios. Por outro lado, o emprego do vidro ainda apresentava restrições quanto às mudanças bruscas de temperatura, considerando-se ainda a questão da altura e do efeito do vento ${ }^{69}$. Portanto, para Mumford a estrutura e seus revestimentos protetores coloridos e com motivos ornamentais abstratos e as aberturas menores estavam em perfeita relação fundidos numa mesma expressão de estrutura e caráter (Mumford, 1928, p. 75-78, Casabella 457/458).

Essas aproximações a partir de Mumford e dos grandes arranha-céus americanos ${ }^{70}$ servem para recortar, para fins comparativos, aspectos do Art Déco ou mesmo expressionista como define Curtis (1996, p. 224), que identificam as possíveis categorias que descrevem os edifícios Chrysler Building e Empire State Building, em Nova York. Dois exemplos representativos de um capitalismo comercial, de um imaginário levado às alturas, no entre guerras, e que tiveram desdobramentos nos edifícios Altino Arantes (Banespa) e o Azevedo Villares, em São Paulo.

Essa breve introdução expõe a extensão do problema e das interpretações, não as resolve evidentemente, mas facilita a abordagem de quatro aspectos importantes que ajudarão no refinamento de qual edifício moderno se trata nessa tese. Primeiro, o sentido da economia de meios, posta em termos amplos por Munford; segundo, o aspecto da tecnologia, indicando a procura pela leveza e transparências envidraçadas; terceiro, a estética [da máquina] de caráter mais ideológico nas correntes representadas por Le Corbusier e Bauhaus; quarto, ao papel conferido à estrutura.

${ }^{69}$ São conhecidos os problemas técnicos enfrentados por Le Corbusier na Cité du Refuge em Paris. No caso em questão, a solução de ar-condicionado proposta simplesmente entrou em colapso no verão parisiense (MOOS, Stanislaus von. Le Corbusier, Elements of a synthesis. Cambridge, The Massachusetts Institute of Technology, 1979. p. 93).

${ }^{70}$ Ver capítulo 5. 
A economia paira sobre todas. Mas a economia associada [e muitas vezes subordinada] a questões estéticas ideológicas que valorizaram de sobremaneira a leveza, a transparência e estrutura, encaixa-se melhor às correntes funcionalistas. Particularmente para a arquitetura moderna brasileira, para a qual a ossatura independente terá papel determinante - para além das primeiras proposições modernas.

\section{Estrutura: pragmatismo e teorização}

A questão da estrutura foi assunto relevante para a arquitetura a partir da segunda metade do século XIX, sobretudo em Chicago onde a indústria oferecia aos arquitetos e engenheiros um amplo leque de opções e soluções, de onde resultaram inúmeras aplicações de cunho pragmático: arquiteturas com ossatura independente, entretanto, sem as conotações e dimensões estéticas elaboradas pelos europeus: que as transformaram num ícone da arquitetura moderna, mais tarde do denominado "estilo Internacional". Em "A Estrutura de Chicago" Colin Rowe afirma que a estrutura é na verdade a essência da arquitetura moderna. No mesmo contexto dirá que na arquitetura contemporânea [moderna], a estrutura passou a deter o papel que na antiguidade clássica e no renascimento cabiam a coluna (1999, p. 91-2). A origem dessa questão, de acordo com Rowe, se encontraria na arquitetura de Chicago, entre outras, nas arquiteturas de William Le Baron Jenney, Louis Sullivan e Frank lloyd Wrigth: que propuseram dois dos principais temas da arquitetura do século XX: o esqueleto estrutural (armação) e a composição por planos em intersecção.

A prioridade da contribuição de Chicago não elimina, segundo Rowe, as legítimas influências que Doesburg e Rietveld poderiam alegar originárias nas inovações introduzidas pelos cubistas, assim como para Le Corbusier em suas preocupações derivadas das estruturas de concreto armado de Auguste Perret. $O$ fato foi que por detrás da arquitetura de Chicago encontrava-se uma forte indústria que fornecia aos arquitetos amplo catálogo de perfis metálicos estandardizados; que atendiam às expectativas da arquitetura comercial: que como tal requeriam um planejamento simples que definisse uma circulação elementar, boa zona de iluminação e um indefinido número de pavimentos. Nessa situação a estrutura metálica reticulada solucionava um problema prático: que depois - já incorporado a uma considerável complexidade espacial - alimentou toda a arquitetura moderna especialmente o chamado estilo internacional. Esse fato explica uma distinção relevante entre a América do Norte e a Europa: nos Estados Unidos a economia [e a tipologia comercial] recomendava o 
emprego dos reticulados ${ }^{71}$; na Europa, empregavam-se igualmente estruturas de tijolos, de concreto armado e seus inovadores mais importantes não davam grande importância às recomendações econômicas (Rowe, 1999, p. 97).

Outras diferenças entre os dois continentes marcam atitudes distintas: o pragmatismo americano de um lado; e o idealismo teorizado do outro. Rowe compara duas obras: o edifício McGlurg (Holabird e Roche, 1899-1900) e o edifício Maison Peuple em Bruxelas (Victor Horta, 1897). Ambos segundo Rowe estão preocupados com a estrutura; porém, no primeiro é possível perceber o cumprimento de necessidades práticas, no segundo, a formulação de certos postulados teóricos. No primeiro, a estrutura de metal se apresenta como solução a um problema específico, com a intenção de construir um entorno racional para as atividades de seus clientes; no segundo, uma previsão em ferro forjado da estrutura metálica [exposição do ferro] vem exposta como manifesto de um programa arquitetônico; com mostras de sofisticação e impacto, provocando reações de aceitação e recusa $(1999$, p. 101-2).

Ainda explorando as diferenças ideológicas entre continentes, Rowe estabelece uma comparação pertinente entre o Reliance Building (Daniel Burnham, de 1894, e o projeto da Torre de Cristal de Mies van der Rohe, 1921). De início distingue o fato de se confrontar um edifício construído e um projeto: um edifício como resultado concreto de um problema particular e a solução abstrata de um problema geral. Um posto numa rua da cidade comercial, outro tendo ao fundo colinas com bosques e telhados góticos. O Riliance é quase desprovido de conotações ideológicas e configura-se como uma resposta direta a um problema técnico e funcional. A torre, ao contrário, tem enorme carga simbólica, uma implícita crítica social e um compromisso diante de interesses morais e estéticos de um sentimento utópico (1999, p. 106).

Na América o edifício vertical era uma realidade, na Europa um sonho. Sob esse rol de diferenças interpõe-se Le Corbusier: cujos arranha-céus da Vila Radiosa apresentavamse como abstrações racionalizadas e capturadas dos arranha-céus americanos. Contudo, sem parecer com esses naquilo que tinham de mais característico: "um cálculo racional (com pertinentes elementos decorativos quando eram necessários) de uma inversão proveitosa em determinada especulação" (Rowe,1999, p. 106). Em suma, na Europa seus inovadores atribuíram à estrutura uma função ideal, geral e abstrata:

O desenho de Le Corbusier para a Casa Dom-ino representa, precisamente, essa valorização; e talvez constitua a ilustração perfeita ao sentido que teve a estrutura para o

71 "Na América do Norte não se usava estrutura de ferro ou concreto armado na arquitetura doméstica talvez por não ser necessária, mas foram muitos os monumentos do movimento moderno que subsistiram provando o contrário" (Rowe, 1999, p. 97, trad. nossa). 
Estilo Internacional. Nela o que encontramos não é tanto uma estrutura, mas um ícone, um objeto de fé, que deve atuar como garantia de autenticidade, o signo exterior de uma nova ordem, uma garantia contra o deslize da iniciativa privada, uma disciplina por meio da qual um expressionismo invertebrado pode ser reduzido à aparência da razão (Rowe, 1999, p. 107).

A polarização proposta por Rowe pode ser transferida para as condições da arquitetura vertical edificada no Centro de São Paulo; abarcando praticamente todos os edifícios e estilos, principalmente aqueles ligados à Arquitetura Internacional. Sob o imperativo da estrutura há manifestações nos dois extremos: da utilidade e da idealidade. Da arquitetura moderna [do edifício] que aqui se trata a estrutura tem papel central no controle das formas e definição de uma linguagem.

\section{A nova técnica: a ossatura independente}

Lúcio Costa em "Razões da Nova Arquitetura" (1933-35) disseca esse elemento chave: a ossatura independente e o entende como a nova técnica que parece ao mesmo tempo subordinar e liberar todas as demais - da planta à fachada livre. Uma vez definida tal condição os assuntos de linguagem (ou estilo) surgiriam como decorrência lógica e natural da nova técnica. Nesse sentido, suas concepções assemelham-se àquelas europeias de caráter idealizado.

"A nova técnica reclama a revisão dos valores plásticos tradicionais. O que a caracteriza e, de certo modo, comanda a transformação radical de todos os antigos processos de construção - é a ossatura independente" (Costa, 2007, p. 27). Dessa forma as paredes foram destituídas do pesado encargo que Ihes fora sempre atribuído, agora Ihes cabendo uma nova função, a de simples vedação. "Assim, aquilo que foi - invariavelmente uma espessa muralha durante várias dezenas de séculos, pôde, em algumas dezenas de anos, graças à nova técnica, transformar-se (quando convenientemente orientada, bem entendido: sul no nosso caso) em uma simples lâmina de cristal" (Costa, 2007, p. 28) Lúcio Costa, mais adiante acrescenta: parede e suporte representam hoje, portanto, coisas diversas; inconfundíveis. Diferentes quanto ao material, quanto à [espessura]. Como consequência, essas poderiam ser fabricadas com materiais leves, à prova de som e das variações de temperatura. De raciocínio a raciocínio a nova técnica não apenas garantiria liberdade à planta como também se estenderia à fachada "já agora denominada livre".

Lúcio Costa ainda afirmará que a nova técnica permitiria à arquitetura uma intensidade de expressão até então ignorada. Nesse momento, a expressão estrutural a que se refere Lúcio Costa está um pouco distante das pioneiras manifestações de Perret; 
primeiro arquiteto a usar o concreto armado como meio de expressão arquitetônica (Giedion, 2004, p. 355). Para Giedion a ossatura de concreto é utilizada sem disfarce e explicita-se como um dos elementos constituintes do edifício. "Porém, a contribuição mais importante de Perret à geração mais jovem de artistas franceses está no tratamento flexível da planta. [...] As divisórias são dispostas com plena liberdade, a fim de ligar pilares de concreto distantes. Perret estava imbuído do mesmo espírito de Horta, e mais tarde Le Corbusier" (Giedion, 2004, p. 356). Por outro lado, Banham dirá que Auguste Perret incorporou a ideia de Choisy de uma moldura que suporta a carga com um enchimento leve, e daí em diante, o conceito da separação entre suporte e roupagem tornou-se uma das ideias mais discutidas, embora das menos praticadas, do movimento moderno" (Banham, 1979, p. 54).

Quando Lúcio Costa escreve "Razões da nova arquitetura”, essa questão colocada anos depois por Banham já estava de certa maneira contemplada. As dificuldades pragmáticas para levar adiante o ideário estético moderno já se mostravam visíveis.

Conquanto a estrutura seja, de fato, independente - o material ainda empregado no enchimento das paredes externas e divisórias é pesado e impróprio para tal fim, obrigandoas assim, naturalmente, a não perder de vista as vigas e nervuras, para evitar um esforço antieconômico das respectivas lajes; daí a preocupação de interpenetrar - numa identificação impossível e estéril - a espessura contraditória das colunas e paredes - e, como ainda procuramos recompor as fachadas reproduzindo as idéias mentirosas de embasamento e parede-suporte - atribuindo, assim, aos nossos edifícios, certas aparências próprias a construções de outro sistema: todas as possibilidades da nova técnica são, praticamente, anuladas - carecendo de significação a maior parte das tentativas, apesar das grotescas feições modernísticas e outras incongruências (Costa/Xavier, 2007, p. 31)

Situações semelhantes envolvendo dois mundos distintos: de um lado o universo das ideologias das vanguardas, por outro o pragmatismo, sobretudo vindo da arquitetura americana. Em 1928, Erich Mendelsohn comenta e compara as experiências das vanguardas Russas dos anos 20 , com a intensa produção americana indiretamente reportada na "Metrópole do Amanhã", de Hugh Ferris. Suas insinuações, em 1928, sublinhavam sinteticamente um problema da arquitetura daqueles anos: os Russos tecnologicamente ainda eram primitivos e procuram salvação no exagero das formas para além de suas possibilidades técnicas, enquanto na América procurava-se uma espiritualidade que Ihe era estranha (Mendelsohn apud Curtis, 1996, p. 226).

Em "Razões da Nova Arquitetura", Lúcio Costa expõe com impressionante clareza o cerne icônico da arquitetura moderna: o esqueleto Dom-ino (embora sem citá-lo 
diretamente, figura 6.1). Ele elabora de certa maneira um roteiro de suas possíveis aplicações e implicações: disseca a nova técnica e por decorrência seus desdobramentos na organização espacial (plantas), nas fachadas (livres) e os cantos que podem estar livres de apoios. Indo adiante trata das expressões plásticas, dos materiais, da industrialização, da ausência de ornamentação, da simetria (como medida); em síntese, descreve um novo estilo.

Em 1936, no memorial descritivo elaborado pela equipe brasileira para o projeto do MESP ${ }^{72}$ é possível identificar minuciosamente os preceitos contidos no texto "Razões..." de Lucio Costa .Então, aplicados num projeto singular implantado em contexto existente e com programa definido: nessas circunstâncias são apresentados - um a um - os argumentos de projeto e os pontos centrais em torno dos quais giravam as preocupações estéticas e construtivas modernas, no lato senso, os cinco pontos na visão corbuseriana:

[...] Em razão do aproveitamento racional da estrutura dos pisos, os suportes foram transferidos do alinhamento das fachadas para o interior do edifício; segundo, dessa transferência resultou que as fachadas - cuja função de suporte exigia, para abertura dos vãos necessários à aeração e iluminação, cuidados excepcionais, sem poder dispensar respeitáveis apoios intermediários - passaram a constituir uma simples vedação, podendo ser rasgadas, portanto, de extremo a extremo ou complemente fechadas: de acordo com as conveniências de orientação, do serviço ou, satisfeitas essas, da aparência; terceiro, sendo assim as fachadas "livres" da estrutura, em cujos pilares internos se concentra todo o esforço, as paredes divisórias - compostas de matéria leves e à prova de ruído, ou formando casiers utilizáveis de ambos os lados do espaço dividido - puderam razoavelmente tomar formas diversas de acordo com o tráfego ou outros motivos, dispondo-se, para os respectivos remates de encontro à fachada, dos inúmeros painéis que dividem os vãos em elementos uniformes; quarto, portanto, "livres" as paredes divisórias tanto das fachadas como da estrutura, tudo recomendou a adoção de um sistema de lajes duplas solidárias com as vigas e nervuras de forma a permitir - em todos os compartimentos - teto liso e contínuo, sem os inconvenientes das vigas aparentes do processo atual que tanto dificultavam o acabamento perfeito das divisões internas; quinto, finalmente, a instalação, no próprio piso, de uma rede contínua de tomadas para telefones, luz, sinais ou campainhas com afastamento mínimo convincente - tornará possível a colocação das mesas de trabalho em qualquer posição, diretamente sobre as referidas tomadas, sem que os fios atravessados comprometam o desembaraço da circulação (Lissosvsky e Sá, 1996, p. 61-2).

Em nota a cerca do parecer de Domingos da Silva Cunha, setembro de 1936, em torno da proposta brasileira há uma clara vinculação entre a ossatura independente (nova

${ }^{72}$ Após anulação do concurso para o MESP é formada uma equipe de arquitetos brasileiros, chefiados por Lúcio Costa que elabora novo projeto, anterior à chegada de Le Corbusier no Brasil. 
técnica) e as novas ideias urbanísticas: portanto, da arquitetura da cidade moderna (figura $6.2)$.

Ressalta-se que ao objeto-conceitual idealizado no texto e proposto em projeto, ainda não havia sido adicionado de outro importante elemento caracterizador da arquitetura moderna e brasileira: o brise-soleil; que seria de fato construído na versão final, já com a participação de Le Corbusier. Esse ideário, sobretudo, a ossatura independente é o elemento prático/conceitual que demarca e explora as diferenças entres os diversos modernos existentes no Centro Histórico de São Paulo. É justamente essa intenção estética e técnica almejada na ação construtiva que diferencia, entende-se aqui, a arquitetura moderna vinculada aos preceitos funcionalistas das demais correntes ou variantes modernas. Ou seja, o moderno que aqui se recorta está contido nos termos gerais propostos por $\operatorname{Argan}^{73}$ e dos quais se ramificam diferentes tendências a partir de enfoques problemáticos distintos quanto a situações objetivas, sociais e culturais, assim apresentados: 1) racionalismo formal (Le Corbusier); 2) racionalismo metodológico-didático (Bauhaus e W. Gropius); 3) racionalismo ideológico (Construtivismo Soviético); 4) racionalismo formalista (Neo-plasticismo holandês); 5) racionalismo empírico (A. Alto); 6) racionalismo orgânico (F. L. Wright); (1984a, p. 325). Sob esse arco, pode-se dizer que contextos particulares produzem arquiteturas particulares.

\section{Estrutura independente e fachada livre: dois modernos}

A contraposição entre os edifícios Banco Paulista do Comércio (atual Edifício Paulista ${ }^{74}$ ) e Azevedo Villares exemplifica parte das distinções modernas que se procura delimitar e esclarecer. Esses edifícios demarcam posições no espectro moderno. Mas, não estão necessariamente no extremo de uma posição antagônica. Entre eles há outras manifestações modernas como os edifícios Davi Cury que expressa enorme clareza estrutural, contudo, não revelando ainda a carga simbólica expressa na identidade dos planos horizontais: no caso predomina ou se acentua mais a verticalidade da torre, que nas manifestações racionalistas formais são preteridas pelas horizontalidades (figura 6.3)

73 "A arquitetura moderna desenvolveu-se em todo o mundo segundo alguns princípios gerais: 1) a prioridade do planejamento urbano sobre o projeto arquitetônico; 2) a máxima economia no aproveitamento do terreno e na construção com fim de poder resolver, ainda que seja ao nível de um "mínimo aceitável", o problema da moradia; 3) A rigorosa racionalidade das formas arquitetônicas, entendidas como deduções lógicas (efeitos) das exigências objetivas (causas); 4) o recurso sistemático da tecnologia industrial, da estandardização e da pré-fabricação em série, ou seja, a progressiva industrialização da produção de objetos pertencentes à vida diária (desenho industrial); 5) a concepção da arquitetura e da produção industrial qualificada como condicionantes do progresso social e da educação democrática da comunidade (Argan, 1984ª̣ , p. 324-25, trad. nossa).

${ }^{74}$ O Banco Paulista do Comércio por ter sido adotado com um "tipo ideal" será novamente abordado no capítulo "Primeiros encontros". 
Os edifícios localizam-se no Triângulo Histórico. O Banco Paulista (Rino Levi, 194754) na esquina da Rua Boa Vista com Ladeira Porto Geral; o Azevedo Villares (Escritório Técnico Ramos de Azevedo, Severo e Villares,1938-46) na esquina da ruas 15 de Novembro e do Tesouro. Ambos foram implantados em lotes de esquina de conformação irregular que remontam aos primeiros traçados coloniais. Ambos são marcados pela mesma legislação, ou seja, os escalonamentos (recuos) sucessivos ${ }^{75}$. Ambos foram construídos em concreto armado e esquadrias de ferro. Ambos eram destinados aos serviços, com comércio $^{76}$ no térreo. Em ambos, também, as disposições dos elevadores e caixas de escada, como sanitários respondem a uma mesma lógica (ou estratégia): estão postados contra as empenas e divisas laterais dos lotes lindeiros, deixando livres as fachadas voltadas para as ruas. Portanto, a disposição do lote numa esquina dita em parte as decisões quanto às aberturas e circulações: privilegia-se, com toda razão, as fachadas principais.

O Azevedo Villares - apesar de possuir um apêndice de pouca altura nos dois primeiros andares - revela-se como uma torre escalonada nos moldes dos arranha-céus de Nova York. Uma perspectiva de lançamento do edifício o representa à maneira das grandes torres americanas, à semelhança das simulações volumétricas dos setback. Grandes contrastes de luz e sombra enfatizam sua altura e imponência, amplificando sua posição privilegiada de esquina (figura 6.4).

No caso do Banco Paulista do Comércio, tais condições não foram possíveis; a irregularidade acentuada do lote e a legislação impuseram uma dupla volumetria. Uma foto de época o enquadra, pela Rua Boa Vista, cercado de edificações ecléticas (que seriam em breve postas abaixo), a imagem dá a entender que se trata de uma única volumetria: mas, pela Ladeira Porto Geral desenvolve-se o outro corpo escalonado conforme legislação pautada nas experiências americanas do "zonings"77.

Se essas implantações denunciam as marcas e forças das leis e da forma urbana nos edifícios, revelando as contradições e impropriedades entre o tecido da cidade tradicional e as ideias de modernização - também vinculadas a uma verticalização especulativa e intensa - um olhar mais atento aos edifícios nos mostra as diferenças entre dois fazeres "modernos: um de caráter mais pragmático e expressionista o Azevedo

${ }^{75}$ Ver capítulo 4.

${ }^{76}$ O Banco Paulista do Comércio foi projetado como um edifício para uma única instituição. No térreo localizava-se a agência bancária (onde ainda hoje funciona como tal) e no subsolo, uma loja.

${ }^{77}$ Ver capítulo 7. 
Villares e o outro imbuído de um programa de arte e arquitetura comprometido com a arquitetura moderna racionalista o Banco Paulista do Comércio; (figuras 6.5 e 6.6).

Rino Levi retornara de seus estudos de arquitetura em Milão convicto dos preceitos modernos depois dos contatos com as ideias e obras de Le Corbusier, Walter Gropius, Mies Van der Rohe e Erich Mendelsohon. No Banco Paulista a ausência dos anteparos solares expõe melhor a ossatura independente e suas mais imediatas consequências: no caso, pilares soltos no espaço sobre os quais se apoiam os planos horizontais (lajes de piso), encerrados pelo pano vertical das esquadrias de ferro e vidro. Em resumo, uma materialização de unidade do esquema Dom-ino, que Curtis aponta um ícone da arquitetura internacional ou moderna; uma meta a ser atingida de diversas formas possíveis. Entretanto, difícil de ser atingindo nos termos da arquitetura, da construção - guardando as diferenças culturais e tecnológicas $^{78}$. Essa é a questão que distingue com clareza os dois edifícios. Ou seja, a construção dos dois planos paralelos e abstratos descarregando suas cargas sobre pilares soltos no espaço - liberando as fachadas e fazendo-as contínuas horizontalmente e apenas interceptadas pelos panos salientes das lajes (figuras 6.7 a 6.11).

As imagens ilustram e sinalizam caminhos possíveis: o mais pragmático (e talvez mais econômico) adotado no Azevedo Villares, no qual uma laje nervurada vence sem pilares intermediários os vãos (10,70 x 13,50 metros) do salão dos escritórios. A regularidade da trama só é quebrada quando se encontra as irregularidades do lote no perímetro externo, como o chanfro de esquina. As nervuras encontram-se expostas (sem forros ou qualquer enchimento que as esconda) e coincidem rigorosamente com pilares postados nas extremidades das fachadas; a ideia de plano contínuo não faz parte das preocupações e nem a intenção de expor os pilares como elementos de expressão arquitetural; até porque, se os pilares fossem mantidos afastados das paredes, implicaria pelas circunstâncias uma perda desnecessária de área.

Então, o que se vê são pilares encostados nas espessas paredes externas e uma aparente desvinculação entre o espaço interior e o tratamento dispensado às fachadas. Aparente porque os pilares são incorporados indiretamente no jogo compositivo das fachadas, marcando a posições dos cheios e vazios: ou seja, o esquema distributivo das janelas e pilaretes verticais são determinados a partir dos espaçamentos dos pilares, incorporando-os na configuração final, ainda que não se possa identificá-los pelas vistas exteriores. Embora, tenha-se uma laje que avança por um pequeno balanço além da laje

\footnotetext{
${ }^{78}$ Colin Rowe, refletindo sobre a arquitetura Mies em ''Neo-Classicismo' e arquitetura moderna II", deixa muito claro a trajetória difícil para se criar a idealidade de dois planos contínuos e paralelos pela construção arquitetônica que impõe seus limites estruturais e econômicos (Rowe, 1999).
} 
nervurada, não se tem propriamente dito uma fachada livre: principalmente porque a opção foi janelas de pequena modulação; fixadas de maneira convencional em parapeitos e montantes de alvenaria: controlando, assim, a estanqueidade das esquadrias de ferro, por meio de sistema convencional já testado. No Banco Paulista do Comércio as esquadrias metálicas são contínuas e estão fixadas nos planos das lajes de caixão perdido; portanto, sujeitas às movimentações que poderiam deformá-las.

As plantas e imagens do Banco do Comércio não deixam muitas dúvidas quanto aos princípios e às operações de projeto: se quer enfaticamente no corpo principal mais elevado nas esquinas, das ruas Boa Vista e Ladeira Porto Geral, a sobreposição dos planos paralelos (lajes) sobre colunas soltas no espaço, promovendo os contínuos espaciais: a ossatura independente nos termos de sua ideação: nessas circunstâncias, fica exposta a técnica que controla a linguagem e deixa manifestar seus elementos essenciais - a planta livre e principalmente a fachada livre e corrida. No limite, conforme, prescreve Lúcio Costa, vedadas quando conveniente por delgadas paredes que não suportam mais carga: no caso, esquadrias metálicas leves fixadas nas faces superiores e inferiores das lajes; no limite das possibilidades técnicas, incluindo os riscos inerentes às inovações. O que significa uma tripla procura: a transparência, a leveza e por decorrência delgadas espessuras. Além desses elementos é a laje tipo cogumelo em grelha, com preenchimento cerâmico entre nervuras, que possibilitava a época, superfícies planas nas partes inferiores e superiores, com isso enfatizando o contínuo espacial.

Um olhar atento pelos edifícios modernos no Centro de São Paulo mostrará uma série de similitudes como as idealidade e referências apresentadas até agora. Nem sempre será possível encontrar ponto a ponto todos os elementos modernos como descritos até aqui, mas eles estarão presentes: os pilares nem sempre estarão afastados das fachadas, mas a intenção de evidenciar planos horizontalizados associados à transparência no limite da esbeltez será uma constante que se estenderá à frente. E parafraseando-se Argan; sob todo edifício construído subjaz um edifício ideal.

De volta ao ponto de partida, pergunta-se então - de qual moderno se trata? Tratase como exposto, do moderno decorrente dos programas de arte e arquitetura das vanguardas racionalistas: mesmo tendo-se em vista as contradições e complexidades das modernizações, mesmo aceitando-se que a modernidade como crítica ao moderno encontra-se aberta, mesmo levando-se em conta que o moderno pode ser visto de modo ampliado, não necessariamente vinculado ao ideário europeu.

Não há dúvidas que parte da arquitetura moderna brasileira enriqueceu-se das ideias sintetizadas e divulgadas por Le Corbusier e Lucio Costa no Brasil. Essas idealidades e 
programas de arte pairam sobre os demais arquitetos, ainda que isso não signifique dizer que essa seja a única fonte de intenções e problemas: pelo contrário, há interpretações e soluções formais e construtivas relevantes de arquiteto para arquiteto, de circunstâncias a circunstâncias que reinterpretam esses postulados. Mas é pertinente concordar com Lúcio Costa e William Curtis; o moderno constituiu-se num verdadeiro estilo - que fincou raízes profundas no fazer arquitetura no século XX e Le Corbusier após os anos 30 foi seu mais importante disseminador. Sob essa onda avassaladora moderna edificou-se inúmeras arquiteturas (e correntes) modernas: umas mais conscientes, outras nem tanto, mas todas trabalharam de um modo ou de outro com o princípio da ossatura independente. 


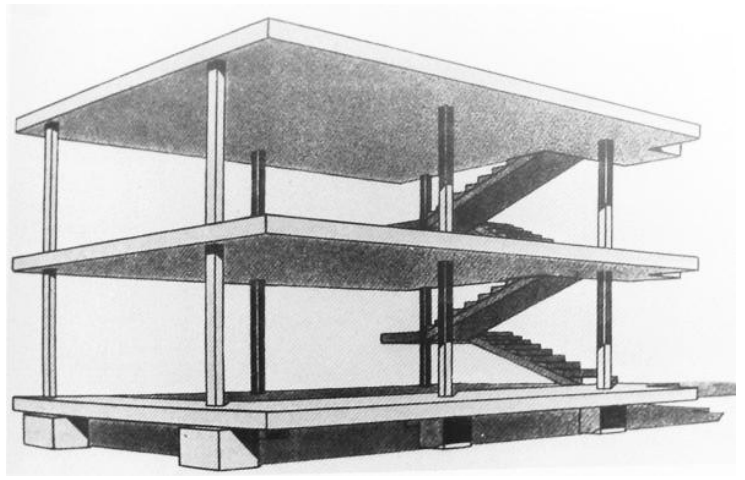

6.1: Esquema Dom-ino, 1914.

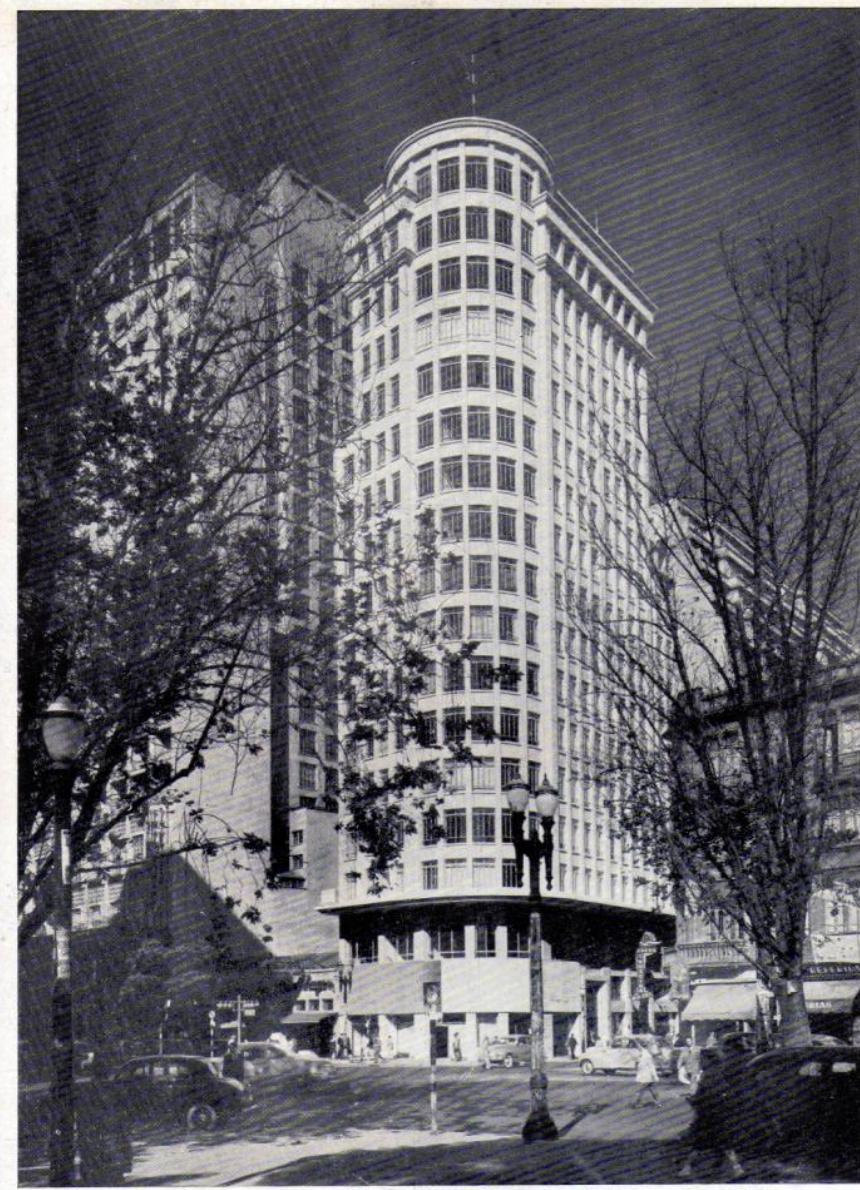

foto: Leon Literemen

EDIFICIO DAVID C. CURY

Rua 24 de Maio esa. Arenida Ipiranga

6.3: Edifício David Cury, Praça da República. 


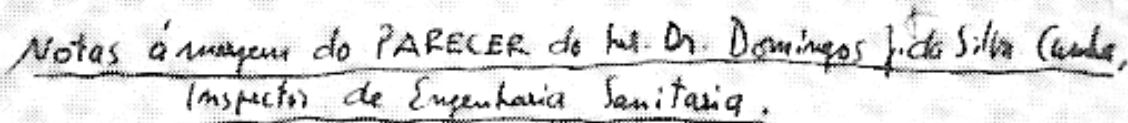

Nota 1. "O partido anchitectanico externo.". assium comece o parecer-ore, "partido anchitsct mico" i una criss só - nầo póde haver un partido exterme cut to intermo; exemplificando: se opartido adoptado é

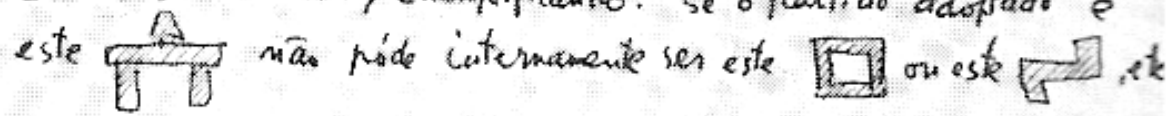

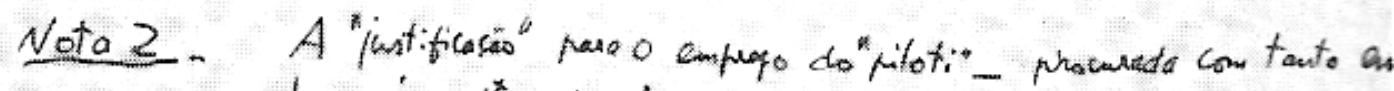
pento-e munito sinfles: wo uso systermatico dellos casean-se to

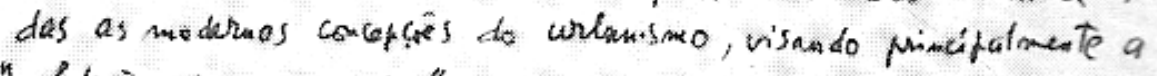
"ablifán da una coredor".

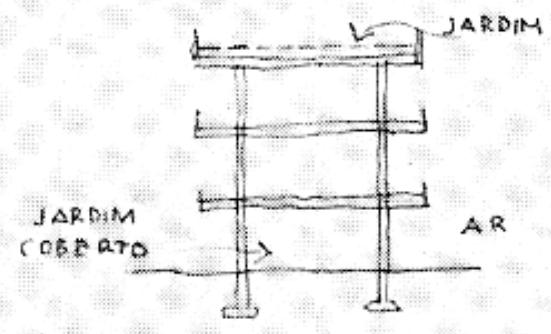

TELANICA MODEENA

Consequencia urbanistica:
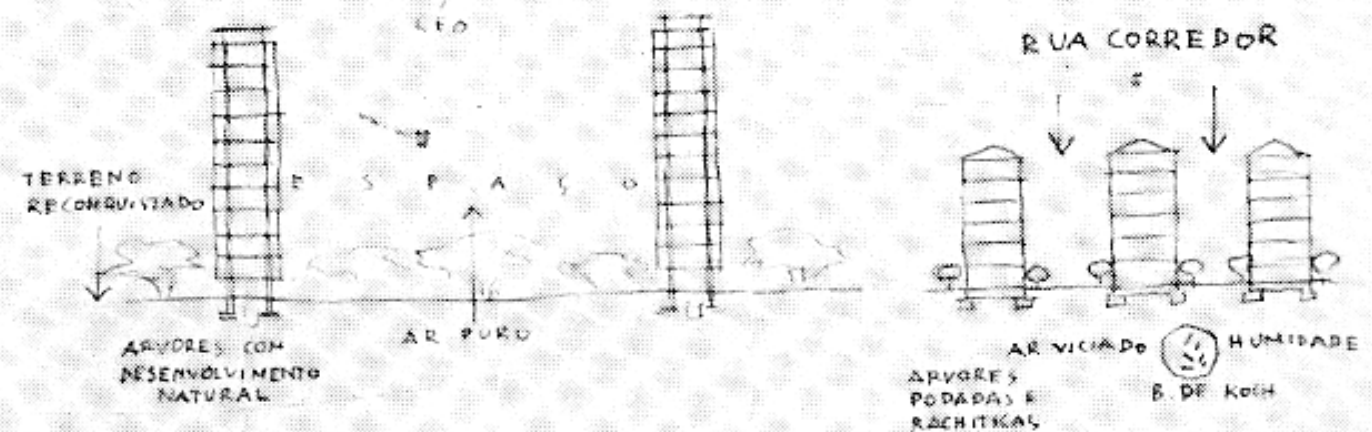

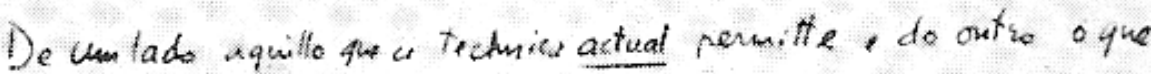
243

6.2: Nota ao parecer de Domingos da Silva Cunha, Esquema Dom-ino, 1914. (Lissosvsky e Sá, 1996, p. 85). 


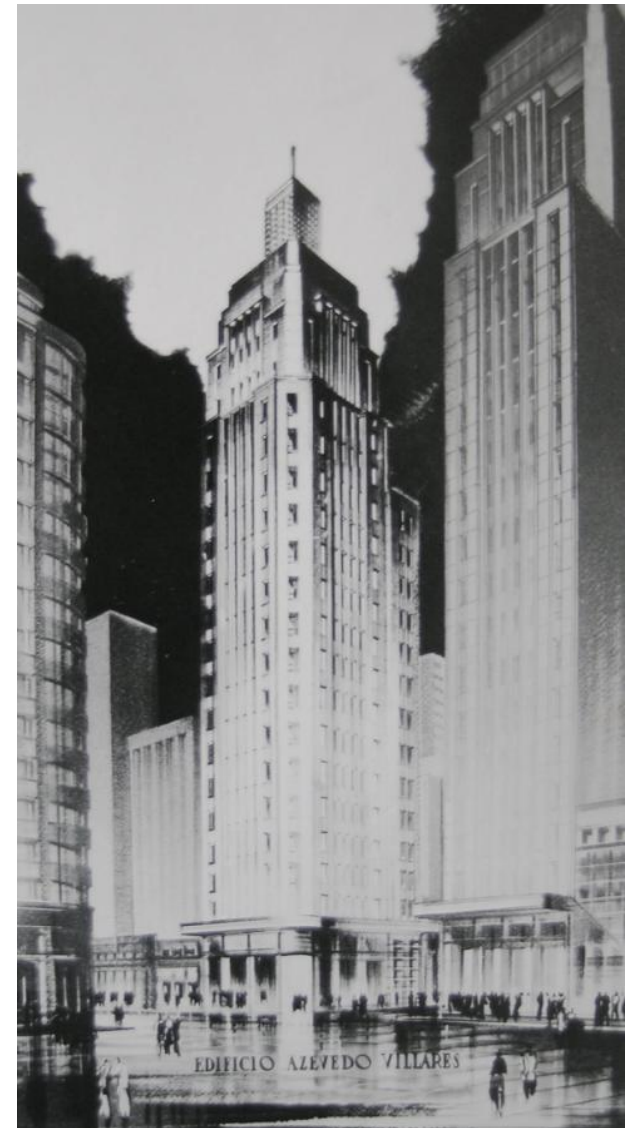

6.4: Edifício Azedo Vilares, perspectiva

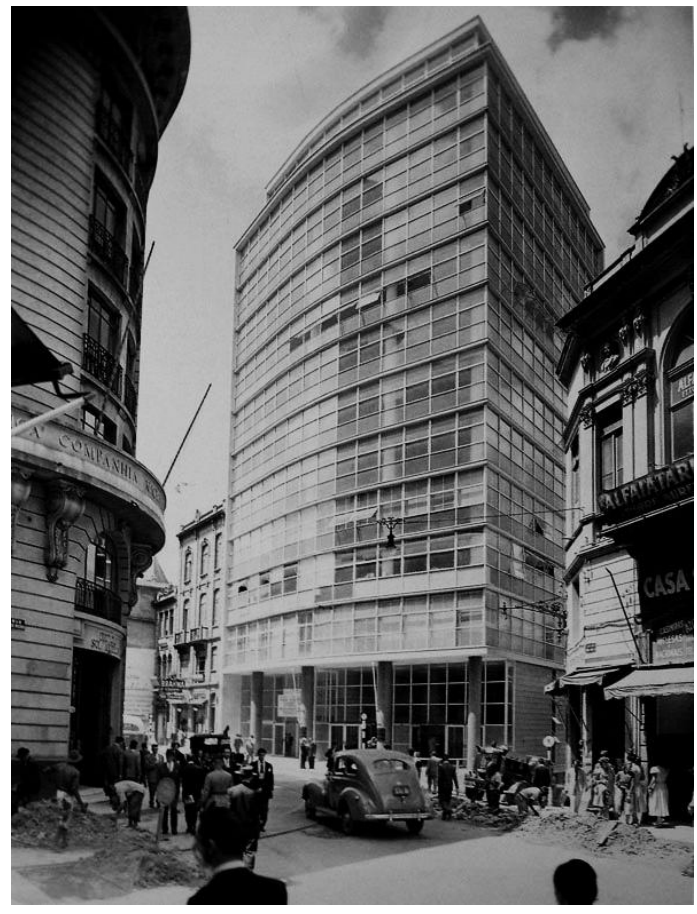

6.5: Banco Paulista do Comércio, 1947-54.

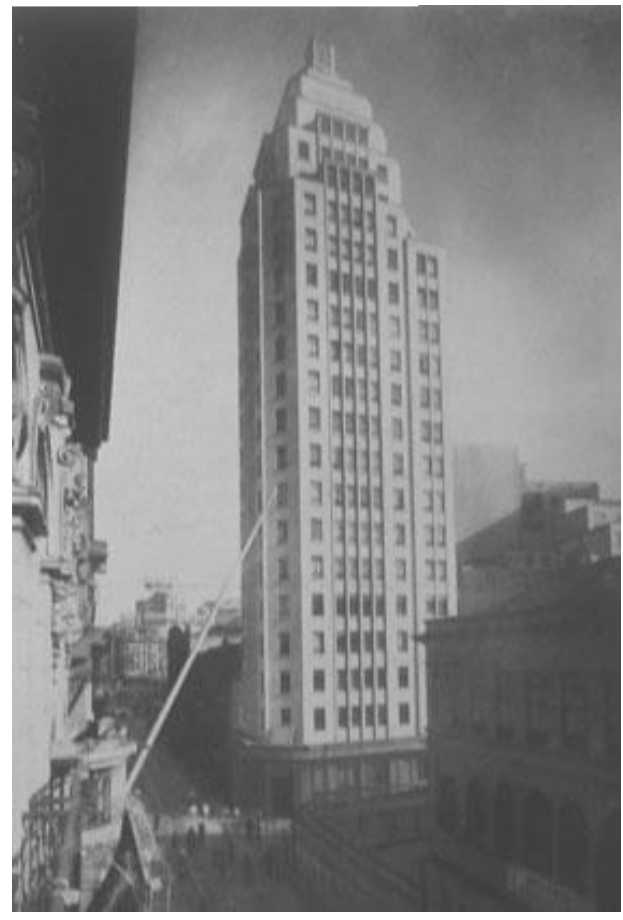

6.6: Edifício Azedo Vilares, 1938-46. 


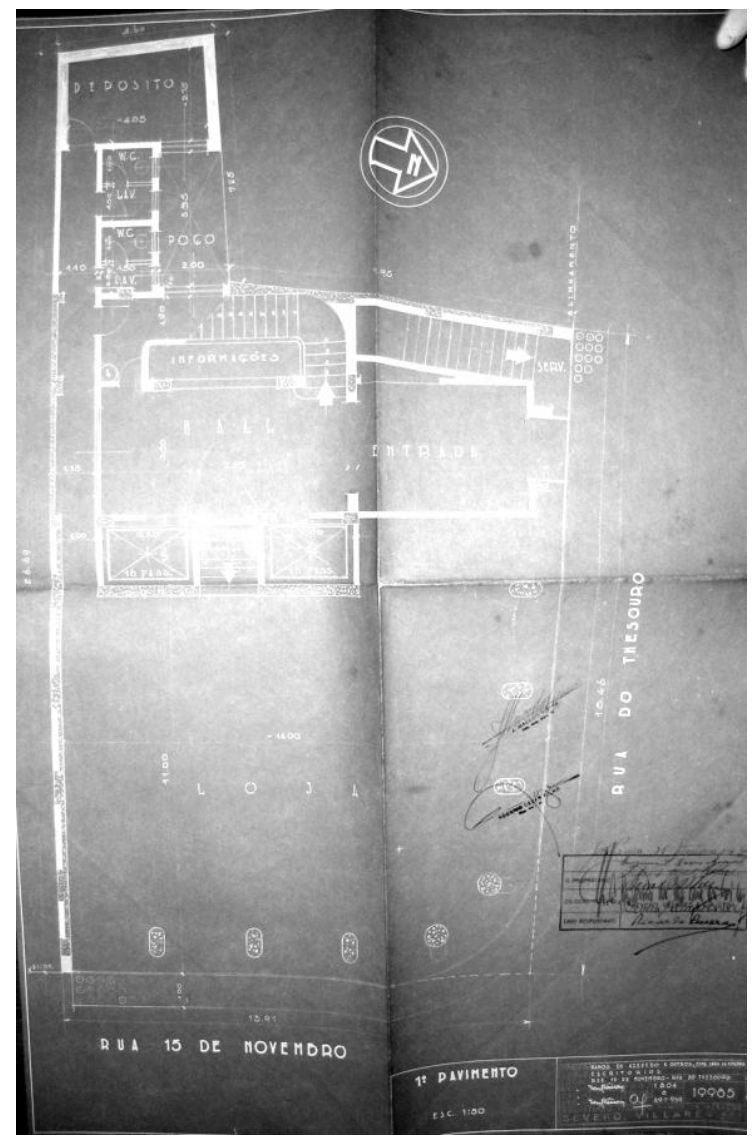

6.7: Planta térreo, Edifício Azedo Villares

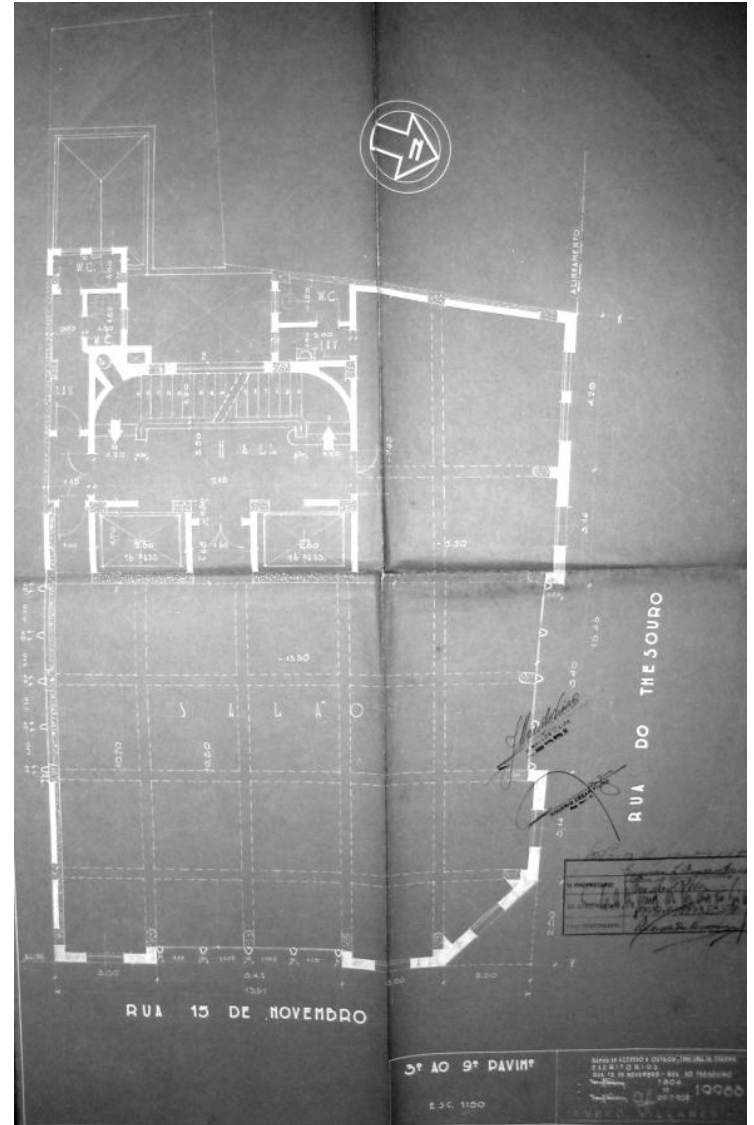

6.8: Planta do $3^{\circ}$ ao $9^{\circ}$ piso, Azevedo Villares,

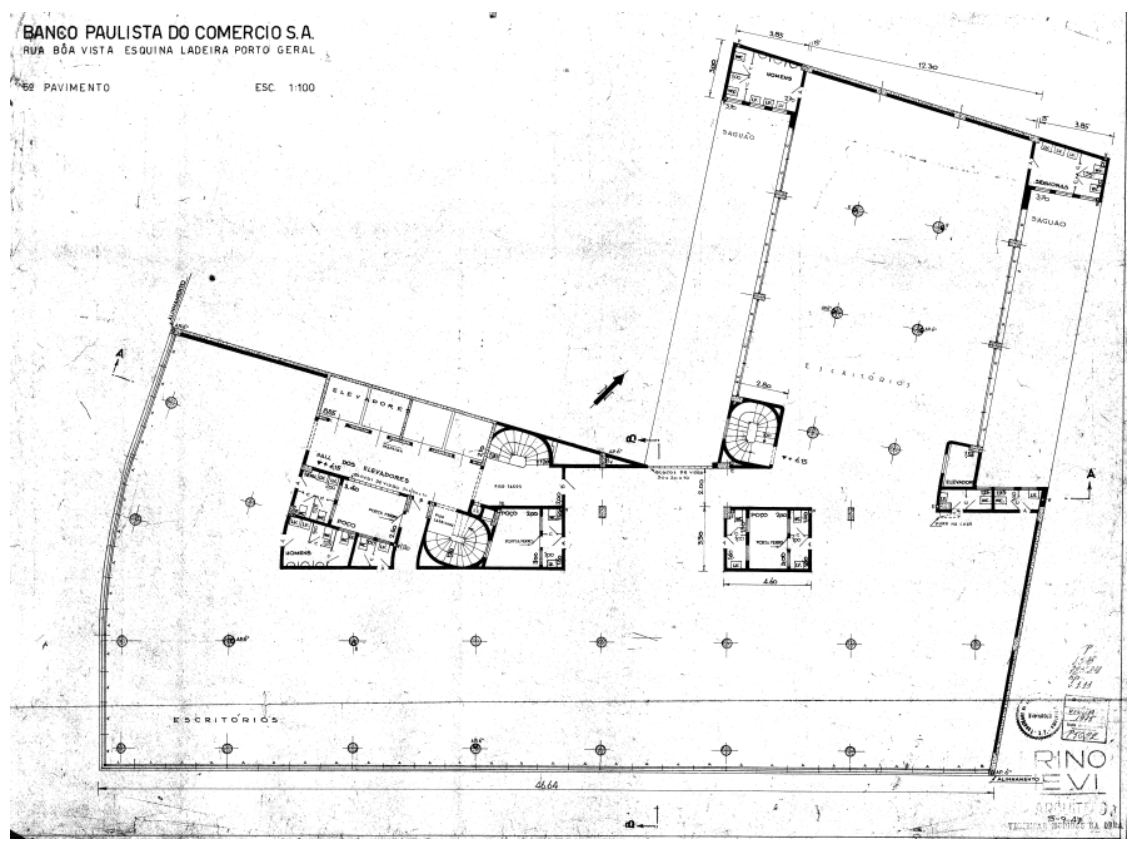

6.9: Planta Tipo - Banco Paulista do Comércio, 1947-54. 

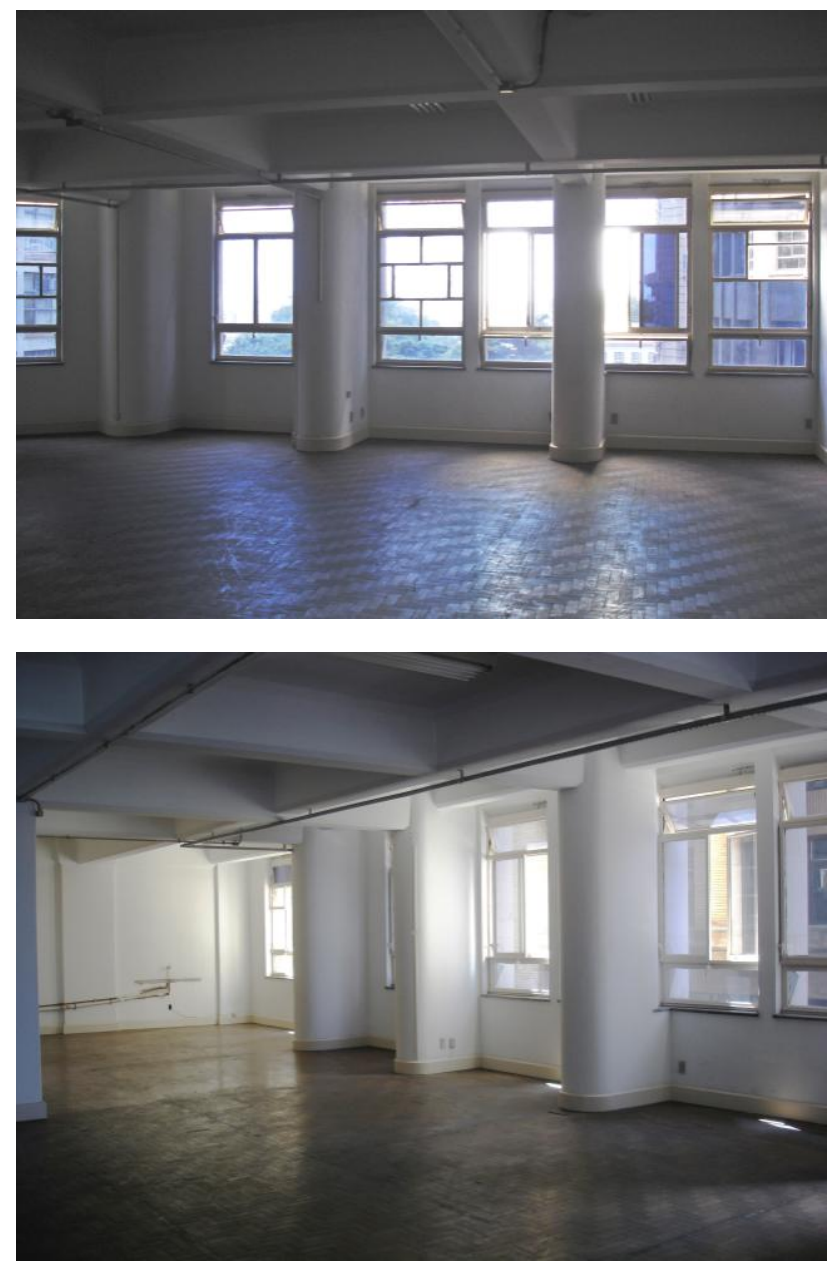

6.9 e 6.10: Interiores do Edifício Azedo Villares, 1938-46.

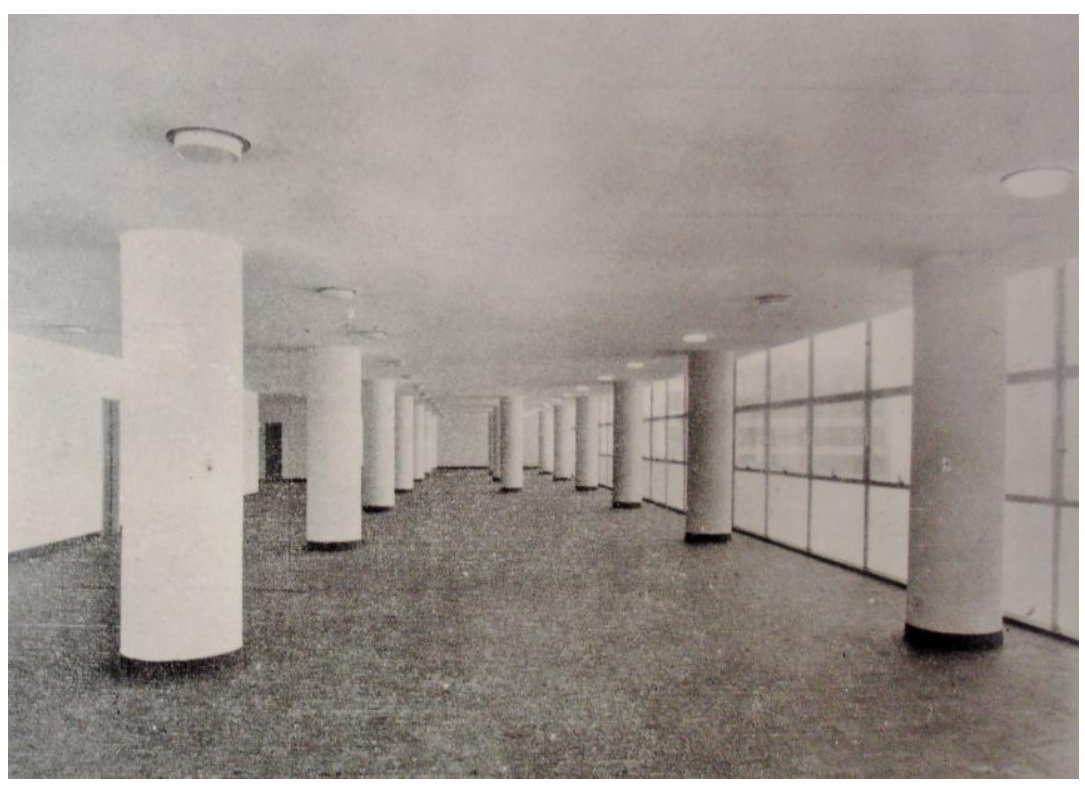

6.11: Interior Banco Paulista do Comércio, 1947-54. 


\section{Primeiros encontros no Centro Histórico de São Paulo}

Se o Ministério da Educação (MESP) pode ser admitido como um objeto-tipo moderno e brasileiro inaugurando um encontro institucional e modelar no Rio de Janeiro; em São Paulo - em particular em seu Centro Histórico - esse encontro entre o moderno e a cidade tradicional, entre o moderno e seu caráter oficial ocorreu inicialmente por sinais contrários, tendo em vista as diferenças entre o tecido urbano, o assoalho topográfico, os padrões urbanísticos, a verticalização nos padrões de Manhattan e a presença decisiva dos agentes comerciais nos destinos da arquitetura da cidade.

Este capítulo discute os primeiros encontros modernos no Centro Histórico de São Paulo nas décadas de 30 e 40, a partir dos aportes teóricos abordados nos capítulos anteriores. A intenção é a de recortar - de um amplo universo - casos e situações urbanas que sustentem as argumentações em torno das hipóteses da tese. Os primeiros edifícios tratados são os Esther e Arthur Nogueira: pioneiros modernos em São Paulo e por excelência um contraponto ao Ministério da Educação no Rio, seja em relação à origem e natureza do empreendimento, seja por conta da situação urbana. Na sequência dois edifícios típicos. O primeiro trata-se do Thomaz Edison pela particularidade de seu lote, pela sua vinculação expressa a um conjunto arquitetônico associado ao Plano de Avenidas e seus melhoramentos no Centro Novo (Praça Dom José Gaspar, ruas Bráulio Gomes e Marconi) e pelo jogo compositivo de uma expressão moderna. O outro edifício é o Banco Paulista do Comércio, localizado no Centro Velho: seu lote remonta aos primeiros traçados coloniais e sua linguagem é aquela que mais tipicamente expressa os primeiros princípios modernos nos termos das primeiras manifestações doutrinárias; a ossatura independente e seus desdobramentos principalmente.

$\mathrm{Na}$ sequência aborda-se a formação de uma quadra moderna e três edifícios de Oswaldo Bratke localizados numa mesma esquina. A quadra exemplifica o vínculo decisivo entre a rua e a volumetria das edificações; e os edifícios ilustram um percurso moderno seguido em muitos de seus aspectos por vários arquitetos; do papel da estrutura na linguagem arquitetônica às transformações da tipologia.

\section{Esther e Arthur Nogueira: usina paulistana}

Os edifícios Esther e Arthur Nogueira foram fruto de um concurso interno, entre 1932 e 1934, patrocinados por Paulo de Almeida Nogueira então comandante da Usina Esther. Os autores do projeto Álvaro Vital Brasil e Adhemar Marinho reformulariam o anteprojeto 
vencedor (entre 1934 e 1935) e concluiriam o projeto final em $1936^{79}$, antes do início das obras. De imediato depreendem-se desses dados o caráter privado do empreendimento conforme relata Fernando Atique, em "Memória Moderna - a trajetória do Edifício Esther" (2004, p. 154). O conteúdo largamente abordado por ele vai de encontro a outras interpretações acerca do Esther e por decorrência da arquitetura moderna construída no Centro de São Paulo.

Carrilho, em texto intitulado "O Edifício Esther" (1999) antecipa esse caráter dos edifícios Esther e Arthur Nogueira comparando-os ao Ministério da Educação e Cultura:

Ao antigo Edifício do Ministério da Educação e Saúde, de 1936, se atribui a condição de marco inicial da Arquitetura Moderna Brasileira, na sua forma mais desenvolvida e consistente. Nesse mesmo ano, inicia-se a construção do Edifício Esther, em São Paulo. Essas duas obras, embora simultâneas e vinculadas à mesma matriz, se contrapõem, no entanto, quanto à origem. De um lado, o prédio do MEC é uma iniciativa oficial do poder público que busca, na sua realização, a afirmação da política renovadora das ações do Estado no campo cultural. O Edifício Esther, em contrapartida, vem responder ao surto de expansão e mudança dos padrões urbanísticos da metrópole paulistana, enquadrando-se no conjunto de investimentos dirigidos aos empreendimentos imobiliários para fins de renda. Atende a um programa de uso diversificado e formulado de maneira original. Essas características, entre outras, o coloca numa posição de particular interesse para a compreensão da história e do desenvolvimento da Arquitetura Moderna Brasileira (Carrilho, 1999, p. 1).

Essa comparação abre caminho para ser ver de outra forma a arquitetura moderna em São Paulo: ela nasce atrelada aos interesses comerciais e embora críticas ${ }^{80}$ as ponham em suspensão o fato é que elas representam uma linhagem moderna particular; com cicatrizes e virtudes. Essa vinculação pode ser observada no programa dos edifícios, sobretudo no Esther, de maior relevância e dimensão: o edifício abrigava além da sede administrativa da usina, lojas, escritórios diversas tipologias de apartamentos para renda; no Arthur Nogueira, havia lojas e apartamentos. Nos termos de Atique "o estudo do Edifício Esther, pelo entendimento das concepções e das ações de seus promotores, revelou outra face na modernização brasileira, diferente daquela em que apenas o Estado é tratado como financiador e patrocinador da renovação construtiva, plástica e urbana" (2004, p. 29).

Sobre o Esther depositam-se diversas interpretações; o cotejamento com o Ministério da Educação (MESP) tem outras nuances relevantes: a relação com a cidade ou ainda os desdobramentos em torno de uma linguagem moderna e seus elementos. O Esther, embora

${ }^{79} \mathrm{O}$ edifício Arthur Nogueira foi projeto apenas por Álvaro Vital Brasil, depois de desfeita a sociedade com Adhemar Marinho (Atique, 2004.p. 195).

${ }^{80}$ Atique faz referência ao prefácio de Siegfried Giedion em "Modern Architecture in Brazil", de Henrique Mindlin. 
de autoria de arquitetos cariocas, ${ }^{81}$ tem um caráter, até pelo seu pioneirismo como empreendimento, distinto da primeira experiência oficial no Rio de Janeiro: mesmo tendo em conta que os arquitetos envolvidos em ambos os projetos integrassem um mesmo universo cultural envolvido nas questões modernas, colocadas pelas vanguardas europeias em especial nas proposições sintetizadas por Le Corbusier ${ }^{82}$.

Como exposto, a origem comercial do empreendimento já lhe conferiu um caráter de partida singular. Mas outras operações de projeto e viabilidades, além da conciliação de interesses contribuíram para a definição final do Edifício Esther: que não deveria ser tratado como um prédio isolado, sobretudo, porque o Arthur Nogueira ("Estherzinho") é a volumetria secundária que justifica a própria existência do Esther como um objeto solto no espaço. Os dois edifícios nascem de um mesmo projeto, a despeito da ordem das concepções, dos tratamentos plásticos e das interligações subterrâneas que "escondem" o vínculo entre eles. De um modo geral o "Estherzinho" não existe. Embora seja mesmo uma volumetria secundária, o descuido é um equívoco porque subestima a relação entre um e outro e não revela a interdependência que existe entre ambos, diluindo assim as ambiguidades da arquitetura moderna e a cidade tradicional. As origens dessa condição formal alojam-se na formação do lote, na legislação, na constituição do sistema viário que lhes conferiu ajustes e paradoxalmente por eles foi reajustado, e na lógica dos rendimentos comerciais.

A esquina onde se encontra implantado o Esther está definida já nas primeiras cartas da cidade de São Paulo no século XIX. Mesmo com alterações e pequenos ajustes, o traçado das ruas ainda permanece como uma marca indelével e provavelmente como o elemento da memória da cidade mais significativo na formação dos edifícios modernos construídos nos limites do Centro Histórico. O Campo do Curro (depois Praça da República), a Rua da Palha (depois 7 de Abril) e Rua Ipiranga, ilustram essa estruturação. Na carta de 1881, é possível identificar o palacete isolado pertencente a Augusto de Souza Queiroz que foi demolido dando lugar aos dois edifícios (Lefèvre, 2006, p. 61). No mesmo mapa vê-se na Rua 7 de Abril construções de ambos os lados e na Ipiranga uma ocupação ainda rarefeita. No mapa Sara-Brasil a ocupação intensifica-se de um modo geral, caracterizando-se por construções no alinhamento das ruas. Exceção fica por conta da Rua São Luiz, então ocupada por palacetes isolados no lote. De qualquer modo, percebem-se na quadra onde seria implantado os edifícios "Esther" dois padrões distintos: a tipologia dos palacetes isolados em lotes generosos e as demais construções com terrenos menores, porém, com taxas de ocupações mais elevadas. No processo de modernização e verticalização da Rua

\footnotetext{
81 Álvaro Vital Brasil é de nascimento paulista.

${ }^{82}$ Ver entrevista concedida a Segawa: O herói desconhecido da moderna arquitetura brasileira. São Paulo, Revista Projeto nº 96, 1987, p.59-64.
} 
São Luiz esse padrão seria invertido: os palacetes seriam demolidos, os lotes originais sofreriam novos parcelamentos e na quadra em questão seriam abertas as ruas Basílio da Gama e Gabus Mendes; decisivas na conformação final dos edifícios Esther e Arthur Nogueira.

Lefèvre em "De Beco a Avenida: a história da Rua São Luiz" (2006) descreve com rigor as transformações viárias que afetaram a Rua São Luiz e nesse processo esclarece também as implicações pertinentes à conformação final da quadra e aos edifícios em questão. As origens das modificações encontram-se no projeto de 1924 de João Florence de Ulhoa Cintra, que tratava da Avenida de Irradiação. Nessa proposta que antecipa o Plano de Avenidas, observa-se uma avenida projetada na bissetriz das esquinas da Ipiranga com 7 de Abril. Nos anos seguintes esse traçado seria alterado, sobretudo, porque no local da então bissetriz se construiria o edifício Esther e no prolongamento desse eixo projetado a Biblioteca Municipal. Fatos que anos depois provocariam mudanças no sistema viário contido no Plano de Avenidas, já em plena administração de Prestes Maia.

Entre um projeto urbano e outro, construíram-se os edifícios Esther e Arthur Nogueira; fato que reproduz uma mesma lógica dos tempos coloniais: ou seja, edifícios entendem-se interesses privados - determinaram traçados e acomodações em detrimentos de outros benefícios mais amplos ${ }^{83}$.

Sob muitos aspectos as construções dos edifícios Esther e Arthur Nogueira demonstram as dificuldades de textura e forma da arquitetura moderna no CHSP. Do caráter do empreendimento à formação final do lote, da manipulação dos princípios (cinco pontos) corbusierianos às condicionantes de ocupação da cidade tradicional. Do ponto de vista estrito da forma e linguagem arquitetônica moderna essas relações são exemplares. A começar pela conformação final do "lote" em que se constituiu o Edifício Esther: que mais que um objeto isolado no lote constituiu-se como um "edifício quadra".

Como decorrência da crise de 1929, os proprietários se viram obrigados a vender o imóvel e parcelar o terreno para melhor aproveitamento imobiliário, e assim foi aberta a Basílio da Gama entre as ruas São Luiz e 7 de Abril, cujo leito foi doado à municipalidade (Lefèvre, p. 63). Dessa forma, novas edificações poderiam ser construídas aproveitando-se a profundidade maior dos lotes voltados para a 7 de Abril, além de propiciar melhores condições de iluminação e aeração. Quando então Álvaro Vital Brasil e Adhemar Marinho fizeram o primeiro projeto para o Esther já estava contemplada a abertura da nova rua; ou

${ }^{83}$ Esta constatação não implica em um juízo acerca de que traçado seria melhor para a cidade. Tudo indica que o traçado executado mostrou-se mais eficiente, pois embora tivesse sacrificado o pavilhão do Jardim de Infância construído atrás da Escola Normal, preservou maior área para a Praça da República. 
seja, a Basílio da Gama. Numa perspectiva - publicada por Conduru (2002, p. 54) - vê-se o edifício Esther a partir de ponto de fuga localizado na Praça da República. enquadramento mostra o edifício como um prisma isolado circundado nos limites do lote por uma vegetação significativa; uma pequena silueta de uma empena cega ao fundo menciona discretamente uma paisagem urbana. Nessa perspectiva a proporção do edifício favorece a horizontalidade e não há indícios do Arthur Nogueira. A imagem assemelha-se a um dos edifícios corbusierianos com fachada corrida e uma natureza generosa circundante.

Se coladas lado a lado a perspectiva do primeiro projeto e a obra construída vêm à tona a contraposição entre uma idealidade ou programa de arte e a dureza dos fatos. Embora, na perspectiva como no projeto, o gabarito máximo seja de dez andares, a disparidade proporcional entre a obra e o projeto é notável. Mas outro fato ou edifício perturba a imagem idealizada. Trata-se do edifício Arthur Nogueira, que recoloca o edifício Esther na lógica de comercial da época, na medida em que ocupa no limite as divisas do lote contíguo - deixando a exemplo de muitos outros prédios, uma empena cega sem tratamento. Por outro, a construção desse segundo bloco permitiria aos empreendedores um aproveitamento maior do potencial construtivo do terreno, o que justifica inclusive a condição do Esther como um edifício quadra visível pelas quatro faces.

Essas relações entre arquitetura moderna e a cidade foram também exploradas por Atique que sublinha a abertura da rua Gabus Mendes entre os dois prédios como uma solução, inclusive defendida pelos autores do projeto, perfeita de ventilação e insolação para o edifício. Outros argumentos vão de encontro às questões modernas que privilegiavam formas primárias e claras, além da resistência às tipologias geradoras de grandes pátios internos para insolação. Essas estratégias e argumentos em torno do projeto, ainda segundo Atique, reforçariam a condição do Artur Nogueira como solução secundária, visíveis no tratamento das fachadas (2004, p. 161-65).

De fato a posição privilegiada dada ao Esther coaduna com as intenções formais modernas em favor de um objeto solto no espaço a ser contemplado por todos os lados. Mindlin também destacou esse mesmo caráter ao destacar na implantação do Esther a peculiaridade da rua aberta no lote que permitiu a visibilidade das quatro faces (1956, p. 84).

Os holofotes sobre o Esther iluminam as percepções em torno das premissas modernas; entretanto, empurram para os fundos as próprias ambiguidades: no caso, o Arthur Nogueira. No Esther há elementos simbólicos que o posiciona ao lado das abstrações modernas: a matriz estrutural (ossatura independente) que flexibiliza planta e programa, a unidade volumétrica que poderia ser reproduzida várias vezes em outras circunstâncias. Nesse sentido, no prédio subjaz a ideia de seriação, de um produto. Conforme aponta 
Colquhoun; "uma persistente tendência no modernismo em direção ao conceito da construção como sistema" (2004, p. 64). Nessas condições o sítio devido às suas orientações é um contratempo que acaba sempre exigindo adaptações na forma das construções. Mesmo no Esther é possível verificar a irregularidade do lote determinando ajuste na forma final do edifício: o paralelismo entre as faces menores não existe, pois a fachada voltada para a Rua 7 de Abril acompanha o alinhamento imposto pela rua. Se no Esther há "desalinhamentos" no Arthur Nogueira o processo é em parte invertido: a forma do edifício enquadra-se melhor nos processos compositivos que exigem ajustes diversos para se resolver espaços num lote excessivamente irregular.

Se há diferenças de operacionalidade projetual entre os dois edifícios, há elementos que paradoxalmente os une; demonstrando uma enorme elasticidade dos elementos modernos. A ossatura independente, bem como a fachada livre e corrida, a marcação da horizontalidade das lajes indicam tratar-se de um mesmo universo. Contudo, a irregularidade do lote do Arthur Nogueira e a condição de uma estreita faixa de terra impuseram variações nos módulos estruturais que quebraram aquela unidade sistêmica posta com mais clareza no Esther. Outra condição dada pela abertura da rua definiu praticamente (exceção a pequena faixa na 7 de Abril) uma única fachada bem iluminada voltada para a Gabus Mendes: assim, os poços de iluminação e as fachadas cegas resultaram como contingências que afastaram conceitualmente um prédio do outro. Como decorrência o "Estherzinho" passou a integrar outra categoria, sobretudo porque seus arredondamentos de canto o enlaçam à cidade; às curvaturas e inclinações das ruas que o circundam. Se essas relações os afastam, as atitudes em relação à estrutura e aberturas são equivalentes: os pilares encontram-se sempre destacados das paredes ou vedações, sempre liberando as fachadas.

Por meio dessa leitura das estruturas nos dois edifícios é possível identificar uma fina zona de fronteira entre atitudes projetuais em torno de uma unidade sistêmica e outra mais próxima das operações compositivas: ambas calcadas nos mesmos princípios estilísticos: ossatura independente e seus correlatos mais diretos (planta livre, fachada livre), a sublinhar, a horizontalidade enfatizada pela marcação das lajes em relevo, que se reportam à abstração - de dois planos paralelos - contida genericamente no esquema Dom-ino. Em resumo, uma modulação estrutural mais regular no Esther indicava maiores proximidades com a industrialização; no Arthur Nogueira, pelas características do lote, uma feição mais a caráter da manufatura do concreto armado.

Essas dualidades ocorreram igualmente no rés-do-chão e por proximidade estenderam-se à rua. Os pilotis imantam essa relação, principalmente pelas conotações e denotações modernas em torno das espacialidades sob eles imaginadas; ou seja, uma nova 
maneira de pensar o chão, uma nova divisão fundiária, na qual o chão seria relativamente pouco ocupado. No Esther e Arthur Nogueira os pilotis (pilares de diâmetro cilíndrico) pontuam os pavimentos térreos mais como menção simbólica aos programas corbusierianos do que efetiva realização: a lógica dominante - nos termos da cidade tradicional - diz que preferencialmente o chão pertence ao comércio e assim foram ocupados os térreos dos dois edifícios.

Se a natureza dos pilotis sugere usos fluidos sob sua sombra, na cidade dos negócios seu uso é essencialmente comercial. Se essa condição desfaz o sentido dos pilotis, também afasta a primeira experiência moderna paulistana do objeto-tipo moderno e brasileiro concretizado no Ministério da Educação (MESP). Não só pelo uso dos pilotis, mas pela própria orientação nordeste do edifício, tendo em conta a hierarquia da fachada principal voltada então para a antiga rua Epitácio Pessoa: à época uma rua estreita (13 m), que posteriormente seria alargada e fundida com a Avenida Ipiranga. A orientação, portanto, foi definida em função da rua principal e dos alinhamentos das edificações, ficando em segundo plano qualquer possibilidade de uma orientação norte/sul nos moldes do MESP. Embora os dispositivos para proteção solar tenham se tornado um tema caro à arquitetura brasileira, seja qual for a tipologia, por meio de diversas variações e desenhos, seu uso mais intenso aconteceu em prédios comerciais para escritórios. No Esther os recursos ficaram restritos a varandas reentrantes e janelas com venezianas ajustáveis. Nos espaços voltados para a fachada sudeste, não há, a exemplo do Arthur Nogueira, varandas reentrantes ou desalinhamentos significativos entre viga e esquadrias para se criar uma faixa de sombra.

Nos edifícios Esther e Arthur Nogueira repousam ainda uma peculiaridade notável diante do Ministério da Educação: sua linguagem moderna está mais próxima das abstrações genéricas divulgada nos textos da doutrina do que do objeto-tipo brasileiro: já contextualizado naquilo que o caracterizaria profundamente - adequação ao clima (execução dos quebra-sóis), uso dos pilotis e o caráter monumental. No caso do Esther, "os cinco pontos da nova arquitetura" encontram-se presentes de uma maneira própria: os pilotis são de uso inteiramente comercial, o terraço-jardim ocupado por duas coberturas e terraços privados, as fachadas livres e corridas - construídas por esquadrias metálicas e sobrepostas - rebatem as qualidades dos espaços interiores, a ossatura independente e flexibilização dos espaços (planta livre) estão fortemente presente através da modulação e separação dos panos de vedação e separação de ambientes.

Embora sejam notáveis essas associações há nos edifícios uma configuração que os mantêm com certeza na atmosfera das manifestações modernas: então, uma nova tradição em construção, rumo a um estilo internacional. Esse sentido "universal" é dado principalmente pela síntese proposta por Le Corbusier: que fincou princípios fundamentais 
possíveis de serem manipulados de diversas formas. Sob esse olhar, os edifícios Esther e Arthur Nogueira se confrontados com o MESP parecem ser de outra ordem. De fato, Álvaro Vital Brasil foi fortemente influenciado por Le Corbusier e por outras experiências ${ }^{84}$, que contribuíram para austeridade construtiva do edifício. Além, evidentemente, do caráter privado do empreendimento, sujeito a recursos mais controlados do que no ministério. Assim, explicam-se algumas diferenças construtivas significativas: o Ministério da Educação foi construído por um sistema de lajes cogumelo e mais dispendioso (Segawa, 1987, p. 62) e o Esther por um sistema de vigas invertidas preenchidas por escórias de carvão (Carrilho; 1999, p. 3).

As diferenças entre Ministério e o Esther quanto ao sistema construtivo das lajes não elimina proximidades de princípios: a procura dos planos horizontais contínuos; que definem boa parte das intenções formais dos edifícios modernos - mesmo tendo em conta as inevitáveis variações. No Esther e Arthur Nogueira a marcação da viga (com revestimentos) chama atenção para a horizontalidade, assim como as janelas em fita. Abstrações que se reforçam com a independência dos planos (ou fachadas) dos edifícios: enquadrados numa moldura externa preta (vitrolit). Se no Ministério as paredes laterais são deixadas lisas no Esther são aproveitadas por janelas e caixa de escada saliente, também emolduradas. Essas variações e significativas diferenças na aplicação dos princípios modernos entre o Ministério e o Esther, explicam-se paradoxalmente pela influência direta de Le Corbusier no projeto do MESP: que pode ser interpretado como um fragmento pinçado em suas ideias urbanísticas, ao contrário do pragmatismo rigoroso do Esther. De qualquer forma a diferença explicita a elasticidade do "verdadeiro estilo" (figuras 7.1 a 7.14 ).

\section{Thomaz Edison: composição exemplar}

O edifício Thomaz Edison (1944) tem autoria de Francisco Beck e Lucjan Korngold e está localizado na Rua Bráulio Gomes 30, adjacente à Praça Dom José Gaspar; em seus 24 andares abriga lojas (térreo e sobreloja). Sua construção no início dos anos de 1940 reporta-se diretamente ao Plano de Avenidas empreendido por Prestes Maia, isso porque seu lote é resultado das enormes operações de abertura, prolongamento e alargamento de vias, bem como de outras melhorias urbanas. Sua forma final expressa uma complexa composição que concilia conceitos modernos, legislação e singularidade de um modesto lote.

Na carta de 1881 já era possível identificar a Rua Bráulio Gomes com sua curta

${ }^{84}$ Álvaro Vital Brasil em entrevista a Hugo Segawa relata aspectos de sua formação na Escola Politécnica do Rio de Janeiro e Escola Nacional de Belas Artes (ENBA). Também fala das influências modernas diretas: os cinco pontos de Le Corbusier, as experiências dos irmãos Vesnin e da Bauhaus (Segawua, 1987, p.60-62). 
extensão conectando as ruas da Consolação e 7 de Abril; naqueles anos, eram poucas as construções em seu alinhamento. Seu traço marcante é uma pequena dobra (cotovelo) que intercepta a 7 de Abril num ângulo de 90: essa característica persistirá nos planos seguintes e estará associada à altura final do edifício. No mapa Sara Brasil (1930) vê-se que a ocupação intensificou-se reforçando os alinhamentos das construções pela via pública. A quadra formada pela Bráulio Gomes, São Luiz, 7 de Abril, Consolação e Epitácio Pessoa aparece ocupada por edificações isoladas - os palacetes familiares decorrentes do parcelamento da Chácara Velha do barão de Souza Aguiar ${ }^{85}$.

$\mathrm{Na}$ Planta Geral dos Melhoramentos Centrais encontram-se marcados os traçados gerais - sobre base do Sara Brasil - do Plano de Avenidas na área central: o perímetro de irradiação e outras intervenções como a criação da Praça Dom José de Barros (e da Biblioteca Mário de Andrade), o alargamento e prolongamento da Bráulio Gomes até a já aberta Rua Marconi; cuja função foi interligar essa nova espacialidade urbana (a nova praça) à Rua Barão de Itapetininga. Nas fotos 74 e 75 (Maia, 1945) é possível identificar as transformações que definiram o formato final do lote onde se encontra o Thomaz Edison. $\mathrm{Na}$ foto 74, 1940, vê-se que a Rua Marconi encontra-se aberta, o cotovelo da Bráulio Gomes ainda não alargado e o casario que seria demolido para dar lugar à Praça Dom José de Barros. Na foto seguinte, vários outros edifícios já haviam sido construídos no alinhamento da Marconi, o cotovelo encontrava-se alargado e a praça em obras. No centro da foto, é notável o terreno do Thomaz Edison então delimitado por murros e tapumes na sua conformação final, inclusive a curvatura suave de sua testada principal (figuras 7.17 e 7.18).

O que se vê então é um lote de conformação irregular: um polígono de seis lados desiguais, aproximando-se grosseiramente de um lote em $\mathrm{L}$, cuja face maior e encurvada (35 m) está voltada para a Rua Bráulio Gomes e a menor $(8,70 \mathrm{~m})$ para os fundos do lote. Em resumo um lote de aproximadamente $630 \mathrm{~m}^{2}$ com taxas de ocupação em torno de $90 \%$ até o $13^{\circ}$ pavimento (o que incluí térreo e sobreloja) e coeficiente de aproveitamento de 19 vezes a área do terreno. No limite se construiu tudo aquilo que era permitido por lei.

Nas condições de satisfazer os imperativos do empreendimento imobiliário, a interpretação da lei e a forma do lote foram fatores decisivos na definição volumétrica. $A$ orientação do lote também o foi, mas de maneira secundária, isso porque a posição da fachada principal, sempre mais valorizada, foi firmada de antemão pela trama e normativa urbana.

\footnotetext{
${ }^{85}$ Ver LEFÈVRE, De Beco a Avenida: a história da Rua São Luiz. São Paulo, EDUSP, 2006,
} p.35. 
A volumetria tem quatro estágios bem definidos. O primeiro ocupa toda a superfície do lote, exceção feita a dois pequenos poços de ventilação e iluminação para os banheiros das lojas e sobrelojas. O segundo corresponde ao desenvolvimento dos pavimentos de escritórios que vai do $1^{\circ}$ ao $12^{\circ}$ piso: ele caracteriza-se por um corpo retangular paralelo à rua Bráulio Gomes e por corpo perpendicular que vai de encontro aos fundos do retangular com dois cantos arredondados orientados para os fundos do lote; uma saliência lateral identifica esse trecho. Por último a finalização da torre que se eleva até $24^{\circ}$ : nesse tramo sua área e volumetrias são reduzidas para atender a mais um recuo mínimo exigido por lei.

A legislação ${ }^{86}$ regulamentava uma altura de $80 \mathrm{~m}$ para os edifícios localizados em vias de largura superior a $18 \mathrm{~m}$. Um esboço de época cota a Bráulio Gomes com $28 \mathrm{~m}$ : dado que confere a situação atual. Um parágrafo do artigo permitia alturas maiores em pontos focais de grande interesse arquitetônico, porém condicionadas a ocupações que variavam de $25 \%$ a $35 \%$ do lote conforme recuos laterais. No caso do Thomaz Edison, o artigo 2ำ (III) explica a altura final de $80 \mathrm{~m}$ do prédio e da torre maior: uma altura maior seria inviável devido às dimensões do lote. Outros dispositivos no mesmo Decreto-Lei (artigo $3^{\text {o }}$ ) determinavam que edifícios construídos na área central, a partir de altura de $40 \mathrm{~m}$, deveriam atender recuos laterais $2,5 \mathrm{~m}$ em relação às divisas do lote; e a partir de $65 \mathrm{~m}$ esses recuos deveriam ser de 4,5 m no mínimo. Essas regulamentações esclarecem os corpos mais baixos e a torre (e sua a pequena saliência) na configuração final do Thomaz Edison. Analisando-se a planta do pavimento tipo (do $1^{\circ}$ ao $11^{\circ}$ ) é possível perceber que a partir do $12^{\circ}$ andar - em se cumprindo os recuos - não era razoável manter o corpo criado para os fundos do lote: não haveria área útil que o justificasse: assim, foi conformada a torre como uma volumetria parcialmente autônoma; que também sofreu um decréscimo do $19^{\circ}$ ao $24^{\circ}$ pavimento; atendendo a um recuo de 4,5 m . Diante desses dispositivos, enquanto o edifício atingia altura um escalonamento em forma piramidal era consequentemente definido; diferente, portanto, do escalonamento decorrente dos recuos sucessivos, identificados na Rua Marconi e outros logradouros da cidade.

Não há dúvidas de que a legislação determinava os contornos da volumetria; entretanto, essas causas não são suficientes para explicar outras escolhas de projeto como a modulação estrutural, a disposição do núcleo rígido (elevadores, escadas e instalações sanitárias), as correções nas proporções e o domínio sobre a intenção formal: aqui entendida como o ideário moderno, ou parte dele.

Por meio da planta do tipo (até $12^{\circ}$ piso) é possível compreender a concepção estrutural do corpo principal paralelo à rua: uma malha de pilares no sentido perpendicular,

${ }^{86}$ Decreto-lei no 92 de maio de 1941. (Ayres Neto, oitava edição atualizada, 1968, p.335). 
distanciados regularmente (vãos de 5,04 m), modula o espaço e estabelece os alinhamentos das fileiras de pilares; o núcleo rígido e apoios embutidos nas paredes laterais encerram o sistema de apoios. No bloco voltado para os fundos, a estrutura está contida nas paredes laterais - sem grande destaque. Duas observações fazem-se necessárias quanto à modulação estrutural: primeiro, a modulação no sentido horizontal $(5,04)$ sofre pequena correção quando se aproxima das divisas laterais e a modulação no sentido vertical (perpendicular à rua) também é ajustada em função da ligeira curvatura da fachada principal. Essas sutilezas evidenciam os contraditórios entre a ideia de um sistema (reprodução seriada) e a composição mais afeita às correções circunstanciais e de execução mais artesanal. Por outro lado, nesse arranjo fica claro o papel da ossatura independente e a consequente liberação das fachadas em suas, então, novas funções modernas: iluminar, radiar e transparecer. Agora, sob o desígnio das abstrações. Nos países de climas mais quentes, adicionadas a essas novas premissas, surge necessidade de proteger e sombrear a nova conquista - a transparência e suas irmãs gêmeas: a leveza e espessura mínima. Possibilidades técnicas, desejos e imperativos climáticos engendraram um novo elemento moderno, o brise-soleil: que de uma bem-sucedida resolução no Ministério da Educação passou por uma provação plena de insucessos: ora por dificuldades construtivas (clientes), ora por desenhos inadequados, ora por idealizar em demasia uma solução de iluminação e ventilação natural para as cidades ${ }^{87}$.

No Thomas Edison, as fachadas livres foram projetadas como uma grelha de $60 \mathrm{~cm}$ de profundidade: tanto na fachada principal, quanto nas fachadas posteriores de cantos arredondados. Essa grelha cumpre dois papéis relevantes: o primeiro o de unificar ${ }^{88} 0$ conjunto da fachada principal e o segundo de sombrear o generoso envidraçamento: por meio de um brise-soleil, mais aberto. A grelha (nessa dupla função, formal e técnica) cumpre ainda o papel de controlar plasticamente o desenho das esquadrias de ferro: de pouca expressividade e de uso corrente na construção civil da época.

Como apontado por Falbel (2003), a questão principal da grelha no Thomaz Edison talvez tenha sido a de unificar formalmente um conjunto de volumetrias desiguais. Essa interpretação reforça-se pela relevância da fachada principal diretamente compromissada com ambiência do fragmento urbano que se erguia: a hierarquia encontrava-se na rua, pois as questões de orientação para a fachada principal (sudeste) não seria a rigor uma situação

${ }^{87}$ Cabe observar que para Le Corbusier a questão do brise-soleil tomou corpo e escala no Ministério da Educação; Cartago(1928) era obra de pequena monta e Argel (1033) ficou restrito ao projeto. Nas propostas executadas no continente europeu estavam contempladas soluções que utilizavam ar-condicionado; como o fracassado sistema proposto para o Cité du Refuge.

${ }^{88}$ Anat FALBEL aponta esta solução em grelha como precursora da solução também em grelha no CBI-Esplanada. Segundo a autora, Korngold justificava a grelha como elemento unificador (2003, p. 232). 
crítica ou exposta a intensa insolação: embora, trata-se de uma fachada ensolarada nas primeira horas do dia nos diversos solstícios. Esse aspecto tem importância, porque nas faces mais ensolaradas, voltadas para os fundos do lote, têm-se o mesmo tratamento técnico plástico para as aberturas mais visíveis; e para aquelas outras, contidas nos poços de iluminação a solução foi de janelas perfurando os panos de alvenaria à maneira tradicional, sem tratamentos importantes.

Essas análises dos pormenores fazem vir à tona as ambiguidades e dificuldades dos arquitetos modernos em lidar com as restrições provenientes da legislação, do lote e do traçado urbano. Em contrapartida, revelam enormes qualidades compositivas tanto ao enquadrar o edifício na paisagem da cidade, quanto ao expressar as novas condições estéticas.

Se uma condição do edifício moderno é postar-se como um volume solto no espaço, o Thomaz Edison é um caso inconcluso e transitório e por isso fascinante. A intenção de figurar a torre solta desde o térreo já se manifesta no pequeno avanço do corpo mais alto e central em relação aos corpos laterais mais baixos; e continua nas faces posteriores nas quais essa mesma torre, já mais livre, tem seus cantos tratados por arredondamentos que reforçam o desgarrar do embasamento comum ou dos primeiros estágios do prédio.

Entretanto, na fachada voltada para a Rua Bráulio Gomes uma leitura diferente contradiz as observações anteriores. Trata-se evidentemente de uma fachada principal que nessa condição dissolve - pela lógica semântica - as afirmações anteriores; uma fachada principal assim o é de fato. Porém, essa ambiguidade põe o edifício na dimensão harmoniosa da configuração de um fragmento urbano; quase único em São Paulo - a continuidade entre as ruas Bráulio Gomes e Marconi. Como elemento dessa conformação o Thomaz Edison e os edifícios contíguos a ele, assim como aqueles outros construídos no lado oposto da Bráulio Gomes e os demais da Rua Marconi acabariam - depois dessa significativa intervenção no tecido da cidade - a configurar uma unidade espacial de alta qualidade. Um caso singular digno de nota, dificilmente reproduzido em outras regiões da cidade.

Essa qualidade seria traduzida na continuidade da massa construída, muito em função das compulsórias leis em vigor: alinhamentos e alturas mínimas nas divisas principais dos lotes e tratamento nobre dos embasamentos ${ }^{89}$ : a loggia do Thomas Edison pilares de altura dupla que encapam as lojas e sobrelojas - foi uma solução clássica que permitiu a continuidade e ao mesmo tempo a distinção entre edifícios. E nesse caso, uma primeira linha de pilotis fica registrada como simples menção ilustrada.

\footnotetext{
${ }^{89}$ Decreto-Lei Decreto-lei o 92 de maio de 1941, p. 335.
} 
Cabe finalmente ressaltar que a despeito de atender as necessidades dos empreendedores a hierarquia espacial ainda se encontrava depositada no espaço público, no sentido proposto por Rowe e Koetter. O espaço e a construção privada estavam contidos nos limites do lote, contemplados nos interesse de reprodução do lote, porém, submetidos a um interesse público. Nesse contexto, a positividade do espaço público (a figuração da rua e da praça) ainda se faz presente com vigor e a arquitetura moderna compartilha essa condição, com a pertinência das técnicas compositivas clássicas que absorvem o ideário moderno e o lançam de encontro ao cenário da cidade tradicional (figuras de 7.15 a .7.31).

\section{Banco Paulista do Comércio: tipicidade suficiente}

O Banco Paulista do Comércio, 1947-50, de autoria de Rino Levi, aglutina em sua forma e linguagem uma série de elementos esclarecedores das relações entre a arquitetura moderna e Centro Histórico de São Paulo. No edifício é notável a origem do lote, a horizontalidade dos planos de laje, a transparência das esquadrias, os pilotis e o escalonamento sucessivo que desenha sua complexa e desigual volumetria final. Mais do que isso; ele de certa forma simboliza a violenta e rápida verticalização empreendida no triângulo histórico - no território das finanças. Uma foto de época enquadra seu corpo principal circundado por prédios ecléticos de três, quatro e sete pavimentos. Operários pavimentam a rua e um "Ford" circula pela Rua Boa Vista; o contraste não poderia ser maior: a arquitetura parece ser de outro tempo. E é. Porém, um olhar mais de perto revela que todas as marcas da cidade, principalmente, aquelas originárias nos traçados mais antigos ainda persistem.

$\mathrm{Na}$ "Planta da Imperial Cidade de São Paulo", 1810, de Rufino José Felizardo e Costa, é possível identificar próximo ao Convento de São Bento a esquina da Rua Boa Vista com a futura Ladeira Porto Geral, que caracterizará o Banco Paulista do Comércio. Na carta de 1842 de José Jacquez da Costa Ourique, a Ladeira Porto Geral já estava nominada e os ajustes futuros nos alinhamentos, conformação e ocupação dos lotes, não alterariam significativamente esses primeiros traçados coloniais. Na carta de 1881 de Henry B. Joyner (Planta da Cidade de São Paulo, levantada pela Companhia Cantareira e Esgotos) a esquina lá está e os lotes que formarão o terreno do banco já se esboçam. No mapa Sara Brasil e numa foto de 1930 o lote e as edificações que darão lugar ao Banco Paulista encontram-se bem definidos ${ }^{90}$ : é possível perceber com clareza a geometria do lote de esquina e do lote que se aprofunda na quadra. Nesse lote, duas volumetrias marcantes revelam o "Teatro Boa Vista"91, projetado em 1915 por Julio Micheli; que depois de demolido

\footnotetext{
${ }^{90}$ Na carta Vasp-Cruzeiro, 1952-57, os lotes e o Banco já construídos estão mal representados.

${ }^{91}$ De propriedade da Sociedade Anônima o "Estado de São Paulo".
} 
daria lugar ao Banco Paulista do Comércio. Nota-se que o teatro era composto por dois corpos: um destinado às atividades administrativas e outro ao teatro propriamente dito, com plateia, palco etc. Esses dois corpos são implantados num lote de conformação final em "L"; resultado de um processo de anexações relativamente constantes e notáveis desde o final do século XIX. Essa disposição em "L" permanecerá a mesma no edifício projetado por Rino Levi. No Gegran (1972) vê-se a solução em "L" mantida: porém, em vez de duas volumetrias, surgirá uma terceira já consequência da legislação da época.

$\mathrm{Na}$ substituição de uma construção por outra, enormes mudanças ocorreram no processo modernizador: na verticalização, na tecnologia, na legislação, no programa, na linguagem da arquitetura. Apesar dessas transformações, a cidade continuou a deixar suas marcas: os vestígios dessas heranças ainda podem ser contados pela morfologia das ruas e lotes. Sob essas condições algumas reentrâncias e disposições das circulações, guardando as diferenças de escala e programa mantêm-se semelhantes: espaços de circulação horizontal e vertical estarão igualmente posicionados contra as empenas laterais, tirando maior proveito das faces voltadas paras as ruas Boa Vista e Ladeira Porto Geral. Pelas mesmas razões, procederam-se os inevitáveis recuos laterais e poços para a busca de insolação e ventilação.

Se confrontados os edifícios modernos e outros nas mesmas circunstâncias de lote, perceber-se a despeito das diferentes configurações atitudes semelhantes diante da disposição dos esquemas de circulação (escadas, elevadores) e sanitários; os "espaços servidores" e os demais espaços; "espaços servidos"92. Retoma-se o exemplo do Edifício Azevedo Villares ${ }^{93}$ : nele também esses elementos estão sempre postados para os fundos do lote ou encostados em suas divisas, privilegiando-se as fachadas principais. Outro argumento, nesse sentido, encontra-se no fato de que a rua como espaço público e simbólico, típico de uma cidade tradicional, determina quase naturalmente a valorização da fachada principal. Não se pode omitir o fato de que esses edifícios são frutos da intensa verticalização ocorrida no Centro Novo e Centro Velho de São Paulo, e por essa lógica, construir atingindo o coeficiente máximo de aproveitamento do terreno era um imperativo de mercado.

De modo que o Banco Paulista do Comércio responde a todas essas condicionantes que moldaram sua forma final - da geometria do lote à legislação.

A legislação na época de construção do Banco estava fundada nos escalonamentos

\footnotetext{
${ }^{92}$ Usa-se os termos espaços servidos e espaços servidores conforme explicitados por Luis Kahn

${ }^{93}$ Ver Capítulo 6 - Ossatura independente.
} 
sucessivos, ou setbacks à semelhança de Nova York, conforme visto em capítulos anteriores. Aqui em São Paulo os gabaritos eram menores ${ }^{94}$, mas decorriam também da largura da rua. Nos desenhos legais identificam-se os cálculos justificativos para as alturas pretendidas. Para a rua Boa Vista foi atribuída uma largura de $15,40 \mathrm{~m}$ e para a Ladeira Porto Geral de $20 \mathrm{~m}$. A legislação ${ }^{95}$ permitia para ruas acima de $12 \mathrm{~m}$, construir no alinhamento até 2,5 (duas vezes e meia) a largura da rua. No caso de ruas com larguras inferiores a $12 \mathrm{~m}$, o limite era de duas vezes a largura da rua. A partir dessas alturas, era permitido construir mais pavimentos, desde que respeitassem os recuos sucessivos delimitados pelo prolongamento da linha inclinada (hipotenusa). Assim, se explicam, parcialmente, as diferenças de altura e os escalonamentos entre as volumetrias voltadas para as ruas Boa Vista e Porto Geral. No mesmo decreto, outro dispositivo da lei permitia nos lotes de esquina, em vias públicas de largura diversa, a altura máxima pela via de maior largura, estendendo-se unicamente até a profundidade de $20 \mathrm{~m}$.

Esses dispositivos determinaram então a configuração final do edifício: um corpo mais homogêneo e regular na esquina e outro menor, na Ladeira Porto Geral, no qual o escalonamento é mais visível e expressivo. Na observação das plantas percebe-se que a razão de alturas finais diferentes para as duas volumetrias encontra-se na forma do lote: pois, a partir de certo escalonamento não era possível atingir maiores alturas porque não se teria área útil suficiente para um bom uso de atividades e aproveitamento das circulações. Dessa forma, a volumetria decorrente da Ladeira Porto Geral gerou a volumetria do corpo que se aprofunda no lote; no tramo complementar do "L".

O Banco Paulista do Comércio foi erguido como um prédio de uma única corporação diferente de outros edifícios para aluguel de salas de escritório. A agência bancária ocupava o térreo, sobreloja e subsolo. Os demais pavimentos eram destinados aos salões de escritórios da instituição, com algumas particularidades como setor da previdência etc. Se o programa não continha grandes complexidades, os arranjos das plantas por decorrência da legislação e forma do lote a tinham: as plantas guardam certa regularidade do térreo ao quinto pavimento. Após, novos arranjos procuram adequar recuos e a redistribuição de parte do programa reunido no "núcleo rígido"96. De qualquer maneira, sempre há a necessidade de reposicionamento de prumadas de sanitários, com a supressão de algumas pela necessidade de diminuir área útil do pavimento; é o caso, da eliminação dos sanitários

\footnotetext{
${ }^{94}$ Conforme explicado nos capítulos 3 , a hipotenusa que determinava a altura máxima no alinhamento da via era em Nova York pega pelo meio da rua: em São Paulo pelo lado oposto. Fato que resultava uma altura menor em São Paulo.

${ }^{95}$ Decreto-Lei ํo 92, de 2 de Maio de 1941.

${ }^{96}$ Circulação horizontal, elevadores, escadas, sanitários, copas, etc.
} 
encostados nos recuos de fundo da parte entrante do "L". A lógica é a de se manter sempre que possível o núcleo rígido encostado nos limites das divisas "cegas" ou menos importantes.

Se o arranjo final das plantas e respectivas volumetrias esboçam uma composição difícil, mais do que uma reprodução pura e simples do lote, a manipulação das premissas modernas ou de seus conceitos mais gerais se mostram ainda mais admiráveis: no edifício há um encontro exemplar entre princípios modernos, que admitem a composição, e a adequação urbana nos termos da cidade tradicional.

Nesse sentido, as orientações das fachadas voltadas para as rua Boa Vista (sudoeste) e Ladeira Porto Geral (sudeste) favoreceram a clareza dos elementos modernos universais: a ossatura independente, a fachada livre e principalmente o binômio transparência e leveza (pouca espessura) das esquadrias de vedação. A intenção da leveza é enfatizada no estreitamento das bordas da laje tipo cogumelo; recurso que omite a espessura da laje, em favor da percepção da leveza, uma ilusão ótica (trompe-l'oeil) comum aos modernos. ${ }^{97}$ Assim, o que se apreende de antemão são as linhas horizontais das lajes e a silueta dos pilares: uma vez que na obra não há brises intermediando as relações entre espaços interiores e exteriores.

Os planos paralelos das lajes e a procura pela regularidade das modulações dos pilares demonstram o confronto entre a idealidade moderna, racionalidade e abstração -e as circunstâncias particulares do terreno. Percebe-se, dessa maneira, a tentativa imperiosa da modulação; que sempre deve ajustar-se às irregularidades do lote. Nos pavimentos voltados diretamente para as ruas a modulação dos pilares é $6,48 \mathrm{~m} \times 5,54 \mathrm{~m}$, alterando-se nas extremidades dos perímetros. No bloco que se aprofunda no lote, os intervalos são 4,30 m x $5,40 \mathrm{~m}$, com quatro linhas de apoios. Na procura dessa regularidade de estrutura e forma é notável a transição dos blocos lindeiros à rua e bloco voltado para os fundos. Neste ainda se vê em suas fachadas o sentido de transparência, no entanto, sem a mesma leveza das fachadas principais, até porque a fachada não é corrida, pois uma linha de pilares interrompe a continuidade das esquadrias. A solução dada ao bloco dos fundos indica uma hierarquia entre as fachadas principais e as demais, mas também revela a disposição de tratar adequadamente a todas ${ }^{98}$ : e nesse caso, as disparidades não são demasiadas.

\footnotetext{
${ }^{97}$ Frank Lloyd Wright a usou muito nas casas Usonianas, estreitando através de escalonamento as vigas projetadas em balanço.

${ }^{98}$ Não raro, muitas soluções propostas pelos arquitetos não vingavam por motivos de custos ou por outra opção técnica. É o caso, do Edifício e Galeria Monteiro, do próprio Rino Levi, que teve seus brises substituídos por vidros especiais importados que prometiam conter o excesso de insolação ( ANELLI, Renato (pesquisa de texto), GUERRA, Abílio (coordenação editorial) e KON, Nelson (ensaios fotográficos), 2001, p.239).
} 
Por outro lado, percebe-se na forma do edifício uma série de ajustes que parecem indicar a procura de uma conciliação entre este e a cidade: ou, a superação de uma aparente contradição entre o moderno e a cidade tradicional, ao menos no Banco Paulista do Comércio. Os primeiros elementos são identificáveis no térreo da Rua Boa Vista ${ }^{99}$ : a loggia, o pé-direito duplo da agência (e os tijolos de vidro que a vedam) e o tratamento em mármore nas paredes e pastilhas nos pilares denotam tal condição de importância do chão. Porém, o principal elemento formal dessa relação entre edifício e cidade se encontra na curvatura da fachada para a Boa Vista, que se desenvolve do segundo ao último piso. Essa curvatura que acompanha o alinhamento é enfatizada pela quebra linear da loggia no térreo e tem ainda o mérito de se encontrar na linha visual dirigida para as cercanias do Pátio do Colégio, de onde se avista o prédio. A intenção de se realçar a forma do edifício na perspectiva da rua é plausível, a despeito do alinhamento curvo da esquina, assim configurado depois dos anos 30 (Figuras 7.32 a 7.52)

\section{Uma quadra em formação e três edifícios de Oswaldo Bratke ${ }^{100}$}

Quando da implantação do Plano de Avenidas na gestão de Francisco Prestes Maia (prefeito de São Paulo entre 1938 e 1945) as ruas Epitácio Pessoa e Ipiranga foram unidas e alargadas. A Avenida São Luiz além de alargada estendeu-se rumo à Praça da República. Na outra extremidade, a Rua Major Sertório seria prolongada até a nova Ipiranga, cruzando no caminho a Rua Araújo: estava então formada uma quadra tipicamente moderna, fruto do processo modernizador iniciado na década anterior, com a colaboração de Ulhôa Cintra ${ }^{101}$.

Sob essas circunstâncias, as Avenidas Ipiranga e São Luiz seriam abertas, constituindo-se em símbolos e marcas de uma modernização já em curso, pautada, sobretudo, na verticalização e no sistema rodoviarista: elemento central de um modelo radial-perimetral que sintetizava em torno de si os desígnios de uma cidade em crescimento já acelerado. O processo modernizador em curso nos anos 40 tinha conteúdo, forma e estrutura: uma verticalização frenética e estimulada, apoiada numa legislação até certo

\footnotetext{
${ }^{99}$ Nos desenhos legais o $3^{\circ}$ piso corresponde ao térreo da Boa Vista; o 1ํo piso e o $2^{\circ}$ pavimento postado para a Ladeira Porto Geral.

${ }^{100}$ Este conteúdo é uma revisão do ensaio intitulado "Oswaldo Bratke e a "Cidade Nova": o Texto e o Contexto, de autoria nossa com Paulo Del Negro (Ribeiro e Del Negro, 2005).

${ }^{101}$ O plano teve colaboração de Ulhôa Cintra que coordenou na administração de Pires do Rio os primeiros estudos para um o "Plano Geral"para a cidade de São Paulo: nesta ocasião elaborou o conceito do perímetro de irradiação, tão caro a Prestes Maia à época seu colaborador. Prestes Maia em sua gestão na prefeitura faz de Ulhôa Cintra, seu mentor no Pano de Avenidas, chefe do Departamento de Obras. CAMPOS, Candido Malta. "Os Rumos da Cidade: Urbanismo e Modernização em São Paulo", 2002, p.398.)
} 
ponto coercitiva, numa estética embelezadora e num sistema de circulação que priorizou, sobretudo, o automóvel; embora o Plano de Avenidas contemplasse diversos outros aspectos.

Entre uma modernidade plural de caráter internacional e um urbanismo modernizador $^{102}$ levado a termos em São Paulo, materializou-se uma arquitetura dos edifícios imersa numa diversidade estilística, à primeira vista, desvinculada do imaginário e da modernização em curso no âmbito do urbanismo e da cidade. A propósito, Candido Malta Campos relata: "até 1945, pelo menos, a produção modernista surgia no meio de ampla gama de propostas, todas modernas, portadoras de considerável diversidade estética e ideológica. Antes de se impor como alternativa hegemônica após a segunda guerra, o modernismo propriamente dito dividia espaços com outras manifestações do moderno e da vontade modernizadora ${ }^{103 "}$.

Em meio a esse ideário e ações, uma nova quadra foi então configurada depois dos cortes no tecido anterior. Nela seriam construídos os três edifícios de Oswaldo Arthur Bratke: o Jaçatuba de 1942; depois nas esquinas adjacentes, o ABC de 1949 e o Renata Sampaio Ferreira de $1956 .{ }^{104}$ Naquele momento em particular, um fragmento urbano estava sendo construído por uma grande empreitada. No decorrer das décadas seguintes uma linguagem moderna de caráter brasileira ficaria manifestada com mais clareza. Assim, as três de obras de Bratke resumem numa mesma esquina parte dessa trajetória da arquitetura brasileira: rumo a uma identidade própria: incorporando as questões climáticas, dos materiais locais e propondo novas tipologias mais libertas das amarras do lote, porém ainda vinculadas à rua.

${ }^{102}$ Nadia Somekh, em seu livro "A cidade Vertical e o Urbanismo Modernizador ", defende a tese de um urbanismo modernizador para a cidade de São Paulo. "A modernização corresponde à necessidade constante do capitalismo de buscar aumento de produtividade, por meio de avanços tecnológicos e organizacionais. A modernidade e as conseqüentes idéias modernistas consistem no desenvolvimento do projeto iluminista de domínio da natureza, baseado na racionalidade e na objetividade. O urbanismo moderno vai além, por surgir na cidade industrial especificamente para enfrentar os problemas sociais que se confundem com as questões urbanas[...]O urbanismo paulistano, apesar de pautado numa racionalidade influenciada pelo ideário internacional, não pode ser considerado moderno, pois a questão social não ocupa o centro de seu discurso, mas sim a eficiência e o desenvolvimento da cidade e do capital." SOMEKH, Nadia: A cidade Vertical e o Urbanismo Modernizador São Paulo 1920-1929.São Paulo, Studio Nobel, 1997, p33.

103 Candido Malta Campos Neto: Os Rumos da Cidade: Urbanismo e Modernização em São Paulo. Tese de Doutorado FAU/USP. Vol I e II, São Paulo, 1999. p.19. A tese foi publicada com o mesmo título original pela editora Senac, com supressão do sobrenome Neto no nome do autor.

${ }^{104}$ As referências de data são aquelas adotadas por Mônica Junqueira de Camargo; segundo seus critérios, ou seja, a primeira da qual se tem notícia. Exceção fica por conta do edifício Jaçatuba que teve data retificada em seu doutorado. Camargo, Mônica Junqueira de. Oswaldo Bratke: uma trajetória moderna. São Paulo: FAU-Mackenzie SP, 1995. Dissertação de mestrado. 


\section{Simultaneidade estilística}

Um ato municipal de setembro de 1938 aprovara o novo traçado do perímetro de irradiação: as primeiras desapropriações ocorrem logo em seguida, dando inicio às obras. $O$ alargamento da Rua Ipiranga e seu prolongamento sobre a Epitácio Pessoa, gerou a Avenida Ipiranga: primeira componente do perímetro de irradiação inaugurada em 27 de abril de 1941, medindo $1.400 \mathrm{~m}$ de extensão por $37 \mathrm{~m}$ de largura. A quadra em estudo foi refeita após o ato, constituindo-se num caso típico: onde um tecido pré-existente é profundamente alterado, conformando uma nova quadra - e seus respectivos lotes - de forma irregular.

A antiga quadra possuía grandes dimensões, pois continha a Escola Normal e o Jardim de Infância. O prolongamento e alargamento das novas avenidas a secionou de forma a distingui-la com clareza da escola, hoje Instituto Caetano de Campos. Consequentemente, seus lotes tiveram suas geometrias e dimensões modificadas parcialmente. Os lotes voltados para a Rua Araújo foram mantidos em seu desenho anterior. Aqueles postados para a antiga Escola Normal, hoje Praça da República e Caetano de Campos, foram ampliados sobre parte do terreno do Jardim de Infância: outra parte foi destinada ao alargamento da São Luiz. Entretanto, os lotes voltados para a Avenida Ipiranga tiveram suas dimensões bastante reduzidas, pois os grandes cortes e alargamentos ocorreram pelos seus lados. Da antiga quadra só remanesceram, até recentemente, dois galpões e um sobrado que agora é ocupado pelo Hotel Mercury.

Os decretos-lei de 1940 e $1941^{105}$ regulamentaram respectivamente as construções nas Avenidas Ipiranga e na zona central. Alturas mínimas e máximas para os edifícios, alinhamentos, padrões de acabamento para o embasamento, verticalização induzida sob pena de aumento de impostos e incentivos para ampliação de passeios públicos foram elementos importantes na definição das volumetrias e caráter estético das edificações e das novas avenidas. Nas Avenidas Ipiranga e São Luiz, as alturas mínimas para as edificações foram determinadas em $39 \mathrm{~m}$ ou 11 pavimentos; quando construídas no alinhamento. Por meio de escalonamentos sucessivos poderia ser atingir novas alturas. Para a Rua Araújo, que não fazia parte da área central a legislação era outra: poderia se atingir no máximo a altura de uma vez e meia a largura da rua com escalonamento progressivo a partir do alinhamento. Tinha-se, portanto, na mesma quadra duas legislações distintas que privilegiavam, sobretudo, as avenidas e sua configuração geral: além dos dispositivos que permitiam altura até $80 \mathrm{~m}$ guardando-se recuos laterais. 256 e p. 264.

${ }^{105}$ Ayres Neto, Gabriel. Código de Obras "Arthur Saboya”. São Paulo, Edições Lep, 1947, p. 
A ideia da quadra como uma volumetria única, à maneira Europeia, como esboçada em perspectivas do plano de Prestes Maia, estava desfeita. O edifício Jaçatuba de Bratke postado numa das esquinas será o caso singular que promoverá a transição entre duas volumetrias e legislações distintas: de maneira a conciliar aquilo que nasce irremediavelmente partido.

O primeiro prédio construído na quadra foi o São Bartolomeo, de Barretto, Xande \& Cia, em 1941, na Avenida Ipiranga, 313: por coincidência, ele foi a principal referência nas definições finais da volumetria Jaçatuba. Em seguida, vieram sucessivamente os edifícios: São Luiz de Jacques Pilon, na atual Praça da República, 77; o Caetano de Campos na Rua Araújo, 79; o São Nicolau na Praça da República, 123; o Jaçatuba na Rua Araújo, 165; o Ferrabino na Ipiranga, 331/7; o Intercap na Praça da República de autoria de Marjan Ryszard Glogowski, 105/7 e o Flamengo na Ipiranga, 345. Os dois últimos são mais elevados, pois fizeram outro uso da legislação que permitia alturas máximas de $80 \mathrm{~m}$, guardando recuos laterais.

Por essa quadra em particular se pode atestar a diversidade e simultaneidade estilística daquela década e a alternância de gosto entre um estilo e outro. O São Bartolomeo é quase despido de ornamentos: no entanto, há nele resquícios de um maneirismo art déco e de elementos da linguagem clássica que distingue embasamento de pedra, imposto pela legislação, um desenvolvimento e um discreto coroamento. O segundo edifício da quadra foi o São Luiz: de caráter eclético. Na sequência, identificada, foram edificados o eclético São Nicolau e o Jaçatuba com seus traços classicistas e modernos. Os outros dois edifícios construídos na década seguinte já manifestam certo predomínio estilístico, naquele momento, favorável ao denominado estilo modernista. É conveniente lembrar que na mesma Ipiranga já havia sido construído, em 1935, o edifício Esther de Álvaro Vital Brasil (figuras 7.53 a 7.59 ) .

\section{Jaçatuba: uma transição entre duas ruas}

O edifício Jaçatuba possui uma aura especial: sua linguagem construtiva e plástica encontra-se entre manifestações ecléticas e a afirmação de uma linguagem mais de caráter modernista. Se a discussão restringe-se penas a questões estilísticas pode-se dizer que ele não é ainda completamente moderno, sobretudo, se a ênfase é depositada na relação entre estrutura e definição espacial: ou seja, na relevância estrutural enquanto elemento expressivo primordial. Há nele sem dúvidas traços e esquemas compositivos de natureza acadêmica: resultantes da formação de Bratke; que Ihe proporcionaram, entre outras coisas, o conhecimento de vários estilos. Mas também, comparecem marcas de seu caráter pragmático, sempre atento às inovações técnicas, à satisfação de sua clientela e, sobretudo, 
às circunstâncias particulares do terreno e seu do contexto imediato ${ }^{106}$.

A primeira data de projeto que se tem referência do Jaçatuba é de 1942. Uma perspectiva sua foi publicada na revista Acrópole em Junho de 1944 : entretanto, sua construção ocorreu após 1945; como pode ser notado numa fotografia contida em "Os Melhoramentos de São Paulo", publicação da administração Prestes Maia de Janeiro de 1945. Nela encontram-se construídos os edifícios São Luís e São Bartolomeo. Donde se constata a importância do edifício São Bartolomeo na definição formal do Jaçatuba. Além de estar voltado para a Avenida Ipiranga, portanto, atendo-se à legislação que impunha uma altura mínima de $39 \mathrm{~m}$ para edifícios no alinhamento da rua, ele dobrava-se à direita na esquina, entrando na recém-prolongada Major Sertório.

O Jaçatuba, então, nasceria dessas pré-existências e seria implantado num lote de esquina de formato irregular: um resíduo urbano irregular e esconso; cujos lados estavam postados tanto para a Rua Major Sertório, quanto para Rua Araújo. Diante dessas circunstâncias, várias atitudes de projeto, posturas e interpretações da legislação por parte de Bratke tiveram relevância na definição final de sua volumetria que aparenta ser a de um edifício constituído por um único corpo. Entretanto, o Jaçatuba é constituído por dois corpos de tamanho e altura desiguais. O corpo principal com 11 pavimentos configura-se como um edifício de esquina com três faces bem definidas: uma côncava na bissetriz da esquina e duas outras planas e simétricas voltadas para as ruas laterais. O resultando foi uma composição de harmonia clássica; sobretudo, pela simetria bem definida. Por outro lado, encostado discretamente nesse corpo principal, encontra-se o "apêndice" com suas dimensões e altura reduzida a seis pavimentos. A primeira impressão prevalece forte no imaginário, pois suprime aquilo que se quer abrandado, a desigualdade volumétrica. Como no caso do Banco Paulista, à altura das edificações, de modo geral, permitia-se em lotes de esquina em vias públicas de larguras diversas, que a medida fosse tomada pela via mais larga. De modo que essa altura máxima permitida pela via de maior largura fosse estendida até a uma profundidade de $20 \mathrm{~m}$; a contar do alinhamento, obedecendo daí em diante à redução decorrente da altura permitida na via de menor largura ${ }^{107}$.

Mônica Junqueira de Camargo (2000) e Hugo Segawa relatam uma negociação

${ }^{106}$ Mônica Junqueira de Carmargo traça um completo perfil de Oswaldo Bratke, no capítulo "Pragmatismo: formação e conduta", de sua tese de doutorado, 2000. Tese de Doutorado: p. 67-78

${ }^{107}$ Este dado explica o rebatimento das volumetrias iguais do Jaçatuba para duas ruas distintas. Porém, a solução de mesma altura entre o Jaçatuba e o São Bartolomeo implicou outros raciocínios e interpretações: do quais não se descartam negociações envolvendo tanto aspectos legais quanto estéticos. Outro artigo de lei, de 1940, destinado à Avenida Ipiranga previa a concessão oportuna de favores especiais para prédios que não possuíssem corpos superelevados e cujos pavimentos térreos apresentassem recuos equivalentes a uma ampliação de passeios utilizáveis para mesas de cafés, bares, etc. (AYRES NETO, Gabriel: 1947, p. 258). 
entre Bratke e a prefeitura para aumentar a altura da edificação. Segundo esses relatos, essa negociação implicou o acréscimo de dois pavimentos no corpo principal do prédio: para tanto, lançou-se mão de um artifício que manipulava virtualmente a distância dos limites do lote até o largo defronte. Esse procedimento teria então gerado a forma côncava da fachada principal.

O Jaçatuba foi projetado como um conjunto para consultórios médicos. Suas formas e linguagem são o desvelar de um saber fazer peculiar a Oswaldo Bratke. Aquilo que a urbe pautou como normativa estava parcialmente dominado por uma volumetria já definida e negociada.

As manipulações do programa e da legislação geraram o esquema clássico de uma bissetriz que divide igualmente dois setores, onde no centro, postado mais ao fundo do lote, aloja-se a circulação vertical (elevadores e escada) e, nos lados, simetricamente, os respectivos consultórios, formando dois grandes conjuntos com salas que se intercomunicavam entre si; complementadas por um corredor interno. Até certo ponto as geometrias de arestas regulares prevalecem. Quando o arranjo espacial se aproxima dos limites irregulares do lote, os espaços tendem a ser mais disformes, mais agudos, ou seja, passam a ser destinados às atividades de menor importância ou mais flexíveis como armários e depósitos. É relevante o espaço/armário incrustado na transição entre o Jaçatuba e o São Bartolomeo. Em planta ele é incorporado como um apêndice secundário de uma sala; na fachada, separado por uma moldura, é o elemento neutro que faz a transição entre os dois edifícios contíguos: permitindo, assim, que o Jaçatuba seja percebido como uma unidade plástica/volumétrica. A solução em planta não permite uma geometria sem arestas e harmoniosa, mas pelas soluções compositivas espaciais e plásticas, no caso, pelas molduras nas fachadas, foi possível estabelecer uma correlação entre conteúdos internos e externos, harmonizando-os.

Há no Jaçatuba uma coincidência entre estrutura e unidade formal: os espaços e suas dimensões correspondem de certa maneira à disposição dos elementos de apoio. Nos pavimentos-tipo não há nenhuma distinção entre elementos estruturais, de concreto armado e os elementos de vedação: com certeza, pilares e vigas independentes, encontram-se embutidos nas alvenarias, porém, seus espaçamentos coincidem, quase sempre, com as paredes divisórias. A exceção fica no piso térreo, ali alguns pilares afloram-se, destacandose dos tijolos de vidro.

Se a estrutura ainda não é um elemento de expressão primordial na sistematização e modulação espacial do Jaçatuba o será nos ABC e Renata Sampaio Ferreira (figuras 7.57 a 7.65). 


\section{Os edifícios ABC e Renata Sampaio Ferreira}

Os edifícios ABC (1949) e Renata Sampaio Ferreira (1956) ilustram bem a trajetória de Bratke rumo à consolidação de sua linguagem moderna, racionalista e pautada na construção de uma brasilidade até certo ponto programática. Que pode ser identificada nos desenhos de componentes construtivos e objetos diversos: adaptados às nossas condições materiais e mão de obra (Camargo, 2000, p. 151). Além de procurar, como outros, um vocabulário plástico que expressasse um caráter nacional, por uma herança ibérica, pelas imposições do clima, pelo enfático uso de elementos vazados.

Os dois edifícios possuem gabaritos definidos pela mesma legislação; que estipulava a altura dos prédios em função da largura da rua. ${ }^{108} \mathrm{~A}$ diferença de altura entre ambos devese às dimensões dos lotes e ao fato de que no Renata Sampaio uma torre de serviços encontra-se solta de seu embasamento - solução incomum naquele momento (Segawa, 1997, p. 192).

Nas esquinas os três edifícios revelam soluções formais bem distintas. A parede côncava do $A B C$ reporta-se aos dois panos do Jaçatuba, contidas na grande concavidade da fachada principal: é particularmente interessante a elipse sugerida pelo coroamento de ambos, à semelhança dos arremates barrocos. Daí, desprender-se, além da clara referência mútua, duas outras leituras: uma retirada das condições de desenho para as esquinas, presente na legislação, que "sugeria" chanfros ou saliências convexas e menos frequente côncavas e, outra, que se aloja na origem de uma questão puramente formal e arquitetônica. Se essa análise estende-se ao Renato Sampaio, nota-se que os procedimentos de mesma natureza são ali também executados: pela grande empena.

Entre o Renata Sampaio e os outros dois edifícios é visível um maior distanciamento quanto ao arranjo volumétrico, à implantação e ao desenho da esquina. A legislação, embora semelhante à do $A B C$, foi interpretada de maneira diferente, sobretudo porque entrava em cena uma nova questão arquitetônica; a torre solta de seu embasamento. Essa nova tipologia, em gestação nos anos 50 , centralizou algumas decisões importantes, no sentido de fazê-la mais expressiva. $O$ fato do edifício se encontrar recuado do alinhamento na Rua Major Sertório é um recurso facilitado pelas dimensões do lote e uma decisão para acrescentar altura à torre. Outra decisão relevante foi a de se eleger o recuo lateral, na Rua Araújo, como referência para o alinhamento da torre e na mesma lógica determinar a ortogonalidade com a face principal do embasamento voltada para a Araújo. Essas

${ }^{108}$ A altura pelo alinhamento da rua era de uma vez e meia a largura desta. Para determinar este altura era usado um triangulo retângulo, cuja base era a largura da rua, sua altura era dada pelo coeficiente, no caso, 1,5 esta largura, a partir da divisa do terreno; através do prolongamento da hipotenusa tinha-se os limites para as alturas. 
operações provocaram duas consequências formais: um imperceptível desvio na divisa frontal do lote e a grande parede chanfrada na esquina; no mesmo sentido do pequeno chanfro deixado na calçada para atender à legislação. De qualquer maneira, essa solução atípica de esquina causa um estranhamento em relação ao desenho adotado nas esquinas do $A B C$ e Jaçatuba.

No Renata Sampaio outras atitudes revelam uma tentativa de conciliar a torre isolada, com seu fascínio próprio e, o embasamento conectado ao rés-do-chão. Porém, essas relações mostram-se ambíguas: a própria torre não é totalmente isolada: um de seus lados é uma empena cega postada na divisa de fundo do lote, qualquer edificação colada ali poderia diluir a leitura da torre; e o embasamento ora é fruto da geometria do lote, ora vincula-se apenas à torre. Nesse sentido, as relações formais entre o embasamento, a torre e a conformação do lote parecem circunstancialmente difíceis; o vínculo entre o lote e a forma final da arquitetura, como no Jaçatuba, deixa suas marcas. A rua, ainda, é tida como desenhada ou perspectivada pelos edifícios ou seu embasamento nela alinhados.

Mesmo na torre isolada, persiste a questão de como tratar a continuidade volumétrica por meio de suas faces. O caminho adotado no Renata Sampaio é da retomada, agora com mais clareza, da parede lisa, contínua, abstrata e quase cega - agora empena. Essa parede "reduz" a questão compositiva e plástica da volumetria a duas fachadas a serem efetivamente tratadas: no caso em questão; norte e a sul.

Entre esses edifícios há outra questão a observar. O ABC foi projetado por conveniência dos incorporadores como três unidades independentes, com circulações, instalações sanitárias e entradas próprias. A estrutura independente de concreto armado já insinuava escritórios panorâmicos; apesar das modestas dimensões de seus compartimentos. A disposição das circulações encostadas em uma das divisas do lote e a solução de poços de iluminação e ventilação são recursos típicos e racionais, adotados para solucionar edifícios de escritório implantados em terrenos de esquina sem recuos laterais. É interessante notar a presença de esquema semelhante no arranjo espacial do Renato Sampaio Ferreira: cujo programa destinava-se também a escritórios, embora esses formassem conjuntos maiores que poderiam ser remanejados com maior flexibilidade. Nele os espaços de circulação e instalações encontram-se alinhados a divisa lateral, indicadores tanto de uma prática anterior, ainda presente, quanto da necessidade de liberar os salões para a fachada maior e mais iluminada.

No $A B C$, o tema que se antevê é o da curtain-wall, ou das paredes externas envidraçadas, preenchendo o vão entre pilares e vigas. A fachada é definida pela malha estrutural, pilares e vigas de concreto armado, explicitados em sua modulação: somente 
modificada nos tramos desiguais juntos à parede côncava na transição das fachadas. De certa maneira, aquilo que é concebido como lógica estrutural e espacial é rebatido didaticamente nas fachadas.

No Renata Sampaio Ferreira, por uma operação distinta, o que se vê é uma parede cortina composta por elementos vazados de concreto, a conformar um plano que protege a primeira pele constituída por esquadrias de madeira e vidro. Essa segunda parede se estrutura por meio de uma lógica modular própria, onde montantes verticais descarregam suas cargas sobre lajes prolongadas a partir de vigas de borda, de forma que suas armações relacionam-se à estrutura principal indiretamente, guardando ritmo e paginação própria.

Do $A B C$ para o edifício Renata Sampaio, nota-se uma transformação significativa na linguagem de Bratke: seja por novas práticas estruturais e pormenores construtivos, seja na busca de novos tratamentos plásticos que expressassem valores de caráter mais nacional, seja na procura de novas tipologias para edifícios verticais. ${ }^{109}$ Nas práticas construtivas procurou-se uma acomodação às condições da indústria nacional, envolta num ideário tomado como paradigma, como os elementos vazados usados para sombrear a fachada tropical, para camuflar instalação de ar-condicionado, para compor plasticamente uma fachada sul (elementos vazados recobrem paredes cegas de alvenaria). O edifício deixa de ser um monobloco, como no $\mathrm{ABC}$, onde comparecem os clássicos elementos de base, desenvolvimento e coroamento, para separar a torre do embasamento; pela linha de sombra criada a partir de seu "arranque" formal.

No fazer arquitetônico de Bratke é possível notar um processo pelo qual a linguagem tradicional vai se transformando numa nova linguagem ${ }^{110}$. Os três edifícios aqui analisados nos permitem em parte constatar essa transformação: porém, as passagens não são tão diretas, imediatas. Os rastros entre um fazer e outro se encontram ali. Entretanto, muitas vezes denotam caminhos distintos. As esquadrias desenhadas sempre pela mesma racionalidade exemplificam a familiaridade: apesar dos diferentes materiais, madeira e ferro, guardam em suas paginações, três linhas divisórias: que separam ventilação e iluminação. Por outro lado, nos raciocínios espaciais e estruturais as diferenças são marcantes: ora pelo programa, ora pela busca da formulação da ossatura independente em seu sentido mais original (7.66 a 7.80$)$.

${ }^{109}$ É o caso da caixa d'água de Olinda, projetada por Luís Nunes, que introduziu o elemento vazado, que viria a se tornar um dos elementos mais expressivos de brasilidade de nosso moderno. Camargo, Mônica Junqueira de. 2000: op.it; p.58

${ }^{110}$ Camargo. 2000: op. cit; p.79 


\section{[Des]encontros}

A leitura dos edifícios, abordados neste capítulo, demonstra que os primeiros encontros entre a arquitetura moderna e o Centro Histórico de São Paulo foram bem distintos da experiência carioca. São determinantes a natureza dos empreendimentos, a legislação e a formação do tecido da cidade tradicional. Nessa relação é possível perceber tanto as idealidades plantadas na doutrina moderna, quanto a força que emana da cidade; essa tensão caracteriza, entende-se aqui, a natureza da arquitetura moderna no Centro de São Paulo, nessa primeira fase nos anos 30 e 40.

Se esses edifícios não se portam como figuras exemplares retiradas da doutrina moderna, eles têm a virtude de portar-se como fundo nas hierarquias ditadas pela cidade. Uma quadra em formação demonstra a hierarquia da rua e as descontinuidades volumétricas.

Se por um lado suas formas estão longe das lâminas ou dos blocos horizontalizados, por outro, elas revelam em suas volumetrias a forma dos lotes e das leis. Mas ao fazê-lo, a despeito de toda adversidade, não deixam de buscar qualidades próprias dos objetos soltos no lote, como o tratamento expressivo e adequado a cada face, atendo-se sobretudo, às questões de salubridade. Nesse sentido, são notáveis as soluções do Thomas Edison e do Banco Paulista do Comércio.

Percebe-se que a ossatura independente é o principio da doutrina mais visível, trazendo à tona toda a carga de significados implícitos: a procura de uma racionalidade sistêmica, como claramente exposta no Esther. Outros elementos como os pilotis, guardam uma relação mais simbólica do que doutrinária. Se em muitos casos a racionalização sistêmica enfrentou empecilhos, em outros demonstrou, por meio da habilidade dos arquitetos, as virtudes compositivas adquiridas nas formações acadêmicas comuns a esses arquitetos: formação que lhes permitia resolver problemas formais imprevistos fora das regras a priori. Se nessa primeira fase não havia uma diferença muito clara entre o embasamento dos edifícios e as torres mais elevadas; rumo aos anos 60, como esboçado no Renata Sampaio, essa separação ficaria mais clara em muitos edifícios. 
Esther e Arthur Nogueira, 1936 (figuras 7.1 a 1.14)

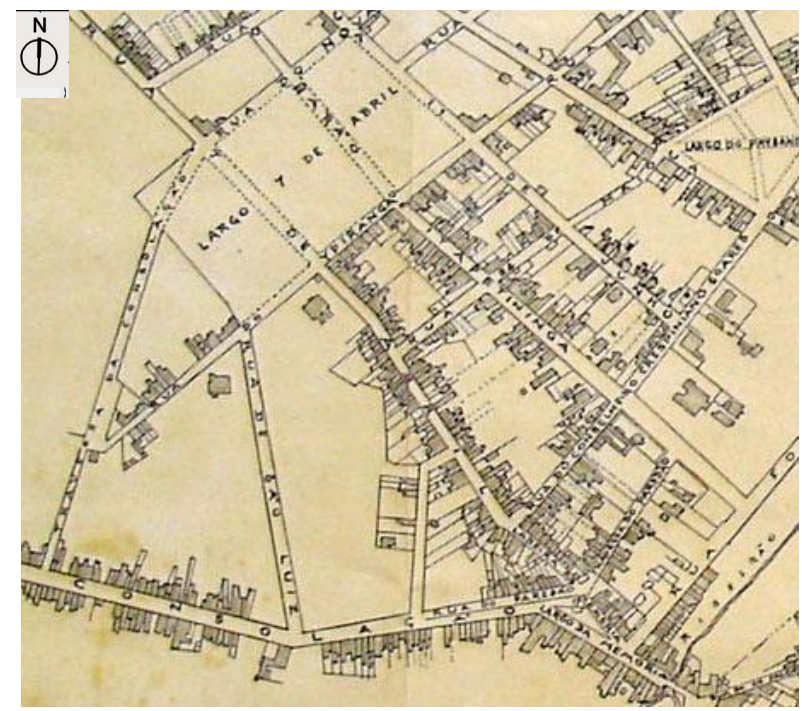

7.1: Planta da Cidade de São Paulo, 1881 Companhia Cantareira e Esgotos

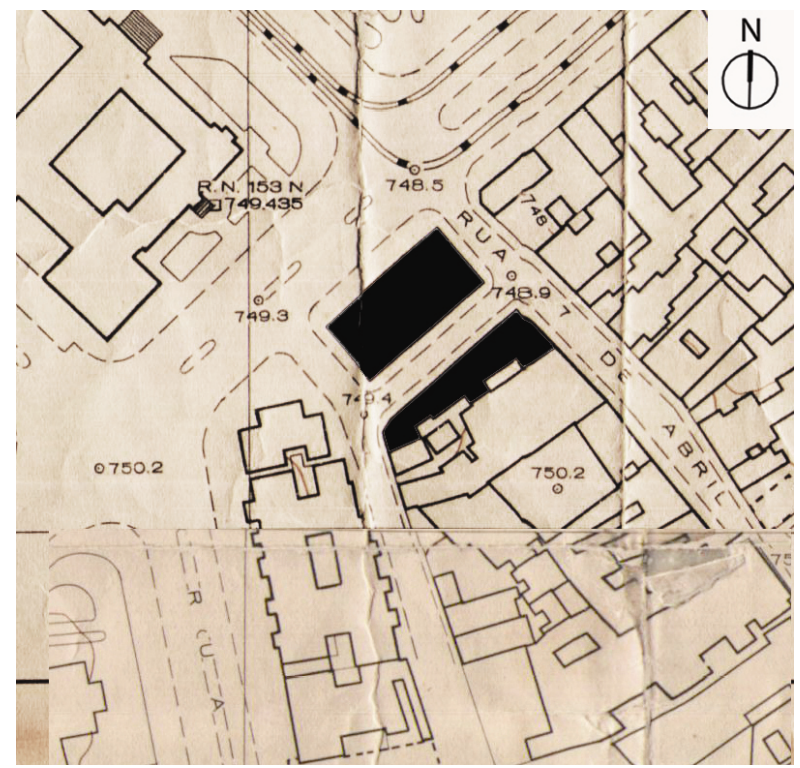

7.3 Esther e Arthur Nogueira. localização no Vasp-Cruzeiro, 1954

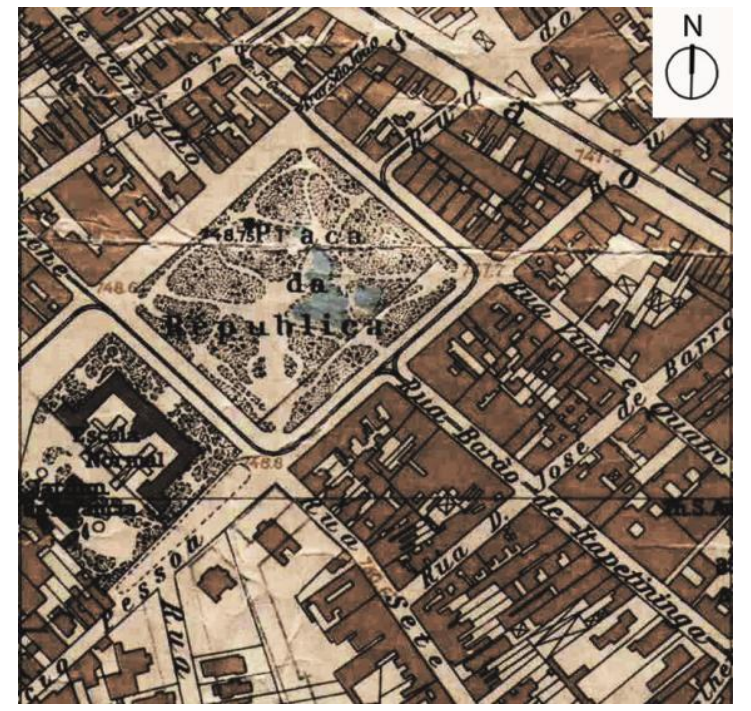

7.2 : Mapa Sara Brasil ,

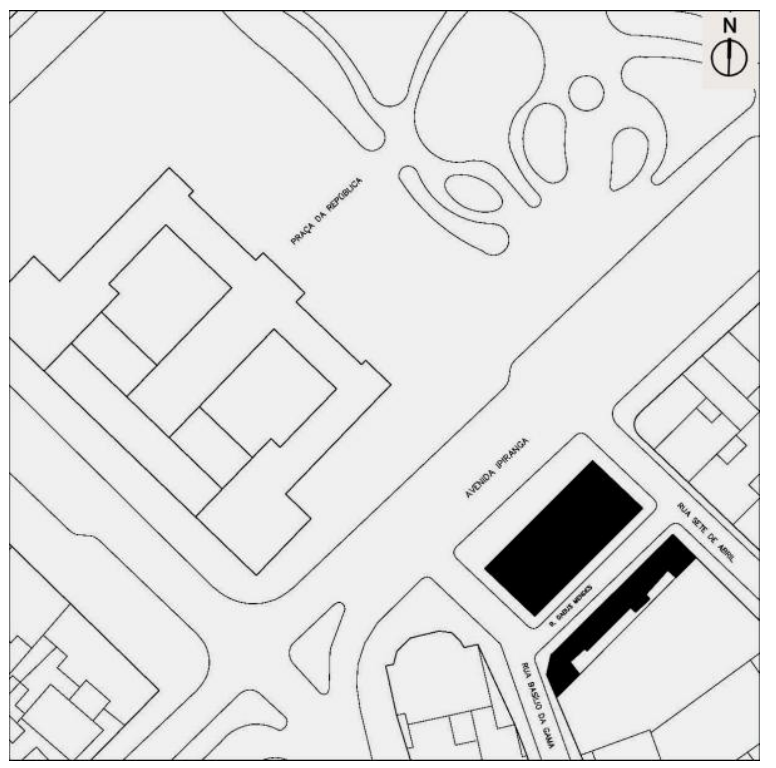

7.4 : situação atual - Mapa Vivo Centro sobre base Gegran, 1974 


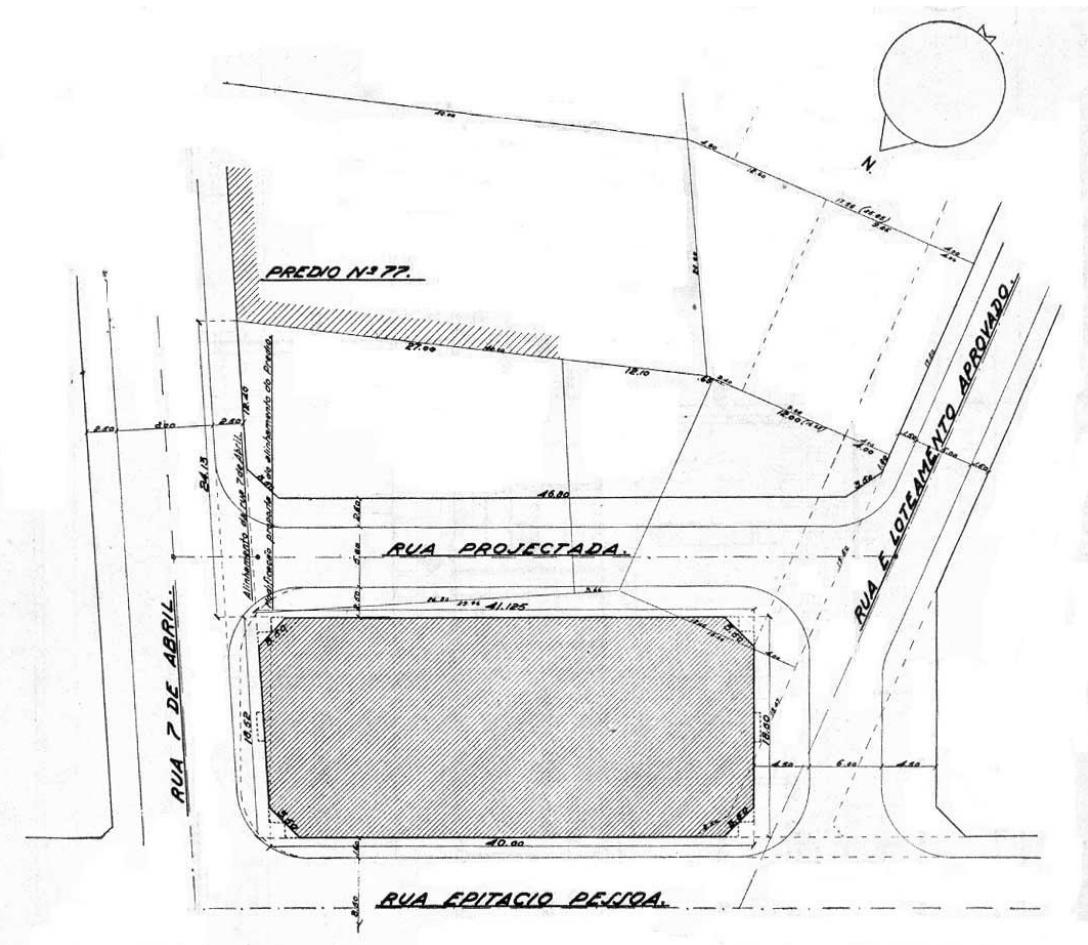

7.5: Implantação Esther, sem o Arthur Nogueira

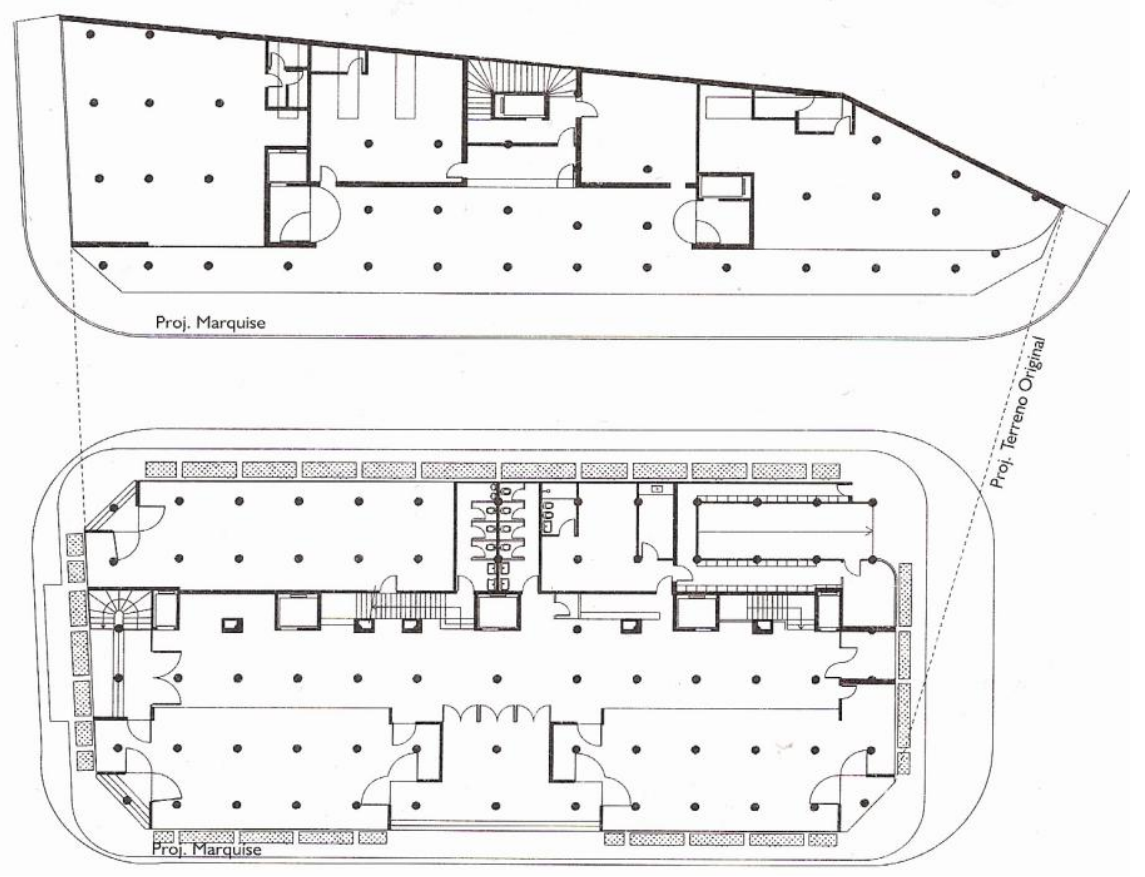

7.6: Planta Pavimento Térreo; Esther e Arthur Nogueira 


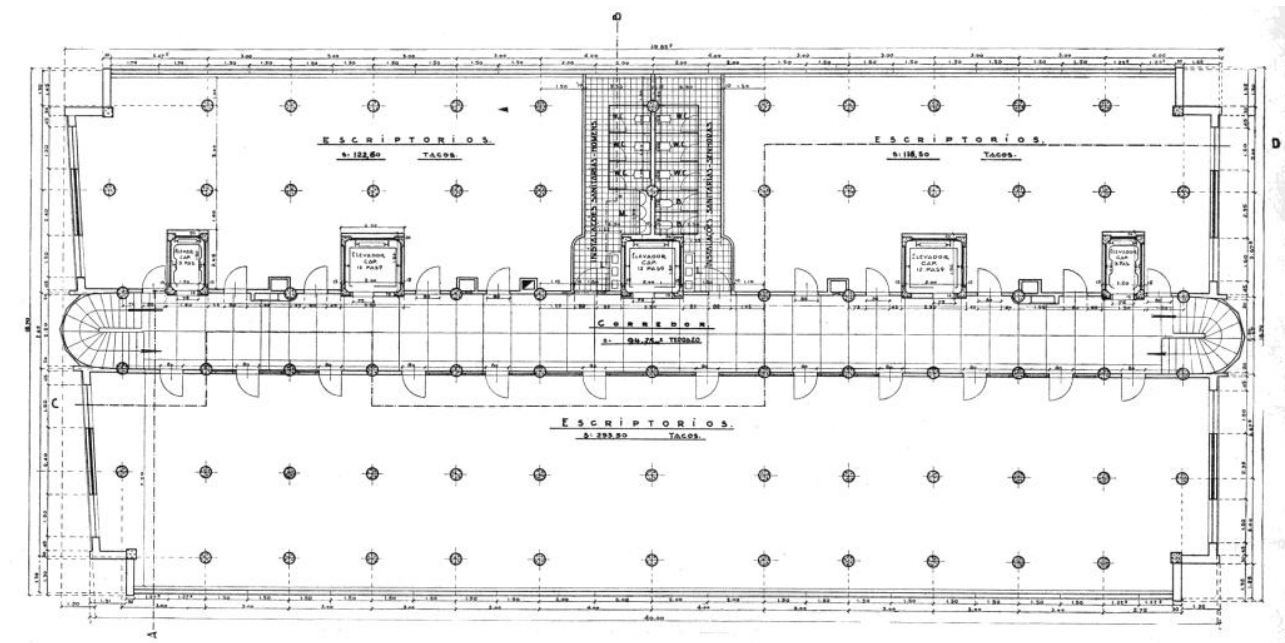

7.7: Planta do $1^{\circ}, 2^{\circ}$ e $3^{\circ}$ Pavimentos

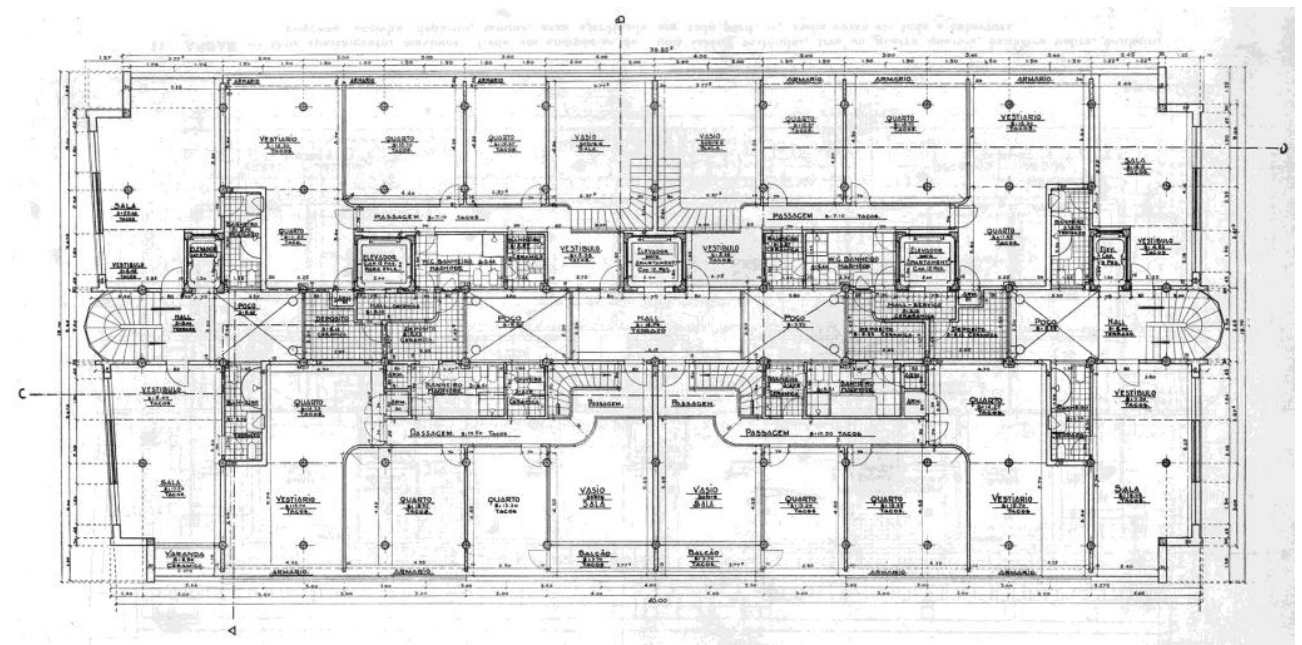

7.8: Planta do $10^{\circ}$,Pavimento

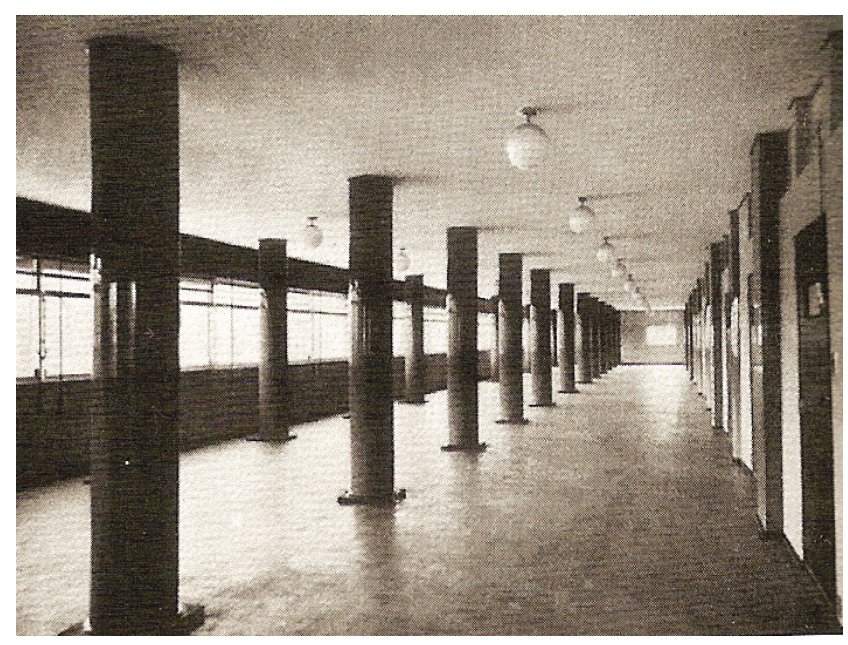

7.9: Esther salão de escritórios 

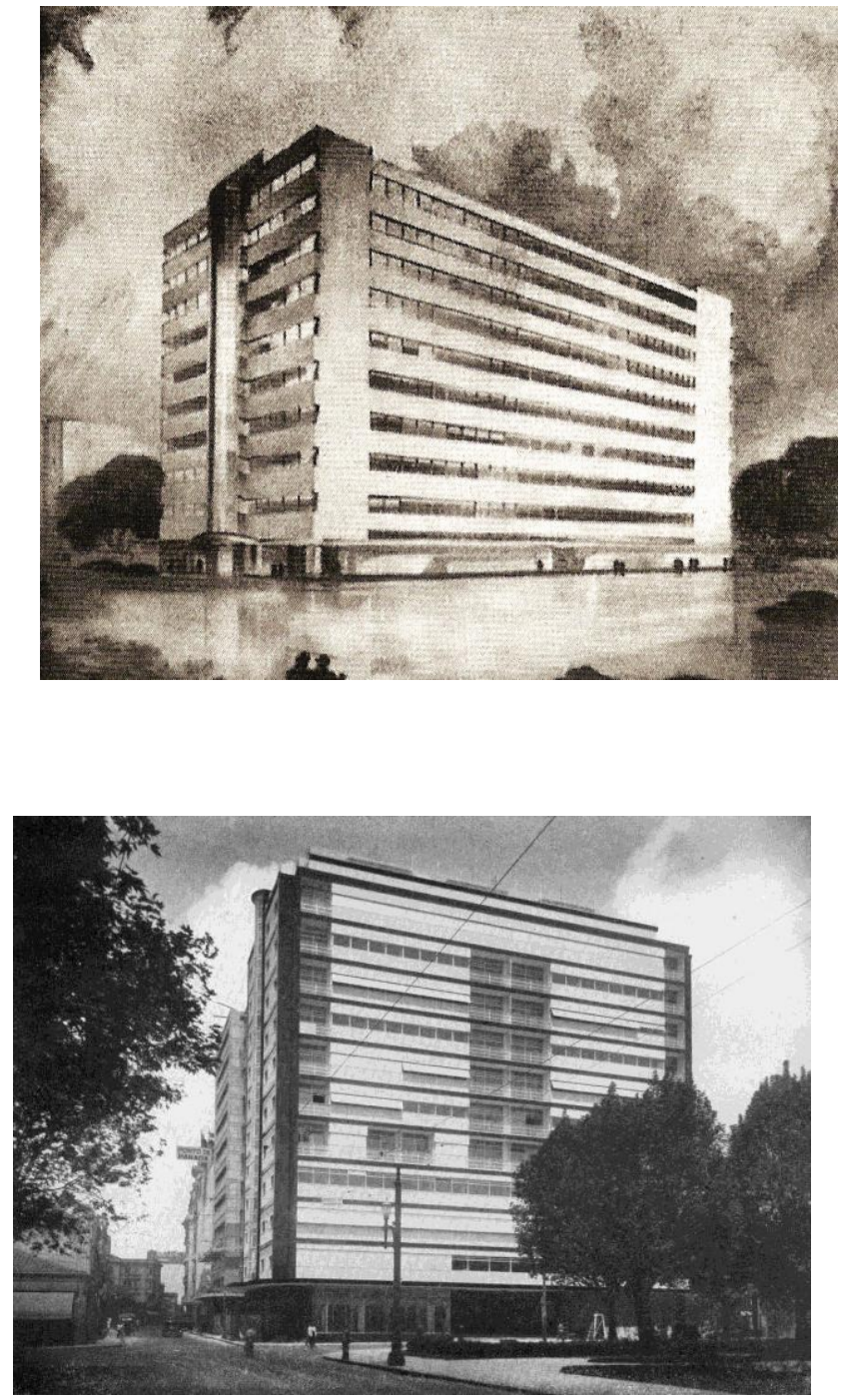

7.11: Esther antes do alargamento da Av. Ipiranga

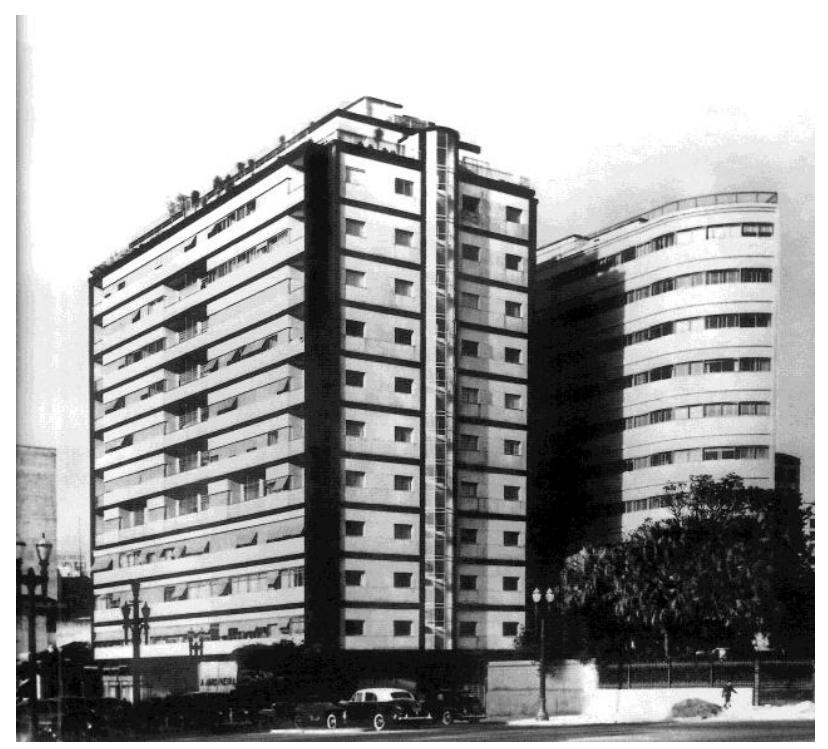

7.12 Esther e Arthur Nogueira anos 40
7.10: Perspectiva do projeto inicial, sem o Arthur Nogueira

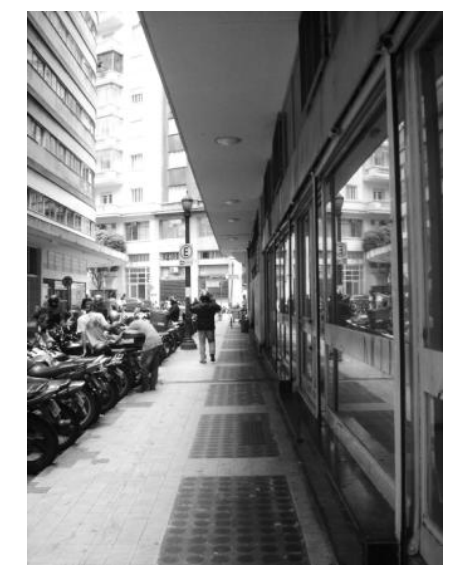

7.13: Esther e Nogueira 2009

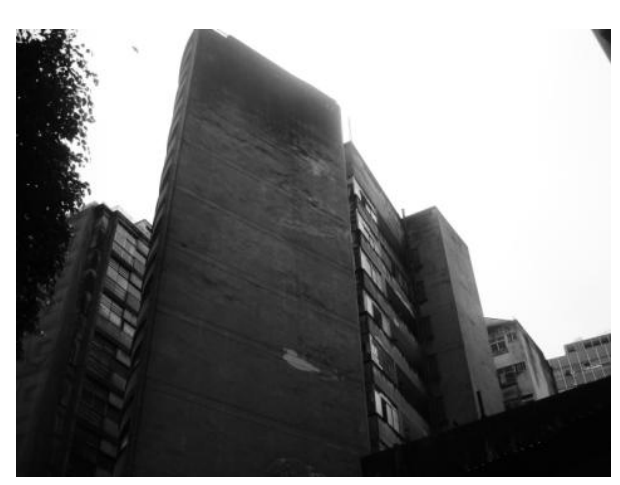

7.14: Empena dos fundos Arthur Noqueira 


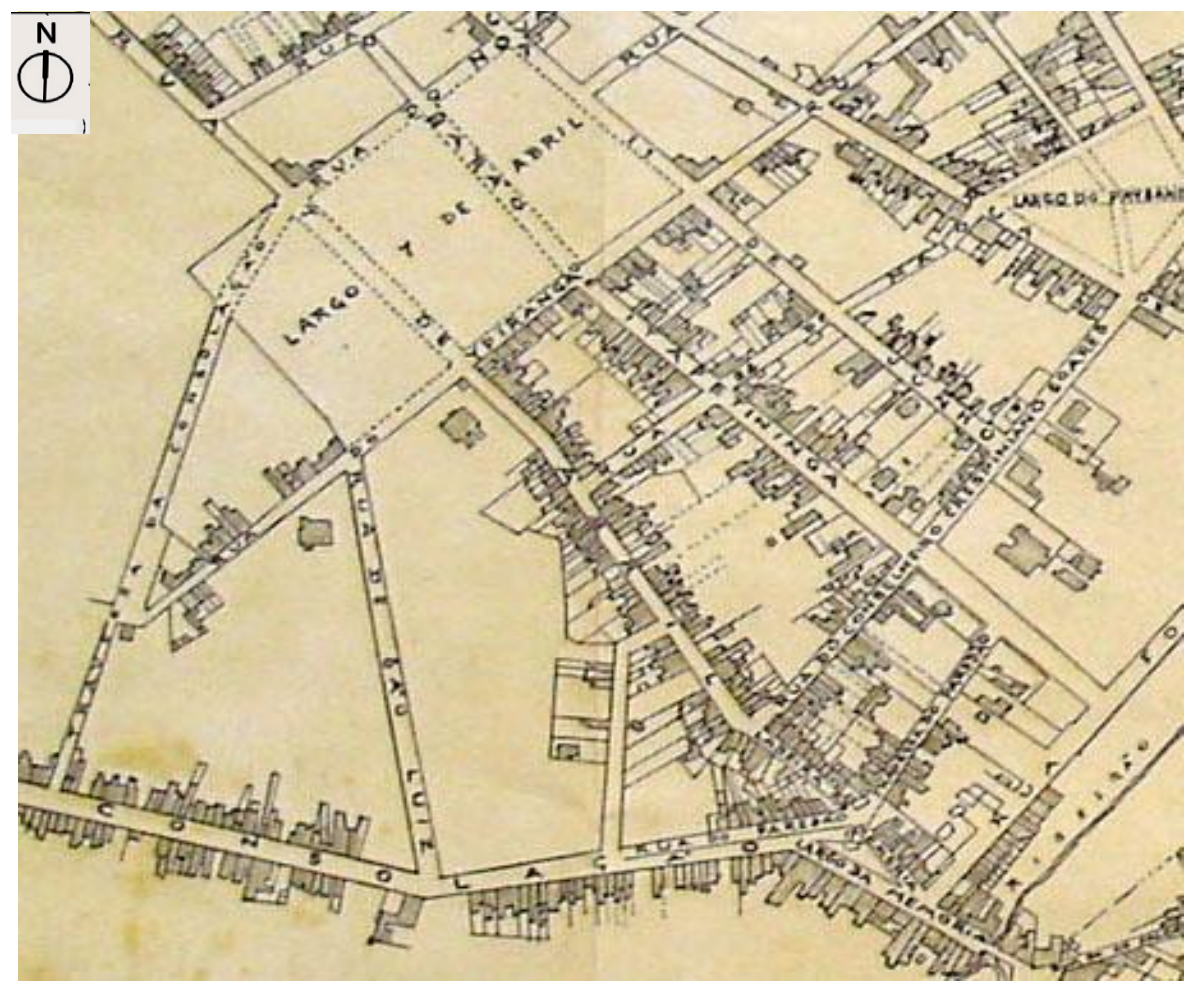

7.15: Planta da Cidade de São Paulo, 1881 Companhia Cantareira e Esgotos

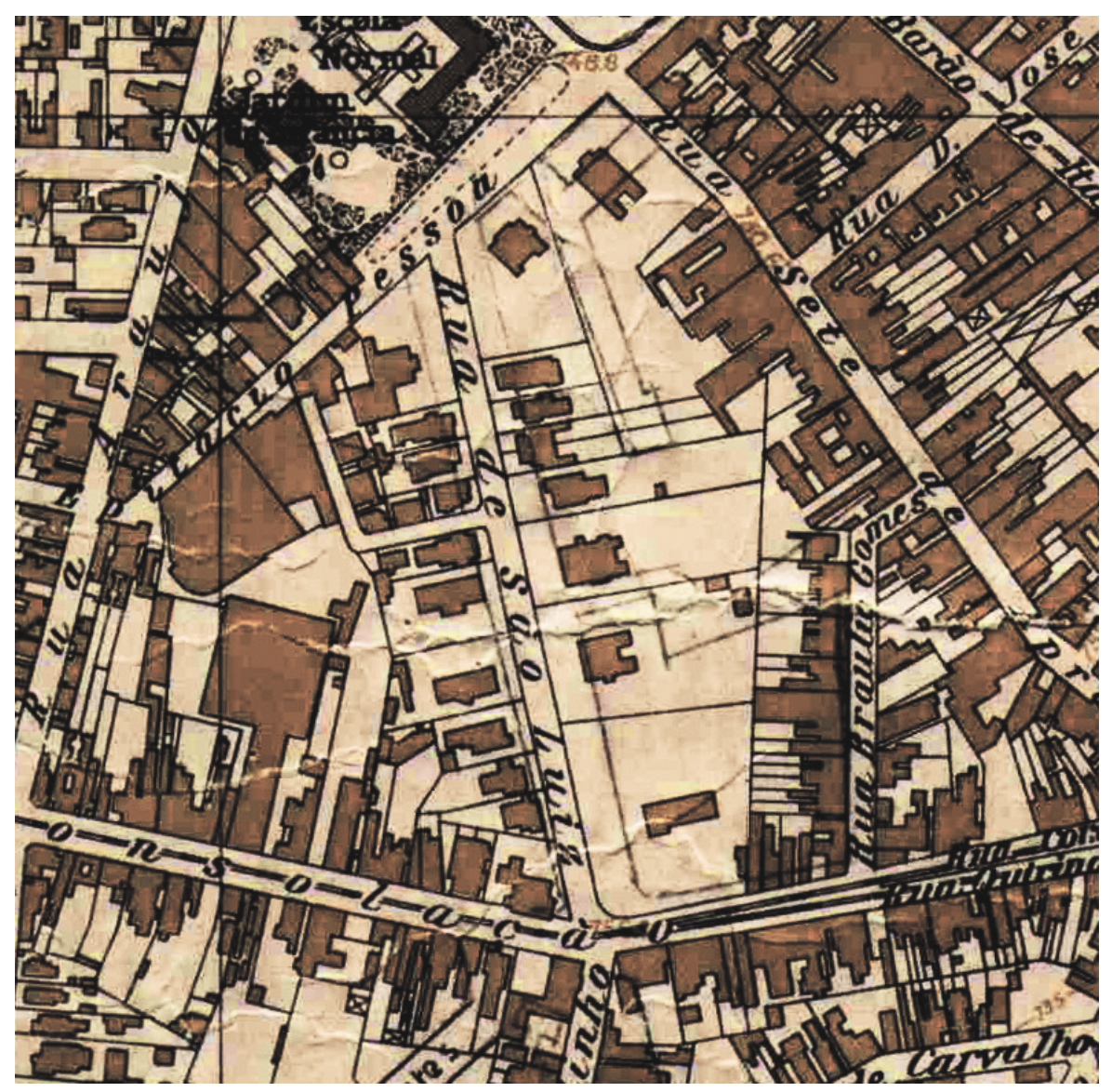

7.16 Mapa Sara Brasil 

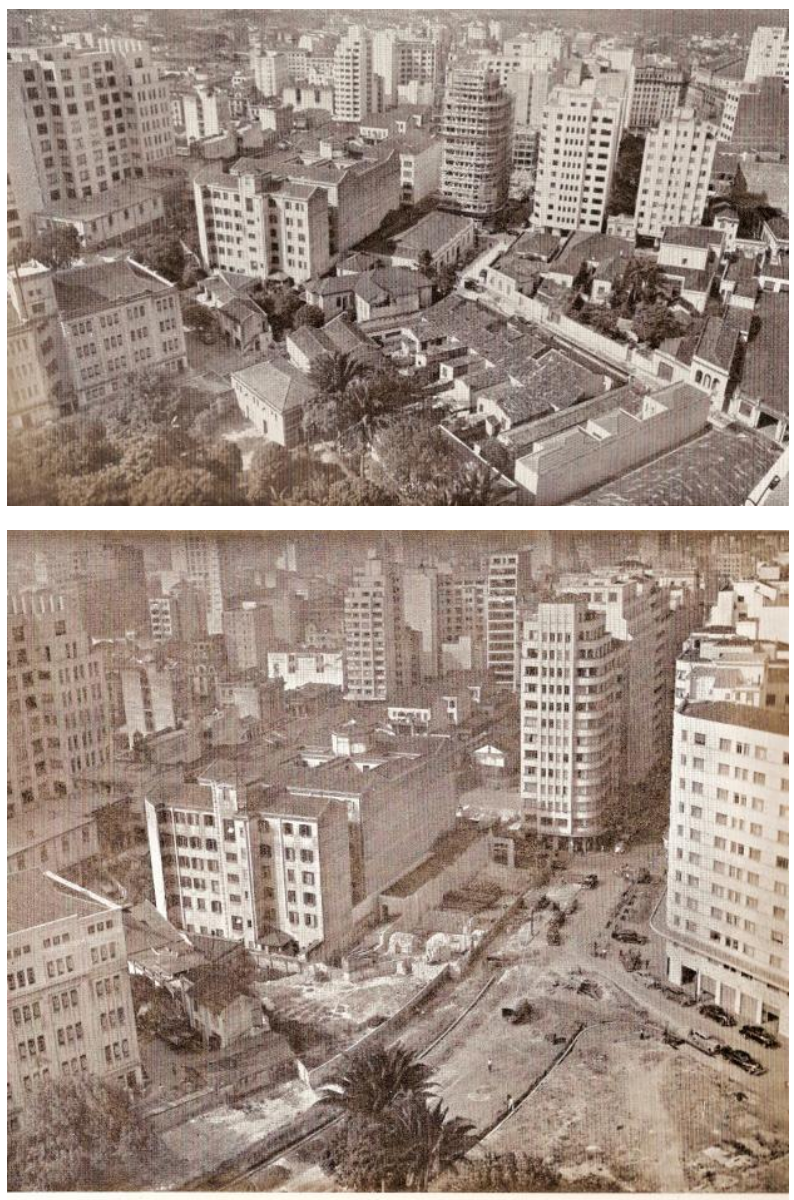

7.17 e 7.18: abertura Intervenções Plano de Avenidas: Alargamento da Rua Bráulio Gomes e lote do Thoaz Edison

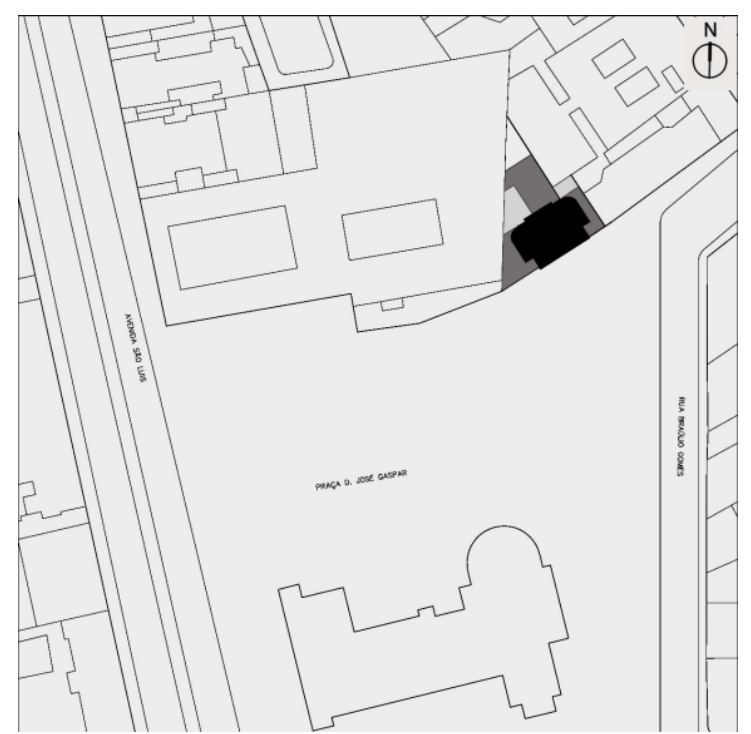

7.19: Gegran, 1974: Em preto volumetria da torre; em cinza volumetrias inferiores 


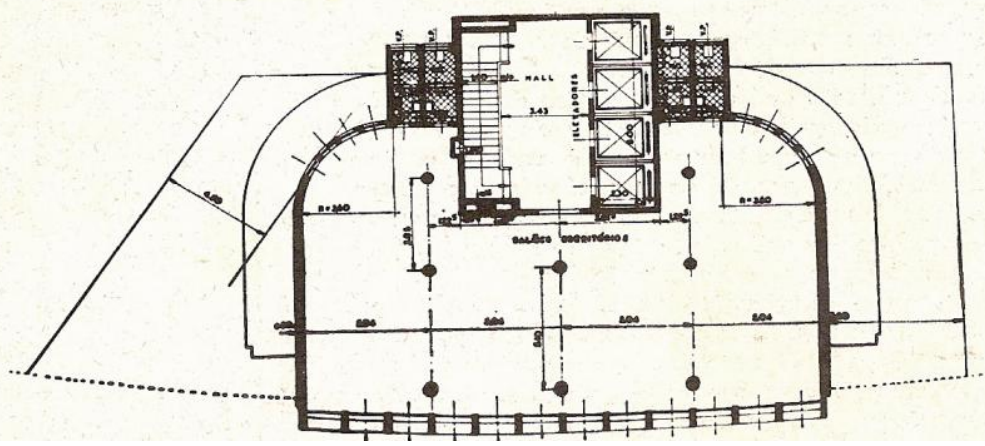

7.20: Planta da torre

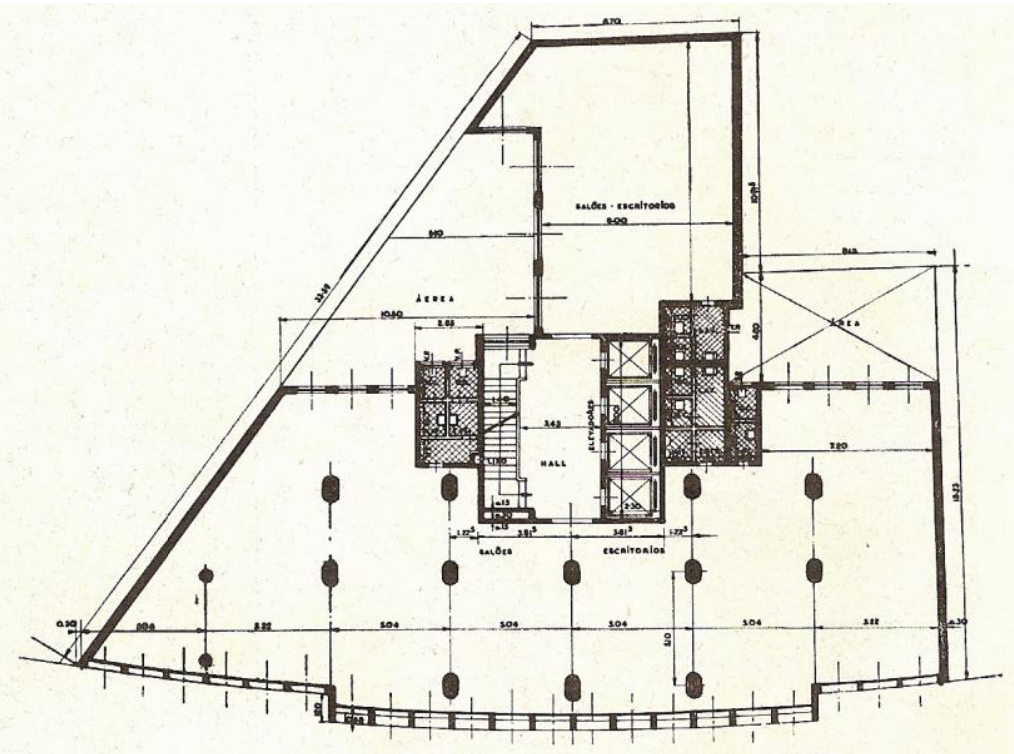

7.21: Planta Pavimento Tipo

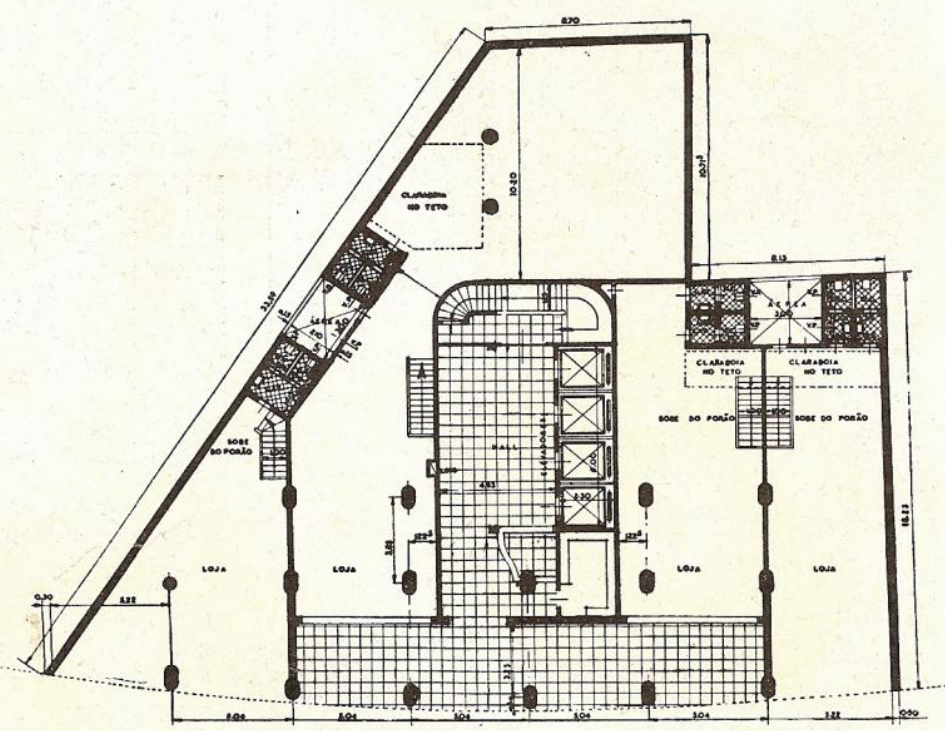

7.22: Planta Pavimento Térreo 


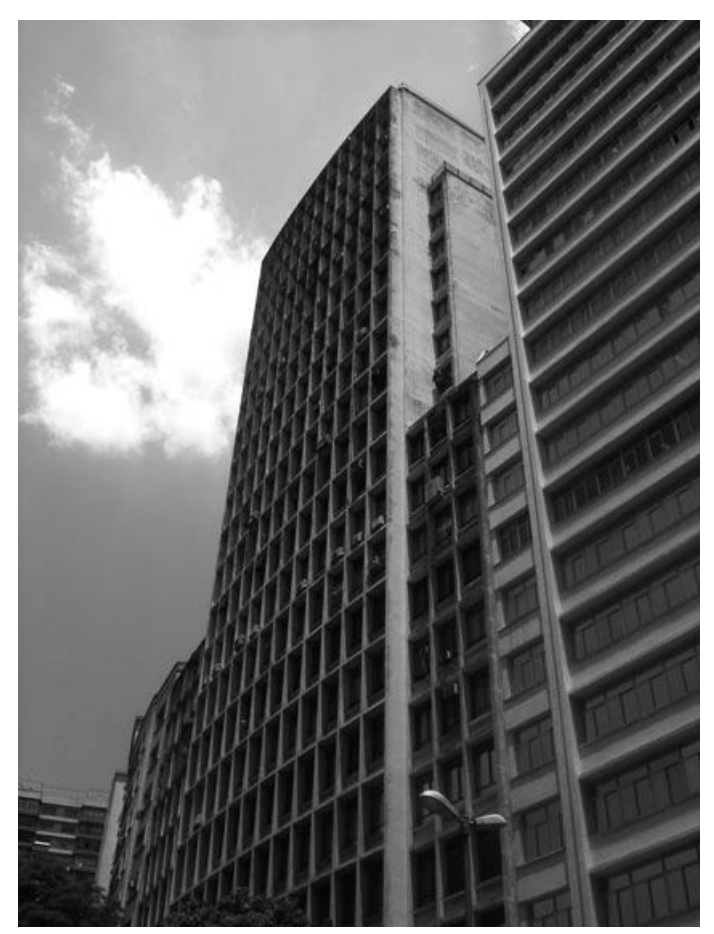

7.23: fachada principal Thomas Edison, 2009

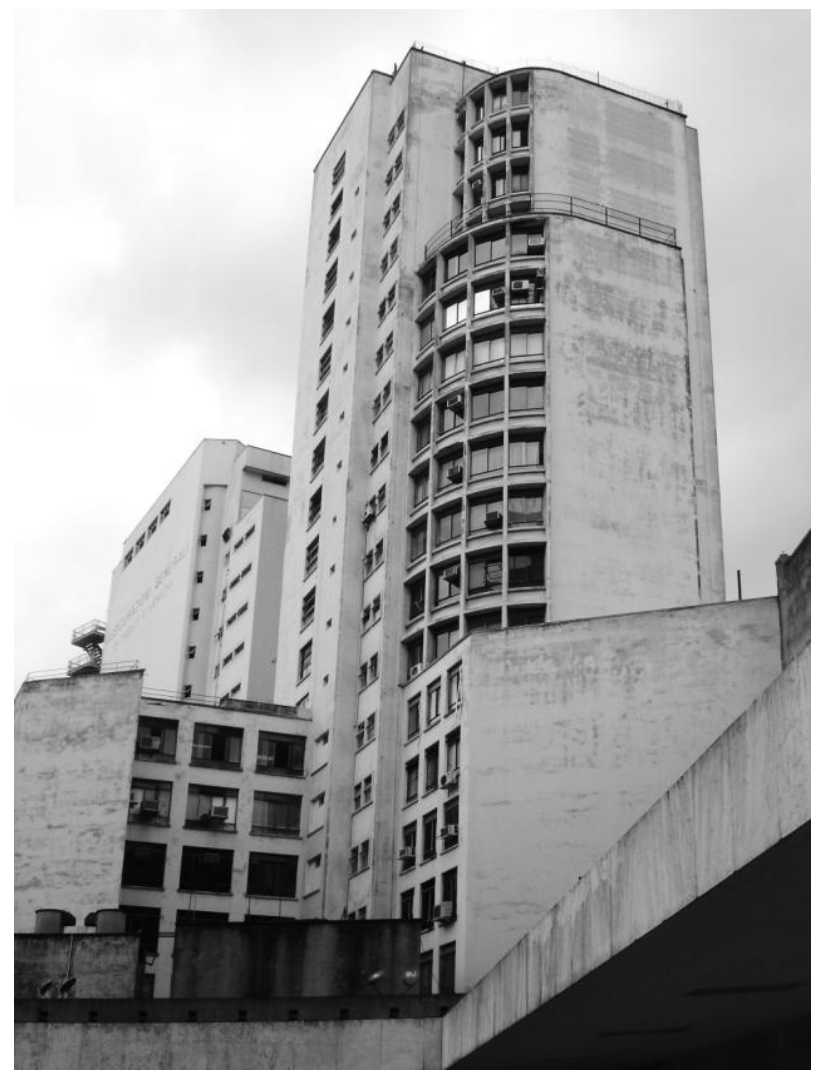

7.25 : fachada posterior Thomaz Edison, 2009

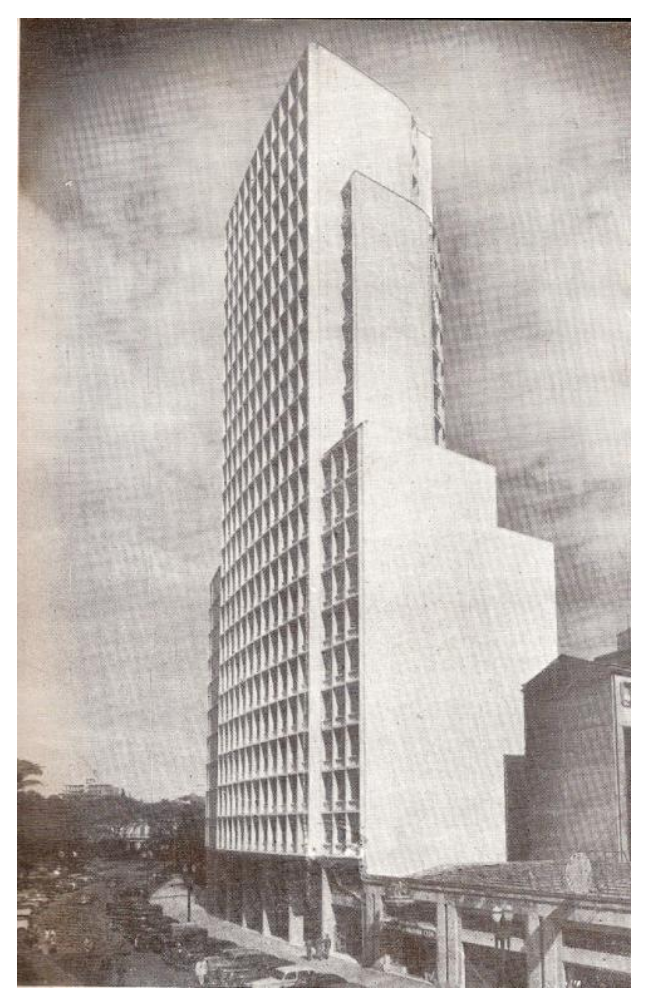

7.24: Thomaz Edison, anos 40 


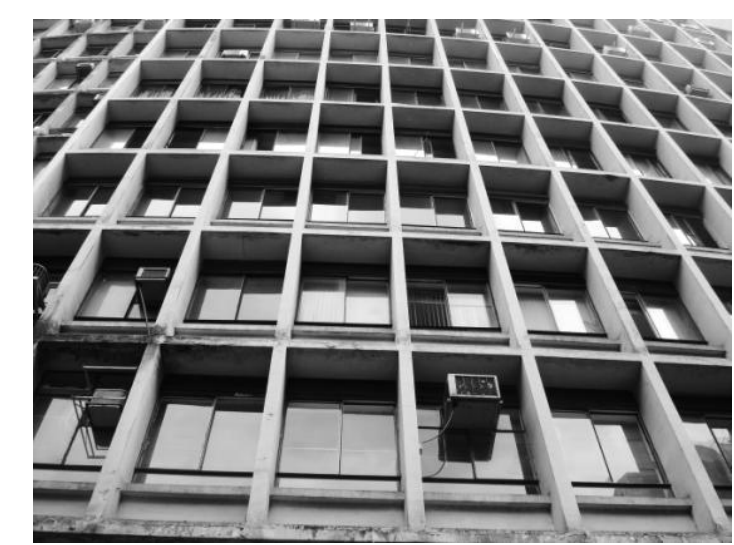

7.26 pormenor brises, fachada Rua Bráulio Gomes, 2009.

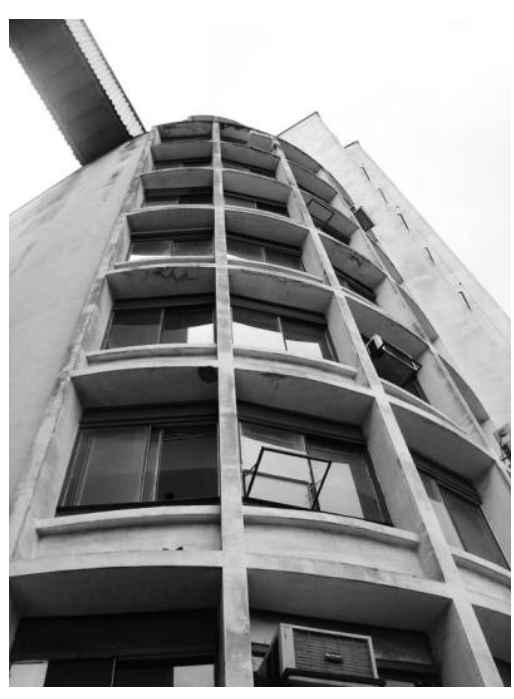

7.27: pormenor fachada fundos 2009

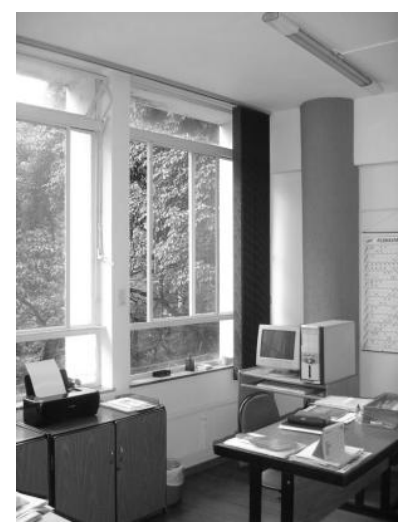

7.28: interiores 2009

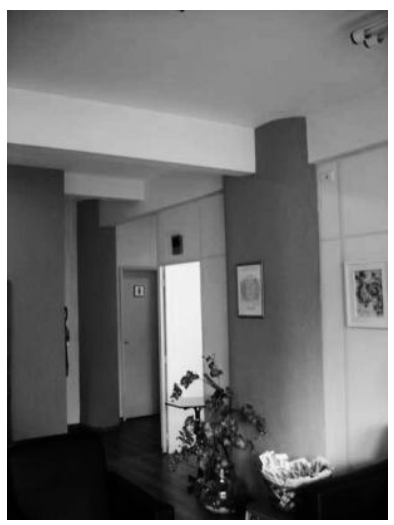

7.29 interiores 2009

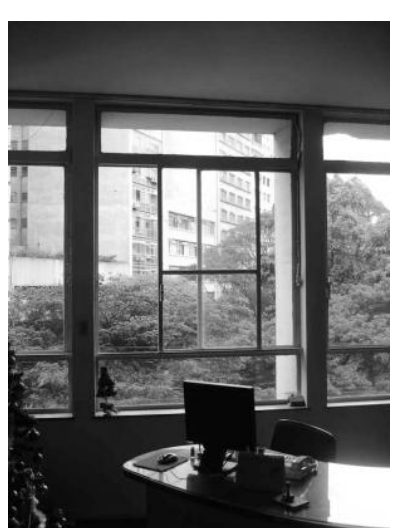

7.30: interiores 2009

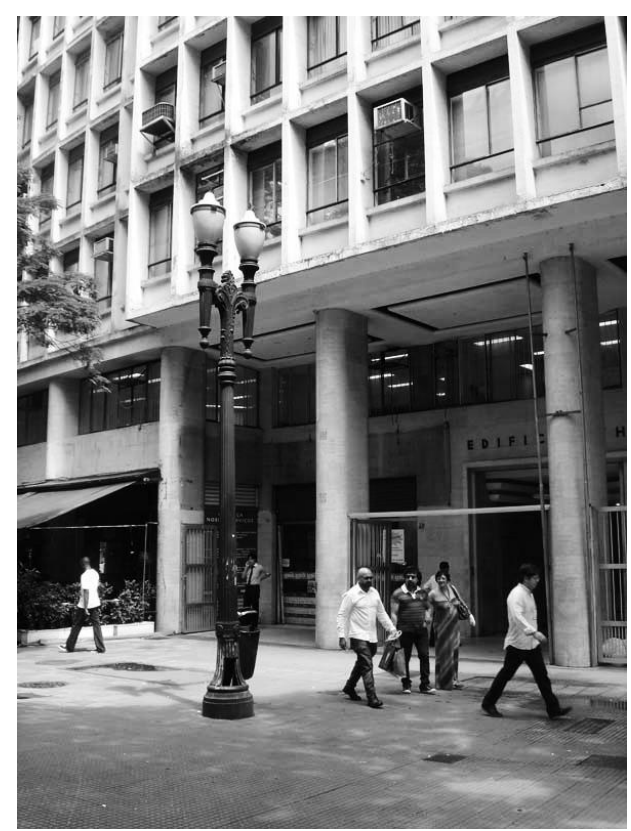

7.31 Thomaz Edison 2009 
Edifício Banco Paulista do Comércio, 1947-50 (figuras de 7.32 a 7.52)

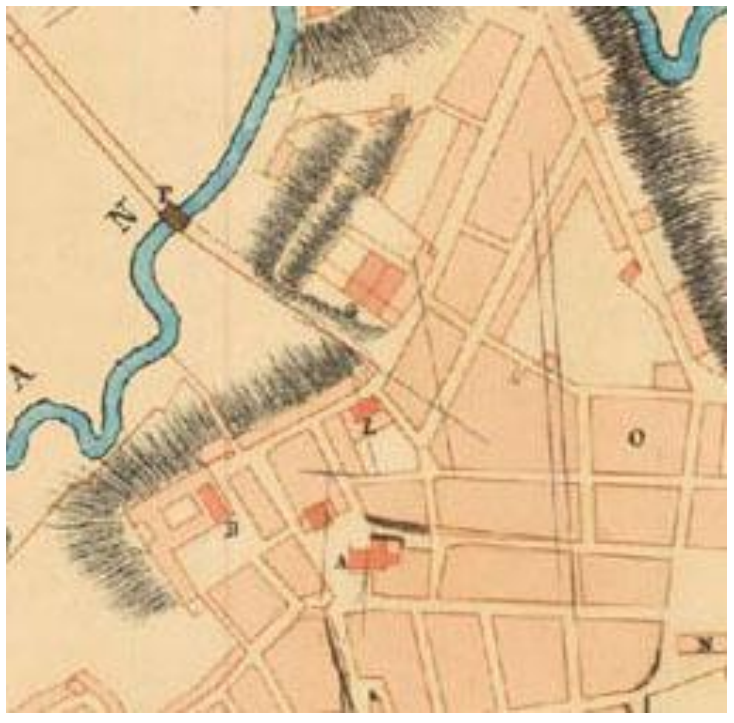

7.32: 1810: pormenor largo São Bento e Ladeira Porto Geral

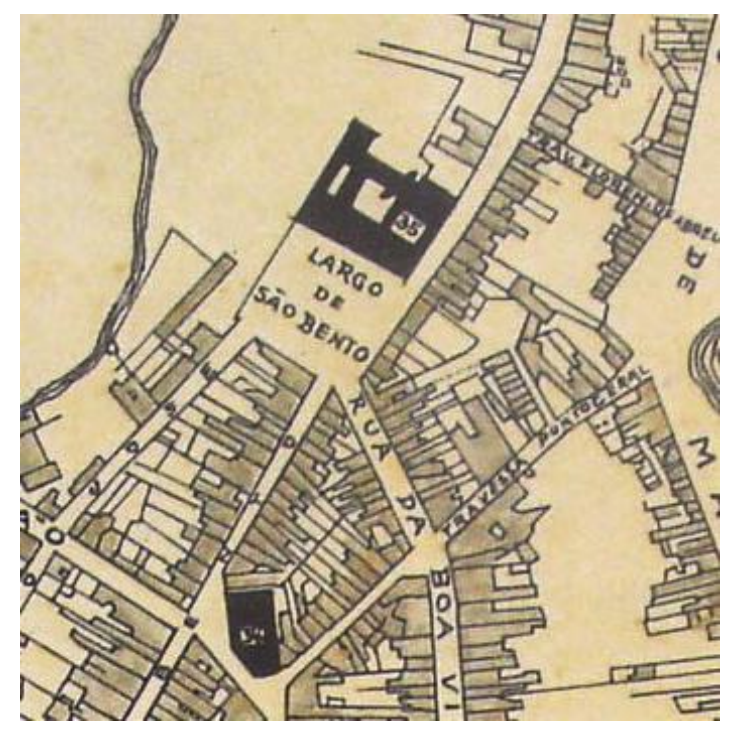

7.33: 1881; pormenor largo São Bento e Ladeira Porto Geral

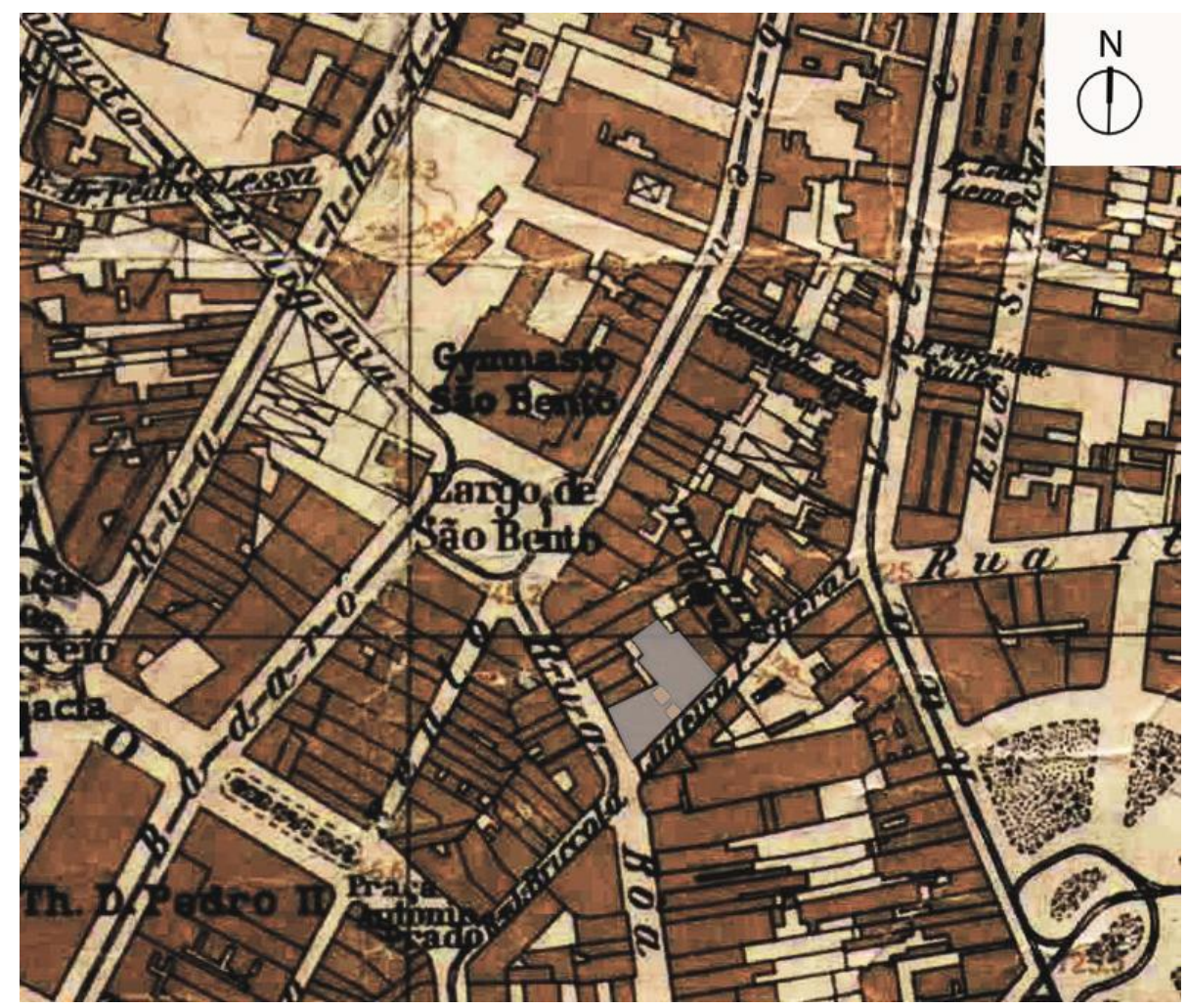

7.34: 1930; pormenor largo São Bento e Ladeira Porto Geral 

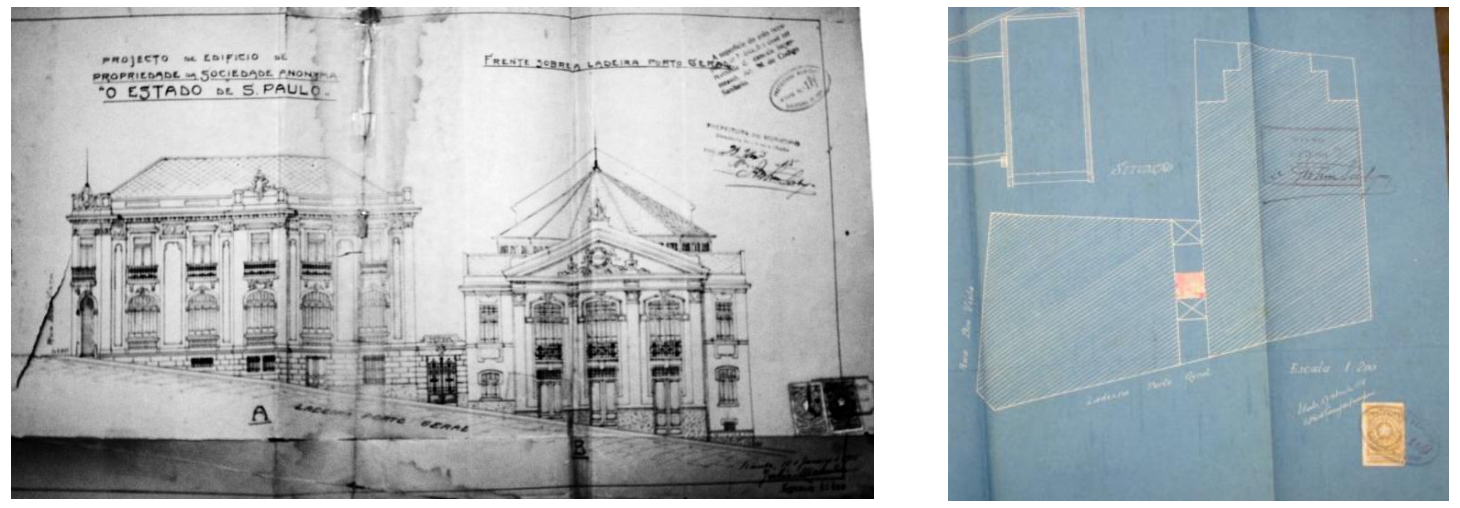

7.35 e 7.36: Teatro Boa Vista (edifício demolido que daria lugar ao Banco Paulista

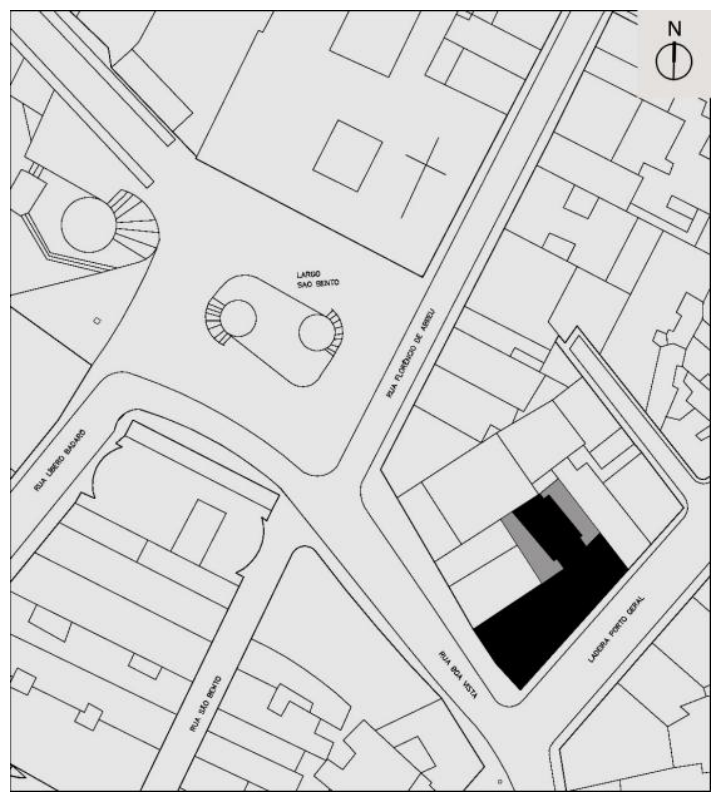

7.37: Gegran, 1974:

atua situação do

Banco Paulista

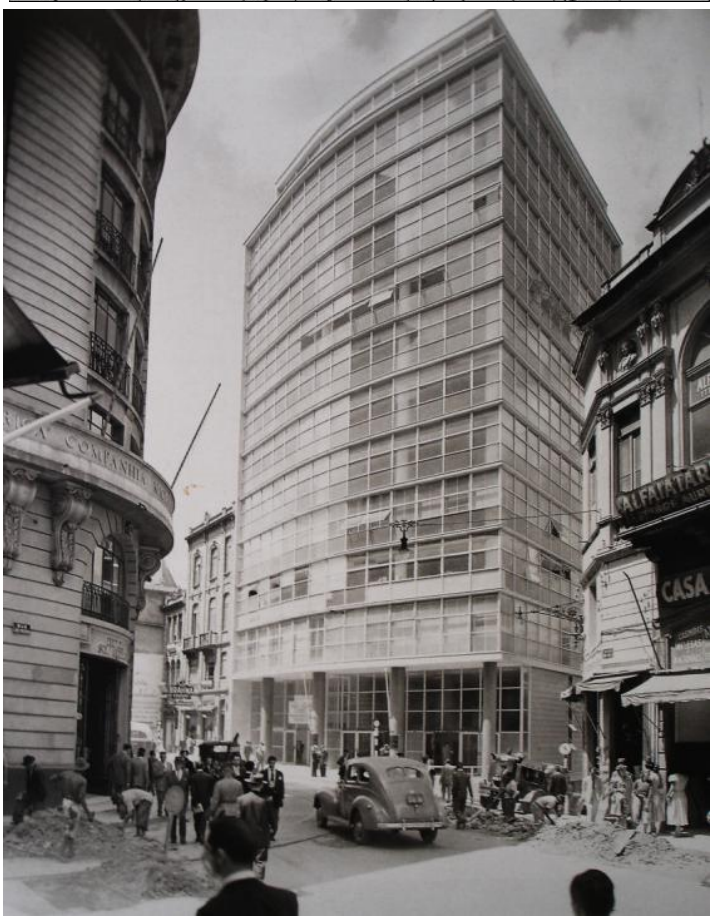

7.38: Banco Paulista e o centro antigo 


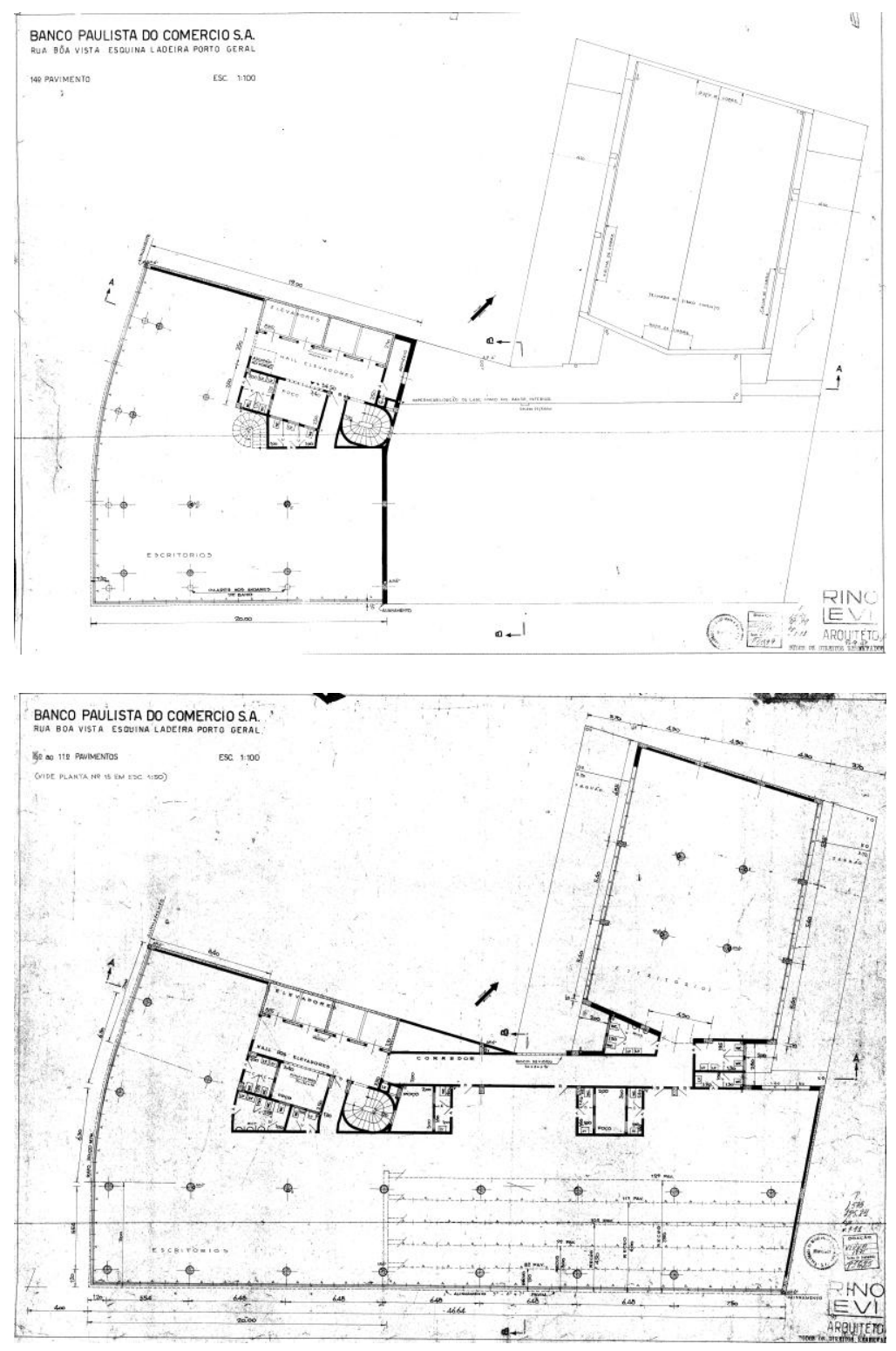

7.39: Planta do $14^{\circ}$ pavimento

7.40: Planta do $5^{\circ}$ ao $11^{\circ}$ pavimentos

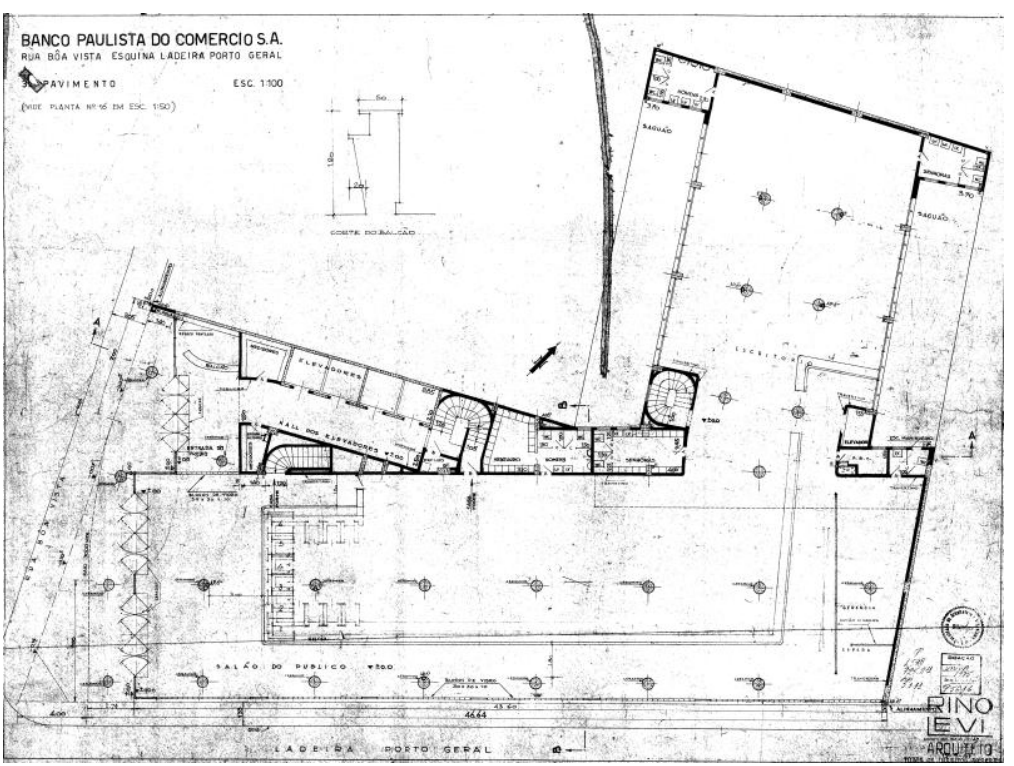




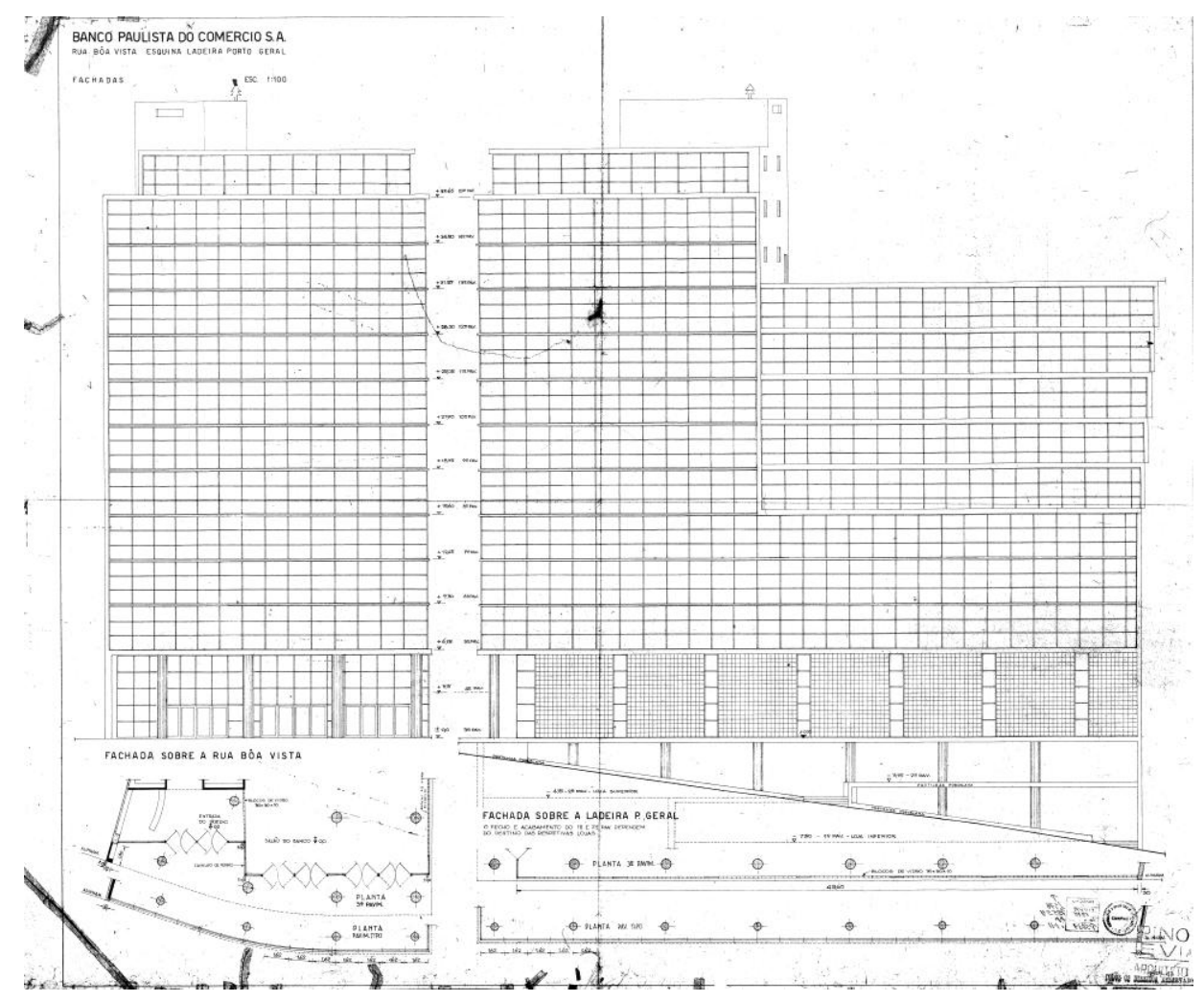

7.42: Elevações pela São Bento e Ladeira Porto Geral,

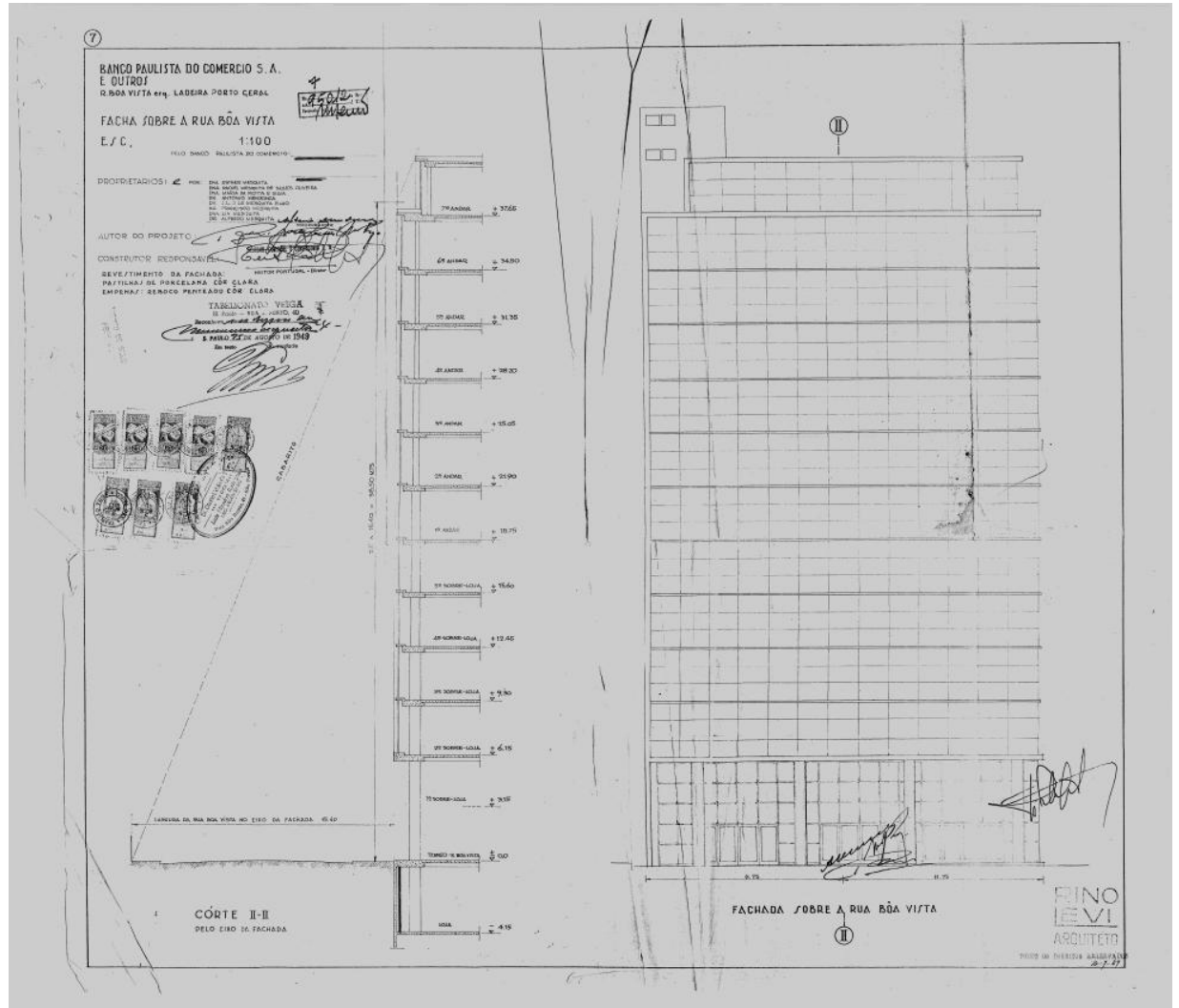

7.43: Corte e elevação pela São Bento 


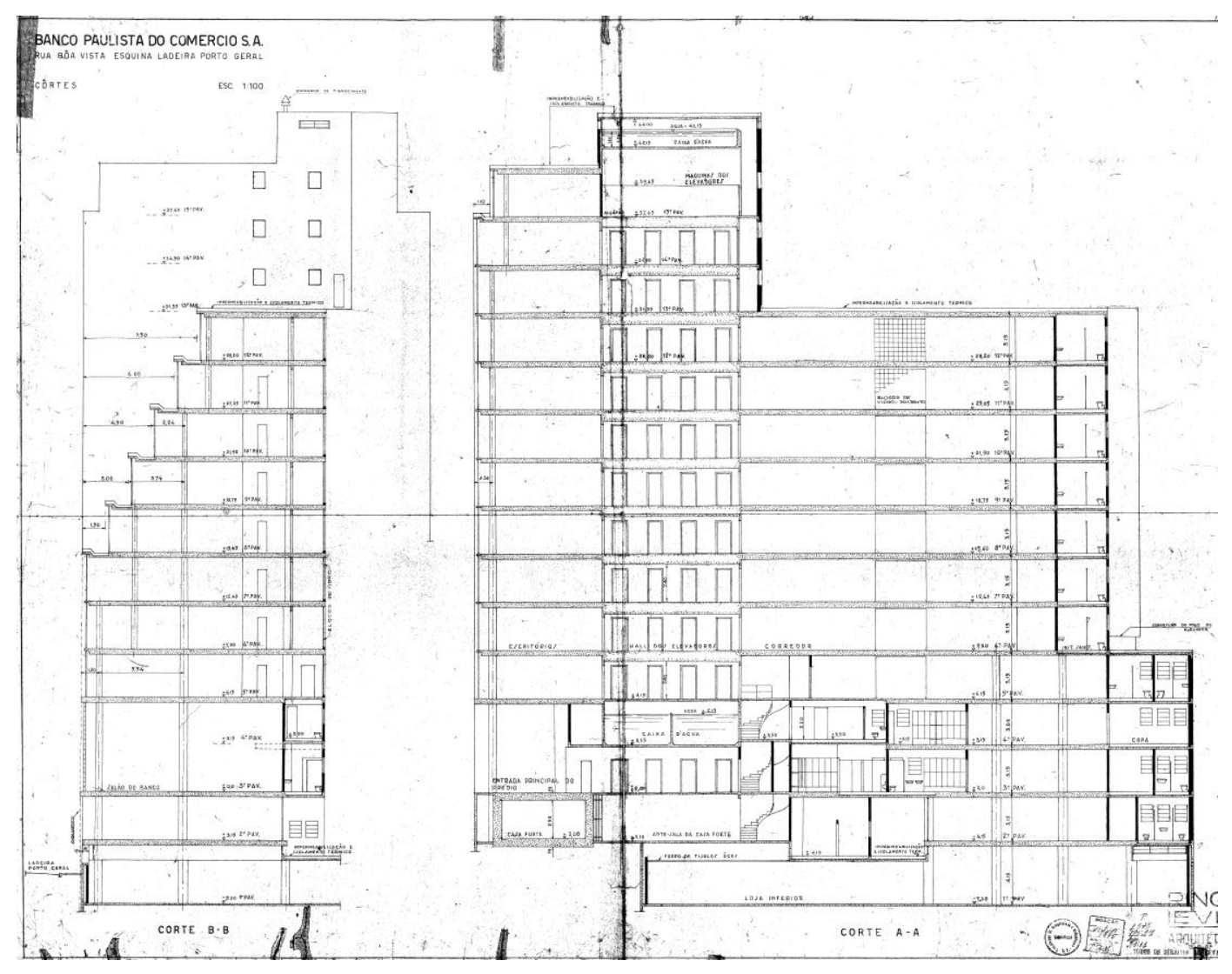

7.44: Corte AA

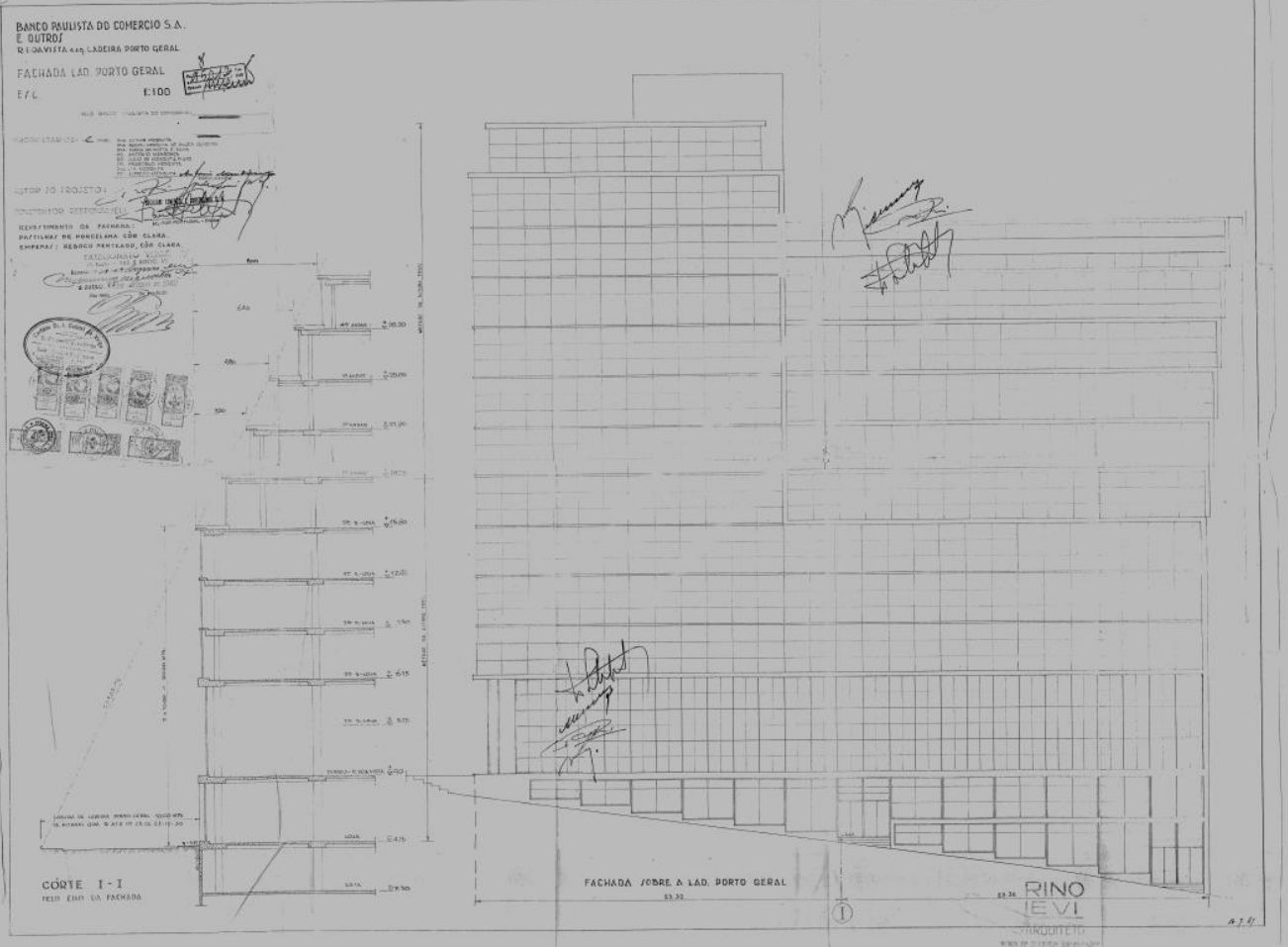

7.45: Corte e demonstração do escalonamento pela Ladeira Porto Geral, 

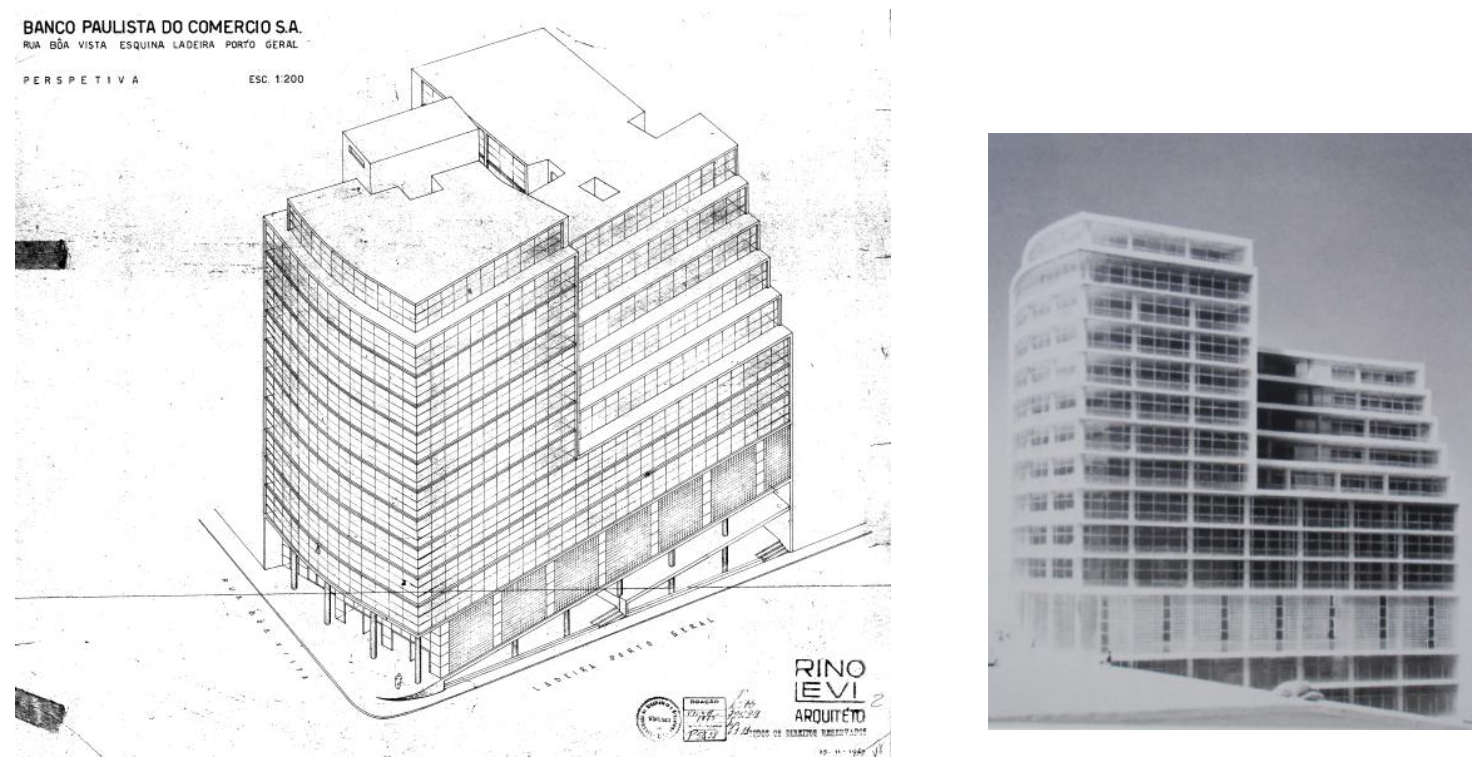

7.46 e 7.47: Banco Paulista: duas volumetrias em função da legislação; duas representações.
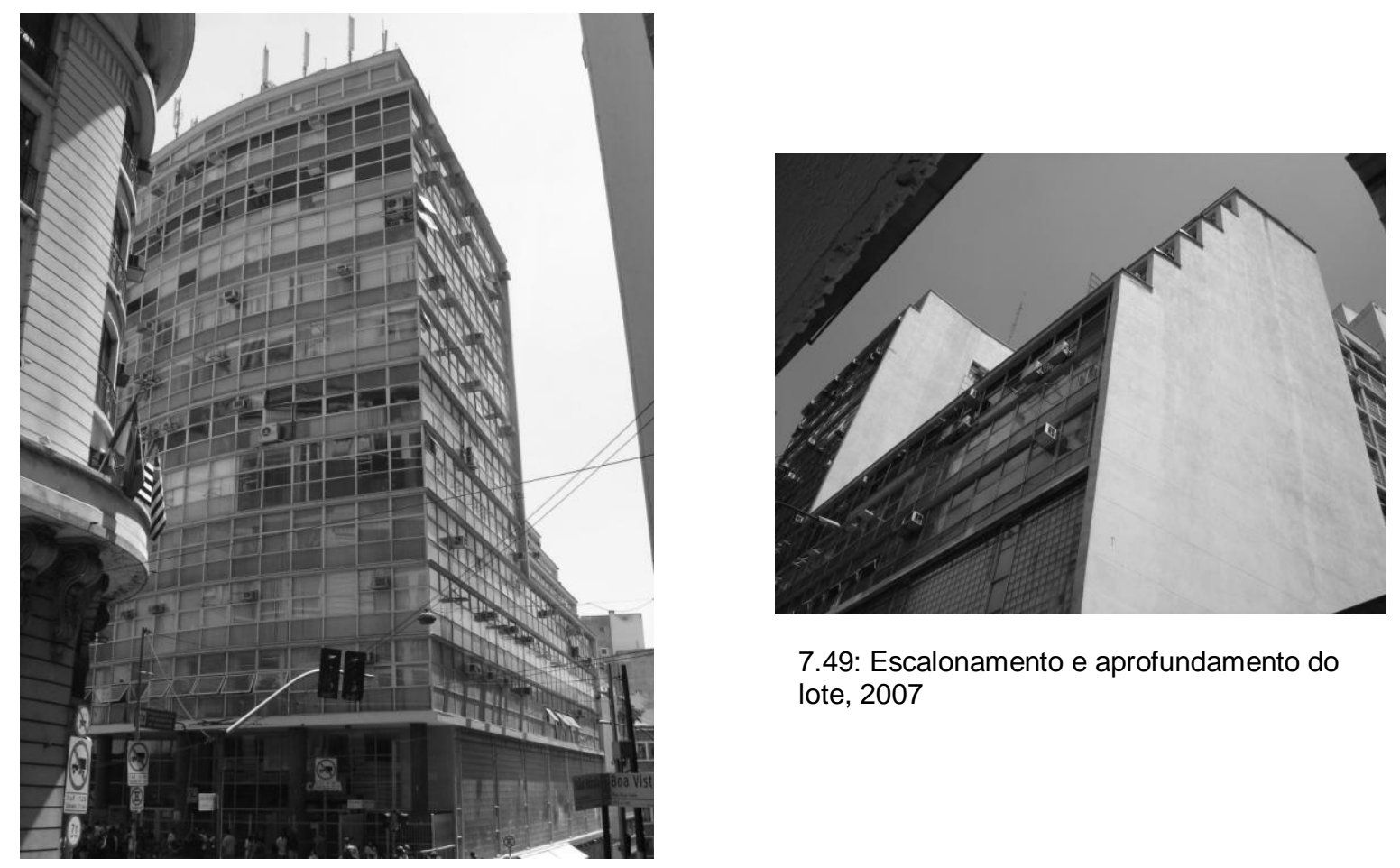

7.49: Escalonamento e aprofundamento do lote, 2007

7.48: Bloco pela São Bento, 2007 


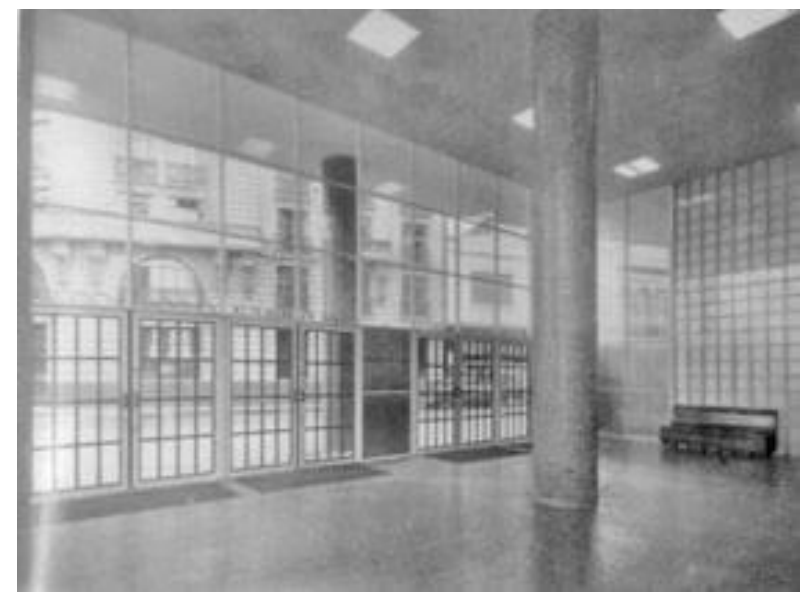

7.50: Interior da agência

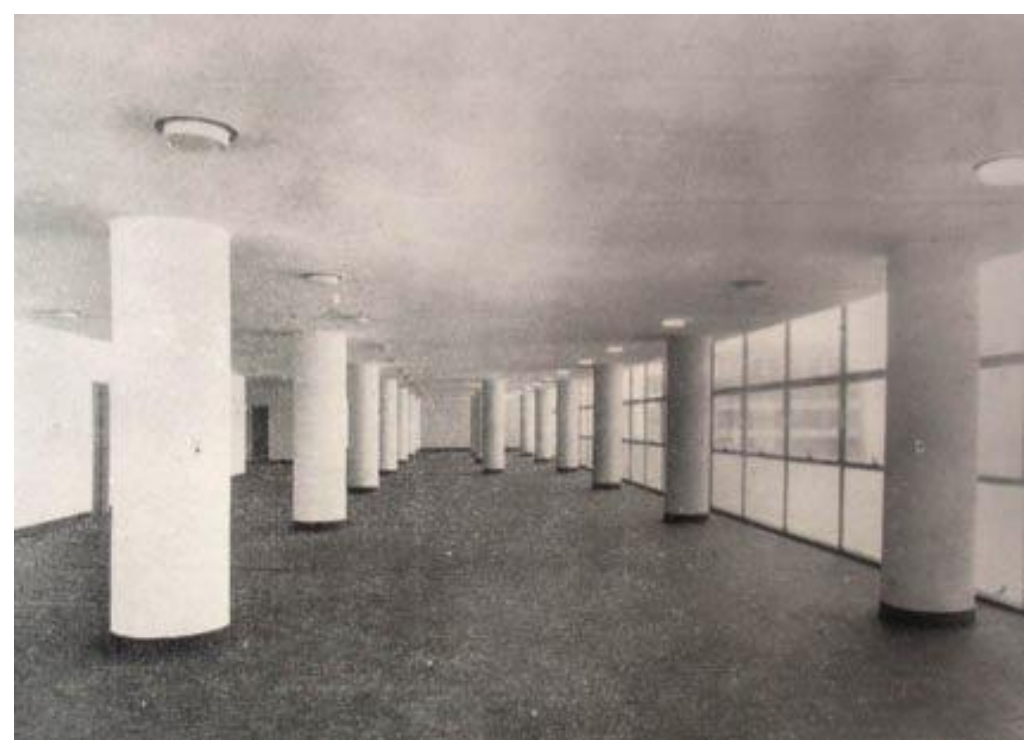

7.51: Ossatura independente e Planta livre do andar tipo

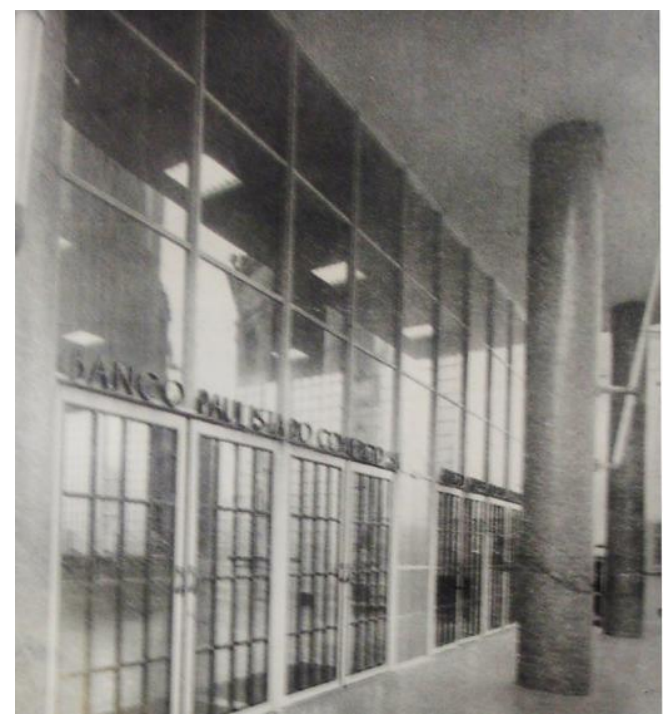

7.52 : Loggia pela São Bento 
Uma quadra em formação e três edifícios de Oswaldo Bratke (figuras de 7.53 a 7.79)

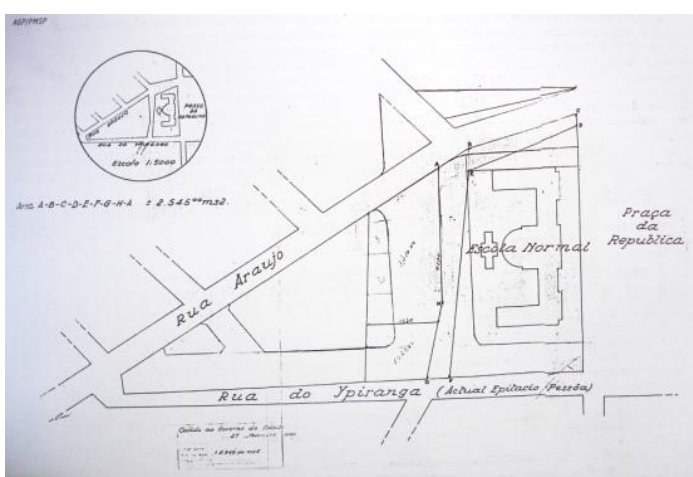

7.53: Projeto do traçado do alargamento da Av. São Luiz e Ipiranga. Uma quadra em formação.

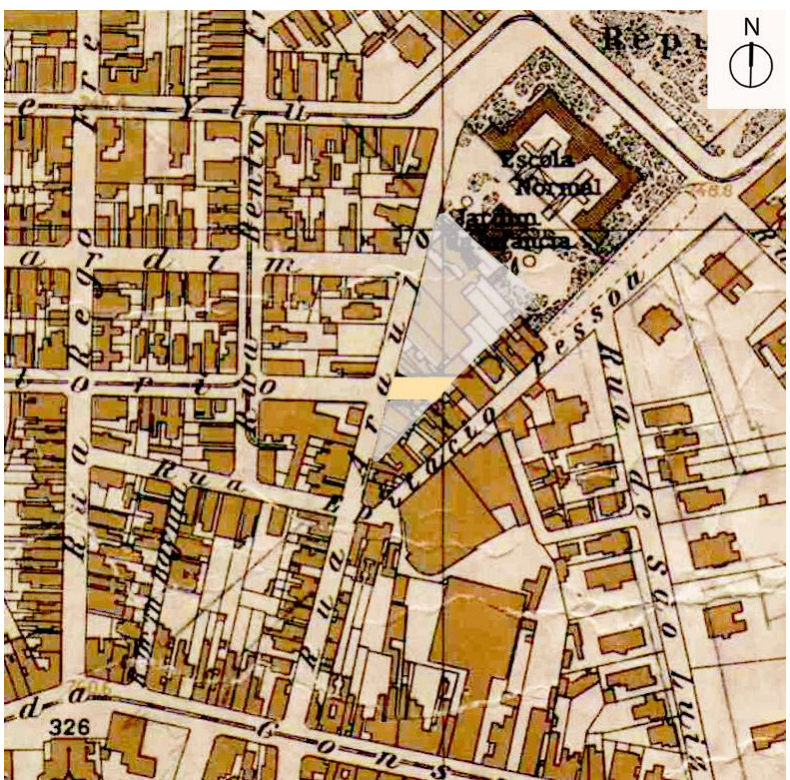

7.54: Desenho sobre Sara Brasil, futura quadra

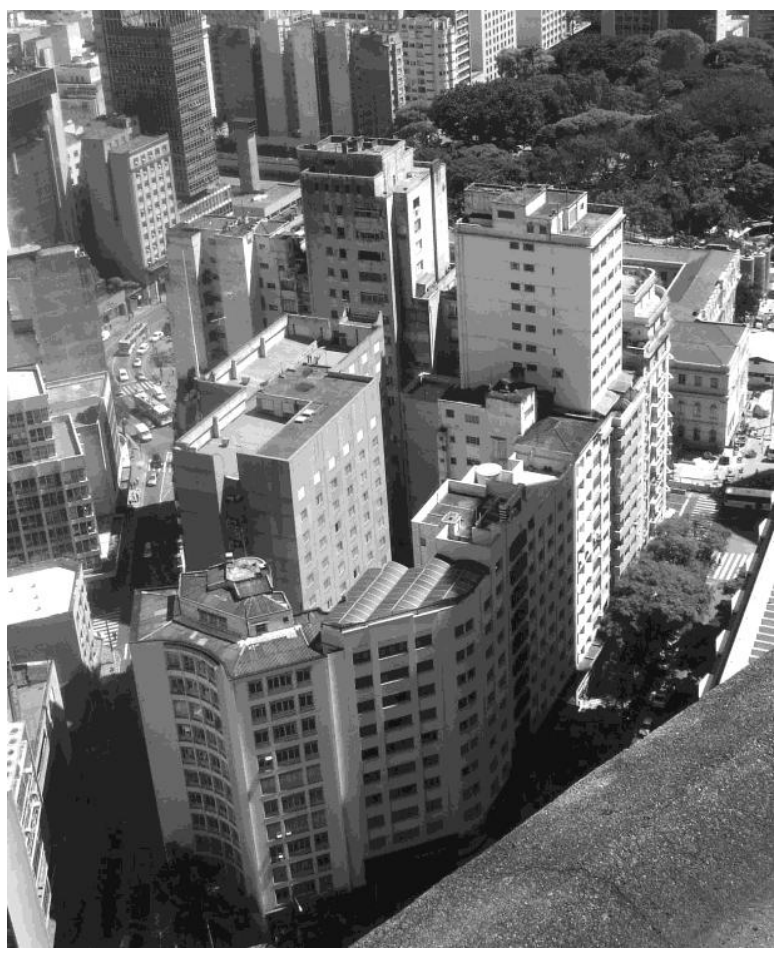

7.56: A quadra formada, 2009.

7.55: Foto aérea alargamento das Av. São Luiz e Ipiranga, 

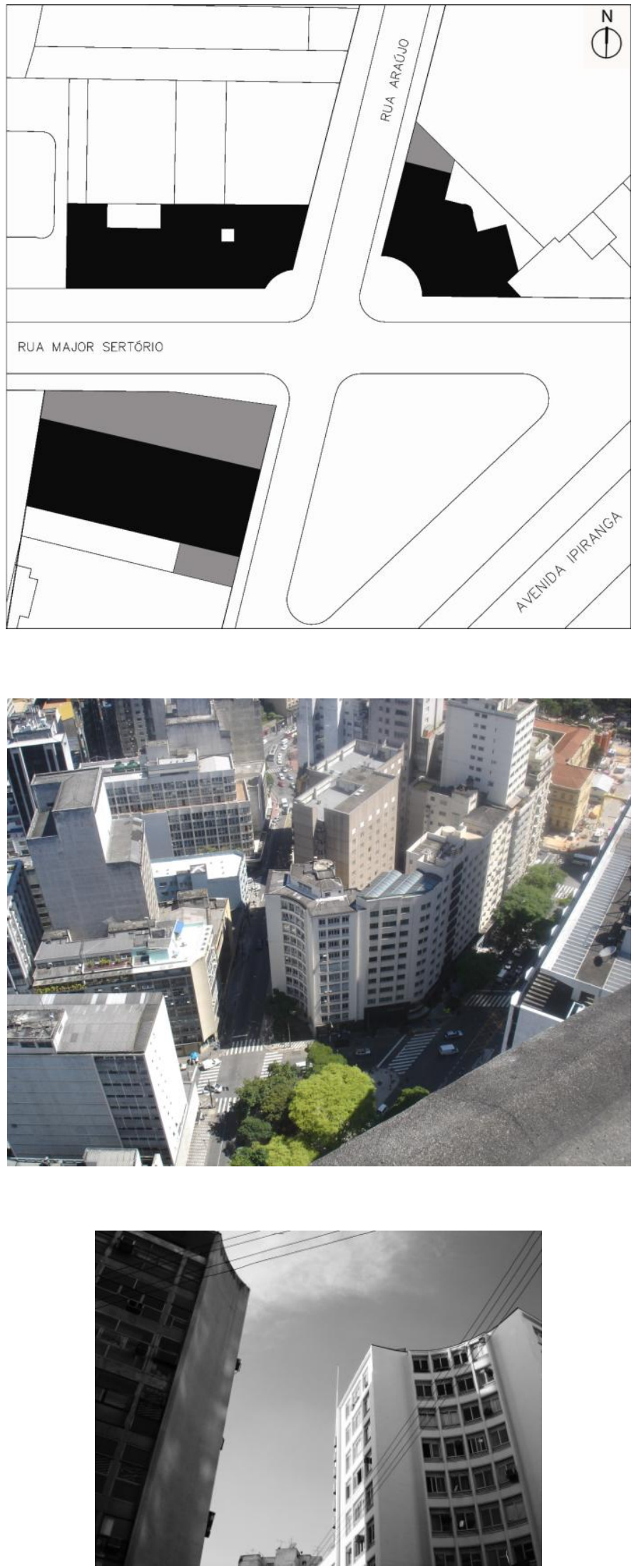

7.57, 7.58 e 7.59: Gregran, foto a partir do COPAN e pelo Chão; Uma esquina singular 
Jaçatuba, 1942 ( figuras 7.59 a 7.65)
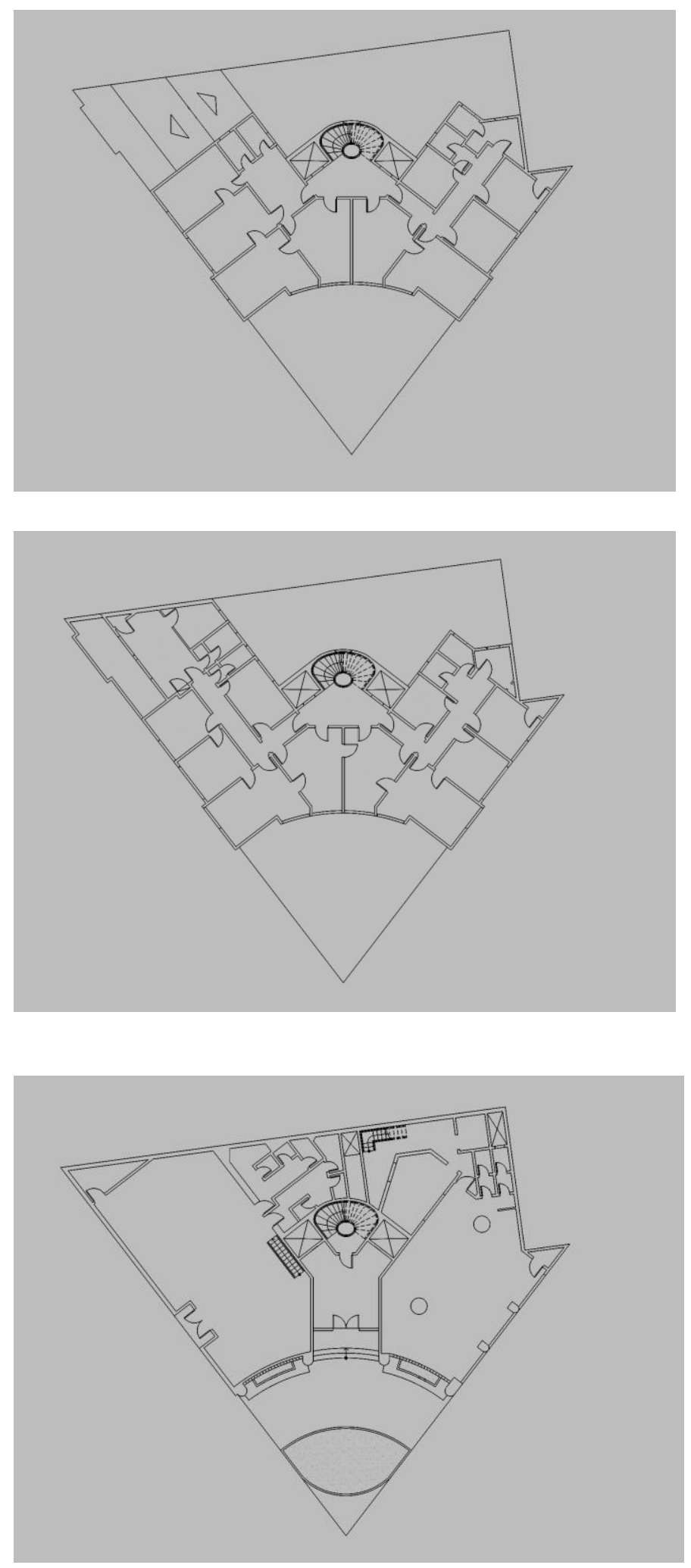

7.60, 7.61 e 7.62; e baixo para cima: Plantas do Térreo , Tipo do $1^{\circ}$ ao $5^{\circ}$ e tipo do $7^{\circ}$ ao $10^{\circ}$ 


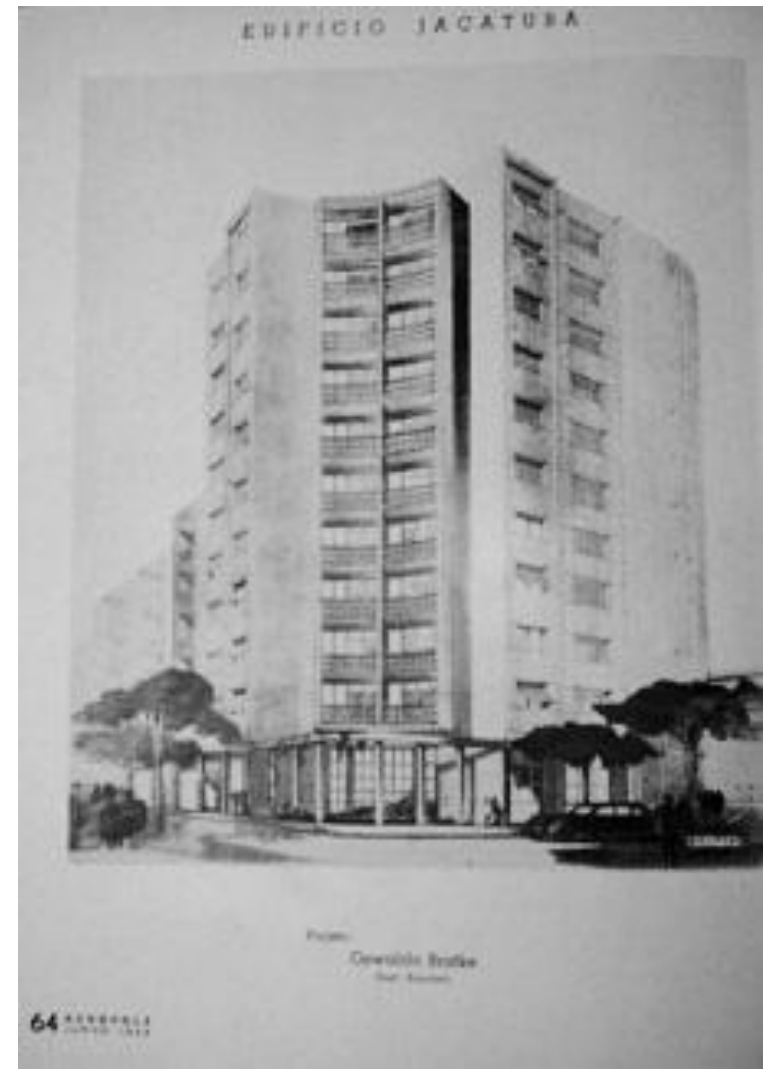

7.63: Perspectiva de Bratke: atentar para a transição das volumetrias na esquina
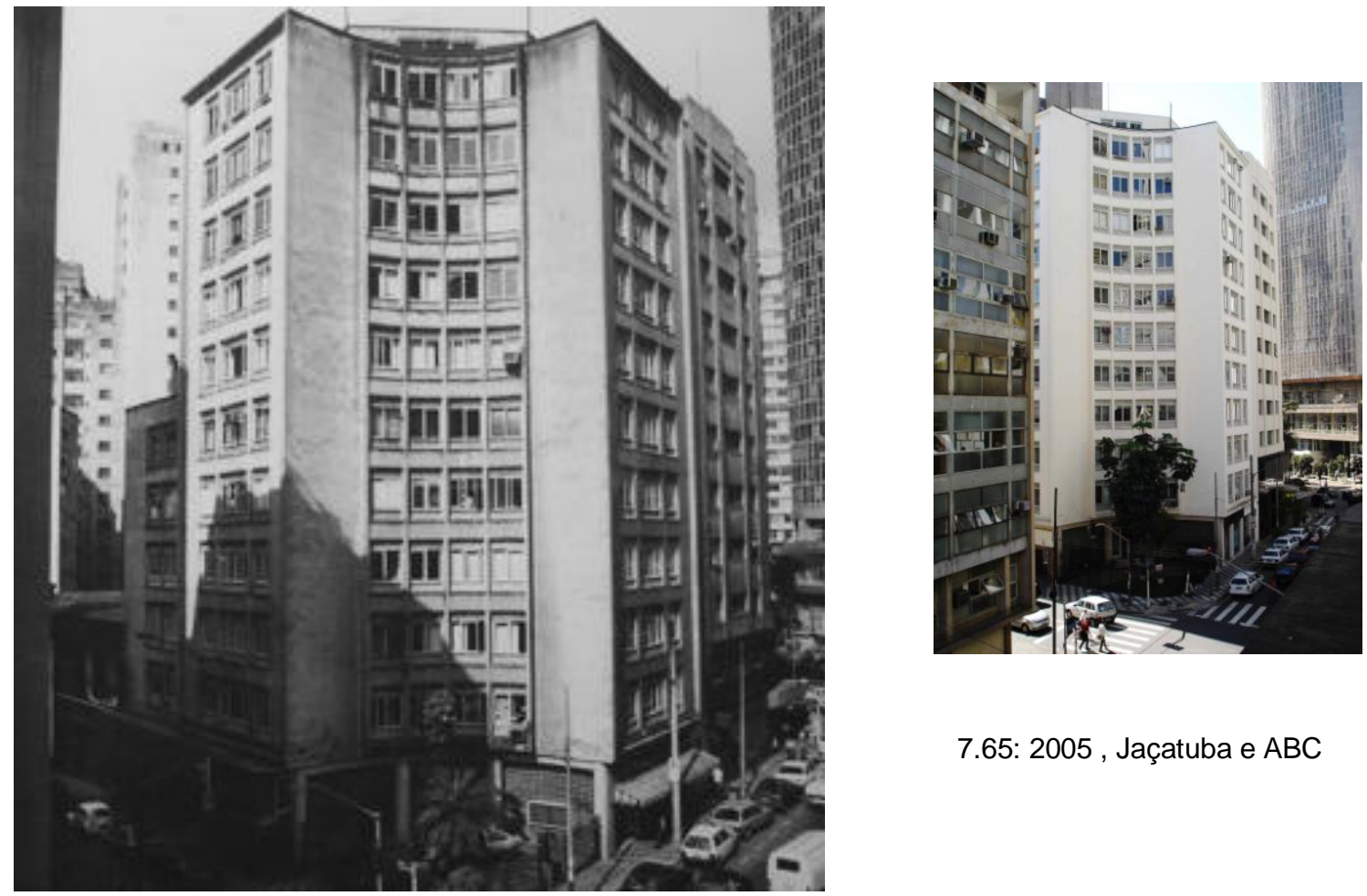

7.65: 2005 , Jaçatuba e ABC

7.64: Obra realizada: atentar para corpo menor à esquerda 
Edifício ABC, 1949 (figuras de 7.66 a 7.70 )
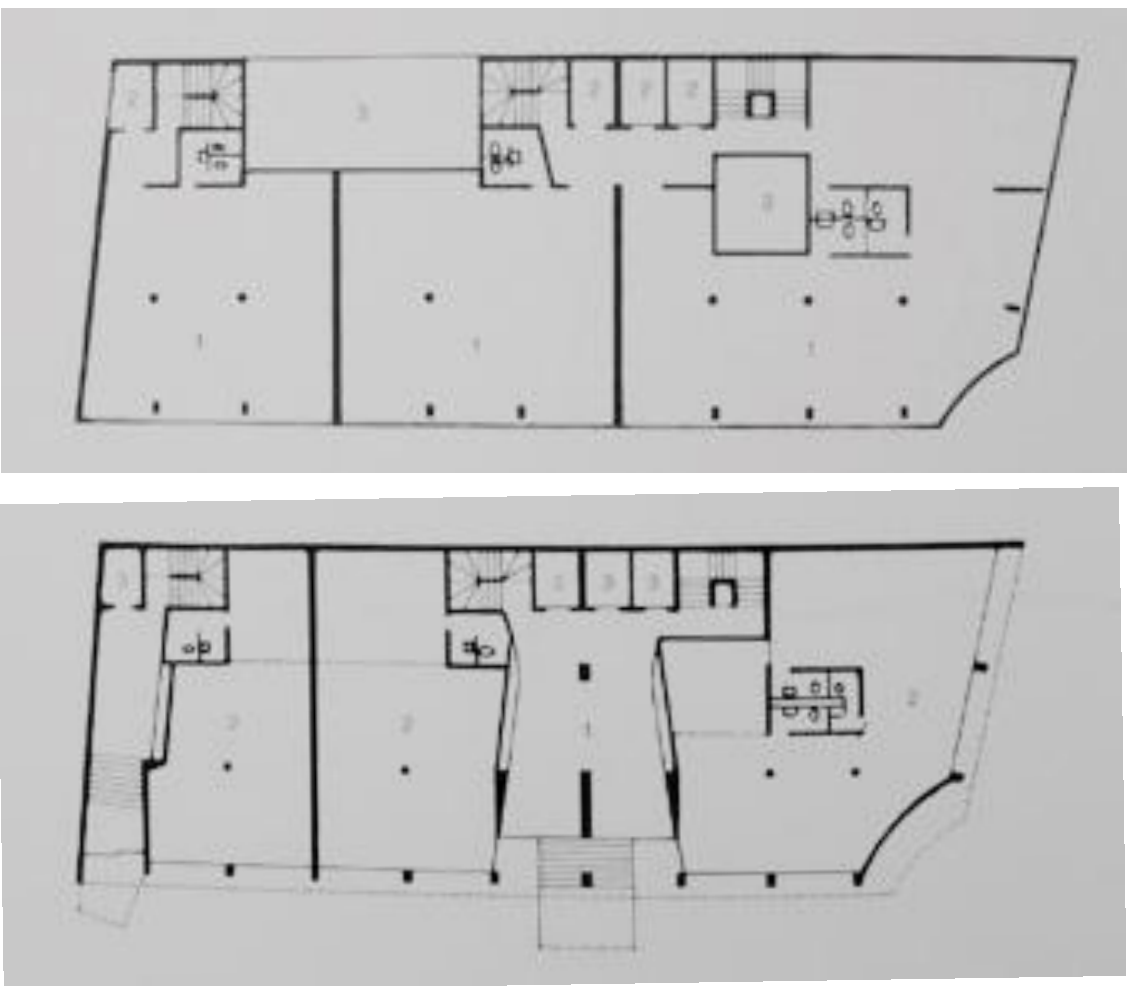

7.66 e 7.67: respectivamente, Planta do pavimento térreo e tipo
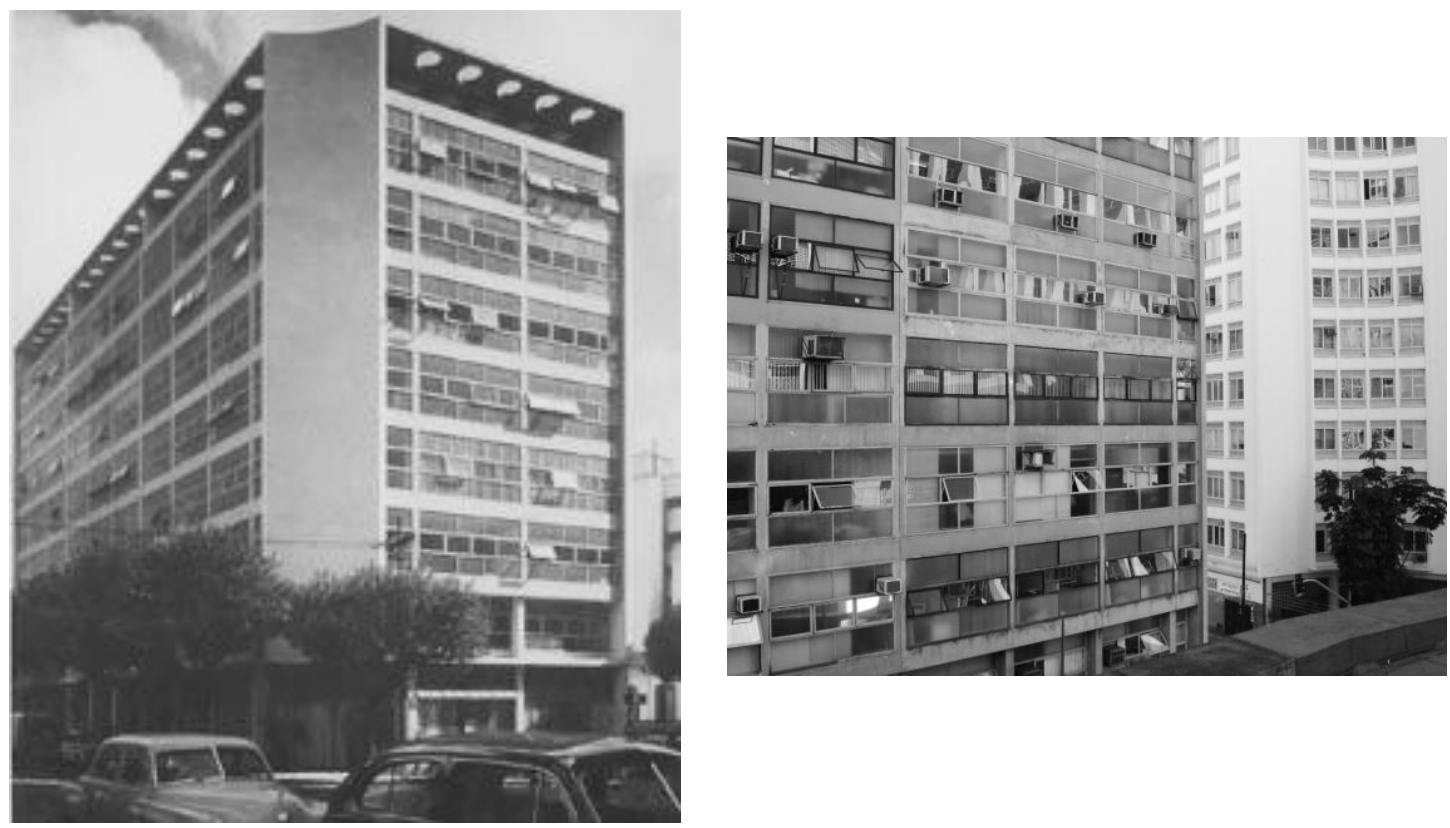

7.69 e 7.70 ABC, 2005 
Edifício Renata Sampaio, 1956 (figuras de 7.71 a 7.80)

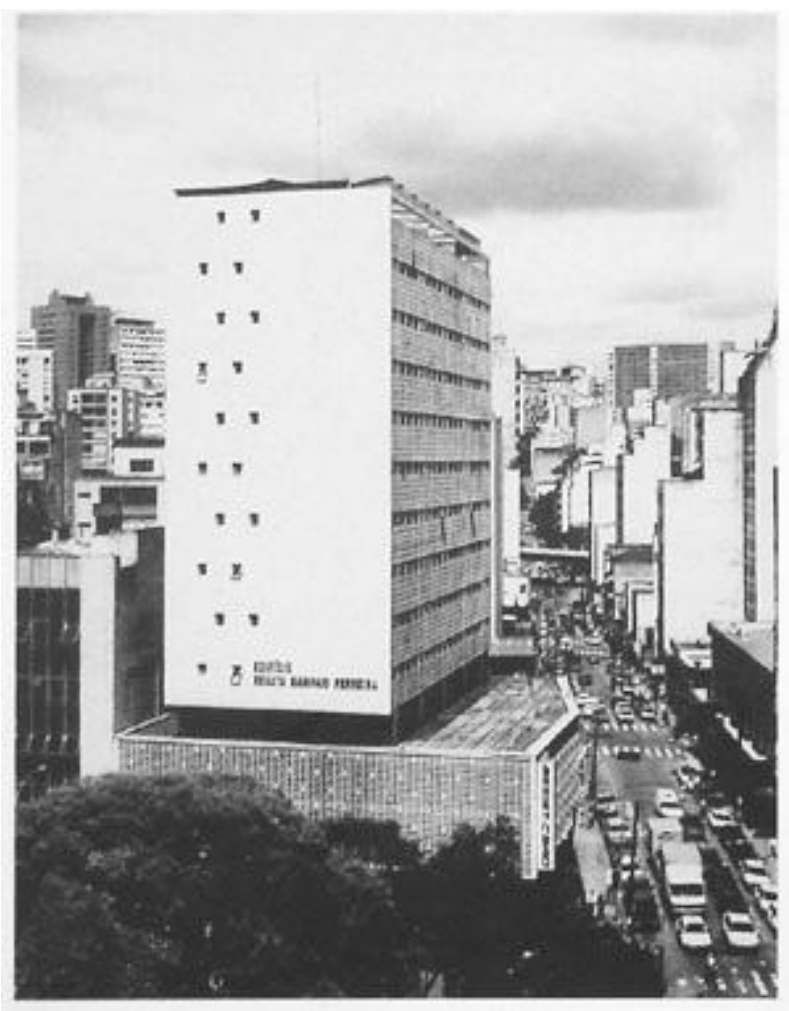

7.71: Renata Sampaio: embasamento e Torre, indícios de uma nova tipologia

Ao lado, 7.72, 7.73 e 7.74: plantas térreo, planta do embasamento e planta tipo da torre
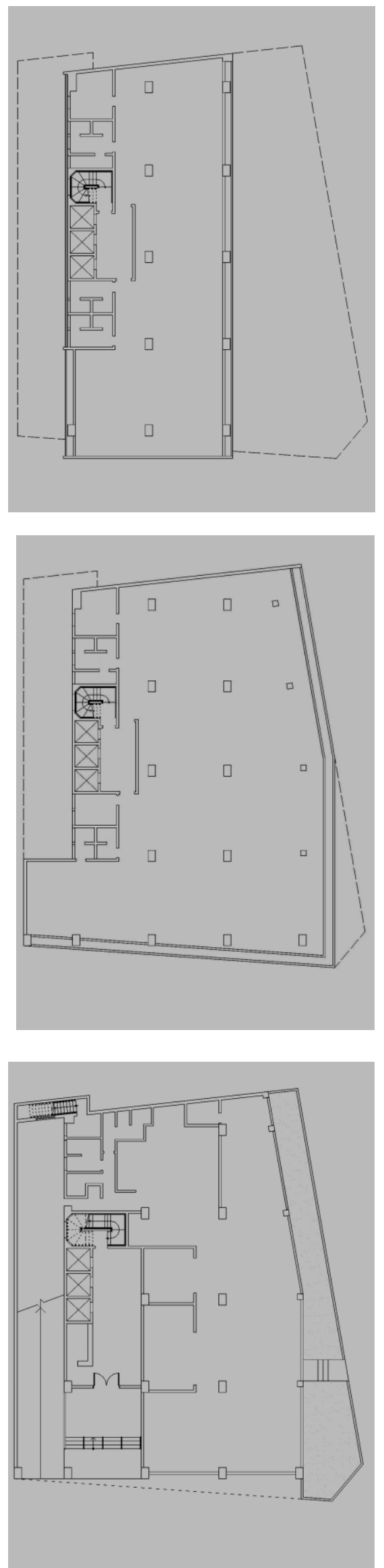


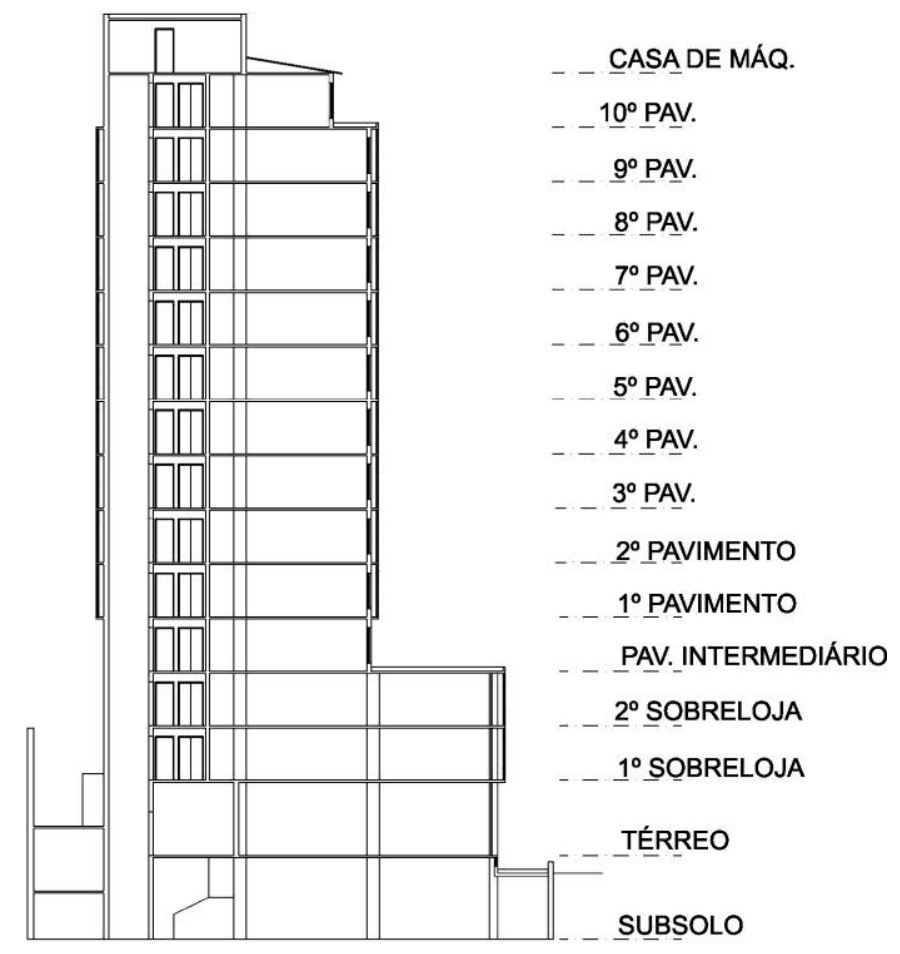

7.75: Corte transversal

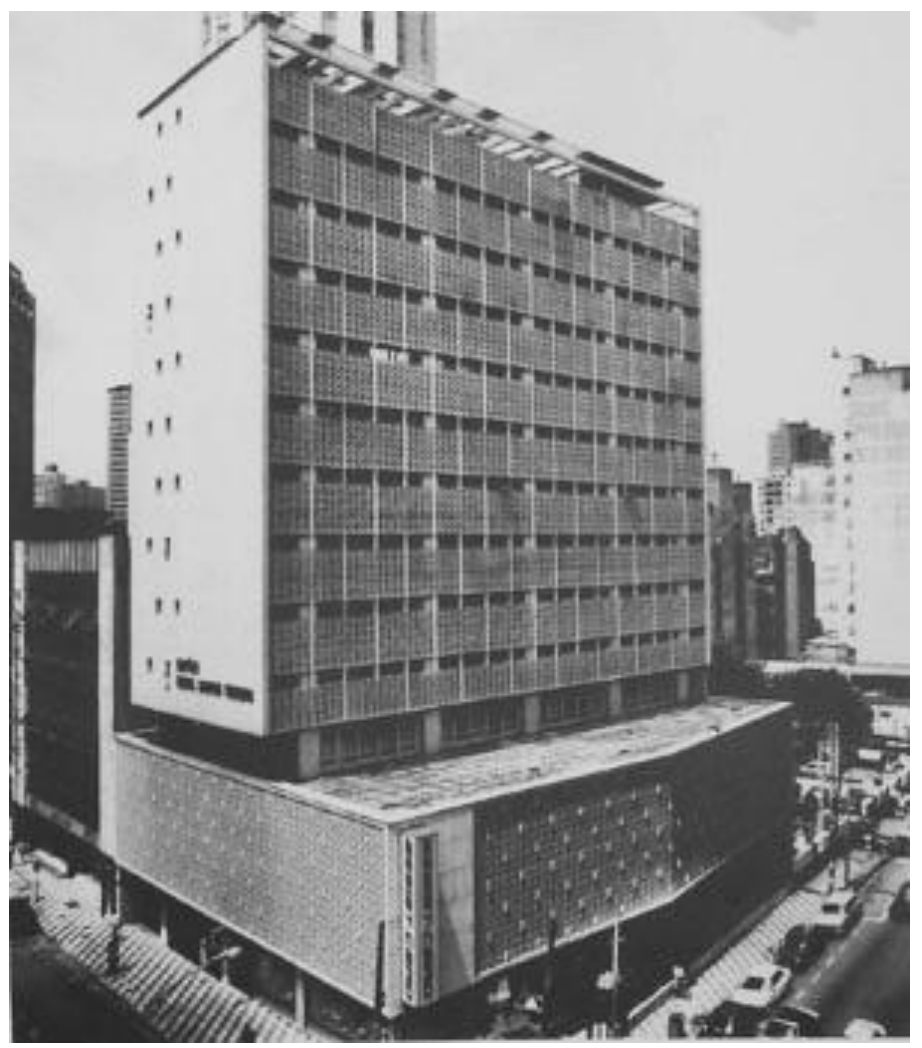

7.76: Renata Sampaio: base e torre, ainda encostada na divisa lateral. 

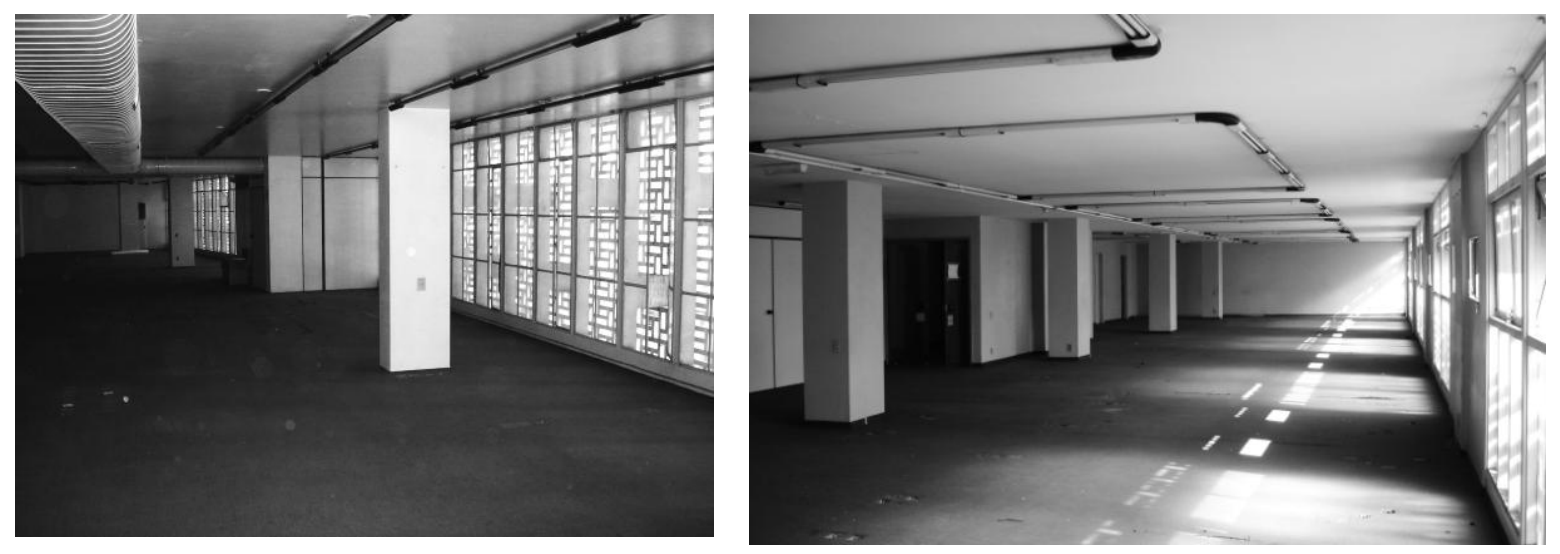

7.77 e 7.78: Renata Sampaio, estrutura independente e brise (cobogó)

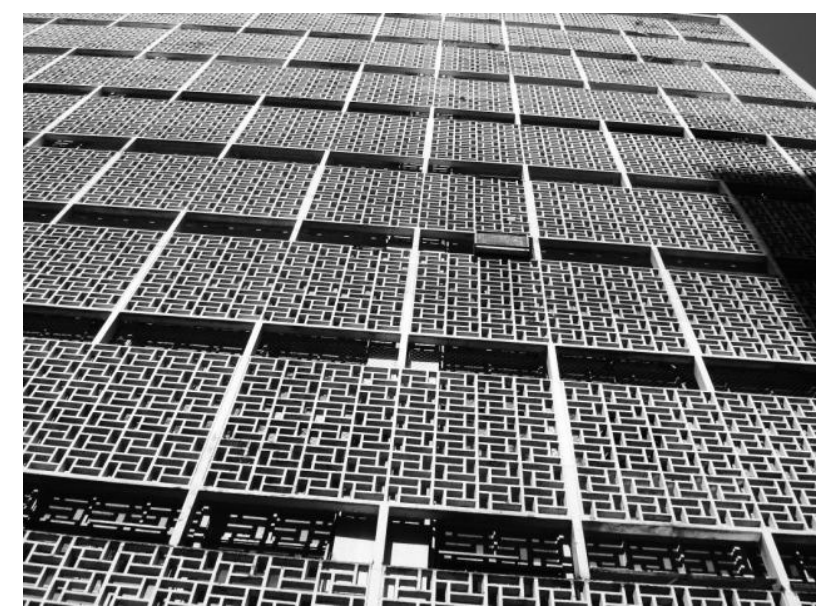

7.79 : Renata Sampaio, pormenor dos brises

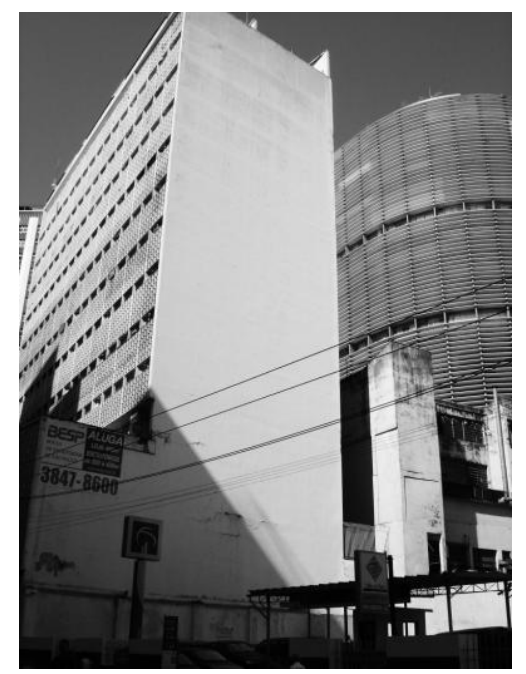

7.80: Renata Sampaio,

empena cega na divisa lateral. 


\section{Oscar Niemeyer: situações abrangentes ${ }^{111}$}

As teorias urbanísticas de Le Corbusier tiveram, aparentemente, pouca influência na determinação nos rumos da modernização empreendida no Centro Histórico de São Paulo $^{112}$. O mesmo não se pode dizer acerca de sua importância para a arquitetura brasileira como um todo e, particularmente, para os edifícios projetados por Oscar Niemeyer no CHSP. Por outro lado, pode ser um equívoco desconsiderar o papel das ideias urbanísticas de Le Corbusier na produção dos edifícios isolados. Como exposto no capítulo 2, é sempre oportuno ressaltar que os edifícios de Le Corbusier, na primeira fase de sua obra, estão estritamente vinculados às suas ideias de cidade e a reprodução de um tipo desvincula-se dos sentidos originais, mas não perdem as raízes.

A obra de Niemeyer no Centro de São Paulo tem sido por diversas razões colocadas num segundo plano: duas são as razões relevantes: a primeira está associada ao caráter comercial dos empreendimentos, a segunda diz respeito às relações entre a arquitetura moderna e a cidade tradicional, objeto desta tese.

A despeito dessas considerações Niemeyer realizou seis obras no Centro de São Paulo. Obras comerciais, para escritórios e habitação. Obras implantadas em diferentes lotes: uma tipologia quase completa de situações urbanas no Centro, além de uma representativa readaptação de tipos corbusierianos.

\section{Edifício e Galeria Califórnia: um encaixe entre ruas}

O projeto do Edifício e Galeria Califórnia, de Oscar Niemayer e Carlos Lemos, foi realizado em 1951. Situado em área de intensa transformação no Centro de São Paulo, o empreendimento, dado seu porte, exigiu o remembramento de lotes que se estendem da Rua Barão de Itapetininga à Rua Dom José de Barros: dando lugar a uma implantação singular, que permitiu alta densidade associada à permeabilidade do interior da quadra.

Nos mapas de 1881 a quadra de origem do Califórnia estava parcelada em lotes estreitos e ocupando em três de seus lados: as edificações encontravam-se no alinhamento da rua e o miolo quadra não havia edificação. No Sara-Brasil esta ocupação intensifica-se pelos quatro lados e o interior da quadra é ocupado por construções maiores. No Vasp-

${ }^{111}$ Parte do conteúdo desta reflexão foi publicada em artigo no $5^{\circ}$ Forum Mackenzie de Pesquisa e no SAL XIII, sob o título de Oscar Niemeyer no Centro Histórico de São Paulo: arquitetura moderna e cidade tradicional, de nossa autoria com Marcos Carrilho.

${ }^{112}$ Sua proposta para São Paulo em 1929 desconsiderava de certa forma a formação existente. 
Cruzeiro (1954), as tipologias já estão modificadas e o lote onde se construiria o Edifício e Galeria Califórnia encontrava-se desocupado, na forma final de um "L".

Como muitos edifícios no Centro da cidade, o Edifício e Galeria Califórnia é o resultado dos novos parâmetros de ocupação. Atendendo às normas e visando obter o maior aproveitamento possível, o edifício foi implantado junto aos alinhamentos do lote, ocupando toda a extensão das faces lindeiras às duas ruas limítrofes. Cada uma dessas faces foi desenvolvida até a altura máxima determinada pela largura do logradouro. A partir dessa altura ou gabarito eram obrigatórios os escalonamentos (ou recuos sucessivos). Nas ruas Barão de Itapetininga e Dom José de Barros eram admitidas alturas no alinhamento de 2,5 vezes a largura da rua. Dessa maneira era possível atingir a altura máxima de $60 \mathrm{~m}$ para ruas com largura entre 12 e $18 \mathrm{~m}$.

Definida as testadas do lote, a parte interna foi conformada por meio da distribuição dos conjuntos de escritórios em quatro corpos distintos, voltadas para um grande pátio interno. Dois corpos encontram-se voltados paras as ruas Barão de Itapetininga e Dom José de Barros. Os outros dois postados no interior do lote, em forma de " $\mathrm{L}$ ", ao lado de um dos cantos do pátio. Os dois primeiros corpos estão encostados nas dividas e possuem aberturas para as ruas e para o pátio interno. Os blocos mais estreitos têm uma face encostada nas divisas de fundo e lateral e outra com as aberturas também voltadas para o pátio. Uma bateria de seis elevadores, situada nesse vértice interno do lote, concentra a circulação vertical. Os corredores de acesso aos escritórios, embora extensos, são largos e se beneficiam de aberturas nos intervalos dos blocos de escritórios. Esses corredores ora correm pela divisa, no trecho em "L", ora penetram pelo meio dos blocos maiores.

Todavia, a realização dessa configuração geométrica não foi tarefa simples em termos de projeto, pois o ajuste de cada um dos blocos foi condicionado por vários fatores. Na face voltada para a Rua Barão de Itapetininga, acima da galeria cujo pé-direito é de 8,40 $\mathrm{m}$, o edifício alcança dez andares de altura, prosseguindo com o acréscimo de mais três pavimentos, mediante recuos sucessivos, do que resulta a forma chanfrada que arremata a parte superior do volume. Na face voltada para a Rua Dom José de Barros, sobre uma galeria mais baixa, devido às diferenças de nível das soleiras e a largura menor da rua o edifício atingiu oito andares no alinhamento. Porém, o desenvolvimento vertical prossegue com o acréscimo de mais cinco pavimentos, mediante um único recuo. Dessa forma, as duas faces dos blocos voltados para o pátio interno igualam-se entre si e aos demais blocos, resultando no final em 13 pavimentos para todo o conjunto.

O intenso aproveitamento da área e as imposições de uma norma urbanística rígida não impediram a adoção de muitos dos dispositivos característicos da arquitetura moderna, 
como a fachada livre e a ossatura independente. Tampouco foram capazes de constranger o desenvolvimento formal de uma obra que soube conciliar os imperativos de aproveitamento imobiliário com um notável resultado arquitetônico, sobretudo pelo arranjo das volumetrias no lote. Assim, ocorre a elegante presença da volumetria das fachadas externas acentuada pela marcação das linhas horizontais, contrasta com a expressão vigorosa e plasticamente dominante dos elementos de sustentação característicos daquele período: os pilares em "V". Correspondente ao pé-direito dessas grandes estruturas de transição, o embasamento do conjunto é atravessado no pavimento térreo por uma galeria que interliga as duas ruas. Ao longo desse percurso, o movimento sinuoso das vitrines das lojas, acentuado pelo desenho livre do forro, faz o contraponto à rigidez da sequência alinhada dos pilares internos de sustentação e de certa maneira aos demais pavimentos.

Nesse sentido, há no Califórnia um duplo significado quanto a sua estrutura e suas formas que correspondem também às diferenças programáticas; à Galeria Comercial e ao Edifício de escritórios respectivamente. Por um lado, há na Galeria uma espacialidade que flui pelo interior do terreno, ocupando-o por inteiro: a forma coincide com o lote. Nesse piso a estrutura participa do jogo das sinuosidades como mais um de seus elementos, oferecendo variações em torno de elementos de pilares em "V", pilares trapezoidais ou colunas. Em parte esses apoios são transições do sistema estrutural concebido no pavimento-tipo; alterando-Ihes vãos e direções. Em contrapartida, no pavimento-tipo há a procura de regularidade estrutural que acomode melhor as irregularidades dos blocos e a disposição das circulações. Por meio das plantas é possível verificar a refinada composição dos blocos de escritórios que joga com as angulações irregulares do terreno, definindo suas formas trapezoidais, cuja deflexão repercute sucessivamente na ligeira inclinação das paredes limítrofes das salas de escritórios e das instalações sanitárias. A intenção não é fortuita, tendo como resultado o estabelecimento de uma ordem perfeitamente definida no interior dessa forma irregular. As estruturas nesses pisos são de uma racionalidade admirável, tanto pela procura de uma modulação, quanto pela correção formal. Nesse sentido, a ossatura independente permite soltar planos irregulares rumo aos cantos de difícil tratamento.

A forma desse edifício, como foi visto, surgiu severamente condicionada pelas normas urbanísticas e à geometria do terreno. Sob essas condições, foi possível pelo edifício e pela galeria reinterpretar uma quadra moderna consolidada sob um tecido préexistente, originário da segunda metade do século XIX. Sua volumetria dá continuidade e completa a ocupação característica das ruas Dom José de Barros e Barão de Itapetininga, especialmente esta última, cuja massa edificada constitui um notável conjunto contínuo de edificações de mesma implantação e altura. Tal condição tem alto valor porque concilia 
unidade da morfologia urbana e expressão individual de cada edifício; limitada ao gabarito de cada face conforme larguras do logradouro público.

Esses condicionamentos, porém, não são propícios à adoção de determinados preceitos da arquitetura tal como o desenvolvimento de volumes autônomos sobre o embasamento ou com recuos em todas as faces. Tratando-se de um empreendimento comercial, não é possível tampouco a liberação integral do térreo pelo sistema de pilotis. Não obstante, ainda que de forma contida ou híbrida tais dimensões encontram lugar na obra realizada. De um lado, a subdivisão dos blocos em prismas trapezoidais parece querer torná-los formas autônomas: os estreitamentos na circulação, soltando os blocos internos ilustram tal condição. Se a solução é parcial, o benefício para a melhoria da iluminação de algumas partes, notadamente dos corredores, é inegável. Se não é possível adotar integralmente a solução de pilotis, o princípio fundamental desse dispositivo foi alcançado, uma vez que a presença da galeria restitui à cidade o nível do chão sob a forma de espaço de utilização pública.

Esse edifício, cuja forma arquitetônica parece ser o resultado de uma tensão entre as normas e parâmetros tradicionais e o impulso para adoção dos princípios da Arquitetura Moderna, alcançou, pragmaticamente, por meio de um pátio interno, uma solução de alta qualidade para iluminação e aeração de suas faces internas; principalmente levando-se em conta que a orientação das fachadas estava determinada por circunstâncias muito longe das ideais. Diante das circunstâncias foi possível solucionar satisfatoriamente as fachadas: o brise-soleil na face voltada para a Barão de Itapetininga atende à orientação nordeste, e sua ausência nas demais faces se justifica ora por ser desnecessário, ora pelo conforto assegurado pelo desenho do pátio interno.

Na solução formal do Edifício e Galeria Califórnia não foi possível contemplar as orientações prescritas nas cartas. A legislação tampouco ajudou na disposição das volumetrias independentes. A solução estrutural modificada no térreo é no mínimo retórica, mas a composição dos volumes no lote e a relação com a cidade são um primor, apesar das condenações de Max Bill ${ }^{113}$. Paradoxalmente, a solução em torno de um pátio interno e a relação com a rua-corredor resgatam morfologia e tipologia condenadas pelo ideário moderno. Nada menos moderno. Porém, nada tão bem tecido na cidade real (figuras 8.1 a 8.17).

${ }^{113}$ Essa obra, a despeito de suas qualidades ocultas, tornou-se o pivô de uma polêmica em torno dos excessos de formalismo da arquitetura de Oscar Niemeyer. Max Bill, em visita ao Brasil, em 1953, para participar da II Bienal de São Paulo, fez uma palestra na Faculdade de Arquitetura da Universidade de São Paulo, ocasião em que manifestou uma crítica franca e direta à arquitetura moderna brasileira. Max Bill realizou por ocasião de sua visita ao Brasil em 1953, palestra na Faculdade de Arquitetura e Urbanismo da Universidade de São Paulo. 


\section{Triângulo: a extrusão de uma quadra colonial}

O edifício triângulo ${ }^{114}$ (1953) é um caso muito especial no Centro Histórico. Ele foi construído em uma área que remonta às origens da fundação da cidade. Mais do que isso, o seu lote é, na verdade, uma pequena quadra, cuja forma pode ser observada nas primeiras cartas de São Paulo produzidas no início do século XIX. Essa pequena quadra de conformação quase triangular foi ocupada por inteiro pelo edifício que a multiplica literalmente por 17 vezes, até o início do escalonamento. Assim, nasceu um edifício cuja forma retém em sua volumetria uma antiga forma colonial.

Na carta de 1810 (Eng. Rufino José Felizardo e Costa) a quadra já está delimitada: sua forma é representada como um triângulo retângulo: com um pequeno chanfro quase imperceptível. Em cartas subsequentes, esse pequeno chanfro é mais ou menos ampliado, conforme precisão da planta - porém sem mudanças significativas. Na carta de 1841 (C.A. Bresser) a quadra assume sua forma quase definitiva: um trapézio de origem triangular. Nesse momento, a espacialidade a sua volta, também, já estava praticamente determinada. Circundavam a quadra: a igreja da Misericórdia e seu largo (hoje Largo da Misericórdia), Rua Direita, Rua do Ouvidor (José Bonifácio), Rua da Cruz Preta (Quintino Bocaiúva). Nos anos seguintes, pequenas retificações no traçado das ruas pouco modificaram seu formato de origem.

Se o edifício Triângulo guarda a memória do lote, o guarda porque sua volumetria final pode ser entendida como uma extrusão literal do lote: ou seja, a fôrma (ou molde) da qual surgiu a volumetria final foi "desenhada" tanto pela forma da quadra quanto pela legislação da época; uma saída forçada. Sua volumetria final reflete essas condicionantes: em última instância, construiu-se o máximo que se podia no exíguo lote de $331 \mathrm{~m}^{2}$. A área final construída corresponde a 20 vezes a área do lote, altíssimo coeficiente para os padrões atuais.

Como foi, então, possível construir um edifício nessas condições?

Uma primeira razão se encontra na formação das cidades de origem portuguesa, essencialmente patrimonialistas: fato que pode explicar uma pequena quadra "perdida" e cercada por ruas de todos os lados e um largo; e mantida nessas condições resistindo às inúmeras modernizações. Outra se encontra na legislação que exigia recuos somente a partir de determinadas alturas. No caso do Triângulo, em ruas com largura superior a $12 \mathrm{~m}$ se podia construir no alinhamento até duas e meia vezes a largura da rua. Como o lote estava cercado por diversas ruas, optou-se evidentemente pela maior largura (20 m), que no

${ }^{114}$ Co-autoria de Carlos Lemos. 
caso, correspondia a uma diagonal entre uma ponta do terreno e a esquina oposta, no encontro das ruas José Bonifácio e Quintino Bocaiúva. Essa distância multiplicada pelo índice permitia nos alinhamentos alturas máximas de $50 \mathrm{~m}$. Altura que corresponde exatamente à primeira volumetria (ou corpo principal) do edifício. Depois dessa altura exigiam-se pavimentos recuados: por isso os últimos três pavimentos do edifício são recuados. $O$ artigo $2^{\circ}$ do Decreto-lei $n^{\circ} 92$ estipulava altura máxima de $60 \mathrm{~m}$ para edifícios construídos em ruas com largura máxima até $18 \mathrm{~m}$, mas esses deveriam atender a um recuo lateral de 2,50 $\mathrm{m}$ a partir da altura de $40 \mathrm{~m}$. No caso do Triângulo adotaram-se as disposições da lei mais favoráveis ou menos restritivas.

A volumetria do Edifício Triângulo se explica, em parte, pelas contingências externas, ou pelo emaranhado de leis da cidade, outras só confirmam tais circunstâncias: na cidade tradicional o chão é destinado ao comércio. No triângulo o pavimento térreo não foge à regra; é destinado a lojas comerciais que se prolongam no $1^{\circ}$ subsolo e no $2^{\circ}$ pavimento. $O$ acesso aos elevadores está posicionado no $1^{\circ}$ subsolo, liberando dessa maneira mais área útil para o comércio, no exíguo pavimento térreo.

Se o edifício isolado numa quadra (arborizada) é um protótipo moderno, sobretudo na visão de Le Corbusier, o edifício Triângulo inserido no cenário de uma cidade tradicional manifesta-se como um paradoxo instigante. Ele é um edifício que ocupa toda uma quadra, por menor que ela seja. E mesmo nessas condições foi possível expressar-se enquanto um objeto solto no espaço, portanto, sujeito a orientações solares de toda ordem. Por isso, Niemeyer o projetou envolto em para-sois horizontais metálicos; que foram mal-sucedidos e tiveram que ser desativados por excesso de ruídos tempos depois.

Talvez não haja dúvidas de o que edifício é fruto de uma extrusão forçada do lote: a forma arredondada do edifício que reproduz fielmente as concordâncias das curvas do lote confirma tal condição. Entretanto, para além dessas circunstâncias houve a afirmação de uma linguagem moderna, expressa: na estrutura independente, na planta livre, na fachada contínua e livre; e no para-sol. Elementos de um programa estético que foram postos à prova em circunstâncias restritivas: que entre outras, condicionou na irregular planta - a única solução razoável para conjunto de elevadores e sanitários - ou seja, deslocados no sentido da maior fachada (figuras 8.18 a 8.31 ).

\section{Eiffel: adaptação a partir do arranha-céu cartesiano}

Um olhar sobre o Edifício Eiffel (1956) na atual Praça da República não revela de imediato o que está por de trás de sua forma. A filiação ao arranha-céu Cartesiano (1938) de Le Corbusier pode ser intuída de imediato, mas é preciso recorrer a suas plantas para 
compreendê-lo melhor e, de alguma maneira, desvendar como foi alcançada sua configuração final.

A Praça da República ocupa o antigo Largo dos Curros, cujas primeiras demarcações já estão presentes nas plantas da cidade de São Paulo de 1810 (Eng. Rufino José Felizardo e Costa). Nas cartas de 1841 (C.A. Bresser) e 1842 (J. Jacques da Costa Ourique) encontra-se definida com a denominação Campo dos Curros vindo, posteriormente se chamar Largo 7 de Abril. Em carta de 1890 (logo após a Proclamação da República) de Jules Martin aparece com a atual denominação com seus limites já perfeitamente definidos. O mapa cadastral Sara-Brasil (1930) reitera essa conformação, acrescida do edifício da Escola Normal e respectivo Jardim de Infância. Em 1940, quando da realização do Plano de Avenidas do engenheiro, depois prefeito, Prestes Maia, seu traçado é novamente modificado. O prolongamento da Av. São Luiz implicou a demolição do Jardim de Infância e a redefinição de três quadras adjacentes. De uma delas, acertados os cortes de alinhamento das vias, surgiu o terreno - de forma triangular - onde hoje se encontra o Edifício Eiffel.

O prolongamento da Av. São Luiz nos anos 40 e simultâneo alargamento alterou em um de seus lados os traçados configurados em 1890. Contudo, apesar dos acertos geométricos, a praça guarda praticamente as mesmas proporções características associadas às suas origens de logradouro destinado às paradas de tropas de muares do período colonial. No entanto, o mesmo não se pode dizer com respeito à volumetria no entorno da praça, hoje altamente verticalizada.

O terreno configurou-se, então, como um triângulo retângulo - apesar do pequeno chanfro e do dente em um de seus catetos. O lado maior tem a face voltada para a Praça da República. De qualquer modo, trata-se de um terreno de configuração irregular, resultante de uma das muitas operações cirúrgicas feitas sobre arruamentos antigos.

O edifício é de uso habitacional com apartamentos de piso duplo, de três e dois dormitórios: nos pavimentos térreos, sobreloja e $1^{\circ}$ andar o uso é destinado ao comércio. Um subsolo para garagem complementa o programa.

Um programa, um lote triangular e uma legislação - que estimulava a verticalização e o máximo aproveitamento do lote - compõem os ingredientes a serem considerados pelo projeto arquitetônico. Em resposta a essas demandas, Oscar Niemeyer, com colaboração de Carlos Lemos, adota um partido referenciado ao modelo do arranha-céu cartesiano: no estrito senso uma transposição direta, porém, sujeita aos imperativos das condições locais.

O arranha-céu cartesiano é uma variação do arranha-céu cruciforme proposto para a Cidade Contemporânea. Como estrutura formal já aparece em alguns estudos para habitação por volta de 1935 . São esboçados como solução crítica aos arranha-céus de 
Nova York, depois que Le Corbusier vivencia pela primeira vez a possibilidade técnica e concreta da verticalização na América. Em "What is the problem of America?", o arranha-céu cartesiano é apresentado e esquematizado como célula de uma reformulação urbana para a ilha de Manhattan: nasce articulado a uma ideia de cidade. No caso em questão, representa uma alternativa aos arranha-céus escalonados (set-backs) e sua intensa ocupação do solo que, além de promover o excessivo adensamento urbano, trazia as mazelas decorrentes da pouca iluminação e da insolação deficiente, na visão do arquiteto. Após essa primeira visita a Nova York, Le Corbusier chegou mesmo a declarar que os arranha-céus da cidade não eram suficientemente altos. Essa afirmação, porém, deve ser vista com reserva, pois o que mais o incomodava eram as disparidades de altura entre os arranha-céus e seus vizinhos, de poucos pavimentos, e a intensa descontinuidade na ocupação territorial. Sua visão pressupunha o alargando da malha existente, reordenando as massas construídas no interior de amplas áreas verdes, redistribuindo usos e funções, promovendo novas formas de ligação transversal entre as margens dos rios Hudson e East.

Dois pontos devem ser salientados nessa proposta de Corbusier: a forma universal e abstrata do arranha-céu e sua total independência à rua, ou a qualquer legislação que dela decorresse.

A forma do arranha-céu cartesiano tem sua origem num exercício de especulação geométrica. Um triângulo retângulo estruturado a partir da bissetriz do ângulo reto. Por esse eixo central - coincidente com a orientação norte-sul - nasce um bloco articulado perpendicularmente a uma grande lâmina horizontal que se desdobra a 45ำ nas duas extremidades, gerando outros dois corpos articulados. Essa forma foi concebida para permitir condições ótimas de iluminação e insolação para suas cinco fachadas, em vez de três, conforme esboçados nas soluções à redents da Vila Contemporânea. Os edifícios encontram-se soltos e isolados no espaço, distantes um dos outros e dispostos no interior de grandes quadras com vegetação abundante.

Dados esses pressupostos, caberia perguntar como Niemeyer poderia se apropriar de tal modelo para um contexto pré-existente nitidamente adverso às idealidades nele contidas? Tudo parece indicar um caminho de tensões e ambiguidades.

Uma primeira digressão se acha na orientação do lote: no Eiffel a linha norte-sul coincide com um dos catetos, portanto, encontra-se deslocada a $45^{\circ}$ da posição ideal sugerida no arranha-céu cartesiano. Esse deslocamento a princípio não é ruim para as condições encontradas em São Paulo, pois propicia três orientações satisfatórias para as fachadas: norte, nordeste e leste. 
A segunda refere-se à definição da volumetria final. Nesse caso, as alterações volumétricas foram maiores, não sendo possível manter a conformação de um único bloco trapezoidal numa mesma altura, como nas diversas formas derivadas do arranha-céu cartesiano. Um corpo central eleva-se acima dos demais, no dobro de suas alturas.

A legislação da época estabelecia limites de altura, em função da dimensão dos logradouros, a partir dos quais eram admitidos nos escalonamentos progressivos, que estabelecia critérios máximos e mínimos construtivos a partir da largura das ruas. No caso do Eiffel, um edifício de esquina, havia três requisitos diferentes a serem conciliados. Dois relativos às ruas laterais e um terceiro em relação à Praça da República. Uma dificuldade a mais se apresentava: as ruas Araújo e Marquês de Itu não possuíam a mesma largura. Portanto, as alturas de cada uma das partes constitutivas do edifício, voltadas para elas, seriam diferentes se mantidos os alinhamentos frontais na divisa do lote. Era comum na época edifícios com variações de volumetria em decorrência de ruas com larguras desiguais $^{115}$. Na face voltada para a República a legislação permitia que as construções atingissem até $80 \mathrm{~m}$ de altura ${ }^{116}$.

A solução adotada por Niemeyer procurou conciliar legislação e máximo aproveitamento, sacrificando a uniformidade volumétrica presente nos projetos do arranhacéu cartesiano. Por isso, a configuração final do Eiffel resultou na expressão de três corpos. Dois iguais, definidos pela altura da rua de menor largura (Rua Araújo) e um a torre maior de aproximadamente $80 \mathrm{~m}$.

Se a uniformidade e simetria foram prejudicadas na elevação das massas, nas soluções de plantas elas se mantiveram coesas até aonde a legislação permitia; pois, o que se prolonga a partir do $12^{\circ}$ pavimento são a torre mais elevada e o corpo saliente da circulação vertical - elevadores e escada - a ela conectada.

Se o arranha-céu cartesiano encontra-se isolado na quadra, no Eiffel acontece o contrário. O edifício está amarrado aos limites do lote, encostado nas divisas laterais e sujeito a alinhamentos frontais. Essa condição retira do edifício parte de sua condição de figura na trama urbana, embora sob determinadas visuais se tenha a torre desgarrada comparecendo com força expressiva autônoma.

O edifício como objeto solto no espaço, como figura, nos termos de Le Corbusier não acontece na singularidade do caso concreto: não só pelas amarras do lote, mas também pelo uso destinado ao pavimento térreo, que substitui os paradigmáticos pilotis por uma

${ }^{115}$ Como mencionada no capítulo 7, Uma quadra em formação [...]

${ }^{116}$ Decreto-lei $n^{\circ}$ 92, de maio de 1941. 
galeria comercial nos moldes de uma configuração urbana tradicional, na qual o comércio surge no chão.

Se o térreo ancora o edifício à cidade, outras soluções o aproximam dos tipos e esquemas propostos por Le Corbusier: tanto contido nas variações de plantas em torno do arranha-céu cartesiano, quanto a outras tipologias e esquemas: os apartamentos dúplex com circulação horizontal alternada, de dois em dois pisos - o sistema de circulação vertical, a fachada livre e a estrutura independente.

Assim, no edifício Eiffell transparece uma série de eleições que não se resolvem plenamente: ora mostrando-se pertinentes, ora inadequadas. A escolha de Niemeyer de confinar o modelo às características do lote faz sentido: as relações geométricas e a orientação a justificavam. Por decorrência tem-se um arranjo de plantas para os apartamentos bem resolvidas, do ponto de vista da circulação, da qualidade dos ambientes e da iluminação. Entretanto, nas definições volumétricas o mesmo não aconteceu: o edifício ficou preso aos limites do lote e à legislação. Em outras palavras, a solução ficou a meio caminho entre o compromisso com as massas construídas pré-existentes e o impulso imanente ao modelo de afirmar a autonomia do volume no lote. Ambiguidades que o afastaram inevitavelmente da referência idealizada, mas que o trouxeram, através da galeria comercial para o chão, para a cidade (figuras 8.32 a 8.46 ).

\section{COPAN: a expressão do objeto}

O edifício Copan, 1951, é conhecido por sua forma plástica. Em qualquer registro visual do Centro da cidade sua presença se destaca. As curvas contínuas de suas superfícies contrastam fortemente com a massa compacta do aglomerado de edifícios vizinhos. Sua imagem gera empatia imediata, desperta o sentido da sensualidade, ativa o olhar do observador e conduz a vista pelo percurso contínuo de suas linhas. Sua forma o desprende do tecido a sua volta.

No entanto, para a sua compreensão é necessário tomar como referência o desenho do terreno no qual o edifício se implantou. Trata-se de uma gleba obtida da reunificação de vários lotes que anteriormente continham dois tipos de uso basicamente - edifícios habitacionais pertencentes a uma antiga vila residencial (Normanda) e no caso dos lotes maiores, instalações de serviços. Esses lotes confrontam com duas vias, a Rua Araújo e a Avenida Ipiranga, sendo ainda atravessados por uma alameda interna que servia às residências, a qual, por sua vez, se conectava com a Avenida São Luiz. A própria Avenida Ipiranga era de abertura recente e fazia parte do programa de melhorias urbanas do Prefeito Prestes Maia: no caso em questão ela avança sobre a Epitácio Pessoa, interrompendo a 
continuidade da Rua Araújo, que hoje tem um pequeno tramo delimitando a quadra no qual se encontra o Copan. A geometria do terreno pode ser percebida na carta Sara-Brasil, de 1930, que apresenta um registro da área. Por ela se verificam as características do parcelamento pré-existente e a configuração do polígono resultante da reunificação de lotes que permitiu a realização do empreendimento. Por outra carta mais recente, de 1954, que já assinala a abertura da Avenida Ipiranga, fica evidente a grande frente do lote voltada para essa face. Essa condição privilegiada, aliada ao requisito da insolação, favoreceu a uma disposição voltada para a avenida principal, induzindo, possivelmente, à acomodação da massa edificada à geometria das linhas limítrofes do terreno. A orientação, no caso, está predominantemente voltada para a face norte, portanto muito próxima das orientações encontradas no Ministério da Educação, por exemplo. E nessas condições no Copan reproduz em parte o esquema implantado no MESP: brises horizontais e acentuados na fachada norte, brises mais abertos nas fachadas intermediárias e envidraçamento na fachada mais na sul.

Mas, a disposição contínua de desenvolvimento linear sugere outros precedentes. O edifício Viaduto de Le Corbusier seria possivelmente o protótipo de sua concepção, seja a partir das formulações pioneiras das propostas para o Rio de Janeiro, seja os desenvolvimentos ulteriores em Argel. Faz lembrar também algumas experiências locais bem-sucedidas como os conjuntos habitacionais da Gávea e de Pedregulho de A. E. Reydi. Mas a semelhança é apenas tópica, uma vez que no Copan não se aplicam o contexto da paisagem montanhosa em que se implantaram os edifícios de Reidy, nem o sentido de megaestrutura que conjuga edifício e sistema de circulação viária de Le Corbusier. Do mesmo modo, a estruturação funcional do edifício Copan não utiliza a assim chamada "rua interna", nem foi concebido para interligar um ponto a outro de seus extremos como ocorre nos precedentes citados. Pode ser visto como um fragmento dessas propostas mais amplas.

Nessas condições que sentido poderia ter essa forma? À primeira vista trata-se apenas de um segmento interrompido de uma estrutura linear, um fragmento daquilo que poderia ser o impulso que lhe deu origem. Mas se sua origem pode parecer o resultado de um impulso arbitrário, sua gênese demonstra o contrário.

Um primeiro estudo, elaborado pelo escritório norte-americano Holabird, Root \& Burgee, do qual persiste apenas um registro publicado pelo jornal a Folha da Manhã, demonstra claramente essa escolha. O empreendimento inicialmente pretendido é constituído de três blocos cuja disposição se ajusta aos limites do terreno. A maquete apresenta um conjunto composto de três blocos sob a forma de lâminas verticais implantadas sobre um bloco de embasamento que reúne todo o conjunto, cuja disposição se 
ajusta aos limites dos fundos do lote, liberando a maior frente possível para as faces voltadas para a avenida.

A esbeltez dessas lâminas e o movimento sugestivo de sua distribuição parecem ter conduzido à forma final adotada pelo projeto de Oscar Niemeyer, reinterpretada, porém, numa forma totalizante, que suaviza as bruscas mudanças de ângulo à redent de Le Corbusier. Desse modo, a solução do Copan parece fundir esses dois arranjos a partir de uma boa solução de partido precedente.

O conjunto compreendia um ambicioso programa que conjugava dois blocos distintos, um destinado ao uso residencial e outro à atividade hoteleira. A viabilidade do empreendimento dependia de uma escala até então sem precedentes e o conjunto de instalações do "Maciço Turístico do Copan", como então era chamado, compreendia além do hotel e do edifício residencial um vasto programa de atividades.

O projeto de Oscar Niemeyer teve pelo menos duas versões. Na primeira, o edifício do hotel se destaca pelo desenvolvimento vertical mais acentuado enquanto a segunda é aquela em que o edifício residencial se projeta com altura maior. Em ambas alternativas o conjunto era composto por um embasamento atravessado por uma rua interna, gerando dois volumes independentes, porém integrados no nível do terraço, de modo que moradores e hóspedes pudessem desfrutar livremente dos serviços oferecidos tanto no hotel como no conjunto residencial.

O edifício do hotel, nunca construído, conheceu ainda uma terceira versão, de autoria do arquiteto Henrique Mindlin. Em seu lugar foi realizado, em 1965, sob autoria de Carlos Lemos, um edifício administrativo para a sede central do Bradesco, que guarda relações com o conjunto original apenas em suas proporções ${ }^{117}$.

Embora os primeiros estudos tenham sido elaborados no final de 1951, o projeto foi submetido à aprovação da municipalidade em 1952, conforme documenta o Processo no 81482/62 (folha 11). A análise feita se detém sobre os parâmetros de ocupação do terreno, correspondente a cerca de $30 \%$ da área do lote, sendo admitida para essa projeção uma altura máxima não superior a $115 \mathrm{~m}$ (decreto-lei 41/40). $\mathrm{O}$ edifício atendia a esse requisito, pois sua altura se limitou a $107 \mathrm{~m}$ de altura. No mesmo processo observa-se que a aprovação incluía o bloco do hotel e o do Edifício de apartamentos (Copan propriamente dito). Nos pareceres dos técnicos observam-se argumentos que acomodavam pequenos desajustes em relação aos alinhamentos na mencionada lei:

Márcio Bariani.

${ }^{117}$ Ver menção na seção Documento, revista AU nำ 185, julho de 2009, p. 65, de autoria de 
A Lei $n^{\circ} 41$ de 1940 e o art. 32 do C.O. determinam construção no alinhamento, procurando impedir diversidade de solução no loteamento fracionário e irregular que se apresenta na cidade, e em consequência, sucessivos avanços e recuos, com exposição à vista das paredes laterais não recuadas; nesse projeto, porquanto a edificação tomará a frente total de uma face do quarteirão, entre a Rua Araújo e a Rua da Vila Normanda (frente de 178 m) [processo 81482/52, folha 31].

Mais adiante no parecer são arroladas justificativas para os pequenos recuos dos blocos no alinhamento, nesse sentido pesou a abertura da via que permitia trânsito de carga e descarga. Confrontando-se os primeiros estudos de Niemeyer e a solução final incompleta percebe-se o quanto a legislação dificultava uma solução moderna de quarteirão isolado, composto por blocos de edifícios isolados. Por outro lado, o pragmatismo da construção transformou os pilotis em rua coberta e comercial.

O edifício residencial é composto de apartamentos para atender a todo tipo de demanda das pequenas unidades, quarto e sala conjugados àqueles de grandes dimensões, setorizados segundo distintas prumadas. Trata-se de uma obra de grandes dimensões, inicialmente prevista com 896 apartamentos e 112 lojas. Embora seu lançamento, ocorrido em 1952, tenha alcançado grande sucesso de vendas, a construção do edifício enfrentou inúmeras dificuldades, tendo sido concluído anos mais tarde, em 1968. O longo período de realização do empreendimento, aliado à falência de seus empreendedores, impôs alterações ao projeto que comprometeram aspectos de sua distribuição interna.

O programa residencial do edifício contemplava grande diversidade de tipos habitacionais, da habitação mínima ao apartamento de luxo. Essa diversidade de tipos se distribuía em uma mesma torre de dimensões constantes, apesar do movimento das curvas. Cada tipo ou grupo de tipos distintos foi distribuído em torno dos núcleos dos elevadores constituídos de seis prumadas. Assim, o grupo de habitações mínimas é servido por um volume de circulação vertical destacado do volume principal, a este associado por meio de lance duplo de rampas que alcançavam os corredores de distribuição das unidades. Para os demais apartamentos as prumadas de elevadores se distribuem internamente em blocos e atendem a duas unidades por andar, à exceção dos apartamentos de quatro quartos. Parte desses últimos blocos sofreu alterações quando a construção já se encontrava adiantada, tendo os apartamentos sido subdivididos.

A dimensão constante da lâmina não favoreceu a boa resolução de algumas das unidades como se verifica no caso dos apartamentos do Bloco $A$, de dois quartos, devido à profundidade excessiva do pavimento, causando deficiências de iluminação e ventilação em alguns compartimentos. O alinhamento das paredes divisórias de algumas unidades não coincide a modulação da estrutura de sustentação das placas horizontais de sombreamento 
das fachadas. Essa condição, aliada à profundidade excessiva desses dispositivos, constitui um dos fatores que perturba o desfrute dos grandes vãos envidraçados dos apartamentos.

O plano de massas inicialmente previsto afinal se realizou. Porém, o contraste entre o volume prismático e a forma ondulante que o envolve é tal que não parecem fazer parte de um conjunto. Da mesma forma, a mudança radical de uso de hotel para edifício administrativo em nada contribuiu para tornar as partes coesas.

Seus atributos parecem residir mais em sua forma plástica que na qualidade de suas unidades internas e nas relações que possam a partir delas se estabelecer. Esse é, certamente, um dos fatores que tem contribuído para a viabilidade dessa enorme estrutura residencial. A figura predomina sobre a textura. O objeto autônomo e a forma escultórica se destacam como foco de atenção e de identidade. Nessa configuração, os brises em lâmina soltos da ossatura como uma segunda pele assumem grande importância, pois como elemento de uma linguagem cumprem papel de reafirmar a intenção formal como meio de fazer ou manifestar visão de arquitetura e cidade (figuras 8.47 a 8.61).

\section{Montreal: uma esquina encurvada}

O edifício Montreal, 1954, ocupa a esquina formada pelas Avenidas Ipiranga e Cásper Líbero: antiga Rua da Conceição que ligava o Triângulo Histórico à Estação da Luz. Mais uma vez, sobre o tecido da cidade colonial o programa de abertura de grandes avenidas, realizado na década de 30 , pelo prefeito Prestes Maia, reformulou as feições urbanas: entretanto, esse traçado ainda permanece configurado nos mesmos termos; a despeito de verticalizações e eventuais alargamentos de vias. No contexto dessas transformações inscrevem-se alguns dos exemplares da nova arquitetura. Se essas melhorias urbanas se dão já no marco de uma cidade cosmopolita de perfil industrial, submetida ao dinamismo de um intenso crescimento populacional, as transformações ocorridas ainda guardam relações com os paradigmas urbanísticos ainda vinculados às concepções de Hausmann e Camilo Site. Assim, apesar de ter se tornado imperativo viabilizar a circulação urbana e o aumento da densidade, os parâmetros de ocupação dos lotes pressupõem a homogeneidade de morfologia urbana, embora o aproveitamento dos lotes seja determinado pela largura dos logradouros.

No caso do edifício Montreal, por se tratar de um imóvel de esquina, é possível alcançar grande desenvolvimento em altura: $80 \mathrm{~m}$. Embora relativamente restrito em suas dimensões, o terreno se beneficia de uma orientação muito favorável sob o aspecto da insolação para um edifício residencial: a face norte encontra-se na inflexão da esquina. Da mesma forma, a posição de esquina permite o destaque da volumetria, permitindo ao 
observador desfrutar amplas visuais. Por outro lado, sua forma trapezoidal, com três faces voltadas para as vias públicas, permitiria examinar várias alternativas de implantação do edifício, em particular aquelas que permitiriam desenvolver um volume autônomo em relação à massa contínua da ocupação predominante no quarteirão. Contudo, a escolha do arquiteto foi por definir o volume do edifício implantado sobre os alinhamentos prediais: condições que permitiam maior aproveitamento do lote ${ }^{118}$.

Projetando-se dentro das normas dos alinhamentos, foi proposto como solução final um volume encurvado de 22 pavimentos e dois outros complementares - quase imperceptíveis - a uma altura correspondente a $39 \mathrm{~m}$ ou 11 andares: um voltado para a Avenida Ipiranga, outro para a Cásper Líbero. O corpo elevado dobrando a esquina se explica, como em outras situações mencionadas, pela possibilidade de rebatimento da volumetria pela via mais largura até a profundidade de $20 \mathrm{~m}^{119}$; depois dessa distância era obrigatória ater-se ao gabarito no alinhamento conforme solução adotada nos corpos menores. Dada à condição de esquina não foi necessário cumprir dispositivo que exigia recuo lateral mínimo de $2,5 \mathrm{~m}$ acima de $39 \mathrm{~m}$.

Essa obra também conheceu dois projetos distintos sem que suas diferenças se repercutissem em alterações na volumetria externa e no partido volumétrico do edifício.

A primeira versão do projeto propunha a implantação da caixa de elevadores na face junto às divisas do terreno de modo que o acesso aos apartamentos se fazia por um corredor distribuído ao longo das unidades. Essa alternativa previa apartamentos-tipo dúplex, de dois pavimentos, quartos na parte superior, sala, cozinha e lavanderia no pavimento inferior. A linha de circulação à volta das unidades ocorreria alternada a cada dois pavimentos. A solução era engenhosa, porém, sendo as unidades de pequenas dimensões, resultava uma solução um pouco constrangida pelos limites de dimensões do lote e do poço interno, de proporções reduzidas em relação à altura de 22 andares.

Porém, o que de fato se realizou foi um segundo projeto, com apartamentos de quarto e sala conjugada. Nesse caso, a torre de elevadores foi deslocada para o centro do triângulo o que, embora diminua a extensão dos corredores, acabou por prejudicar ainda mais as já reduzidas dimensões do poço interno.

Tratando-se de edifício para finalidades comerciais o aproveitamento do imóvel é levado até o último limite, seja em termos de gabarito e taxa de ocupação, seja em relação

${ }^{118}$ Situado no ponto de convergência de três grandes avenidas esse edifício corresponde, sem muitas variações, a outro projeto realizado no mesmo período em Belo Horizonte, para o Banco Mineiro da Produção. A diferença, nesse caso, é que se trata de um edifício residencial.

${ }^{119}$ Art. 4, $\S 1^{\circ}$, Decreto-lei $n^{\circ}$ 92, de 2 de maio de 1941. 
ao agenciamento de algumas de suas partes. A fim de permitir o máximo aproveitamento do pavimento térreo para lojas comerciais, o saguão de acesso foi localizado no subsolo do edifício, a exemplo do Edifício Triângulo.

Assim, as soluções de projeto nascem comprometidas sob vários aspectos, não apenas em relação às necessidades comerciais e às demandas de mercado, mas subordinadas às normas urbanísticas e seus parâmetros reguladores. Nesses limites, a possibilidade do desenvolvimento de determinados pressupostos da arquitetura moderna se defronta com as exigências de ordem prática. Nem por isso o resultado arquitetônico deixa de alcançar êxito e revelar, muitas vezes, resultados inesperados. Em alguns casos, como nesse edifício, chega mesmo a haver considerável autonomia entre forma e conteúdo, entre solução plástica e compromissos pragmáticos. O desenho dos brises e a hierarquia no tratamento entre volumetrias sublinham a intenção da forma autônoma. Nessa condição os brises como elementos centrais de uma linguagem moderna e brasileira são empregados tanto como função de sombreamento, mas também como elemento de arquitetura que faz ou promove a continuidade da massa que se quer independente. Chama atenção a interrupção das abas horizontais dos brises na fachada nordeste voltada para a Avenida Ipiranga; ou melhor, sua extensão na fachada leste voltada para a Cásper Líbero. No caso, talvez tenha se privilegiado a unidade formal quando tomada pelas visuais provenientes da Cásper Líbero no sentido de seu encontro com a Senador Queiróz (figuras 8.62 a 8.81).

\section{Seguradoras: o lote de meio de quadra}

O edifício Seguradoras localiza-se na Avenida São João $n^{0}$ 313. Seu alvará de construção data de 1958. Essa foi a última obra projetada por Niemeyer no Centro Histórico de São Paulo: trata-se de uma obra construída em terreno situado em meio de quadra. Portanto, uma situação bastante comum, que abarca considerável variação tipologia.

A Avenida São João é sulco marcado e identificável na cartografia de São Paulo desde seus primórdios: nascendo no Largo do Rosário e transpondo o Anhangabaú foi por muito tempo a saída para incursões rumo ao Oeste. Durante o século XIX passou por consideráveis padrões de ocupação. O lote do edifício Seguradoras encontra-se no primeiro trecho depois de transposto o vale do Anhangabaú. Confrontando-se os mapas de 1881 e Vasp-Cruzeiro percebe-se que um padrão dos lotes estreitos permaneceu. No Sara-Brasil produzido entre os dois não fica claro a divisão dos lotes: mas pelas fotos de época se deduz que o padrão ainda permanecia sob uma mesma massa construída. A profundidade dos lotes ficou pouco alterada. No mapa Vasp-Cruzeiro identifica-se com clareza o lote que dará origem ao Seguradoras: com certeza fruto de um remembramento. A particularidade 
desse lote está justamente na sua regularidade: grosso modo, apenas a divisa dos fundos apresenta uma leve inclinação; as demais são ortogonais - condição pouco comum no centro.

Se o lote facilitava pela regularidade o projeto, sua profundidade e largura, somadas às normas legais nem tanto. Em decorrência desses fatores foram propostos para o edifício dois corpos de alturas diferentes intermediados por pátio de iluminação entre eles. O bloco mais alto, de frente para a avenida, tem dois estágios: um primeiro de $39 \mathrm{~m}$, que compreende o térreo e mais 12 andares e um segundo que atinge os $80 \mathrm{~m}$ permitidos, mantendo-se os recuos laterais. No corpo voltado para os fundos, a altura se limitou aos 39 m. Nesse bloco a torre não vai mais alto devido à pouca área útil que resultaria se fossem mantidos os recuos obrigatórios.

Nesse sentido se explica também a solução engenhosa da circulação e sanitários, que pelas dimensões do lote teriam que estar deslocadas para um dos recuos laterais - se postadas no meio perderia-se área útil. Dessa forma, até o $12^{\circ}$ piso têm-se quatro elevadores abrindo para um corredor colado na divisa lateral, interligando os dois blocos. $\mathrm{A}$ partir desse piso interrompe-se essa ligação e inverte-se a abertura dos elevadores, pois não mais existe o bloco dos fundos.

Essa solução empregada no Seguradoras pode ser identificada em situações semelhantes no Centro. Tudo parece indicar que as diferenças fundamentais repousam na ossatura independente e seus desdobramentos. Portanto, na linguagem e seus princípios. Sob esse aspecto, o Seguradoras é até didático: planta e fachadas livres e pouco espessas. A ausência dos brises explica-se, provavelmente, por questões comerciais, tendo-se em conta que a orientação da fachada voltada para a Avenida São João coincide com a orientação nordeste do Califórnia. Por esse mesmo motivo há uma diferença no tratamento das fachadas: nas faces voltadas para a rua as esquadrias tripartidas vão do teto ao piso nos termos da doutrina. Nessas esquadrias, uma faixa de vidro fosco faz as vezes de um parapeito. Nas fachadas dos fundos os parapeitos na mesma proporção são de alvenaria; e assim interrompe a intenção formal em igualar esteticamente todas as fachadas (figuras 8.82 a 9.94).

\section{Uma tipologia abrangente}

Nada mais adequado e rico do que ver as tensões entre a arquitetura da cidade moderna e a cidade tradicional por meio das obras de Niemeyer; particularmente no CHSP. Em outras circunstâncias, o olhar teria que ser necessariamente outro. Nessa análise, tudo parecia indicar um caminho de tensão e inadequação de toda ordem. Elas ocorrem com 
certeza. Mas na singularidade das obras foi possível, também, perceber situações ricas, onde a arquitetura moderna e a cidade tradicional entraram em perfeita sintonia. Nesses casos, prevaleceu a força e a dinâmica da cidade tradicional. Ora impondo-se por meio de uma morfologia enraizada, ora impondo-se pela força imperiosa da legislação e dos interesses nela embutidos.

O edifício Triângulo é paradigmático: ele é ao mesmo tempo um objeto solto no espaço, uma quadra colonial, uma extrusão do lote, uma expressão da linguagem moderna e também seu insucesso. Mas ele é também a memória de um fragmento de terra que persiste admiravelmente no tempo.

Do outro lado têm-se o Eiffel e o Copan. Ambos se apresentam como objetos soltos no espaço: figuras. O Copan com certeza atingiu seu destino: sinuoso e imponente destacase em meio a uma enorme massa edificada. Por circunstâncias históricas da formação do lote, e daquele fragmento da cidade, ainda permitiu uma singular porosidade entre o piso térreo, a galeria e a rua. $O$ Eiffel também favorece as trocas entre o espaço público e o privado por meio da galeria comercial. Porém, sua forma elevada, atada parcialmente ao lote, ficou a meio caminho entre a condição de um objeto isolado e a continuidade das volumetrias lindeiras. Contribuiu para essa situação a opção pela transposição do modelo corbusieriano: a forma triangular do terreno sugeria a pertinência da escolha, mas submetida à legislação, mostrou-se oscilante, como uma forma inacabada.

Entre essas duas polaridades acham-se os edifícios Califórnia, Montreal e Seguradoras: exemplos de fusões bem-sucedidas com a trama urbana. O Edifício e Galeria Califórnia, a despeito das críticas de Max Bill e outros, conformou-se como uma precisa cunha que encerra um conjunto urbano. A disposição dos volumes externos compondo as "paredes internas" da rua e a permeabilidade da galeria, interligando as ruas Barão de Itapetininga e Dom José de Barros, é de extraordinário significado para persistência das qualidades da cidade histórica. No "Seguradoras" se faz uso de um pátio interno para garantir máxima ocupação e boa iluminação às salas de escritório, assim como no Califórnia, uma implantação é pragmaticamente resolvida no limite. No outro extremo, o Montreal encerra uma quadra e faz a transição entre duas ruas tangentes: promove essa transição e ao mesmo tempo dá continuidade aos gabaritos previstos para os logradouros; a exemplo do Copan seus brises horizontais desempenham importante papel na expressão formal. 
Edifício e Galeria Califórnia, 1951. (figuras 8.1 a 8.17.)

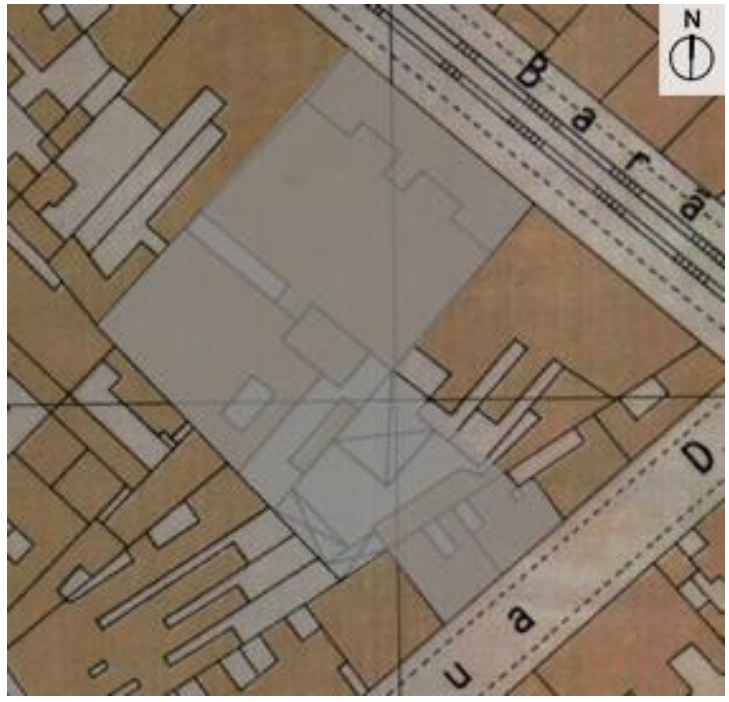

8.1: Sara Brasil - Localização do terreno

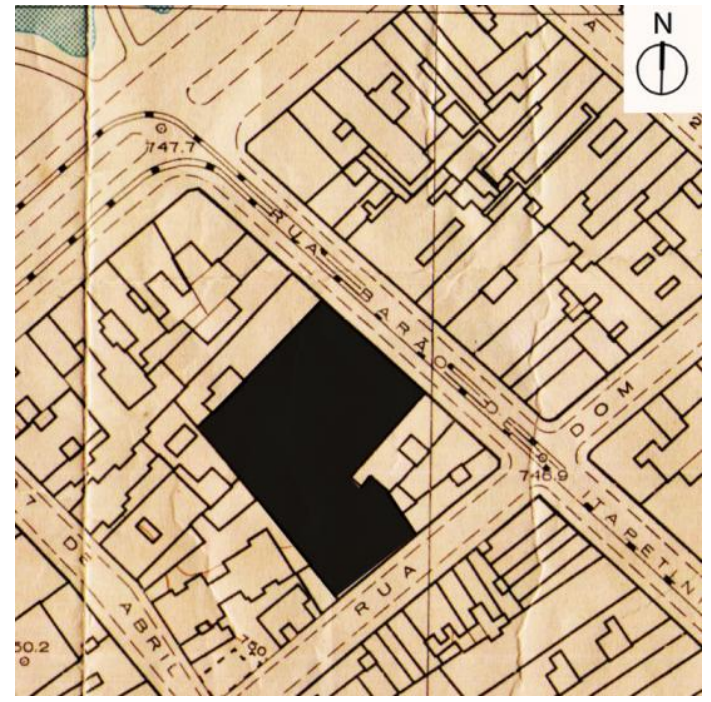

8.2: Vasp-Cruzeiro - terreno ainda vago

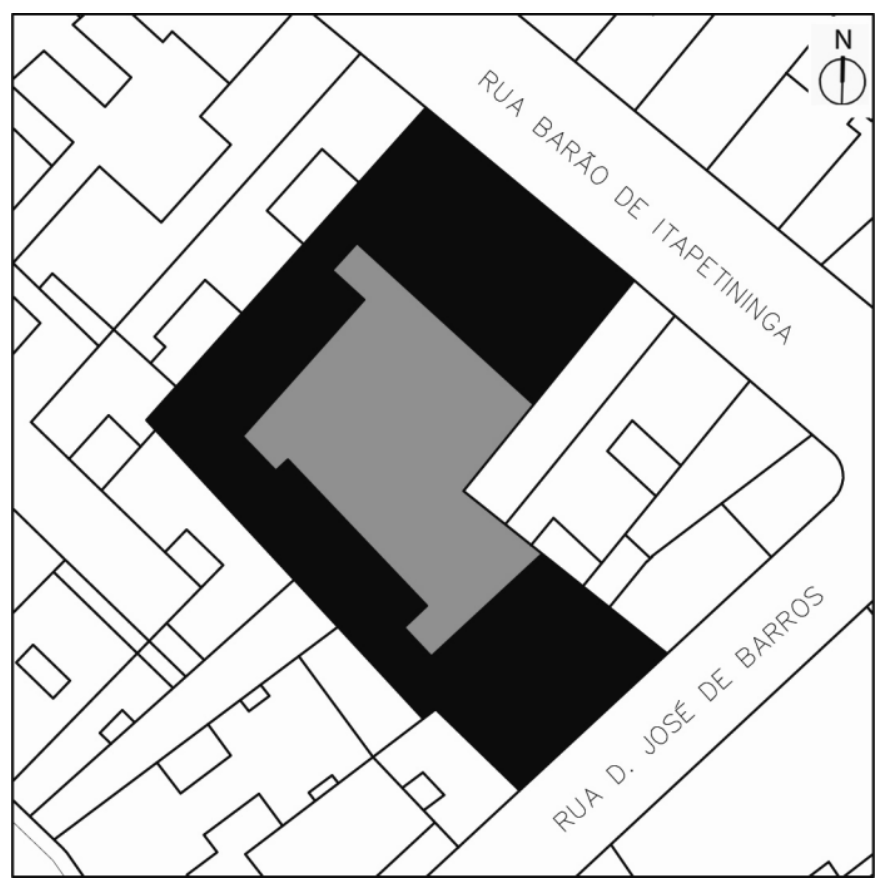

8.3: Situação atual, em preto volumetria mais alta, em cinza embasamento e pátio 

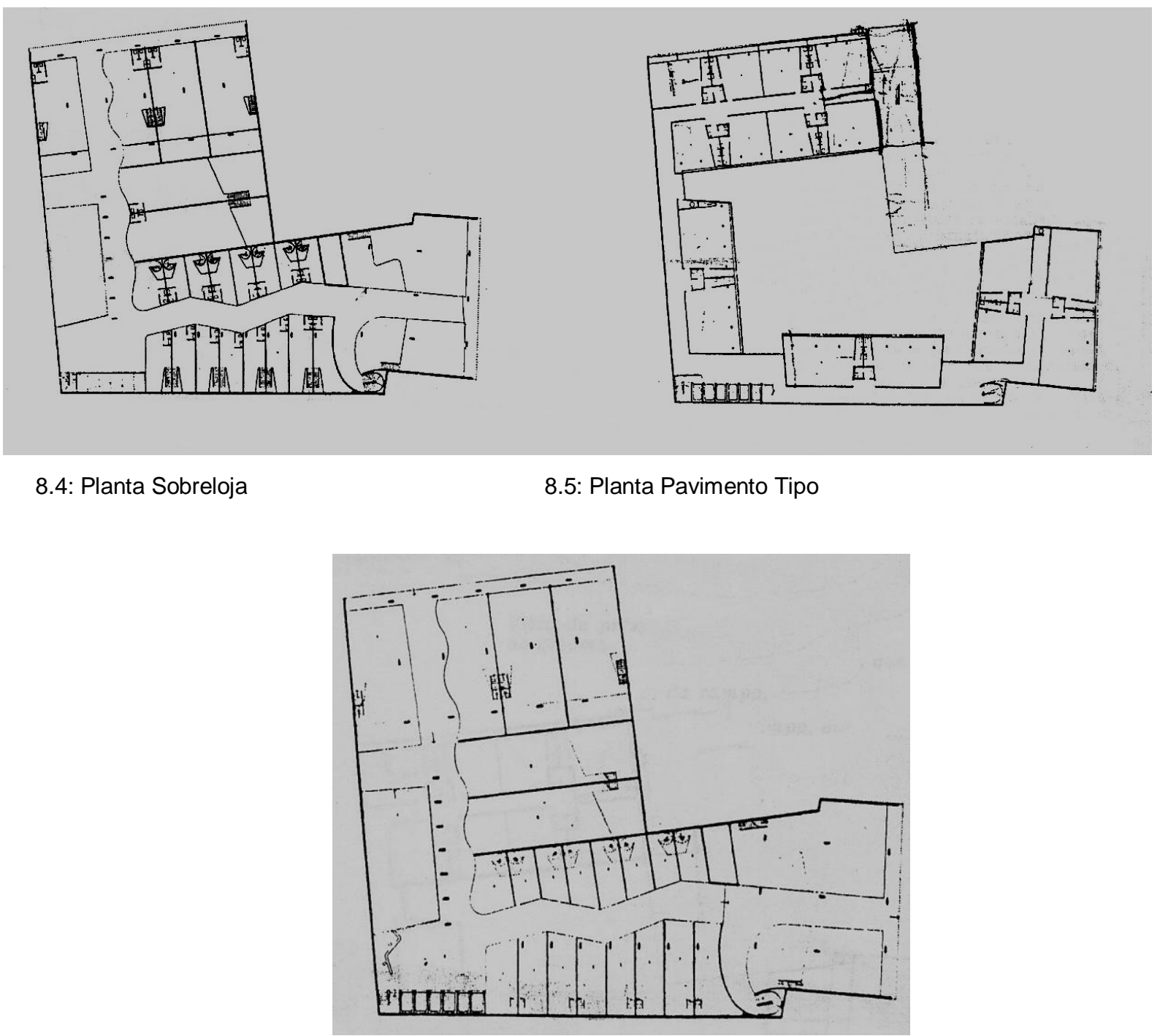

8.6: Planta Galeria - térreo

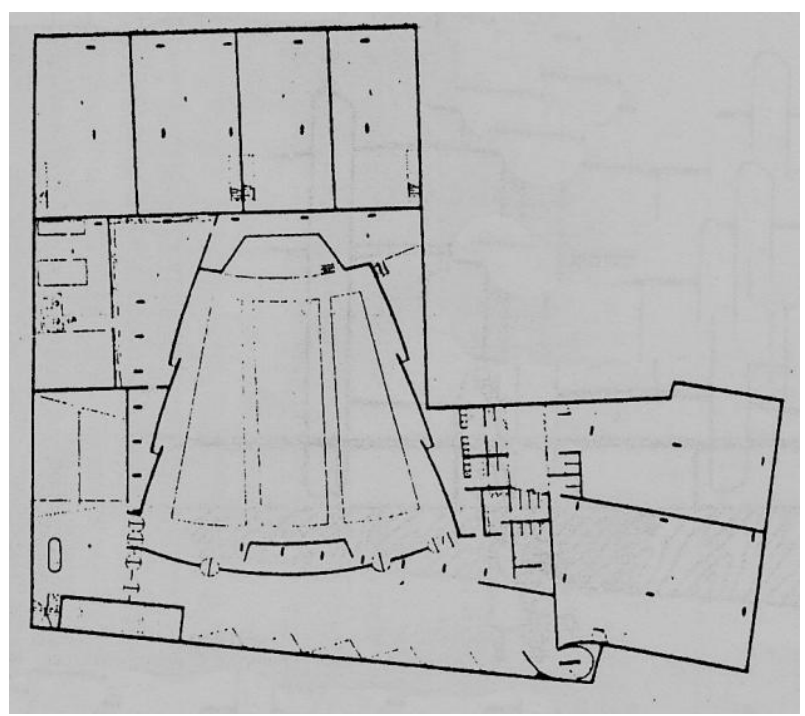

8.7: Subsolo. 


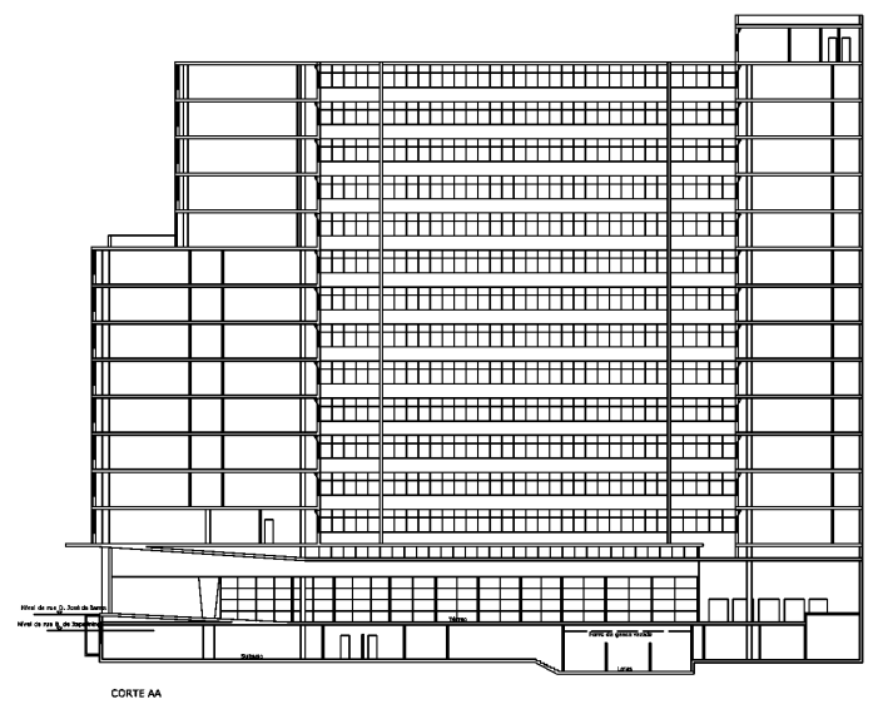

8.8: Corte pela Dom José de Barros

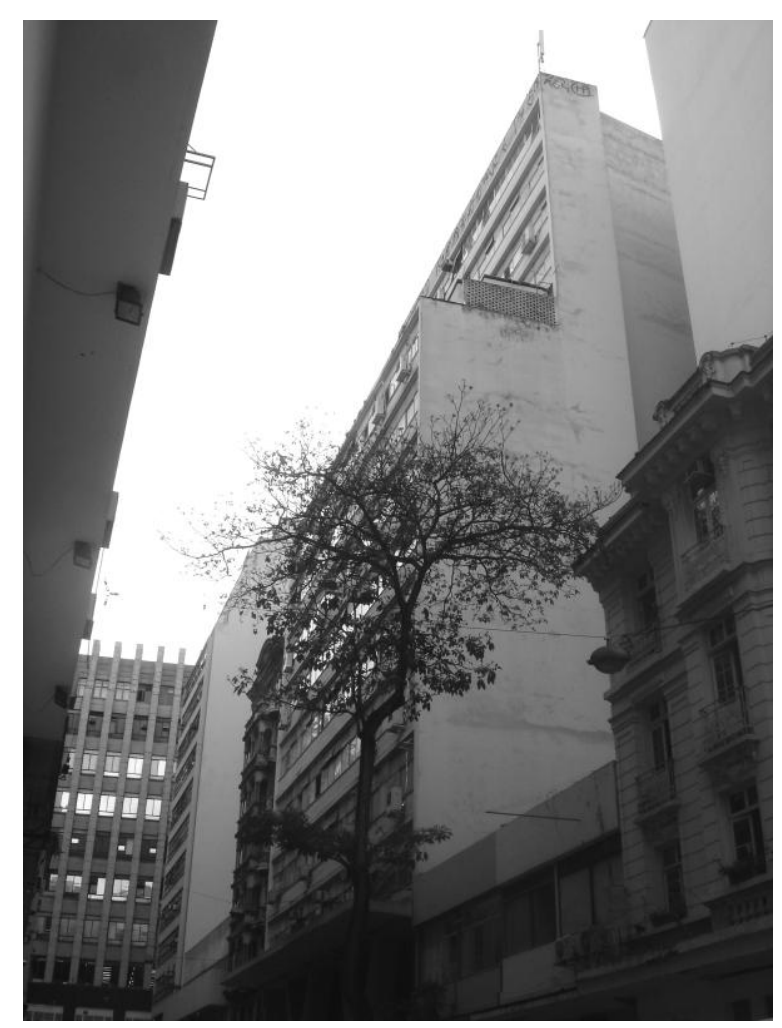

8.10: Foto pela Rua Dom José de Barros, 2009.

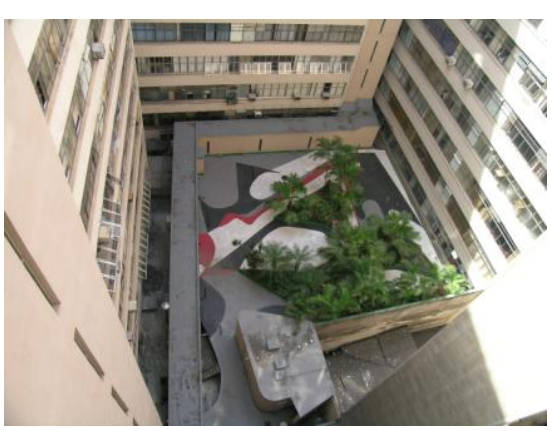

8.11: Galeria Califórnia Pátio, 2008.

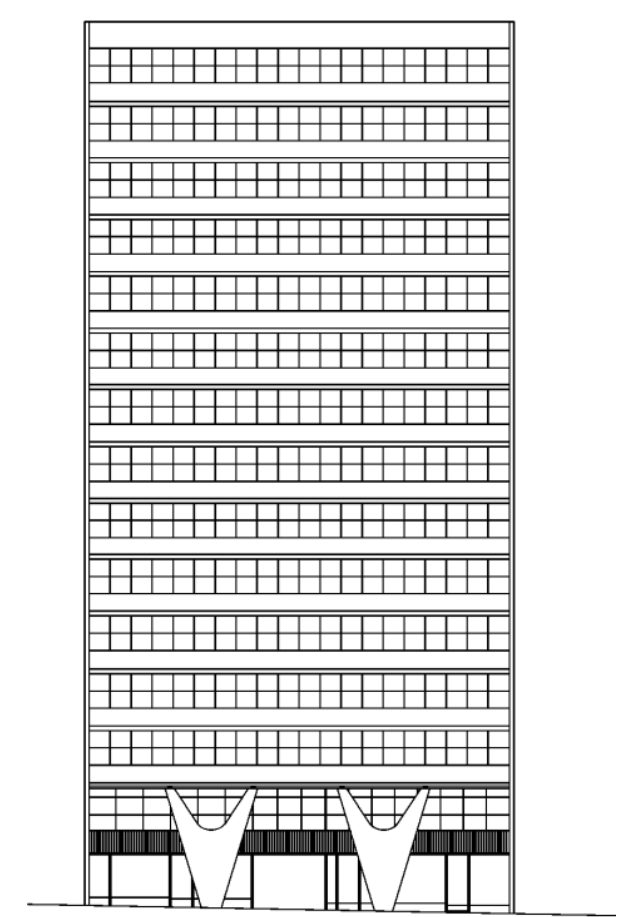

Rua D. José de Barros

8.9: Fachada Dom José 


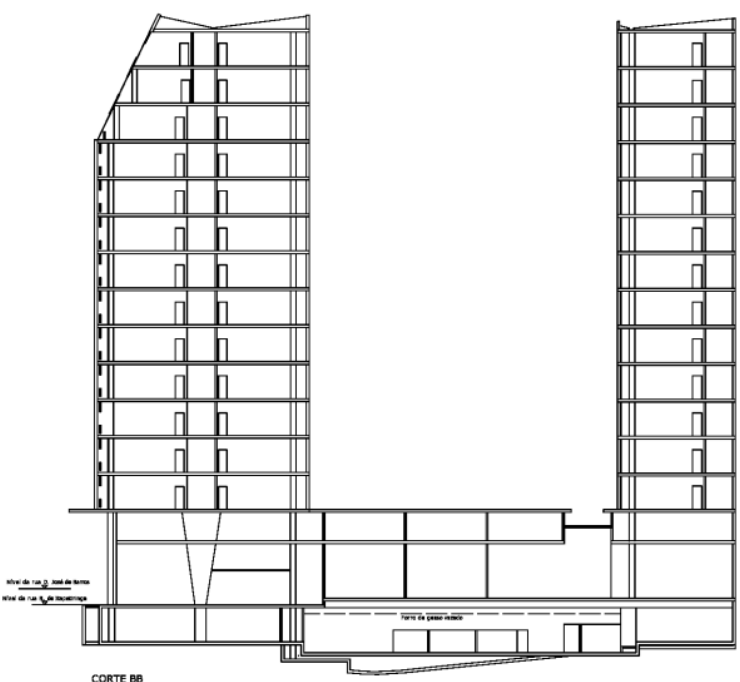

8.12: Corte pela Barão de Itapetininga

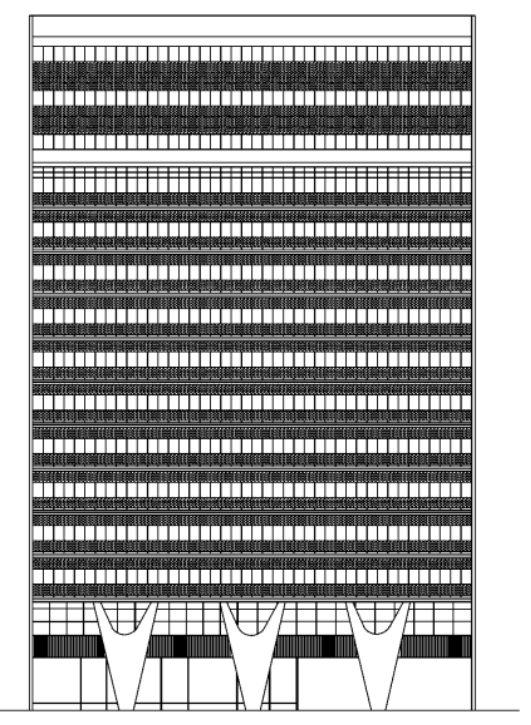

8.14: Califórnia, fachada Barão de Itapetininga

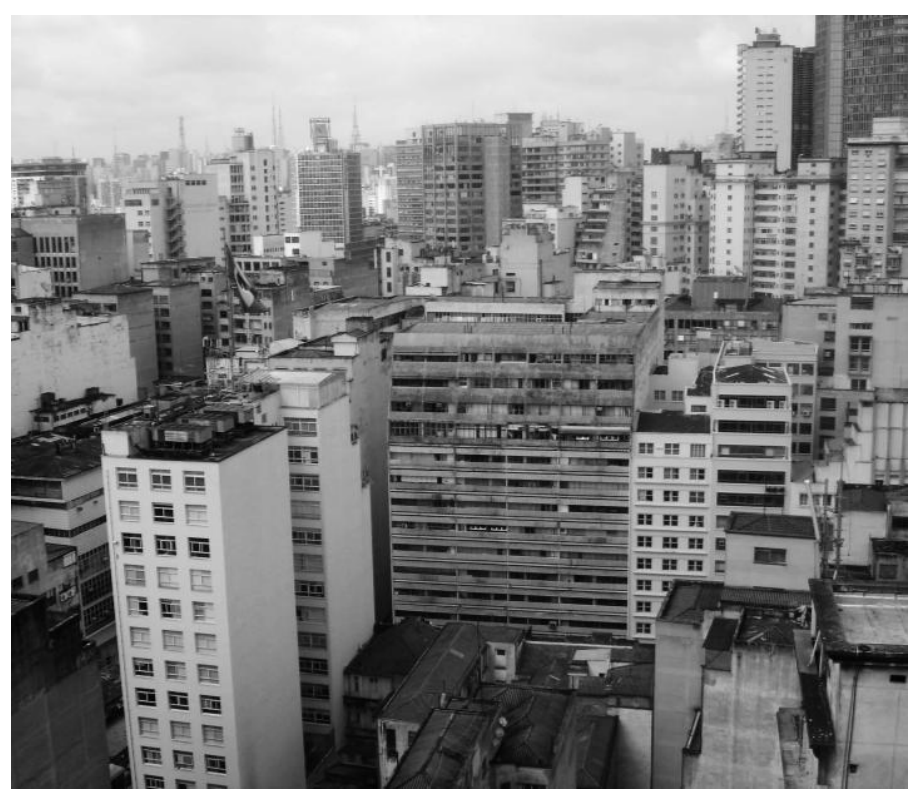

8.13: Califórnia vista para a Rua Barão de Itapetininga, pelo Hotel.Excelsior, 2009.

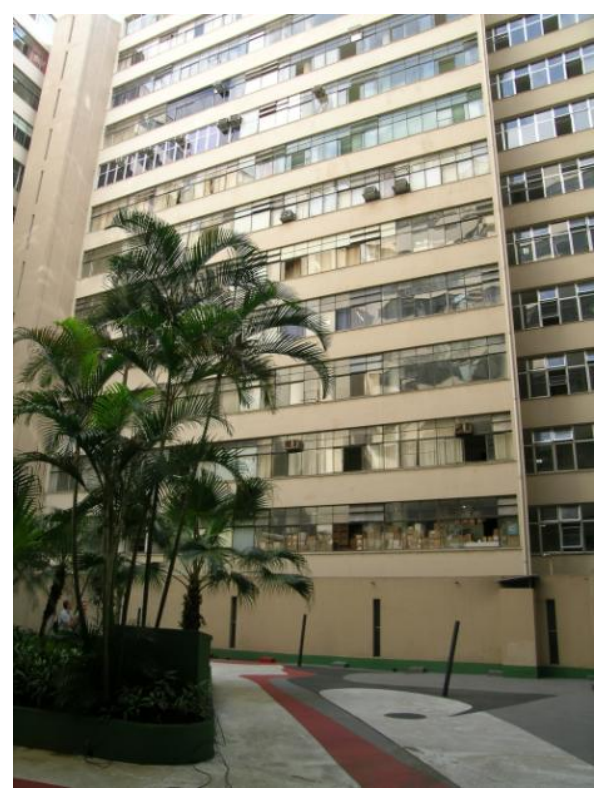

8.15: Califórnia, Vista pelo Pátio, 2008. 


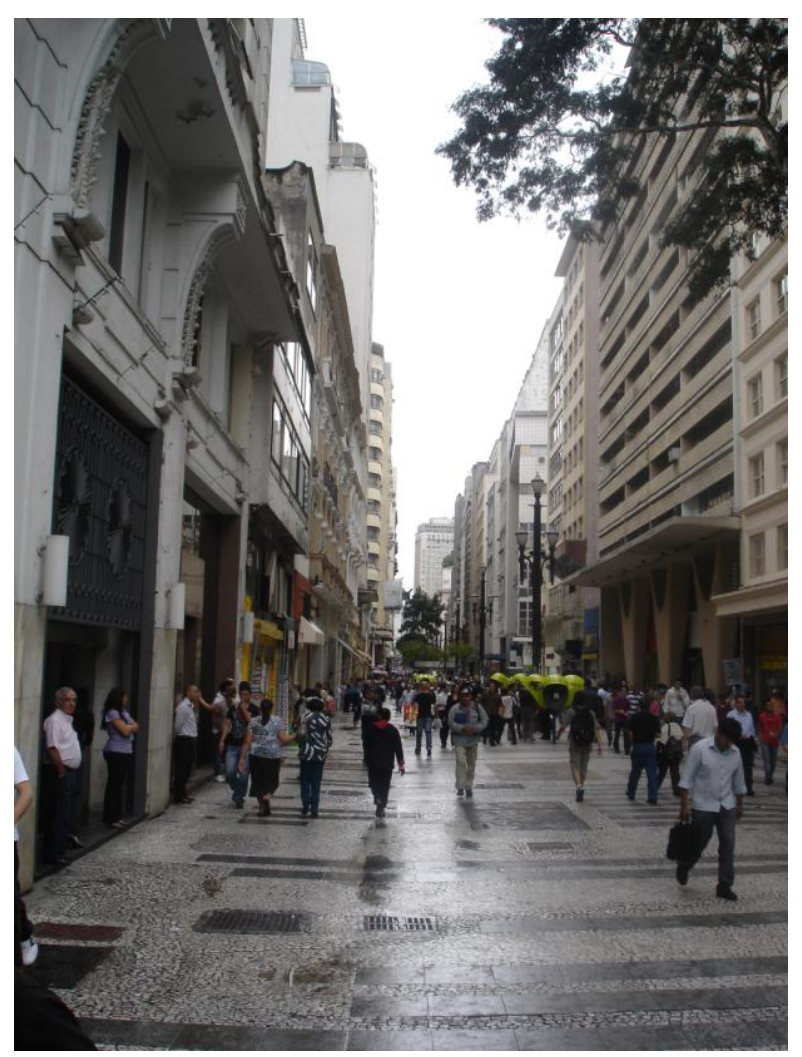

8.16: Barão de Itapetinga, 2009.

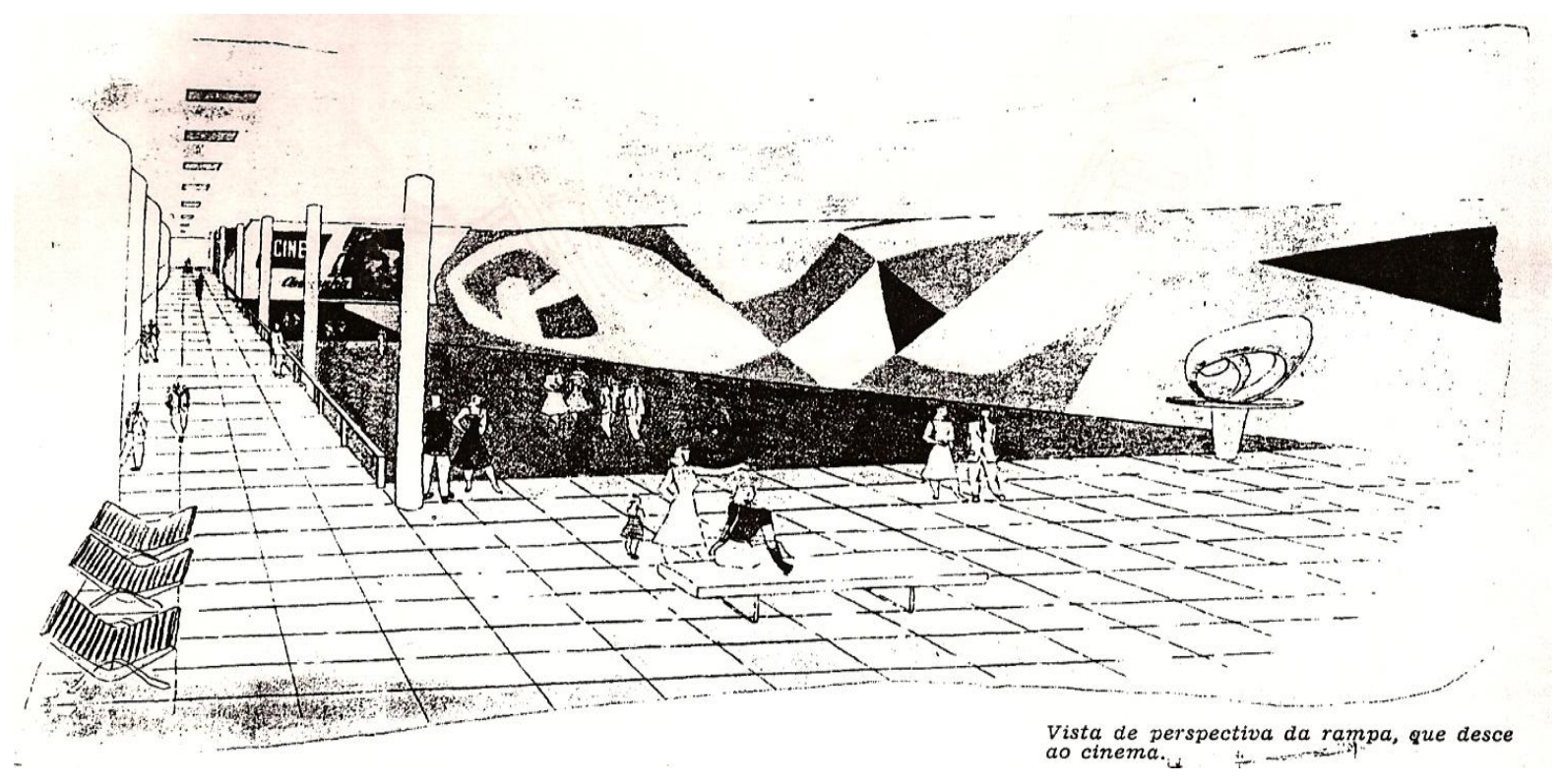

8.17: Galeria. 
Edifício Triângulo, 1953. (figuras 8.18 a 8.31)
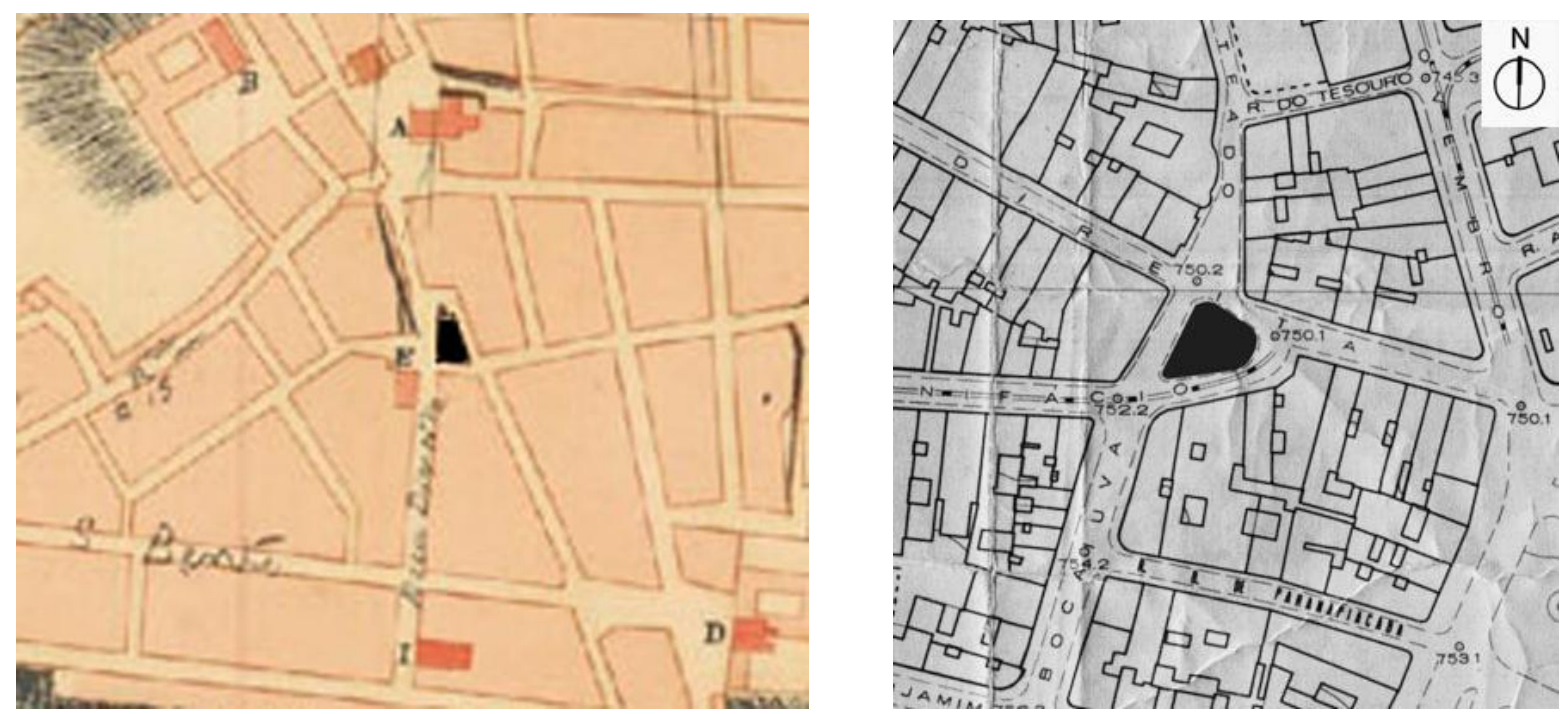

8.18: Vasp - cruzeiro, Fotografia

8.19: 1810

Cruzeiro

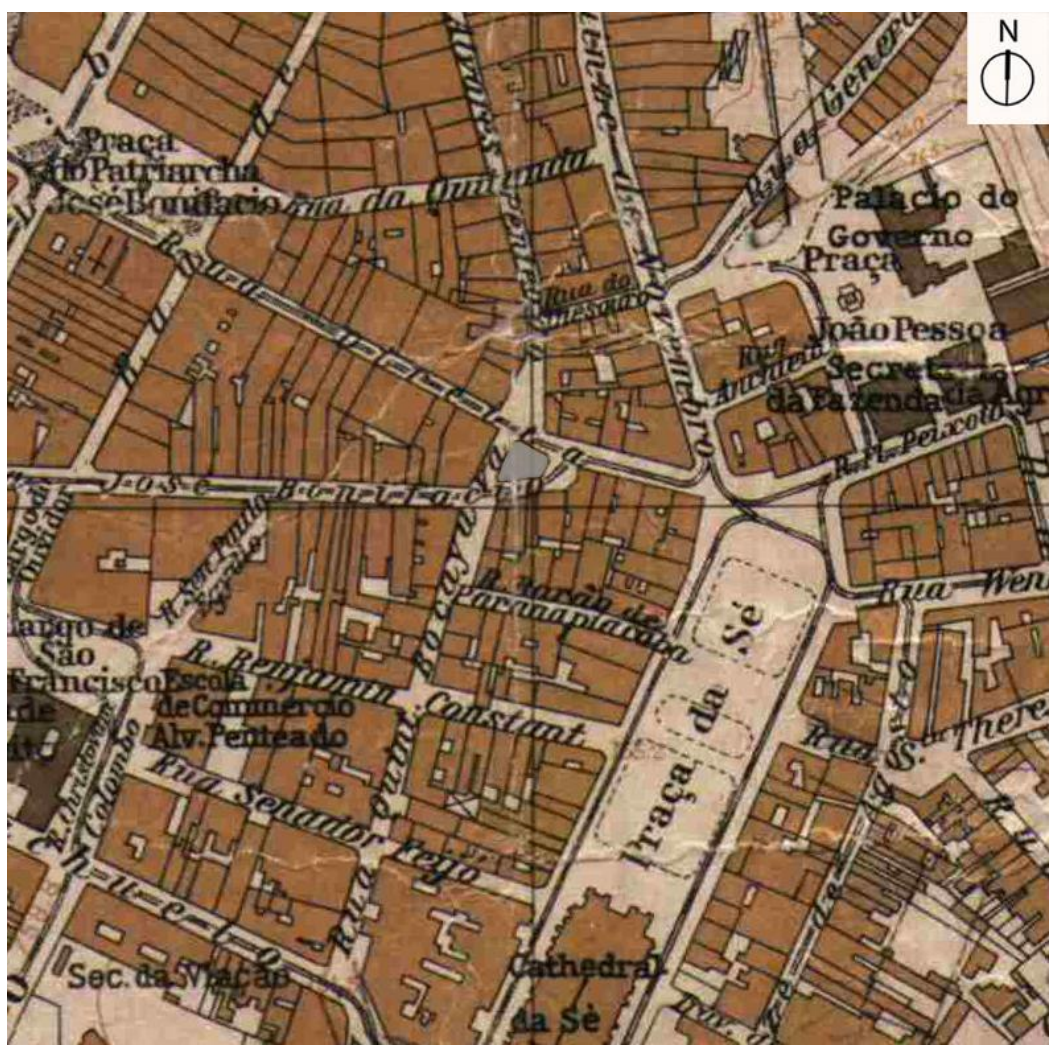

8.20: Sara Brasil, 1930.: 


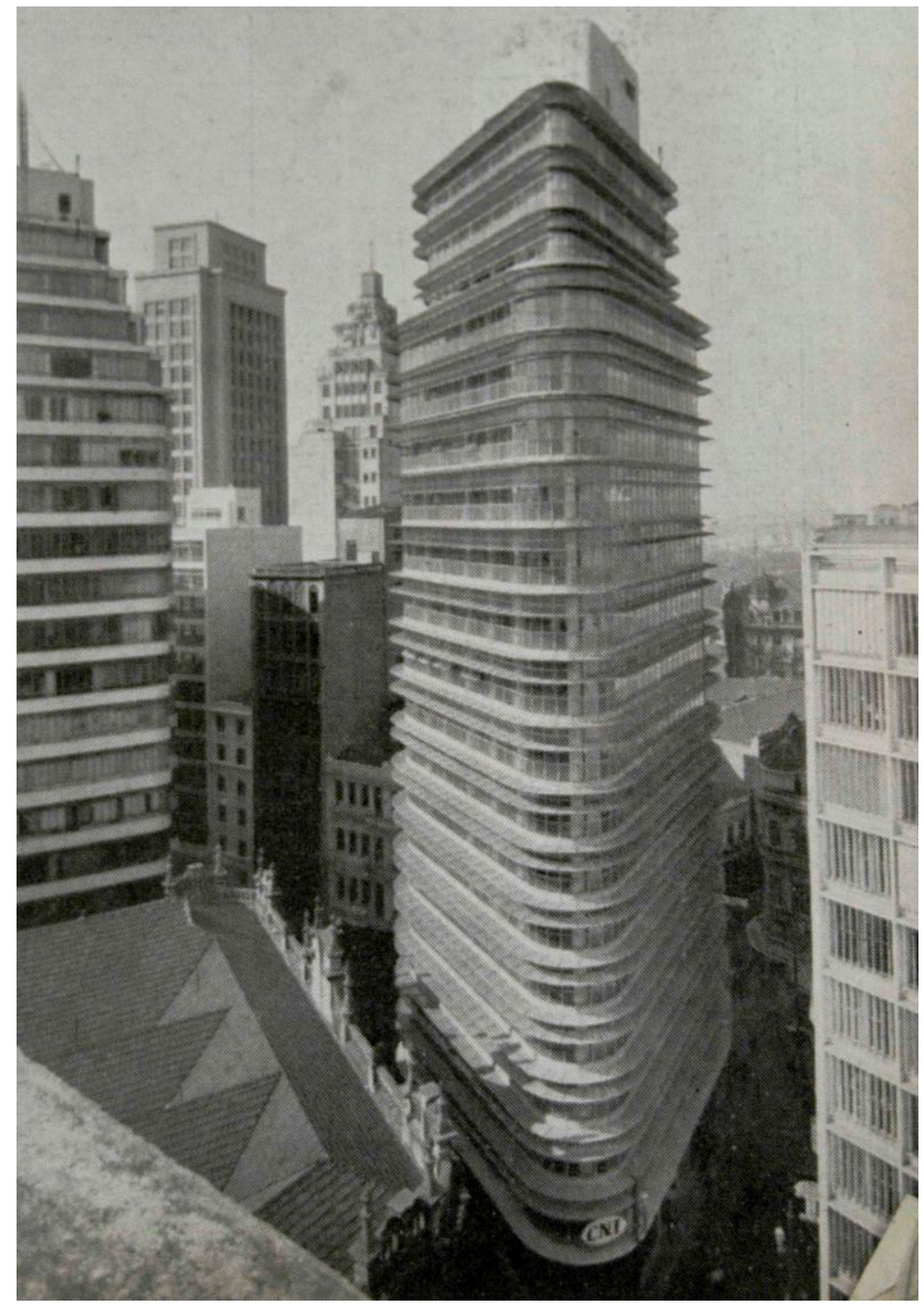

8.21: Edifício Triângulo com os brises originais

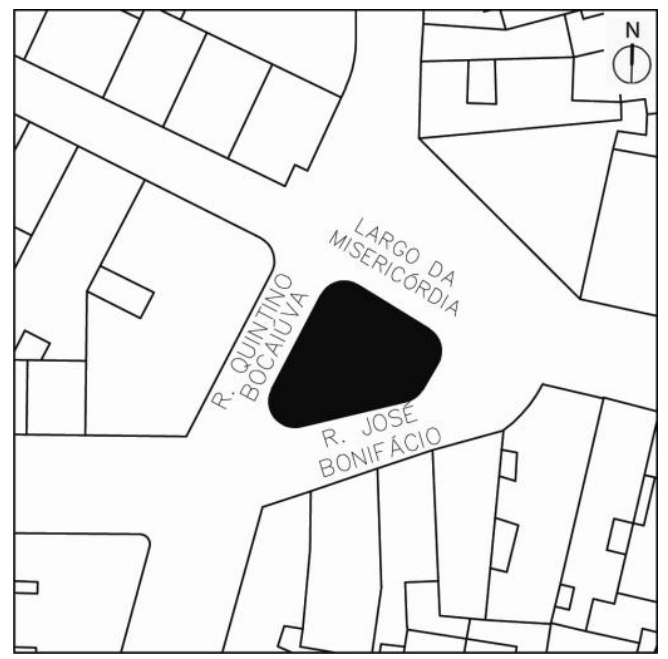

8.22: Situação atual, Gegran - Viva o Centro 


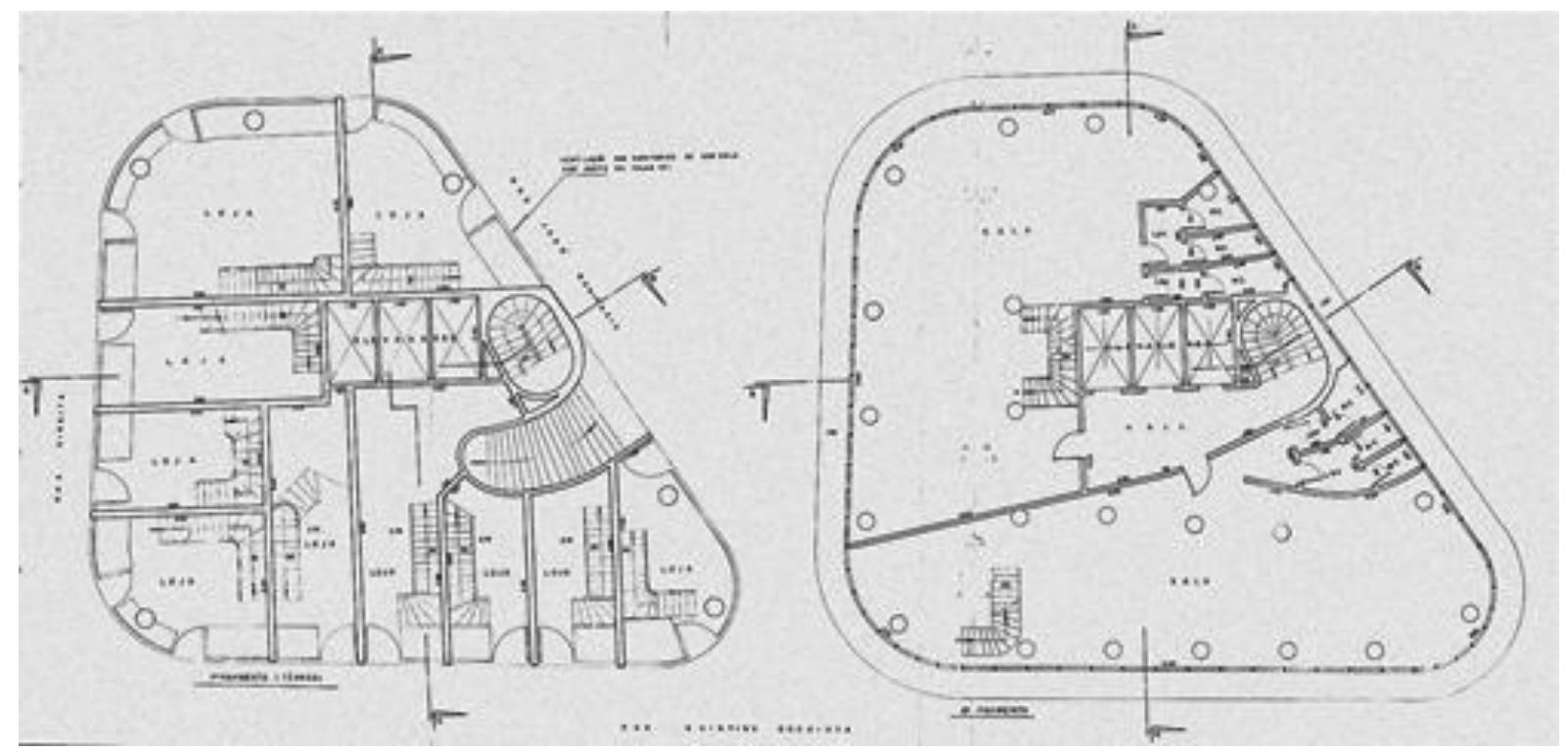

8.23 e 8.24: Plantas térreo e tipo

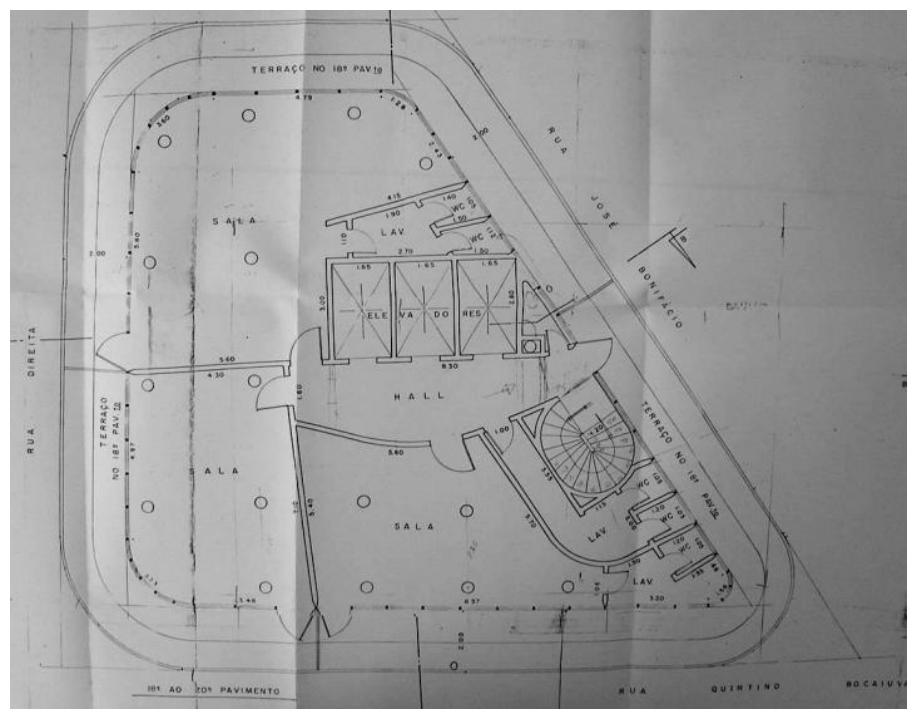

8.25: Planta do $18^{\circ}$ ao $20^{\circ}$

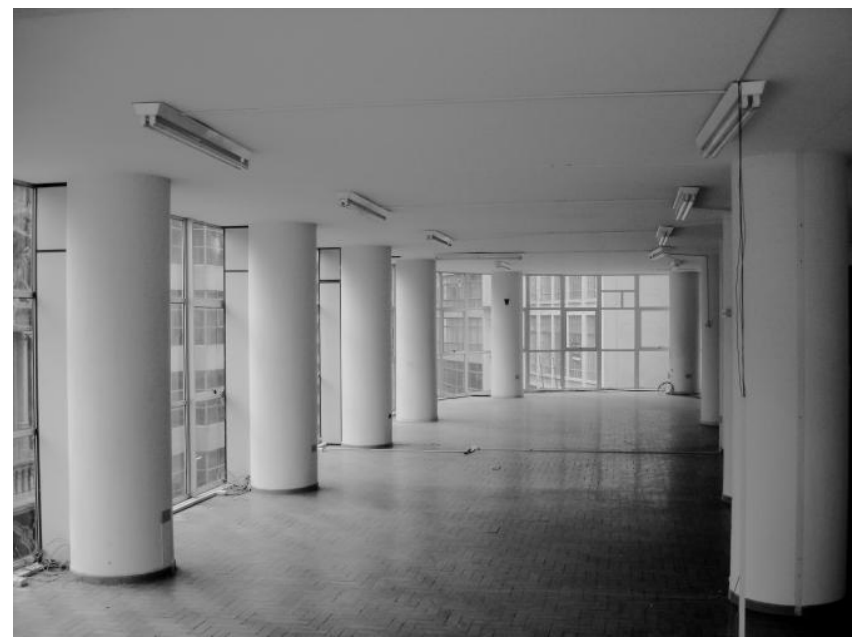

8.26: Edif. Triângulo, 2009

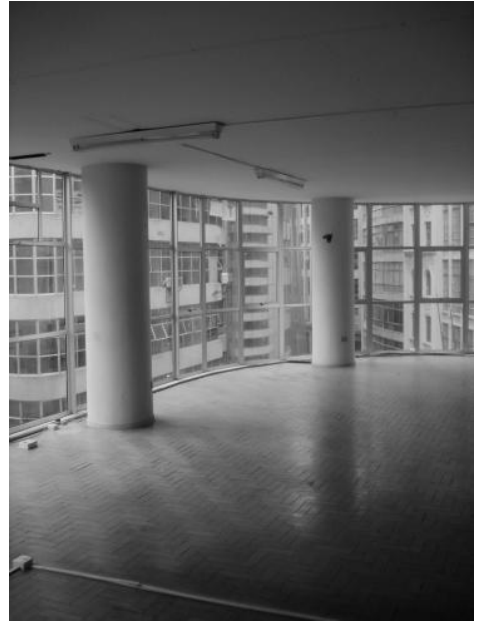

8.27: interior, 2009: 


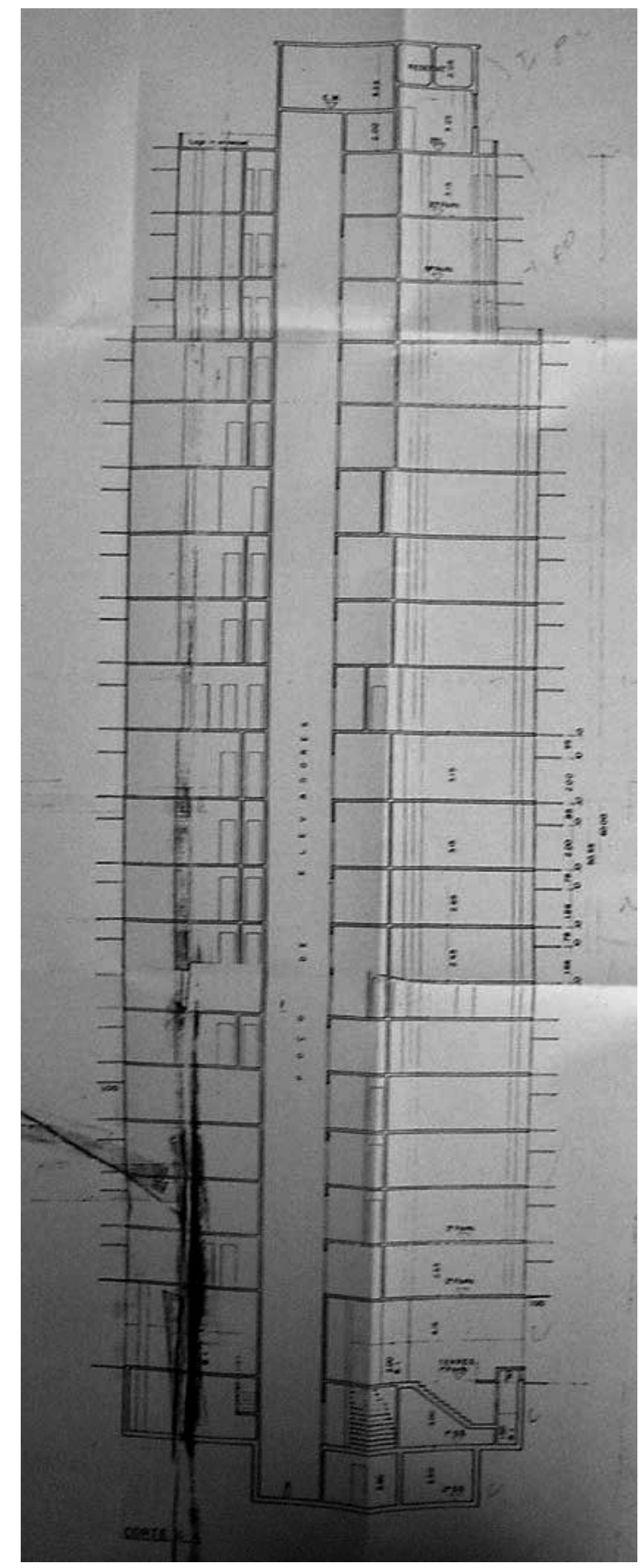

8.28: Edif. Triângulo, Corte AA

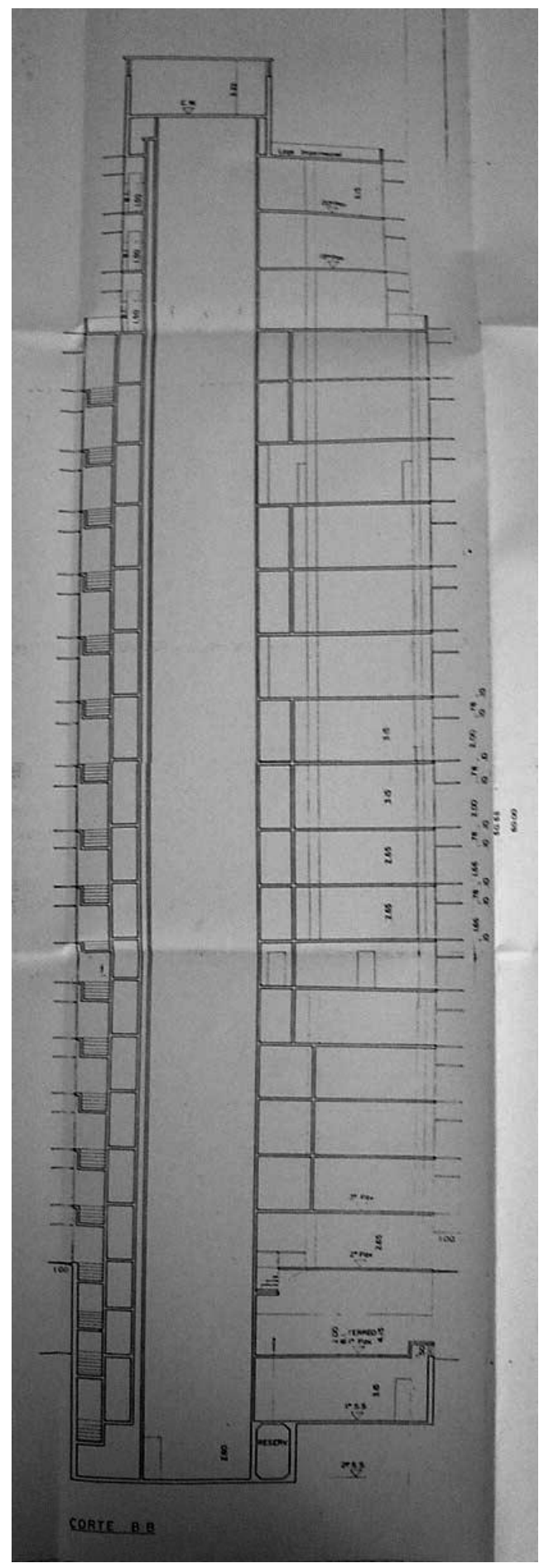

8.29: Edif. Triângulo, Corte BB 

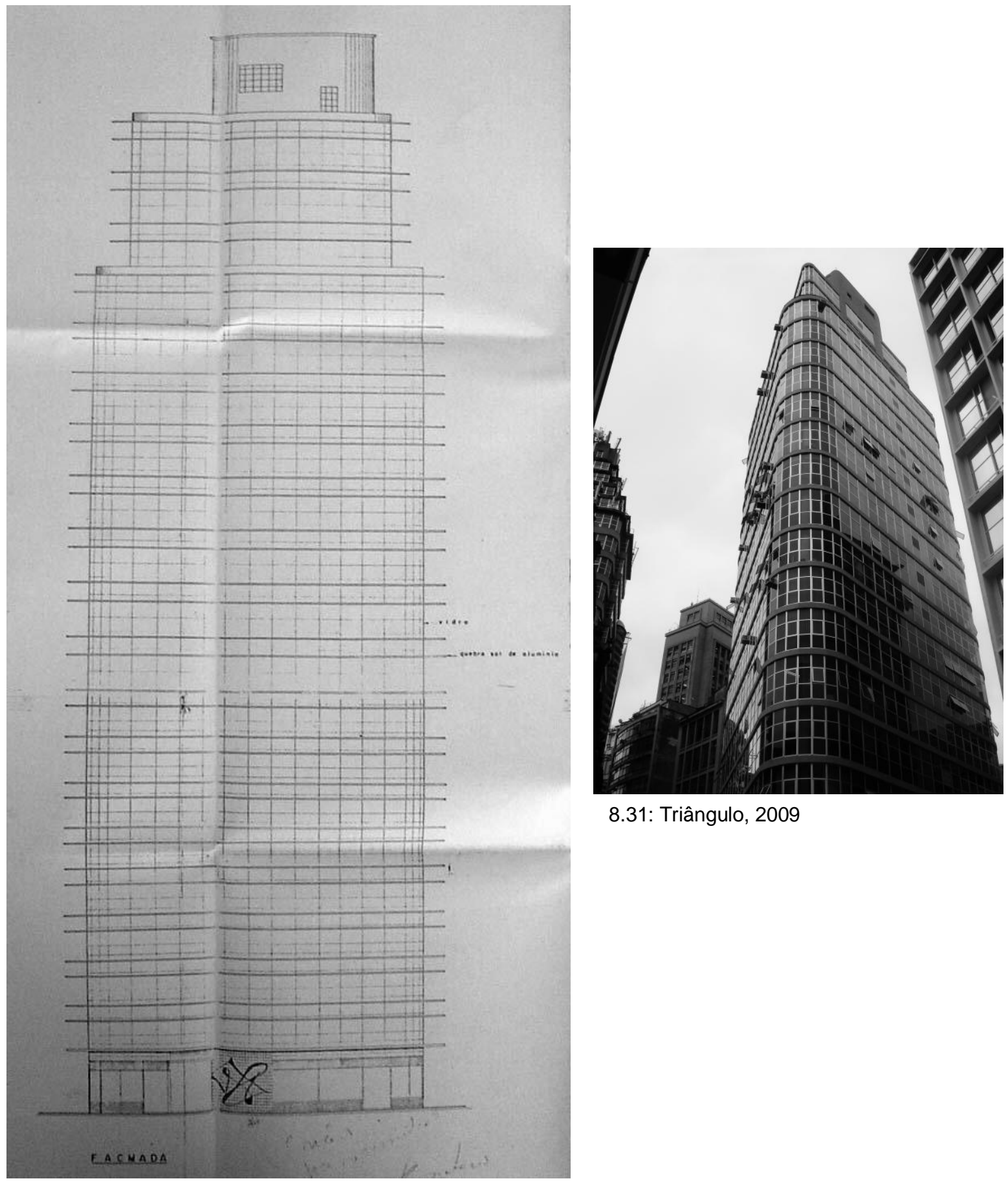

8.31: Triângulo, 2009

8.30: Fachada pela José Bonifácio 
Edifício Eiffel, 1956. (figuras 8.32 a 8.46)

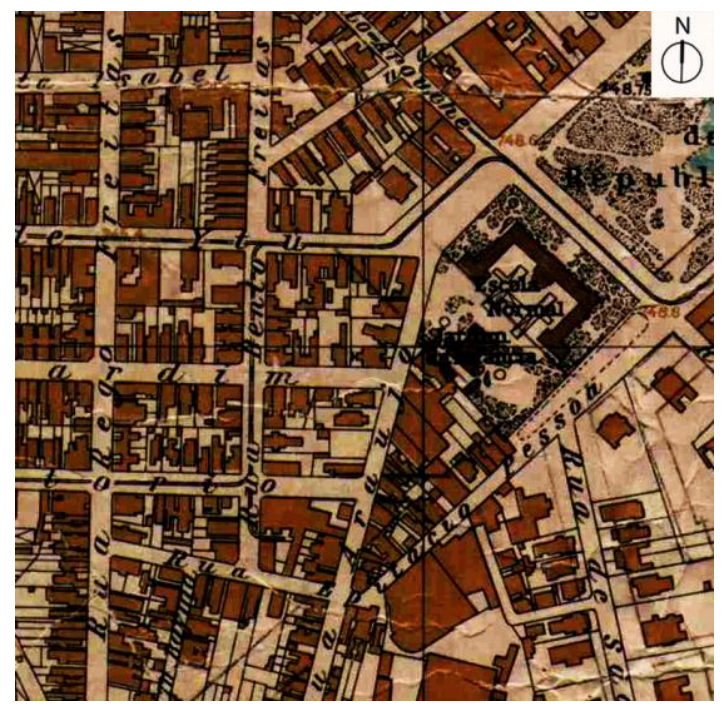

8.32: Sara Brasil

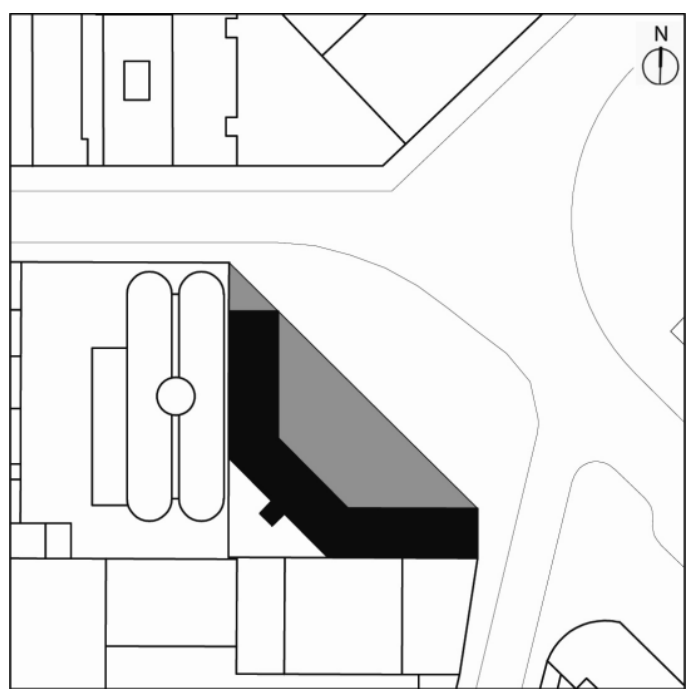

8.33: Situação atual: em cinza corpo mais baixo e preto a Torre.

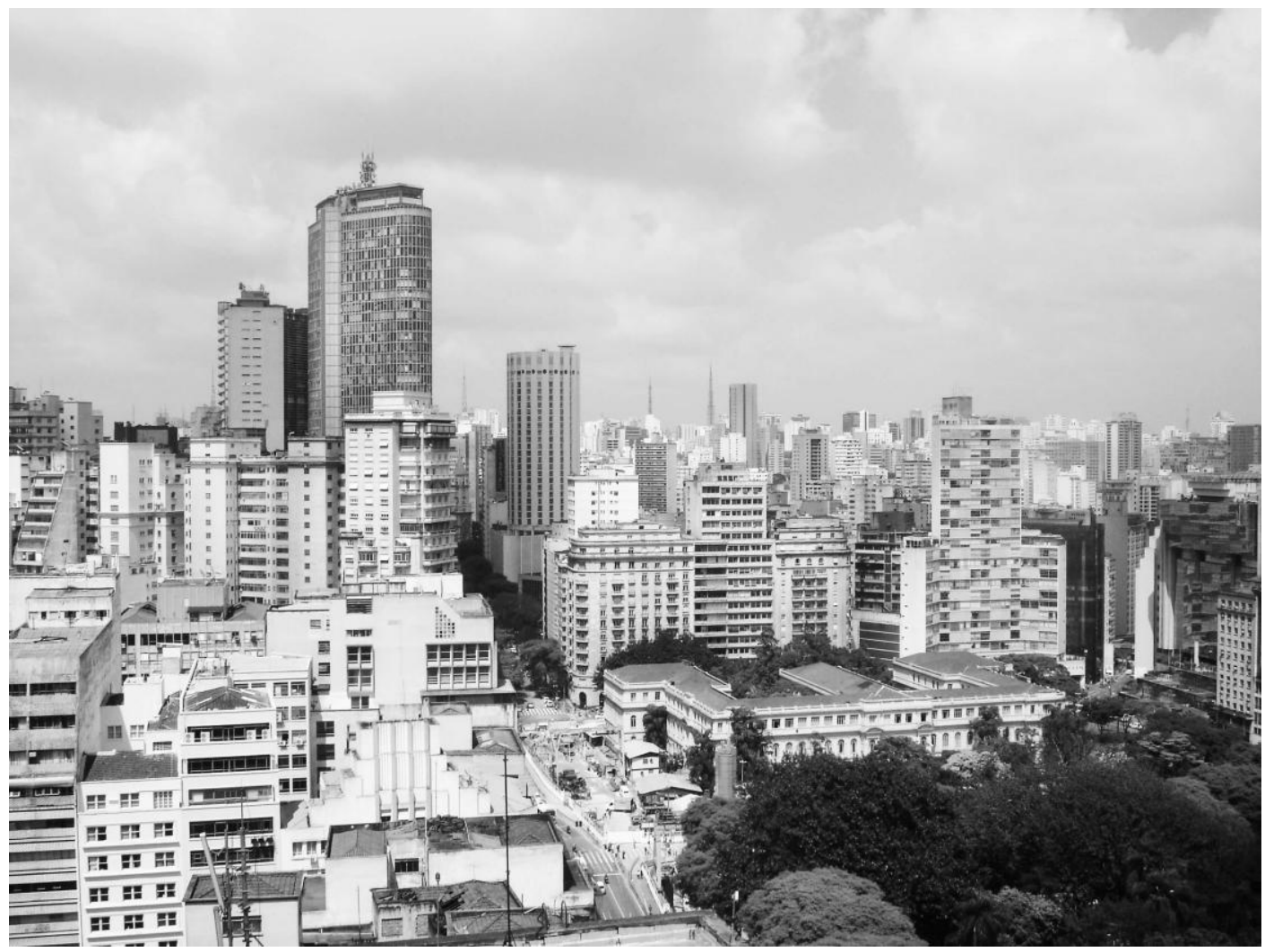

8.34: Fotografia panorâmica. Ponto de referência: Hotel Excelsior 

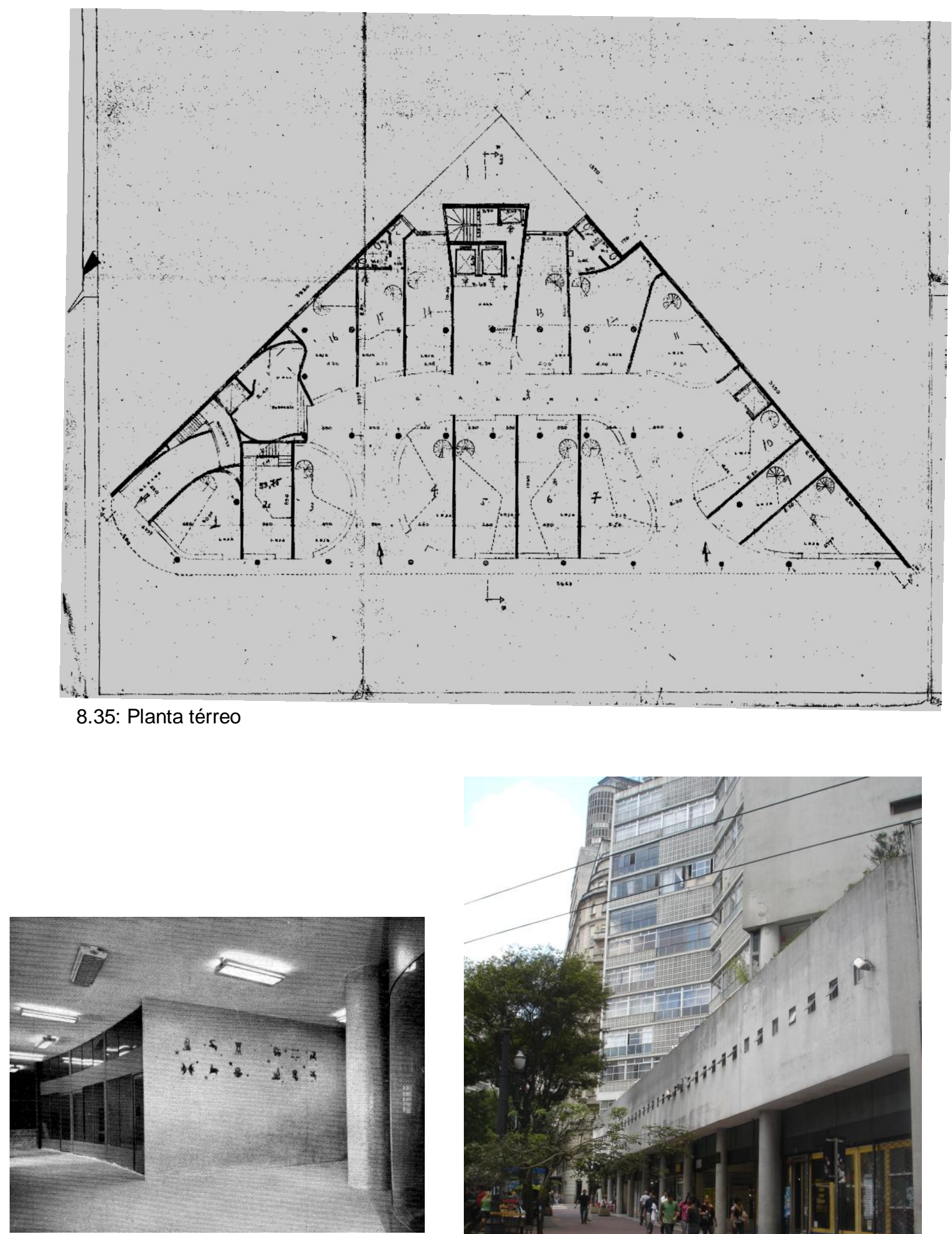

8.36: Foto interna pela galeria de comércio

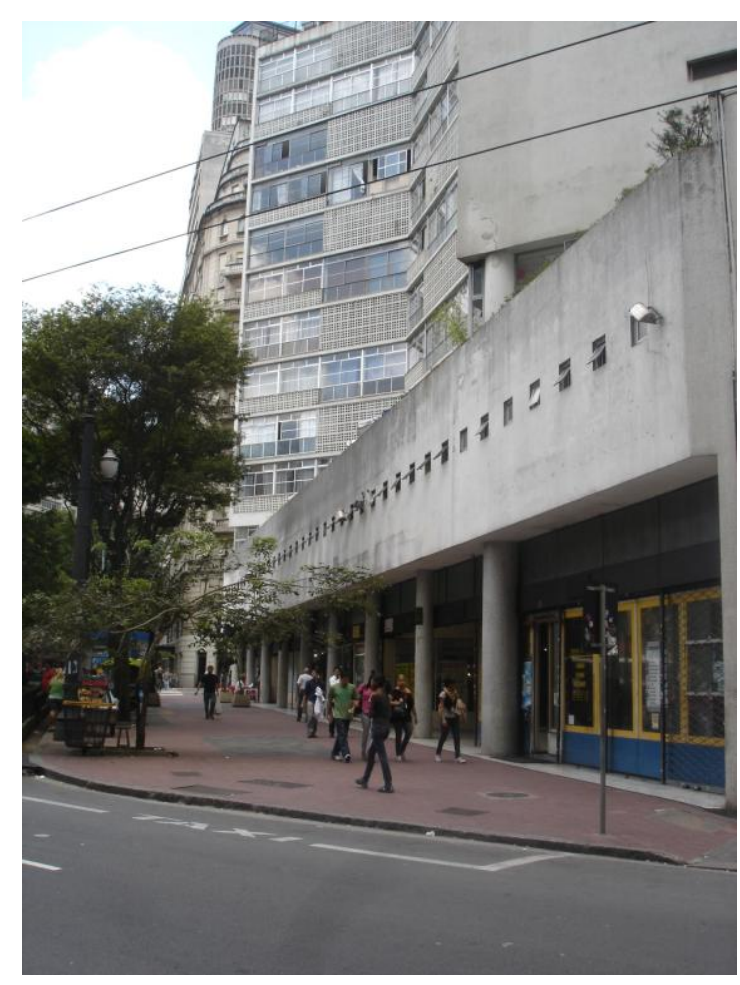

8.37:Eiffel, 2009, pelo chão 

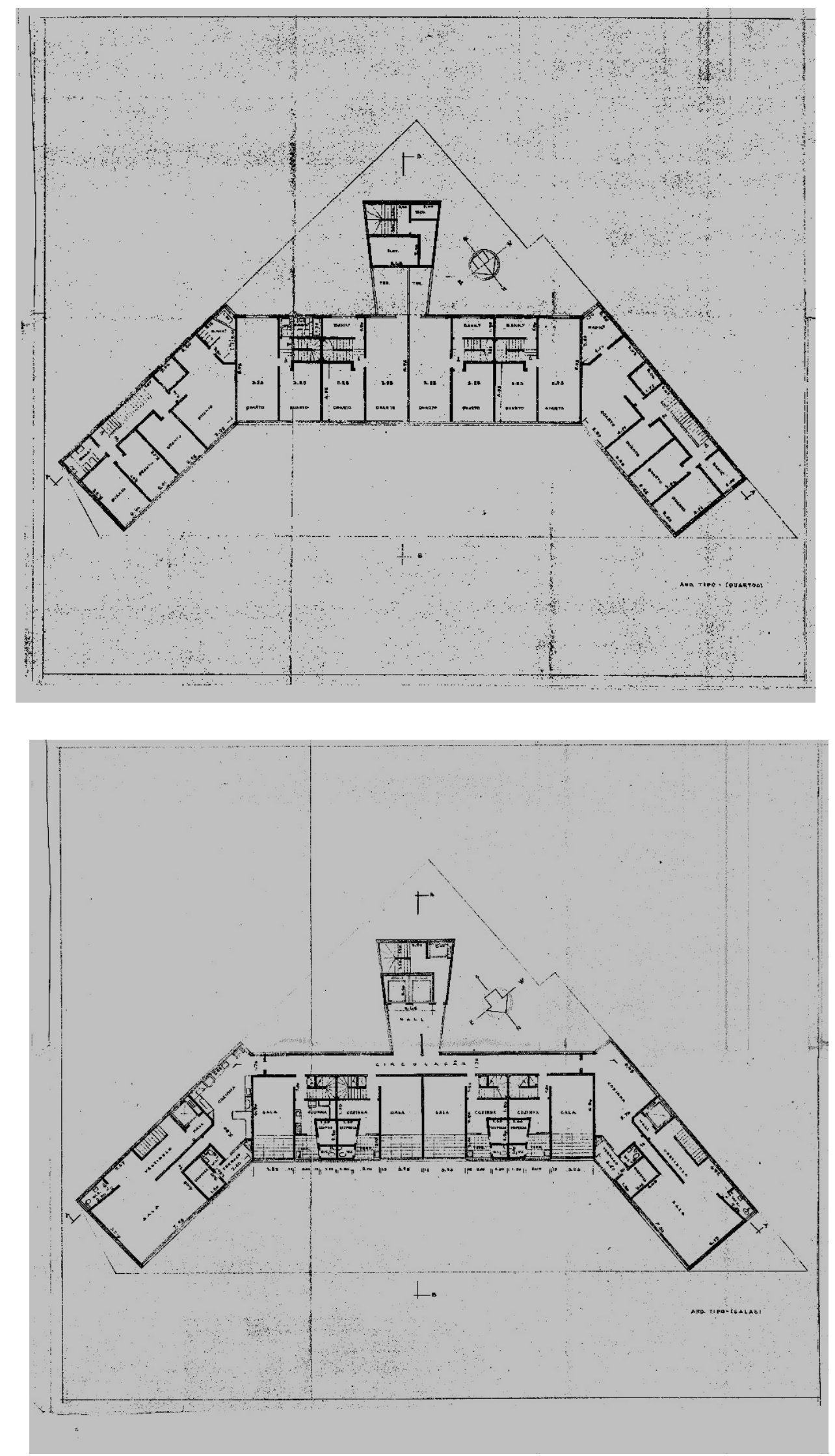

8.38 e 8.39: Respectivamente; tipo social e dormitórios - apartamentos duplex: 

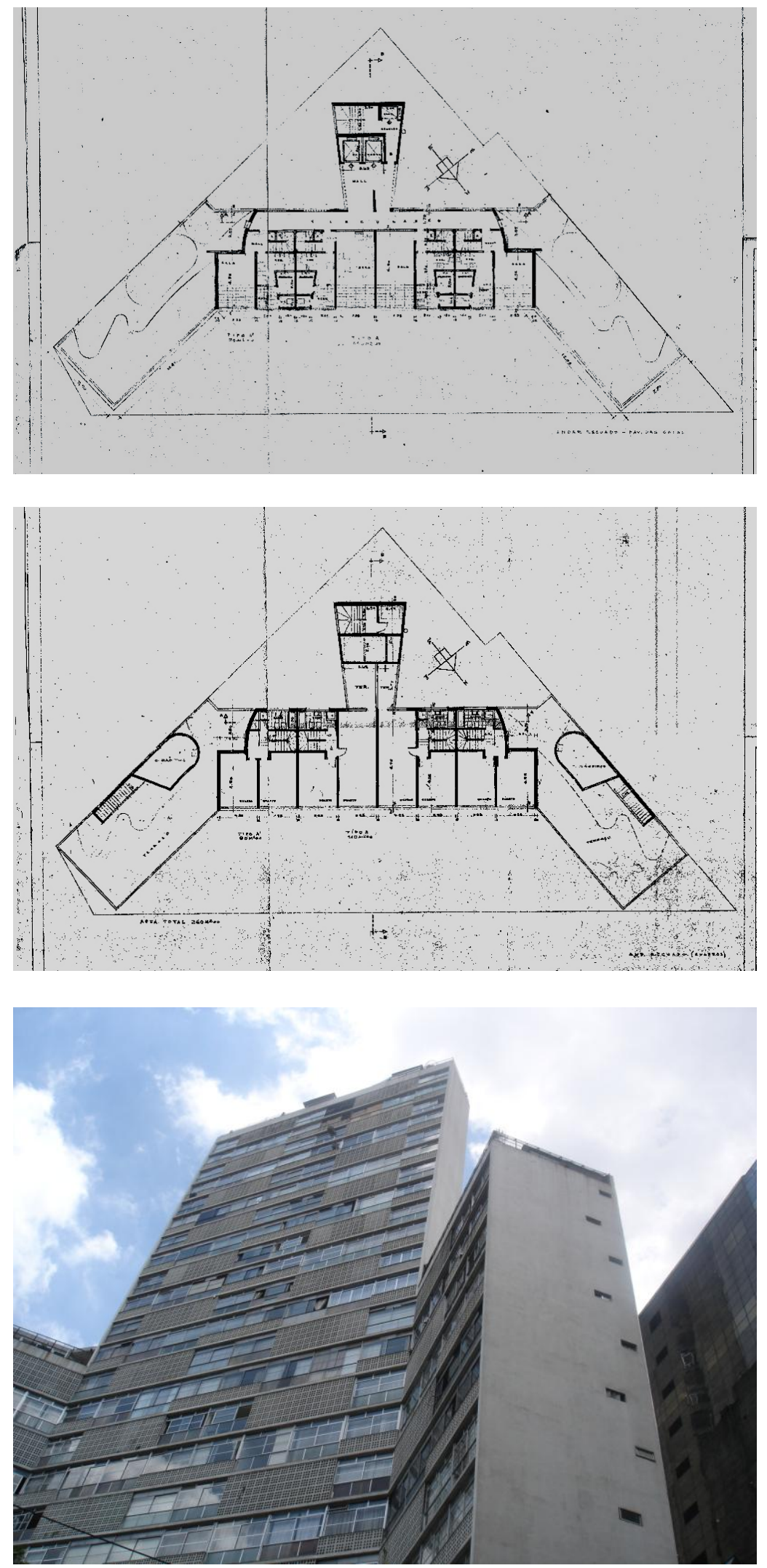

8.40, 8.41 e 8.42: de baixo para cima; 2009; piso dormitórios e piso social planta da torre 

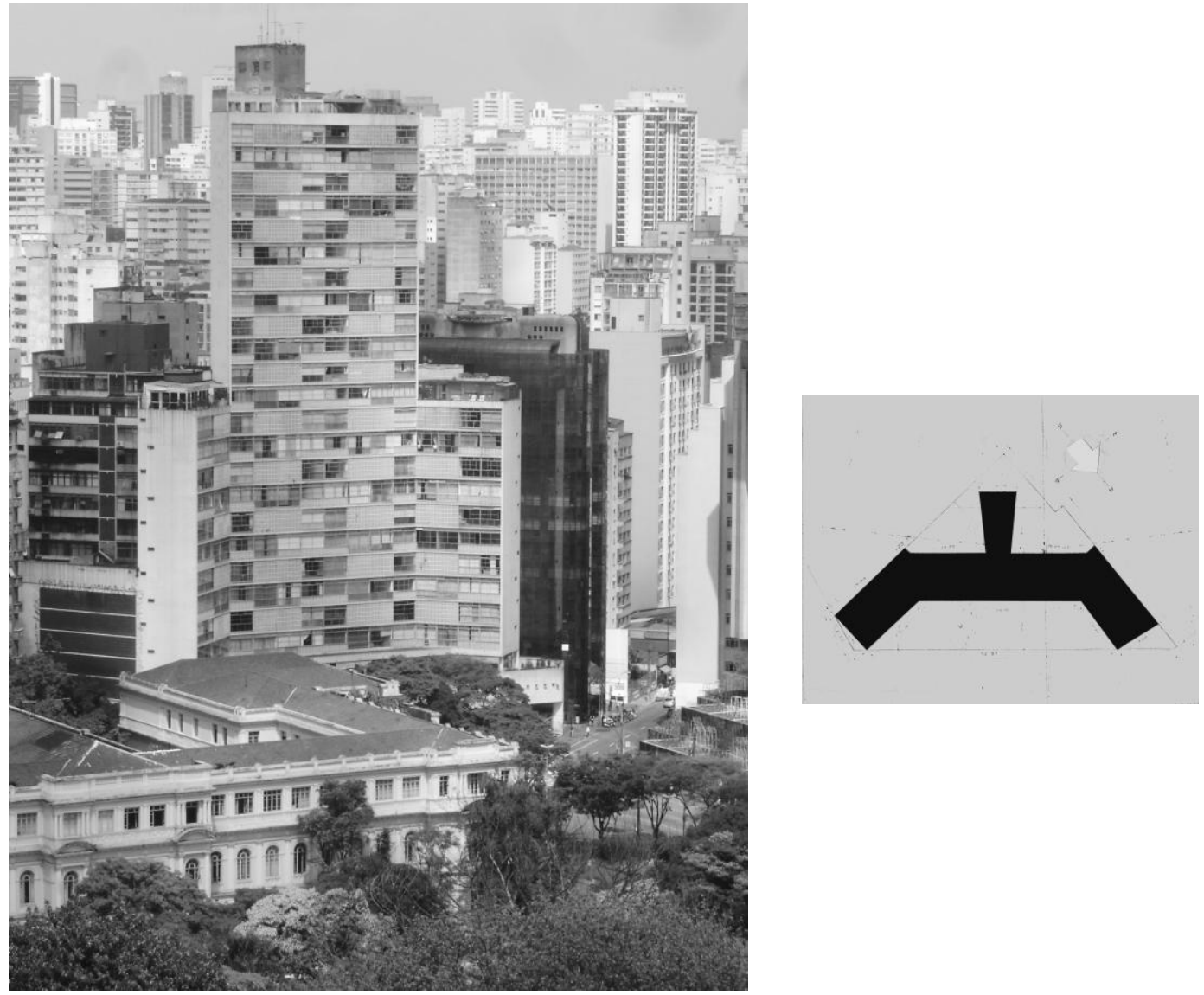

8.43 e 8.4: Eiffel, 2009 e esquema volumétrico.
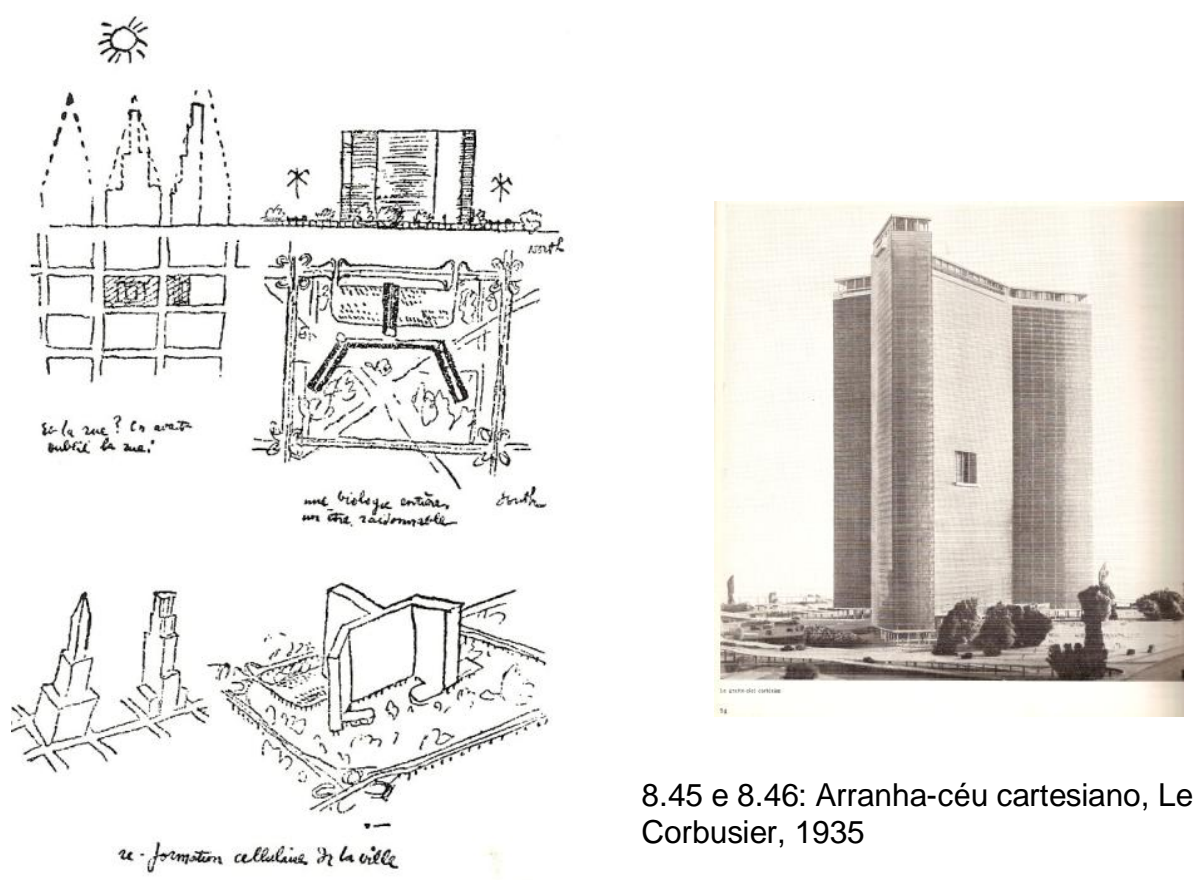

8.45 e 8.46: Arranha-céu cartesiano, Le Corbusier, 1935 
Edifício COPAN, 1951. (figuras 8.47 a 8.61 )

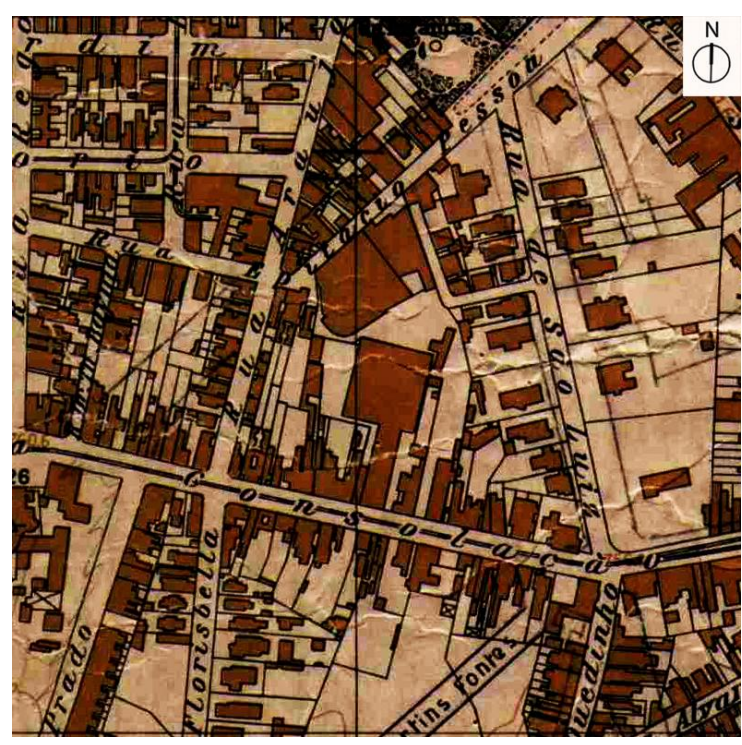

8.47: Sara Brasil, 1930

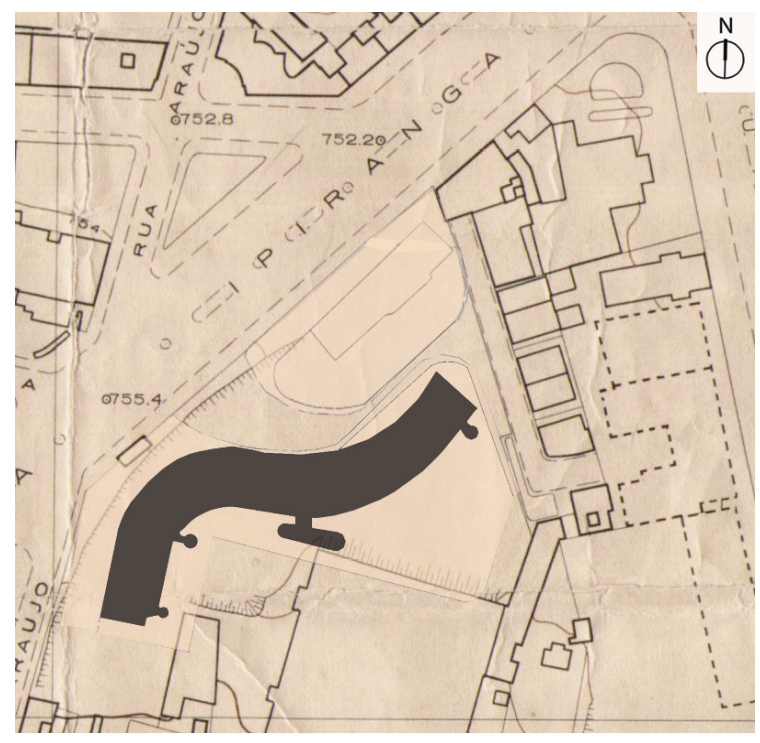

8.48: Vasp-Cruzeiro, 1954

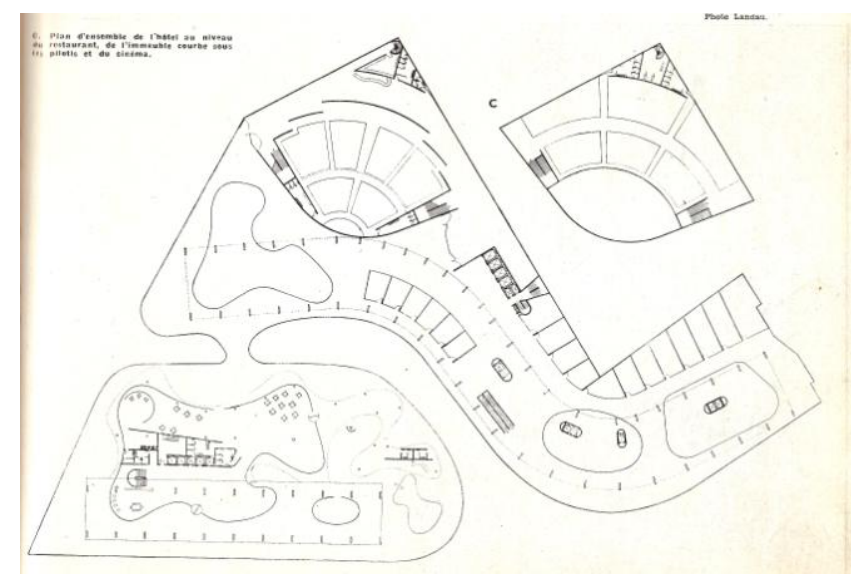

8.49: Proposta inicial do Conjunto; com Hotel e Edifício de Apartamentos
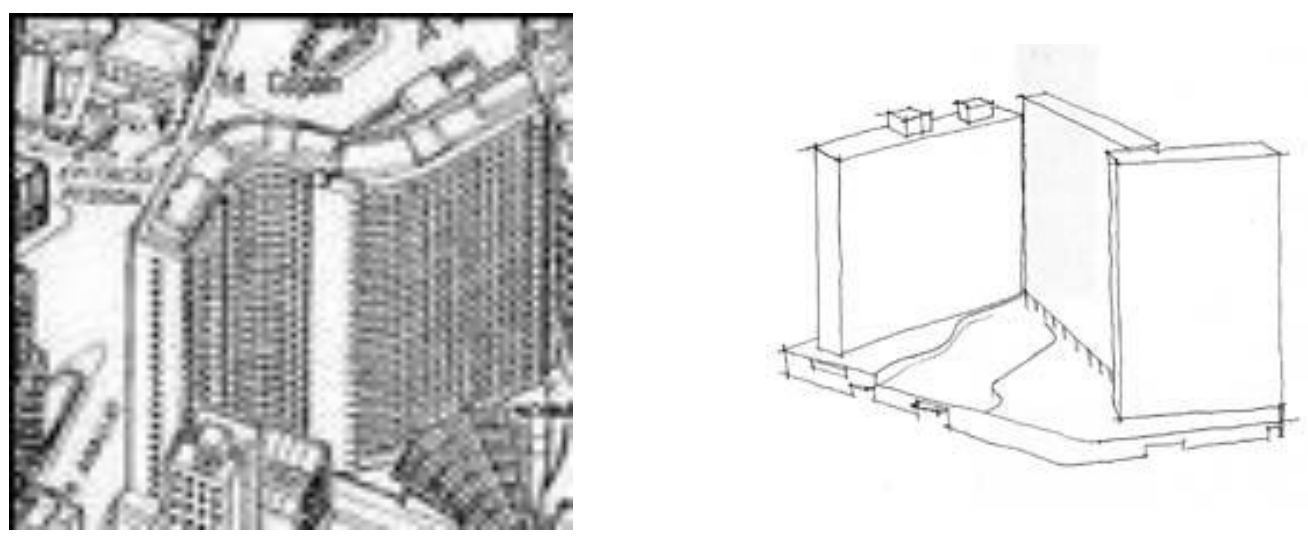

8.50: Primeiro estudo, elaborado pelo escritório norte-americano Holabird, Root \& Burgee. 8.51: Croqui sobre proposta americana , por Marcos Carrilho. 

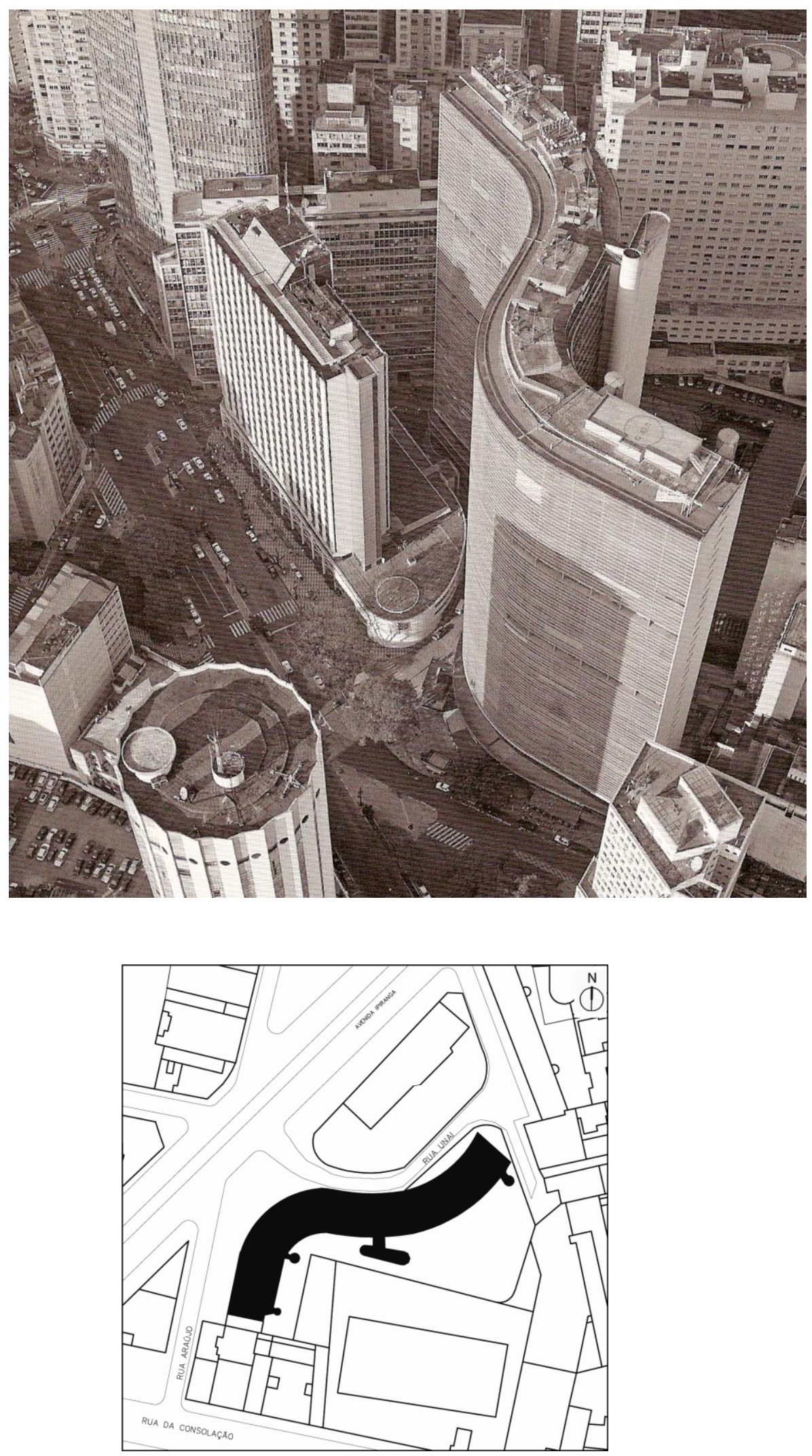

8.52: Copan, aérea e 8.53, implantação sobre base Gegran / Viva o Centro. 


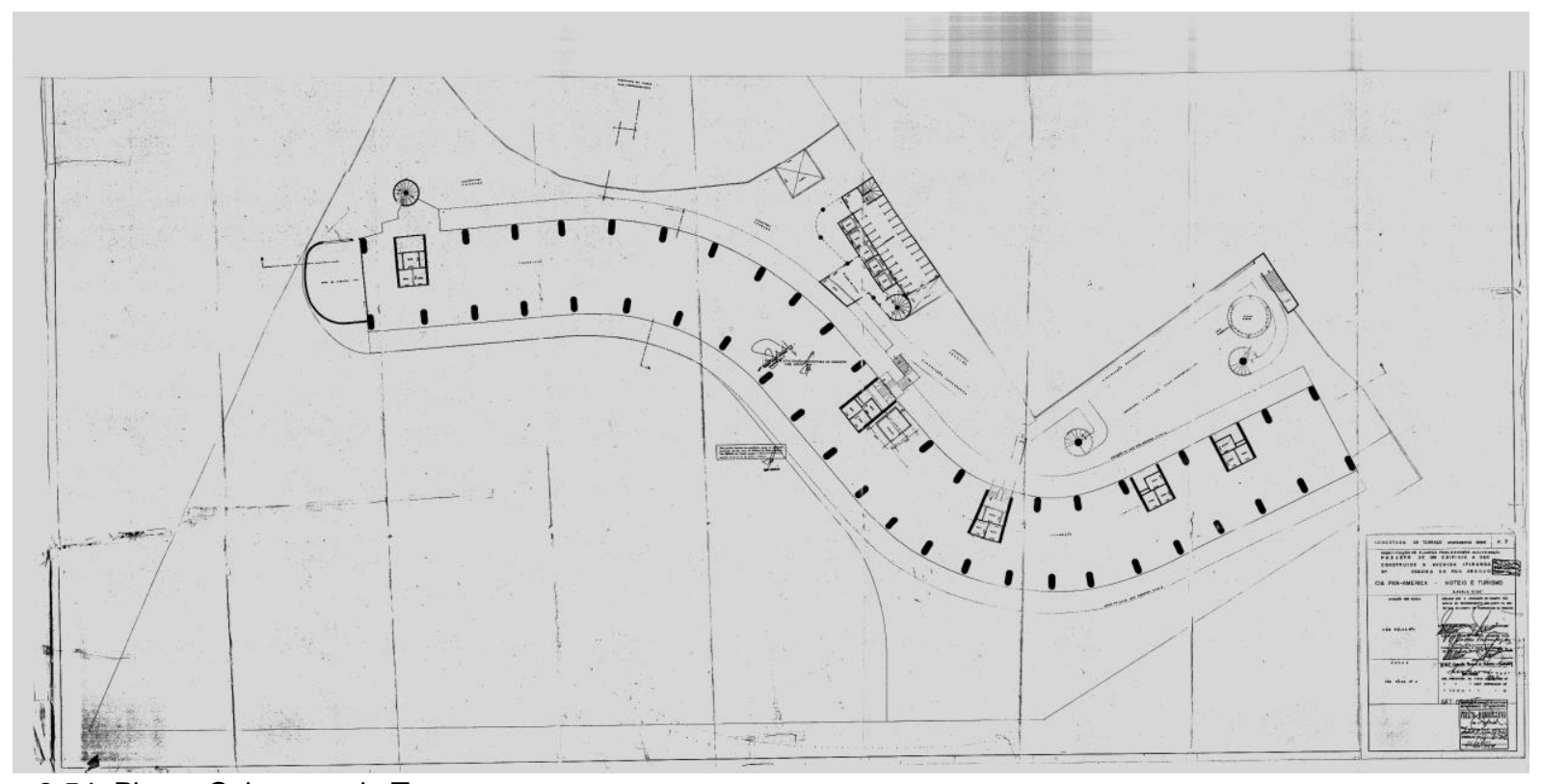

8.54: Planta Cobertura do Terraço

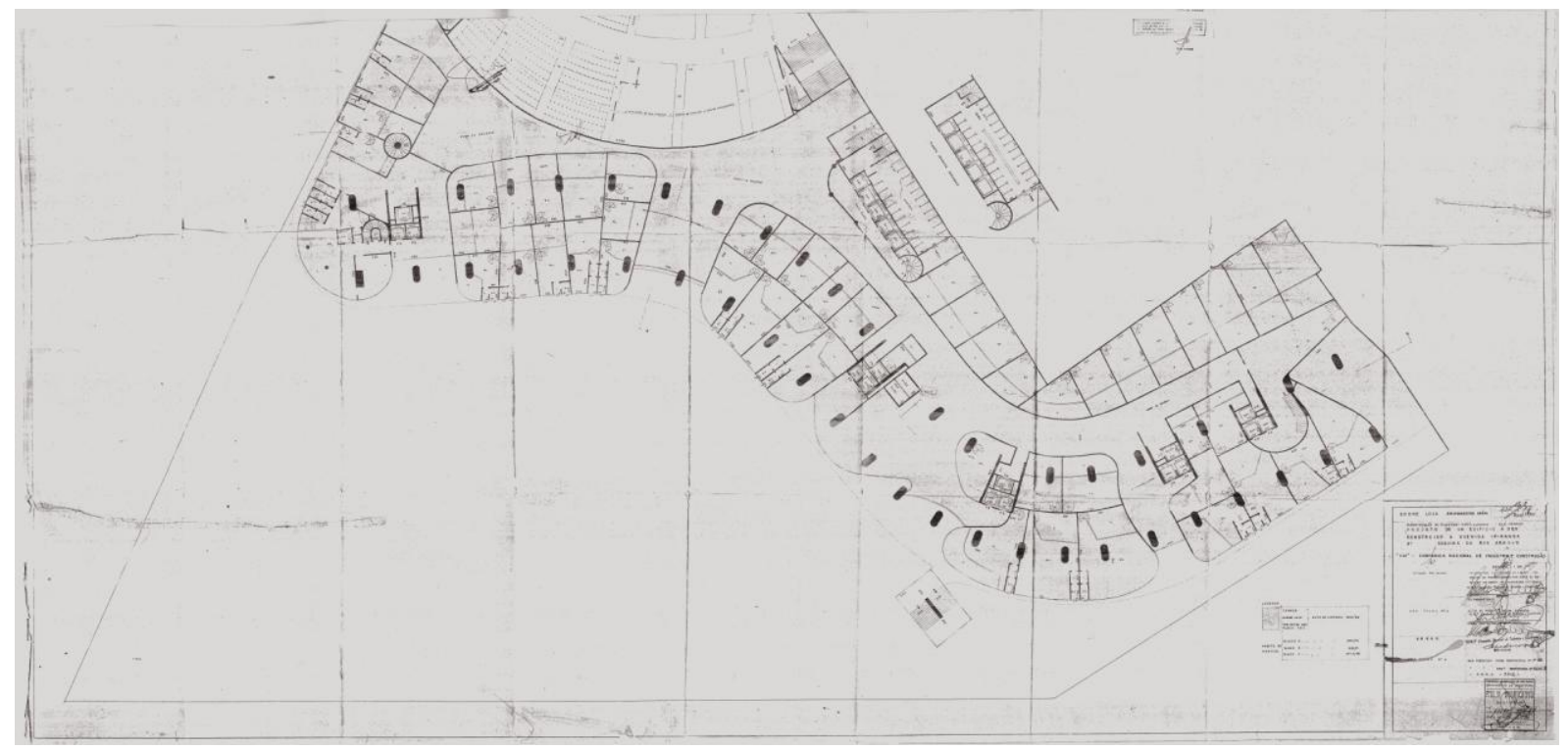

8.55: Planta Pavimento Térreo 


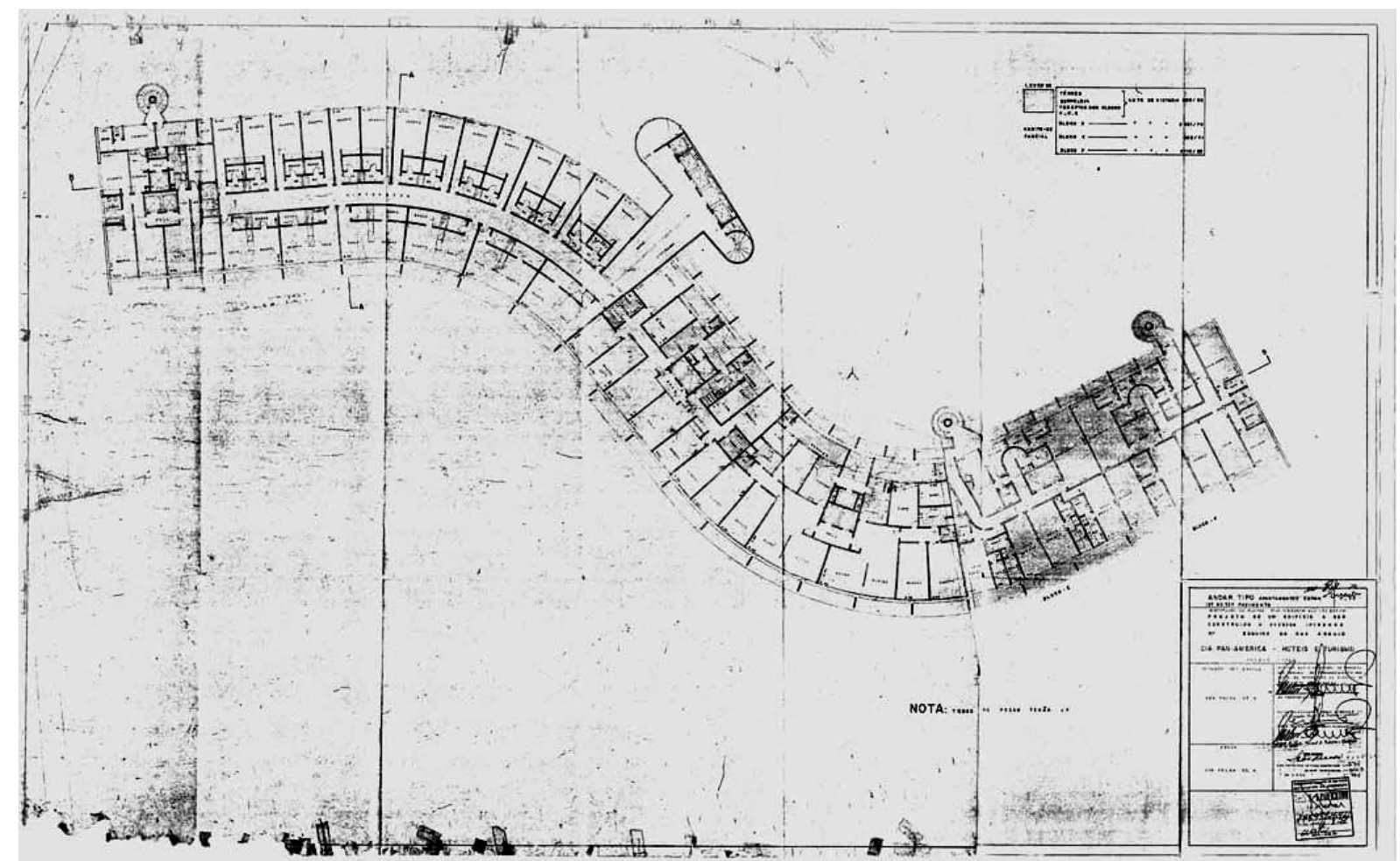

8.56: Planta Tipo

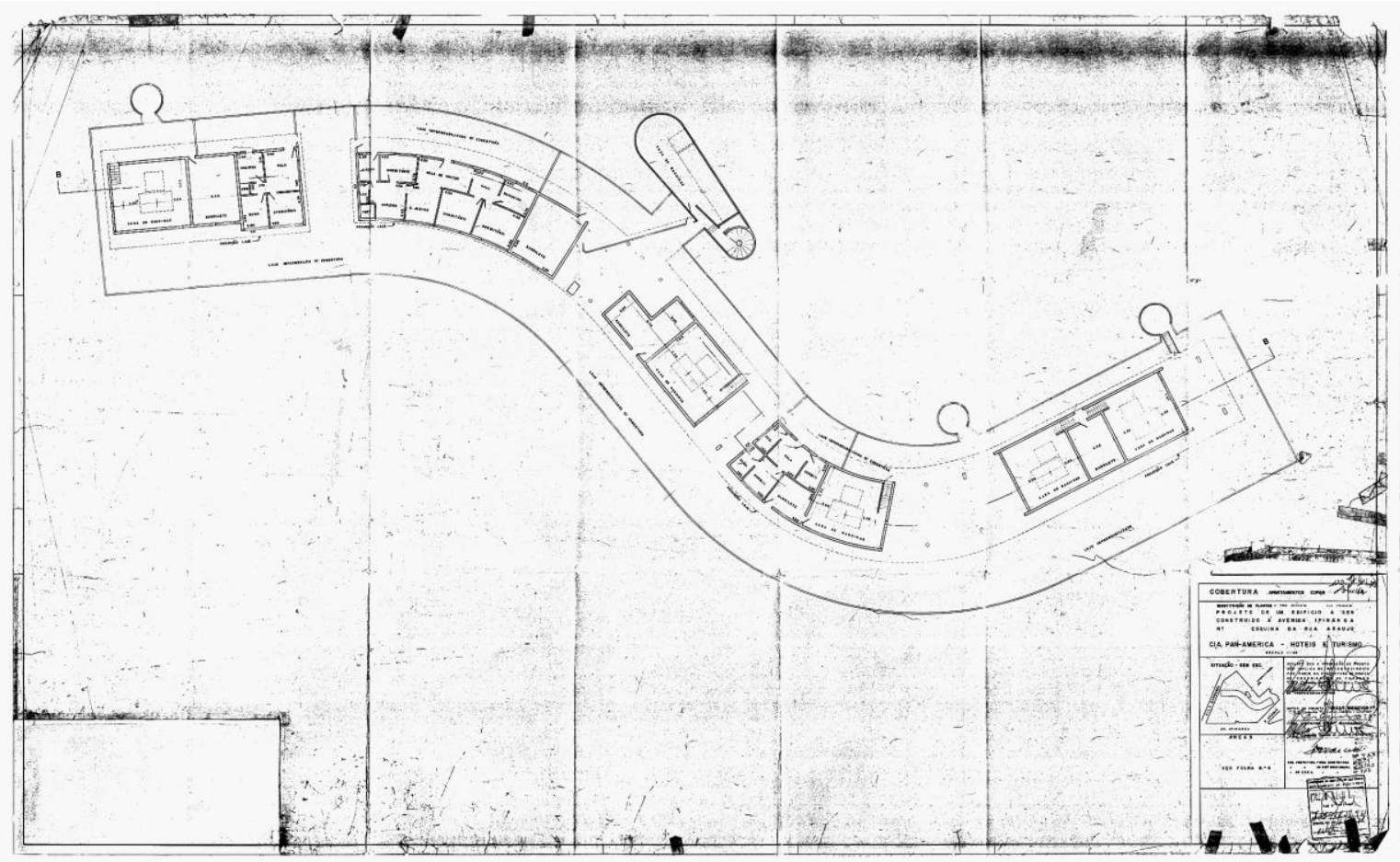

8.57: Planta Cobertura 


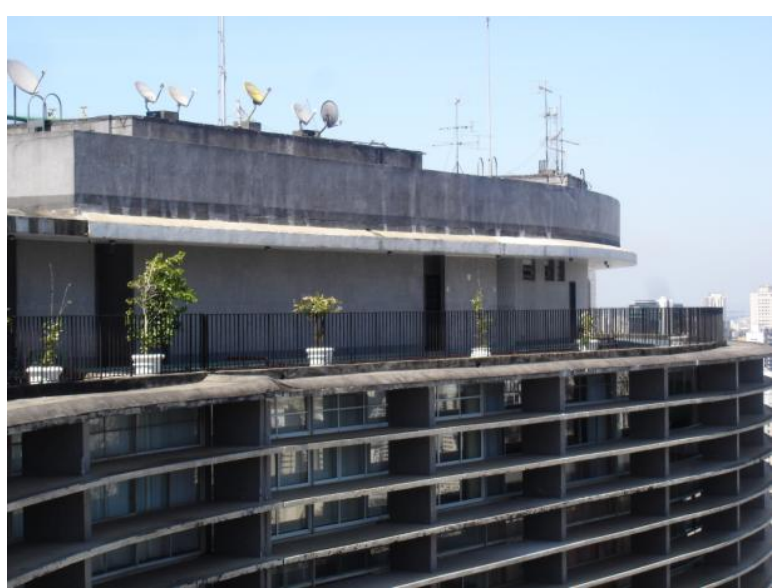

8.58: Brise -Soleil, fachada norte, 2009.

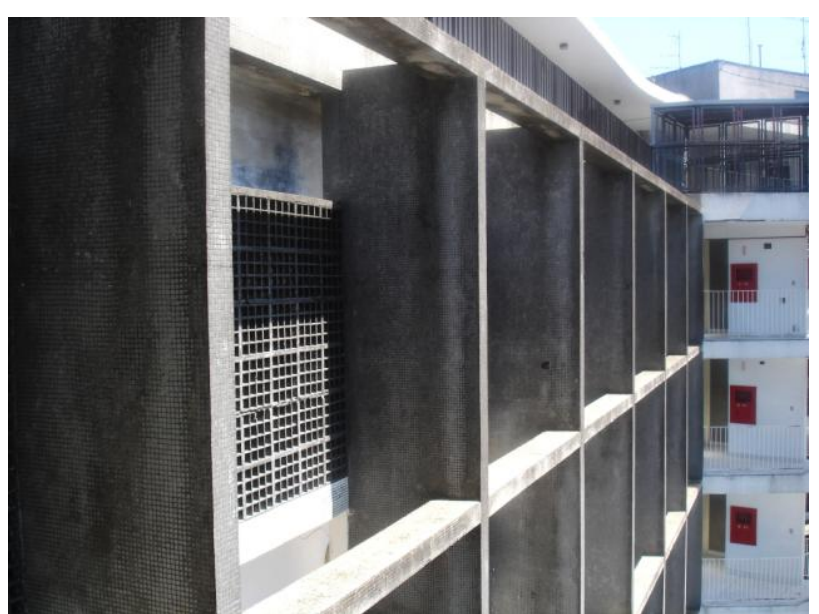

8.59: Brise à Sudeste , 2009

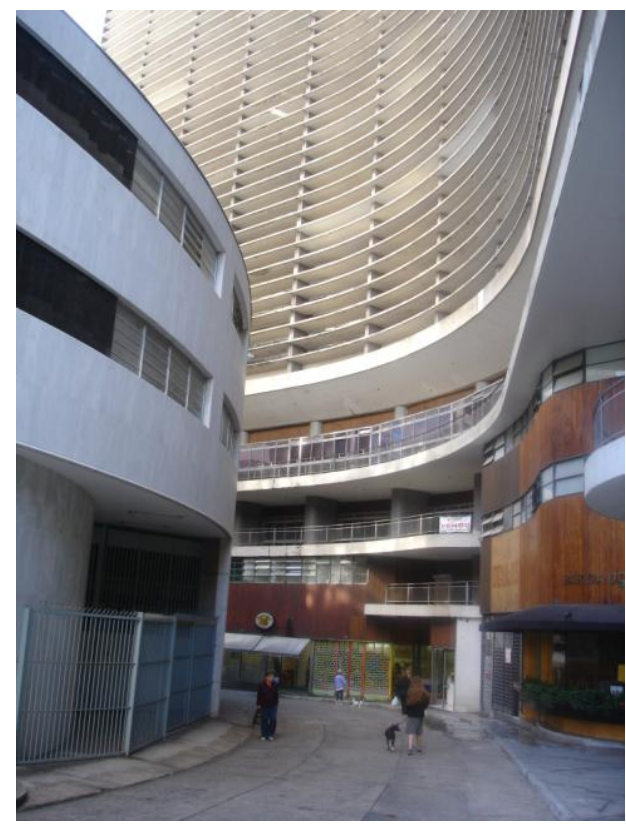

8.60 e 8.61: Fotos pela rua interna, 2009

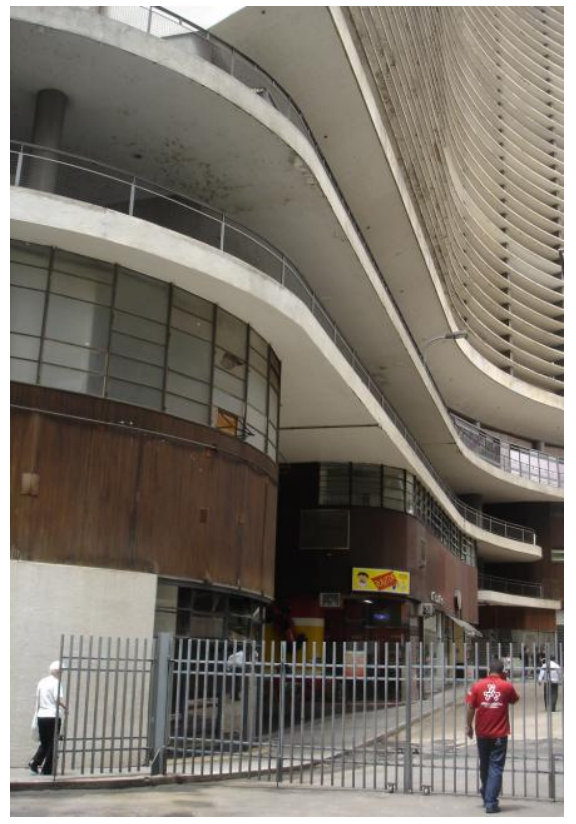


Edifício Montreal: 1954. (figuras 8.62 a 8.81)

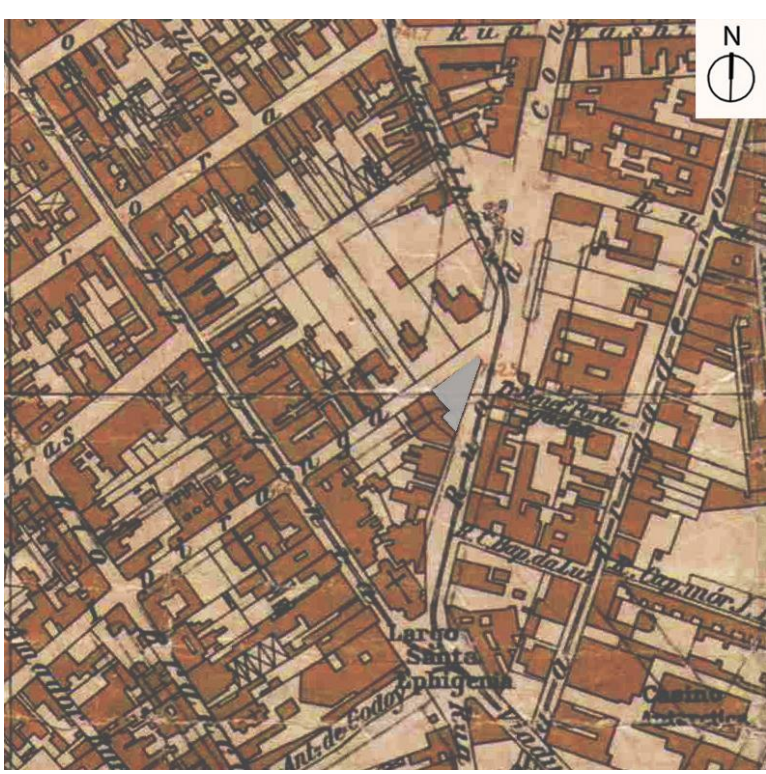

8.62: Sara Brasil, 1930

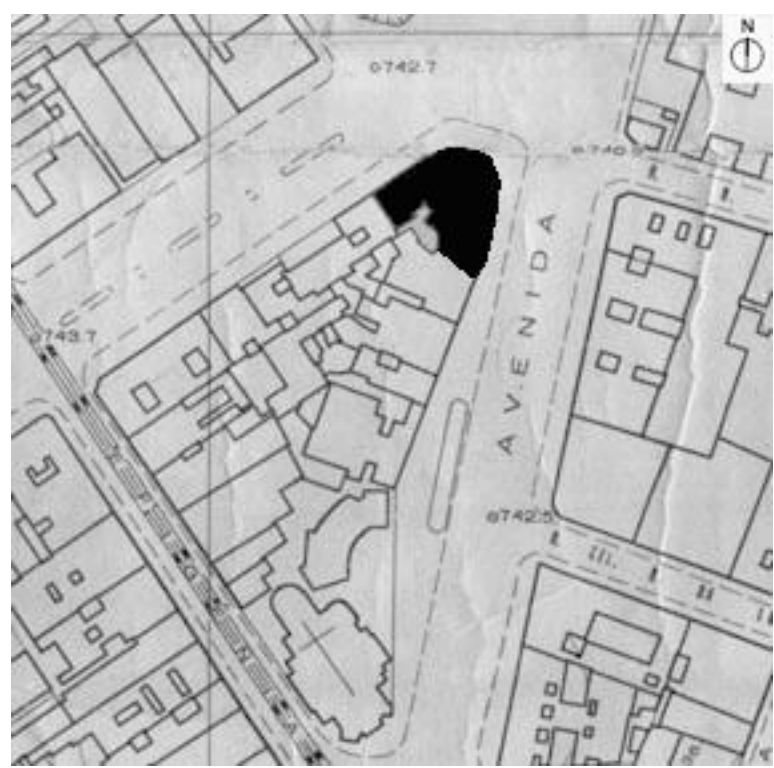

8.63: Vasp-cruzeiro, Montreal

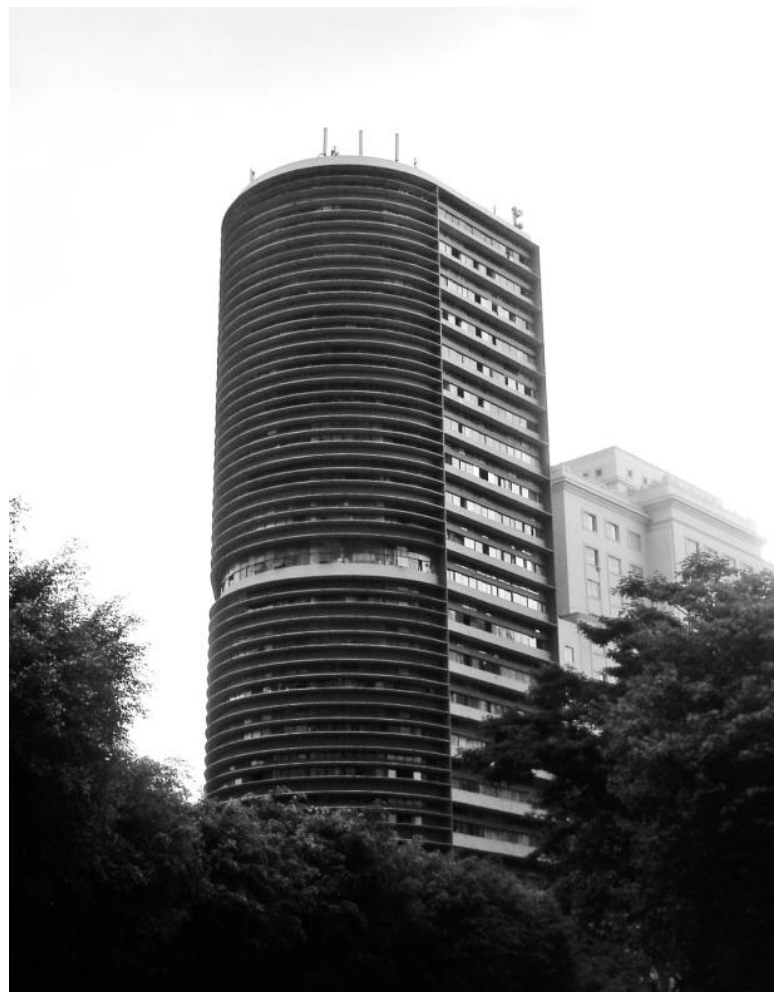

8.64: Montreal, 2009 


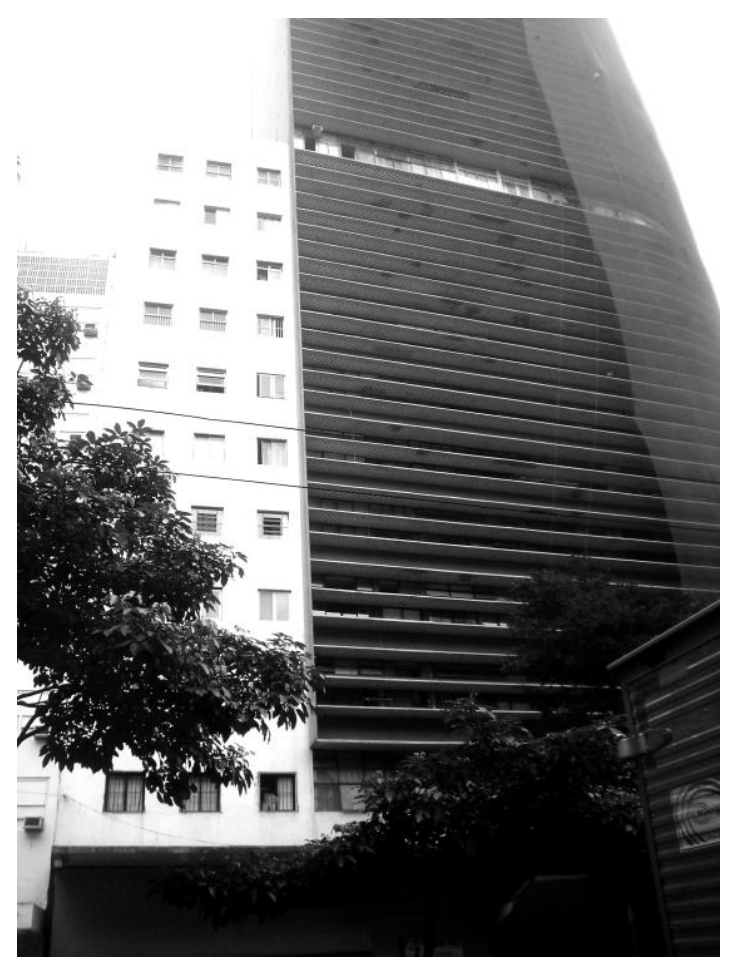

8.65: Montreal pela Casper Libero,2010

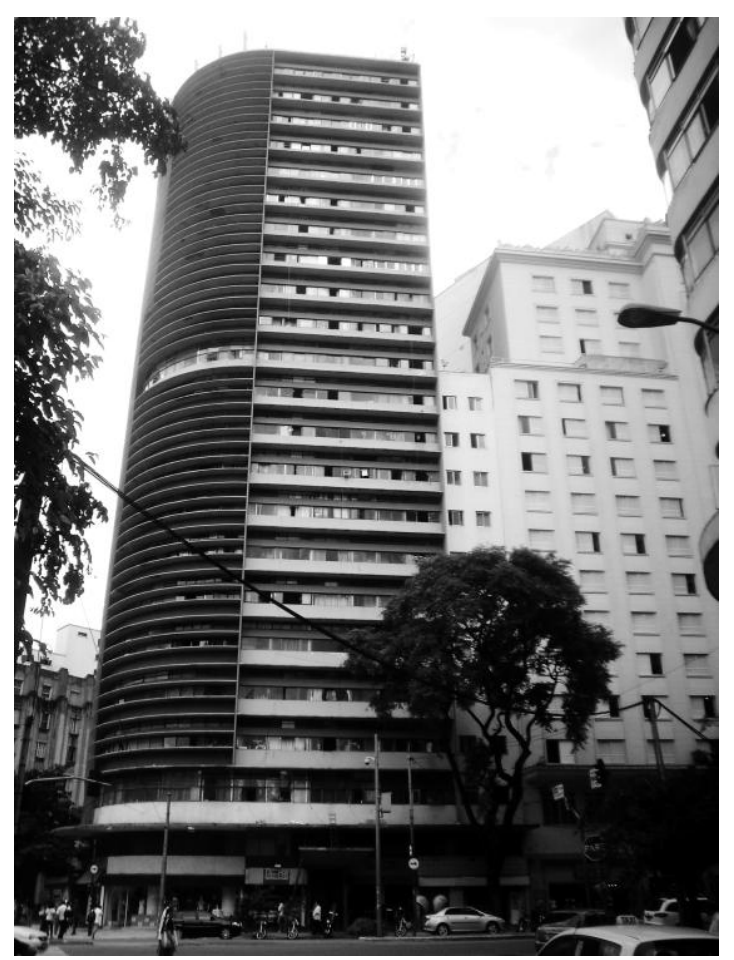

8.66: Montreal pela Ipiranga,2009

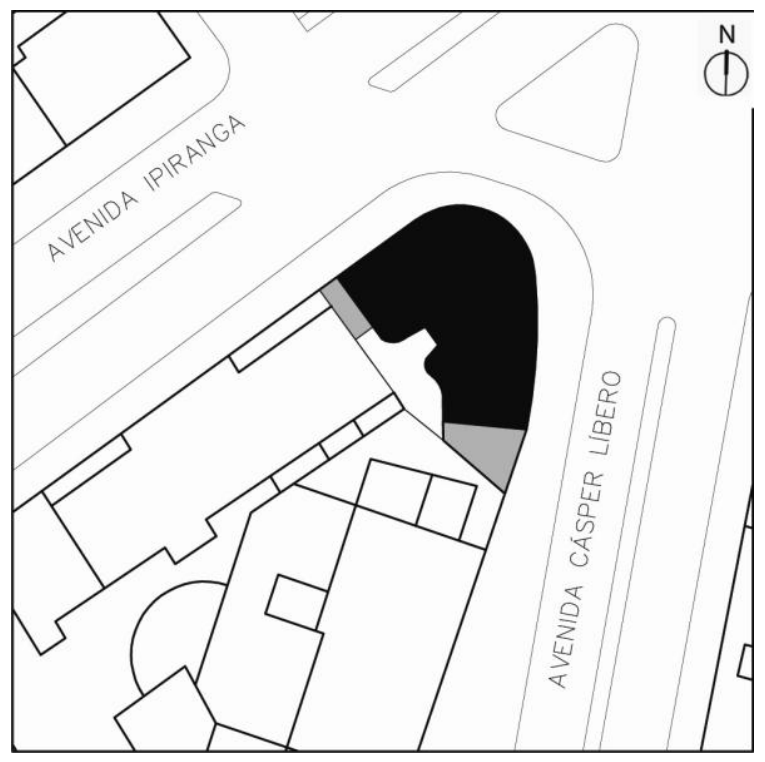

8.67: Localização no mapa Viver Centro 

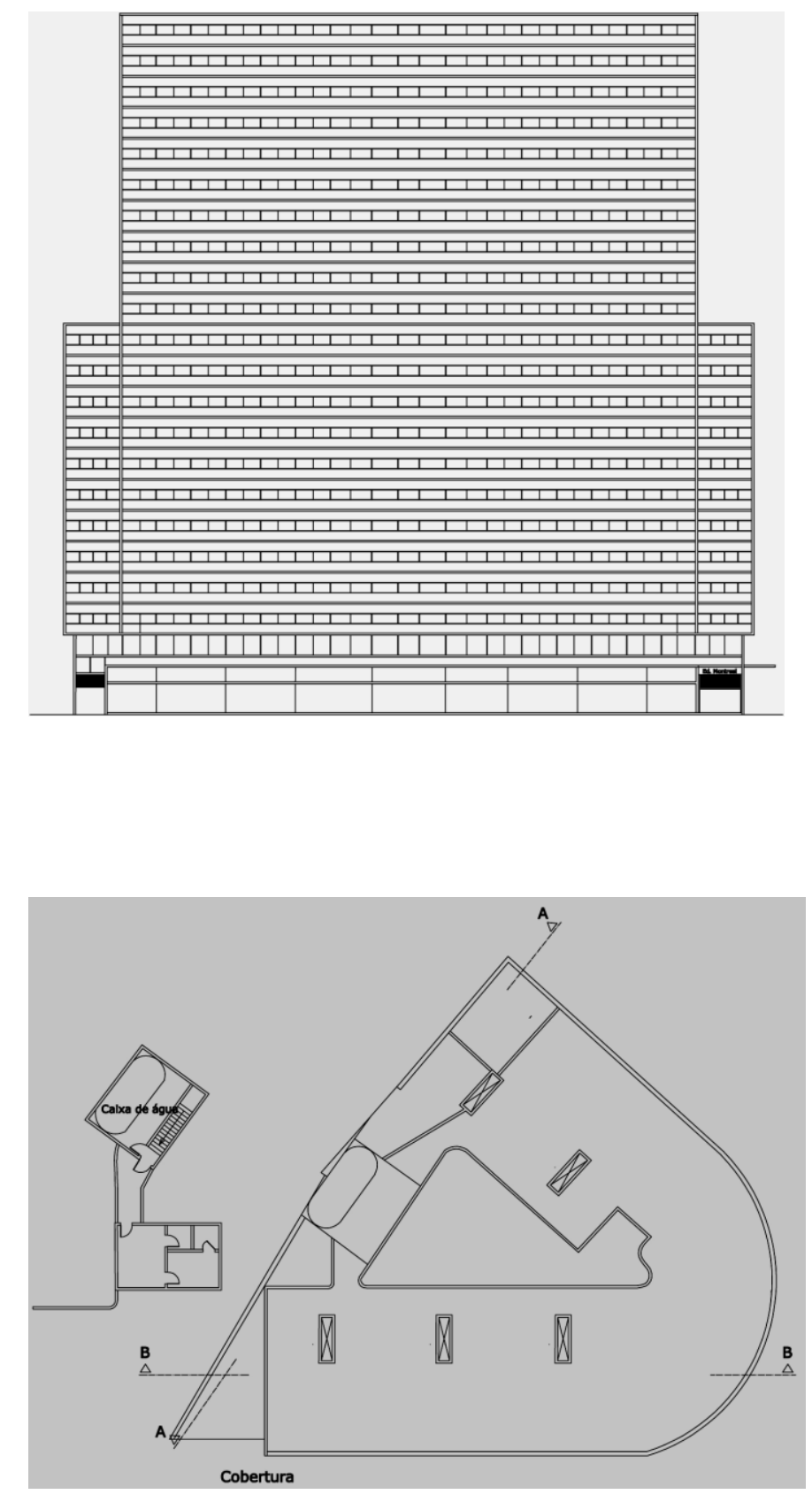

8.68 e 8.69: Planta de Cobertura da e Elevação da primeira proposta, substancialmente alterada. Atentar para as diferenças de altura entre os corpos. 


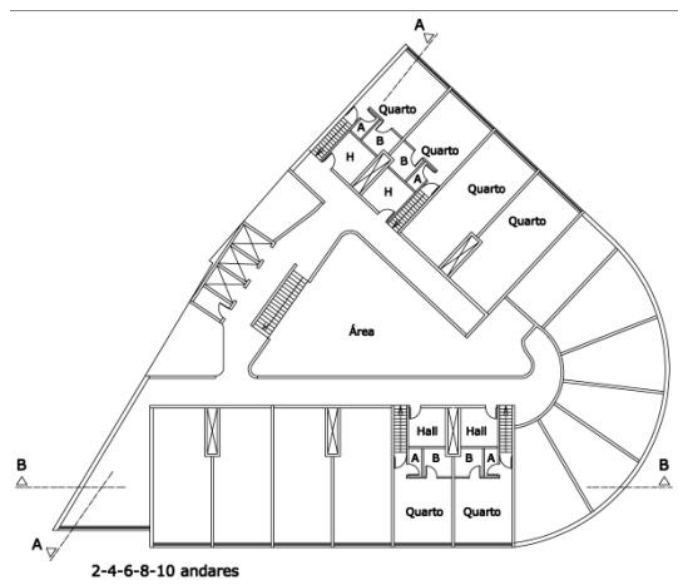

8.70

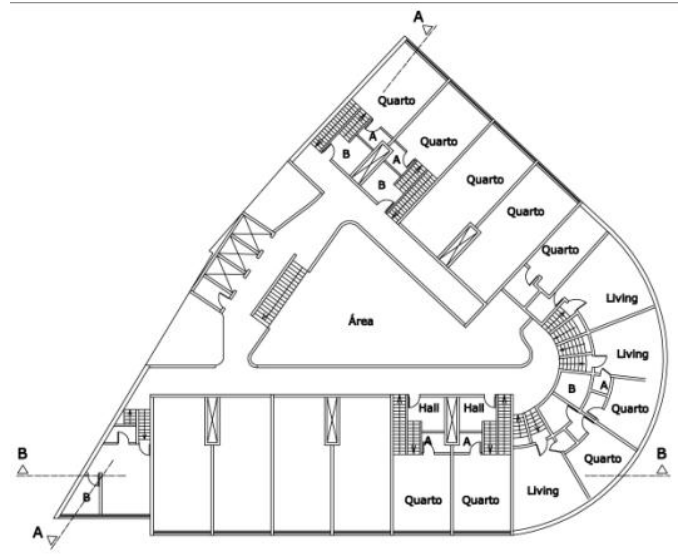

1-3-5-7-9 andares

8.71

8.70 e 8.71: Plantas do primeiro estágio do edifício: a solução era de apartamentos duplex. Plantas ímpares e pares, Primeiro Projeto; do 1ㅇ ao $10^{\circ}$.

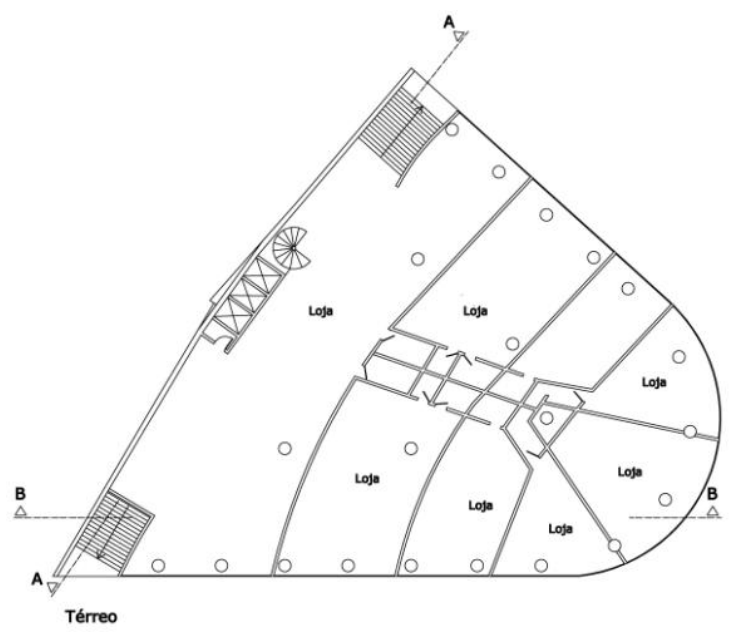

8.74: Planta Térreo - Primeiro projeto

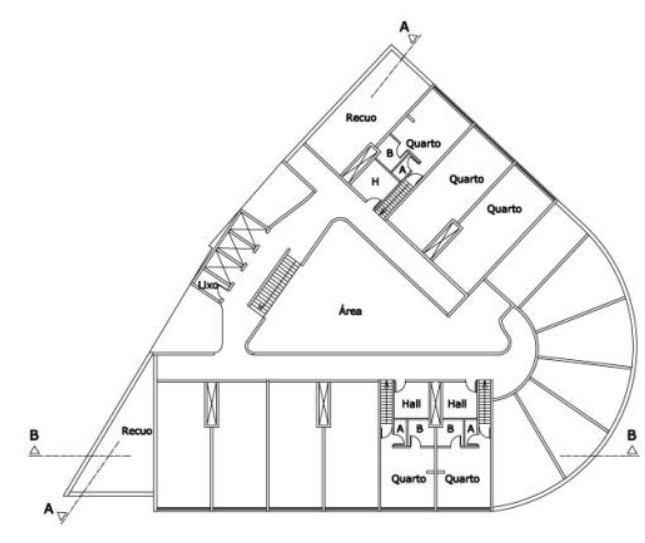

12-14-16-18-20 andares

8.73

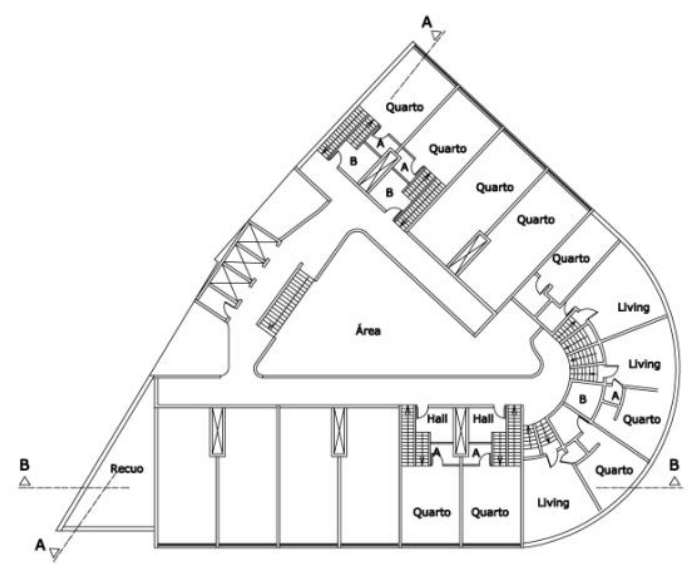

11-13-15-17-19 andares

8.72

8.72 e 8.73: Plantas do segundo estágio do edifício: a solução era de apartamentos duplex. Plantas ímpares e pares, Primeiro Projeto; do $11^{\circ}$ ao 20 응

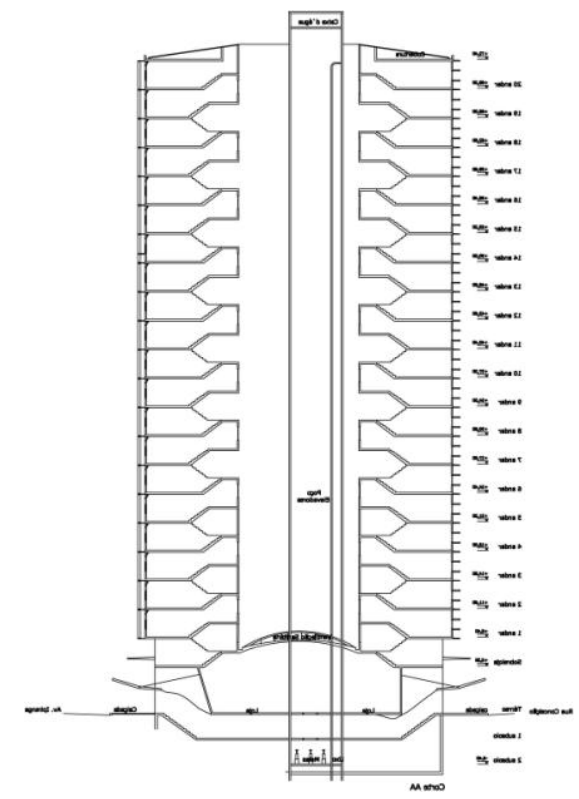

8.75: Corte pelo vazio centrall 


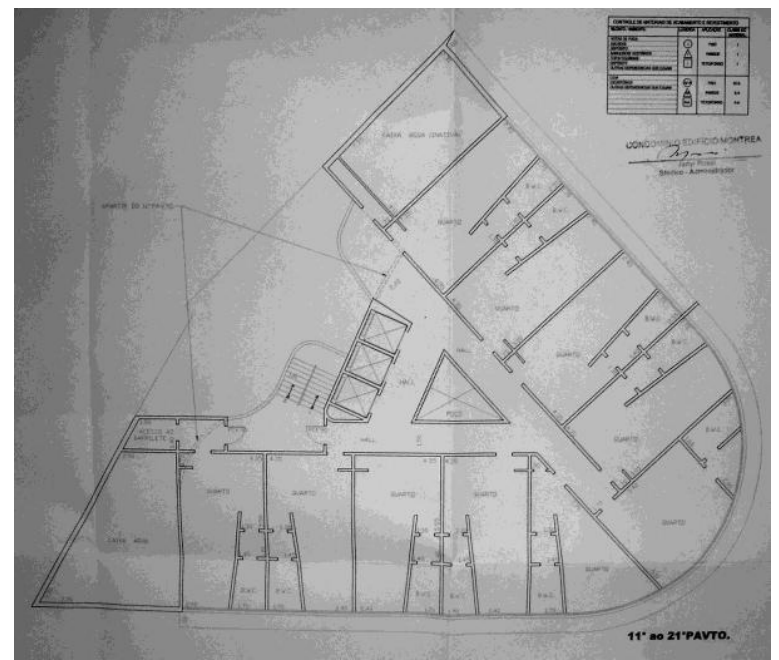

8.78

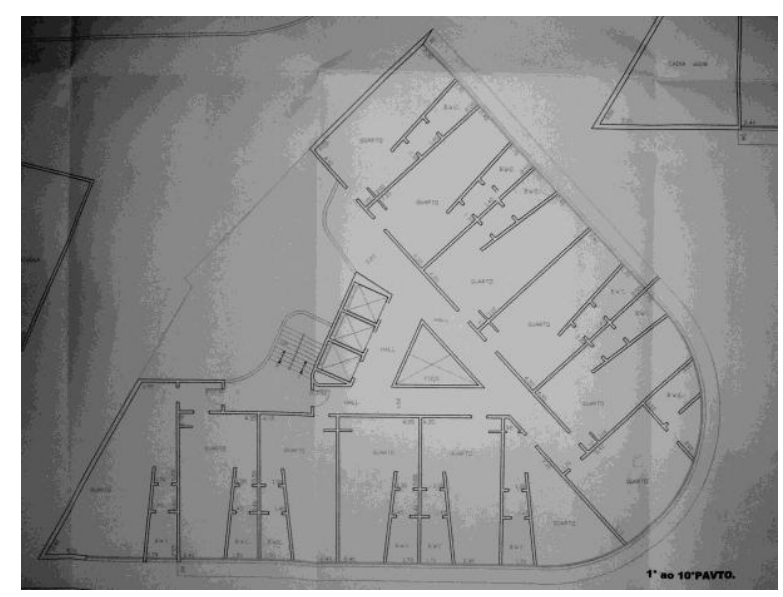

8.77

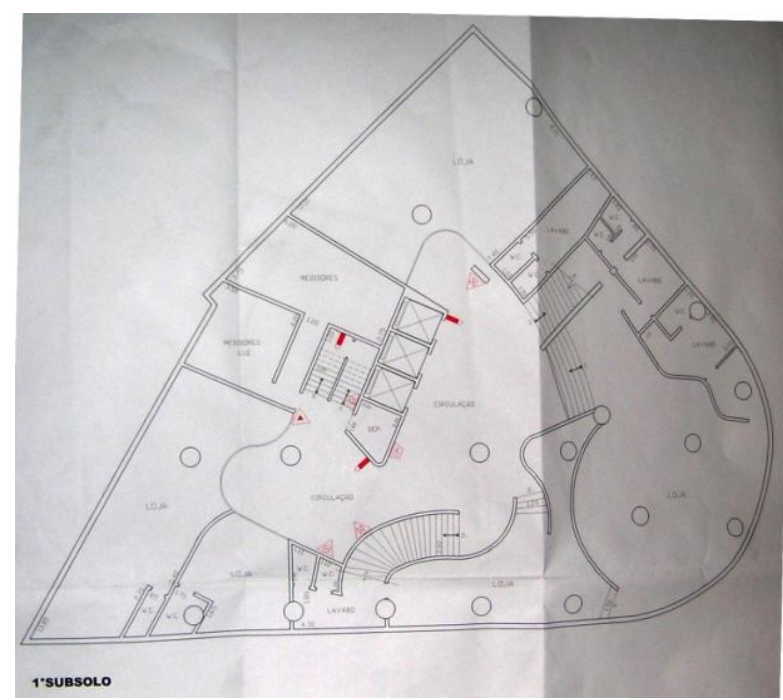

8.76

8.76, 8.77 e 8.78: Respectivamente, plantas atuais do acesso, pelo subsolo; tipo do $1^{\circ}$ ao $10^{\circ}$ e do $11^{\circ}$ ao $21^{\circ}$
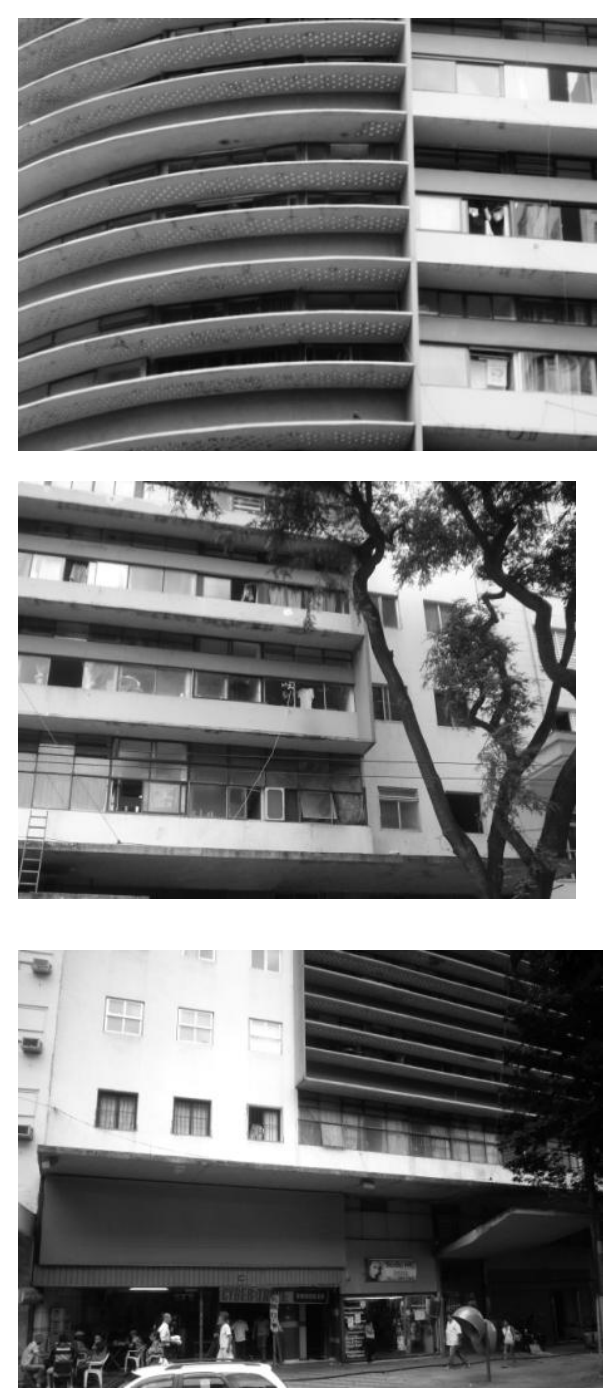

8.79 a 8.81: Atentar para a diferença de tratamento entre as volumetrias do edifício, 2009. 
Edifício Seguradoras: 1958. (figuras 8.82 a 8.94)

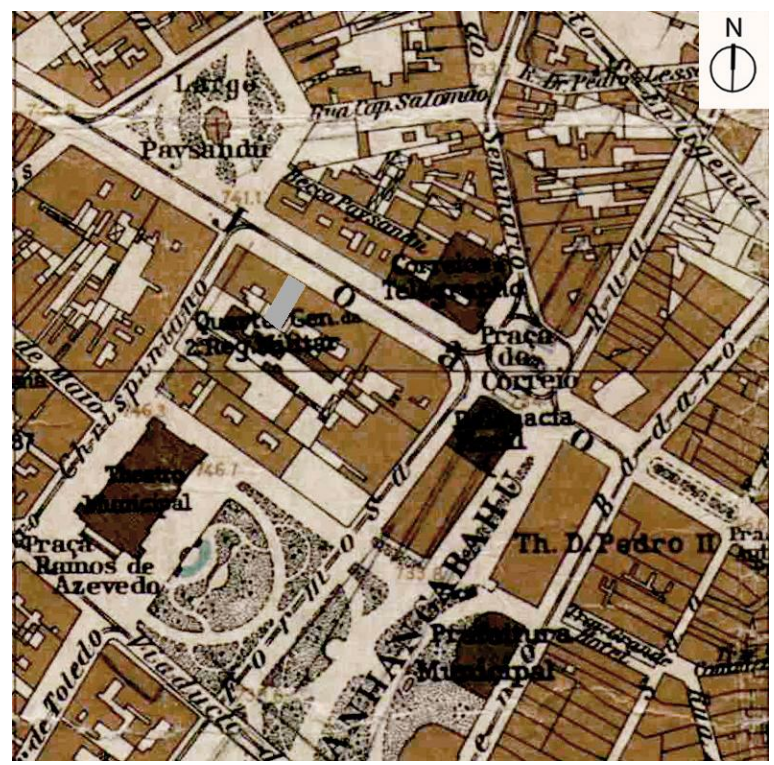

8.82: Sara Brasil, localização

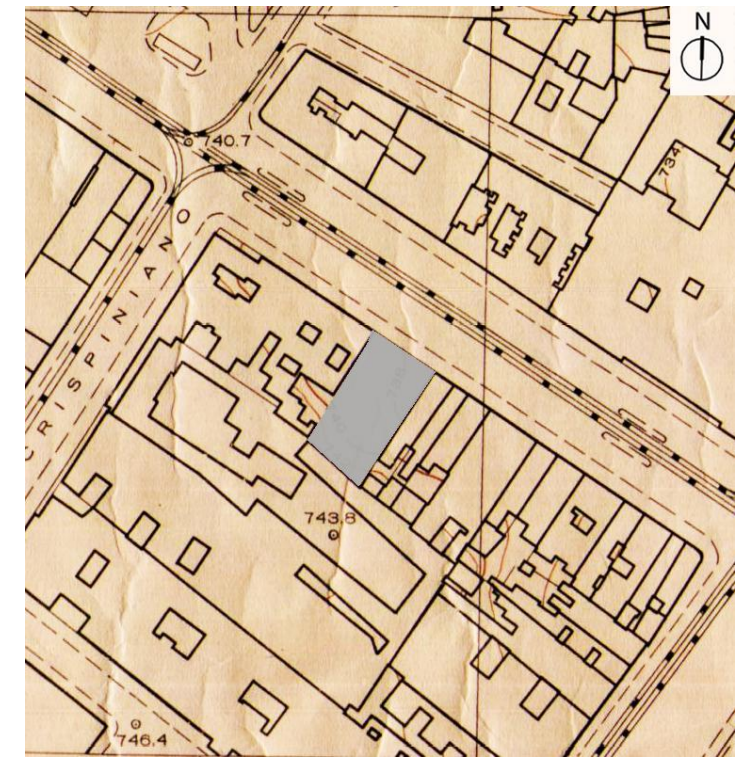

8.83: Mapa Vasp-cruzeiro, localização

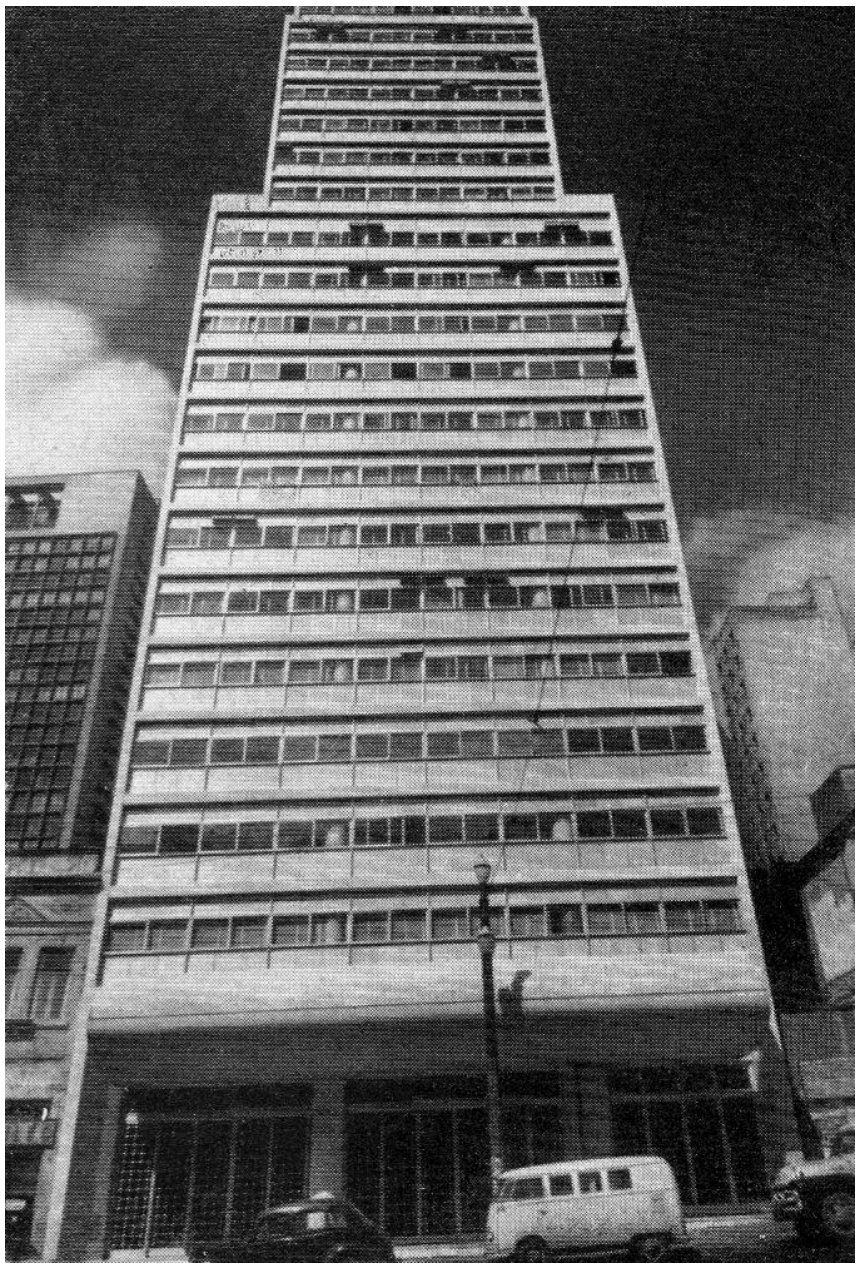

8.84: Seguras, 1958 ("habite-se") 


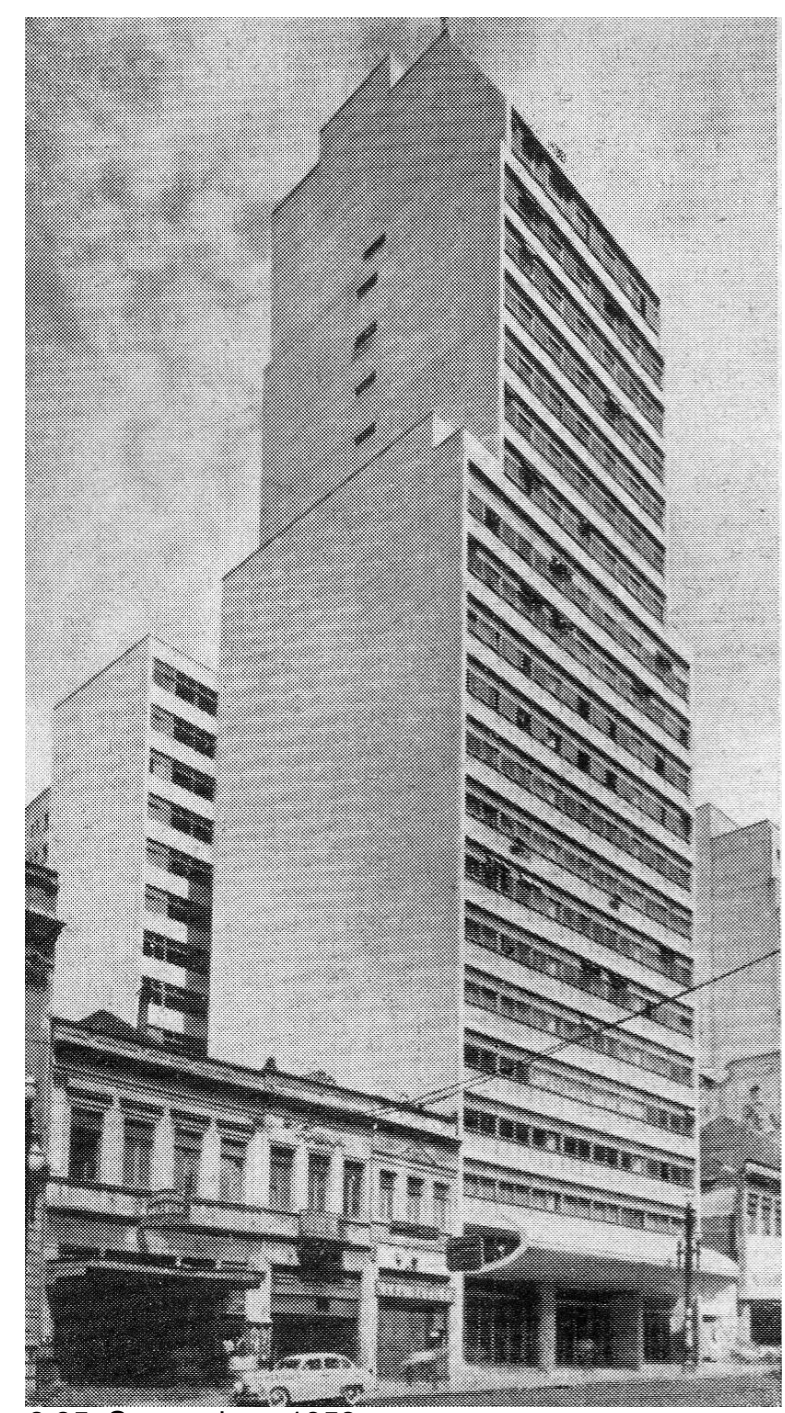

8.85: Seguradora, 1958

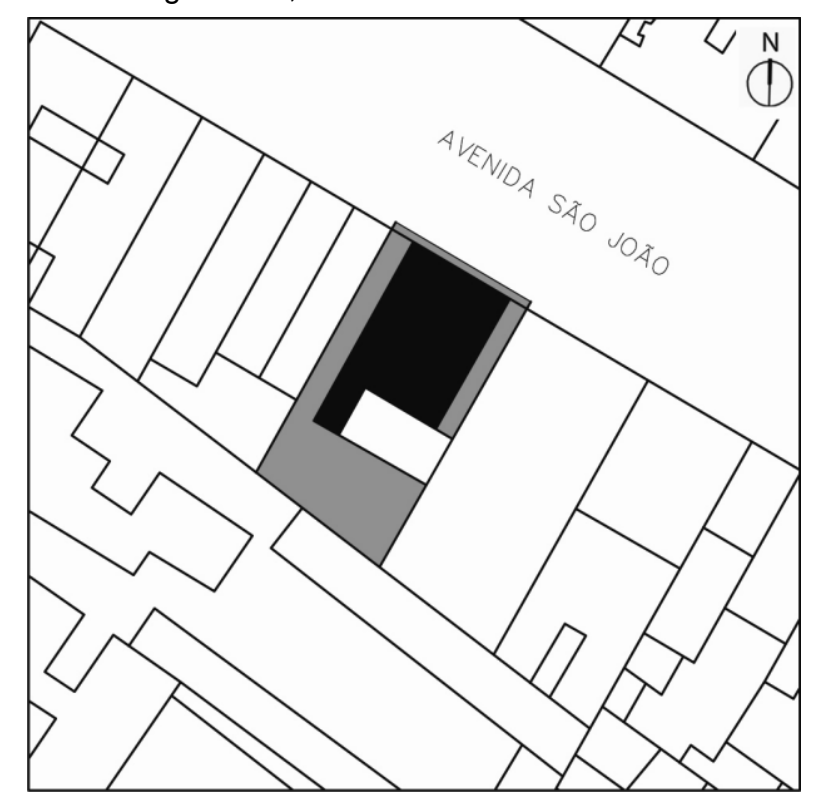

8.86: Gegran- -Viva Centro; cinza volumetrias mais baixas e preto altas. 


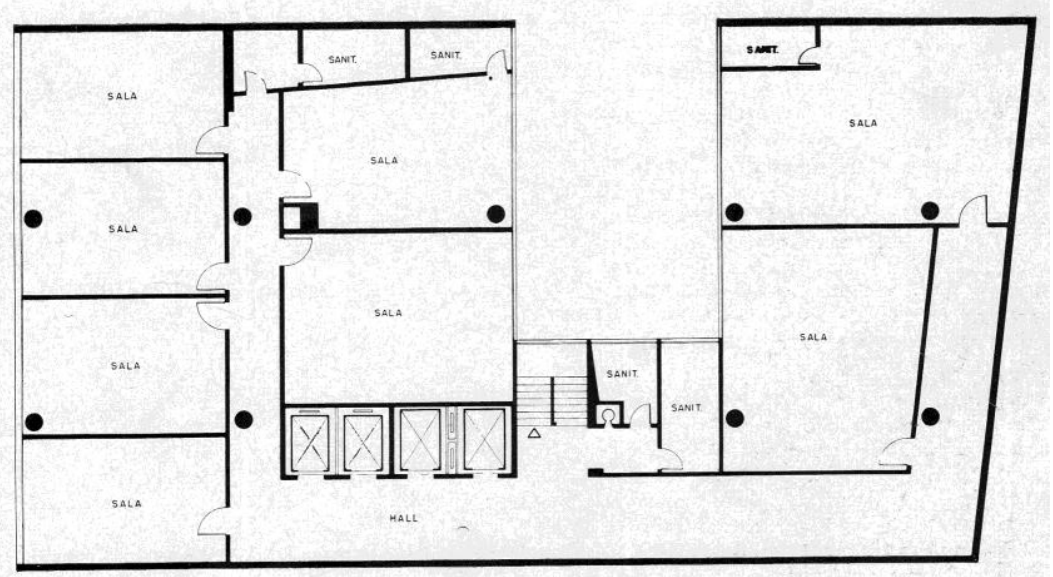

8.87: Planta tipo até 12 pavimento

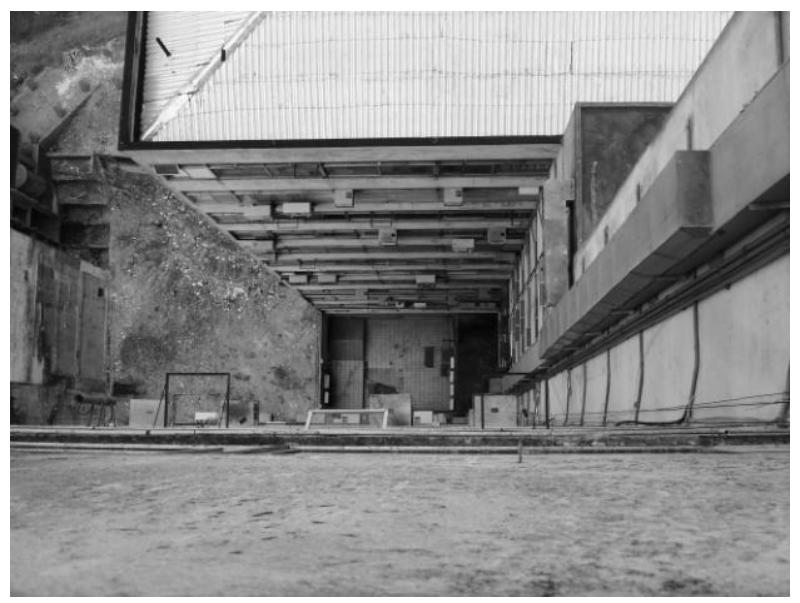

8.88: Pátio, 2009
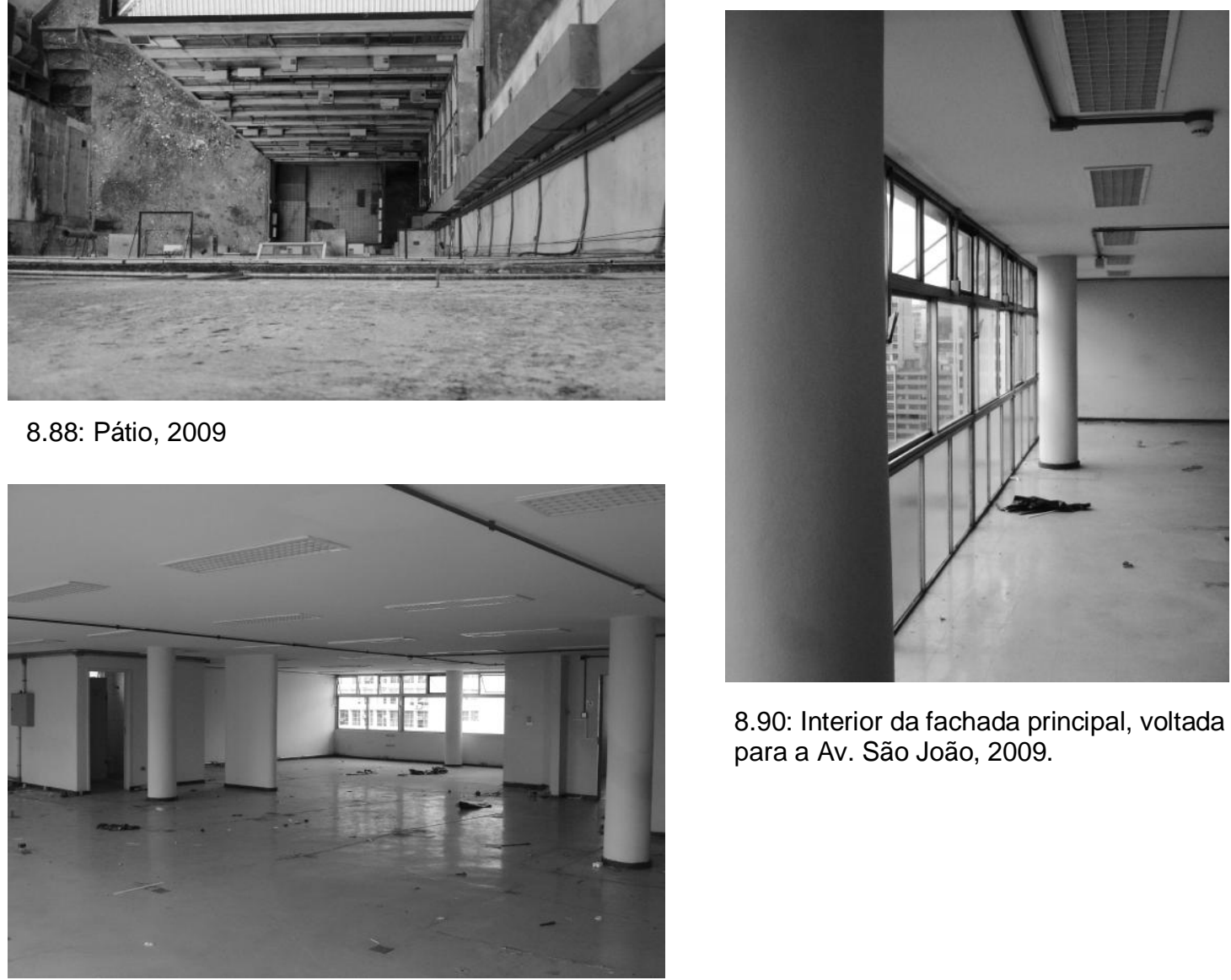

8.90: Interior da fachada principal, voltada para a Av. São João, 2009.

8.89: Sala de escritórios, bloco da frente, ao fundo aberturas para o pátio interno, 2009. 


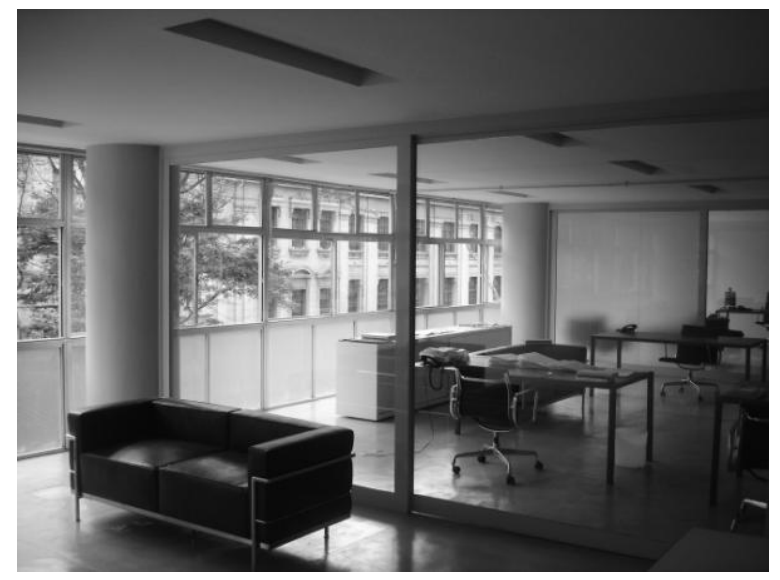

8.91: Interior ocupado, fachada principal
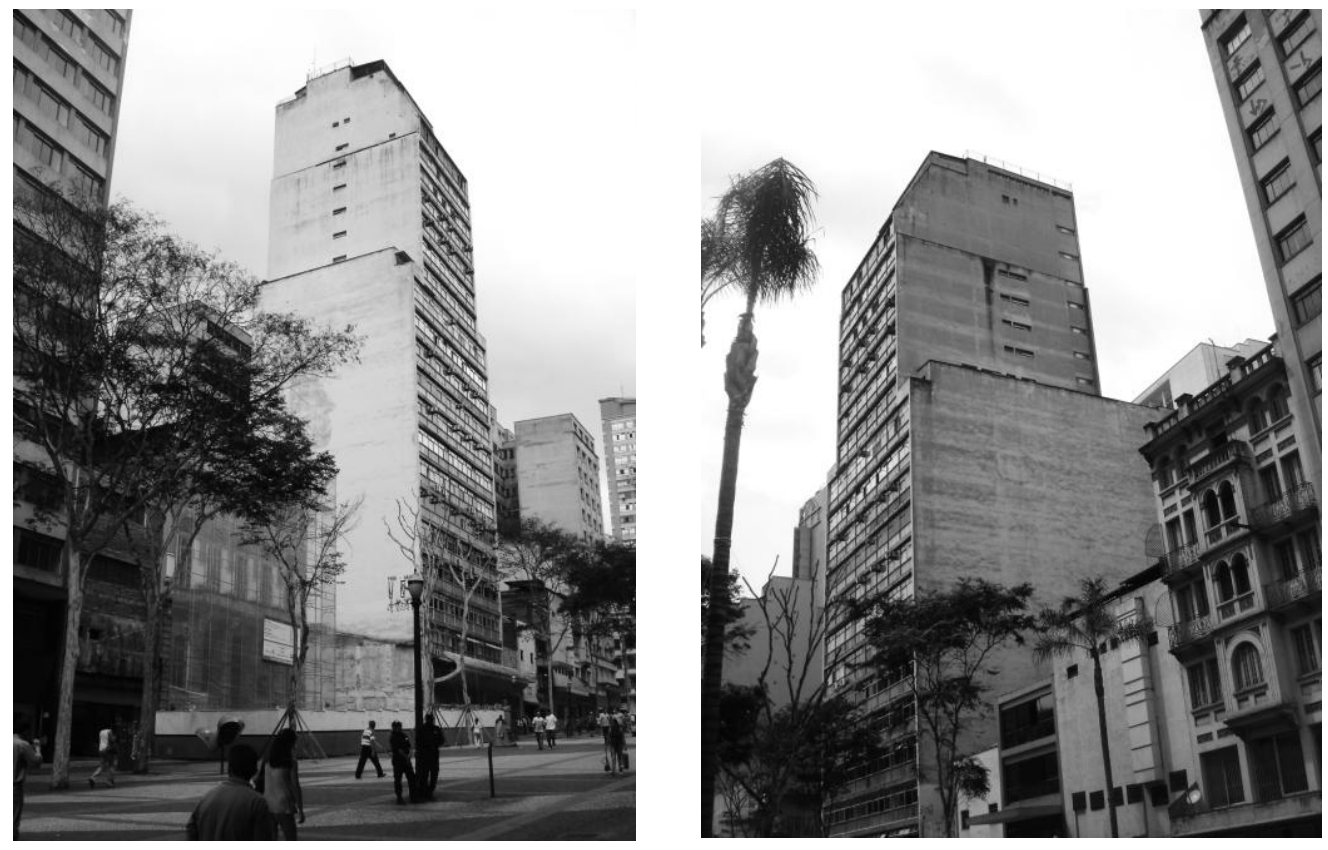

8.92 e 8.93: Edif.Seguradoras vistas pela Avenida São João, 2009

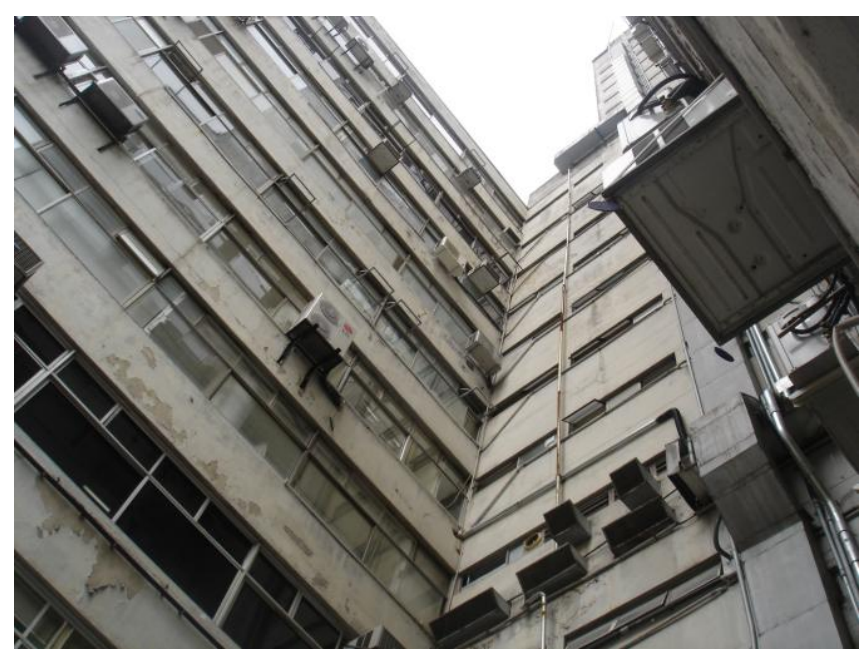

8.94: Edif. Seguradoras, bloco dos fundos e caixa de escada, voltados para o pátio. 


\section{Rumo aos anos 60}

No capítulo anterior, abordou-se uma significativa variação tipológica a partir da obra de Oscar Niemeyer no Centro de São Paulo nos anos 50. Com certeza as tipologias descritas não esgotam as ocupações possíveis, mas abarcam uma gama rica de situações. No estrito senso, cada edifício no Centro Histórico possui uma forma particular, mas não necessariamente uma tipologia. Neste capítulo serão analisados quatro edifícios que complementam as tipologias e os casos já descritos. Novas variações e circunstâncias enriquecem o quadro das arquiteturas, assim como apontam uma tendência rumo aos anos 60 cada vez mais à caráter dos edifícios isolados no lote. Essa tendência não implica necessariamente uma regra inviolável. O Edifício São Marcos, 1959, de Franz Heep, localizado na Praça da Sé com fachadas voltadas também para as ruas 15 de Novembro e Anchieta, confirma que o sistema de escalonamentos sucessivos ainda estava plenamente em vigor no final dos anos 50 . Os casos aqui tratados estão sujeitos à mesma legislação, porém adaptada para as circunstâncias de rua e lote. Mas como os demais respondem aos imperativos da cidade.

Por ordem cronológica iniciam-se as análises pelo CBI-Esplanada, Conde de Prates, Edifício Itália e Conjunto Metropolitano. O que os une é a procura da autonomia da torre de escritórios; o que os afasta são além da linguagem e as circunstâncias de projeto e formação dos lotes.

\section{CBI-Esplanada: preso a um apêndice}

O CBI-Esplanada ${ }^{120}$, de autoria de Lucjan Korngold, foi projetado em 1946; como linguagem ele segue a experiência anterior realizada no Thomaz Edison ${ }^{121}$. A solução da grelha que sombreia a fachada é retrabalhada em outra circunstância: sua localização no Vale do Anhangabaú favoreceu outras relações com a cidade; a exemplo dos edifícios Conde Prates, Grande São Paulo e Banco Mercantil Finasa, todos postados para o Vale.

Na carta cadastral de 1881, o Vale do Anhangabaú não se encontrava ocupado entre o Largo da Memória e a Rua de São João; nem havia a transposição pelo viaduto do Chá, ligando as duas colinas. Embora a chácara do Barão de Itapetininga estivesse loteada, no final do século XIX o trecho do Vale, onde seria implantado o projeto do Parque do

${ }^{120}$ Anat Falbel (2003) faz importante estudo da obra do arquiteto Lucjan Korngold, resgatando a obra desse valoroso arquiteto moderno. Sua tese explora com rigor a formação do edifício o $\mathrm{CBI}$.

${ }^{121}$ No capítulo 7 tratou-se, entre outros, do edifício Thomas Edison de autoria do arquiteto polonês Lucjan Korngold e do húngaro Francisco Beck. 
Anhangabaú e posteriormente o CBI-Esplanada, era assim descrito por Benedito Lima de Toledo: "O trecho do Vale entre o Piques e a Rua de São João mantinha seu caráter de chácara. A antiga propriedade do Barão de Itapetininga estava agora loteada, mas a ocupação se fazia pela periferia dessa diagonal; a saber, a Rua Formosa começou a ser ocupada por um conjunto de casas geminadas, com fundos para o Vale. No lado oposto, as casas da Rua Líbero Badaró, igualmente, reservaram para o Vale o mesmo caráter de fundo de quintal" (1989, p. 48). O viaduto, concebido por Jules de Martin e inaugurado em 1892, prenunciava a efetiva ocupação do Vale já no século XX. Os teatros São José (1909), a inauguração do Teatro Municipal em 1911 e a construção do jardim anexo - a Praça Ramos de Azevedo - de fato consolidou-se a tendência de ocupação do Vale, depois reordenado pelo Parque do Anhangabáu projetado por Joseph-Antoine Bouvard.

Bouvard seria convidado a São Paulo num momento em que o ambiente era favorável aos melhoramentos urbanos, então engendrados pela elite paulistana. Nesse contexto, elaborou um plano global que abarcava um sistema de parques, praças e novos traçados viários na área central da cidade: o Parque do Anhangabaú era um dos projetos do plano, fazendo parte desse sistema ${ }^{122}$.

Portanto, a construção do teatro Municipal, da Praça Ramos de Azevedo e do Parque do Anhangabaú uniram as duas colinas em torno de um arranjo paisagístico e arquitetônico que proporcionou uma nova espacialidade urbana de caráter monumental nos termos de uma metrópole emergente. Quando se analisa o mapa Sara-Brasil, essa espacialidade está configurada e nela é possível identificar as precedências diretas do CBI: a saber; o Hotel Esplanada já construído, o terreno vago na esquina da Praça Ramos de Azevedo com a Rua Formosa, e o lote estreito que seria incorporado ao lote final maior. Defronte ao futuro terreno do $\mathrm{CBI}$ percebe-se uma quadra ocupada que ainda delineava a Rua Formosa. Quadra que seria demolida para receber as intervenções previstas no Plano de Avenidas: "No início da década de 40, o Parque Anhangabaú sofria radical transformação: seria integrado a um sistema de avenidas de irradiação idealizada pelo prefeito-urbanista Prestes Maia, cuja premissa era a utilização do Vale do Saracura, do Vale do Itororó (com era conhecido o Anhangabaú), para implantar avenidas de fundo de vale, convergindo para o Parque e desse para a Avenida Tiradentes (Toledo, 1989, p. 197)". Com essa nova reurbanização que alargaria o parque estendendo a ocupação do Vale, estariam concretizadas e configuradas as condições físicas de implantação do CBI e por decorrência da verticalização que reforçaria a monumentalidade já desenhada por Bouvard, dando sequência à substituição dos palacetes pelas torres de serviço.

${ }^{122}$ Para maior detalhamento ver os trabalhos de Toledo (1989) e Simões Junior (2004), duas referências importantes para a compreensão da formação do Anhangabaú. 
Falbel fez em sua tese um minucioso estudo do CBI-Esplanada a partir dos arquivos correntes da prefeitura e outros. Desses documentos relata e interpreta o histórico dos projetos. Segundo a autora, em 1938 em plena administração de Francisco Prestes Maia seria dado entrada junto à Prefeitura um requerimento para aprovação de um prédio complementar ao Hotel Esplanada. Esse projeto estava a cargo da Elisiário Bahiana (2003, p. 228). Em 1946 esse primeiro projeto foi substituído por outro de autoria de Korngold que seria efetivamente construído. A substituição de um projeto pelo outro implicou profundas mudanças na obra final. Mudanças significativas e intrigantes do ponto de vista da interpretação da legislação, da estrutura (e depois ossatura independente), da linguagem e princípios modernos, da expressão e composição volumétrica.

O CBI-Esplanada nascia em 1938 como um complemento ao Hotel Esplanada e previa um edifício de 28 andares, com hotelaria e apartamentos ${ }^{123}$. Por meio dos processos da prefeitura é possível identificar desde o primeiro projeto de Bahiana as reivindicações a favor de um edifício que estivesse em acordo com a importância do local: ou seja, a monumentalidade do espaço do parque e das edificações vizinhas como o Municipal e o prédio da Light. Pela legislação da época a altura máxima permitida era de $80 \mathrm{~m}$, porém tendo-se em conta para efeito de construções no alinhamento da rua a respectiva largura da mesma: no caso a restrição ficava por conta da Rua Formosa de $17 \mathrm{~m}$ de largura, podendo atingir no máximo a $51 \mathrm{~m}$. Os processos demonstram uma série de argumentos para aumentar a altura máxima do hotel: o que de fato ocorreu. $O$ argumento mais forte encontrava-se na localização do empreendimento, defronte da esplanada (jardins) do Teatro Municipal. Nos estudos de Bahiana uma torre mais elevada nasce de um embasamento mais baixo que atende às limitações da rua mais estreita. Essa primeira volumetria ainda expressava em sua forma final os imperativos da legislação.

Em 1946 um novo projeto de Lucjan Korngold substitui o antigo projeto de Bahiana. Os estudos e os processos continuavam a indicar a continuidade dos acertos finais da volumetria e da altura final do prédio: pretendia-se manter as alturas aprovadas em 1941, que poderiam ultrapassar os $80 \mathrm{~m}$ de altura, entretanto, mantendo-se uma projeção do lote (ocupação) de $30 \%$. O fato importante nesse momento é que nos desenhos de Korngold ainda era possível perceber os recuos nas laterais da volumetria à medida que o edifício atingia altura. Num desses desenhos pela elevação da esplanada um primeiro recuo na cota de $20 \mathrm{~m}$, um segundo na cota de $40 \mathrm{~m}$; um terceiro na de $80 \mathrm{~m}$ culminado a última volumetria na cota 92. Na elevação pela Rua Formosa os escalonamentos são praticamente iguais, com exceção do primeiro estágio que tem início na cota 40 m: atendendo dispositivo

${ }^{123} \mathrm{O}$ edifício teria 28 andares sendo: dez pavimentos para o hotel e 18 pavimentos para apartamentos (Falbel, 2003, p. 228). 
que determinava altura máxima de $40 \mathrm{~m}$ para o terreno vizinho ${ }^{124}$. Nessa primeira fase dos estudos de Korngold, ficam claras ainda as marcas da lei na volumetria do edifício e a traçado do brise-soleil em forma de grelha.

Nos desenhos seguintes, a depuração da volumetria ficaria clara pela eliminação de alguns recuos. A intenção apontava para uma volumetria despida de escalonamentos, mais a caráter de um prisma, de uma torre limpa e racionalista. O coroamento do edifício, ocupando seu perímetro com pórticos reentrantes, reforça esse caráter, na medida em que disfarçam os recuos existentes nos últimos pavimentos. Mais do que isso; uma torre liberta das amarras do lote. Desejo que de fato não se realizou devido ao pequeno apêndice colado ao edifício pela antiga Rua Formosa. Um apêndice estranho de pouca altura (40 m), muito estreito e que só garantia um afastamento legal da construção vizinha, que no decorrer do projeto foi reduzido a quase nada para garantir iluminação adequada à fachada lateral. Se não fosse por esse apêndice (geralmente omitido nas plantas em publicações) o CBIEsplanada seria uma torre limpa, como poucas no Centro de São Paulo, pois a solução final se apresentou recuada de todas as divisas.

Se o apêndice depõe contra a volumetria final do edifício, a solução estrutural e a composição final o redimem à condição de digno exemplar moderno.

Quando Korngold refaz o projeto, as fundações do edifício encontravam-se prontas. Ele teve que repensar a estrutura, segundo Falbel, a partir das fundações já executadas e correspondentes ao perímetro da edificação. A esse respeito Falbel pondera: "E nesse sentido, o uso da fachada independente da estrutura, e portanto, dos pilares recuados, não constituía somente parte da retórica modernista, mas necessidade de adaptação do projeto" (2003, p. 256).

Essa ponderação de Falbel procura explicar a solução estrutural - entenda-se a ossatura independente - como uma consequência operativa e funcional, destituída de qualquer intenção "retórica", ou estética. Entretanto, essa saída é frágil. A pretensa racionalidade moderna não existe separada da intenção estética - desinteressada. A ossatura independente é um elemento estruturador de uma linguagem: ela deve ser compreendida simplesmente como uma consequência lógica. A intenção formal de Korngold em controlar a volumetria final do CBI tem correspondência direta com a manipulação da estrutura independente e da fachada livre: motivo de discussões nos processos legais. Explica-se, os balanços da grelha externa avançavam sob os recuos legais e foram justificados como elementos estéticos relevantes na conformação final do edifício.

${ }^{124}$ Conforme páginas 1 e 2 do processo 28531 de 1946. 
A manipulação da estrutura independente enquanto linguagem é fundamental para perceber a própria linguagem da arquitetura moderna: no CBI-Esplanada e como se verá no Conde de Prates as origens estruturais já estavam dadas. A ossatura independente - como exposta no capítulo 6 - é um princípio estruturador de uma linguagem para diversas correntes; mas não pode ser vista como reduto da racionalidade, pois a estrutura independente foi usada pragmaticamente sem estar necessariamente vinculada ao movimento moderno no estrito senso.

Se as estruturas estão correlacionadas às fundações pressupõem-se que a racionalidade já estava presente no projeto anterior; nesse sentido o projeto de Korngold reafirmar essa condição deixando mais clara e limpa a solução da planta livre ${ }^{125}$ e do continuum espacial. Da mesma maneira limpa é pensado o sistema estrutural composto por pilares acompanhando a borda dos pavimentos, pelos dois núcleos rígidos que complementam o contraventamento do sistema, e aglutinam em torno de si elevadores, caixas de escada e sanitários. Os dois sistemas de verticalização - que corresponderiam a dois edifícios separados - têm origem no programa inicial dividido em hotel e apartamentos. Hoje as duas portarias continuam a funcionar separadamente, embora se tenha conjuntos com saídas para as duas circulações.

A volumetria final não revela esses dois edifícios em um único corpo, mas indicia princípios clássicos de composição: em planta há uma simetria pelo eixo longitudinal, claramente marcado pela disposição pelas caixas de escadas e pelos elevadores mesmo quando estes se encontram em posição perpendicular. Nas elevações percebe-se divisão tripartida do embasamento, desenvolvimento e coroamento. Essa divisão é comum no Centro de São Paulo; além das intenções e princípios de formação, existiam as prescrições da lei que exigiam tratamento nobre nos embasamentos até a altura de $8 \mathrm{~m}$ conforme 0 caso. Nas operações compositivas estavam colocadas as discussões em torno das fachadas. Nos processos transcritos por Falbel ficam claras a importância das fachadas e da estética final do edifício: diga-se da hierarquização das fachadas conforme posicionadas para uma ou outra rua. No caso do CBI-Esplanada há uma dualidade nesse sentido. Isso porque a fachada moderna deveria decorrer em parte do conteúdo espacial, em parte das condições de insolação e ventilação. Por um lado a composição tripartida remete a um classicismo e os coroamentos indicam o decoro que distingue fachadas principais das secundárias: o coroamento e o pórtico no térreo de frente para o Anhangabaú são mais relevantes do que os laterais, dispostos para a Praça Ramos de Azevedo. A fachada voltada

${ }^{125}$ Esse fator associado às áreas dos pavimentos permite ainda hoje ocupações flexíveis; é o caso dos Call Centers lá instalados. 
para o antigo hotel Esplanada encerra de maneira despojada o conjunto de elevadores, sanitário e sala da ala menor do prédio.

Se essa configuração indica uma precedência dos valores da cidade tradicional sobre os valores modernistas, há no $\mathrm{CBI}$ outras relações que o levam de encontro à operatividade moderna. É o caso da grelha que envolve três das quatro fachadas a partir do embasamento. Falbel descreve assim sua construção e intenção:

As fachadas sul, norte e leste apresentam uma marquise horizontal de $50 \mathrm{~cm}$, que forma uma grelha, com espaletas e tremós pré-fabricados no canteiro, cuja intenção é funcionar como um sistema de brise-soleil combinado com as janelas recuadas de $50 \mathrm{~cm}$, que protegem o interior do edifício contra os ventos e as chuvas tropicais, cujas origens podem ser recuadas à grelha corbusiana projetada para o Albergue do Exército da Salvação, em Paris, de 1933" (2003, p. 258). ${ }^{126}$

Sobre a grelha repousam três questões importantes que alojam o CBI-Esplanada mais claramente nas experiências modernas. A primeira, na intenção de fazer as peças préfabricadas, pouco espessas e leves. A segunda, na função de sombreamento e proteção das esquadrias. A terceira, no papel formal e gráfico da grelha como elemento que confere harmonia e unidade ao conjunto: portanto, uma função estética. Função esta de enorme relevância se se admite que cada fachada deva ser tratada de acordo com sua orientação específica: ou seja, uma solução de brise ou abertura para cada orientação, ponderando que algumas fachadas recebem pouca incidência de sol ${ }^{127}$.

Como exposto, do CBI-Esplanada emanam sinais de uma rica relação entre o edifício moderno e a cidade tradicional; entre suas origens e intenções abstratas e a herança da tradição; entre uma vontade de ser um objeto solto no espaço e o fio que o prende ao lote. Uma perspectiva e estudo das fachadas principais - expõe um ponto de partida mais próximo das abstrações, mas ainda guardando a força da massa tripartida; nesses mesmos estudos, percebe-se o tratamento secundário dispensado ao estreito apêndice: na obra acabada constata-se essa mesma intenção realizada: a loggia inferior ao nível do Anhangabaú interrompe-se ao se encontrar com o indesejável acréscimo (figuras 9.1 a 9.18$)$.

${ }^{126}$ A grelha mencionada foi acrescentada ao prédio do Exército da Salvação após a segunda guerra, por Le Corbusier e Pierre Jeanneret. Como é de conhecimento a primeira solução fracassou no primeiro verão em seguida a sua inauguração. Ver Cohen (2005, p. 51).

${ }^{127}$ No caso do CBI-Esplanada, as orientações são as seguintes: fachada para o Anhangabaú, sudeste; fachada para a Praça Ramos de Azevedo, sudoeste; fachada lateral, nordeste. 


\section{Conde de Prates: o palacete e a torre}

O edifício Conde de Prates, 1952, é de autoria de Giancarlo Palanti ${ }^{128}$. Ele é uma das poucas torres modernas isolada no lote no Centro Histórico de São Paulo ${ }^{129}$. Diga-se uma torre que se desenvolve de forma contínua com poucas interferências da legislação escalonada, porém vinculada ao tipo antecedente. Uma torre lisa e contínua a partir de um embasamento com fortes marcações horizontais: à maneira moderna corbusieriana, um arranha-céu que não enfatiza a verticalidade. Ainda assim, uma torre que guarda profundas ligações com suas precedências mais imediatas: os Palacetes Prates. Se a leitura retrocede um passo atrás, vai de encontro ao Viaduto do Chá e ao plano de Bouvard e seus melhoramentos. Em resumo, sua localização privilegiada nas vertentes do Anhangabaú articula três espacialidades importantes: o próprio Parque do Anhangabaú, a Praça do Patriarca e o Viaduto do Chá - que realiza a passagem em nível entre as duas colinas, entre o Centro Velho e o Novo pela Rua Barão de Itapetininga. Na história do edifício subjaz parte dos processos de modernização e urbanização de São Paulo.

Os arruamentos que dariam origem à formação do seu lote remontam aos primeiros e marcantes traçados coloniais: a Rua São Bento ligando os conventos de São Bento e São Francisco, a Rua Direita dando na Igreja da Misericórdia e a Rua da Quitanda penetrando para o interior do Triângulo. A construção do primeiro viaduto do Chá de Jules de Martin estabeleceria o ponto de contato entre as duas colinas, mas será o plano de Bouvard que definirá a espacialidade da Praça do Patriarca, com a demolição de casarios no prolongamento da rua da Quitanda: "o alargamento da Líbero aconteceu, em sua maior parte, entre os anos de 1911 e 1914, interligando a outras obras e melhoramentos, como a abertura de uma praça na esquina com a rua Direita (a futura praça do Patriarca, concluída em 1924) e o alargamento da rua de São João" (Simões Júnior, 2004, p. 140).

Se as precedências deixam sempre seus rastros é no plano de Bouvard para o Parque do Anhangabaú que se encerra a pré-volumetria que daria origem ao edifício Conde de Prates. Como mencionado, o plano foi objeto de um acordo entre as elites locais e teve que acomodar interesses diversos: parte deles vinculados ao Conde Prates. De forma que Bouvard ao elaborar o parque como uma articulação entre as duas colinas, o fez de uma orgânica procurando tecer essa passagem e ao mesmo tempo configurando a volumetria das edificações fronteiriças. Toledo trata esses palacetes como "Os Blocos do Parque do Anhangabaú" e assim os explica:

${ }^{128}$ O primeiro projeto data de 1952. Segundo Xavier, Lemos e Corona, Palanti chefiou o setor de projetos do escritório de Alfredo Mathias em 1952 (1983, p. 30). O primeiro projeto foi alterado entre 1952 e 1953. lote/quadra.

${ }^{129} \mathrm{O}$ edifício Triângulo de Niemeyer também é uma torre limpa; uma torre nos limites do 
A expressão bloco deixa claro que os novos edifícios seriam volumes bem definidos no Parque, subordinados à ordenação da área. Quando se tem em mente a preocupação do Vereador Silva Telles de que novos edifícios na Rua Líbero Badaró deveriam ter frente para o Vale, ou de propostas ulteriores, que falavam em frente para "os dois lados", isto é, para a Rua e para o Vale, a ideia de bloco vinculava-se a um conceito de volume, uma concepção espacial, portanto. Era o que a população já aprendera a admirar no Teatro Municipal, aquele elegante volume desfrutando ampla vista sobre o Vale, assentado em sua esplanada (1989, p. 94).

Ainda segundo Toledo a fórmula foi bem aceita pelo Conde Prates que mandou construir um terceiro bloco na cabeceira do Viaduto do Chá. Os prédios inicialmente destinavam-se a comércio no térreo e escritórios nos demais pavimentos; se os propósitos dos edifícios não ficavam muitos claros quanto ao uso (programa), na intenção formal, ao contrário, ficariam - os blocos arquitetônicos faziam parte da composição urbana.

Portanto, a ideia de bloco como uma peça dessa espacialidade terá continuidade no projeto de Conde Prates não mais como um palacete, mas como uma torre de serviços que o reproduz e o alonga: dos iniciais seis pavimentos aos 33 andares de hoje - literalmente uma extrusão a partir da base, ou melhor, do embasamento. O primeiro palacete que dá origem ao Conde Prates encontrava-se implantado na vertente do Vale, tinha um embasamento que nascia na cota inferior mais próximo do leito do parque e encerrava-se no nível mais alto na cota da Líbero Badaró: nesse nível um belvedere circundava em forma de "U" o bloco do palacete propriamente dito, definindo acessos ao prédio, que ocorriam pelo próprio e pela Líbero.

Em 1938 seria construído o segundo Viaduto do Chá em concreto armado, de autoria de Elisiário Bahiana, em substituição ao antigo viaduto. $O$ antigo viaduto seria mantido durante a construção do novo; só depois seria demolido: fato que também explica o novo traçado passando lindeiro ao palacete dos Prates. Nos anos 40 o Parque sofreria as alterações decorrentes do Plano de Avenidas. O projeto do Conde de Prates tem início em 1952: o ponto de partida do projeto seria o antigo palacete. Ou seja, sua projeção era o limite do perímetro do novo edifício. Entenda-se a projetação em duas etapas: a primeira referindo-se diretamente ao embasamento (subsolos do antigo palacete) e a segunda ao corpo elevado da construção. Esses dois segmentos são quase integralmente mantidos na nova torre. Sob esse aspecto, o tipo embasamento + torre mantém-se o mesmo, guardandose as disparidades de altura final das edificações. As modificações na geometria do terreno foram poucas. Em parte decorrentes da construção do novo Viaduto do Chá - que limitou e 
interferiu na área original do terreno. $\mathrm{Na}$ "Escritura de compromisso de permuta e obrigações" ${ }^{\text {"130 }}$, são acordados entre os proprietários e a municipalidade:

- a permissão de estender a construção até o alinhamento da rua Líbero Badaró [os motivos encontram-se nas necessidade de fundações em conter com arrimo a encosta da Líbero], com isso a área do terreno passaria de $1.153 \mathrm{~m}^{2}$ para $1.250 \mathrm{~m}^{2}$, permitindo um poço "inglês" sob a calçada da rua;

- a manutenção do terraço público e da galeria coberta pela Líbero Badaró [o antigo belvedere, que já era uma concessão], dessa maneira mantinha-se a servidão pública;

- ficava também proibida qualquer ligação interna do prédio com o viaduto, assim como pelo lado oposto, que poderia apenas ter aberturas para iluminação e ventilação;

- na fachada para o Vale do Anhangabaú ficou permitido o acesso com portas pela rua do Vale;

- o novo gabarito ficaria determinado por um volume de 42,5 x 28,25 x 80 m;

- para suportar o terraço, foi permitida uma ampliação dos porões do prédio para o terreno circundante.

Pelos termos do acordo, entende-se que o edifício teria então $80 \mathrm{~m}$ de altura, a contar pela cota mais alta da Líbero Badaró, desconsiderando-se os pavimentos inferiores contidos na primeira volumetria do embasamento. Dessa maneira, estavam definidas as diretrizes para a construção do edifício e um primeiro projeto foi apresentado em 1952 e, posteriormente, substituído pela versão final propriamente dita, ainda em 1953. A substituição de um projeto pelo outro releva e ilustra a tênue divisão - naqueles tempos entre as linguagens de caráter moderno. Entre uma linguagem mais pragmática e outra mais vinculada ao discurso mais próximo do racionalismo formal; mais conjugada na expressão formal e plástica.

Confrontando-se as perspectivas de um projeto e outro, vê-se de imediato as diferenças de linguagem: o primeiro enfatiza as linhas verticais e o segundo a horizontalidade. No primeiro prevalece um equilíbrio entre cheios e vazios, o que se vê são janelas. No segundo, em vez de janelas, têm-se aberturas corridas em faixa; separadas por duas linhas de laje. As volumetrias dos dois projetos são semelhantes: um embasamento até a altura da Líbero Badaró, um pé-direito duplo, seguido pelo desenvolvimento do edifício e em ambos uma cobertura [coroamento] recuada do perímetro (um restaurante não

${ }^{130}$ A escritura foi lavrada em 14 de outubro de 1949 , no $19^{\circ}$ Tabelionato de Notas São Paulo; e se encontra nos arquivos do Condomínio Conde de Prates. Como proprietário constam Guilherme Prates e sua esposa Candida Pinto Prates. 
construído). A diferença entre as volumetrias se resume na colunata de pé-direito quíntuplo, marcando o arranque do edifício desde o Vale do Anhangabaú. Na proposta final prevaleceu por meio de blocos mais prismáticos [regulares] uma passagem mais clara entre as partes do edifício.

Se as análises atêm-se às plantas e aos cortes, percebe-se que a modulação estrutural é a mesma nos dois projetos: ou seja, quando se optou por mudar o projeto os cálculos de estrutura e demais projetos complementares já estavam em andamento. $\mathrm{E}$ o fato que desencadeou a mudança foi a possibilidade de se construir um novo sistema de fachada com um vidro mais resistente à irradiação solar ${ }^{131}$; portanto, uma mudança de tecnologia. Embora a estrutura já estivesse projetada foi possível o manuseio do fechamento; facilitado, pela ossatura independente; enquanto fundamento de uma linguagem, enquanto expressão vinculada a uma estética internacional.

Analisando-se as plantas-tipo do primeiro e segundo projeto identifica-se a mesma modulação e número de pilares no sentido paralelo à Líbero Badaró (e Anhangabaú) e no sentido transversal, excluindo-se os pilares de canto, têm-se espaçamentos de $10 \times 6$ pilares - com vãos iguais. O sistema estrutural é complementado por iguais núcleos centrais (elevadores, caixa de escada, sanitários) e duas linhas de quatros pilares entre esse e a borda do edifício, no sentido do vão maior.

Se não houve alterações na disposição e modulação estrutural houve com certeza na geometria da seção do pilares: na proposta final os pilares são simplesmente retangulares e encontram-se recuados da linha externa da laje, de forma a permitir a continuidade das esquadrias, apenas interrompidas nos pilares de canto. Em sintonia com os mesmos princípios são executadas as lajes em caixão perdido, formando planos horizontais entre os pisos de $3,15 \mathrm{~m}$. Duas vigas de borda complementam o sistema, travando o conjunto e ao mesmo tempo diminuindo o vão vertical das esquadrias de alumínio. Assim, enfatizam a horizontalidade moderna na expressão da arquitetura, aspecto importante para a concepção moderna corbusieriana e um contraponto aos arranha-céus americanos: mais ao caráter do primeiro projeto.

Essas análises em torno do Conde de Prates trazem à tona duas questões relevantes: a cidade [suas leis, formação etc.] sempre deixa sua marca independente da linguagem arquitetônica; e a fronteira entre os modernos encontra-se, sobretudo, na vontade

${ }^{131}$ Segundo relata o Sr. Oswaldo Ferreirinha - atual síndico do prédio - e na época trabalhando na construtora, o engenheiro e construtor Alfredo Mathias foi levado à Argentina para verificar uma solução em vidro e esquadria de alumínio mais resistente à irradiação. Pelo visto, a solução técnica convenceu proprietários e construtor a modificarem o projeto inicial. 
ou intenção formal - pois ossatura independente indicava ser senso comum (figuras 9.19 a 9.35).

\section{Itália: um arranha-céu moderno}

Se o edifício Condes de Prates configura-se como uma torre isolada no lote, mais como decorrência da formação e dos interesses históricos [e particulares] do que uma intenção estética plantada nos primeiros traços; o Edifício Itália, 1956, de Adolf Franz Heep, aparenta ser uma torre isolada no lote, ou melhor, um dos poucos arranha-céus em São Paulo que revelam ou explicitam uma vontade de ser do objeto moderno. A forte expressão de sua forma elíptica e os brises o reporta tanto ao objeto tipo brasileiro o MESP, quanto às variações do arranha-céu cartesiano de Le Corbusier ensaiado em Argel, no Bairro da Marinha, $1938^{132}$.

Se os rastros da forma do Itália podem inicialmente ser reportados ao edifício de Argel - sem os arredondamentos das pontas dos trapézios espelhados - sua configuração final distancia-se da origem ideal; ela também decorre da formação do lote e da legislação.

No mapa Sara-Brasil, 1930, é possível identificar o lote e a casa ocupada pelo Circolo Italiano em 1925. Lefèvre identifica um primeiro embrião já existente no mapa de 1881, que sofrendo acréscimos resultaria na sede da associação italiana (2006, p. 49-55). Dois aspectos chamam atenção: um diz respeito à forma do lote, outro à implantação da casa. O que se observa do lote é que sua forma e perímetro pouco foram alterados até a implantação do Edifício Itália: é notável o pequeno tramo perpendicular à Ipiranga. Nesse sentido, as correções de traçado feitas no alargamento da Ipiranga e São Luiz pouco o alteraram (Lefèvre, 2006, p. 172): mas é marcante o arredondamento da esquina, até então concordadas como arresta de um triângulo. A casa ocupada pelo Circolo Italiano era, em 1930, composta por três massas, estando as duas maiores na diagonal do terreno, o acesso principal ocorria pela Av. São Luiz. Essas situações vão, guardando-se as devidas distâncias programáticas e de volumetria, manter uma mesma ocupação no lote.

Nesses termos, o Edifício Itália continua e realça uma posição de esquina: invertendo a linha de visibilidade, mas não necessariamente, a posição das massas. No caso das casas a ocupação na diagonal do lote libera áreas para os jardins, no caso do arranha-céu vai permitir a liberação da torre e melhor aproveitamento da área construída. Nas duas obras a ocupação nos fundos do terreno garantia a liberação ou visibilidade dos blocos mais significativos. Mas com uma diferença; se na rua São Luiz prevalecia os palacetes isolados,

${ }^{132}$ Fujioka faz menção mais direta ao à torre da Pirelli de Gio Ponti, de 1956 (1996, p. 82). 
houve aparentemente um retrocesso, do ponto de vista do conforto ou da salubridade, as construções grudaram-se umas nas outras criando um parede quase contínua ${ }^{133}$. Retrocesso por um lado - multiplicação do lote por outro.

Essa inversão na ocupação da São Luiz foi decisiva na definição formal do edifício Itália, que teve que responder ou atender às novas demandas.

Os argumentos que o explicam pela legislação sempre enveredam por um acordo com a municipalidade. Xavier, Lemos e Corona mencionam que a prefeitura adotou como módulo a diagonal do cruzamento entre a São Luiz e a Ipiranga (Xavier, 1983, p. 38) ${ }^{134}$. O que de fato explica em parte a altura final do edifício em torno de $151 \mathrm{~m}$ e 45 pavimentos ${ }^{135}$ : a legislação já previa alturas superiores acima de $80 \mathrm{~m}$ nos pontos focais. Entretanto, os corpos elevados, quando isolados não poderiam ocupar mais do que $35 \%$ de sua área do lote. A área do lote é de $2.382 \mathrm{~m}^{2}$, a do andar-tipo é de aproximadamente $1.045 \mathrm{~m}^{2}$ : correspondente a $43,8 \%$ - portanto acima do permitido em lei. Como se vê a exceção ultrapassou a diagonal.

A altura da torre se explica por esses acordos. As alturas das duas alas encostadas nas divisas explicam-se em parte pela altura mínima exigida para edificações no alinhamento da via e não pelo índice máximo permitido na região central ${ }^{136}$. De fato a condição desses corpos, restrita na altura mínima, se justifica, assim como o embasamento mais baixo do que exigido, pela estratégia em fazer a torre mais expressiva e solta: as alas [ou asas] criam um pano de fundo e o embasamento, que ocupa toda a área do terreno, desprende-se da torre por meio de pilotis; na essência um térreo para lojas.

Esses arranjos compositivos das volumetrias são importantes para afirmar essa condição do edifício isolado no lote. Xaxier, Lemos e Corona sublinham: "até a altura permitida para construções na divisa, desenvolve-se, em cada alinhamento, volume baixo de tratamento diverso da torre, fazendo-Ihe contraponto e garantindo uma harmonização que dificilmente seria obtida somente com as construções lindeiras”. Essa explicação aclara uma questão relevante para os modernos “ [...] fugindo à tradição fachadista e aos correspondentes pátios internos, garante com sua planta elíptica, um tratamento contínuo à fachada" (1983, p. 38).

${ }^{133}$ Que se repetiu na Ipiranga e Senador Queiroz.

${ }^{134}$ Explica-se: diagonal admitida de $60 \mathrm{~m}$; recuo no alinhamento de $2,5 \mathrm{~m}$ de largura da rua ou no caso diagonal; aplicando-se a fórmula têm-se $60 \mathrm{~m} \times 2,5 \mathrm{~m}=150 \mathrm{~m}$.

${ }^{135}$ Com a construção posterior do restaurante na cobertura a altura final ficaria em torno de 164 m (Fujioka, 1996, p. 85).

${ }^{136}$ Decreto-Lei no 92 , de 02 de maio de 1941. 
Essa questão plantada nas cartas e posto em obra no objeto-tipo é também mencionada pela revista Habitat: [...] "Ali então se projetou um bloco de uma unidade rítmica admirável, na esquematização elíptica atingida pela síntese orientada para um índice ideal de insolação" (1956, no 29, p. 56). Mais adiante os autores descrevem a organização espacial e o continuum das superfícies. A organização do espaço interno, essencial numa boa arquitetura, distendeu-se até àquela conformação elíptica, emprestando-lhe um rigor de limite exato para empolgar com a sua ressonância de rítmos numa autêntica manifestação monumental.[...] De tudo, resulta, não apenas a unidade da fachada que tantos alardeiam, mas uma formulação orgânica, cuja projeção externa não revelará ao espectador onde começa e onde acaba - o monumento é para ser visto por todos os lados, a noção de fachada foi totalmente eliminada, como o preconiza a moderna arquitetura (idem, p. 56-7).

Índice ideal de insolação e noção de fachada totalmente eliminada, são pontos centrais preconizados pela doutrina da arquitetura moderna. Sob esse olhar o edifício Itália é exemplar: o que vê é precisamente a torre e sua orientação no sentido norte-sul; um pequeno desvio à direita não modifica substancialmente a orientação. $O$ índice ideal parece se referir mais às condições dos edifícios como propostos por Le Corbusier nas cidades ideais ou como resolvido no Ministério: uma fachada norte protegida por brises e outra envidraçada. Mas no Itália esta condição não se repete: o edifício não tem uma forma prismática e os brises estão postos igualmente em todas as faces. Embora os brises sejam ajustáveis $^{137}$ eles parecem atender igualmente aspectos funcionais e formais. Ou seja, de fato a Torre apresenta-se como um volume único e o sentido gráfico das tramas da estrutura e paletas dos brises reforçam essa irresistível figuração aos olhares dos comentadores.

Se a hierarquização das fachadas ditadas pela rua-corredor "desaparece" parcialmente na torre (afinal sua altura foi determinada pela diagonal da rua ) ela se encontra muito presente nas asas laterais e no embasamento. Aliás, também na curvatura da própria torre que acompanha a curva de visibilidade na esquina das avenidas Ipiranga e São Luiz. Nesses termos, o raciocínio funcionalista de um projeto gerado a partir do espaço interior e pela lógica dos diagramas de insolação não se encaixa plenamente nas leituras a partir da rua, a partir de uma perspectiva urbana. O edifício Itália configura-se como uma torre solta e soberana. Entretanto, ainda atada no rés-do-chão ao imperativo da galeria comercial $^{138}$.

${ }^{137}$ Neutra já havia criticado os brises do Ministério da Cultura por serem móveis e não calculados exatamente de acordo com a posição particular da face e latitude.

${ }^{138}$ Grosso modo a posição da torre não está voltada para nenhuma linha profunda de perspectiva e os argumentos de ponto focal de relevância . 
Mas essa condição de ambiguidade entre torre e demais volumes revela no Itália um de seus mais importantes atributos; a maestria dos autores em lidar com a lei, com as circunstâncias do lote e com manuseio de uma linguagem moderna que se reporta ao objeto-tipo moderno e brasileiro esquadrinhado no Ministério da Educação. Assim, ocorrem as transições pelo embasamento entre o edifício Itália e as edificações vizinhas, entre uma rua e outra, entre seus altos pilotis comerciais.

Se na relação entre o edifício Itália (e todas as suas partes) há uma identidade com as questões da arquitetura da cidade moderna, na estrutura reaparece ou reafirma-se o tema da ossatura independente; agora de uma maneira muito própria de Heep. Assim, a estrutura do prédio é descrita por Fujioka: "o esqueleto de concreto é composto de lajes nervuradas e vigas embutidas, com a redução do volume de concreto e material inerte para permitir o acabamento em tetos lisos. Os apoios perimetrais estão modulados em pilares esbeltos firmando uma grelha estrutural, um reticulado para os brises-soleil e as janelas. A grelha está amarrada numa estrutura de transição (cinta), que transfere as cargas para as colunas do embasamento" (1996, p. 88).

A transferência da estrutura em grelha para a superfície externa constitui-se numa variação da estrutura independente: a fachada não se encontra propriamente livre, nos moldes do esquema dom-ino. Mas também não deixa de formar sistemas com as demais partes da estrutura: pilares interiores, planta livre e as lajes lisas conformando planos horizontais. Por outro lado, nessa solução a estrutura ou ossatura recebe mais uma função, ou seja, de fundir-se ao elemento de proteção solar, maximizando o aproveitamento dos espaços interiores e diminuindo a espessura externa da parede, na medida em que os pilares próximos às bordas ou colocados para fora estão incorporados no sistema de estrutura e vedação. Sob esse aspecto, a intenção de igualar na fachada pilares e laje horizontalidade e verticalidade - reafirma a procura de uma leveza, facilitada pela posição das aletas dos brises, que não só reforçam essa disposição, como sombreiam os parapeitos das janelas interiores.

Um edifício, ou sua forma, pode ser explicado por diversos caminhos: o lote, a lei, as referências dos arquitetos mais diretas, pela estrutura, pela aerodinâmica e efeitos do vento: de qualquer maneira sempre será uma interpretação nascida nas complexidades. No caso dos argumentos desta tese, o edifício Itália é exemplar em demonstrar questões modernas de relevância e ao mesmo tempo atender aos imperativos da cidade, em manifestar os desejos de uma comunidade, de postar-se como um verdadeiro arranha-céu na dimensão de sua altura, de seus delírios. Ou melhor, ele desempenha dois papéis aparentemente ambíguos: ele é nos termos gráficos (estritos) de figura e fundo um edifício que conforma a rua, portanto, um fundo para o espaço público. Quando vivenciado pelas diagonais ou 
visuais urbanas ele se apresenta como um objeto solto no espaço. E nessa condição ele também é um monumento moderno, no Centro de São Paulo, à maneira de São Paulo (figuras 9.36 a 9.51 ).

\section{Conjunto Metropolitano: racionalidade e matéria}

No edifício Itália a torre desprende-se da base, mas as massas complementares ainda o fazem pesadamente preso ao chão. No Conjunto Metropolitano ocorreram mudanças significativas: a separação entre torre e embasamento é mais evidente e limpa. A racionalidade começa na rua e estende-se para os interiores da galeria comercial: ali, a força da geometria abstrata domina os desacertos ou incômodos vindos da periferia do lote. Nesse fluxo houve uma inversão operativa significativa; o pátio interno - ou vazio - é a racionalidade recôndita que potencializa intenções manifestadas no exterior.

O Conjunto Metropolitano projetado ${ }^{139}$ por Salvador Candia e Giancarlo Gasperini, em $1960^{140}$, encerra os anos 50 e inicia os 60. Não por acaso: sua forma, implantação, linguagem e programa são articulados de tal maneira que deixam claras as intenções e diferenças entre a arquitetura moderna e a cidade tradicional; embora não sem alguma dificuldade de forma. De textura nem tanto.

Localizado na esquina da Praça Dom José Gaspar com Avenida São Luiz, o Conjunto tem seu lote decorrente em parte das ocupações na rua São Luiz já no início do século XX, mas principalmente como decorrência do Plano de Avenidas, a saber: o alargamento da São Luiz e da Bráulio Gomes, o prolongamento da Marconi, ligação com a Basílio da Gama; além do importante acerto da geometria entre a esquina do Conjunto com a Praça Dom José Gaspar (biblioteca). Esse desenho sugere (apenas em projeção) uma simetria "barroca" a enquadrar um pequeno eixo monumental compreendendo as ruas Bráulio Gomes e Marconi. Dessa dilatação resultou-se uma reentrância que seria incorporada como indício de uma rua interna ligando a praça Dom José de Barros à rua Basílio da Gama. Começava assim um profícuo percurso projetual que aprofundaria essa particularidade engendrada nas visões urbanísticas de Prestes Maia.

Jaime Cunha Jr. fez uma extensa abordagem do edifício Metrópole, em parte suas análises em torno do edifício e a cidade coincidem com os propósitos aqui enfrentados. A documentação do edifício é farta, sobretudo a narrativa da evolução das formas pelos

${ }^{139} \mathrm{O}$ projeto foi fruto de um concurso fechado em 1959, denominado de conjunto de edifícios "Maximus", sob iniciativa da Companhia Santista de Administração e Comércio e Sociedade Comercial e Construtura S.A. (Cunha Jr., 2007, p. 59).

${ }^{140}$ Primeiros dados do processo são de 1959: processo $0.148344 / 1959$, Alvará de Construção, 30/10/1959. 
croquis de estudos (2007). De início Cunha Jr. relaciona já nos primeiros estudos a importância da ligação entre a Basílio da Gama e Dom José Gaspar: ali, pelo recorte já citado. "O memorial descritivo da proposta menciona a importância de tal acesso para a viabilidade das atividades comerciais, e seu valor na estruturação do partido arquitetônico, que originou, segundo as próprias palavras do arquiteto o 'Centro de Gravidade' de todo o edifício" (2007, p. 121).

Nos estudos a cronologia segue critério de proximidade com a solução final. Numa primeira hipótese há dois edifícios intermediados por uma esplanada que liga a Praça e Basílio da Gama. O corpo mais alto é prédio de escritórios, o menor o setor comercial que se encontra encostado e na mesma altura do edifício já existente ). Uma variação dessa proposta apresenta o conjunto comercial ainda separado, encostado na divisa, porém mais baixo. Na sequência, uma prancha mostra ainda os subsolos e a procura de um desenho para o embasamento, croquis subsequentes já insinuam uma marquise, entre os edifícios; a esplanada já é rua, mas ainda não totalmente coberta. O vai-e-vem dos acertos da volumetria prosseguem, alternando soluções que ora encostam ou não o bloco comercial ao edifício existente na praça. Em uma perspectiva a torre encontrava-se solta do embasamento, porém um corpo menor o alinhava e o encostava, à esquerda, ao edifício Princesa Isabel (São Luiz; percebe-se ainda que os dois blocos da torre de escritórios e o conjunto comercial já estavam conectados. A certa altura Gasperini justifica no memorial o partido apresentado no concurso, salientando que a diferença de gabaritos existentes nos lotes contíguos favorecia uma solução em torre para o prédio, que estaria "encostada" à empena do edifício Princesa Isabel na São Luiz; e teria gabarito limitado a 11 pavimentos formando conjunto com o prédio limítrofe na Praça Dom José de Barros (Cunha Jr., 2007, p. 132). Além das variantes da volumetria e da torre à procura de um ajuste é possível identificar a presença de dois vazios - ou pátios internos, conforme o olhar.

Bem, desse processo comum na evolução dos projetos desprende-se desde os primeiros estudos quatro questões ou decisões relevantes: a decisão de articular a Praça e a Rua Basílio da Gama, inicialmente por uma esplanada; o embaraçoso e constante acerto entre as divisas do lote e as construções vizinhas e por decorrência das volumetrias; a intenção da torre isolada inicialmente posta no chão; as aberturas ou pátios internos. Todos esses elementos foram contemplados na proposta final, evidentemente com ajustes.

A esplanada, que nasceu na divisa do edifício vizinho, foi transformada numa rua interna e coberta que interliga a Dom José Gaspar com a Basílio da Gama, por uma dobra a 90ํㅡ trás para dentro a Avenida São Luiz: estabelecendo uma vinculação espacial entre três níveis (ou cotas) distintos. Quanto às volumetrias do conjunto comercial, optou-se por 
um conjunto de menor altura desalinhado, pela altura, às edificações vizinhas ${ }^{141}$. Essa decisão contribuiu para um acerto mais harmonioso entre conjunto e torre - deixando-a mais exposta. Por outro lado, a torre em seus $80 \mathrm{~m}$ libertou-se de vez das divisas do lote e do chão, nessa condição ela nasceria do embasamento. Os dois vazios presentes nos estudos preliminares foram transformados num pátio central de quatro pavimentos: um enterrado e três acima do térreo. Diga-se necessário devido à profundidade do lote.

Acerca dessas escolhas há duas observações ou interpretações necessárias: uma abarcada pela potência da obra em articular espacialidades e fluxos urbanos sob o teto de um empreendimento comercial, sob os imperativos da legislação etc. Nessas condições, a despeito da desarticulação ou continuidades volumétricas com o entorno imediato, a forma (e o conteúdo comercial) do embasamento atende sem restrições à função intencionada. $A$ segunda, também relacionada à primeira, diz respeito à expressão da torre - observa-se, mais destacada em razão do embasamento em relação às construções vizinhas. A torre é enfim exposta livre em suas quatro faces; e nessa disposição manifesta-se pelo lado de fora a racionalidade da ossatura independente, agora visível sem a intermediação da fachada livre - estrito senso.

Essa configuração final do conjunto não acontece sem dificuldades e polêmica. Para se garantir a expressividade da torre isolada do perímetro da base (três primeiros andares), foi necessário recorrer, além dos recursos já mencionados, a artifícios em desacordo com a lei, como o avanço em balanço $(4 \mathrm{~m})$ das galerias sobrepostas sobre as calçadas. Sem esse recurso a torre não "desprenderia" da base nos termos da intenção formal: explica-se; a torre encontra-se no alinhamento da rua como os demais edifícios da Avenida São Luiz; ${ }^{142}$ essa condição era obrigatória para os edifícios construídos na zona central, conforme artigo 32ํ do Código Arthur Saboya e ratificado pela Lei 4.615, de 31 de janeiro de 1955.

O Conjunto Metropolitano desperta o imaginário racionalista e abstrato, vinculado diretamente ao caráter das torres envidraçadas de Mies van der Rohe: racionalismo poético pautado na "orgulhosa técnica moderna" e na idealidade da forma que agrada de imediato os sentidos. Uma idealidade contida mais no edifício do que na cidade, então em crise na visão de Mies, como exposto por Argan, que dirá que Mies não delineou problemas sociais ou urbanísticos diretamente, provavelmente pensando que as velhas cidades estavam

${ }^{141}$ Essa decisão foge à lógica dos empreendimentos comerciais no Centro. A ocupação dos lotes era intensa (máximo possível) nos limites da lei -0 parágrafo $2^{\circ}$ do art. $3^{\circ}$, Decreto Lei $n^{\circ} 92$, 1941, dispõe: Excetuam-se as construções cujo prédio vizinho, já construído, se elevar mais alto na prumada da divisa do lote, caso em que a nova construção a ele poderá justapor-se em toda a altura, sem prejuízo do disposto nos artigos $2^{\circ}$ e $4^{\circ}$ deste decreto-lei.

${ }^{142}$ As galerias avançavam, em projeção, $4 \mathrm{~m}$ sobre as ruas. A lei permitia 1,20 m. $\mathrm{O}$ assunto foi objeto de contestação; e posterior permissão. 
condenadas a desaparecer. Assim, para ele, os arranha-céus seriam os primeiros elementos da cidade futura, feitos de enormes prismas transparentes, com grandes vazios entre si (1984a, p. 338-339). Se em parte uma referência do edifício Metrópole está na torre envidraçada, outra mais próxima encontra-se no Laver House Building, Nova York, 1951-2, de Skidmore, Owings e Merrill: nesse caso, além da torre isolada foi posta em prática uma nova tipologia moderna da embasamento regular encimado por uma torre deslocada de seus eixos centrais; dessa forma, diferentemente de Mies o que se pretendeu foi restabelecer relações modernas com a rua e a cidade - no caso de Nova York, assentada sobre uma trama mais regular.

Se a racionalidade se expressa nas volumetrias, ela é melhor medida no espaço do pátio descoberto: o desenho apurado e proporcionado das espessuras das lajes e vigas que circundam o vazio reforçam as ortogonalidades das linhas, reafirmando o continuum espacial dos planos abstratos e paralelos sem a retórica dos pilotis, presentes em vários edifício modernos no Centro.

O Conjunto Metropolitano é uma variação das galerias comerciais no Centro Novo: com a introdução de estacionamento. Como outras galerias ele ocupa interiores de quadras e interligam ruas: mas de um modo mais independente, mais a caráter de vontade moderna. Por isso, o Conjunto Metropolitano é emblemático. Por suas formas é possível recortar as dificuldades da idealidade moderna diante da cidade tradicional: de uma maneira clara ele encerra e exemplifica esse embate. A torre está solta e o embasamento tem expressão própria; ele quase se desprende do lote, para isso sacrifica a continuidade volumétrica com os edifícios lindeiros. Ao mesmo tempo ele promove as capilaridades contidas no Centro Novo, interligando espaços e ruas como já promovido por outras galerias comerciais no Centro Novo (figuras 9.52 a 9.70). 
Edifício CBI-Esplanada, 1946 ( Figuras de (9.1 a 9.18)

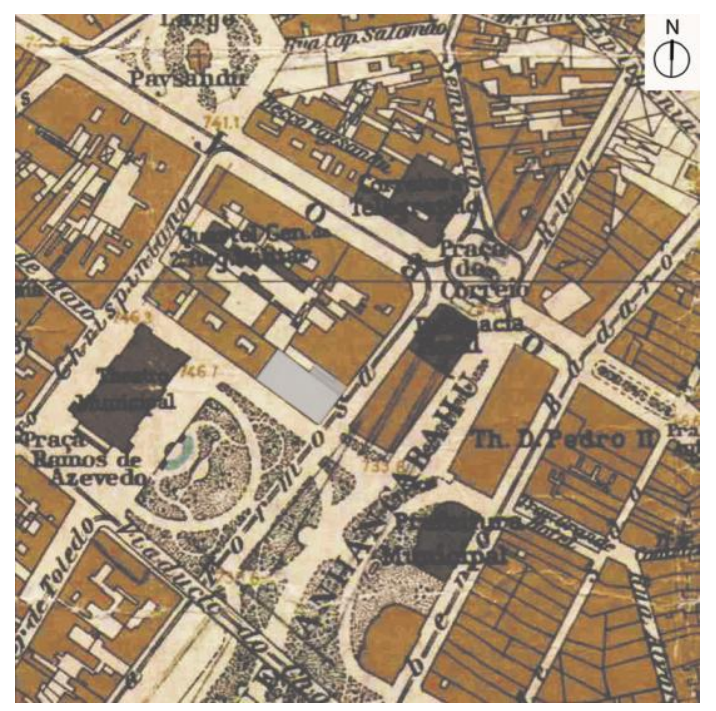

9.1: Mapa Sara Brasil

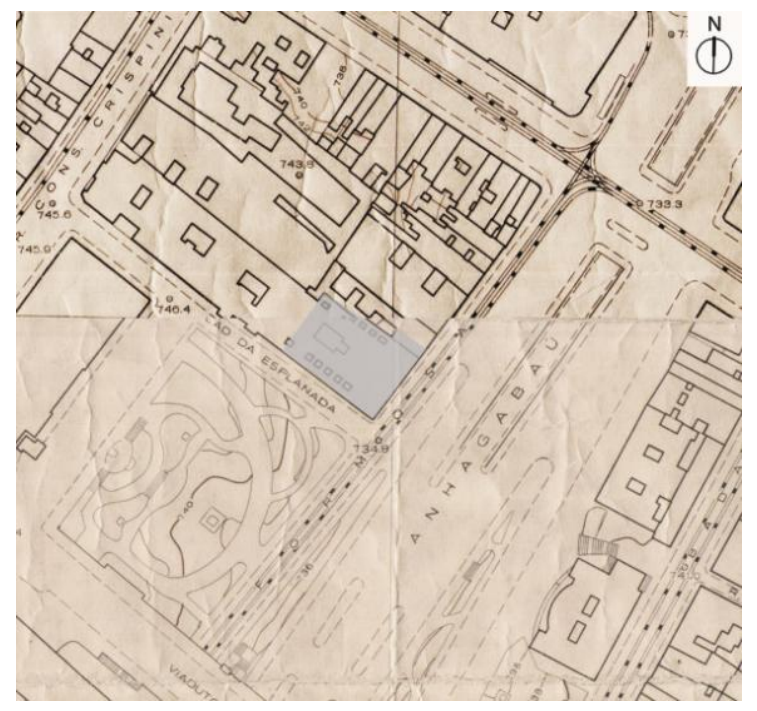

9.2: Localização no mapa Vasp-Cruzeiro

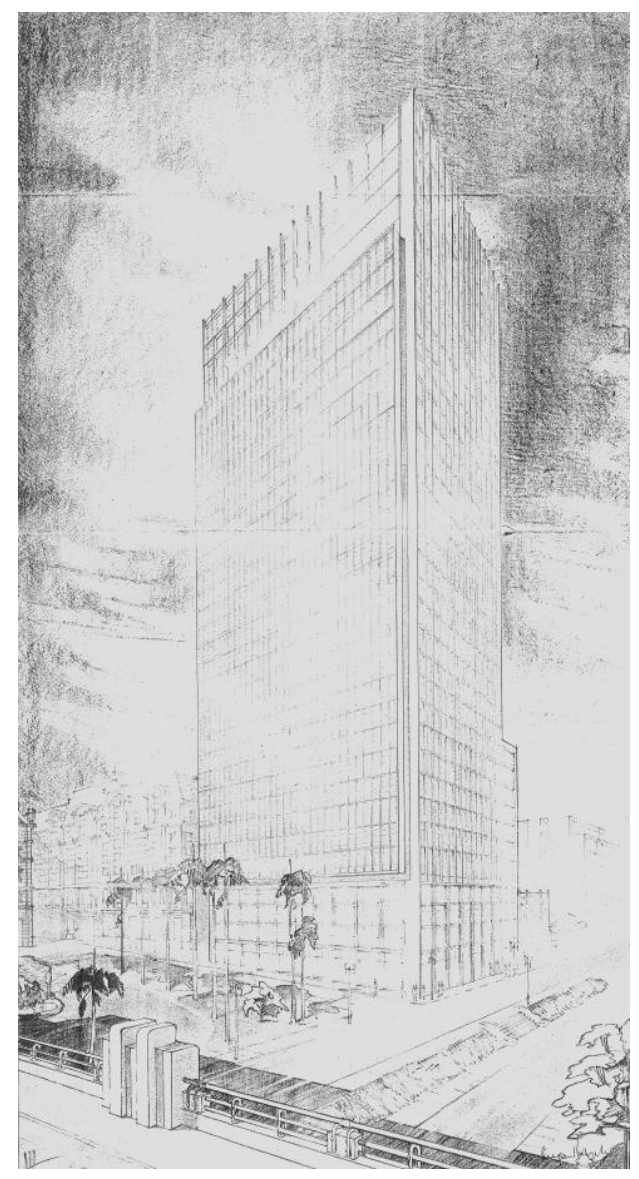

9.3: Perspectiva 


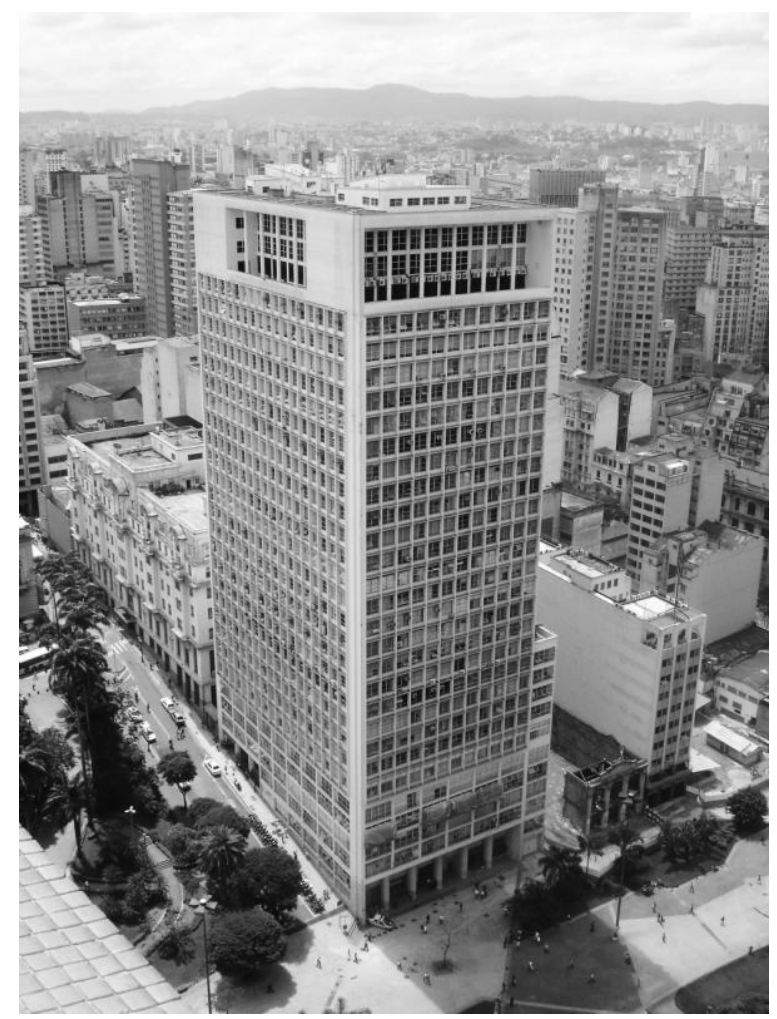

9.4: CBI-Esplanada, 2009

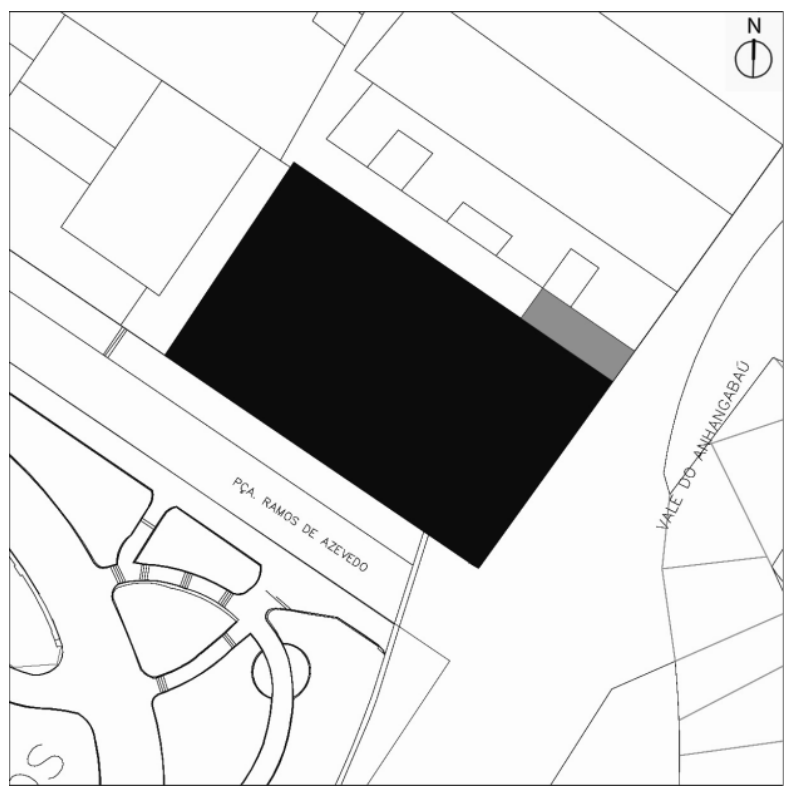

9.5: Localização Gegran: Viva o Centro 

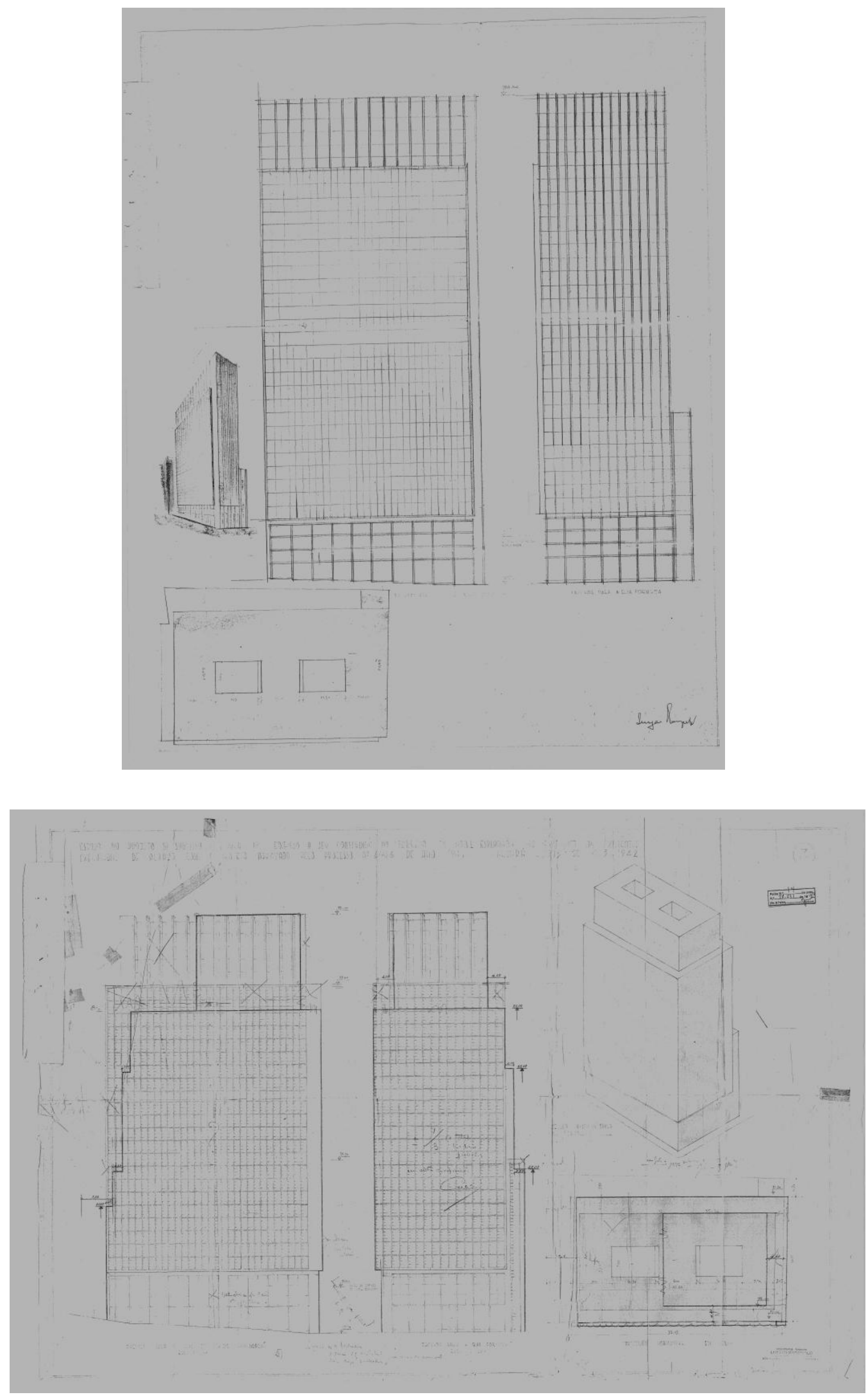

9.6 e 9.7: estudos de fachada e volumetria 

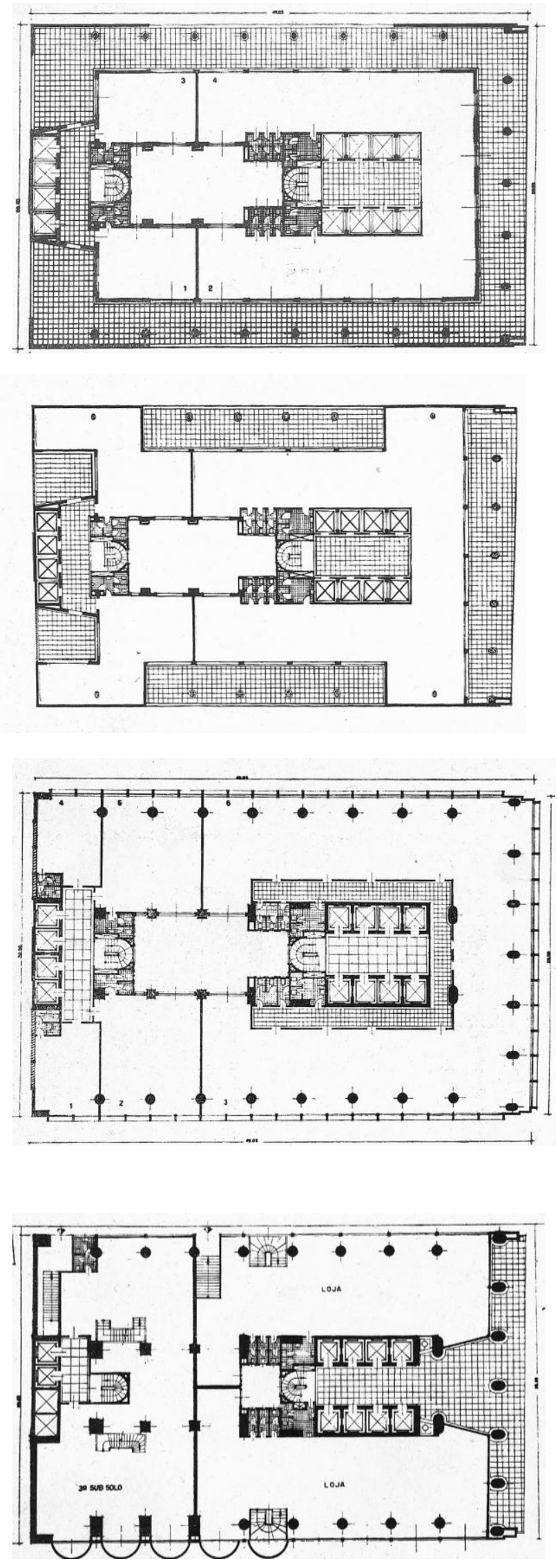

9.8: $24^{\circ}$ e $25 \stackrel{\circ}{ }$ Pavimentos

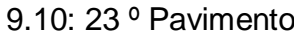

9.12: Planta Térreo 


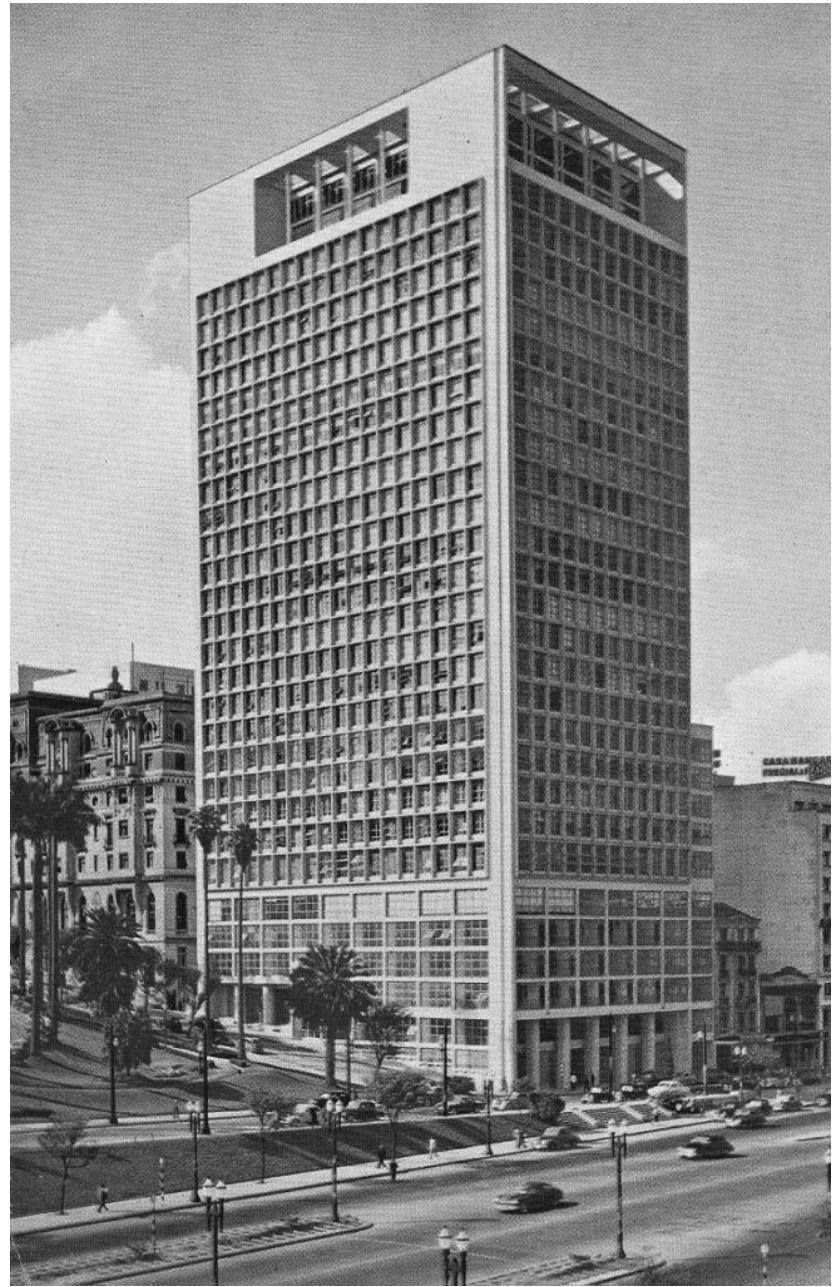

9.13: CBI - Esplanada, 1946

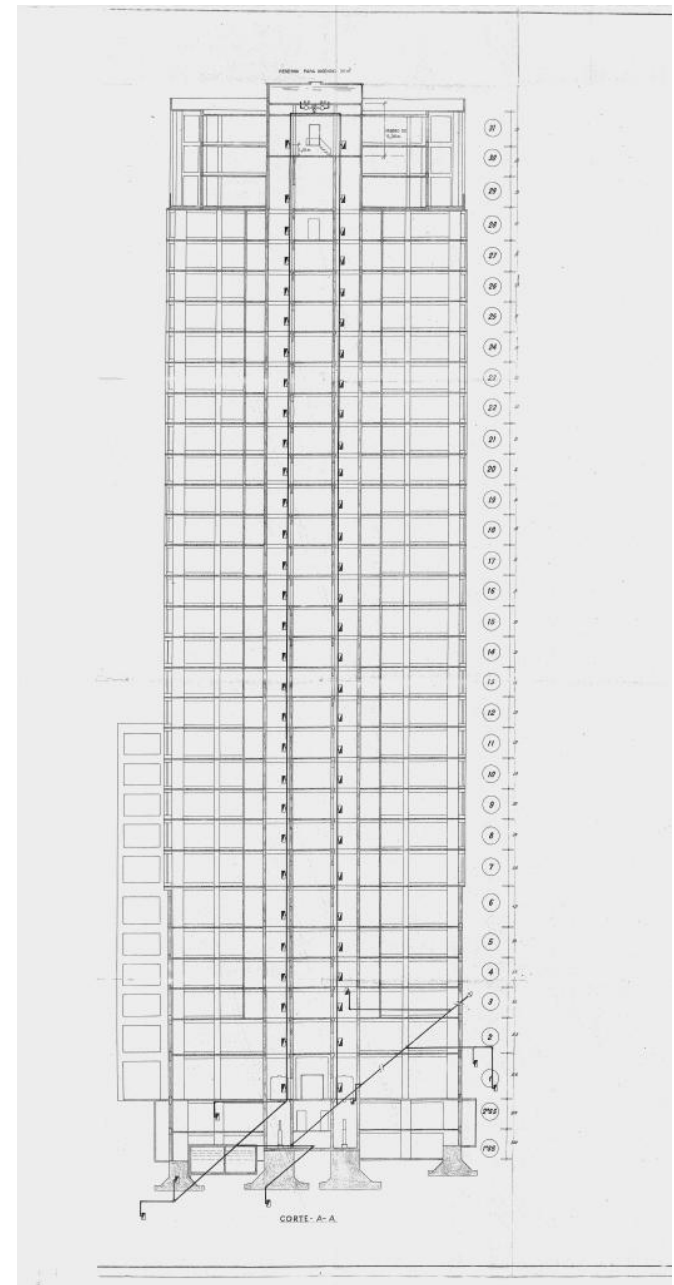

9.14: Corte transversal 


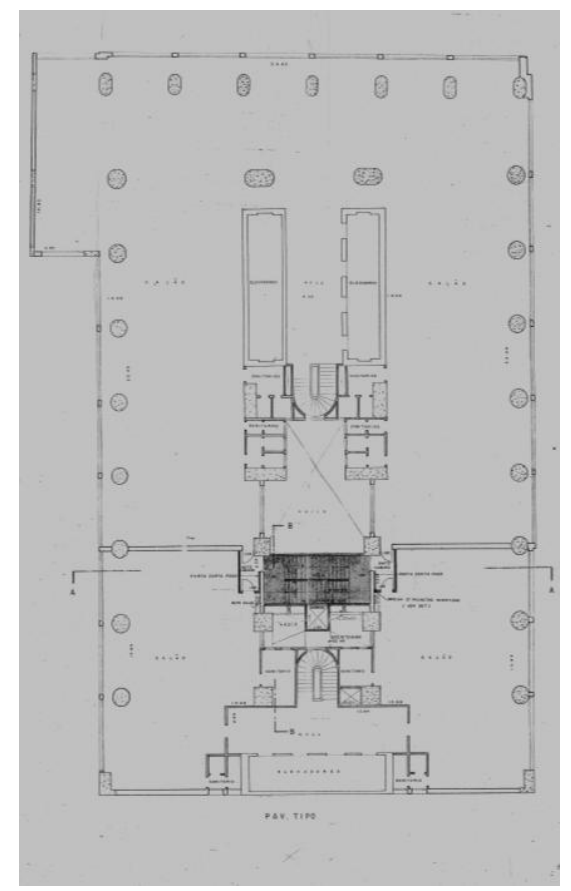

9.15: mezanino, com a

representação do apêndice, por vezes omitido nas plantas para publicação.

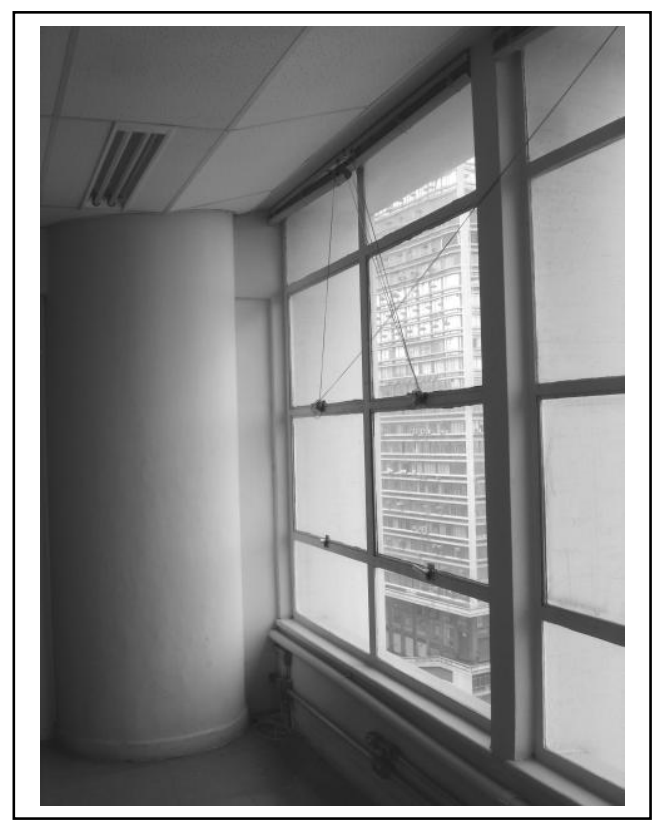

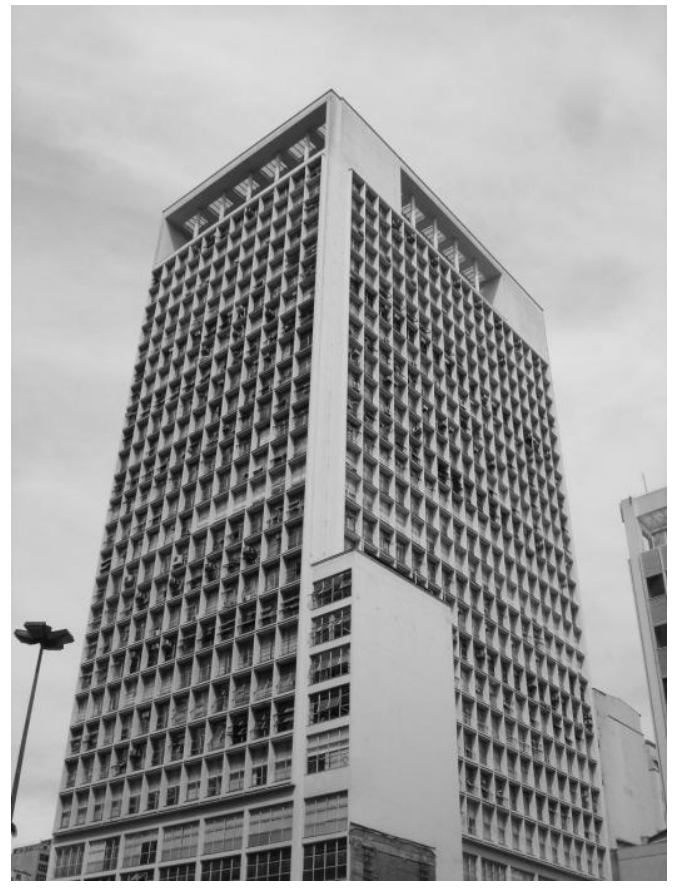

9.16: CBI, 2009

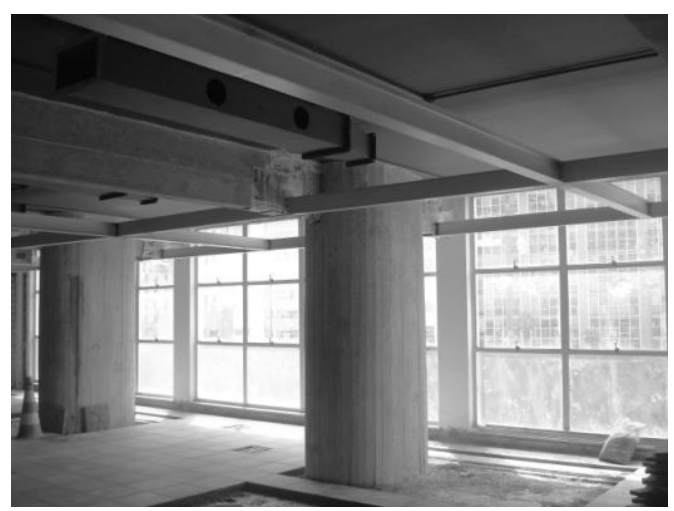

9.17: 2009

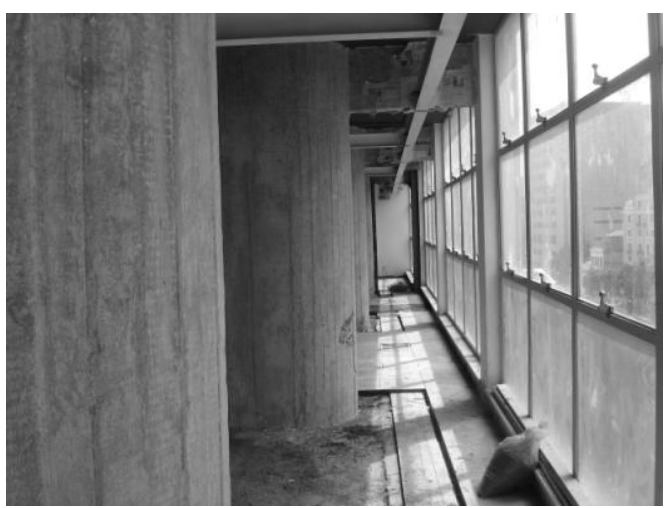

9.18: 2009 
Edifício Conde de Prates: 1952 (Figuras de 9.19 a.9.35.)

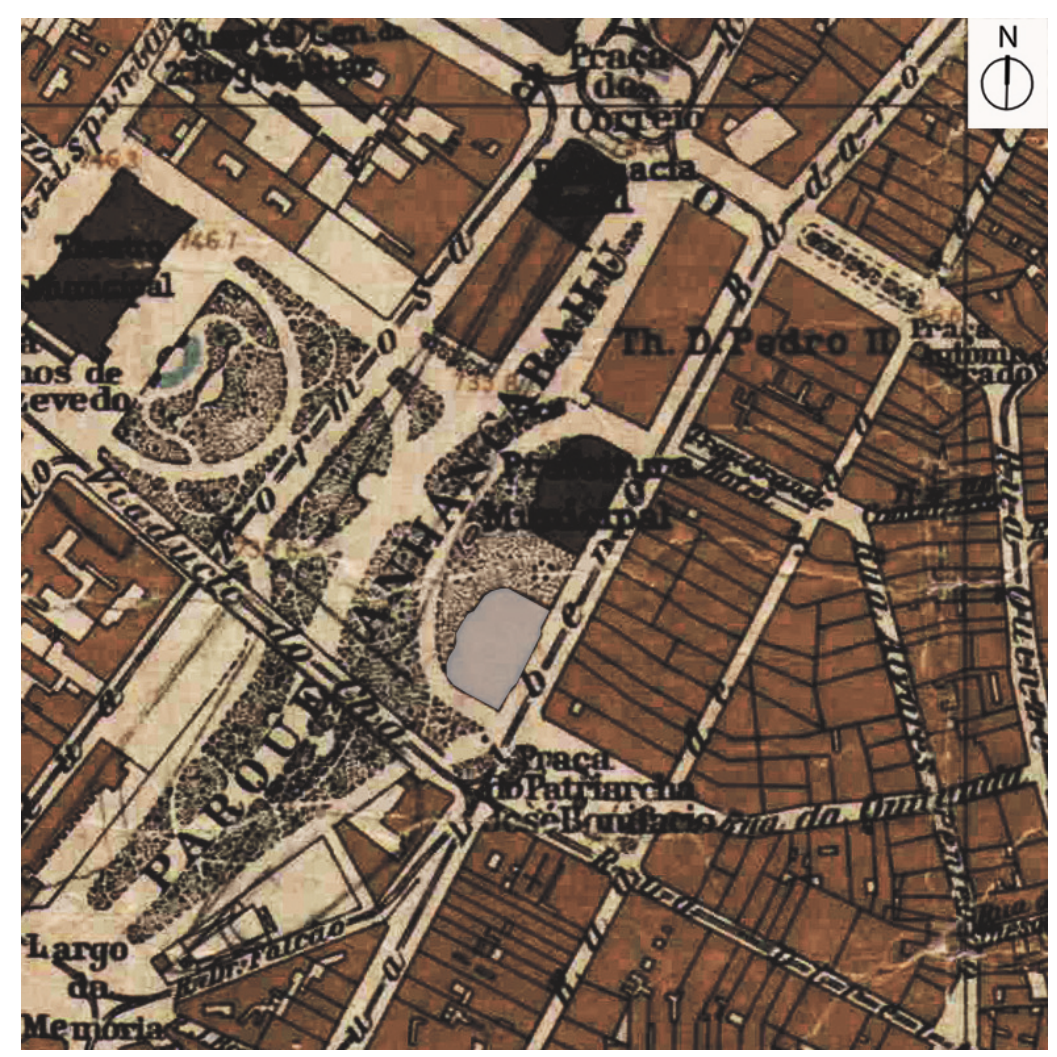

9.19: Mapa Sara Brasil

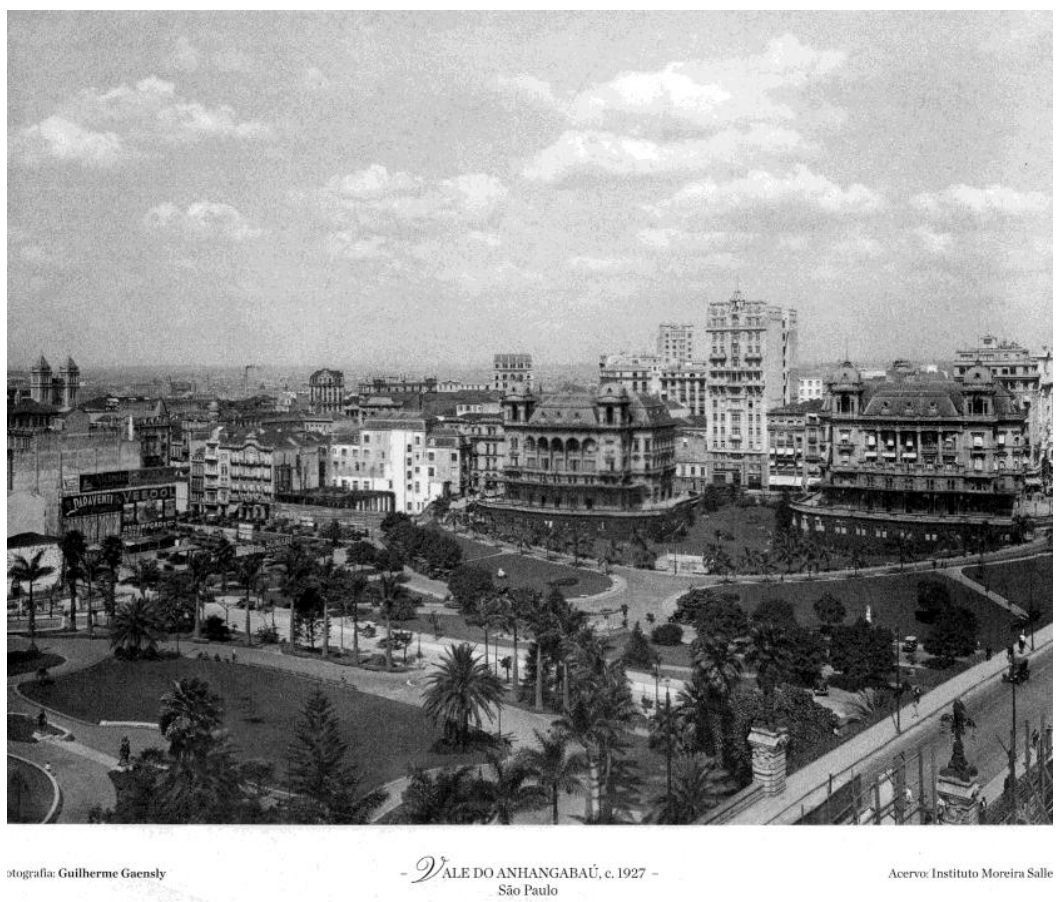

9.20: Postal Anhangabaú, Palacetes do Prates 


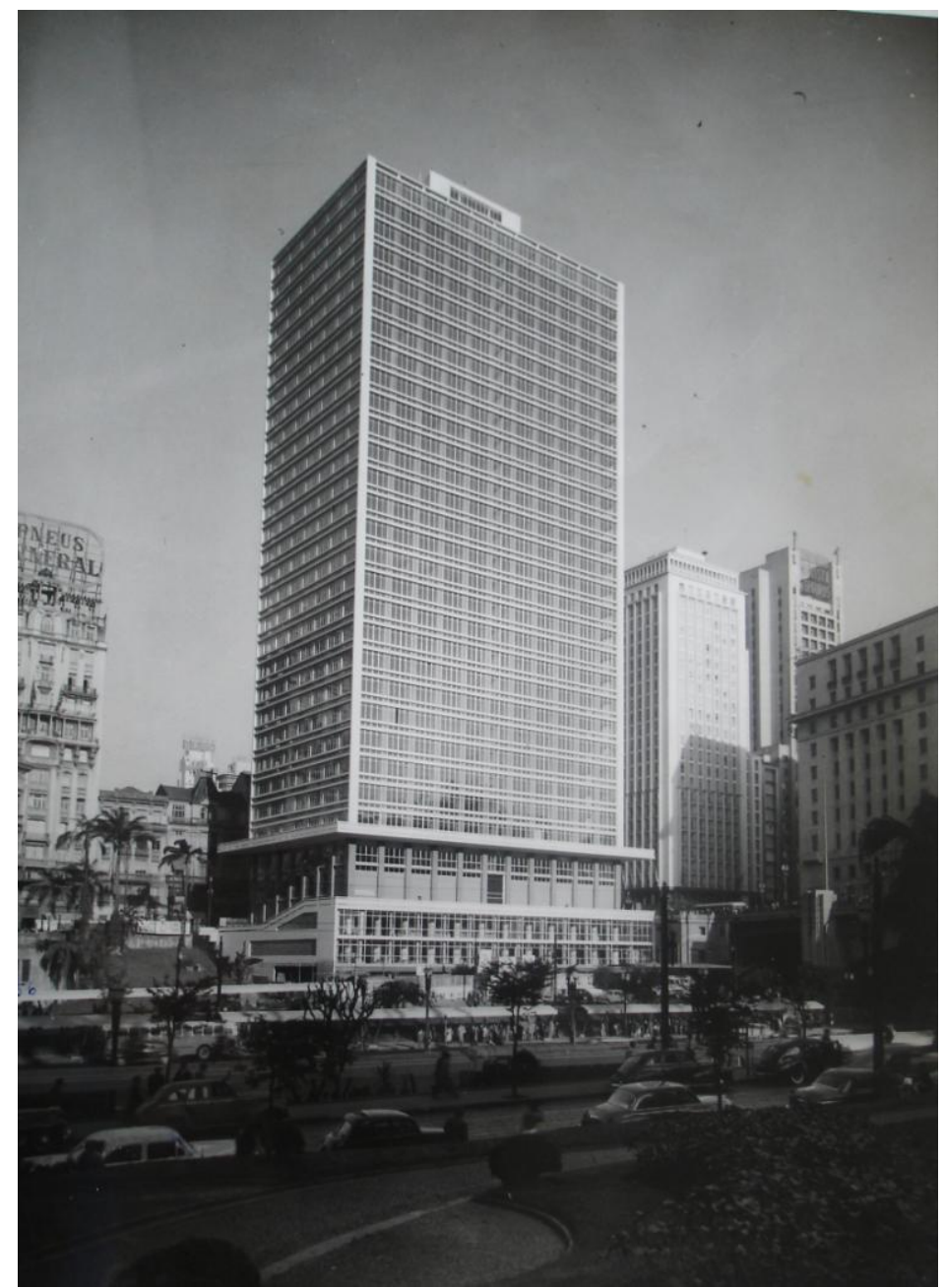

9.21: Conde Prates, 1952

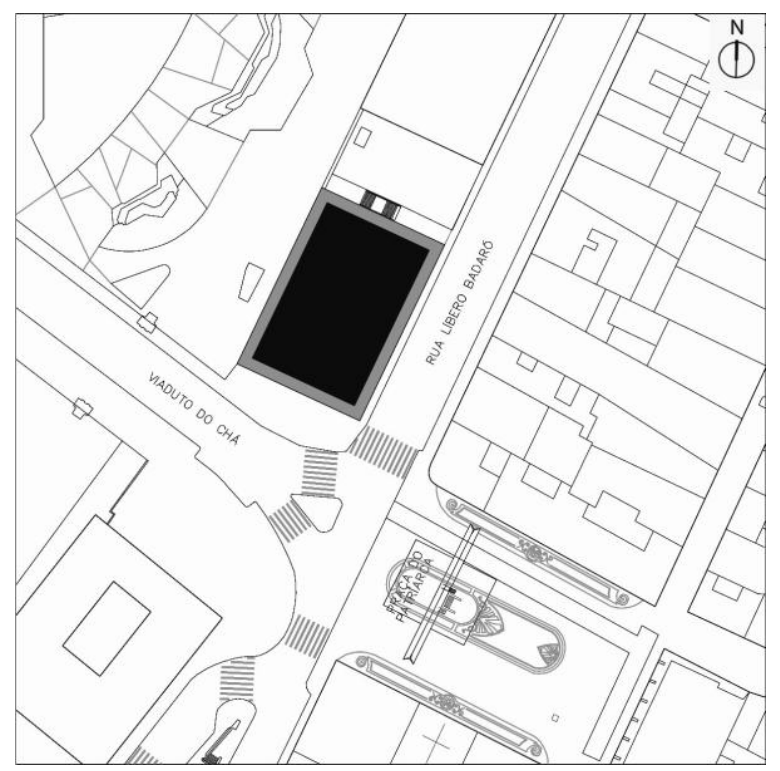

9.22: Situação atual, Gegran -Viva O Centro 


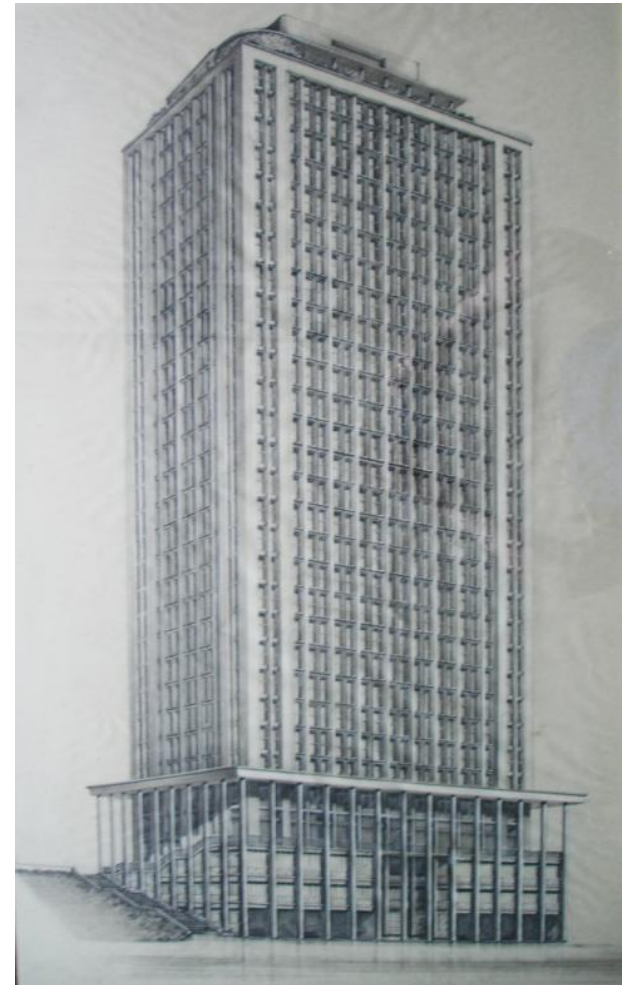

9.23: Conde de Prates. Perspectiva do 1ํ primeiro projeto

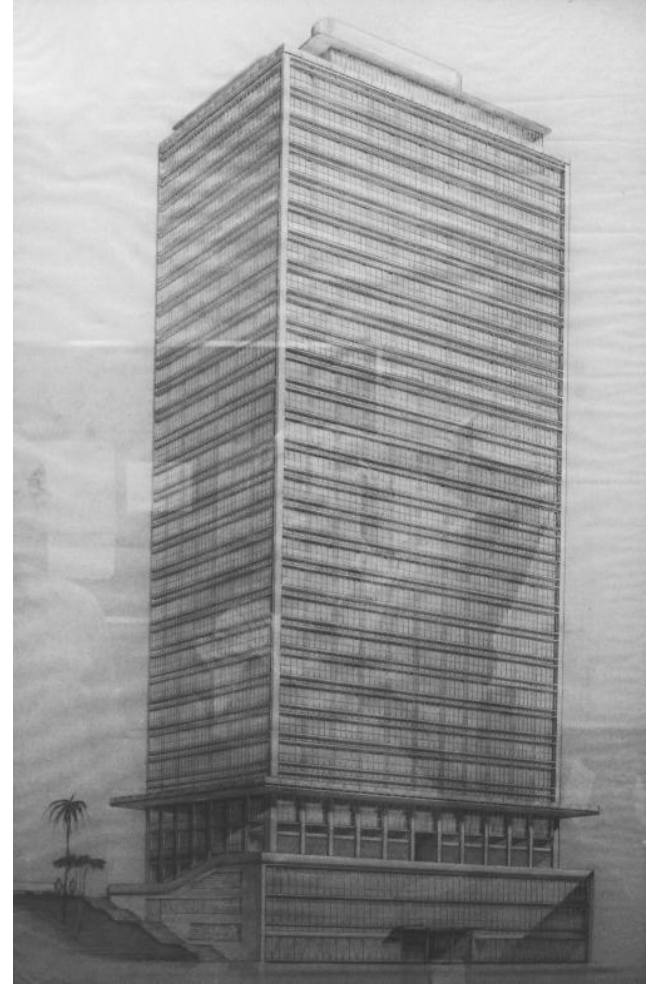

9.24: Conde de Prates. Perspectiva do $2^{\circ}$ projeto

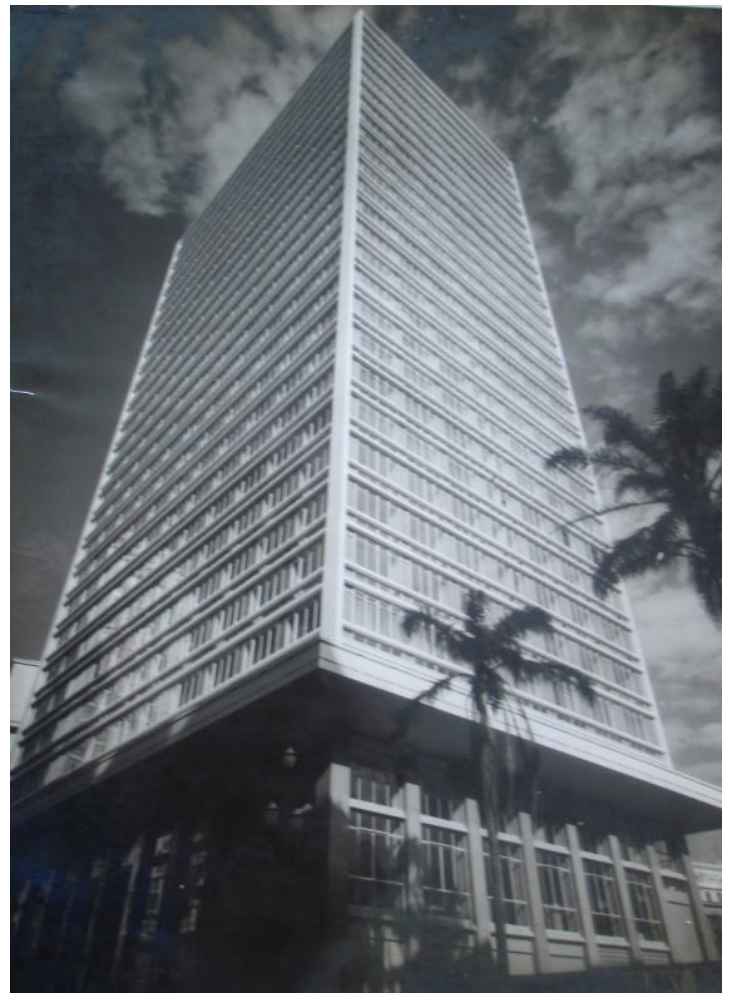

9.25: Conde de Prates, obra construída 


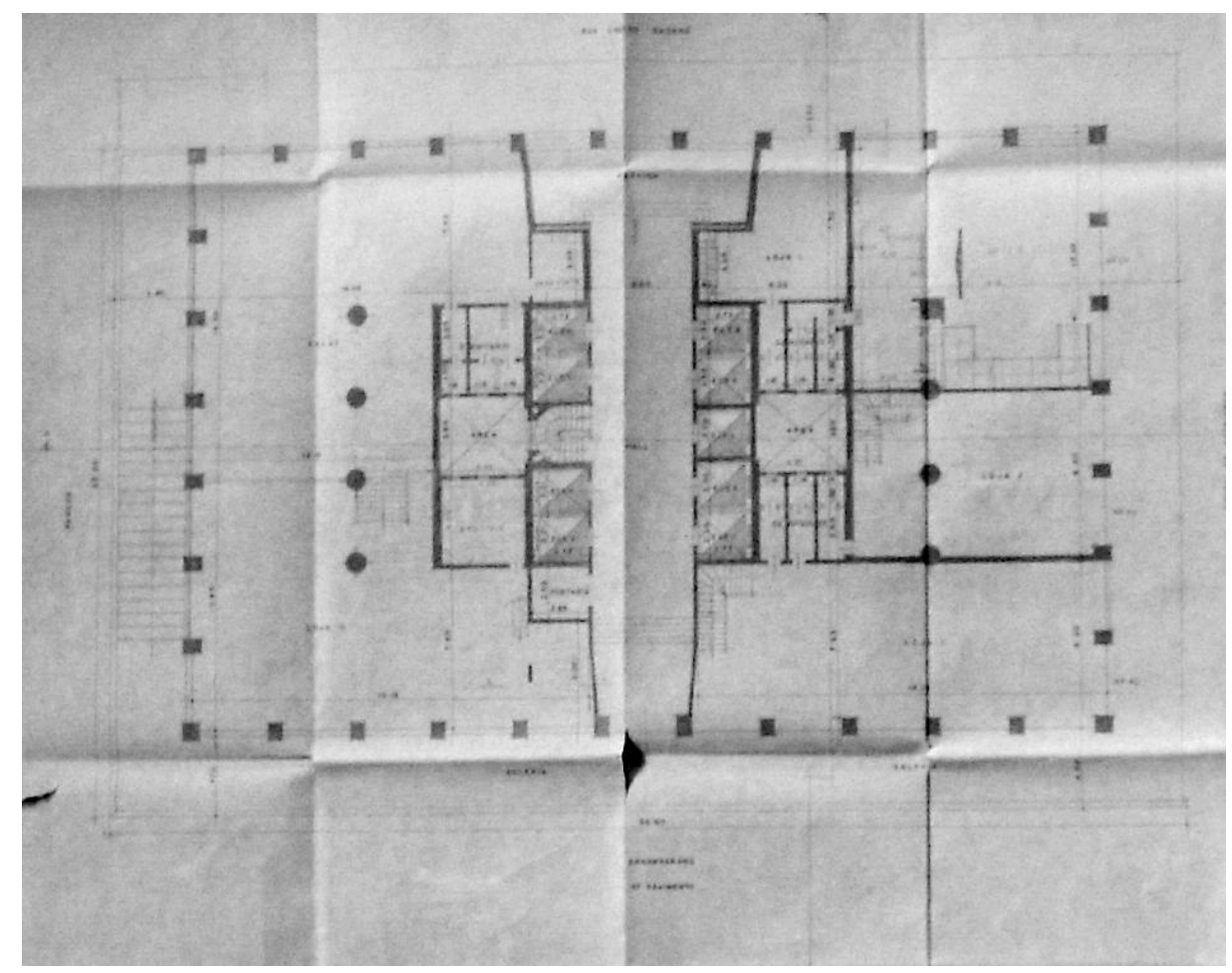

9.26: Planta nível da Libero Badaró

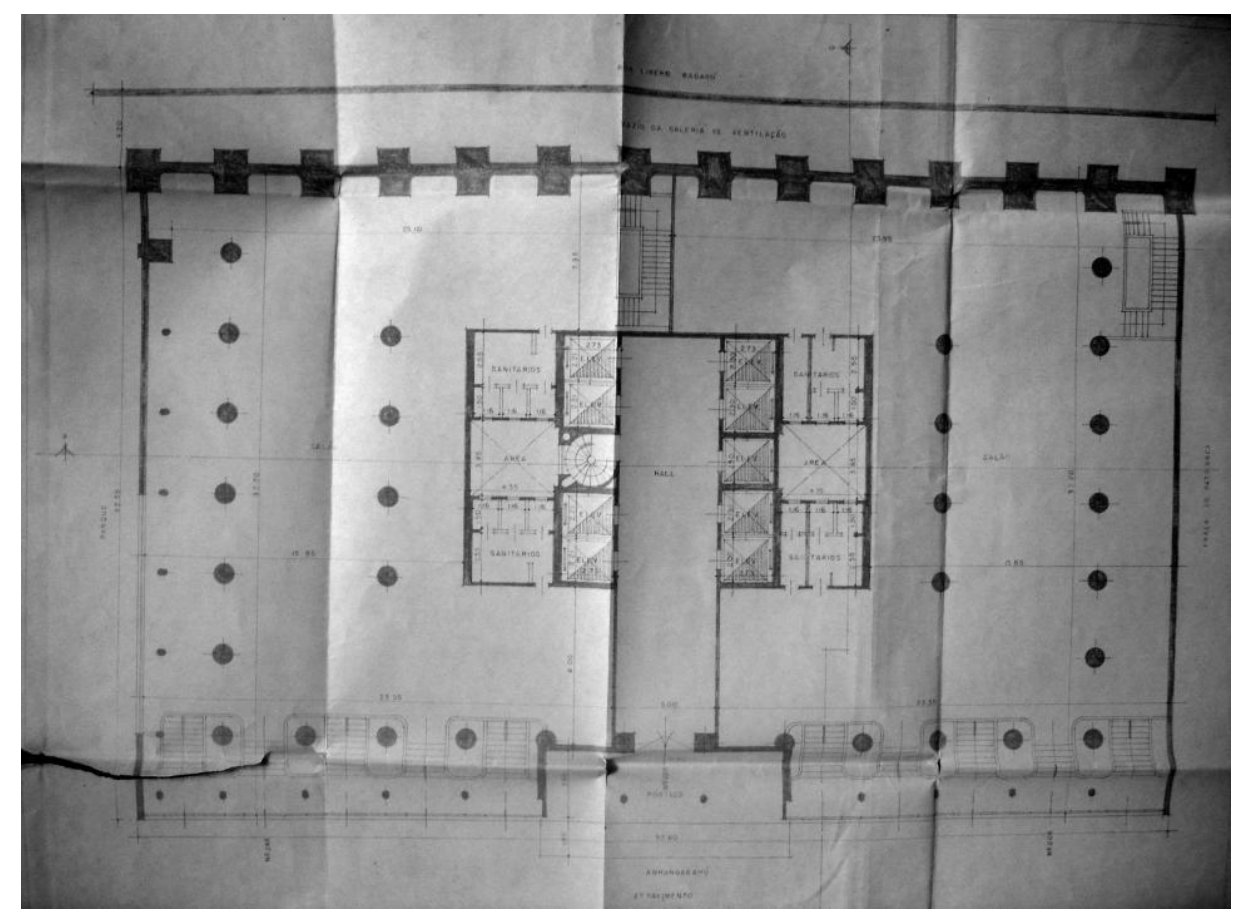

9.27: Planta nível do Anhangabaú 


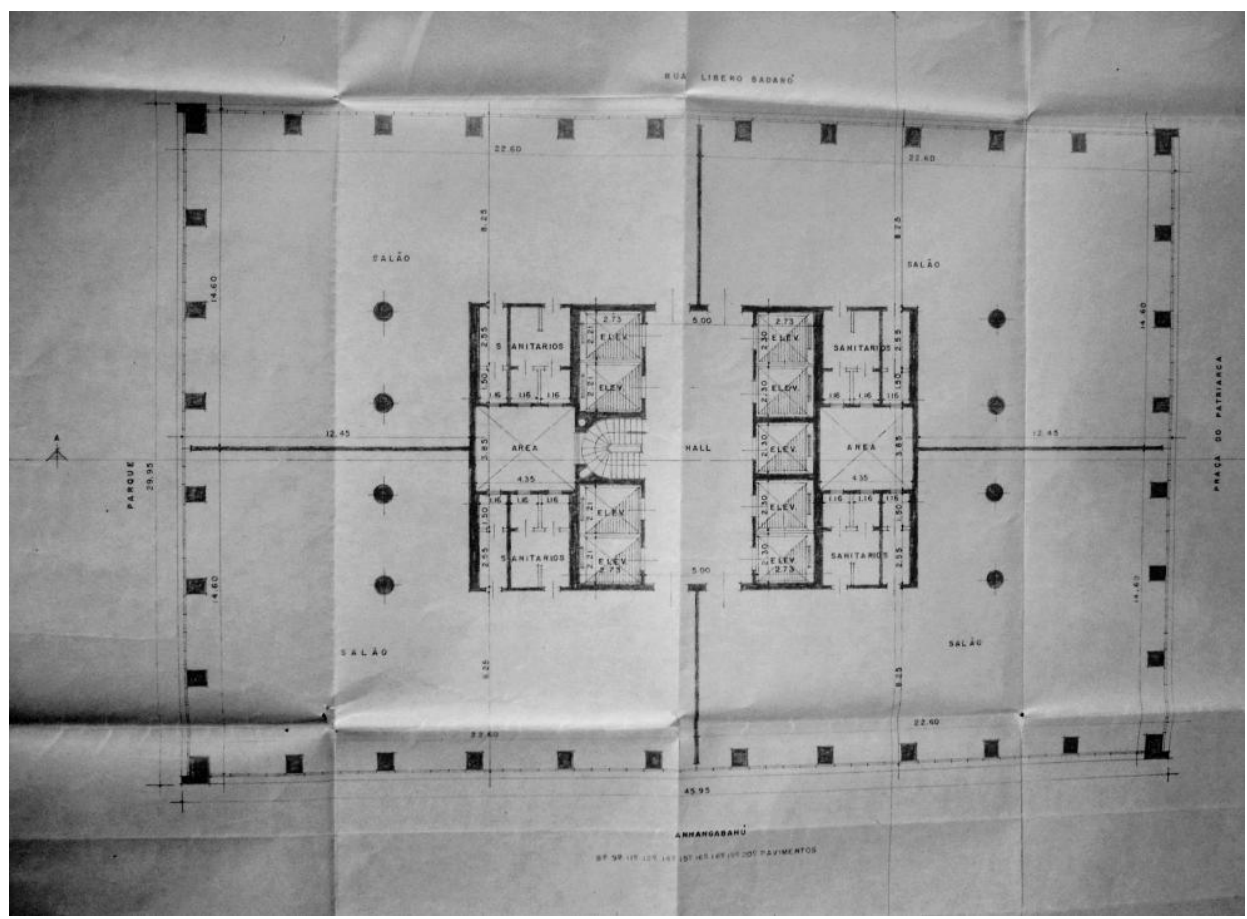

9.28: Planta tipo

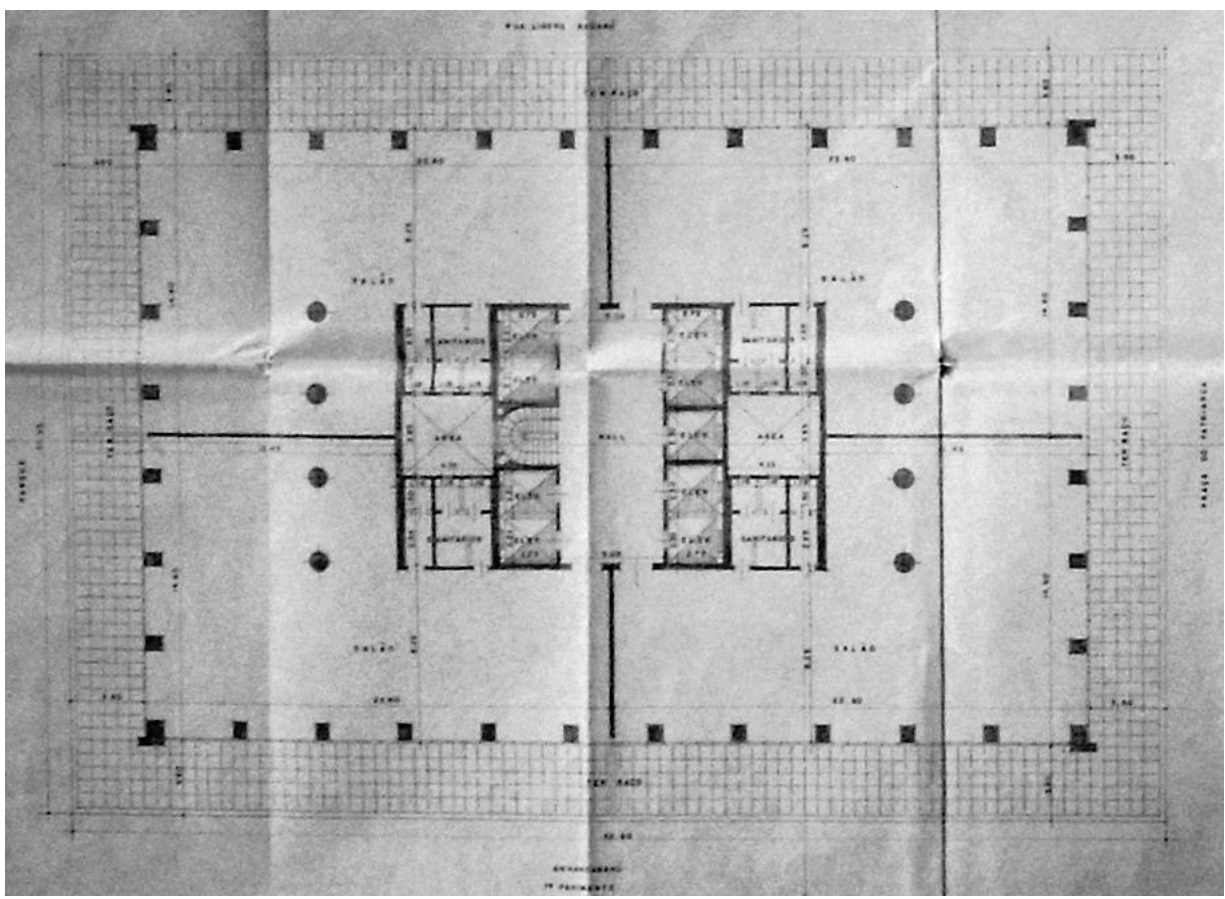

9.29: Planta do terraço, nível Praça do Patriarca 


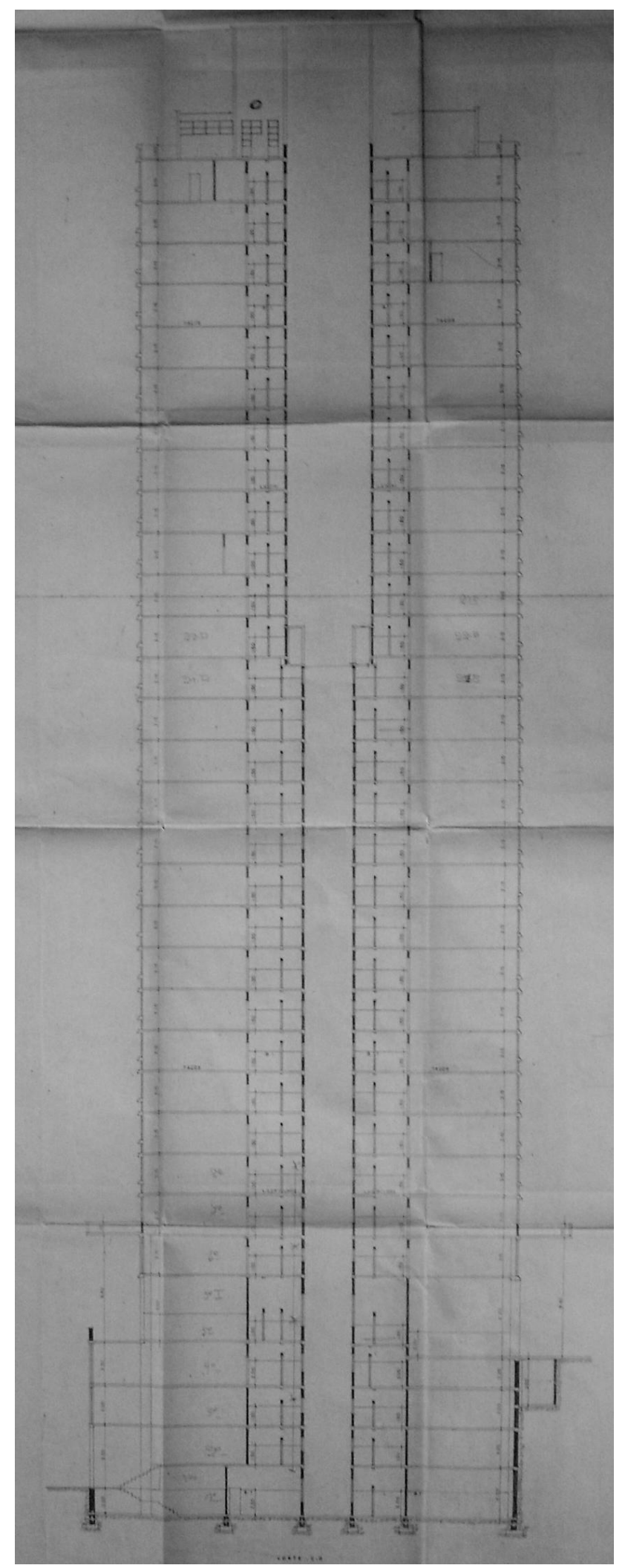

9.30: Corte transversal: passando pelo Anhangabaú e Libero Badaró. 

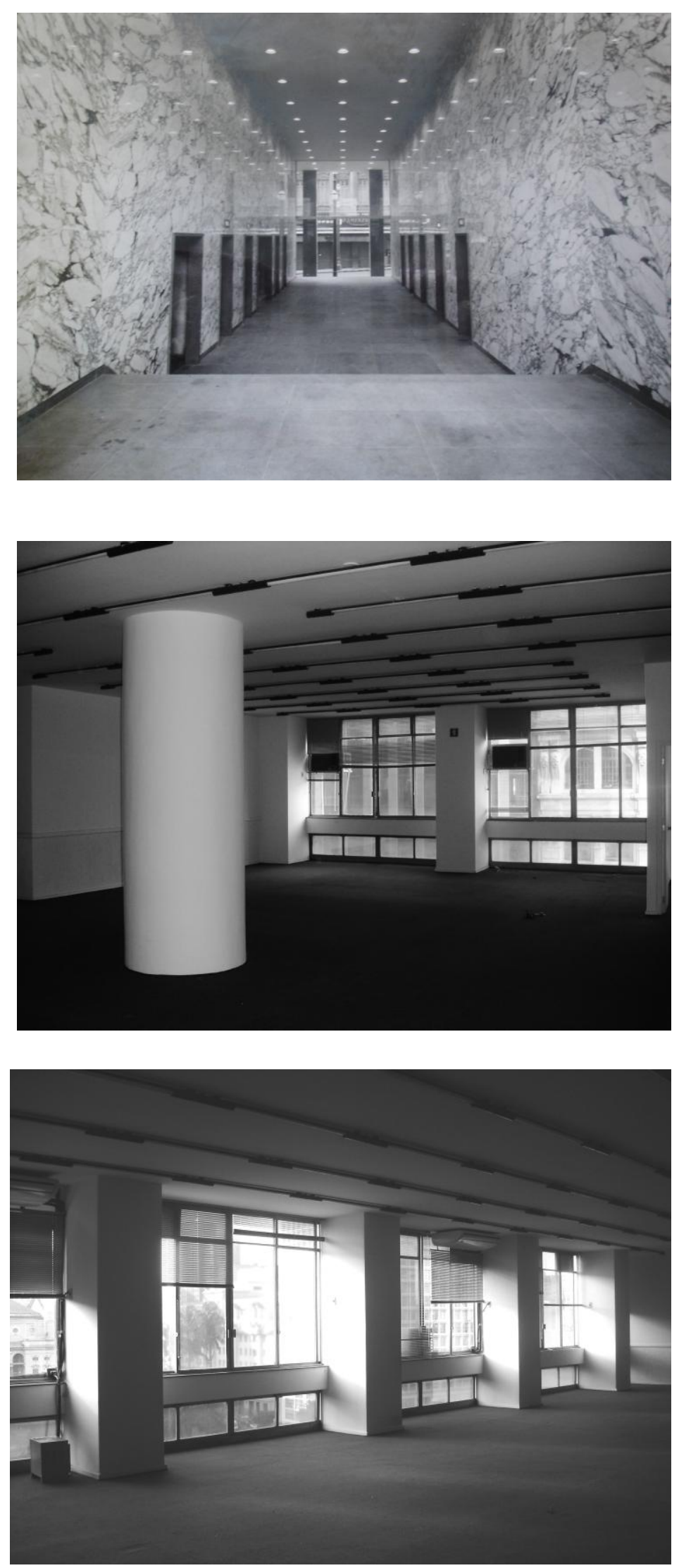

9.31: Entrada pela Libero

Badaró e ligação com terraço.

9.32: Salão de escritórios

9.33: Salão de escritórios 


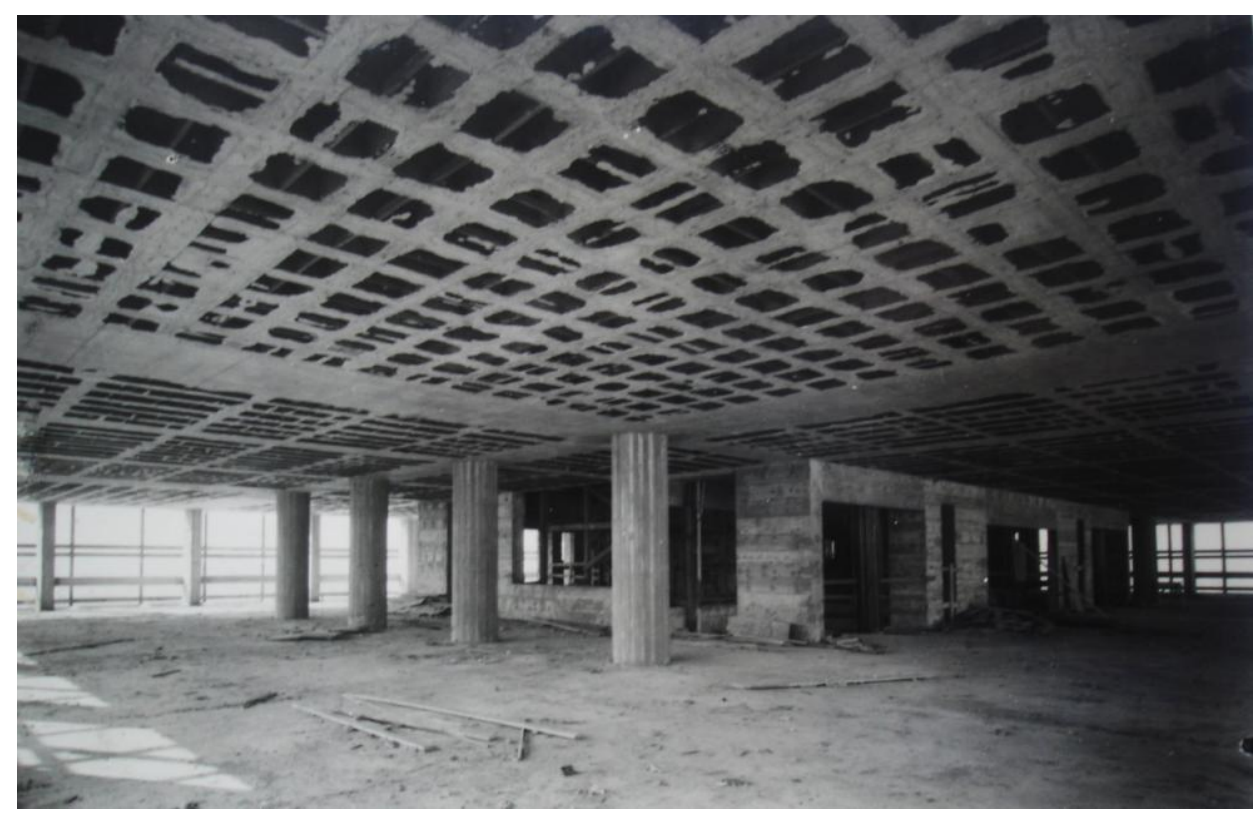

9.34: Tipo em obra

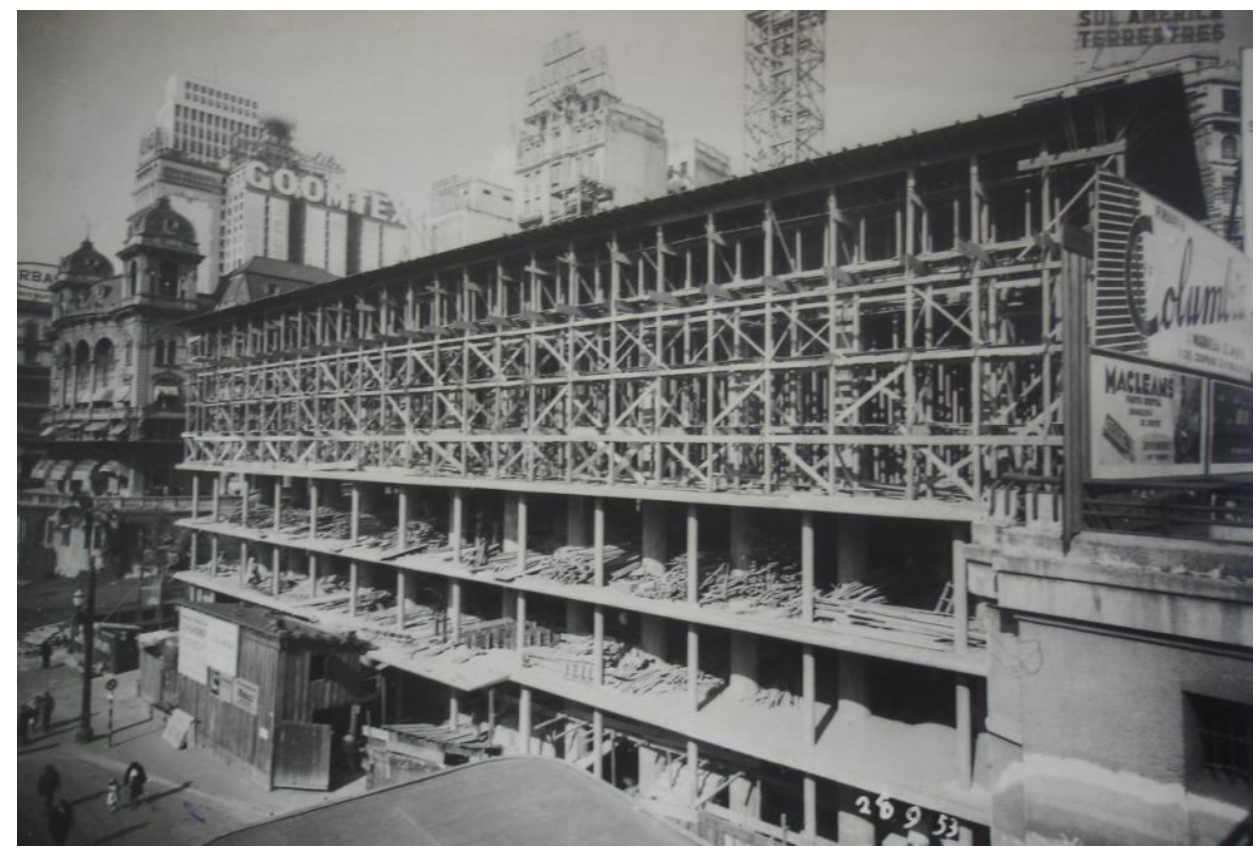

9.35: Embasamento em obras 
Edifício Itália, 1956 (Figuras de 9.36 a 9.51)

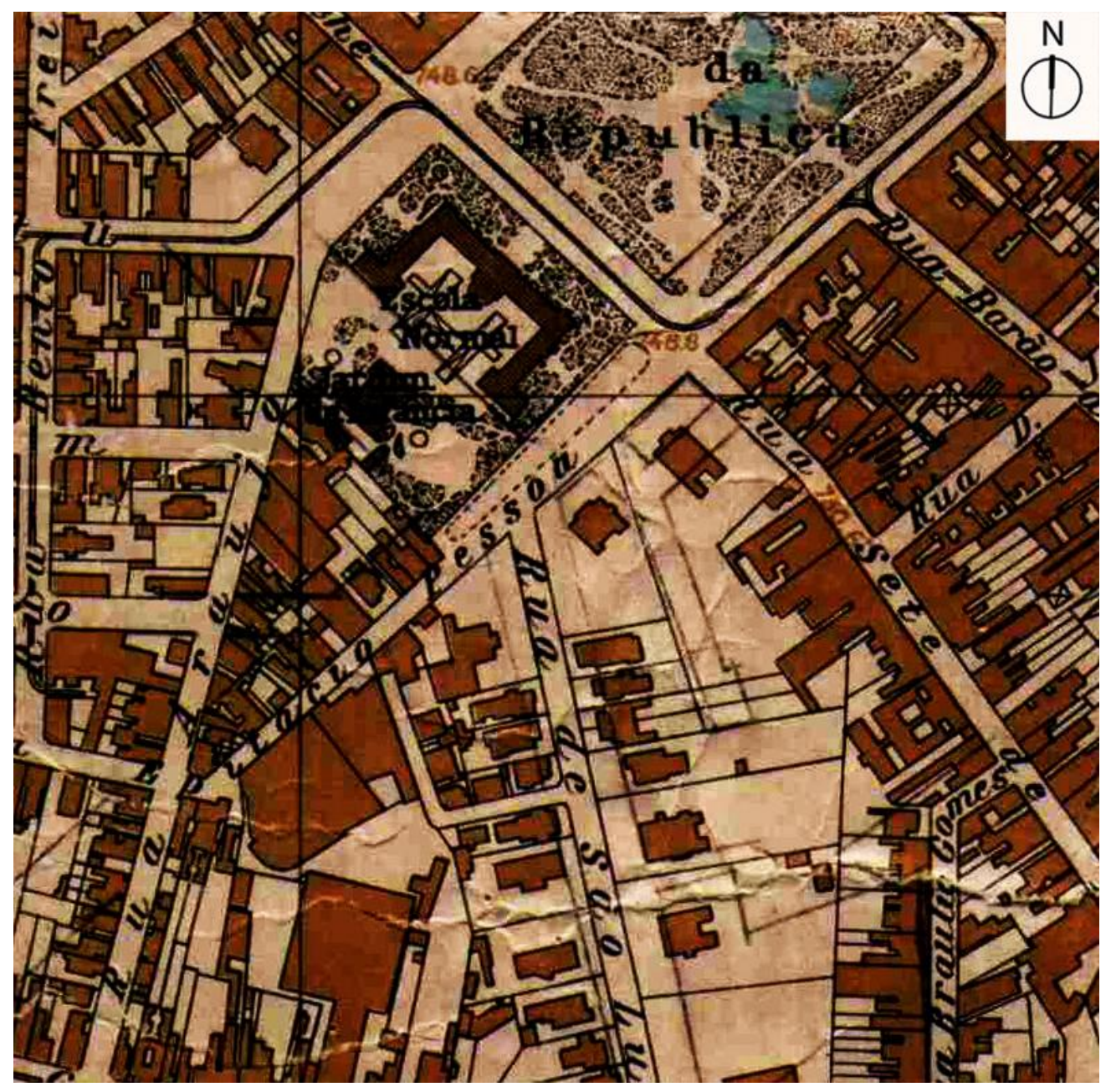

9.36: Sara Brasil, atentar para as construções na diagonal do lote 

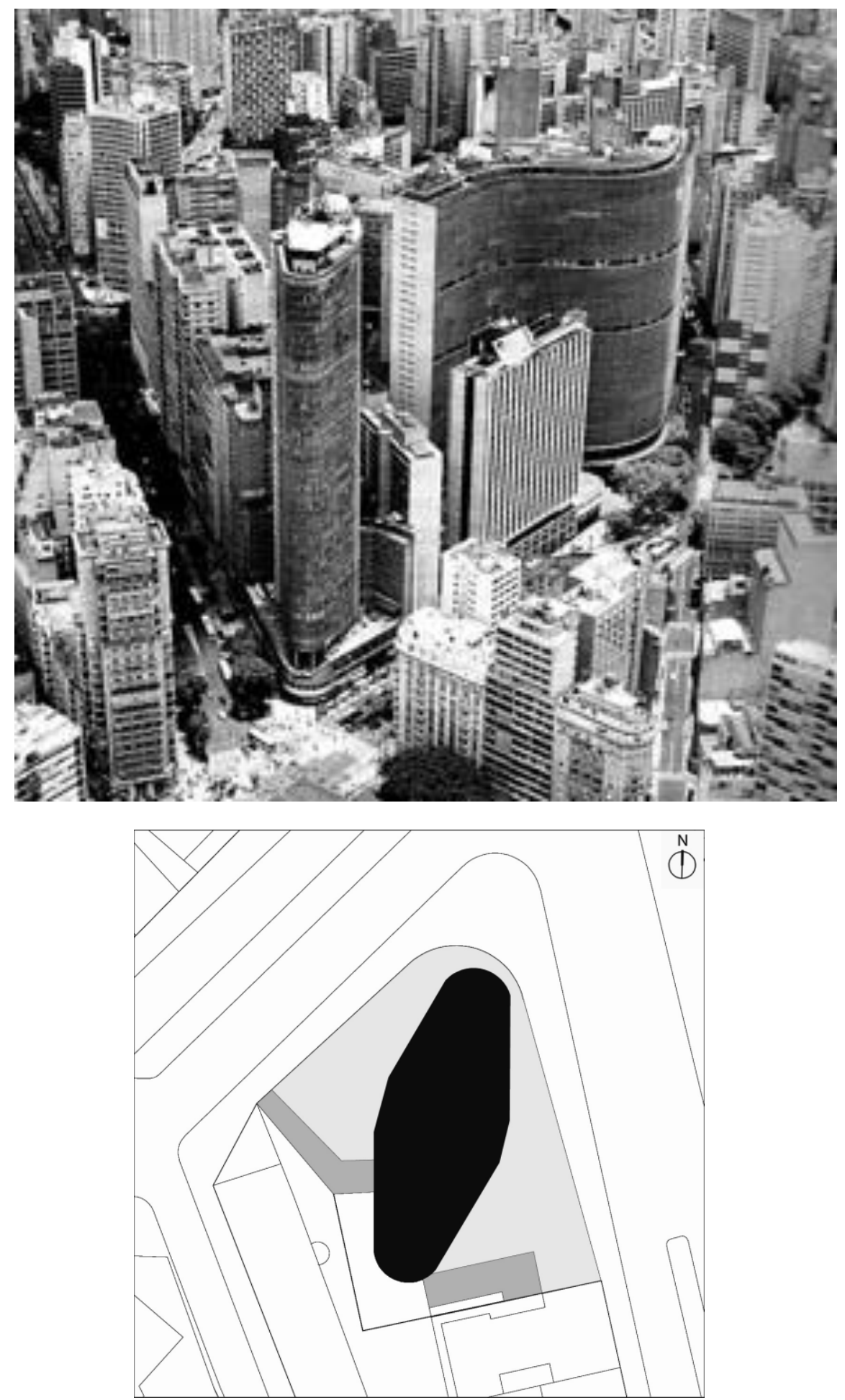

9.37 e 9.38: Edifício Itália, 1956 e situação atual. Em cinza volumetrias mais baixas em preto a torre. 


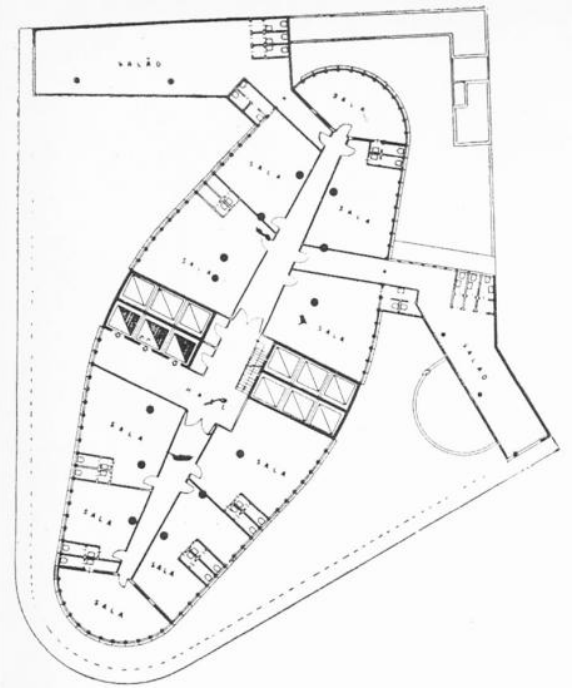

9.41: piso de transição

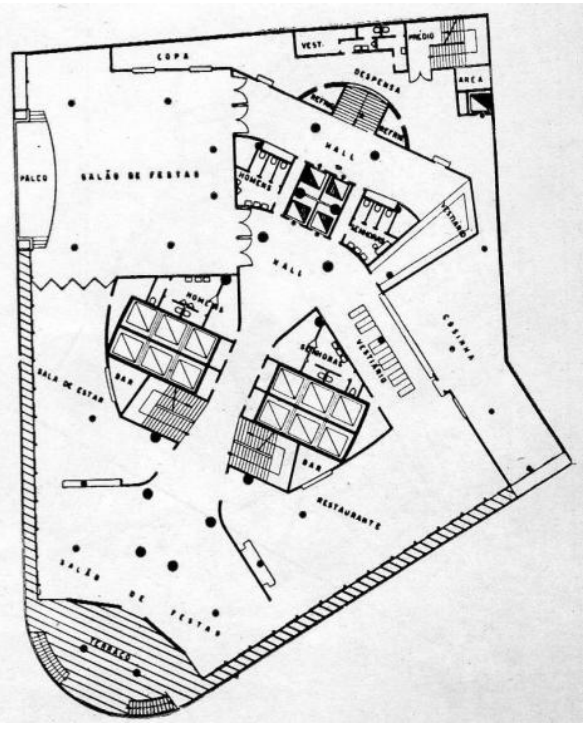

9.40: Piso Circolo Italiano

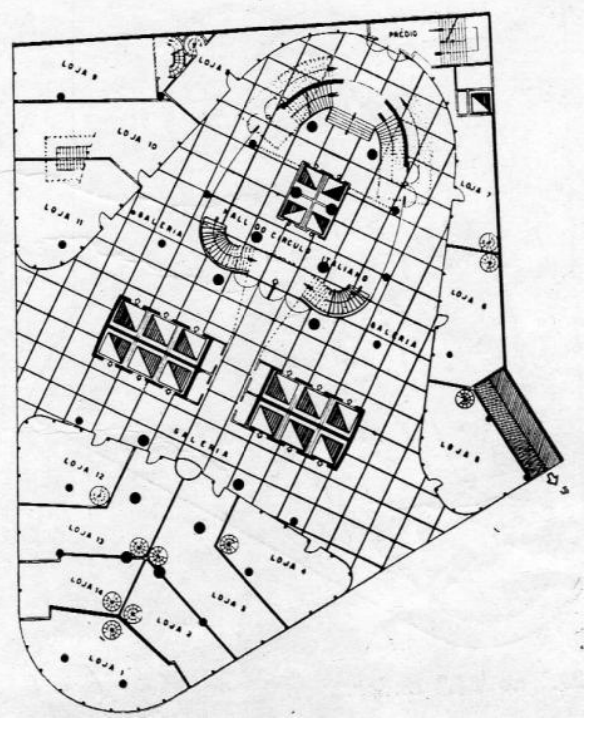

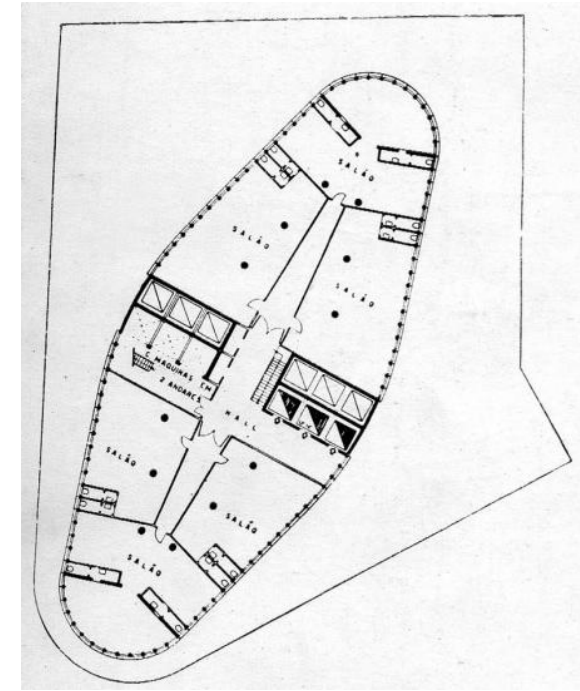

9.42: Tipo

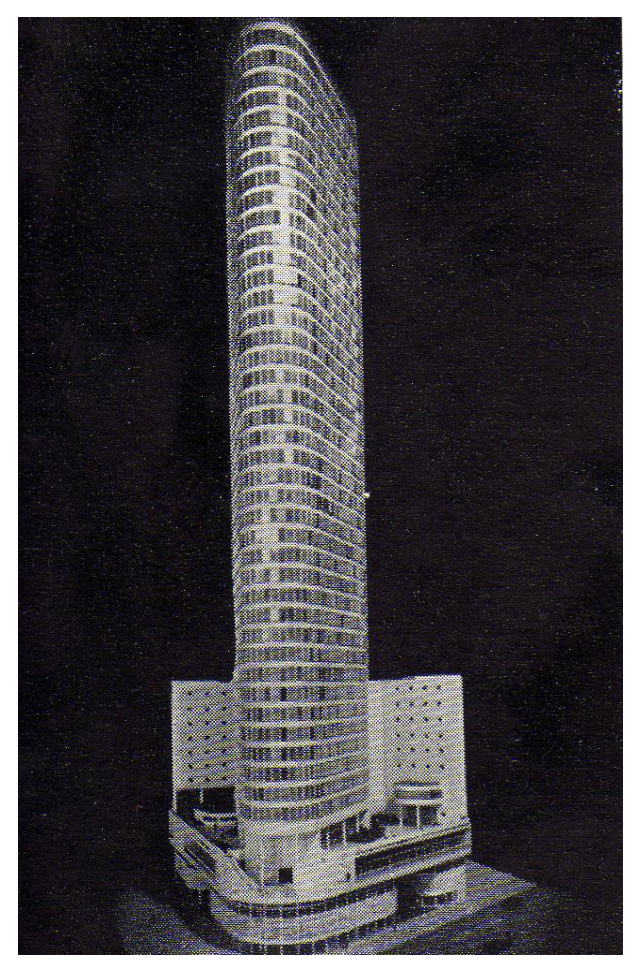

9.43: Maquete

9.39: Térreo. 


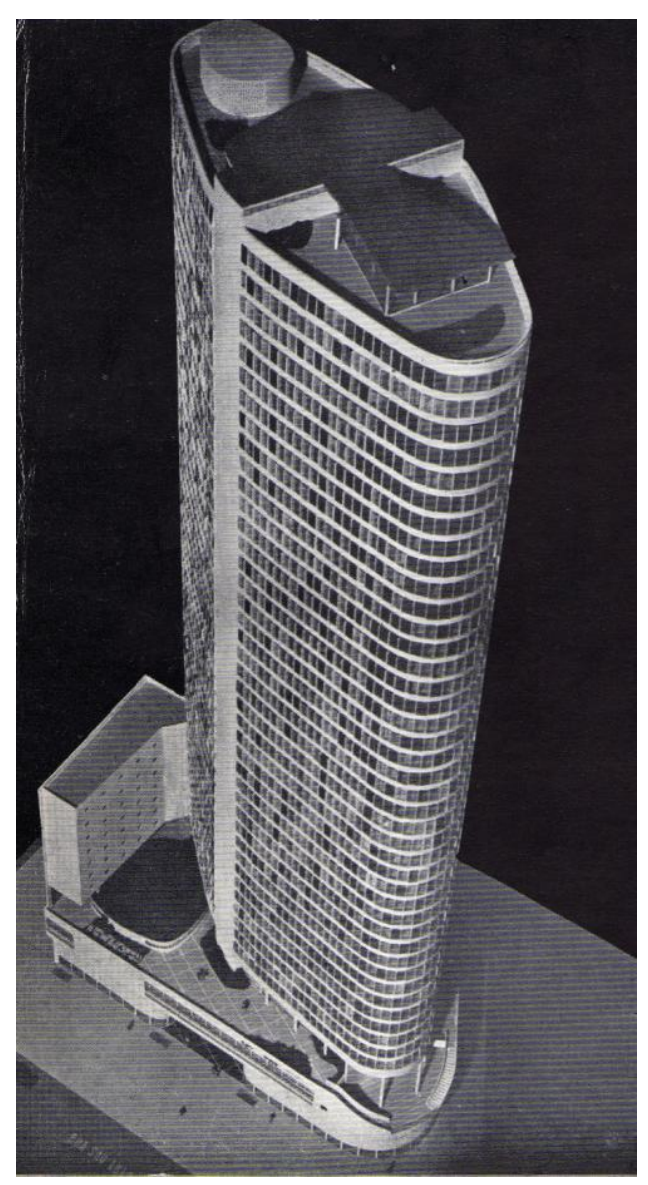

9.44. Maquete

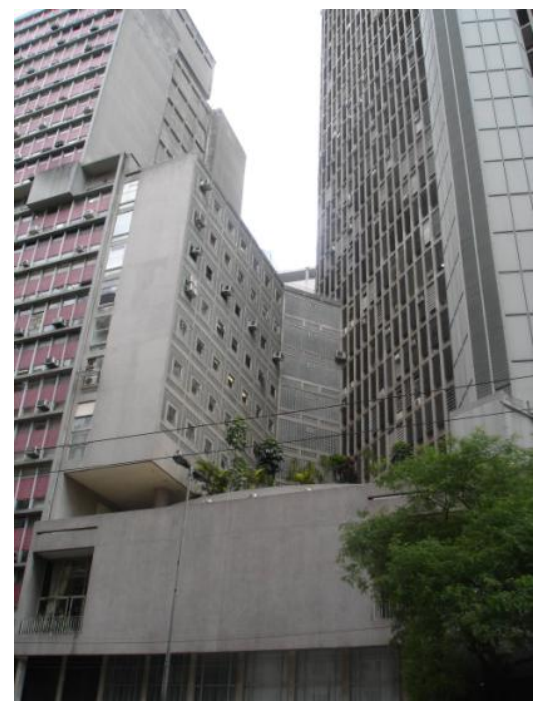

9.45: 2009

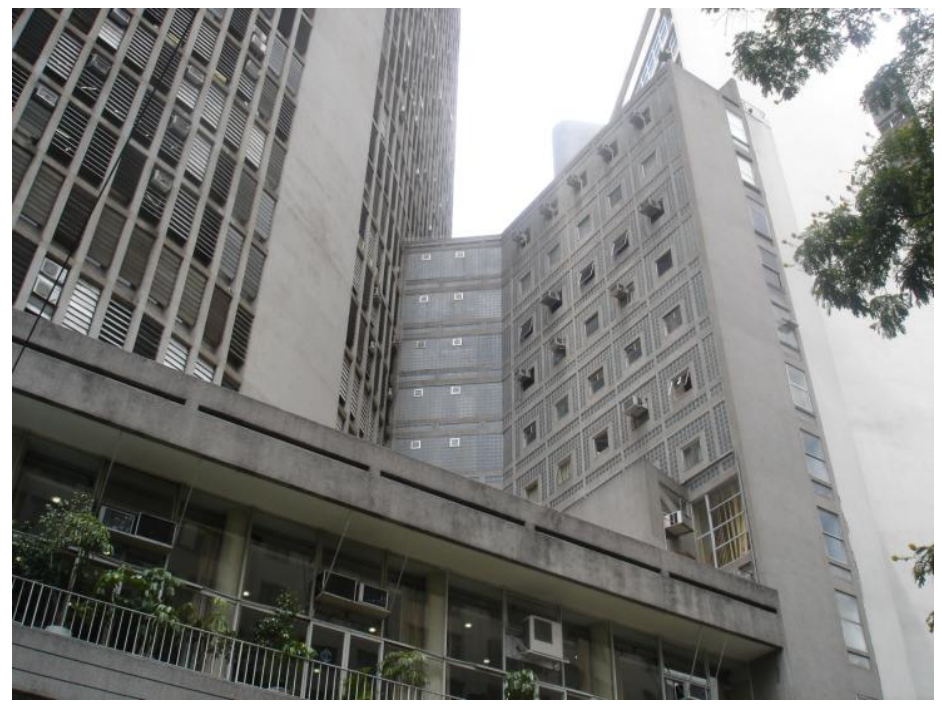

9.46: 2009 

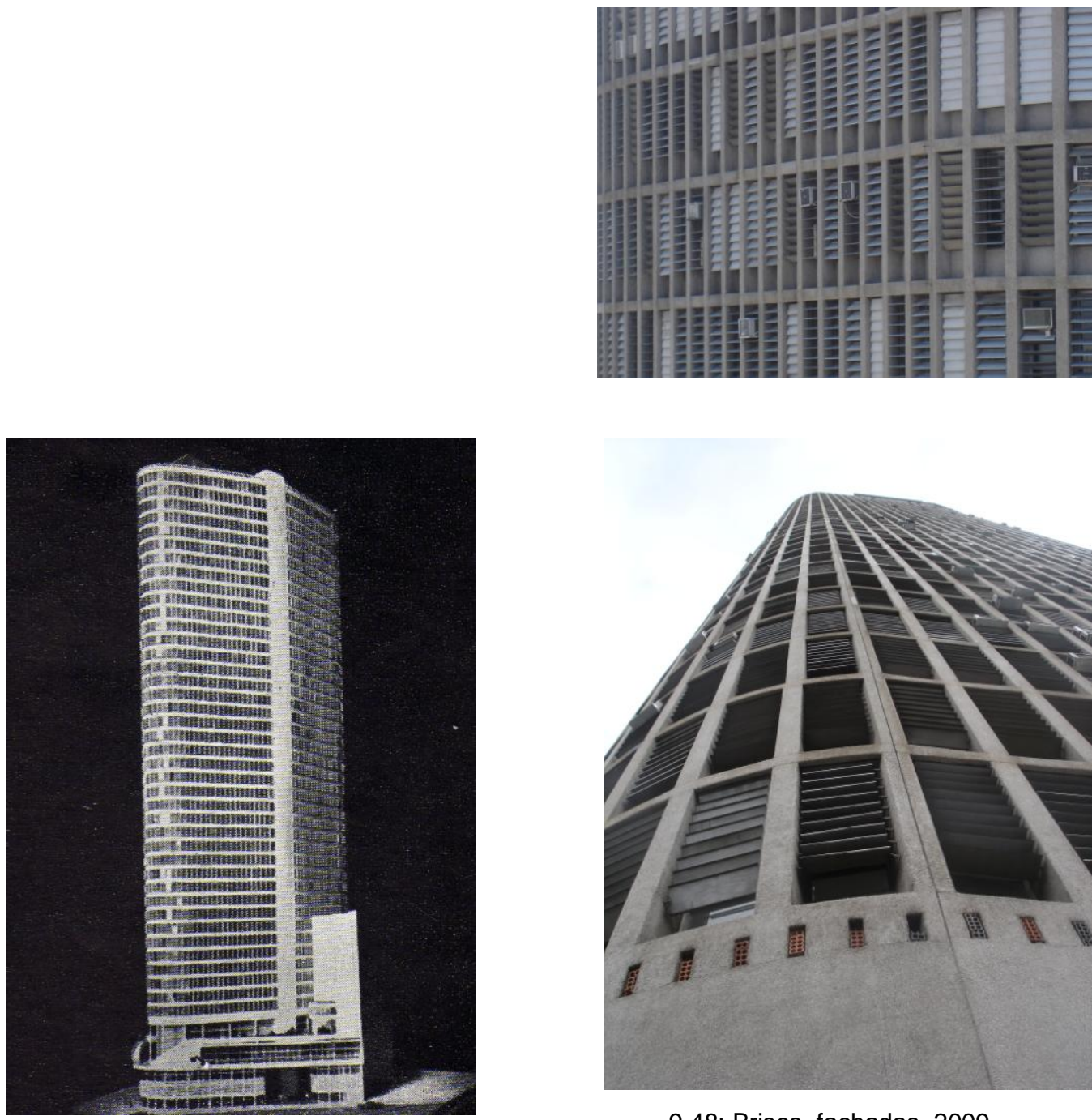

9.48: Brises, fachadas, 2009

9.47: Maquete

9.49: Piso transição, 2009

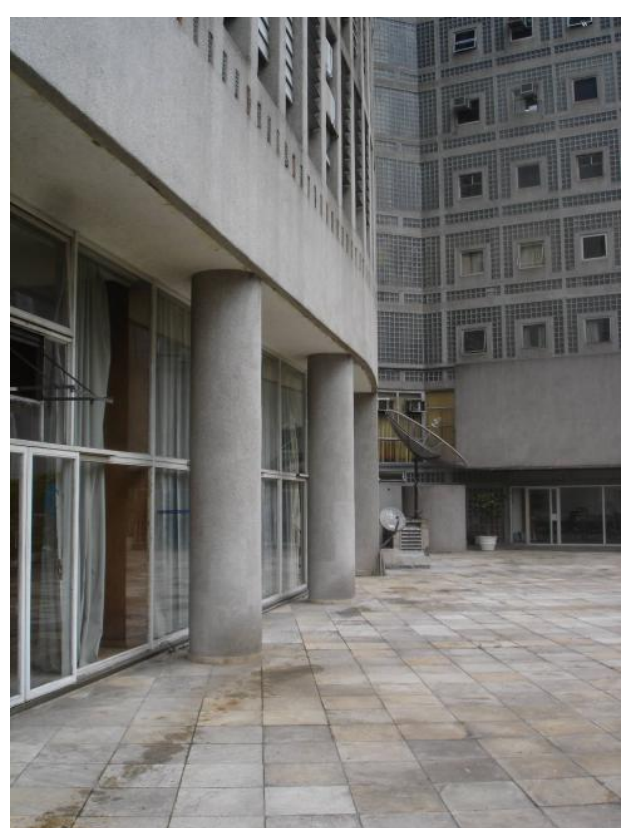



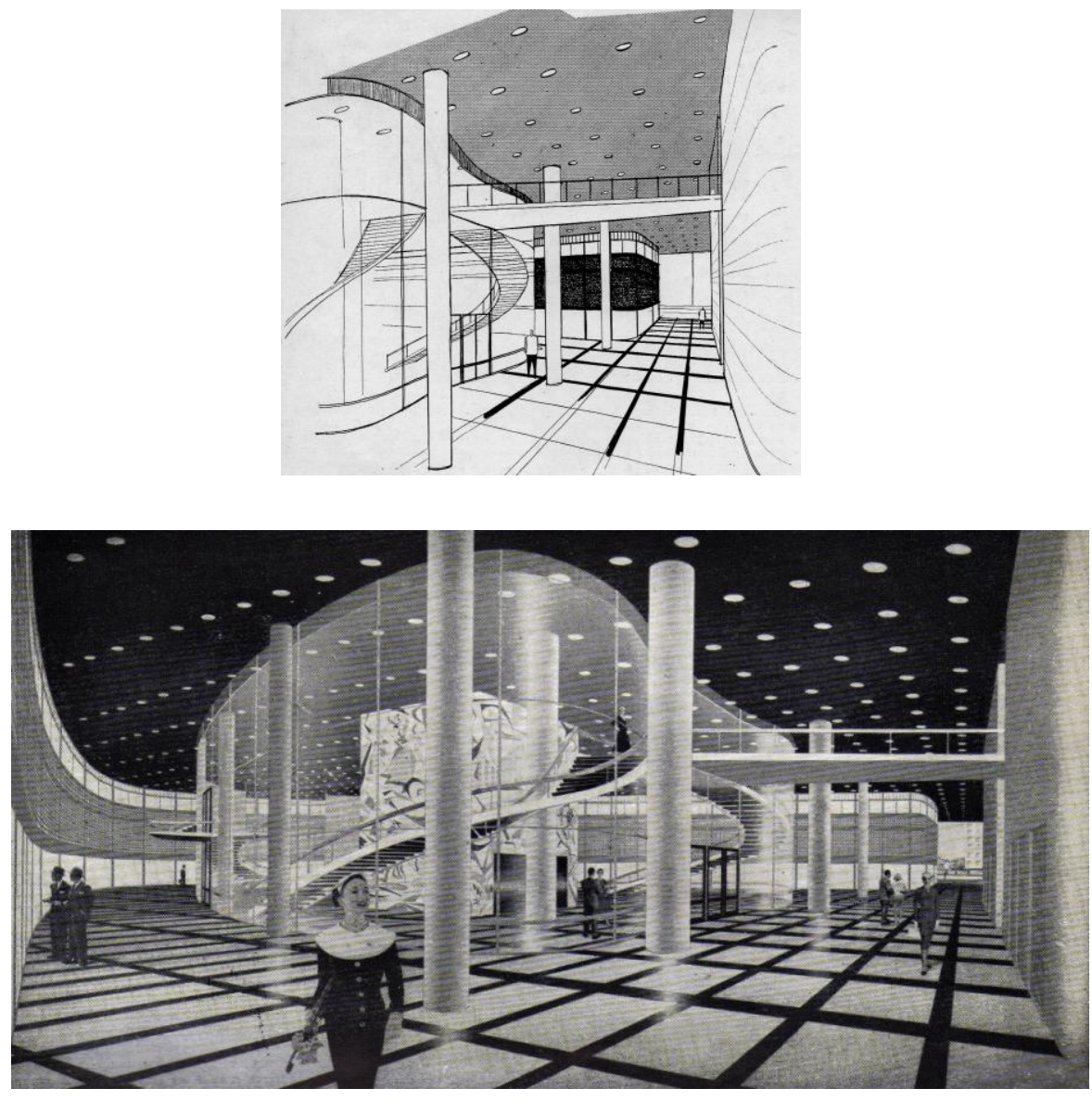

9.50: Pilotis projeto

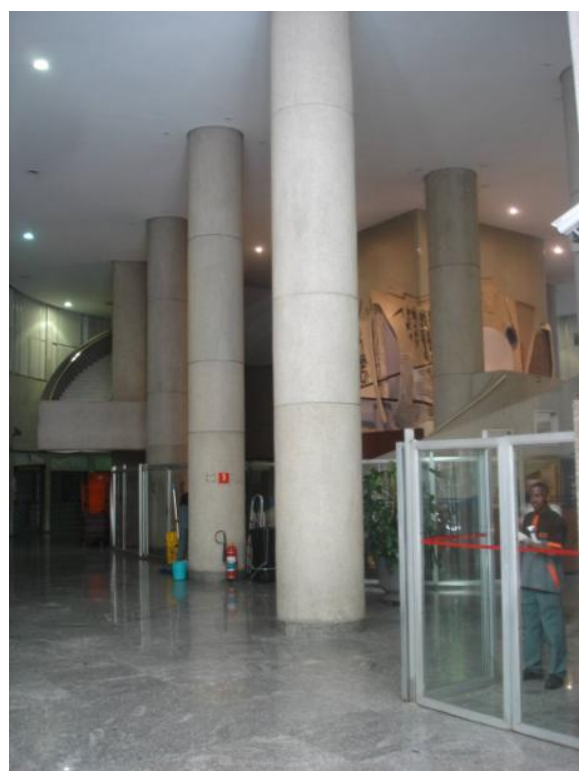

9.51: Pilotis comerciais, 2009 
ConjuntoMetropolitano, 1960 ( Figuras de 9.52 à 9.70)

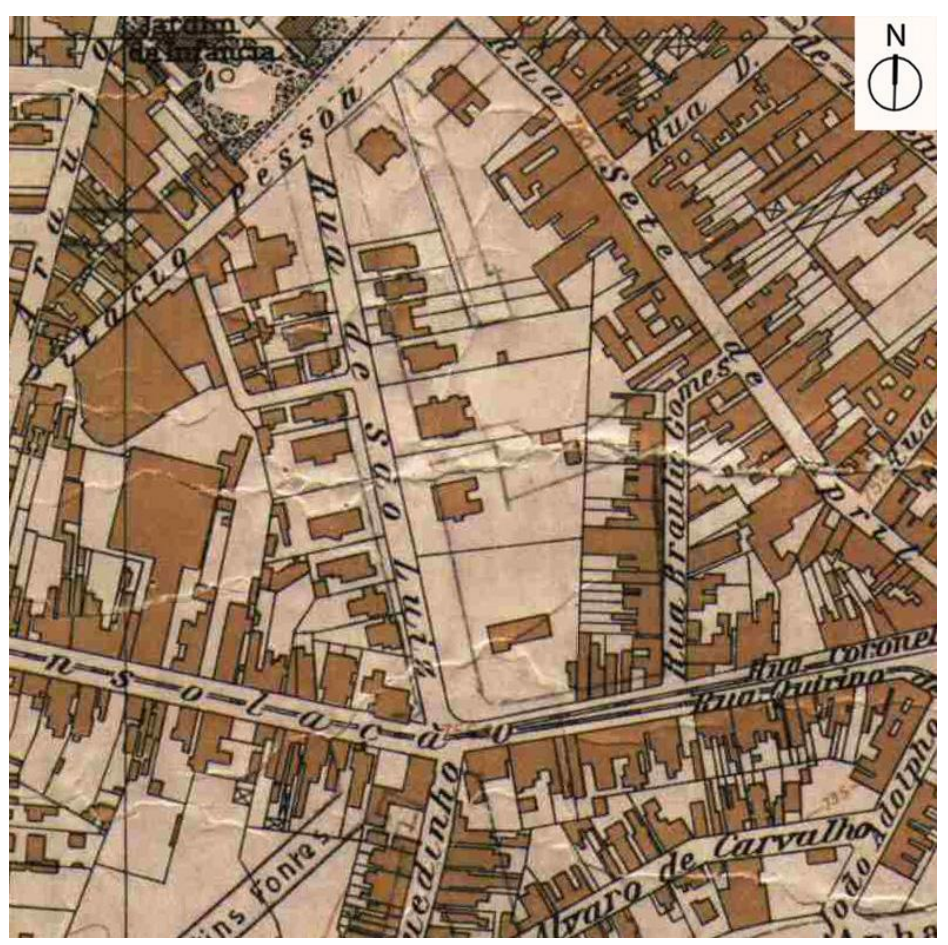

9.52: Mapa Sara Brasil, 1930

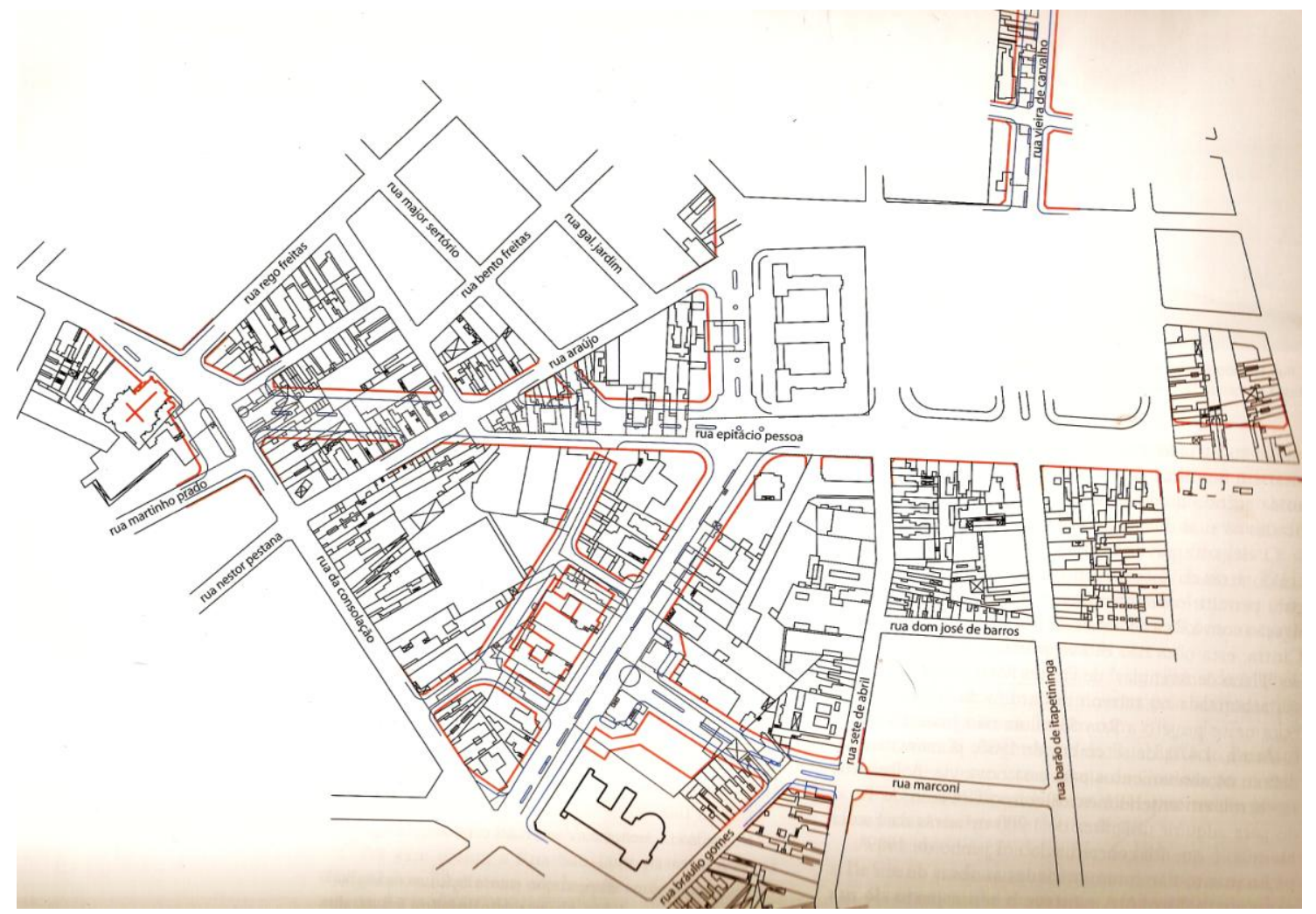

9.53: Traçado de alargamento da Av. São Luiz, extensão da Bráulio Gomes e Marconi. Fonte, Lefèvre, 2006. 


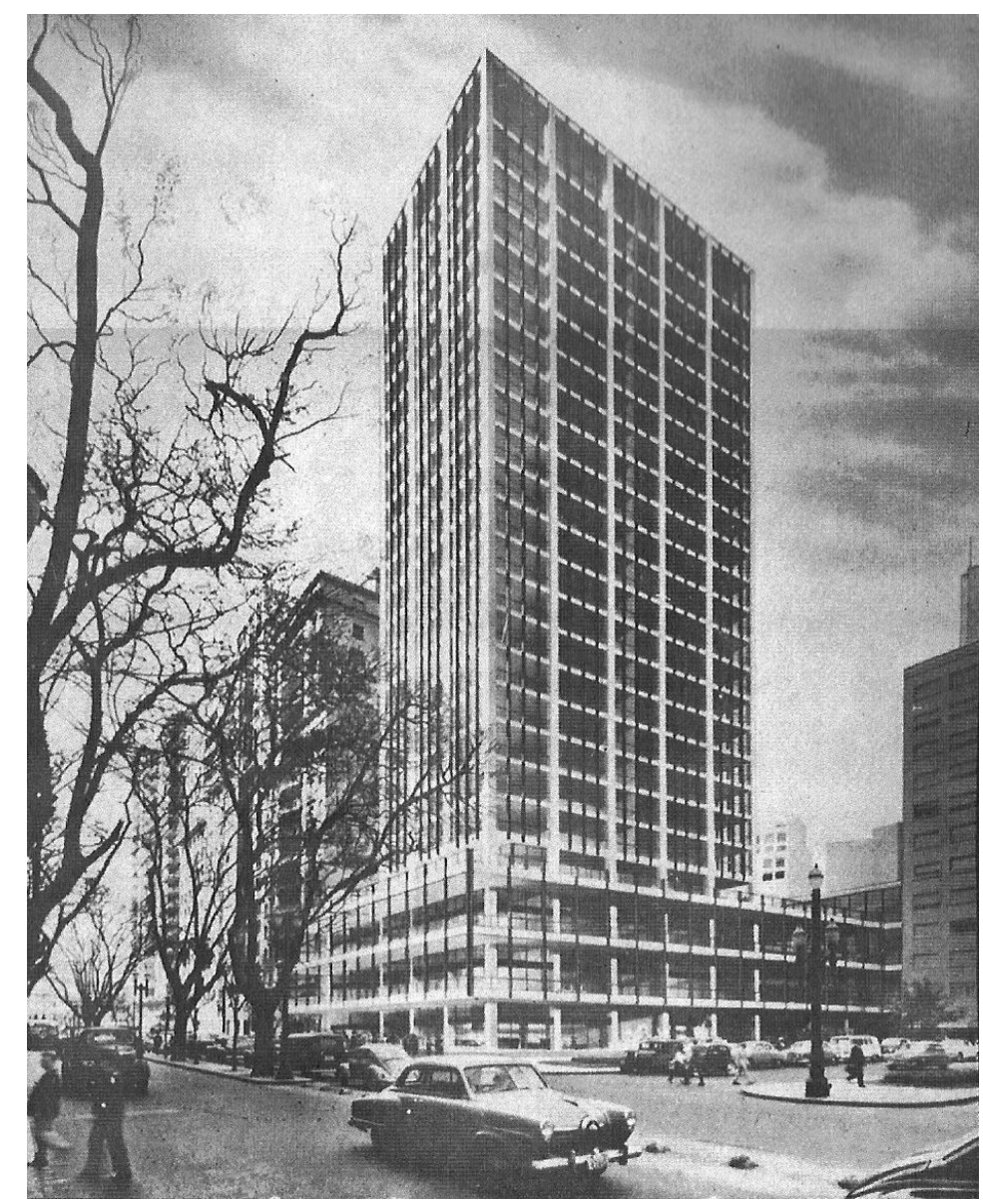

9.54: Conjunto Metropolitano, 1960

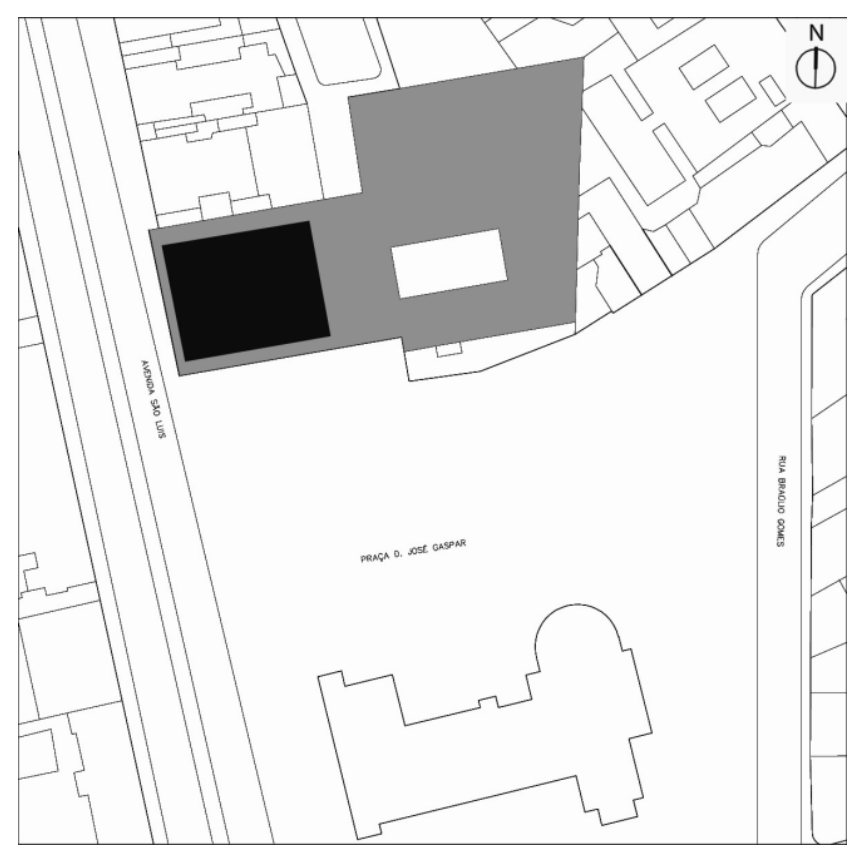

9.55: Situação Mapa Gegran-Viva o Centro: em cinza corpo da Galeria comercial; em preto a torre de escritórios 


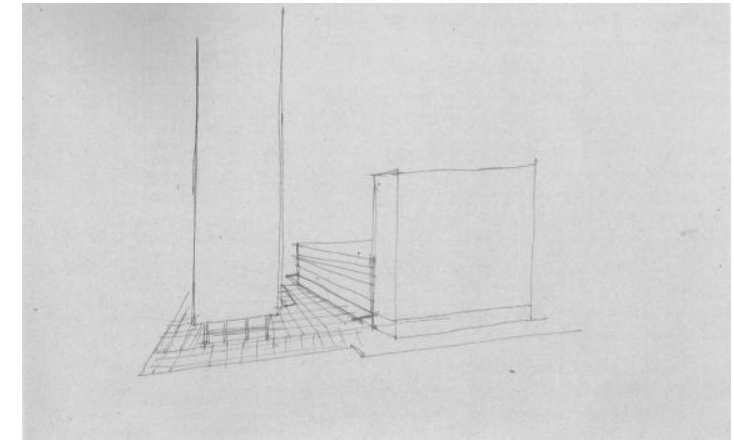

9.56: Partido inicial: a interligação entre a Rua Basilio da Gama e Praça Dom José Gaspar.

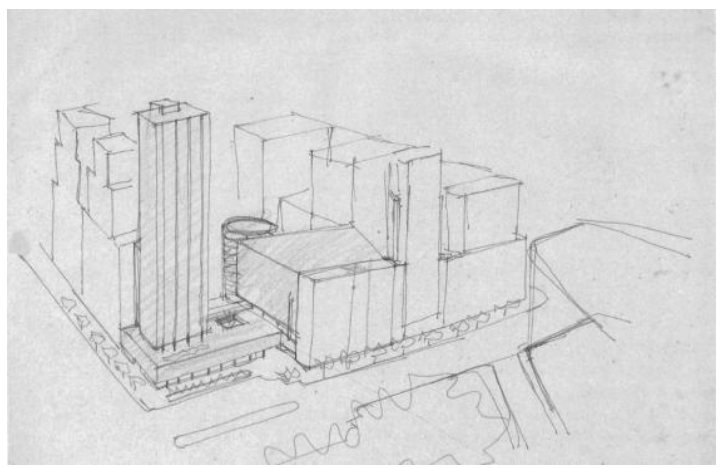

9.57

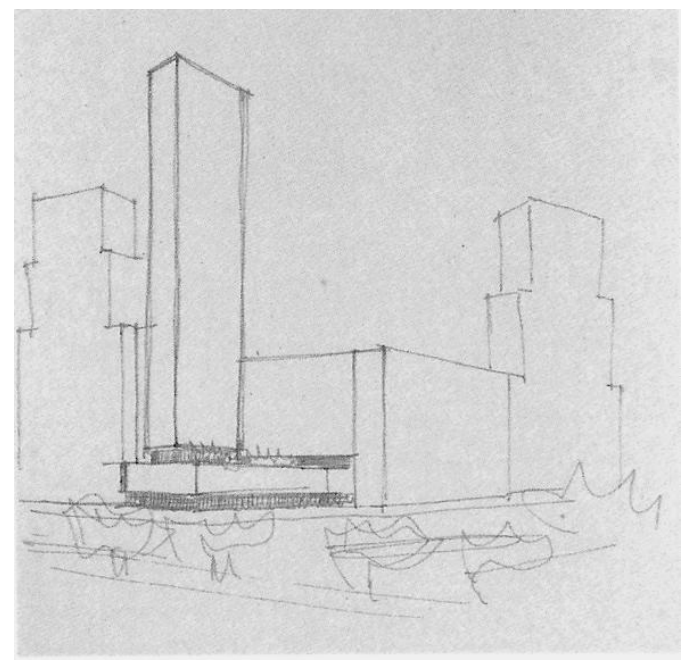

9.58: e 9.57: alternativas para o Conjunto "Maximus" estabelecendo relações com as volumetrias lindeiras, postadas na Av. São Luiz e Bráulio Gomes.

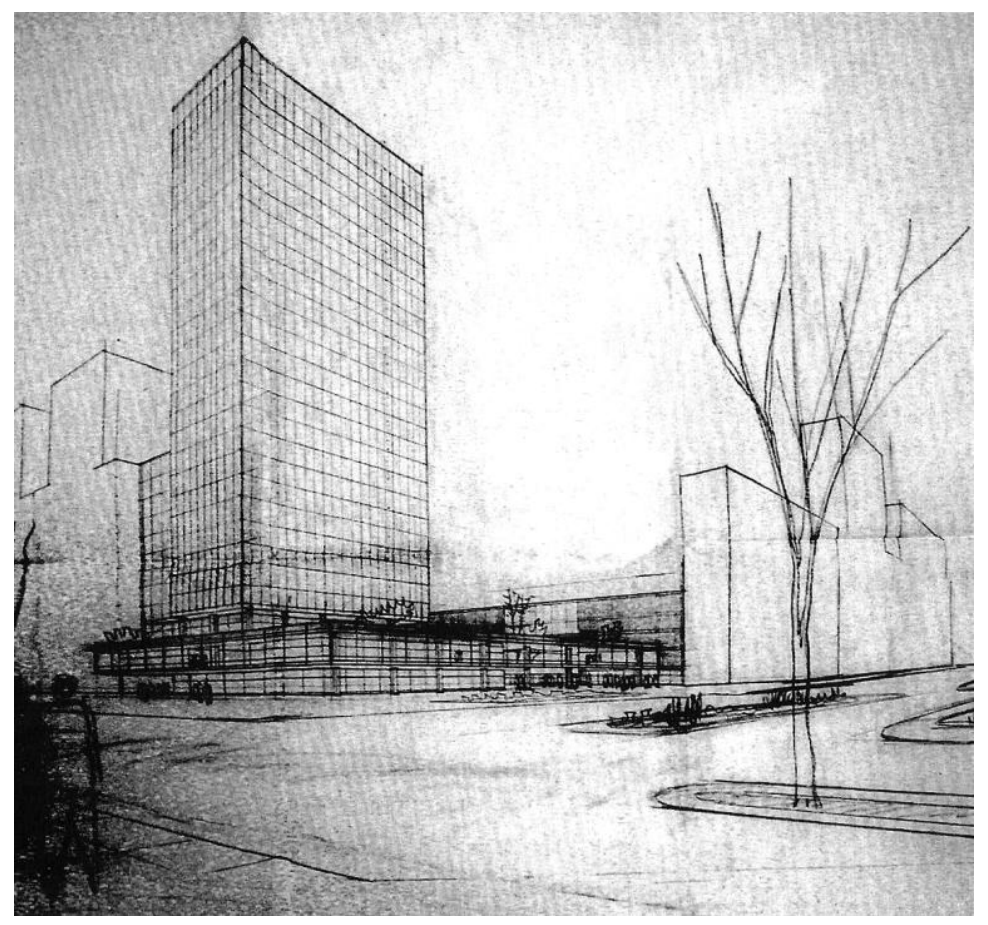

9.59: Perspectiva apresentada no concurso de edifícios "Maximus". (Conjunto Metropolitano). Observar o alinhamento da Torre junto ao edifício vizinho da Av São Luiz. 


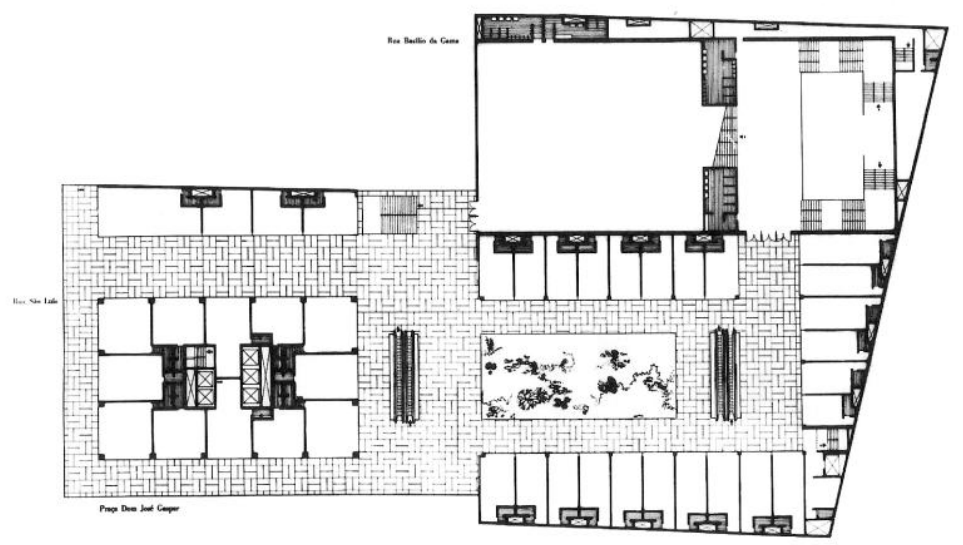

9.60: Planta 1a Sobreloja

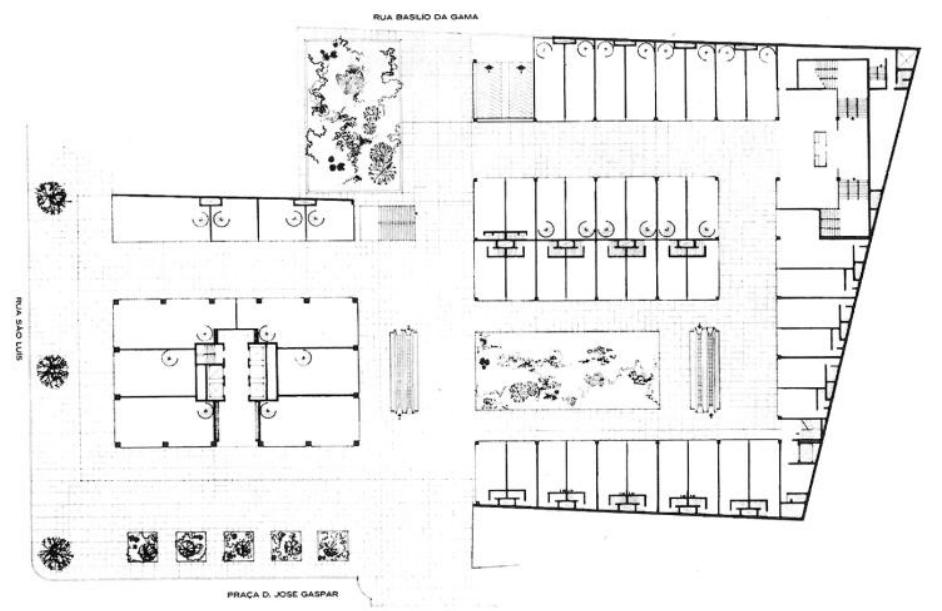

9.61: Planta do térreo - Galeria Metrópole

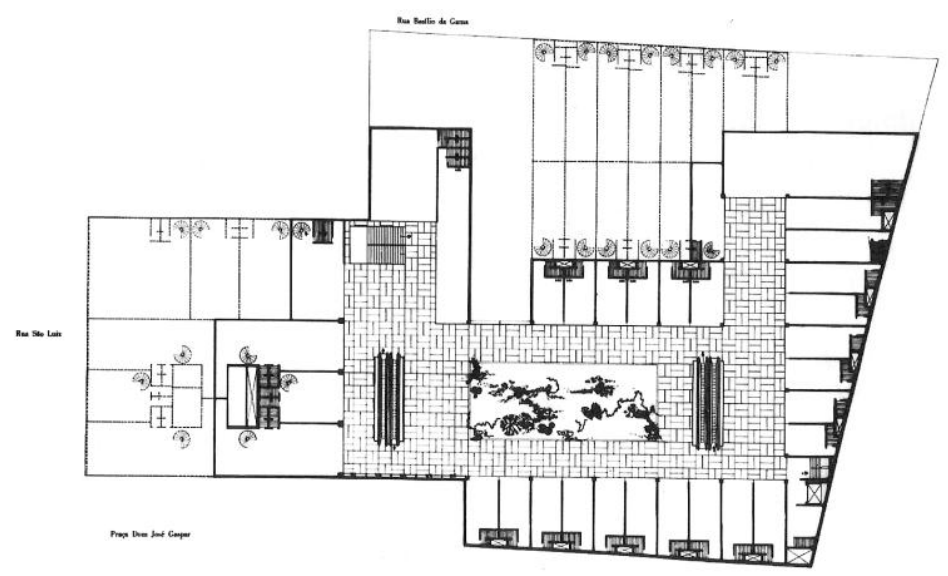

9.62: Planta 1ํ Subsolo 


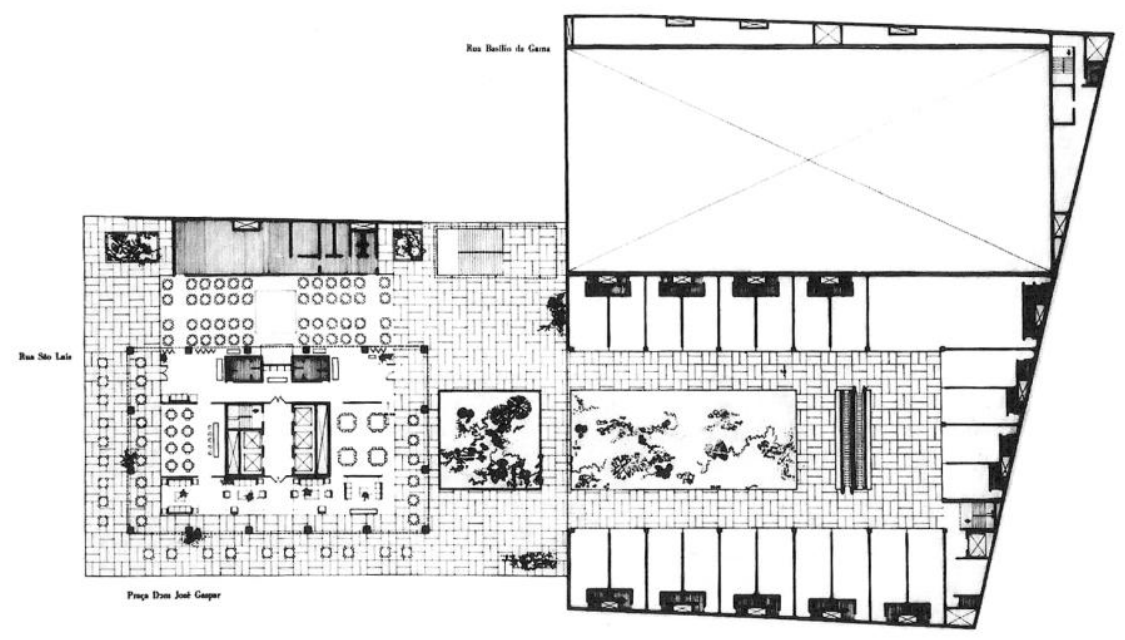

9.63: Planta 3ª Sobreloja

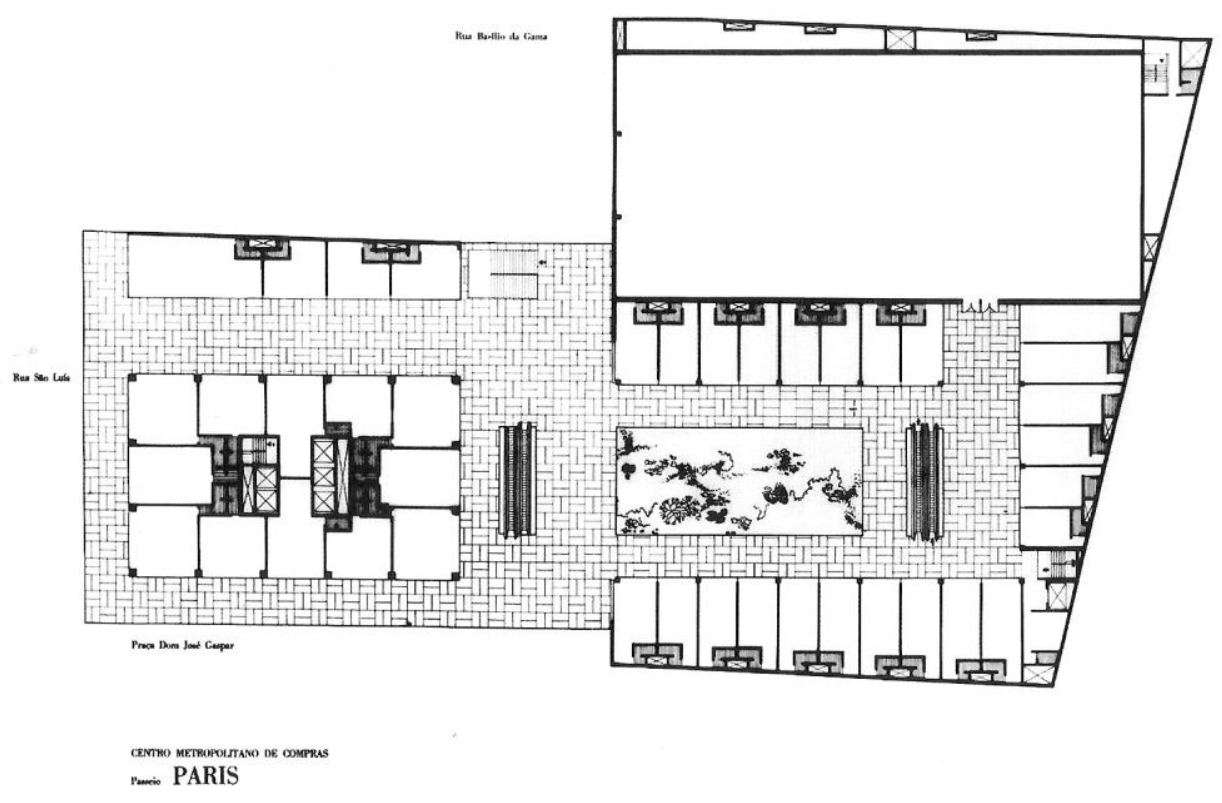

9.64: Planta $2^{a}$ Sobreloja 


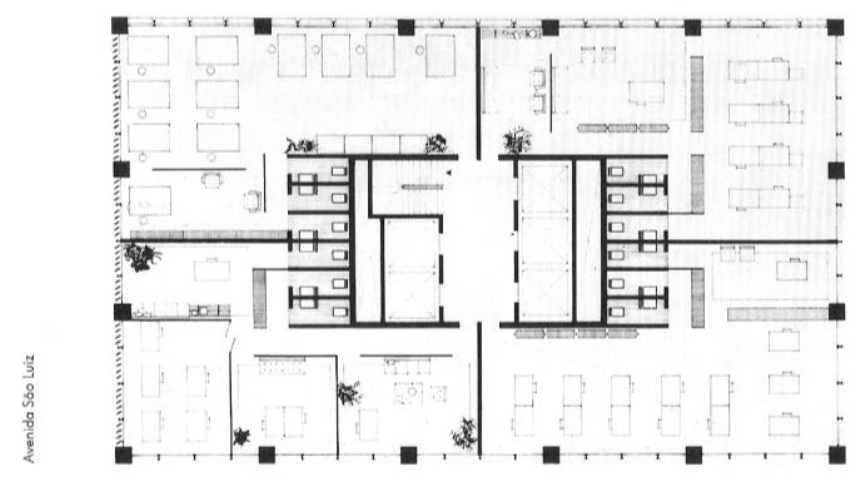

Rua Dom José Gaspar

9.65: Planta Tipo

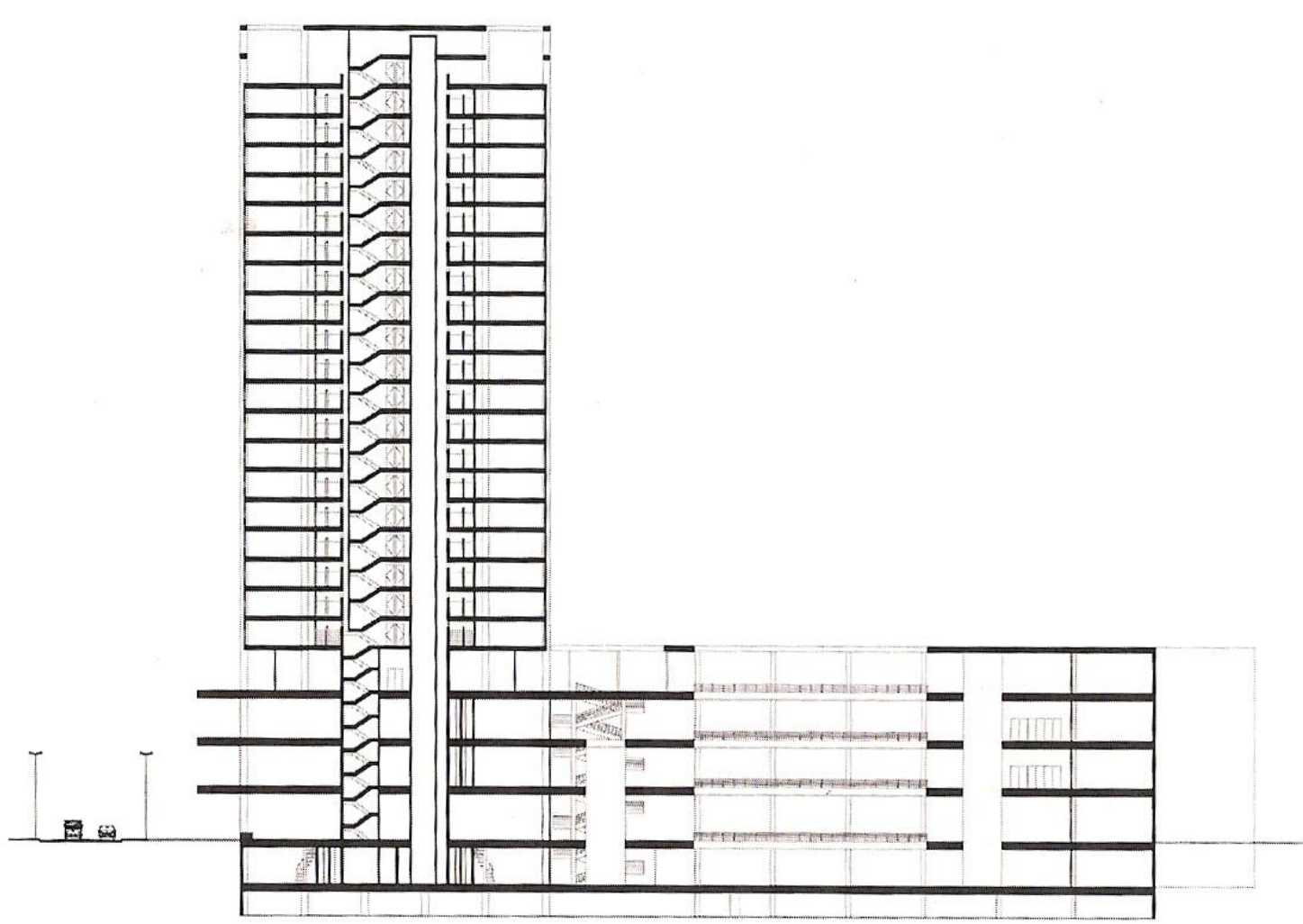

9.66: Corte longitudinal 

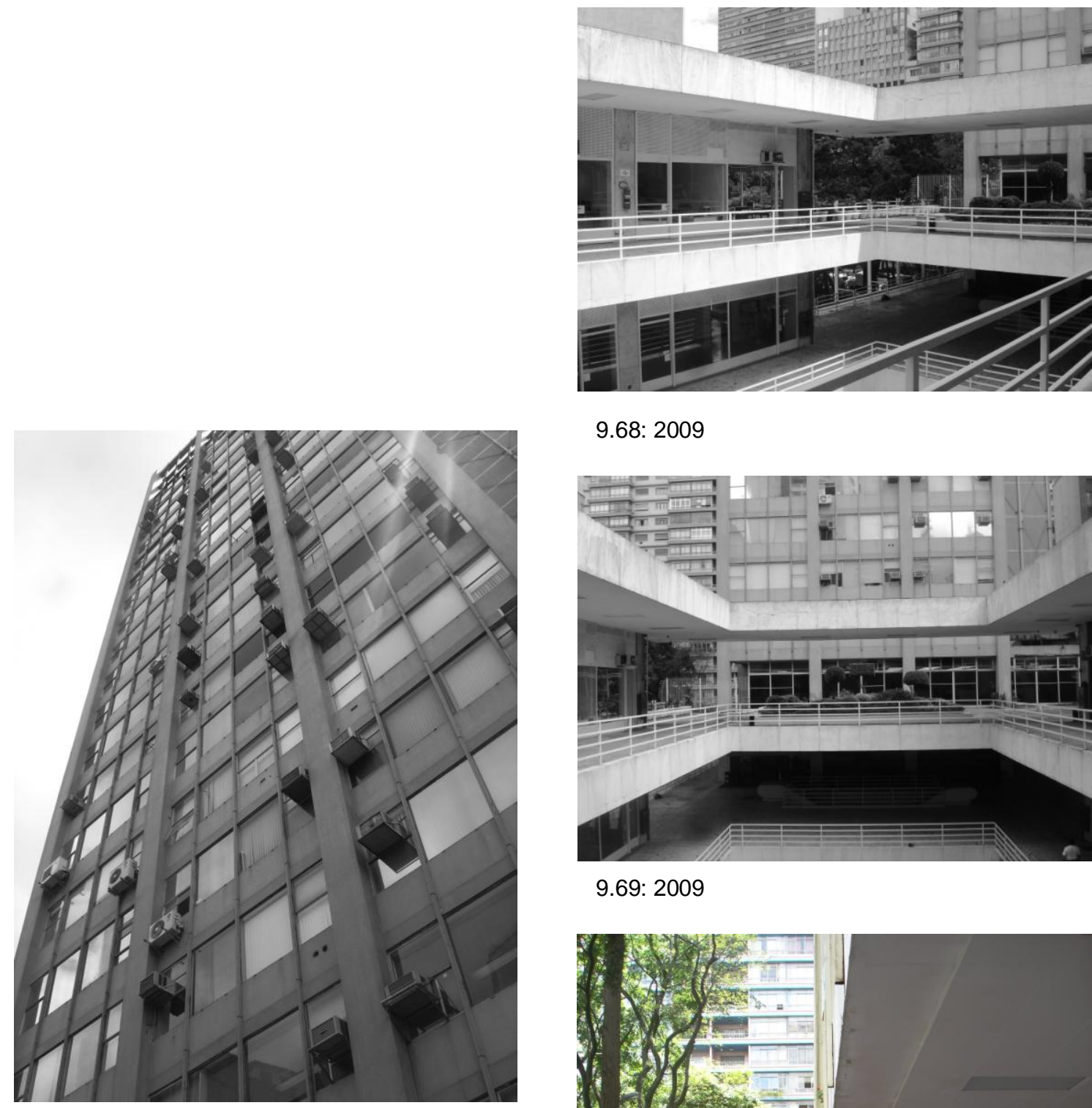

9.68: 2009

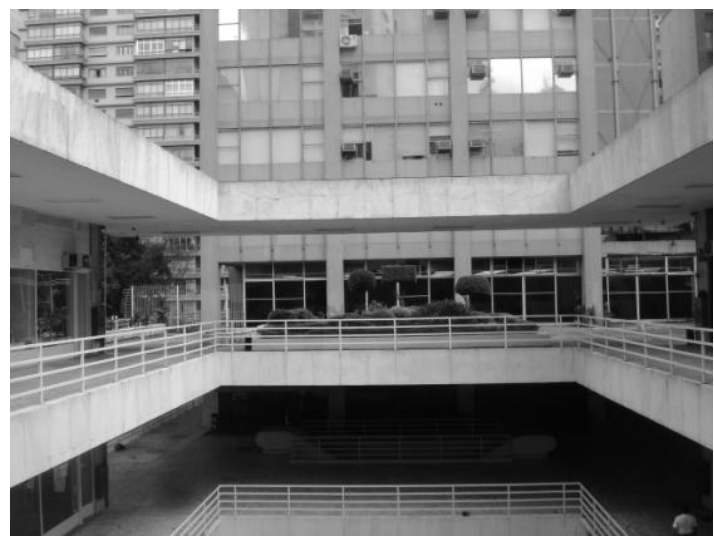

9.69: 2009

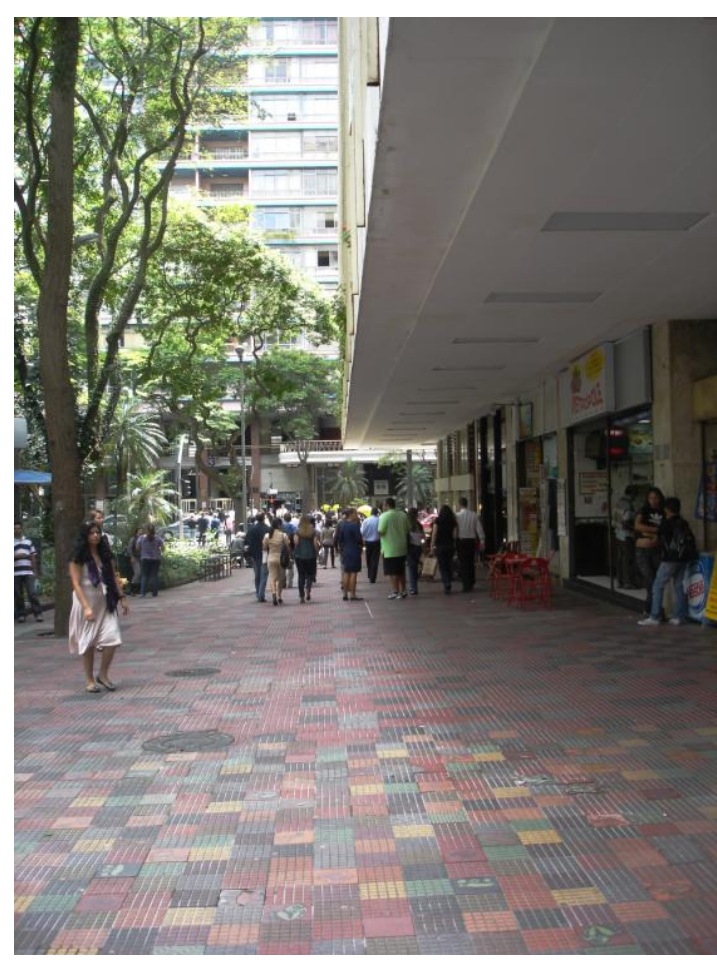

9.70: 2009 


\section{Discussão final}

Algumas observações de autores relevantes são significativas e estimulantes para o propósito desta discussão final. Descrevendo a relação entre o edifício e o lote nos anos 30 e 40 Nestor Goulart Reis Filho, assevera: "No conjunto [os edifícios], porém, o resultado seria lamentável. Os novos tipos de edificação conservariam os mesmos lotes e os mesmos esquemas de relacionamento com esses, como as antigas habitações, cujos terrenos tinham vindo ocupar. Torturavam-se então as plantas, a tentar conciliar os velhos esquemas com as novas estruturas. Ocupando-se novamente dois ou três dos limites laterais dos terrenos, sobravam as áreas internas como solução para arejamento e iluminação dos vários compartimentos afastados da rua". No mesmo contexto diz que plasticamente os edifícios eram solucionados em termos de fachada, acompanhando os estilismos, até mesmo o "modernismo" (Reis Filho, 1970, p. 79). Mais adiante, sobre uma foto do edifício de apartamentos de autoria de Julio de Abreu, anuncia: a solução racionalista compensa a implantação tradicional. Em outra legenda complementa: a implantação racional compensa a estrutura tradicional.

Nos anos 40 e 60, segundo Reis Filho:

Os problemas da implantação da arquitetura urbana seriam corajosamente enfrentados pelos arquitetos e muitos de seus sucessos seriam devido ao elevado grau de consciência com que reconheciam as suas responsabilidades. As habitações individuais isoladas aproveitariam de modo especial as inovações arquitetônicas, decorrentes do avanço técnico e econômico. Pela primeira vez seriam exploradas amplamente as possibilidades de acomodação ao terreno, em que pese à exiguidade dos lotes em geral. Para isso, contribuiria principalmente o uso das estruturas de concreto, que viriam libertar as paredes de sua primitiva função de sustentação e as estruturas de sua rigidez. [...] Passavam, pois, a vigorar os princípios da "planta livre", com ampla flexibilidade de modo que, pelo menos na teoria, somente seriam satisfeitas nos projetos as exigências de funcionalidade e da própria composição. [...] Externamente as inovações plásticas corresponderiam à decadência do fachadismo e ao tratamento arquitetônico homogêneo de todas as elevações (1970, p. 90-92). 
Suas abordagens abarcam um quadro brasileiro amplo, nem sempre a referência direta são os centros das cidades. Entretanto, suas colocações tratam evidentemente das relações entre a estrutura tradicional e os preceitos modernos. $O$ autor vai de encontro ao centro do incômodo: o lote a torturar as plantas imaginadas na racionalidade da arquitetura moderna. Fica claro mesmo nos limites do lote o valor do tratamento homogêneo de todas as fachadas. Fala-se de uma reconciliação da arquitetura com a paisagem e da disposição funcional deslocando-se compartimentos para as melhores condições de clima.

Leonardo Benevolo emite juízos semelhantes: "De fato, a cada reconstrução feita guardam-se da cidade anterior somente os vínculos inúteis: os limites dos terrenos, os alinhamentos das vias públicas, que antes eram coerentes com os volumes edificados e que se tornaram cada vez mais incoerentes" $(1980)^{143}$.

Pois bem, esses juízos explicitam a natureza da dificuldade da arquitetura da cidade moderna e a resistência das estruturas tradicionais. Uma incompatibilidade a priori dada a natureza de uma e outra, principalmente quanto à divisão fundiária.

A condenação é sistemática. O encontro entre os dois modelos não se ajustam. Rowe e Koetter revelam a crise do objeto e partem de uma dificuldade de textura, mas admitem uma formação ou estrutura que está entre esses dois modelos; provavelmente um encontro em outros termos. Mas não nos moldes ocorrido no Centro Histórico de São Paulo; cuja estrutura tradicional de cidade prevaleceu e deitou suas normas sobre a arquitetura moderna. As hipóteses iniciais admitiam de antemão esses contrapontos: essas dificuldades de textura. Uma impossibilidade justificada porque afinal a arquitetura dos edifícios modernos tem correspondência direta com as ideias de cidade, mesmo no caso de Mies van der Rohe, que pressupunha que elas desapareceriam enquanto tal.

Como então se qualificam as dificuldades de textura e forma dos edifícios modernos no Centro Histórico de São Paulo? Que relações sobressaem nesse encontro entre estruturas tão diferentes? Que papel tem a linguagem da arquitetura moderna, enquanto decorrência da ossatura independente nesse contexto? Que juízo se faz dessa arquitetura.

${ }^{143}$ Apresentação de São Paulo: três cidades em um século, de Benedito Lima de Toledo, 1980). 
Pelo juízo.

Para alguns autores o encontro entre a arquitetura moderna [edifício] e a cidade tradicional só produz incoerências, uma vez constatado que as idealidades e preceitos de origem são incondicionalmente afetados. Não há dúvidas de que as plantas eram "torturadas". Não há dúvidas de que a legislação e os interesses econômicos as contaminaram. Não há dúvidas que a estrutura da cidade tradicional se impôs. Mas essas máculas também a fez singular e os atributos não são poucos.

A começar pela estrutura da cidade tradicional. Embora ela seja - nos termos aqui expostos - ponto a ponto uma negação da cidade da arquitetura moderna. Ao manter qualidades e hierarquias próprias do espaço público, por meio de elementos como a rua-corredor, largos, alinhamentos, essa cidade histórica transferiu caracteres a essa arquitetura moderna, conferindo-Ihe valores, memórias; principalmente de um traçado marcado pela topografia e impregnado de sentidos. Não é pouco. Nessas circunstâncias a neutralidade de uma paisagem ou de continuum natural não pode sequer ser aludida.

Quanto aos dois modelos de cidade prevaleceu no Centro de São Paulo o modelo tradicional: diga-se, a despeito das modernizações. Sob esse aspecto, a crise do objeto - do objeto moderno - não se realiza no CHSP. Se a cidade da arquitetura moderna não se realizou por inteiro, muito menos ali. A condição do objeto isolado nos termos propostos no imaginário moderno, sob desígnios de uma funcionalidade interna ou, para citar um exemplo, nas condições ótimas de insolação raramente ocorre. Os edifícios modernos configurados como objetos soltos o são por razões que emergem de condicionantes pré-existentes. O Copan talvez seja o caso mais próximo de uma condição moderna: ele o é por razões de forma uma figura destoante. Outras torres no Anhangabaú e pontos focais também podem ser assim vistas, se as análises deslocaram-se das relações planificadas representadas nas abstrações de figura e fundo. Mas só quando observadas em situações panorâmicas e em determinadas posições. Como já mencionado, essa massa verticalizada também se anula sob determinados pontos de vista. Uma interpretação decorre dessas constatações: a verticalização - arranha-céus - simbolizaram uma mudança de sinal nas representações do poder - ainda assim, continuaram atadas a um chão: de geometria e uso pré-definidos.

Todavia, a intenção de figurar-se como um objeto solto no espaço não significou uma impossibilidade absoluta. Tampouco, foi deixada de lado. A todo o momento, vê-se que o desejo - legítimo nos moldes de uma cidade para os novos 
tempos - de fazer o objeto isolado foi perseguido e de certa forma transformado em um atributo. A necessidade ou vontade de tratar igualmente [dada as particularidades de orientação e planta] todas as fachadas é por vezes notada e como consequências em casos bem-sucedidos trouxe benefícios para cidade. Dentro dos limites foi possível amenizar o destrato das fachadas secundárias dos edifícios. Por outro lado, não se resistiu ao imperativo das fachadas principais, salvo alguns casos em que as torres soltaram-se de seus embasamentos liberando suas faces; mesmo nessas circunstâncias os alinhamentos inferiores não deixam de lembrar de que liberdade se trata.

Como exposto nas discussões entre São Paulo e Nova York, a formação da trama urbana - sistemas de vias e divisão fundiária - configurou sob semelhante sistema legislativo, com volumetrias muitos distintas. Em São Paulo, o escalonamento desmanchou as tentativas de se estabelecer um controle volumétrico, como intencionadas em alguns planos urbanísticos: o primeiro alinhamento pela largura da rua não foi suficiente para conter as descontinuidades de toda ordem. Em Nova York, nas áreas verticalizadas parece haver uma homogeneidade maior, seja pela maior regularidade do lotes, seja pela possibilidade de se fazer aberturas em quase todas as faces. Nas duas cidades a legislação marcou indistintamente os edifícios independentemente de suas linguagens. Seria então a linguagem um aspecto secundário na constituição da cidade? Sem desprezar a precedência das tecnologias, a potência das normativas e interesses urbanos? Aqui, pensa-se que não.

Nessas relações ambíguas e imbricadas, a linguagem da arquitetura moderna tem papel decisivo e expressivo. Primeiro porque a linguagem moderna, como se entende aqui, não vem desvinculada dos princípios modernos; das concepções de espaço e tecnológicas, da idealidade contida na cidade e nos edifícios. Nesse sentido, a ossatura independente e seus desdobramentos são princípios operativos centrais da linguagem e da ideologia; e estritamente atada a uma ordem ideal das coisas como pondera com Rowe em a Estrutura de Chicago: sob esse olhar a ossatura independente tem uma função ideal, geral e abstrata e o arranha-céu, no caso, uma função social (1999, p.106-7). Ou seja, a ossatura independente é análoga à ordem das coisas no mundo. Do ponto de vista operativo a estrutura independente e as plantas livres ao promoverem planos sobrepostos, pontuados pelos pilares, estabeleceram uma continuidade interna que facilitou os arranjos compositivos das edificações em seus lotes: principalmente ao facilitar o resgate (aproveitamento) de espaços residuais. Se em alguns casos, um fazer sistêmico ficou comprometido, o 
fazer compositivo, por sua vez, se fez presente dando conta de resolver problemas práticos como a continuidade de planos contíguos e limítrofes nas fachadas principais.

O Ministério da Educação é realmente uma obra memorável. De um jeito ou de outro ela pairou sobre o fazer moderno brasileiro, assim como pairaram as idealidades manifestadas na Carta de Atenas. Mesmo se ponderando diferenças relevantes de formação e poéticas dos arquitetos. A obra do Ministério formatou uma agenda; um roteiro e um modelo: que foi levado ao cabo em muitas obras modernas brasileiras porém, parcialmente e com dificuldades no CHSP. Em nenhum momento ${ }^{144}$, os pilotis na integridade, provisória, de sua concepção veio acontecer: os pilotis ocupados por lojas e galerias comerciais reduzem-se a uma retórica, se não vazia, pelo menos distanciada do sentido original. Tampouco a regularidade da forma em lâmina dos edifícios e seus arranjos espaciais ideais. Os brises foram frequentemente perseguidos: em diversos casos não foram construídos ou resultaram num fracasso. Em outros, resultaram aí sim, numa retórica desnecessária do ponto de vista funcional, mas relevante do ponto de vista plástico.

Os edifícios estudados exemplificam situações urbanas, mais do que diferenças poéticas entre linguagens, embora essas diferenças tenham aflorado nas descrições. Não esgotam com certeza as tipologias possíveis. Algo fabuloso e contraditório ocorre no Centro Histórico de São Paulo: todo edifício - tendo-se em conta a formação do lote e respectiva volumetria - é um caso particular. Ao mesmo tempo, sujeitam-se às situações que indiciam uma tipologia. Poder-se-ia dizer o mesmo acerca de qualquer obra em particular - no entanto, sem tamanha propriedade; porque nele não há dois lotes iguais.

Não cabe retomar as singularidades de cada edifício. Mas os sentidos gerais que confirmam as hipóteses levantadas.

Nos primeiros encontros, vê-se que os primeiros encontros entre a arquitetura moderna e o Centro Histórico de São Paulo foram bem distintos da experiência carioca, o Ministério. São determinantes a natureza dos empreendimentos, a legislação e a formação do tecido da cidade tradicional. Nessa relação é possível perceber tanto as idealidades plantadas na doutrina moderna, quanto a força que emana da cidade; essa tensão caracteriza, entende-se aqui, a natureza da arquitetura moderna no Centro de São Paulo, nessa primeira fase nos anos 30 e 40.

Se por um lado suas formas estão longe das lâminas ou dos blocos

${ }^{144}$ Salvo, muito discretamente a passagem entre passagem sob o edifício Conde Silvio Penteado, ligando a rua particular da Vila Normanda à Avenida São Luiz. 
horizontalizados, por outro elas revelam em suas volumetrias a forma dos lotes e das leis. Mas ao fazê-lo, a despeito de toda adversidade, não deixam de buscar qualidades próprias dos objetos soltos no lote, como o tratamento expressivo e adequado a cada face, atendo-se sobretudo, às questões de salubridade. Nesse sentido, são notáveis as soluções do Thomas Edison e do Banco Paulista do Comércio dado as condições adversas do lote. Como o são também as transições entre as superfícies contíguas entre edifícios, com no caso do Jaçatuba.

Percebe-se que a ossatura independente é o principio da doutrina mais visível, trazendo à tona toda a carga de significados implícitos: a procura de uma racionalidade sistêmica, como claramente exposta no Esther. Outros elementos como os pilotis guardam uma relação mais simbólica do que doutrinária. Se em muitos casos a racionalização sistêmica enfrentou empecilhos, em outros demonstrou, por meio da habilidade dos arquitetos, as virtudes compositivas adquiridas nas formações acadêmicas comuns a esses arquitetos: formação que lhes permitia resolver problemas formais imprevistos fora das regras a priori. Se nessa primeira fase não havia uma diferença muito clara entre o embasamento dos edifícios e as torres mais elevadas; rumo aos anos 60, como esboçado no Renata Sampaio, essa separação ficaria mais clara em muitos edifícios.

As obras de Niemeyer; particularmente no CHSP são enriquecedoras. Niemeyer é a mais evidente referência corbusieriana. Tudo parecia indicar um caminho de tensão e inadequação de toda ordem. Elas ocorrem com certeza. Mas na singularidade das obras foi possível, também, perceber situações ricas, onde a arquitetura moderna e a cidade tradicional entraram em perfeita sintonia. Nesses casos, prevaleceu a força e a dinâmica da cidade tradicional. Ora impondo-se por meio de uma morfologia enraizada, ora impondo-se pela força imperiosa da legislação e dos interesses nela embutidos.

O edifício Triângulo é paradigmático: ele é ao mesmo tempo um objeto solto no espaço, uma quadra colonial, uma extrusão do lote, uma expressão da linguagem moderna e também seu insucesso. Mas ele é também a memória de um fragmento de terra que persiste admiravelmente no tempo.

Do outro lado têm-se o Eiffel e o Copan. Ambos se apresentam como objetos soltos no espaço. O Copan com certeza atingiu seu destino: sinuoso e imponente destaca-se em meio a uma enorme massa edificada. O Eiffel também favorece as trocas entre o espaço público e o privado por meio da galeria comercial. Porém, sua forma elevada, atada parcialmente ao lote, ficou a meio caminho entre a condição de 
um objeto isolado e a continuidade das volumetrias lindeiras. Contribuiu para essa situação a opção pela transposição do modelo corbusieriano: a forma triangular do terreno sugeria a pertinência da escolha, mas submetida à legislação mostrou-se oscilante, como uma forma inacabada.

Entre essas duas polaridades acham-se os edifícios Califórnia, Montreal e Seguradoras: exemplos de fusões bem-sucedidas com a trama urbana. O Edifício e Galeria Califórnia conformou-se como uma precisa cunha que encerra um conjunto urbano. A disposição dos volumes externos compondo as "paredes internas" da rua e a permeabilidade da galeria, interligando as ruas Barão de Itapetininga e Dom José de Barros, é de extraordinário significado para persistência das qualidades da cidade histórica. No "Seguradoras" se faz uso de um pátio interno para garantir máxima ocupação e boa iluminação às salas de escritório, assim como no Califórnia, uma implantação é pragmaticamente resolvida no limite. No outro extremo, o Montreal encerra uma quadra e faz a transição entre duas ruas tangentes: promove essa transição e ao mesmo tempo dá continuidade aos gabaritos previstos para os logradouros.

Rumo aos ano 60, recortam-se as torres - os arranha-céus. Num primeiro olhar estão altaneiros na paisagem. Em outros suas histórias caminham de encontro aos esquemas da cidade. O CBI-Esplanda tem a imponência correspondente ao Parque do Anhangabaú: mas um apêndice mesquinho o prende de forma inaceitável ao terreno. No limite não escapa da lei. O Conde de Prates é no período o arranha-céu mais expressivo em sua forma limpa, ele de fato é um edifício solto no lote: mas as circunstâncias desse fato não decorrente de uma intenção formal direta. As circunstâncias do Palacete dos Prates determinaram sua volumetria final. O Itália sim tem a intenção de ser uma torre, de ser um objeto solto no espaço, vinculado estritamente ao ideário moderno na forma e nas intenções de linguagem. Em parte é um caso bem-sucedido, ainda assim, com restrições: uma torre homogênea eleva-se de um embasamento tortuoso, que foi manipulado com maestria para enfim soltar a torre.

O Conjunto Metropolitano é uma variação das galerias comerciais no Centro Novo; ele ocupa interiores de quadras que interligam ruas: mas de um modo mais independente, mais a caráter de vontade moderna. Por isso, o Conjunto Metropolitano é emblemático. Por suas formas é possível recortar as dificuldades da idealidade moderna diante da cidade tradicional: de uma maneira clara ele encerra e exemplifica 
esse embate. A torre está solta e o embasamento tem expressão própria; ele quase se desprende do lote, para isso sacrifica a continuidade volumétrica com os edifícios lindeiros. Ao mesmo tempo ele promove as capilaridades contidas no Centro Novo, interligando espaços e ruas como já promovido por outras galerias comerciais no Centro Novo.

Então de volta às dificuldades de textura e forma. De volta a Amilcar de Castro e a uma de suas esculturas de geometria e aço; dobradas na rua. ${ }^{145}$

A imagem é poderosa. A obra muito mais. Retém em poucos elementos aquilo que foi dito e argumentado em mil e uma palavras. A racionalidade moderna quer dobrar a matéria resistente - o aço - e o faz. Mas a matéria resiste. Em alguns cantos não cede por inteiro, em algumas espessuras não dobra.

O Centro Histórico de São Paulo é a matéria resistente, que cede e por vezes absorve preceitos modernos, mas não se dobra nos termos de sua idealidade universal e abstrata. Por outro lado, as dificuldades de textura e forma são constatáveis, contudo, não significam a impossibilidade do encontro. As objeções modificaram idealidades e ao mesmo tempo conferiram-Ihes novos valores. Da mesma forma que numa escultura de Amilcar o jogo que se realiza está na tensão entre ideação e matéria, entre sentido de ordem e conteúdo resistente no tempo longo da geologia.

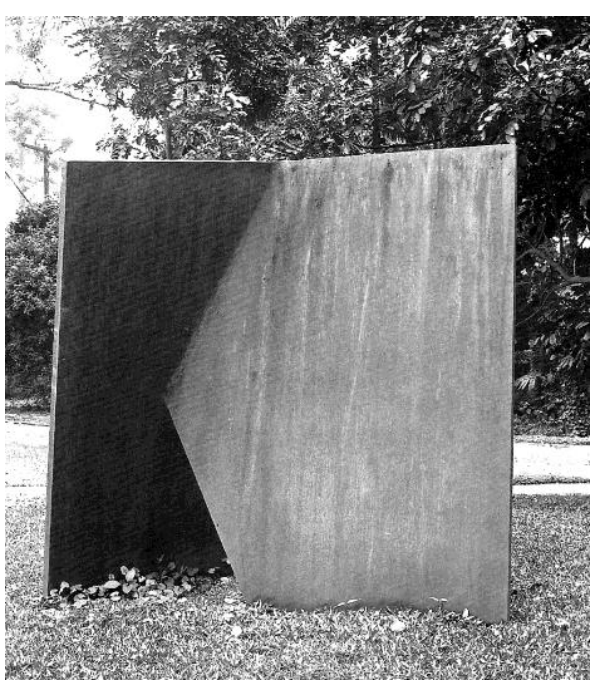

Amilcar de Castro. Sem título, fins da década de 70. Ferro, $200 \times 82 \times 5 \mathrm{~cm}$. (fonte, Naves, 1996.

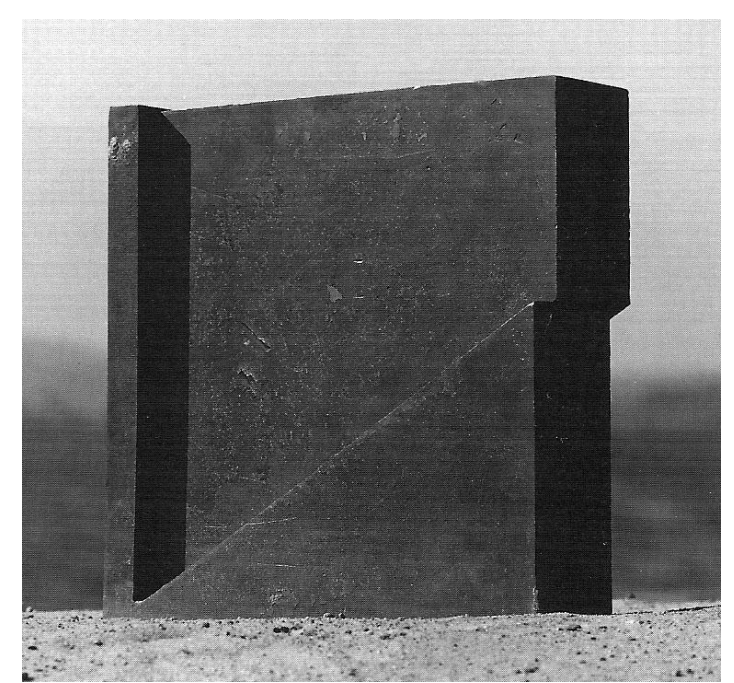

Amilcar de Castro. Sem título, fins da década de 80 . Ferro, $30 \times 30 \times 7,5 \mathrm{~cm}$. (fonte, Naves, 1996.

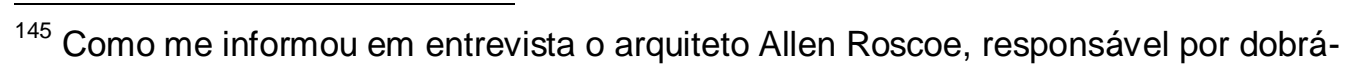
las na rua por meio de um caminhão com guindaste. 


\section{Bibliografia}

AB'SÁBER, Aziz. Geomorfologia do sítio urbano de São Paulo. São Paulo, Ateliê Editorial, 2007.

ALBA, Lilian Bueno. Trinta anos de edifícios modernos em São Paulo. Dissertação de Mestrado. FAU-USP, 2004.

ADAMS, Thomas. The Building of New York, V. 2. New York: Regional Plan of New York and its Environs, 1931.

ALEIXO, Cynthia Augusta Poleta. Arquitetura e Comércio na Cidade de São Paulo, anos 50 e 60. Dissertação de mestrado. Escola de Engenharia de São Carlos da Universidade de São Paulo, 2005.

ANELLI, Renato (pesquisa de texto), GUERRA, Abílio (coordenação editorial) e KON, Nelson (ensaios fotográficos). Rino Levi: Arquitetura e cidade. São Paulo: Romano Guerra, 2001.

ARGAN, Giulio Carlo. Arte e crítica de arte. Trad. Helena Gubernatis, $2^{\underline{a}}$ ed., Lisboa: Editorial Estampa, 1995 (teoria da arte).

El arte moderno. Trad. Joaquin Espinosa Carbonell Valencia,Fernando Torres - Editor, 1975, reimpressão, 1984a.

El concepto del espacio arquitetônico desde el barroco a Nuestros dias, rad. Liliana Rainis, Bueno Aires, Nueva Vision, 1966.

Projeto e destino. Trad. Marcos Bagno - São Paulo, Ática, 2000.

A. História de la arte como historia de la ciudad. Trad. Beatriz Podestá - Barcelona, Editorial, Laia, 1984.

B. Walter Gropius e a Bauhaus. Trad. Emilio Campos Lima Lisboa, Editorial Presença, 1984b.

ATIQUE, Fernando. Memória moderna: a trajetória do Edifício Esther. São Paulo: Rima/FAPESP, 2004.

AYRES NETO, Gabriel. Código de Obras. São Paulo, Edições Lep, 7ª edição, 1962 Ayres Neto, Gabriel. Código de Obras "Arthur Saboya”. São Paulo, Edições Lep, 1947, p. 256 e p. 264.

AYMONINO, Carlo. El significado de las ciudades. Trad: Francisco Pol Mendez. Rosário/Madri, H. Blume ediciones, 1981.

AZEVEDO, Ricardo Marques de. Fontes iluminadas. São Paulo, versão de 1998, inédito.

Metrópole e Abstração. São Paulo, perspectiva, 2006.

ARISTÓTELES. Metafísica: Londres, Loeb Classical, livro I. 
BANHAM, Reyner. Teoria e Projeto na era da máquina. Trad: A. M. Goldberger Coelho. São Paulo, Perspectiva, 1979.

BARBOSA, Marcelo Consiglio. A obra de Adolf Franz no Brasil. Dissertação de Mestrado. Faculdade de Arquitetura e Urbanismo- USP. São Paulo, 2002.

BARBUY, Heloisa. A cidade exposição: comércio e Cosmopolitismo em São Paulo, 1860-1914. São Paulo, Edusp, 2006.

BAUDELAIRE, Charles - As florez do mal, trad. Jamil Haddad, 2a ed., Difusão Européia do Livro, São Paulo, 1964

A modernidade de Baudelaire, apresentação Teixeira Coelho, trad. Suely Cassal, Rio de Janeiro, Paz e Terra, 1988.

Poesia e prosa: volume único, organizada por Ivo Barroso, Rio de Janeiro, Nova Aguilar, 1995.

BENEVOLO, Leonardo. Historia de la arquitectura moderna. Trad. Mariuccia Galfetti y Juan Dias de Aturi - Barcelona, Gustavo Gili, $2^{\mathrm{a}}$ ed.,

BENEVOLO, Leonardo; MELOGRANI, Carlo; LONGO, Tommaso Giura. Projectar a

Cidade Moderna. Trad. Rafael Moreira. Lisboa, Editorial Presença, 1987.

BERMAN, Marshall - Tudo que é sólido se desmancha no ar: aventura da modernidade. Trad. Carlos Felipe Moisés, Ana Maria L. Ioriatti, São Paulo, Companhia das Letras, 1986.

BOESIGER, Willy: Le Corbusier.São Paulo, Matins Fontes, 199.

BRANCO, Ilda H. D Castelo. Arquitetura no centro da Cidade: edifícios de uso coletivo. Dissertação de mestrado, Faculdade de Arquitetura e Urbanismo, Universidade de São Paulo. São Paulo, 1989.

BRANDÃO, Carlos A. L.. A Formação do homem moderno vista através da arquitetura, Belo Horizonte, AP Cultural, 1991.

BRUAND, Yves. Arquitetura contemporânea no Brasil. São Paulo, Perspectiva, 1981.

BUCCI, Angelo. São Paulo: quatro imagens para quatro operações [da dissolução dos edifícios e de como atravessar paredes]. Tese de doutorado - Faculdade de Arquitetura e Urbanismo, São Paulo, 2005.

Caderno de Fotografia Brasileira: São Paulo 450 anos. São Paulo, Instituto Moreira Salles, 2004.

SEVCENKO, Nicolau. De mameluca, mulata e gótica a moderna: as metamorfoses de Piratininga. p.314;

LEMOS, Carlos A. C. Paisagem arquitetônica.p .334; 
TOLEDO, Benedito Lima de. O triângulo e a configuração de suas ruas e largos, p.360.

CAHEN, Nádia Oliveira. O edifício como qualificador do espaço urbano no centro novo de São Paulo: Avenida São Luís, interpretação e resposta. Dissertação de mestrado, Universidade Presbiteriana Mackenzie. São paulo:2004.

CAMARGO, Mônica Junqueira de. Princípios de Arquitetura Moderna na obra de Oswaldo Arthur Bratke. Tese de doutorado - Faculdade de Arquitetura e Urbanismo, São Paulo, 2000.

Oswaldo Bratke: uma trajetória moderna. São Paulo: FAU- Mackenzie SP, 1995. Dissertação de mestrado.

CAMPOS, Candido Malta. Os Rumos da Cidade: Urbanismo e Modernização em São Paulo. São Paulo, Editora Senac, 2002.

CARTA DE ATENAS. CIAM: Congresso Internacional de Arquitetura Moderna. Novembro de 1933: versão pdf; IPHAN.

Código de Obras Arthur Saboya: consolidação aprovada pelo ato n 663 de 10 de Agosto de 1934. São Paulo; Escola Profissionaes Salesianas, 1935.

CAMPOS, Vitor José Baptista. "O Art Déco e a Construção do Imaginário Moderno: um estudo do imaginário moderno". Tese de doutoramento na Fau-USP, 2003.

CARRILHO, Marcos José. Lucio Costa, Patrimônio Histórico e Arquitetura Moderna. Tese de Doutorado apresentada à Faculdade de Arquitetura e Urbanismo da USP. São Paulo: 2002.

O Edifício Esther. IN: Seminário DO.CO.MO.MO BRASIL , 3.,São Paulo, 1999. \{versão DO.CO.MO.MO, [Marcos_Carrilho. Pdf].

COHEN, Jean-Louis. Le Corbusier 1887-1965: lirismo na época da máquina.

Tradução Francisco Paiva Boleo. Köln, 2005.

COLLINS, Peter. Los ideales de la arquitectura; su evolución (1750 - 1950). Trad. Ignasi de Solá-Morales Rubió - Barcelona, Gustavo Gilli, 1970, 1998.

COLQUHOUN, Alan. Modernidade e tradição clássica: ensaios sobre arquitetura 1980-87. Trad. Chirstriane Brito. São Paulo, Cosac \& Naify, 2004

La arquitectura moderna una historia desapasionada. Trad.: Jorge Sainz. Barcelona, Gustavo Gili, 2005.

COMAS, Carlos Eduardo Dias. Arquitetura Moderna, Estilo Corbu, Pavilhão

Brasileiro. São Paulo, Pini, 1989, revista Arquitetura e Urbanismo 26 , Out/Nov 89, pp 92-101.

Questões de Base e situação: arquitetura moderna e edifícios de escritórios. Rio de Janeiro, 1936-45.

http://vitruvius.com.br/arquitextos/arq078/arq078_00.asp 
COMAS, Carlos Eduardo (org.). Projeto arquitetônico - disciplina em crise, disciplina em renovação - MAHFUZ, Edson. São Paulo: Projeto, 1986.

Projeto e monumento, um ministério, o ministério. São Paulo, Revista Projeto 102, 1987, p.133-49.

CONDURU, Roberto (orgs). Um modo de ser moderno: Lucio Costa e a crítica contemporânea. São Paulo, Cosac \& Naify, 2004.

Vital Brasil. São Paulo, Cosac \& Naify, 2000.

CORONA \& LEMOS. Dicionário da arquitetura brasileira. $2^{\underline{a}}$ ed. - São Paulo, Companhia das Artes, 1998.

COSTA, Lucio. Lucio Costa : Sobre Arquitetura [sic]/Lucio Costa; organizado por Alberto Xavier. - 2 ed. / coordenada por Anna Paula Canez. Porto Alegre; UniRitter, 2007.

COSTA, Lucio. Registro de uma vivência. São Paulo, Empresa de Artes, 1995.

CUNHA JR., Jaime. Edifício Metrópole: um diálogo entre arquitetura moderna e cidade. Dissertação de mestrado, Faculdade de Arquitetura e Urbanismo, Universidade de São Paulo. São Paulo, 2007.

CURTIS, William J. R. Modern Architecture since 1900. London, Phaidon Press Limited, third edition, 1996.

Le Corbusier: ideas and forms. New York: Phaidon,2006

DE BEM, José Paulo. São Paulo: cidade/memória e projeto. São Paulo, FAU-USP, 2006. Tese de Doutorado.

FALBEL, Anat. Lucjan Korngold: a trajetória de um arquiteto imigrante. Tese de Doutorado. Universidade de São Paulo, Faculdade de Arquitetura e Urbanismo. São Paulo, 2003. http://www.cbiesplanada.com.br/historico.htm

FIALHO, Roberto Novelli. Edifícios de escritórios na cidade de São Paulo. Tese de Doutoramento - Faculdade de Arquitetura e Urbanismo, Universidade de São Paulo. São Paulo, 2007.

FRAMPTON, Kenneth. Le Corbusier. London, Thames e Hudson, 2001.

História crítica de la arquitectura moderna. Trad. Esteve Riambaui Sauri - Barcelona, Gustavo Gili, 1991.

Le Corbusier. London, Thames \& Hudson, 2001. 
FUJIOKA, Paulo Yassuhiede. O edifício Itália e a arquitetura dos edifícios de escritório em São Paulo. Dissertação de mestrado. São Paulo, Fau-USP

FUSCO, Renato de. A idéia de arquitetura. Trad. José Eduardo Rodil - Lisboa, Edições 70, 1972.

GATI, Catharine. Franz Heep: um artífice do racionalismo. São Paulo, Editora Pini, Revista AU, nº 53, seção Documento, 1994.

GIEDION, Sigfried. Espaço, tempo e arquitetura: o desenvolvimento de uma nova tradição. Trad. Alvamar Lamparelli. São Paulo: Martins Fontes, 2004.

GUERRA, Abílio. Lúcio Costa: modernidade e tradição, montagem discursiva da arquitetura moderna brasileira. Tese de doutorado. Universidade Estadual de campinas- Unicamp, 2002.

GOMBRICH, E. H. A história da arte. Trad. Álvaro Cabral. Rio de Janeiro, LTC Livros Técnicos e Científicos, 1993

GOODWIN, Philip L.. Brazil Buids. New York, The Museum of modern Art, 1943.

HARRIS, Elizabeth D.. Le Corbusier: Riscos Brasileiros. Trad: Antonio de Pádua Donesi e Gilson César Cardoso de Souza. São Paulo, Nobel, 1887.

HEYNEN, Hilde. Architecture and Modernnity: a critique. Cambridge:

Massachusetts Institute of Technology, 1999.

História da Cidade de São Paulo. V. 1. A cidade colonial 1554-1822. Org. Paulo Porta. São Paulo: Paz e Terra, 2004. V.2. A cidade do Império 1823-1889.

V.3. A cidade na primeira metade do século $\mathrm{XX}$

HOLSTON, James. A cidade modernista: uma crítica de Brasília e sua utopia. Trad: Marcelo Coelho. São Paulo: Companhia das Letras, 1993.

KAUFMANN, Emil. Tres arquitectos revolucionarios: Boullée, Ledoux y Lequeu. Barcelona, Gustaco Gili, 1980.

De Ledoux a Le Corbusier, origen e desarrolo de la arquitectura autónoma. Barcelona, Gustavo Gili, 1982.

KOOLHAAS, Rem. Nova York delirante. Trad. Denise Bottmann. São Paulo, Cosac Naify, 2008.

LAMAS, José M. Garcia. Morfologia urbana e desenho da cidade. Lisboa: Fundação Calouste Gulbenkian: Fundação para a Ciência e a Tecnologia; 2007.

LE CORBUSIER. Precisões. Trad: Carlos Eugênio Marcondes de Moura. São Paulo, Cosac \& Naify,2004.

Urbanismo. Trad. Maria Ermantina Galvão. São Paulo, Martins Fonte, 2000. 
Por uma Arquitetura. Trad. Ubirajara Rebouças. São Paulo,

Perspectiva, 1981.

Le Corbusier: Le Grand. New York: Phaidon, 2008.

Le Corbusier \& P. Jeanneret. Oevre complète -1929-34, 1934-38. Zurich, Edition Girsberg, 1964/1995.

LEFÈVRE, José Eduardo de Assis. De Beco a Avenida: a história da Rua São Luiz. São Paulo, EDUSP, 2006.

LEMOS, Carlos A. C. O morar no modernismo Paulistano. In O caderno de São Paulo, edição Rhodia, 1079.

LÉVI-STRAUSS, Claude. Tristes Trópicos. Trad: Rosa Freire D’Aguiar. São Paulo, Companhia das Letras, 1996.

Saudades do Brasil. Trad: Paulo Neves. São Paulo,

Companhia das Letras, 996.

LISSOVSKY, Maurício; SÁ, Paulo Sérgio Moraes de. Colunas da Educação: a construção do Ministério da Educação e Saúde (1935-1945). Rio de Janeiro: MINC/IPHAN; Fundação Getulio Vargas/CPDOC, 1996.

MAIA, Francisco Prestes. Estudo de um Plano de Avenidas para a Cidade de São Paulo.São Paulo: Cia Melhoramentos de São Paulo, 1930.

Os melhoramentos de São Paulo - Palestra pelo Engenheiro Francisco Prestes Maia - Prefeito Municipal: 2ª tiragem, São Paulo,Janeiro de 1945.

MARTINS, Carlos Alberto Ferreira. Razon, Ciudad y Naturaleza: La génisis de los comceptos en El urbanismo de Le Corbusier. Tesis Doctoral - Departamiento de Estética y Composición Escuela Técnica Superior de arquitectura de Madrid, 1992.

MEYER, Regina Maria Prosperi Meyer. Metrópole e Urbanismo: São Paulo anos 50. Tese de Doutoramento - Faculdade de Arquitetura e Urbanismo, Universidade de São Paulo. São Paulo, 1991.

GRONSTEIN, Marta Dora; BIDERMAN, Ciro. São Paulo Metrópole. São Paulo, Edusp/Imprensa Oficial, 2004.

MINDLIN, Henrique E.. Modern Architecture in Brazil. Rio de Janeiro/Amsterdam, Colibris editora, 1956.

MOOS, Stanislaus von. Le Corbusier, Elements of a synthesis. Cambridge, The Massachusetts Institute of Technology, 1979.

MUMFORD, Lewis. A cultura das cidades. Trad. Neil R. da Silva. Belo Horizonte, Itatiaia, 1961.

A cidade na História. Trad: Neil R. Da Silva. São Paulo, Martins Fontes, 1998.

L' architettura americana oggi. MiLão, Casabella, 
457/458, 1980.

NAVES, Rodrigo. A forma difícil: ensaios sobre arte brasileira. São Paulo, Ática, 1996.

O vento e o Moinho: ensaios sobre arte moderna e contemporânea.

São Paulo, Companhia das Letras, 2007.

NESBITT, Kate (org.). Uma nova agenda para a arquitetura; antologia teórica (1965-1995). São Paulo: Cosac\&naify, 2006.

PAREYSON, Luigi. Os problemas da estética. Trad. Maria Helena Nery Garcez, 2. ${ }^{\text {a }}$ ed., São Paulo: Martins Fontes, 1989.

PEREIRA, Claúdio Calovi. Transparência e Permeabilidade: diálogos entre tradição e modernidade nos pisos térreos dos irmãos Roberto no Centro do Rio de Janeiro (1936-52). Em " A segunda idade do vidro: transparência e sombra na Arquitetura Moderna do Cone Sul Americano - 1930-1970; org. Carlos Eduardo Dias Comas e Sergio Marques. Porto Alegre, Editora UniRitter, 2007.

PINHEIRO, Maria Lucia Bressan. Modernidade ou moderna? Tese de Doutoramento, Faculdade de Arquitetura e Urbanismo da Universidade de São Paulo. São Paulo, Outubro de 1997.

PORTZAMPARC, Christian de. A terceira era da cidade. Trad. Denio Munia Benfatti. Campinas, Óculum 9, 1997, p.34-49.

QUEIROZ, Rodrigo. Oscar Niemeyer e Le Corbusier: encontros. Tese de

Doutoramento - Faculdade de Arquitetura e Urbanismo, Universidade de São Paulo. São Paulo, 2007.

ROSA, Marcos. São Paulo Vista do Céu. São Paulo, Editora Caras, 2004.

REIS, Nestor Goulart Filho. Quadro da arquitetura no brasil. São Paulo, Perspectiva, 1970.

Imagens de vilas e cidades do Brasil Colonial. São Paulo, edit. da Universidade de São Paulo: Imprensa Oficial do Estado: Fapesp, 2000.

São Paulo: Vila, Cidade e Metrópole. São Paulo, Prefeitura De São Paulo, 2004.

Rino Levi. Milão, Edizione di Comunità, 1974.

RIBEIRO, Alessandro José Castroviejo; DEL NEGRO, Paulo Sérgio. Oswaldo Bratke e a cidade nova: o texto e o contexto. São Paulo, 2005, Http://vitruvius.com.br/arquitextos/arq078/arq078_01.asp

RIBEIRO, Alessandro José Castroviejo; CARRILHO, Marcos José. Oscar Niemeyer no centro histórico de São Paulo: arquitetura moderna e a cidade tradicional. Trabalho apresentado no 5 ํ Fórum de pesquisa FAU-Mackenzie e no XIII SAL Seminário de Arquitetura lationoamerica (resumo). 2009. 
ROSSI, Aldo. Tre Cittá (Three Cities): Perugia, Milano e Mantova. Quaderni di Lótus/Lótus Documents. Milano: Electa, 1984. Collana diretta da Pierluigi Nicolin. Trad: Giorgio Bersano, Huw Evans e Serena Marchi. Con testi di Bernard Huet e Patrizia Lombardo.

A arquitetura da cidade. Trad: José C. Monteiro e José da Nóbrega Sousa Martins. Lisboa, Edições Cosmos, 1977.

Autobiografia científica. Trad: Juan José Lahuerta. Barcelona, Gustavo Gilli, 1981.

ROWE, Colin. Manierismo y arquitectura Moderna y otros Ensaios. Barcelona, Gustavo Gili, 1978,1999.

ROWE, Colin; KOETTERr, Fred. Ciudad Collage. Trad: Esteve Riambau Sauri. Barcelona: Gustavo Gili, , 1998.

RYKWERT, Joseph. A sedução do lugar: a história e o futuro da cidade. Trad: Valter Lellis Siqueira e revisão técnica de Sylvia Ficher. São Paulo: Martins Fontes, 2004;

A idéia de cidade: a antropologia da forma urbana em Roma, Itália e no Mundo Antigo. Trad: margarida Goldsztajn; Revisão técnica, Anat Falbel. São Paulo, Perspectiva, 2006.

SANTOS, Cecília Rodrigues do ...[et al.]. Le Corbusier e o Brasil. São Paulo, Tessela/Projeto Editores, 1987.

SANTOS, Pedro Alberto Palma dos. A concepção estrutural nos edifícios de escritórios: uma análise em São Paulo, Rio de Janeiro e Brasília a partir da década de 30. Dissertação de mestrado, Faculdade de Arquitetura e Urbanismo, Universidade de São Paulo. São Paulo, Dezembro 2000.

SCULLY JR. Arquitetura Moderna: a arquitetura da democracia. Trad. Ana Luiza Dantas Borges. São Paulo, Cosac \& Naify, 2002.

SIMÕES JÚNIOR, José Geraldo. Anhangabaú: história e urbanismo. São Paulo: Senac São Paulo: Imprensa Oficial do Estado de São Paulo, 2004.

SOMEKH, Nadia. A cidade Vertical e o Urbanismo Modernizador São Paulo 19201929. São Paulo, Studio Nobel, 1997.

CAMPOS, Candido Malta (organizadores). A cidade que não pode parar: planos Urbanísticos de São Paulo no século XX. São Paulo, Mackpesquisa, 2002.

SEGAWA, Hugo. Arquiteturas no Brasil - 1900 -1990. São Paulo, Edusp, 1998.

Oswaldo Arthur Bratke. São Paulo: ProEditores, 1997.

O herói desconhecido da moderna arquitetura brasileira. São Paulo, Revista Projeto no 96, 1987, p.59-64.

SOLÁ-MORALES, Ignasi de. Territorios. Barcelona, Gustavo Gili, 2002. 
STANGOS, Nikos, org. Conceitos de arte moderna. Trad. Álvaro Cabral. Rio de Janeiro, Jorge Zahar Editor, 1991.

SZABO, Ladislao Pedro. Em busca de uma luz paulistana: a concepção de luz natural no projeto de arquitetos da cidade de São Paulo. Tese de doutorado - Faculdade de Arquitetura e Urbanismo, São Paulo, São Paulo; FAU-USP: 2002.

TOLEDO, Benedito Lima de. Prestes Maia e as Origens do Urbanismo Moderno em São Paulo. São Paulo: Empresa das Artes, 1996.

0 triângulo e a configuração de suas ruas e largos. Cadernos de Fotografia Brasileira, São Paulo 450 anos. São Paulo, Instituto Moreira Salles, 2004, p.360- 80.

São Paulo: três cidades em um século. 4a edição revista. São Paulo: CosacNaify e Duas Cidades, 2007.

Anhangabahú. São Paulo, Federação das Indústrias do Estado de São Paulo,1989.

VENTURI, Robert. Complejidad y contradicción en la arquitectura. Trad. Antón Aguirregoitia Arechavaleta y Eduardo de Felipe Alonso, arquitectos, Y Esteve Riambau I Saurí, segunda edición - Barcelona, Gustavo Gili, 1974, 1978.

WARCHAVCHIK, Gregori. Arquitetura do século XX e outros escritos. São Paulo, Cosac \& Naify, 2006.

WILLIS, Carol. Form Follows Finance: Skyscrapers and Skylines in New York and Chicago. New York, Princeton Architectural Press, 1995.

XAVIER, Alberto, LEMOS, Carlos, CORONA, Eduardo. Arquitetura Moderna Paulistana. São Paulo, Pini, 1983.

XAVIER, Alberto (org.). Arquitetura Moderna Brasileira: depoimentos de uma geração. São Paulo, Cosac \&Naify, 2003.

Arquitetura moderna em Curitiba. São Paulo, Pini; Curitiba, Fundação Cultural de Curitiba, 1986.

MIZOGUCHI, Ivan. Arquitetura moderna em Porto Alegre. São Paulo, Pini, 1987.

BRITO, Alfredo, NOBRE, Ana Luiza. Arquitetura moderna no Rio de Janeiro. São Paulo, Pini; Fundação Vilanova Artigas; Rio de Janeiro, Rioarte,1991.

XAVIER, Denise. Arquitetura metropolitana. São Paulo, AnnaBlume/Fapesp, 2007.

Zein, Ruth Verde. Três Momentos de Oscar Niemeyer. MCB, 100 Obras de São Paulo, Museu da Casa Brasileira, 2007.

ZEVI, Bruno, A linguagem moderna da arquitetura. Trad. Luís Pignatelli, Lisboa, Publicações Dom Quixote, 1984. 


\section{Arquivos Consultados}

Arquivo digital - Estudo de Tombamento do Centro Histórico da Cidade de São Paulo - Instituto do Patrimônio Histórico e Artístico Nacional - 9ª -SR- São Paulo

Arquivo Rino Levi: desenhos legais e executivos (FAU-USP)

Banco de Dados Digital - Centro Histórico de São Paulo - Universidade Presbiteriana Mackenzie.

Arquivo Corrente da Prefeitura de São Paulo: DAMP

Arquivo histórico Washington Luís (AHMWL)

\section{Periódicos}

HABITAT no 29, 1956

Acrópole nำ146, Junho de 1950.

Acrópole no 97, Maio de 1946

L'Architecture D'Aujourd'Hui, 21, Dezembro de 1948.

Casabella 457/458

Revista Projeto, ํㅡ 102

Revista Acrópole, ำ146

Acrópole 202

Acrópole 208

Habitat 59, Abril de 1960

Revista Habitat n2, jan/mar. 1951

Revista AU, nํ53, seção Documento, 1994

\section{Mapas}

Comissão IV centenário da cidade de São Paulo. São Paulo Antigo - Plantas da Cidade, São Paulo, 1954.

Sara Brasil

Gregran 


\section{2. Índice e fonte das ilustrações}

\section{Entre dois modelos de Cidade}

- 2.1 e 2.2: Lamas, José M. Garcia. Morfologia urbana e desenho da cidade. Lisboa: Fundação Calouste Gulbenkian: Fundação para a Ciência e a Tecnologia; 2007.

- 2.3 e 2.4: Le Corbusier \& P. Jeanneret. Oevre complète - 1934-38. Zurich, Edition Girsberg, 1964/1995.

- $\quad 2.5$ e 2.6: Le Corbusier: Le Grand. New York: Phaidon, 2008.

- 2.7e 2.8: ROWE, Colin; KOETTERr, Fred. Ciudad Collage. Gustavo Gili, 1998.

- 2.9: HOLSTON, James. A cidade modernista: uma crítica de Brasília e sua utopia. São Paulo: Companhia das Letras, 1993.

- 2.10, 2.11 e 2.12: Mapa figura e fundo sobre base Gegran (Viva o Centro) - Alessandro J. Castroviejo Ribeiro e Tiago Azzi Collet e Silva.

- 2.14: Desenho de José Paulo De Bem sobre base da Carta da Capital de São Paulo, 1842, executada por José Jacques da Costa Ourique, 2006.

- 2.15: Mapa Sara-Brasil- 1930.

- 2.16 a 2.22: do autor

-

- 3. Nova Yok/São Paulo: aproximação necessária

- 3.1: REIS, Nestor Goulart Filho. São Paulo: Vila, Cidade e Metrópole. São Paulo, Prefeitura

- de São Paulo, 2004.

- 3.3:, 3.4, 3.5, 3.6, : WILLIS, Carol. Form Follows Finance: Skyscrapers and Skylines in New York and Chicago. New York, Princeton Architectural Press, 1995.

- 3.7, 3.8, 3.9: ADAMS, Thomas. The Building of New York, V. 2. New York: Regional Plan of New York and its Environs, 1931.

- 3.10: KOOLHAAS, Rem. Nova York delirante. Trad. Denise Bottmann. São Paulo, Cosac Naify, 2008.

- 3.11, 3.12: Casabella 457/458 - Grattacielo: casa dello spechio, 1980.

- 3.13: Le Corbusier \& P. Jeanneret. Oevre complète - 1934-38. Zurich, Edition Girsberg, 1964/1995.

\section{São Paulo/Nova York: dos traçados aos edifícios}

- 4.1: Sara Brasil, 1930.

- 4.2, 4.9, 4.12, 4.13, : TOLEDO, Benedito Lima de. Prestes Maia e as Origens do Urbanismo Moderno em São Paulo. São Paulo: Empresa das Artes, 1996.

- 4.3: WILLIS, Carol. Form Follows Finance: Skyscrapers and Skylines in New York and Chicago. New York, Princeton Architectural Press, 1995.

- 4.4, 4.10: ADAMS, Thomas. The Building of New York, V. 2. New York: Regional Plan of New York and its Environs, 1931.

- 4.5, 4.14: Casabella 457/458 - Grattacielo: casa dello spechio, 1980.

- 4.6, 4.7, 4.8: Alessandro J. Castroviejo Ribeiro e Tiago Azzi Collet e Silva.

- 4.11: 7.17 e 7.18 . Os melhoramentos de São Paulo - Palestra pelo Engenheiro Francisco Prestes Maia - Prefeito Municipal: 1945.

- 4.14: foto do autor (São Paulo).

- 4.15: 9.37: ROSA, Marcos. São Paulo Vista do Céu. São Paulo, Editora Caras, 2004.

\section{Objeto-tipo: moderno e brasileiro}

- 5.1, 5.9 e 5.10: Plano Voisin, 1930. CURTIS, William J. R. Le Corbusier: ideas and forms. New York: Phaidon,2006. 
- 5.2 ,5.3, 5.5, 5.6, 5.7, 5.8: COLQUHOUN, Alan. Modernidade e tradição clássica: ensaios sobre arquitetura 1980-87, . São Paulo, Cosac \& Naify, 2004.

- 5.4; Oevre complète -1929-34, 1934- Le Corbusier \& P. Jeanneret

- 5. 13, 5.15, 5.16, 5.17, 5.18. Revista Projeto, no 102.

- 5.14. SANTOS, Cecília Rodrigues do ...[et al.]. Le Corbusier e o Brasil. São Paulo, Tessela/Projeto Editores, 1987.

- $\quad 5.18$ e 5.19. XAVIER, Alberto ;BRITO, Alfredo, NOBRE, Ana Luiza. Arquitetura Moderna no Rio de Janeiro. PINI, 1991.

\section{Ossatura independente}

- 6.1: BOESIGER, Willy: Le Corbusier.São Paulo, Matins Fontes, 199.

- 6.3, 6.6: Acrópole oㅜ 57.

- 6.2: LISSOVSKY, Maurício; SÁ, Paulo Sérgio Moraes de. Colunas da Educação: a construção do Ministério da Educação e Saúde (1935-1945). Rio de Janeiro: MINC/IPHAN; Fundação Getulio Vargas/CPDOC, 1996.

- 6.4, 6.7, 6.8, : Banco de Dados Digital - Centro Historio de São Paulo - Universidade Presbiteriana Mackenzie.

- 6.5: ANELLI, Renato (pesquisa de texto), GUERRA, Abílio (coordenação editorial) e KON, Nelson (ensaios fotográficos). Rino Levi: Arquitetura e cidade. São Paulo: Romano Guerra, 2001.

- 6.9: arquivo Rino Levi, FAU-USP.

- 6.10 e 6.11: fotos do autor.

\section{Primeiros encontros modernos no CHSP}

- 7.3: desenhos sobre base Vasp-Cruzeiro, Alessandro j Castroviejo Ribeiro e Tiago Collet e Silva.

- 7.4, 7.19, 7.57: desenhos sobre base Gegran -Viva o Centro- Alessandro j Castroviejo Ribeiro e Tiago Collet e Silva.

- 7.5, 7.7, 7.8, 7.37, : Arquivo digital - Estudo de Tombamento do Centro Histórico da Cidade de São Paulo - Instituto do Patrimônio Histórico e Artístico Nacional - 9ª -SRSão Paulo

- 7.6, 7.9, 7.11: ATIQUE, Fernando. Memória moderna: a trajetória do Edifício Esther. São Paulo: Rima/FAPESP, 2004.

- 7.10, 7.12: CONDURU, Roberto._Vital Brasil. São Paulo, Cosac \& Naify, 2000.

- 7.13,7.14, 7.23,7.25 a 7.31, 7.48,7.49, 7.58, 7.59, 7.64, 7.65, 7.77 a 7.80: foto do autor

- 7.17 e 7.18 . Os melhoramentos de São Paulo - Palestra pelo Engenheiro Francisco Prestes Maia - Prefeito Municipal: 1945.

- 7.20, 7.21, 7.22: L’Archiecture D"Aujourd'hui, nº 21, dezembro de 1948.

- 7.35 e 7.26: Banco de Dados Digital - Centro Historio de São Paulo - Universidade Presbiteriana Mackenzie.

- 7.38, 7.47 : ANELLI, Renato (pesquisa de texto), GUERRA, Abílio (coordenação editorial) e KON, Nelson (ensaios fotográficos). Rino Levi: Arquitetura e cidade. São Paulo: Romano Guerra, 2001.

- $\quad 7.39,7.40,7.41,7.42,7.43,7.44,7.45,7.46$ : Aquivo Rino Levi, FAU USP

- 7.50, 7.5,7.52: Revista Acrópole, №146.

- 7.53 e 7.55: LEFÈVRE, José Eduardo de Assis. De Beco a Avenida: a história da Rua São Luiz. São Paulo, EDUSP, 2006.

- 7.60, 7.61 e 7.62: do autor de original para bombeiros.

- 7.63: Acrópole

- 7.66,7.70, 7.68: XAVIER, Alberto, LEMOS, Carlos, CORONA, Eduardo. Arquitetura Moderna Paulistana. São Paulo, Pini, 1983.

- 7.70, 7.75: SEGAWA, Hugo. Oswaldo Arthur Bratke. São Paulo: ProEditores, 1997. 
- $7.71,7.72,7.73,7,74:$ do autor sobre plantas legais

\section{Oscar Niemeyer situações abrangentes}

- $\quad 8.3,8.22,8.32,8.67,8.86$ : desenhos sobre base Gegran -Viva o Centro- Alessandro j Castroviejo Ribeiro e Tiago Collet e Silva.

- 8.4, 8.5, 8.6, 8.7, 8.17: revista Habitat $\mathrm{n}^{0}$ 2,

- $8.8,8.9,8.12,8.14$ : desenhos IPHAN

- $8.11,8.10,8.13,8.16,8.25,8.26,8.30,8.34,8.35,8.36,8.37,8.42,8.4,8.58$ a 8.61 , $8.64,8.79$ a $8.7,8.88$ a 8.94 : fotos do autor

- 8.15: foto, Marcos Carrilho

- 8.21: Acrópole 202

- $\quad 8.22,8.23,8.24,8.27,8.28,8.29,8.35,8.38,8.39,8.40,8.41,8.54,8.55,8.56,8.57$, : Arquivo digital - Estudo de Tombamento do Centro Histórico da Cidade de São Paulo Instituto do Patrimônio Histórico e Artístico Nacional - 9aㅡ-SR- São Paulo

- 8.45 e 8.46: 2.3 e 2.4: Le Corbusier \& P. Jeanneret. Oevre complète - 1934-38. Zurich, Edition Girsberg, 1964/1995.

- 8.50: Holabird, Root \& Burgee

- 8.51: croqui de Marcos Carrilho.

- 8.52: Zein, Ruth Verde. Três Momentos de Oscar Niemeyer. MCB, 100 Obras de São Paulo, Museu da Casa Brasileira, 2007.

- 8.65 e 8.66: Tiago Azzi Collet e Silva.

- 8.68 a 8.75: desenhos IPHAN

- 8.76, 8.77 e 8.78: digital sobre plantas legais do condomínio.

- 8.34, 8.85, 8.87: Revista Acrópole ํo 245.

\section{Rumo aos 60}

- 9.3, 9.6, 9.7, 9.15, : Arquivo digital - Estudo de Tombamento do Centro Histórico da Cidade de São Paulo - Instituto do Patrimônio Histórico e Artístico Nacional - 9a -SRSão Paulo

- $9.4,9.16$ a 9.18, 9.32, 9.33, 9.45, 9.46, 9.48, 9.49, 9.51, 9.67 a 9.70 : fotos do autor

- 9.5, 9.22, 9.38, 9.55: desenhos sobre base Gegran -Viva o Centro- Alessandro j Castroviejo Ribeiro e Tiago Collet e Silva

- 9. 8, 9.12, 913, 9.14: L’Archiecture D"Aujourd'hui, n² 21, dezembro de 1948

- 9.20: Acervo Instituto Moreira Salles

- $\quad 9.52,9.23,9.24,9.25,9.26,9.27,9.28,9.29,9.30,9.31,9.34, .35$ : arquivo Condomínio Conde de Prates

- 9.37: ROSA, Marcos. São Paulo Vista do Céu. São Paulo, Editora Caras, 2004.

- 9.41 a 9.44, 9.47, 9.50, 9.54: Habitat 29, abril de 1956.

- 9.53: LEFÈVRE, José Eduardo de Assis. De Beco a Avenida: a história da Rua São Luiz. São Paulo, EDUSP, 2006.

- 9.56 a 9.59, 9.66: CUNHA JR., Jaime. Edifício Metrópole: um diálogo entre arquitetura moderna e cidade. 2007.

- 9.60 a 9.65: Habitat 59, Abril de 1960 